МИНИСТЕРСТВО НАУКИ И ВЫСШЕГО ОБРАЗОВАНИЯ

РОССИЙСКОЙ ФЕДЕРАЦИИ

РОССИЙСКАЯ АКАДЕМИЯ НАУК

Отделение сельскохозяйственных наук РАН

КОМИТЕТ АПК КУРСКОЙ ОБЛАСТИ

Федеральное государственное бюджетное научное учреждение «КУРСКИЙ ФЕДЕРАЛЬНЫЙ АГРАРНЫЙ НАУЧНЫЙ ЦЕНТР»

ВНИИ земледелия и защиты почв от эрозии

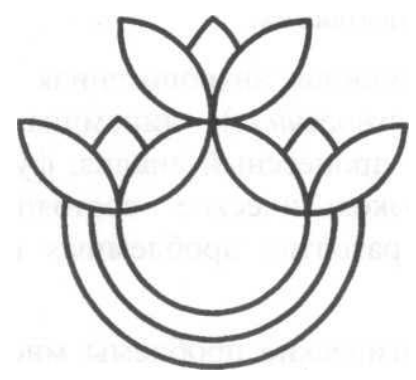

\title{
РАЦИОНАЛЬНОЕ ЗЕМЛЕПОЛЬЗОВАНИЕ: ОПТИМИЗАЦИЯ ЗЕМЛЕДЕЛИЯ И РАСТЕНИЕВОДСТВА
}

СБОРНИК ДОКЛАДОВ

V Международной научно-практической конференции, посвященной посвященной 8о-летию со дня рождения академика РАСХН А.П. Щербакова

28-30 сентября 2021 года

Курск - 2021 
УДК 63:001.892

DOI 10.18411/isbn978-5-907407-49-7-285

Рациональное землепользование: оптимизация земледелия и растениеводства. Сборник докладов V Международной научно-практической конференции, посвященной 80-летию со дня рождения академика РАСХН А.П. Щербакова, Курск, 28-30 сентября 2021 г. - Курск: ФГБНУ «Курский федеральный аграрный научный центр», 2021. - 289 с.

Представленные в сборнике доклады посвящены проблемам рационального землепользования, оптимизации земледелия, растениеводства и 80-летию со дня рождения академика РАСХН А.П. Щербакова. Сборник включает 67 докладов из основных регионов Российской Федерации и стран ближнего зарубежья: Беларуси, Молдовы и Казахстана. Важное внимание уделено вопросам перехода к передовым цифровым, интеллектуальным производственным технологиям в земледелии. Рассмотрены проблемы ресурсосбережения и интенсификации в земледелии. Предложены инновационные технологии возделывания сельскохозяйственных культур. Показаны влияние основной обработки почвы на урожайность и качество сельскохозяйственной продукции, инновационные ресурсы повышения качества зерна сельскохозяйственных культур, проблемы защиты растений. Рассмотрены проблемы и перспективы сохранения и повышения плодородия почв, биодиагностика экологического состояния почв, агрогенная деградация почв и земель и её предотвращение, защита почв от эрозии, оценки последствий эрозии. Освещена научно-практическая деятельность академика А.П. Щербакова в годы работы во ВНИИ земледелия и защиты почв от эрозии и Воронежском государственном университете. Показана его роль в развитии теоретических и прикладных проблем агрохимии, ландшафтного земледелия и агроэкологии.

Сборник представляет интерес для научных работников, преподавателей, аспирантов, студентов ВУЗов, ССУЗов сельскохозяйственного и биологического профиля, работников АПК и специалистов агрохозяйств всех форм собственности.

\section{Редакционная коллегия:}

А.В. Гостев, врио директора ФГБНУ «Курский ФАНЦ», кандидат сельскохозяйственных наук;

Д.В. Дубовик, первый заместитель директора ФГБНУ «Курский ФАНЦ», профессор РАН, доктор сельскохозяйственных наук;

Н.П. Масютенко, заместитель директора ФГБНУ «Курский ФАНЦ», по научной работе, профессор, доктор сельскохозяйственных наук.

Ответственные за выпуск:

Г.П. Глазунов, кандидат сельскохозяйственных наук, зав. отделом, М.Ю. Дегтева, учёный секретарь ФГБНУ «Курский ФАНЦ», кандидат биологических наук,

Компьютерная верстка: Г.П. Глазунов

Перевод Л.Е. Тарасовой.

ISBN - 978-5-907407-49-7

(C) ФГБНУ «Курский федеральный аграрный научный центр», 2021 г. 
THE MINISTRY OF SCIENCE AND HIGHER EDUCATION

THE RUSSIAN FEDERATION

THE RUSSIAN ACADEMY OF SCIENCES

Department of Agricultural Sciences of the Russian Academy of Sciences

Federal State Budgetary Scientific Institution

«KURSK FEDERAL AGRICULTURAL RESEARCH CENTER»

All-Russia Research Institute of Arable Farming and Soil Erosion Control

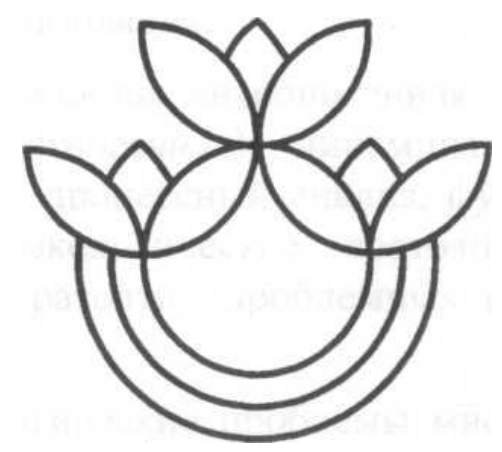

\title{
RATIONAL LAND USE: \\ OPTIMIZATION OF ARABLE FARMING AND CROP PRODUCTION
}

\author{
Proceedings \\ of V International Scientific and Practical Conference, \\ devoted to the $8^{\text {th }}$ Anniversary of Academician A.P. Shcherbakov's Birth \\ September 28-30, 2021
}

Kursk-2021 
UDC 63:001.892

DOI 10.18411/isbn978-5-907407-49-7-285

Rational land use: optimization of arable farming and crop production. Proceedings of V International Scientific and Practical Conference, devoted to the $80^{\text {th }}$ Anniversary of Academician A.P. Shcherbakov's Birth, Kursk, September 28-30, 2021. - Kursk: FSBSI «Kursk Federal Agricultural Research Center», 2021. - 289 p.

The reports presented in the volume are devoted to the issues of rational land use, optimization of arable farming, crop production and the $80^{\text {th }}$ anniversary of RAS Academician A.P. Shcherbakov's birth. The volume includes 67 papers from major regions of the Russian Federation and neighboring countries: Belarus, Moldova and Kazakhstan. Great attention is payed to the issues of transition to digital, intellectual production technologies in agriculture. The problems of resource saving and intensification in arable farming are discussed. Innovational technologies of crop cultivation are proposed. The influence of primary tillage on crop yield and quality of agricultural product, innovational resources of improving crop grain quality, problems of plant protection are shown. Problems and prospects of conservation and increase of soil fertility, biodiagnostics of ecological soil condition, agrogenic degradation of soils and lands and its prevention, soil erosion control, assessment of erosion consequences are considered. Scientific and practical activities of Academician A.P. Shcherbakov in the years of his work in All-Russia Research Institute of Arable Farming and Soil Erosion Control and Voronezh State University is highlighted. His role in the development of theoretical and applied issues of agrochemistry, landscape farming and agroecology is shown.

The volume is of interest to researchers, teachers, postgraduates, students of universities, agricultural and biological colleges, agricultural workers and specialists of agricultural enterprises and farms of all forms of ownership.

\section{Editorial Board:}

A.V. Gostev, Director, FSBSI «Kursk FARC», Candidate of Agricultural Sciences,

D.V. Dubovik, First Deputy Director of FSBSI «Kursk FARC», Professor of RAS, Doctor of Agricultural Sciences,

N.P. Masyutenko, Deputy Director on Scientific Work of FSBSI «Kursk FARC», Professor, Doctor of Agricultural Sciences.

Persons responsible for the volume release:

G.P. Glazunov, Candidate of Agricultural Sciences, Head of the Department, M.Yu. Degteva, Scientific Secretary of FSBSI «Kursk FARC»,

Candidate of Biological Sciences.

Computer layout: G.P. Glazunov.

Translated by L.E. Tarasova.

ISBN - 978-5-907407-49-7

(C) FSBSI «Kursk Federal Agricultural

Research Center», 2021 


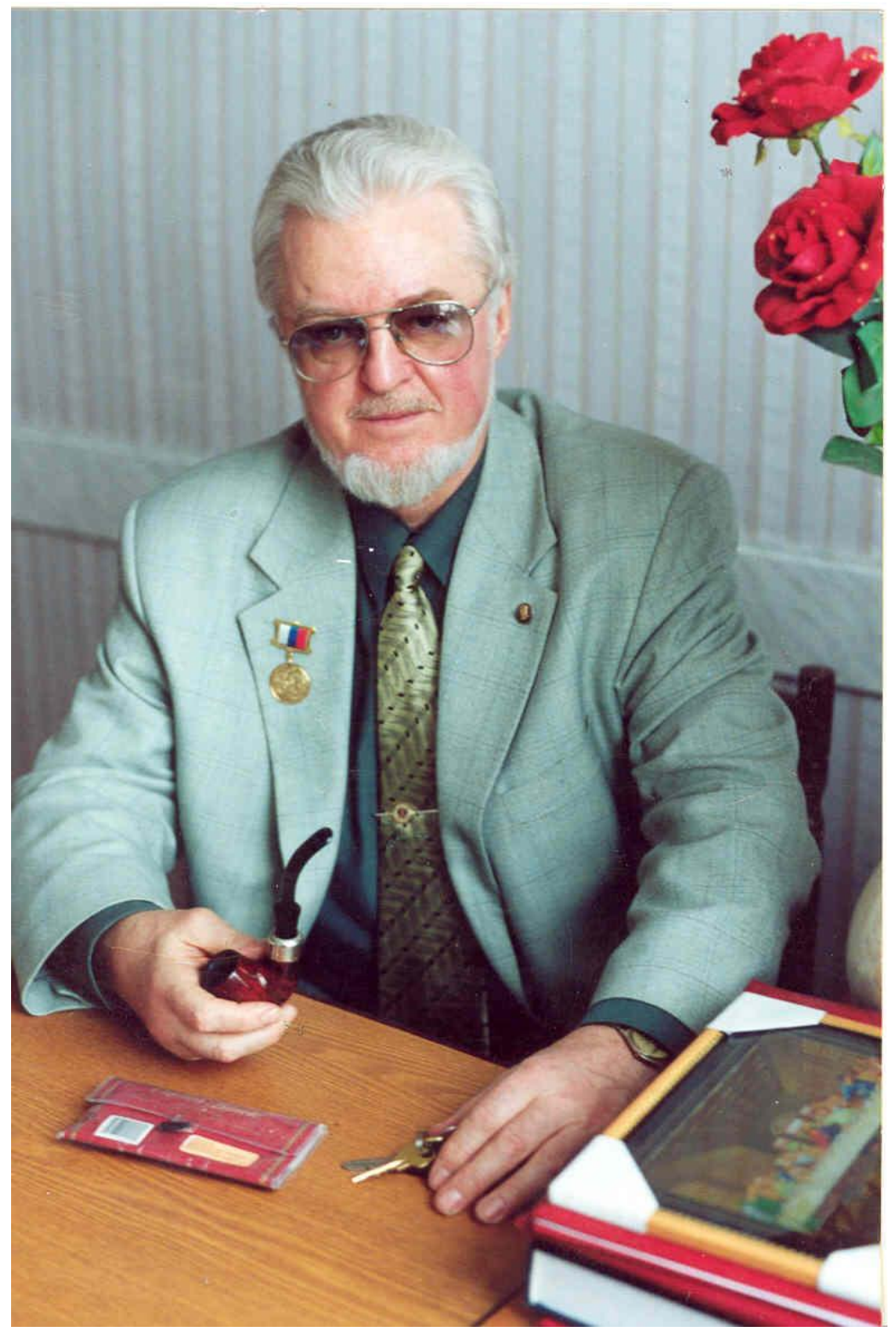

К 8о-летию со дня рождения академика Андрея Павловича Щербакова 



\section{НАУЧНО-ПРАКТИЧЕСКАЯ ДЕЯТЕЛЬНОСТЬ АКАДЕМИКА А.П. ЩЕРБАКОВА В ГОДЫ РАБОТЫ ВО ВНИИ ЗЕМЛЕДЕЛИЯ И ЗАЩИТЫ ПОЧВ ОТ ЭРОЗИИ}

Гостев А.В., Масютенко Н.П.

ФГБНУ «Курский федеральный аграрный научный центр»ВНИИ земледелия и защиты почв от эрозии, г. Курск

Щербаков Андрей Павлович - действительный член Российской академии сельскохозяйственных наук, лауреат Государственной премии России, доктор биологических наук, профессор, посвятивший свою жизнь изучению и спасению знаменитого русского чернозема.

С 1988 по 1997 год Андрей Павлович возглавлял Всероссийский научноисследовательский институт земледелия и защиты почв от эрозии. В 1988 году А.П. Щербаков был избран членом-корреспондентом, в феврале 1991 - действительным членом РАСХН. Под его руководством институт получил дальнейшее развитие в области совершенствования систем земледелия, как в научном, так и в практическом направлениях.

Уже в первый год работы были созданы две научно-производственные системы (НПС) по освоению почвозащитных систем земледелия в двух районах Курской области. При непосредственном участии сотрудников института в хозяйствах районов создавались системы лесных насаждений, осуществлялась корректировка структуры посевных площадей и севооборотов, внедрялись почвозащитные технологии возделывания сельскохозяйственных культур, мероприятия по улучшению естественных кормовых угодий. Так, в результате освоения почвозащитной системы земледелия в колхозе «Рассвет» Мантуровского района урожайность зерновых культур увеличилась на 28\% с 26,5 до 33,8 ц/га.

А.П. Щербаков принимал активное участие в подготовке выездной научной сессии ВАСХНИЛ по вопросам земельной реформы и проблем развития земледелия СССР, которая состоялась 16-18 января 1991г. в г. Курске на базе Всесоюзного НИИ земледелия и защиты почв от эрозии. На рассмотрении сессии были вынесены проблемы земельной реформы и развития земледелия в рыночных условиях. С докладом по проблемам сохранения русского чернозема выступил А.П. Щербаков. Решением научной сессии предусматривалось дальнейшее совершенствование зональных систем земледелия на ландшафтной основе. И после окончания научной сессии ВАСХНИЛ коллектив института был направлен на разработку систем земледелия нового поколения на ландшафтной основе.

В девяностых годах резко сократилось финансирование исследований и не превышало 15-30\% от потребности. Руководить крупными коллективами в этих условиях стало сложнее, так как заработная плата была самой низкой за всю истории развития аграрной науки России. Многие руководители научных учреждений дрогнули и не устояли перед трудностями в начале 90-х годов. 
Андрей Павлович Щербаков выдержал это испытание, сохранил институт от развала (из воспоминаний академика РАН А.Н. Каштанова).

Под руководством и при непосредственном участии А.П. Щербакова в 1992 году впервые была разработана «Концепция формирования высокопродуктивных экологически устойчивых агроландшафтов и совершенствования систем земледелия на ландшафтной основе», Курск, 1992. - 138 с. Основные положения этой концепции были изложены в докладе и одобрены сессией, посвященной 100-летию Особой экспедиции В.В. Докучаева. В 1993г. разработаны и опубликованы «Методические рекомендации по разработке ландшафтных систем земледелия в многоукладном сельском хозяйстве», Ландшафтное земледелие. Часть 2. Курск, 1993. - 54c.

Общие принципы организации высокопродуктивных экологически устойчивых агроландшафтов, разработанные во ВНИИ земледелия и защиты почв от эрозии и изложенные в концепции и методических рекомендациях, изданных в 1992-1993 годах, были реализованы при научно-методическом обеспечении ВНИИЗиЗПЭ Роскомземом и РАСХН совместно с НИУ России в 1994 году путем разработки проектов землеустройства на ландшафтной основе в различных регионах России на примере базовых хозяйств 9-ти областей.

Проектирование проводилось в крупных сельскохозяйственных предприятиях и фермерских (крестьянских) хозяйствах, расположенных в различных почвенно-географических и природно-сельскохозяйственных зонах Российской Федерации (Белгородская, Брянская, Волгоградская, Курская, Саратовская, Тульская, Челябинская области, Краснодарский край).

По завершении проектно-изыскательских работ в качестве научно-технической продукции представлены по каждому хозяйству «Системы земледелия и землеустройства на ландшафтной основе», состоящие из текста пояснительной записки, схем, картограмм и других графических и табличных материалов.

Анализ результатов разработки систем земледелия и землеустройства базовых хозяйств в различных регионах России показал направленность ученых и практиков на решение проблем, свойственных каждому конкретному региону. Так, в условиях интенсивного развития эрозионных процессов в Алтайском крае, Белгородской, Саратовской, Тульской областях в основу разработки систем земледелия и землеустройства положена стабилизация и предотвращение водной эрозии почв, в Волгоградской и Челябинских областях - разработка противоэрозионной и противодефляционной инфраструктуры агроландшафта, в Краснодарском крае - противодефляционная инфраструктура и восстановление плодородия земель путем их консервации.

В основу разработки систем земледелия и землеустройства Брянской области положены принципы рационального использования земель с различным уровнем загрязнения территории радионуклидами. В целом, направленность разработки систем земледелия и землеустройства в этих регионах осуществлялась с целью предотвращения ущерба от наиболее значимых негативных последствий, что несомненно является определенным шагом в создании 
экологически устойчивых агроландшафтов, и данный эксперимент заслуживает внимания и всестороннего изучения.

Более комплексный подход осуществлен при разработке системы земледелия и землеустройства на ландшафтной основе в базовых хозяйствах Курской области (АО «Россия», ОППХ ВНИИЗиЗПЭ, фермерское хозяйство «Ландшафт» и др.), где в основу типизации земель были положены принципы анализа потенциала основных природных ресурсов, поступающей суммарной радиации, плодородия и влагообеспеченности почв в зависимости от рельефа и организация противоэрозионной инфраструктуры. То есть, произведена оценка природного, а также и антропогенного ресурсного потенциала и разработаны на этой основе организация территории и комплекс мероприятий, направленные на повышение продуктивности земель и охрану окружающей среды.

Разработка экспериментальных проектов систем земледелия и землеустройства на ландшафтной основе в основных регионах земледелия страны явилась важным шагом вперед на пути создания физических моделей ландшафтно-экологического устройства территории и рационального использования земель с учетом разнообразия условий основных регионов земледелия страны.

Результатом третьего, завершающего этапа в развитии адаптивно- ландшафтного земледелия, явилась «Методика разработки систем земледелия на ландшафтной основе» (Курск, 1996). В ней получили дальнейшее развитие и реализацию теоретические положения и практические рекомендации, содержащиеся в двух первых методических работах авторского коллектива, возглавляемого академиками РАСХН А.Н. Каштановым и А.П. Щербаковым. В определенной степени был учтен практический опыт разработки ландшафтных систем земледелия в различных почвенно-климатических зонах, накопленный зональными институтами при использовании наших методических подходов.

За цикл проведенных исследований и их практическую реализацию в различных регионах чернозёмной зоны России творческий коллектив, возглавляемый академиками РАСХН А.Н. Каштановым и А.П. Щербаковым, был удостоен в 2000 г. Государственной премии Российской Федерации в области науки и техники.

Наряду с разработкой систем земледелия на ландшафтной основе Андрей Павлович уделял большое внимание экологическим проблемам Центрального Черноземья, и особенно волновала его судьба чернозёмов. Им была организована и проведена агроэкологическая экспедиция «Русский чернозём, 100 лет работ В.В. Докучаева, которая прошла за 2 полевых сезона,1991 и 1992 годов маршрутами В.В. Докучаева и его учеников по территории девяти чернозёмных областей центра России.

Исследования показали статистически достоверное уплотнение пахотных и подпахотных горизонтов чернозёмов, деградацию их структуры с резким снижением содержания агрономически ценных водопрочных агрегатов. 
В большинстве пахотных чернозёмов ЦЧР установлена сильная активизация процессов дегумификации с уменьшением до 2-2,5\% гумуса за последние три-четыре десятилетия. Отмечено подкисление в оподзоленных и выщелоченных чернозёмах, перепад с контролем по значениям $\mathrm{pH}$ может достигать 2,0 единиц. Очень высоким пространственным варьированием в зависимости от подтипа характеризуются чернозёмы по содержанию подвижного фосфора и обменного калия.

В работе «Агроэкологическое состояние чернозёмов ЦЧО» указывается, что педодинамические и процессно-диагностические модели должны служить надежной научно-информационной основой для управления плодородием чернозёмов, разработки систем земледелия на ландшафтной основе. И понятно, что агроэкологическая оценка земель является основой для проектирования адаптивно-ландшафтных систем земледелия.

Щербаковым А.П. было опубликовано более 400 научных трудов, из них около половины за время работы в институте. Среди них 17 коллективных монографий, таких как: «Концепция развития земледелия в условиях перехода к рыночным отношениям и многоукладному сельскому хозяйству» (1991), «Научно обоснованная система ведения агропромышленного производства Курской области» (1991), «Повышение продуктивности и устойчивости производства зерна» (1992), «Ландшафтное земледелие: Ч1. Концепция формирования высокопродуктивных экологически устойчивых агроландшафтов и совершенствования систем земледелия на ландшафтной основе» (1993), «Ландшафтное земледелие: (вопросы теории методики исследований, проектирования и агроэкологического мониторинга ландшафтных систем земледелия)» (1994), «Агроэкологическое состояние чернозёмов ЦЧО» (1996), «Вековая динамика, экологические проблемы и перспективы использования чернозёмов» (1996), «Система управления плодородием почв в Центрально-Чернозёмной зоне» (1996), «Концепция формирования гибких агротехнологий в ландшафтном земледелии» (1998), «Модели управления продуктивностью агроландшафта» (1998), «Антропогенная эволюция чернозёмов» (2000) и др.

С 1997 года Андрей Павлович Щербаков работал главным научным сотрудником лаборатории геоинформационных систем и агроэкологического мониторинга ВНИИЗиЗПЭ.

Андрей Павлович неоднократно выступал с лекциями и докладами во многих ведущих зарубежных университетах (Галле и Лейпциг, Германия, 1988; Леон, Испания, 1988; Упсала, Швеция, 1989; Айова, Миннесота, Огайо, Мичиган и др., США, 1989, 1991; Чапинго, Мексика, 1994; Нанкин, Китай, 1997; Брауншвейг и Оснабрюк, 1996, 1998, 2000 и др.).

А.П. Щербаков проявил себя талантливым руководителем и организатором, приложив немало энергии для улучшения координации исследований институтов академии в области земледелия, почвоведения, агрохимии и смежных научных дисциплин. Под его руководством коллектив Всероссийского НИИ земледелия и защиты почв от эрозии сумел сконцентрировать свои усилия на 
важнейших направлениях аграрной науки, выйдя на передовые рубежи в области ландшафтного земледелия и агроэкологии.

УДК 631.512:631.58.03

\title{
ВЛИЯНИЕ ТЕХНОЛОГИЙ ВОЗДЕЛЫВАНИЯ НА ПРОДУКТИВНОСТЬ ПОЛЕВЫХ СЕВООБОРОТОВ И ИХ ЭКОНОМИЧЕСКАЯ ОЦЕНКА В ЮЖНОМ ЗАУРАЛЬЕ
}

\author{
Агеев А.А., Анисимов Ю.Б., Калюжина Е.Л. \\ ФГБНУ «Челябинский НИИСХ», г. Челябинск \\ E-mail:ageev.aa62@mail.ru
}

\begin{abstract}
Резюме. Исследования лаборатории агроландшафтного земледелия ФГБНУ «Челябинский НИИСХ» за период 2017-2019 гг. на базе опьлтного поля ФГУП «Троиикое» южного лесостепного агроландшафта Южного Зауралья являются актуальными и востребованными производством. Экспериментальная работа заключалась в оченке ресурсосберегающих технологий воздельвания зерновых культур, включая систему прямого посева, на показатели плодородия выщелоченного чернозема и продуктивность пашни. Дана экономическая оценка эффективности производства зерна при различных технологиях воздельвания основных сельскохозяйственных культур.
\end{abstract}

Ключевые слова: технология, зерновые культуры, севооборот, минилизация обработки почвы, прямой посев, плотность почвы, растительные остатки, урожайность, рентабельность.

В Южном Зауралье основным направлением стабилизации производства зерна является совершенствование общепринятых технологий возделывания зерновых культур на основе ресурсосберегающих и почвозащитных систем обработки почвы в полевых севооборотах.

Задача современных исследований заключается в выявлении закономерностей влияния минимизации обработки почвы под различные культуры и отказа от нее на свойства и режимы почв, функционирование агроценозов и обоснование оптимальных вариантов систем обработки применительно к различным условиям ведения земледелия. Мульчирующие обработки почвы, особенно нулевая, имеют существенное преимущество, поскольку способствуют предотвращению деградации почв [1].

Цель настоящих исследований заключалась в оценке различных технологий возделывания сельскохозяйственных культур в полевых севооборотах на ресурсосберегающей основе с соблюдением почвозащитных требований и рационального использования биоклиматических ресурсов южного лесостепного агроландшафта Челябинской области.

В задачи исследований входило:

1. Изучить агрохимические и агрофизические свойства почвы и их изменения в зависимости от применения технологий возделывания;

2. Изучить влияние технологий возделывания на водный режим почвы;

3. Оценить влияния технологий на урожайность и качество зерна яровой пшеницы; 
4. Провести сравнительную агроэкономическую оценку ресурсосберегающих технологий возделывания зерновых культур;

Исследования проводились в 2017-2019 гг. лабораторией агроландшафтного земледелия ФГБНУ «Челябинский НИИСХ» в научно- производственном полевом опыте, заложенном в условиях южного лесостепного агроландшафта на выщелоченном черноземе на территории землепользования ФГУП «Троицкое» Челябинской области.

Почва опытного участка чернозём выщелоченный, имеющий следующие на момент закладки опыта характеристики: реакцию среды, близкую к нейтральной $-\mathrm{pH}=5,86$, повышенную степень насыщенности основаниями, повышенное содержание обменного калия, средние запасы подвижного фосфора и содержание гумуса $6,5 \%$ (табл. 1 ).

Таблица 1 - Исходные агрохимические показатели почвы опытного участка

\begin{tabular}{|c|c|c|c|c|c|c|c|}
\hline Гумус, \% & $\mathrm{pH}_{\text {н2о }}$ & $\mathrm{pH}_{\text {ксl }}$ & $\begin{array}{c}\mathrm{P}_{2} 0_{5}, \\
\mathrm{M \Gamma} / \mathrm{\kappa} \Gamma\end{array}$ & $\begin{array}{c}\mathrm{K}_{2} 0, \\
\mathrm{M \Gamma} / 100 \text { г. }\end{array}$ & $\mathrm{Mg}$ & Са & $\begin{array}{c}\text { Азот лег.- } \\
\text { гидр., мг } / 100 \\
\Gamma\end{array}$ \\
\hline 6,5 & 6,52 & 5,86 & 75,4 & 20,0 & 6,9 & 22,9 & 66,6 \\
\hline
\end{tabular}

Технологии возделывания сельскохозяйственных культур базировались на следующих системах обработки почвы по классификации Кирюшина В.И., [2] и включали следующие варианты:

1 - отвальная (мелкая), обработка дискатором с оборотом почвы ежегодно на глубину 12-14 см под все культуры и в паровом поле по типу раннего, предпосевная обработка под все культуры севооборота культиватором АПК 7,2 ;

2 - мульчирующая (минимальная), плоскорезная мелкая обработка почвы, с сохранением стерни, на глубину 12-14 см в паровом поле и под все культуры севооборота культиватором АПК - 7,2;

3 - нулевая (без механической обработки), до посева на всех культурах севооборота и в пару применялся гербицид сплошного действия (глифосат) в дозе 3-4 л/га;

Технологии возделывания изучались в двух полевых севооборотах со следующим чередованием культур: зернопаровом - пар-пшеница-горох + овес-ячмень и плодосменном - рапс-пшеница-горох +овес-пшеница с насыщением зерновыми культурами от $75 \%$ до $100 \%$.

В севооборотах вносили $\mathrm{N}_{20-30}$ кг д.в. на 1 га пашни, которые дифференцировались под отдельные культуры в зависимости от технологии их возделывания и размещения в севообороте. Общая площадь делянок первого порядка $3600 \mathrm{~m}^{2}$, второго порядка - $1200 \mathrm{~m}^{2}$, учетная - $105 \mathrm{~m}^{2}$, повторность трехкратная, размещение вариантов последовательное. Посев культур проводился сеялкой CC-6, оборудованной дисковыми сошниками и специальным приспособлением (турбодиски) для прямого посева. В системе прямого посева предусматривалось внесение глифосата за 7-8 дней до посева. Система защиты растений предусматривала опрыскивание посевов полевых культур баковой смесью 
рекомендованных гербицидов с фунгицидом и инсектицидом в оптимальные фазы развития.

Климат зоны проведения опытов характеризуется континентальностью. Сумма температур за период вегетации более $10^{\circ} \mathrm{C}$ составляет 2000-2200 ${ }^{\circ}$. За вегетационный период (май-сентябрь) выпадает 175-225 мм, ГТК составляет 1,2. Погодные условия в годы проведения исследований были различными. ГТК составил в 2017, 2018 и 2019 годах соответственно 1,1; 1,3 и 1,3. В исследованиях использовались общепринятые методики по определению агрофизических свойств и агрохимических показателей почвы, засоренности посевов и учета урожайности культур $[3,4,5]$. Экономическую эффективность изучаемых агротехнологических приемов определяли расчетно-нормативным методом.

Исследованиями установлено, что минимальная и нулевая технологии при возделывании яровых зерновых культур, обладая влагонакопительной функцией за счёт стерни предшественника, имеют наибольшие запасы продуктивной влаги в метровом слое почвы. В среднем за 2017-2019 гг. содержание продуктивной влаги к периоду посева культур было выше при нулевой технологии и составило 142 мм. Обусловлено это тем, что в технологии с оставлением на поверхности растительных остатков предшествующих растений больше накапливается и лучше сохраняется влага в почве [6]. Особенно сильно преимущество прямого посева по накоплению и сохранению влаги в почве проявляется в засушливые годы [7].

Анализ плотности сложения почвы по плодосменному севообороту в период, когда она приобрела равновесное состояние, показал, что она находилась в оптимальном диапазоне для роста и развития зерновых культур по всем технологиям возделывания и составила для пахотного слоя в среднем 1,15-1,20 $\Gamma / \mathrm{cm}^{3}$.

Нулевая технология возделывания по содержанию нитратного азота в начале вегетации для слоя почвы 0-20 см уступала минимальной и отвальной в среднем на 2,8-3,4 мг/кг. Уменьшение глубины обработки почвы способствовало постепенной дифференциации содержания фосфора и калия по горизонтам, сосредотачивая их в верхних слоях почвы.

Уровень засоренности посевов при применении минимизации обработки почвы не имел тенденции к ее увеличению и в большинстве случаев не превышал порога вредоносности в 10\%. Это связано не только с применением эффективной системы химической защиты растений, но и с более поздним сроком посева, когда основная масса сорняков прорастает и уничтожается до посева культур.

Наибольшее влияние на уровень содержания клейковины в яровой пшенице оказывает предшественник. Лучшим предшественником в данном опыте являлся чистый пар с использованием мелкой отвальной обработки почвы, на втором месте предшественник бинарный посев гороха с овсом.

Минимальная технология возделывания зерновых культур была наиболее эффективной. Самая высокая продуктивность полевых севооборотов была при 
минимальной системе обработки почвы, но различия были не существенными (табл. 2).

Таблица 2 - Продуктивность полевых севооборотов в зависимости от технологии возделывания, з.ед. в т с 1 га, среднее за 2017-2019 гг.

\begin{tabular}{|c|c|c|c|c|}
\hline \multirow{2}{*}{ Севооборот } & \multicolumn{4}{|c|}{ Технология } \\
\hline & отвальная & минимальная & нулевая & среднее \\
\hline Рапс-пшеница-горох+овёс-пшеница & 1,73 & 1,84 & 1,74 & 1,77 \\
\hline $\begin{array}{l}\text { Пар- пшеница-горох+овёс-пшеница-яч- } \\
\text { мень }\end{array}$ & 1,61 & 1,66 & 1,71 & 1,68 \\
\hline В среднем по обработкам & 1,67 & 1,75 & 1,72 & 1,72 \\
\hline
\end{tabular}

Максимальная рентабельность производства зерна на уровне $125 \%$ получена на варианте минимальной технологии возделывании в 4-х польном плодосменном севообороте. Снижение рентабельности при нулевой технологии возделывания до 58\% обусловлено необходимым увеличением применения химических средств защиты растений, имеющих высокие стоимость и затраты на внесение препаратов. Аналогичная закономерность проявлялась и в 4-х польном зернопаровом севообороте (табл. 3).

\section{Таблица 3 - Экономические показатели производства сельскохозяйственной продукции в зависимости от технологии возделывания, среднее за 2017-2019 гг.}

\begin{tabular}{|c|c|c|c|}
\hline \multirow[b]{2}{*}{ Технология } & \multicolumn{3}{|c|}{ Показатели } \\
\hline & $\begin{array}{l}\text { затраты, } \\
\text { руб./ га }\end{array}$ & $\begin{array}{l}\text { чистый доход, } \\
\text { руб./ га }\end{array}$ & $\begin{array}{l}\text { рентабельность, } \\
\%\end{array}$ \\
\hline \multicolumn{4}{|c|}{ Плодосменный севооборот } \\
\hline Отвальная & 9138 & 7973 & 87 \\
\hline $\begin{array}{l}\text { Минималь- } \\
\text { ная }\end{array}$ & 8315 & 10452 & 125 \\
\hline Нулевая & 10864 & 6275 & 58 \\
\hline \multicolumn{4}{|c|}{ Зернопаровой севооборот } \\
\hline Отвальная & 8083 & 6485 & 80 \\
\hline $\begin{array}{l}\text { Минималь- } \\
\text { ная }\end{array}$ & 7275 & 7476 & 102 \\
\hline Нулевая & 9806 & 6229 & 63 \\
\hline
\end{tabular}

Таким образом, исследованиями, проведенными на базе опытного поля ФГУП «Троицкое» южного лесостепного агроландшафта Южного Зауралья определена эффективность ресурсосберегающих технологий возделывания основных сельскохозяйственных культур. Исходя из вышеизложенных показателей плодородия выщелоченного чернозема, продуктивности и экономической эффективности полевых севооборотов с различным насыщением зерновыми культурами можно рекомендовать применение минимальной (мульчирующей) технологии, основанной на применении почвообрабатывающих орудий 
плоскорежущего типа и прямого посева специальными сеялками без существенного нарушения стерни.

\title{
Библиографический список
}

1. Методические рекомендации по разработке минимальных систем обработки почвы и прямого посева / Под редакцией А.Л. Иванова и В.И.Кирюшина. - М.: ООО «Изд-во МБА», 2019. - 136 c.

2. Кирюшин В.И. Агроэкологическая оценка земель, проектирование адаптивно-ландшафтных систем земледелия и агротехнологий. Методическое руководство / Под редакцией академиков РАСХН В.И. Кирюшина и А.Л. Иванова. М.: «Росинформагротех», 2005. - 784 c.

3. Вадюнина А.Ф. Методы исследований физических свойств почв и грунтов / А.Ф. Вадюнина, 3.А. Корчагина. М.: Агропромиздат, 1986. - 416 с.

4. Доспехов Б.А. Методика полевого опыта (с основами статистической обработки результатов исследований) / Б.А.Доспехов. - Изд. 5-е доп. и перераб. М.: Агропромиздат, 1985. $-351 \mathrm{c}$.

5. Система защиты растений в ресурсосберегающих технологиях / Под общей редакцией Немченко В.В. Куртамыш, ГУП «Куртамышская типография», 2011. - 525 с.

6. Дридигер В.К. Состояние проведения исследований по минимизации обработки почвы и прямому посеву // Сельскохозяйственный журнал, 2019. - № 5 (12). - С. 8-16.

7. Иванов А.Л., Кулинцев В.В., Дридигер В.К., Белобров В.П. Освоение технологии прямого посева на черноземах России // Сельскохозяйственный журнал, 2021. - № 2 (14). - С. 18-36.

УДК 546.47:631.445.24:633.353:631.421

\section{ПОВЕДЕНИЕ ЦИНКА В КОМПОНЕНТАХ МОДЕЛЬНОЙ СИСТЕМЫ ПОЧВА - ПОЧВЕННЫЙ РАСТВОР - РАСТЕНИЕ}

Анисимов В.С., Анисимова Л.Н., Санжаров А.И., Фригидов Р.А. Всероссийский НИИ радиологии и агроэкологии, Обнинск, Россия, E-mail: vsanisimov@list.ru

\begin{abstract}
Резюме. Исследованы процессы водной миграции и биологического поглощения элементов методом водной культуры растений на примере дерново-подзолистой почвы легкого гранулометрического состава, с известным содержанием природного (стабильного) Zn и дополнительно внесенного в качестве радиоактивной метки ${ }^{65} \mathrm{Zn}$.
\end{abstract}

Ключевые слова. Цинк, вегетационный опыт, радиоизотоп, почвенный раствор, формыл.

Целями настоящей работы являлись: 1) изучение распределения внесенного в почву в водорастворимой форме ${ }^{65} \mathrm{Zn}$ между различными формами нахождения и сравнение с формами нахождения нативного стабильного $\mathrm{Zn} ; 2$ ) оценка параметров миграции ${ }^{65} \mathrm{Zn}(\mathrm{Zn})$ в системе почва - почвенный раствор растение.

Вегетационный эксперимент с водной культурой ячменя, проводился с использованием специального стенда, включающего проточную лизиметрическую установку циклического действия, обеспечивающей гравитационный сток почвенной влаги. Предварительная подготовка почвы включала внесение радионуклида в виде раствора ${ }^{65} \mathrm{Zn}\left(\mathrm{NO}_{3}\right)_{2}$ перед внесением удобрений. Затем добавляли питательные элементы в виде водных растворов солей $\left(\mathrm{NH}_{4} \mathrm{NO}_{3}\right.$, и $\mathrm{K}_{2} \mathrm{SO}_{4}$ ) из расчета $\mathrm{N}_{100}$, и $\mathrm{K}_{100}$. Удельная активность почвы, обусловленная 
присутствием радиоизотопа ${ }^{65} \mathrm{Zn},\left(\mathrm{A}_{\mathrm{m}}{ }^{65} \mathrm{Zn}_{\text {почва }}\right)$ на начало вегетационного опыта составила $68700 \pm 2800$ Бк/кг.

В ходе вегетационного опыта определялись значения водно-миграционных показателей в отношении $\mathrm{Zn}\left({ }^{65} \mathrm{Zn}\right)$, в частности, коэффициентов распределения $K_{d}(\mathrm{Zn})=[\mathrm{Zn}]_{\text {почва }} /[\mathrm{Zn}]_{\text {почв.раствор }}, K_{d}\left({ }^{65} \mathrm{Zn}\right)=\mathrm{A}_{\mathrm{m}}{ }^{65} \mathrm{Zn}_{\text {почва }} / \mathrm{A}_{\mathrm{v}}{ }^{65} \mathrm{Zn}_{\text {почв.раствор }}$, a также показателей доступности цинка растениям - коэффициентов концентрирования: $\quad K K(\mathrm{Zn})=[\mathrm{Zn}]_{\text {растение }} /[\mathrm{Zn}]_{\text {почв.раствор, }}, \quad K K\left({ }^{65} \mathrm{Zn}\right)=$ $\mathrm{A}_{\mathrm{m}}{ }^{65} \mathrm{Zn}_{\text {растение }} / \mathrm{A}_{\mathrm{v}}{ }^{65} \mathrm{Zn}_{\text {почв.раствор. }}$ Здесь $\mathrm{A}_{\mathrm{m}}{ }^{65} \mathrm{Zn}_{\text {почва }}, \mathrm{A}_{\mathrm{m}}{ }^{65} \mathrm{Zn}_{\text {растение }}-$ массовая удельная активность радионуклида ${ }^{65} \mathrm{Zn}$ в почве, растении, Бк/кг; $\mathrm{A}_{\mathrm{v}}{ }^{65} \mathrm{Zn}_{\text {почв.раствор }}$ объемная удельная активность радионуклида ${ }^{65} \mathrm{Zn}$ в фазе почвенного раствора, Бк/дм ${ }^{3}$.

Значения ключевого параметра, условно названного нами "удельная активность ${ }^{65} \mathrm{Zn”}$ в почвенном растворе (лизиметрических водах) и в отдельных химических фракциях (формах) цинка в почве, были определены на основе стабильного $\mathrm{Zn}$, содержащегося в этом растворе: $\mathrm{A}_{\text {уд,Zn }}\left({ }^{65} \mathrm{Zn}\right)_{\text {почв.раствор }}=$

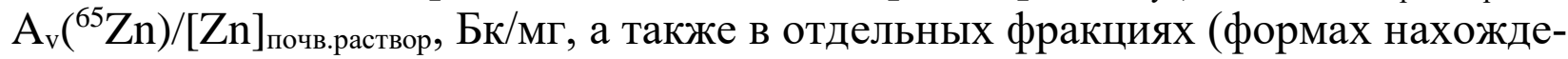

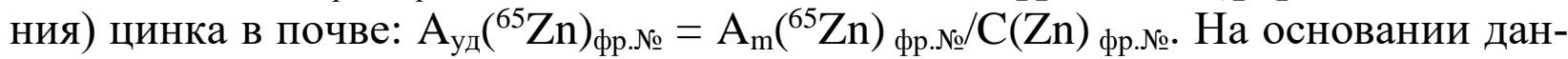
ных показателей были рассчитаны значения коэффициентов обогащения $(K O)$ соответствующих форм нахождения природного $\mathrm{Zn}$ радиоактивной меткой ${ }^{65} \mathrm{Zn}$ по отношению к главному компоненту нашей модельной системы - почвенному раствору: $K O_{\text {фр.\# }}{ }^{65} \mathrm{Zn}=\mathrm{A}_{\text {уд }}\left({ }^{65} \mathrm{Zn}\right)_{\phi р . №} / \mathrm{A}_{\text {уд }}\left({ }^{65} \mathrm{Zn}\right)_{\text {почв.раствор }}$

Установлено, что уменьшение концентрация Zn в почвенном растворе со временем удовлетворительно описывается степенной функцией с отрицательным показателем вида $[\mathrm{Zn}]_{\text {почв.раствор }}=\mathrm{a} \times t^{\mathrm{b}}$, где $\mathrm{a}$ и $\mathrm{b}-$ параметры, $t-$ время, сут (рис. 1a). Динамику объемной активности ${ }^{65} \mathrm{Zn}$ в почвенных растворах (рис. 1б), также как и в случае с Zn, можно удовлетворительно описать степенными уравнениями вида: $\mathrm{A}_{\mathrm{v}}\left({ }^{65} \mathrm{Zn}\right)_{\text {почв.раствор }}=\mathrm{c} \times t^{\mathrm{d}},(\mathrm{a}$ и $\mathrm{b}-$ параметры, $t-$ время, сут $)$.
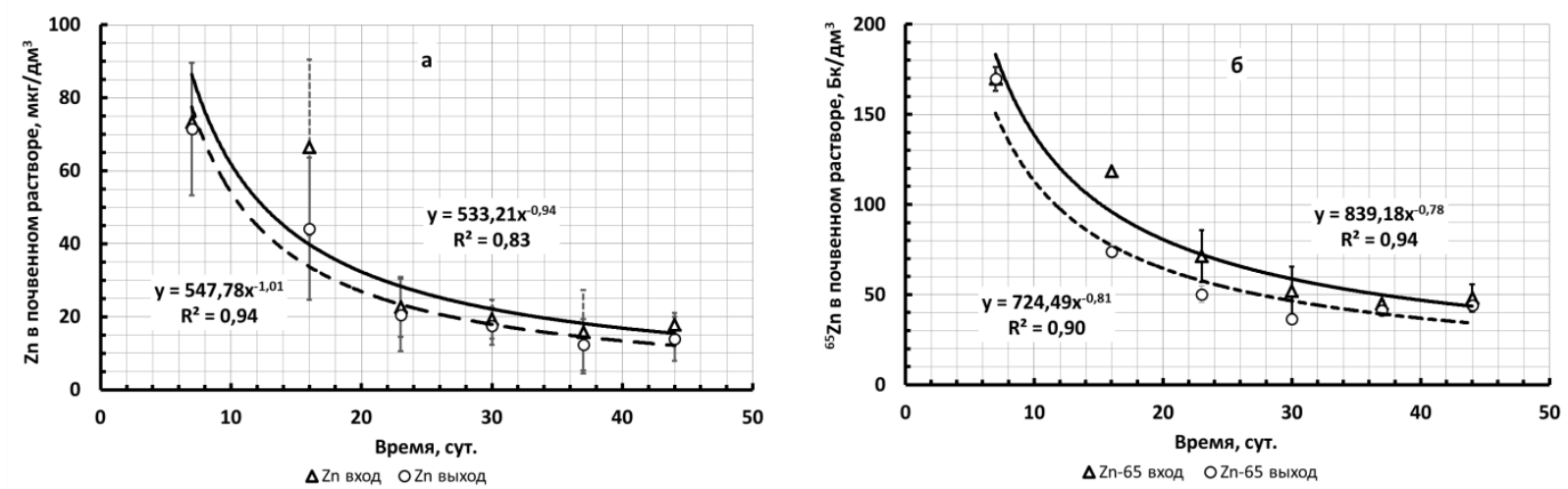

Рисунок 1 - Динамика концентрации стабильного цинка (а) и объемной активности ${ }^{65} \mathrm{Zn}(б)$ в квазиравновесном почвенном растворе

В ходе вегетационного опыта происходит увеличение коэффициентов распределения как стабильного (природного), так и радиоактивного изотопов (рис. 2). Они удовлетворительно описываются степенными уравнениями типа $K_{d}=\mathrm{a} \times t^{\mathrm{b}}$, где a $\left(\right.$ дм $\left.^{3} \times \kappa^{-1} \times \mathrm{cyT}^{-\mathrm{b}}\right)$ и $\mathrm{b}-$ параметры, $t-$ время, сут. Удельная активность водорастворимой фракции $\mathrm{Zn}$ (перешедшей в почвенный раствор) 
$\mathrm{A}_{\text {sp. }}\left({ }^{65} \mathrm{Zn}\right)_{\text {soils solution }}$ незначительно возрастает (недостоверно) составляет, в сред-

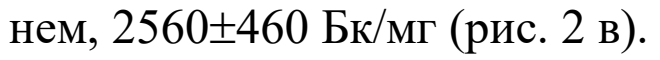
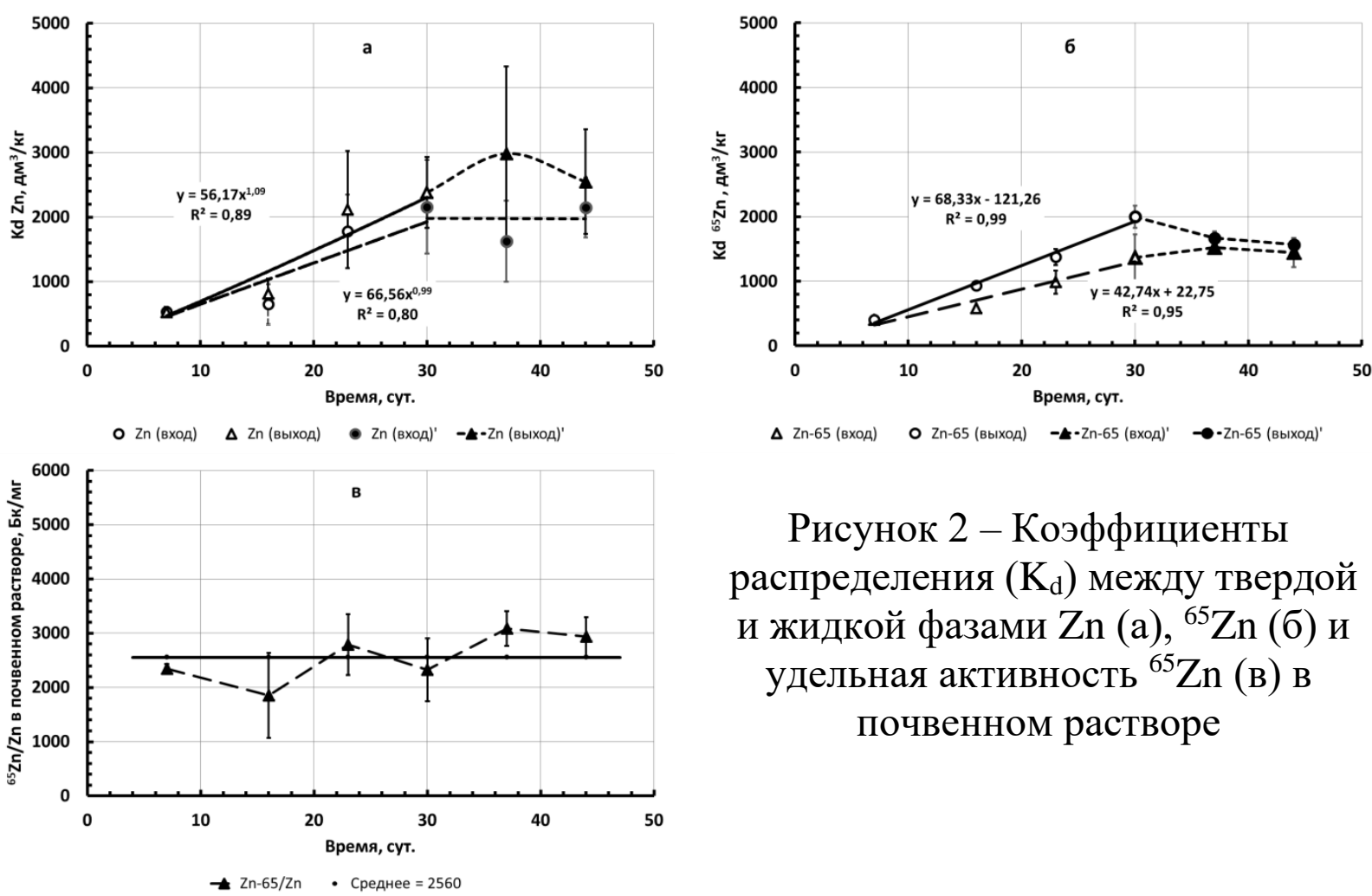

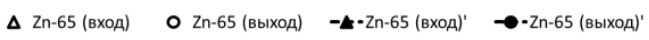

Рисунок 2 - Коэффициенты распределения $\left(\mathrm{K}_{\mathrm{d}}\right)$ между твердой и жидкой фазами $\mathrm{Zn}(\mathrm{a}),{ }^{65} \mathrm{Zn}($ б) и удельная активность ${ }^{65} \mathrm{Zn}$ (в) в почвенном растворе

Для оценки подвижности в системе почва - почвенный раствор и потенциальной доступности растениям ${ }^{65} \mathrm{Zn}(\mathrm{Zn})$ произведено последовательное фракционирование почвенных образцов по схеме Tessier в модификации Förstner $[1,2]$. Сравнительный анализ полученных данных показывает следующее соотношение различных форм нахождения (фракций) $\mathrm{Zn}\left({ }^{65} \mathrm{Zn}\right)$ в исследуемой почве:

a) обменная форма (фракция I) - 2.1 (7.1) \%\% соответственно;

б) связанная с карбонатами (фракция II) - 2.5 (13.6) \%\%;

в) связанная с легко восстанавливаемыми оксидами $\mathrm{Mn}$ (частично $\mathrm{Fe}$ ), (фракция III) - 8.7 (36.2) \%\%;

г) связанная с восстанавливаемыми оксидами Fe-Mn (фракция IV) - 10.5 (21.3) $\% \%$;

д) связанная с окисляемым органическим веществом и сульфидами (V) - 30.6 (10.2) \%\%;

е) остаточная (связанная с кристаллической матрицей первичных и вторичных почвенных минералов) (VI) - 45.7 (13.0) \%\%.

Установлено, что обогащение подвижных и условно подвижных форм

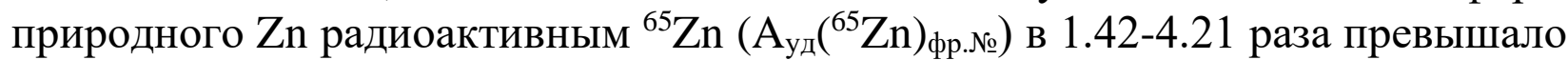

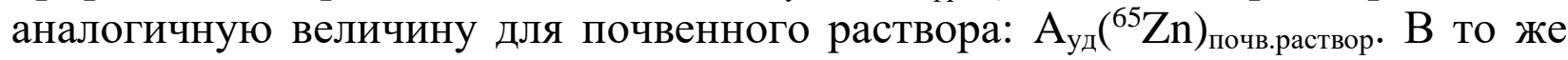
время, обогащение консервативных (неподвижных) форм $\mathrm{Zn}$ в почве радионуклидом ${ }^{65} \mathrm{Zn}$ (определяемых по методу Tessier-Förstner) было в 0.19-0.37 раза ниже соответствующего значения для почвенного раствора $\left(A_{\text {уд }}\left({ }^{65} \mathrm{Zn}\right)_{\text {почв.раствор }}\right.$ $=2560 \pm 460$ Бк/мг. Анализ соотношений $\mathrm{A}_{\text {уд }}\left({ }^{65} \mathrm{Zn}\right)_{\text {фр.№l }} \mathrm{A}_{\text {уд }}\left({ }^{65} \mathrm{Zn}\right)_{\text {почв.раствор }}$ 
позволил с помощью радиоактивной метки ${ }^{65} \mathrm{Zn}$ рассчитать величины пула подвижных " $E$-value" $\left(E_{\mathrm{Zn}}\right)$ и доступных растениям " $L$-value" $\left(L_{\mathrm{Zn}}\right): E_{\mathrm{Zn}} \cong$ $\Sigma \mathrm{C}(\mathrm{Zn})_{\text {почва,фр.I-Iv }}, L_{\mathrm{Zn}} \cong \Sigma \mathrm{C}(\mathrm{Zn})_{\text {почва,фр.I-V. }}$

Динамика концентрации $\mathrm{Zn}$ (рис. $3 \mathrm{~A}$ ), удельной активности ${ }^{65} \mathrm{Zn}$ (рис. 3 Б) в вегетативной массе ячменя аппроксимировалась с помощью уравнения Вуда $[3,4]$. Значения параметров $a\left(\right.$ мг $\left.^{\times} \kappa^{-1} \times \mathrm{cyT}^{-b}\right), b$ и $c\left(\right.$ сут $\left.^{-1}\right)$, рассчитанные по результатам настоящего модельного эксперимента с водной культурой ячменя, составили, соответственно: 0.090, 2.829 и 0.086. Статистические показатели, характеризующие достоверность аппроксимации экспериментальных данных уравнением Вуда были следующими: $\eta=0.86 ; \mathrm{s}_{\eta}=0.29 ; \mathrm{t}_{\eta}=2.94>\mathrm{t}_{0.1}$ $=2.35(\mathrm{n}=5, v=3)$. Параметры кривой Вуда $a\left(\right.$ мг $^{\times} \kappa^{-1} \times$ сут $\left.^{-b}\right), b$ и $c\left(\right.$ сут $\left.^{-1}\right)$, описывающей изменение концентрации $\mathrm{Zn}$ в корнях в ходе онтогенеза в условиях опыта составили, соответственно: $1.242,1.473$ и 0. Статистические показатели, были следующими: $\eta=0.88 ; \mathrm{s}_{\eta}=0.27 ; \mathrm{t}_{\eta}=3.27>\mathrm{t}_{0.05}=3.18(\mathrm{n}=5, v=$ $3)$.

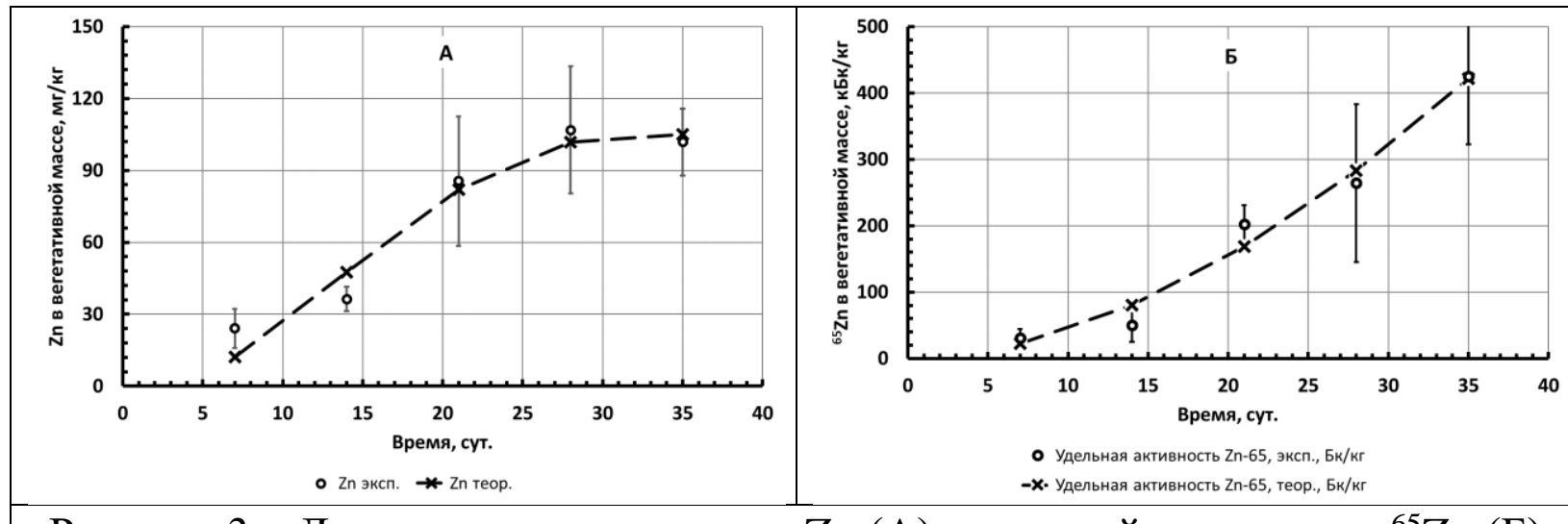

Рисунок 3 - Динамика концентрации $\mathrm{Zn}(\mathrm{A})$, удельной активности ${ }^{65} \mathrm{Zn}($ Б) в вегетативной массе ячменя

Аналогичный подход применялся и для количественного описания динамики удельной активности ${ }^{65} \mathrm{Zn}$ в вегетативной массе ячменя. Значения параметров $a\left(\kappa Б \kappa \times \kappa \Gamma^{-1} \times\right.$ сут $\left.^{-b}\right), b$ и $c\left(\right.$ сут $\left.^{-1}\right)$, рассчитанные по результатам настоящего модельного эксперимента с водной культурой ячменя, составили, соответственно: $0.615,1.862$ и 0.003. Статистические показатели, характеризующие достоверность аппроксимации экспериментальных данных уравнением Вуда были следующими: $\eta=0.92 ; \mathrm{s}_{\eta}=0.23 ; \mathrm{t}_{\eta}=4.00>\mathrm{t}_{0.05}=3.18(\mathrm{n}=5, v=3)$. Для корней значения параметров составили, соответственно, $\mathrm{a}=8.29 \times 10^{-9}, \mathrm{~b}=$ $10.28, \mathrm{c}=0.340\left(\eta=0.84 ; \mathrm{s}_{\eta}=0.31 ; \mathrm{t}_{\eta}=2.68>\mathrm{t}_{0.1}=2.35\right)$.

Динамика выноса Zn с надземной биомассой в пересчете на 1 растение представлена на рисунке 4 (А). Значения параметров полученной логистической кривой $W_{\max }$ (мкг) $W_{0}$ (мкг), $u\left(\right.$ сут $\left.^{-1}\right)$ рассчитанные по результатам настоящего модельного эксперимента с водной культурой ячменя, составили, соответственно: $5.148,0.015$ и 0.283. Статистические показатели, характеризующие достоверность аппроксимации экспериментальных данных уравнением Вуда были следующими: $\eta=0.96 ; \mathrm{s}_{\eta}=0.15 ; \mathrm{t}_{\eta}=6.26>\mathrm{t}_{0.01}=5.84(\mathrm{n}=5, v=3)$. Для 
корней значения параметров составили, соответственно, $W_{\max }=4.05$ мкг, $W_{0}=$ 0.081 мкг, $u=0.171$ сут $^{-1}\left(\eta=0.89 ; \mathrm{s}_{\eta}=0.26 ; \mathrm{t}_{\eta}=3.38>\mathrm{t}_{0.05}=3.18\right)$.
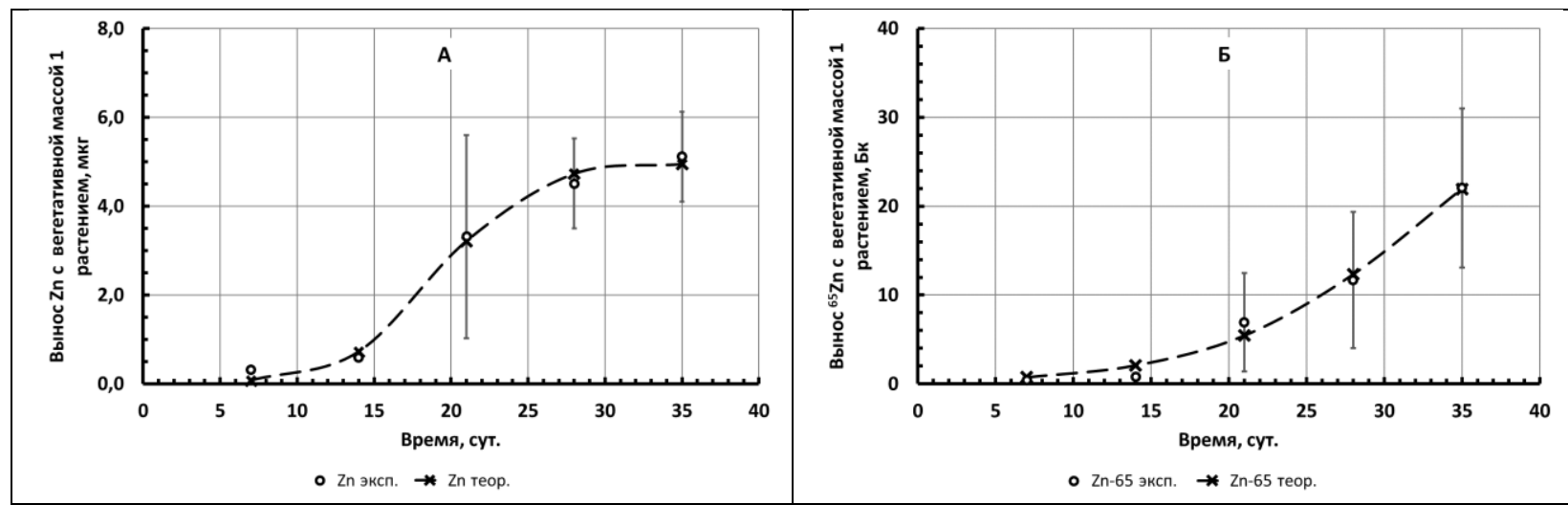

Рисунок 4 - Динамика выноса $\mathrm{Zn}(\mathrm{A})$ и ${ }^{65} \mathrm{Zn}($ Б) вегетативной массой ячменя

Для динамика выноса ${ }^{65} \mathrm{Zn}$ с надземной биомассой в пересчете на 1 растение представлена на рисунке 4 (Б). Рассчитанные значения параметров полученной логистической кривой $W_{\max }$ (Бк) $W_{0}$ (Бк), $u$ (сут ${ }^{-1}$ ) составили, соответственно: 34.2, 0.143 и 0.173. Статистические показатели, характеризующие достоверность аппроксимации экспериментальных данных уравнением Вуда были следующими: $\eta=0.88 ; \mathrm{s}_{\eta}=0.28 ; \mathrm{t}_{\eta}=3.19>\mathrm{t}_{0.05}=3.18(\mathrm{n}=5, \mathrm{v}=3)$. Для корней значения параметров составили, соответственно, $W_{\max }=10.49$ Бк, $W_{0}=$ 0.020 Бк, $u=0.267 \mathrm{cyT}^{-1}\left(\eta=0.81 ; \mathrm{s}_{\eta}=0.34 ; \mathrm{t}_{\eta}=2.43>\mathrm{t}_{0.01}=2.35\right)$.

Важным показателем для оценки вклада форм нахождения ${ }^{65} \mathrm{Zn}$ в миграционную цепочку почва - почвенный раствор - растение является значение удельной активности ${ }^{65} \mathrm{Zn}: \mathrm{A}_{\text {уд.раст. }}{ }^{65} \mathrm{Zn}=\mathrm{A}_{\text {раст. }}\left({ }^{65} \mathrm{Zn}\right) / \mathrm{C}_{\text {раст. }}(\mathrm{Zn})$, Бк $/$ мг. Усредненные за весь период вегетационного опыта значения соответствующего показателя составили: для вегетативных частей растений ячменя (ВЧР) $=2420 \pm 840$ Бк/мг, для корней $\mathrm{A}_{\text {уд.корни }}{ }^{65} \mathrm{Zn}=2190 \pm 530$ Бк/мг. Тренда, свидетельствующего о достоверном уменьшении (увеличении) данного показателя в ходе онтогенеза ячменя, в условиях настоящего эксперимента выявить не удалось.

\section{Библиографический список}

1. Minkina, T.M., Mandzhiev,a S.S., Burachevskaya, M.V., Bauer, T.V., Sushkova, S.N. (2018) Method of determining loosely bound compounds of heavy metals in the soil . Methods $X$ 5 217-226. doi.org/10.1016/j.mex.2018.02.007

2. Анисимов В.С., Анисимова Л.Н., Фригидова Л.М. [и др.] /Оценка миграционной способности Zn в системе почва - растение // Почвоведение, 2018. - № 4. - С. 427-438.

3. Анисимов В.С., Фригидова Л.М., Корнеев Ю.Н. [и др.] /Исследование миграционной способности $\mathrm{Zn}$ в системе дерново-подзолистая почва - кормовые бобы в условиях вегетационного опыта // Агрохимия, 2019. - № 3. - С. 72-84.

4. Витковская С.Е., Дричко В.Ф., О.В. Хофман О.В. /Оценка скорости нарастания биомассы сельскохозяйственных культур // Доклады РАСХН, 2014. - №1. - С. 50-53. 


\title{
УДК 631.582:631.58:631.98
}

\section{ЭФФЕКТИВНОСТЬ ПОЛЕВЫХ СЕВООБОРОТОВ В ТЕХНОЛОГИИ ПРЯМОГО ПОСЕВА В УСЛОВИЯХ ЧЕЛЯБИНСКОЙ ОБЛАСТИ}

\author{
Анисимов Ю.Б., Агеев А.А., Калюжина Е.Л., Мошкина Ю.С. \\ ФГБНУ «Челябинский НИИСХ», г.Челябинск \\ E-mail:anisimov.1964@bk.ru
}

\begin{abstract}
Резюме. В статье проведена сравнительный анализ эффективности воздельвания бессменной культуры, с зернопаровым и зерновым севооборотами на фоне прямого посева с 2014 по 2020 г2. Высокие показатели эффективности получены в зернопаровом севообороте пар - оз. рожь - горох +овёс - пшеница. С продуктивностью 2,07 m/2а зе. ед. на фоне без минеральных удобрений и 2,67 m/2а с внесением минерального азота.
\end{abstract}

Ключевые слова: бессменная культура, прямой посев, продуктивность севооборота, минеральные удобрения, клейковина, экономическая эффективность.

Требования сельскохозяйственных культуры к условиям окружающей среды является определяющим, главным фактором. Правильно подобранный севооборот представляет собою совокупность элементарных полей сельскохозяйственных культур, оказывающих существенное взаимное влияние. Оптимальное размещение культур наиболее эффективно в экономическом отношении и в наибольшей мере увеличивает продуктивность и устойчивость агроландшафтов, поскольку учитывается положительное влияние культур и технологий возделывания.

Севооборот имеет признаки единого целого, и его необходимо рассматривать как агроэкосистему, но более высокого порядка. Основная задача агроэкосистем - производство растениеводческой продукции высокого качества экологическими безопасными мерами [1]. При интенсификации земледелия положительное влияние научно обоснованного чередования культур не снижается, а вносит новые элементы в теорию и принципы построения севооборотов [2].

Целью исследования было получить новые экспериментальные данные по продуктивности и рентабельности полевых севооборотов и бессменной культуры яровой пшеницы на фоне система прямого посева.

Методика исследований. В полевом опыте сельскохозяйственные культур возделывались с 2014 года в системе прямого посева. Азотные удобрения вносились перед посевом сеялкой с дисковыми сошниками. За 7 дней до посева проводили обработку гербицидами сплошного действия от сорняков и проросшей падалицы. В требуемые сроки посевы опрыскивали рекомендованными пестицидами от сорняков и вредных организмов. Посев осуществляли в третьей декаде мая сеялкой СС - 6 с приспособлением для прямого посева (турбодиски).

Сельскохозяйственные культуры размещались на двух фонах минерального питания без удобрений и с применением азотных удобрений. В зернопаровом севообороте вносилось $\mathrm{N}_{17,5}$, зерновом $\mathrm{N}_{30}$ и бессменной культуре $\mathrm{N}_{40}$ на гектар севооборотной площади. 
Почва опытного участка представлена черноземом выщелоченным маломощным. Реакция почвенной среды слабокислая $\mathrm{pH}=5,1$; обеспеченность подвижным фосфором средняя и повышенная 9,6-12 мг/100 г почвы; повышенное содержание обменного калия 12,0 мг/100 г почвы; содержание общего гумуса - 6,0-6,5 \%; сумма поглощенных оснований 28-30 мг-экв./100 г почвы; гранулометрический состав соответствует тяжелосуглинистому. Размер делянок 154 $\mathrm{M}^{2}$ (5,5м х 28м). Учетная площадь $64,4 \mathrm{~m}^{2}$ (2,3м х 28м). Повторность в опыте четырехкратная, делянки расположены в два яруса, ориентированы с севера на юг, ограниченной рендомизацией. Учет урожая проводился комбайном Sampo500.

Результаты исследований. Для сравнительной оценки вариантов опыта урожайность сельскохозяйственных культур, пересчитана в зерновые единицы и представлена в таблица 1.

Таблица 1 - Продуктивность полевых севооборотов на различных фонах минерального питания, т/га, в среднем за 2014 - 2020 гг.

\begin{tabular}{|c|c|c|c|c|}
\hline \multirow[b]{2}{*}{ Севооборот, культура } & \multicolumn{2}{|c|}{$\begin{array}{c}\text { Фон минерального } \\
\text { питания } \\
\end{array}$} & \multirow{2}{*}{ Прибавка } & \multirow{2}{*}{$\begin{array}{c}\text { Окупаемость } \\
\text { минеральных } \\
\text { удобрений, } \\
\text { кг з.е/кг }\end{array}$} \\
\hline & $\begin{array}{c}\text { без удоб- } \\
\text { рений }\end{array}$ & $\mathrm{N}$ & & \\
\hline Пшеница (бессменная) & 1,59 & 2,01 & 0,42 & 10,5 \\
\hline Пар-оз.рожь-горох+овёс-пшеница, & 2,07 & 2,67 & 0,60 & 34,3 \\
\hline Рапс-пшеница-горох+овёс-пшеница & 1,97 & 2,48 & 0,51 & 17,0 \\
\hline
\end{tabular}

За годы исследований севообороты имели достоверно высокую продуктивность на различных фонах минерального питания в сравнении с бессменной культурой яровой пшеницы.

Применение минеральных удобрений повысило продуктивность до показателей свыше 2,0 т/га на всех вариантах опыта. При внесении минеральных удобрений продуктивность этих вариантов существенно увеличилась на 0,42 - 0,6 т/га з.е. Высокий рост продуктивности в результате применения минерального удобрения получен в зернопаровом севообороте и составил с 2,07 т/га до 2,67 т/га.

В среднем за время исследований окупаемость 1 кг д. в. удобрений зерновыми единицами составила: при бессменной пшенице 10,5 кг/кг, в зернопаровом 34,2 кг/кг и зерновом 17,0 кг/кг.

Самая высокая эффективность от минеральных удобрений получена в зернопаровом четырёхпольном севообороте с чередованием культур пар оз.рожь - горох + овёс - пшеница, где окупаемость удобрения была выше контроля на 23,8 кг и зернового севооборота на 17,3 кг.

Бессменное возделывание пшеницы при применении минеральных удобрений имело самую низкую окупаемость, в среднем 10,5 кг/кг.

В улучшении качества зерна существенное значение имеет обеспеченность растений азотным питанием, позволяющее наиболее полно 
реализовать потенциал сорта. Яровая пшеница, посеянная после бобовых культур, имеет лучшую обеспеченность азотным питанием, чем культуры, размещённые по зерновым предшественникам. Последействие возделывания бобовых культур как предшественников, в зависимости от климатических условий, проявляется на протяжении 2 - 3 лет [3]. Применение минеральных удобрений в оптимальных пределах повышает содержание белка одновременно с увеличением урожая и компенсирует то снижение белка, которое наблюдается в условиях достаточной влагообеспеченности [4; 5].

В среднем за годы исследований на фоне без применения минеральных удобрений, показатель качества зерна яровой пшеницы по содержанию клейковины соответствовал требованиям ГОСТа третьему и четвёртому классу (табл. 2).

\section{Таблица 2 - Содержание клейковины (\%) в зерне яровой пшеницы в зависимости от предшественника и фона минерального питания, в среднем}

за 2014 - 2020 гг.

\begin{tabular}{|l|c|c|c|}
\hline \multirow{2}{*}{$\begin{array}{c}\text { Предшественник, } \\
\text { (№ севооборота) }\end{array}$} & \multicolumn{2}{|c|}{ Фон минерального питания } & Различия, \\
\cline { 2 - 4 } & Без удобрений & $\mathrm{N}$ & \pm \\
\hline Пшеница (б/к) & 22,8 & 26,1 & 3,3 \\
\hline Горох+овёс ( №1) & 18,6 & 24,4 & 5,8 \\
\hline Горох+овёс (№2) & 22,4 & 26,4 & 4,0 \\
\hline Рапс (№2) & 22,7 & 25,6 & 2,9 \\
\hline Среднее & 21,8 & 26,1 & 4,3 \\
\hline \multicolumn{2}{|c|}{ НСР 05предшественник 2,197 \%; НСР 05 удобрения $1,389 \% ; \mathrm{Sx}=3,34 \%$} \\
\hline
\end{tabular}

Примечание: 1. пар-оз.рожь- горох +овёс-пшеница; 2. рапс-пшеница-горох +овёс-пшеница; 3. пшеница бессменно (б/к)

Внесение минеральных удобрений на всех вариантах опыта достоверно увеличило содержание клейковины в зерне яровой пшеницы, при этом получено зерно не ниже третьего класса. На фоне лучшего предшественника гороха, внесение азотного удобрения даёт значительную прибавку показателя клейковины в зерне яровой пшеницы. В зернопаровом севообороте с самым низким уровнем внесения минерального азота, после предшественника гороха + овёс получена увеличение содержания клейковины на 5,8 \%.

Высокие показатели рентабельности, чистого дохода и низкими затратами на гектар севооборотной площади среди вариантов опыта достигнут в четырёхпольном зернопаровом севообороте с чередованием культур пар оз.рожь - горох +овёс - пшеница (табл. 3).

В этом севообороте получена самая низкая себестоимость продукции и низкие затраты средств при возделывании сельскохозяйственной продукции на гектар севооборотной площади на фонах минерального питания за счёт снижения затрат на химические средства защиты и удобрения в звене севооборота пар - оз.рожь - горох + овёс. 
Таблица 3 - Экономические показатели производства сельскохозяйственной продукции в полевых севооборотах на различных фонах минерального питания, среднее за 2014 - 2020 гг.

\begin{tabular}{|l|c|c|c|c|}
\hline \multirow{2}{*}{ Севооборот } & \multirow{2}{*}{ Фон } & \multicolumn{3}{|c|}{ Показатели } \\
\cline { 3 - 5 } & & $\begin{array}{c}\text { прибыль, } \\
\text { руб./га }\end{array}$ & $\begin{array}{c}\text { затраты } \\
\text { руб./га }\end{array}$ & $\begin{array}{c}\text { рентабель- } \\
\text { ность, \% }\end{array}$ \\
\hline \multirow{2}{*}{ Пшеница (бессменно) } & $\mathrm{N}_{0}$ & 5573 & 9226 & 60 \\
\cline { 2 - 5 } & $\mathrm{N}_{40}$ & 10304 & 11895 & 86 \\
\hline \multirow{2}{*}{ Пар-оз.рожь+горох +овёс-пшеница } & $\mathrm{N}_{0}$ & 11546 & 6631 & 174 \\
\cline { 2 - 5 } & $\mathrm{N}_{17,5}$ & 16104 & 8189 & 196 \\
\hline \multirow{2}{*}{ Рапс-пшеница-горох +овёс-пшеница } & $\mathrm{N}_{0}$ & 10185 & 8983 & 113 \\
\cline { 2 - 5 } & $\mathrm{N}_{30}$ & 14526 & 11535 & 126 \\
\hline
\end{tabular}

Уровень рентабельности севооборотов изменялся по годам в зависимости от погодных условий вегетации и изменения цен на сельскохозяйственном рынке региона. За годы исследований наиболее высокая и стабильная рентабельность была в зернопаровом севообороте - пар - оз. рожь - горох +овёс - пшеница. В среднем за годы исследований она составила $174 \%$ на фоне без удобрений и $196 \%$ с применением минеральных удобрений.

При бессменном возделывании яровой пшеницы получена высокие затраты на гектар и самая низкая рентабельность.

Таким образом, в условиях северного лесостепного агроландшафта Челябинской области высокопродуктивное возделывание сельскохозяйственных культур возможно в зернопаровом и зерновом четырёхпольных севооборотах со средней по годам рентабельностью более $100 \%$.

\section{Библиографический список}

1. Чулкина В.А. Интегрированная защита растений: фитосанитарные системы технологий/ В.А. Чулкина, Е.Ю. Торопова, Г.Я. Стецов. Под ред. М.С. Соколова и В.А. Чулкиной. - М.: Колос, 2009. -670 с.

2. Глухих, М.А. Плодородие чернозёмов Зауралья и его динамика [Текст]: Монография/ М.А. Глухих, В.Б. Собянин, О.Б. Собянина; под ред. докт. с.-х. наук М.А. Глухих. - Челябинск: ЧГАА, 2010. - $300 \mathrm{c}$.

3. Анисимов Ю.Б. Разработать ресурсосберегающие агротехнологии возделывания сельскохозяйственных культур различной интенсивности для устойчивого производства растениеводческой продукции и сохранении земельных ресурсов/Ю.Б. Анисимов//Отчёт, ФГБНУ «Челябинский НИИСХ», 2014. - 28 с.

4. Созинов А.А., Хохлов А.Н. Проблемы увеличения белковости зерна пшеницы//Проблемы повышения качества зерна: науч. Тр. ВАСХНИЛ. М.: Колос. - 1977. - С. 18 - 30.

5. Павлов А.Н. Повышение содержания белка в зерне/М.: Наука, 1984. - 119 с. 
УДК $631.41(470.32)$

\title{
ВАРЬИРОВАНИЕ АГРОХИМИЧЕСКИХ ПОКАЗАТЕЛЕЙ ПОЧВЫ В СКЛОНОВОМ АГРОЛАНДШАФТЕ ЦЧР
}

\author{
Афонченко Н.В. \\ ФГБНУ «Курский ФАНЦ», г. Курск \\ E-mail: afonchienko53@mail.ru
}

\begin{abstract}
Резюме. В статье приводятся исследования по варьированию агрохимических показателей почвы на полигоне куполообразной формы, которые проводились в 2011-2013 годах и 20192021 годах. Исследованиями было установлено, что наиболее высоким коэффициент вариации оказался для гидролитической кислотности - 45,9\% и содержания аммонийного $и$ нитратного азота - 35,3 и 79,1\%, средним - для подвижных форм фосфора и калия 14,6 и $24,9 \%$ и незначительным - для гумуса - $\mathrm{pH}_{\mathrm{KCl}} ; \mathrm{N}$ щчг, содержания обменных оснований $\left(\mathrm{Ca}^{2+} u \mathrm{Mg}^{2+}\right)$.
\end{abstract}

Ключевые слова: почва, агрохичические показатели, варьирование, склоновый агроландшафот.

Охрана и рациональное использование почвы, воды, воздуха, флоры и фауны - важнейшие составляющие стратегии сбалансированного развития агропромышленного комплекса страны. Почвы склонов, сформированные в условиях пересеченного рельефа и подверженные воздействию водной эрозии, имеют пониженное плодородие и нередко неблагоприятные агроэкологические условия для выращивания сельскохозяйственных культур [1].

На склоновых землях проявляется варьирование агрохимических показателей, то есть количество питательных элементов, необходимых для растений, что связано с различным содержанием влаги и количеством поступающего тепла. Склоны полярных экспозиций существенно отличаются по количеству поступающей солнечной радиации, водному, питательному и температурному режимам [2]. Растения раньше начинают развиваться на южных склонах, и в связи с большим количеством поступающей солнечной радиации раньше происходит их созревание. На противоположных склонах по-разному складываются условия роста и развития растений при одной и той же крутизне. Северные склоны получают на 10 \% меньше солнечной радиации, а южные склоны, наоборот, получают на 5\% больше, чем почвы, расположенные на плакоре. На склонах полярных экспозиций разница в количестве выпадающих осадков может достигать 11-26 \% по сравнению с плакором [3,4,5]. Проявление таких природных факторов привело к варьированию различных почвенных показателей. По данным исследований Е.В. Дубовик и Д.В. Дубовик потери гумуса на склонах южных экспозиций при уклоне $5^{0}$ превышали в 2 раза потери на склонах северной экспозиции, На склонах полярных экспозиций по сравнению с водораздельным плато в верхних гумусовых горизонтах $\mathrm{A}_{\text {пах. }}$ и $\mathrm{A}_{1}$ отмечено уменьшение содержания форм фосфора и калиях [6]. Поэтому варьирование агрохимических показателей на склоновых землях необходимо учитывать при возделывании сельскохозяйственных культур. Все это позволяет более эффективно использовать имеющиеся ресурсы и рациональнее размещать культуры в агроландшафте. 
Цель исследований - изучение пространственного варьирования агрохимических показателей почвы в склоновом агроландшафте для разработки системы поддержки принятия решений по использованию природно-ресурсного потенциала в агроландшафтах ЦЧР.

Методы исследований. Объектом исследований является опыт на поле с куполообразной формой рельефа площадью 86 га. Исследования начали проводить в 2011-2013 годах на участке пашни на водоразделе и склонах северной экспозиции на площади 18.8 га на опытном поле ФГБНУ «Курский ФАНЦ» в Медвенском районе Курской области. Поверхность склона отличалась явно выраженной волнистостью. Высота территории над уровнем моря составляла 170-220 м. Были выбраны 5 микропрофилей. Почвы - чернозём типичный и выщелоченный различной степени смытости и намытости на лессовидных суглинках. Характер комплексности почвенного покрова меняется от вершины вниз по склону. В точках исследований с помощью GPS-приемника были определены координаты, проведена топографическая съёмка и картирование почв (рисунок 1)

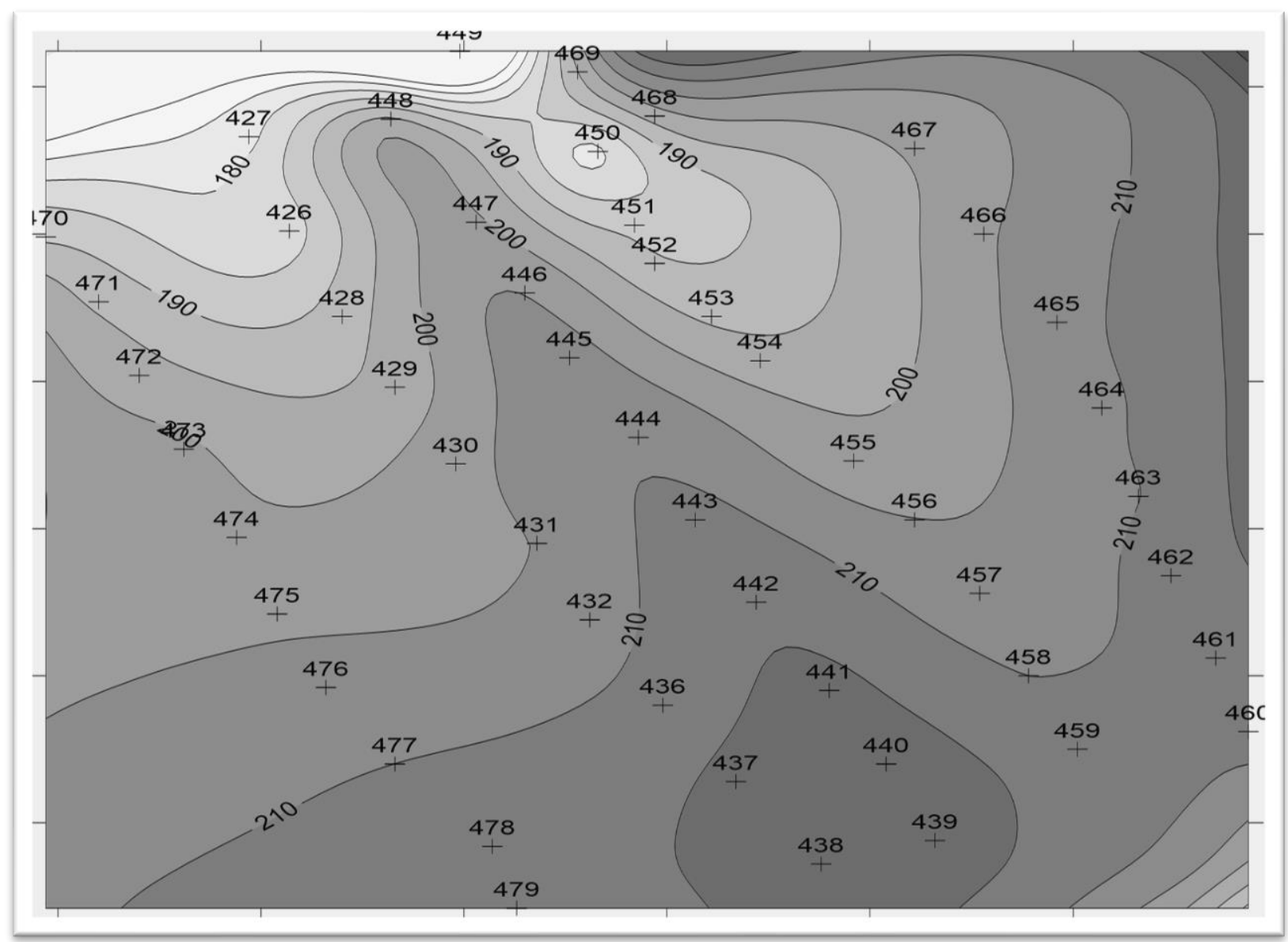

Рисунок 1 - Картосхема рельефа исследуемого поля

с точками отбора почвенных образцов и горизонталями, 2011 г.

Средний уклон на склонах северных экспозиций составил более $6^{\circ}$. В 2018-2021 годах были продолжены исследования, но уже на всех экспозициях (водораздельное плато, северная, южная, восточная, западная, северо-восточная, северо-западная, юго-восточная и юго-западная) (рисунок 2). Почвенные 
образцы для агрохимического анализа и почвы из 0-20 см слоя почвы отбирались методом конверта.

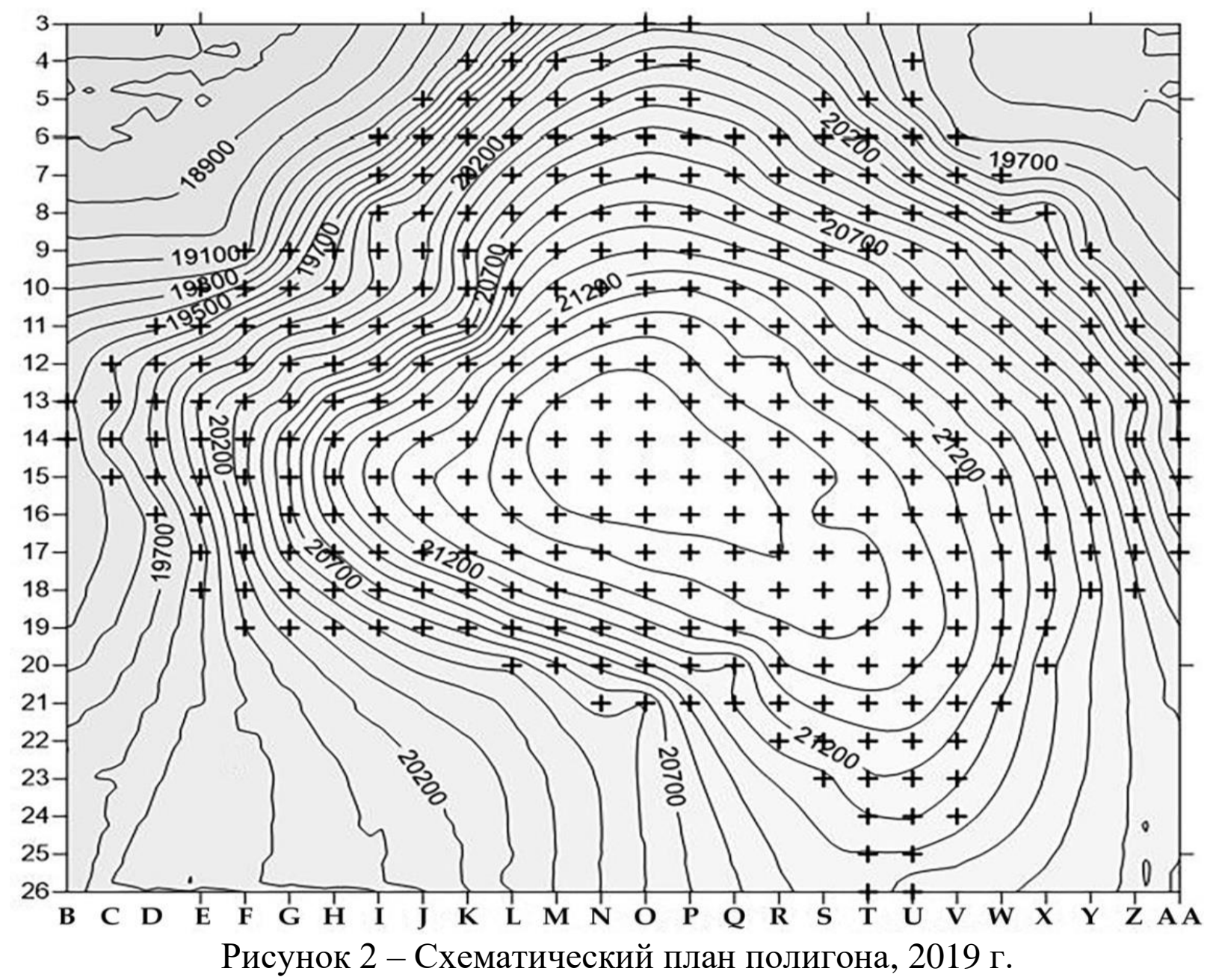

Содержание гумуса определяли по методу И.В. Тюрина в модификации Б.А. Никитина со спектрофотометрическим окончанием по Д.С. Орлову и Н.М. Гриндель; содержание щелочногидролизуемого азота - по методу Корнфильда, нитратный азот $\left(\mathrm{N}-\mathrm{NO}_{3}\right)$ - колориметрическим методом с дисульфофеноловой кислотой (по Грандваль-Ляжу), аммонийный азот $\left(\mathrm{N}-\mathrm{NH}_{4}\right)$ - колориметрическим методом с реактивом Несслера в модификации ЦИНАО (ГОСТ 26489-85), подвижных форм фосфора и калия - по Чирикову (ГОСТ 26204-91); кислотность $(\mathrm{pH})$ солевой вытяжки устанавливали потенциометрическим методом (ГОСТ 26483-85)); сумма поглощенных оснований $\left(\mathrm{Ca}^{2+}+\mathrm{Mg}^{2+}\right)-$ по Каппену-Гильковицу (ГОСТ 27821-88) [6]. Для обработки полученных данных применяли статистические методы анализа [7] с использованием программных средств Microsoft office EXCEL, STATISTICA.

Результаты исследований. В таблице 1 представлены результаты агрохимического обследования полигона в 2011 году, средние показатели на плакоре и склонах северных экспозиций (северная, северо-восточная и северо-западная). Исследованиями было установлено, что агрохимические показатели изменялись в зависимости от местоположения в рельефе. Содержание гумуса, 
Таблица 1 - Статистические параметры агрохимических показателей полигона 2011г.

\begin{tabular}{|c|c|c|c|c|c|c|c|}
\hline \multirow{3}{*}{ Экспозиция } & \multirow{3}{*}{$\begin{array}{c}\text { Гумус, } \\
\%\end{array}$} & \multirow{3}{*}{$\begin{array}{l}\text { Nщг, } \\
\text { мг/100г }\end{array}$} & \multicolumn{2}{|c|}{ Подвижные } & \multicolumn{2}{|c|}{ Обменные } & \multirow{3}{*}{$\mathrm{pH}_{\mathrm{KCl}}$} \\
\hline & & & $\mathrm{P}_{2} \mathrm{O}_{5}$ & $\mathrm{~K}_{2} \mathrm{O}$ & $\mathrm{Ca}^{2+}$ & $\mathrm{Mg}^{2+}$ & \\
\hline & & & \multicolumn{2}{|c|}{ мг/100 г } & \multicolumn{2}{|c|}{ мг*экв/100 г } & \\
\hline Плакор & 5,39 & 17,83 & 18,27 & 13,68 & 23,08 & 3,25 & 5,8 \\
\hline $\begin{array}{c}\text { Склоны северной } \\
\text { экспозиции }\end{array}$ & 5,04 & 16,47 & 16,14 & 11,43 & 23,41 & 3,08 & 6,1 \\
\hline $\begin{array}{c}\text { Стандартное } \\
\text { отклонение (S) }\end{array}$ & 0,31 & 0,84 & 1,94 & 5,82 & 0,23 & 0,09 & 0,16 \\
\hline $\mathrm{V}, \%$ & 8.3 & 29,9 & 16,2 & 22,3 & 5,4 & 11,9 & 10,3 \\
\hline
\end{tabular}

$\mathrm{V}, \%$ - коэффициент варьирования

щелочногидролизуемого азота, подвижные элементы фосфора и калия в среднем на плакоре были выше, чем на склонах северных экспозиций.

В таблице 2 представлены статистические параметры агрохимических показателей почвы полигона. Было установлено, что содержание гумуса (\%) в почве снижалось при увеличении угла склона $(\alpha)$ и возрастании степени прогреваемости $\left(\mathrm{K}_{\mathrm{P}}\right)$ склонов:

$$
\mathrm{Y}=10,6-0,11 \cdot \alpha-4,71 \cdot \mathrm{K}_{\mathrm{P}}, \mathrm{F}=19,4, \mathrm{R}_{\mathrm{MH}}=0,75, \mathrm{P}<10^{-4}
$$

Таблица 2 - Статистические параметры агрохимических показателей полигона, 2018 г.

\begin{tabular}{|c|c|c|c|c|c|}
\hline Показатели & Среднее & Минимум & Максимум & Ст.откл. & $\mathrm{V}, \%$ \\
\hline $\mathrm{pH}_{\mathrm{H} 2 \mathrm{O}}$ & 7,0 & 6,3 & 8,0 & 0,5 & 7,2 \\
\hline $\mathrm{pH}_{\mathrm{KCl}}$ & 6,0 & 5,3 & 7,2 & 0,5 & 8,8 \\
\hline Нг, мг-экв/100г & 2,7 & 0,7 & 5,1 & 1,2 & 45,9 \\
\hline Гумус, \% & 5,59 & 5,03 & 6,12 & 0,33 & 6,0 \\
\hline $\mathrm{N}-\mathrm{NH}_{4}, \mathrm{Mг} / 100 \Gamma$ & 0,83 & 0,30 & 1,43 & 0,29 & 35,3 \\
\hline $\mathrm{N}-\mathrm{NO}_{3}, \mathrm{M \Gamma} / 100 \Gamma$ & 0,82 & 0,23 & 3,54 & 0,65 & 79,1 \\
\hline $\mathrm{P}_{2} \mathrm{O}_{5}, \mathrm{M \Gamma} / 100 \Gamma$ & 12,6 & 8,8 & 16,9 & 1,8 & 14,6 \\
\hline $\mathrm{K}_{2} \mathrm{O}, \mathrm{M \Gamma} / 100 \Gamma$ & 14,0 & 9,9 & 25,2 & 3,5 & 24,9 \\
\hline $\mathrm{Ca}^{2+}$, мг-экв/100г & 25,1 & 22,5 & 27,9 & 1,7 & 6,6 \\
\hline $\mathrm{Mg}^{2+}$, мг-экв $/ 100 \Gamma$ & 4,1 & 3,3 & 5,0 & 0,6 & 13,9 \\
\hline
\end{tabular}

Анализ полученного материала свидетельствует о варьировании агрохимических показателей (таблица 2). Об этом свидетельствует характеризующий этот процесс коэффициент вариации. Наиболее высоким он оказался для гидролитической кислотности - 45,9 \%, содержания аммонийного и нитратного азота - 35,3 и 79,1 \%, средним - для подвижных форм фосфора и калия 14,6 и $24,9 \% ; \mathrm{Mg}^{2+}-13,9$. и незначительным - для гумуса 6,$0 ; \mathrm{pH}_{\mathrm{KCl}}-8,8 ;$ содержания $\mathrm{Ca}^{2+}-6,6$.

\section{Библиографический список}

1. Каштанов, А.Н. Агроэкология почв / А.Н. Каштанов, В.Е Явтушенко. - М.: Колос, 1997. $-240 \mathrm{c}$. 
2. Стахурлова, Л.Д. Влияние экспозиции склона на основные показатели плодородия черноземов типичных / Л.Д. Стахурлова, А.И. Громовик, Г.Н. Черкасов // Вестник ВГУ. Серия: Химия, Биология, Дармация, 2017. - № 2, - С. 99-105

3. Чуян, Г.А. Агрохимические свойства типичного чернозема в зависимости от экспозиции склона / Г. А. Чуян, В.В. Ермаков, С.И. Чуян // Почвоведение, 1987. - № 12. - С. 39-46.

4. Чуян, О.Г. База данных для регулирования физико-химических свойств кислотных почв в адаптивно-ландшафтном земледелии (для Центрального Черноземья) / О.Г. Чуян. Курск ГНУ ВНИИЗиЗПЭ РАСХН, 2012. - 78 с. - ISBN 978-5-905622-18-2.22.

5. Чуян, О.Г. База данных для регулирования физико-химических свойств кислотных почв в адаптивно-ландшафтном земледелии (для Центрального Черноземья) / О.Г. Чуян. Курск ГНУ ВНИИЗиЗПЭ РАСХН, 2012. - 78 с. - ISBN 978-5-905622-18-2.22.

6. Дубовик, Е.В. Агрохимические свойства чернозема в зависимости от экспозиции и крутизны склона / Е.В. Дубовик, Д.В. дубовик // Агрохимия, 2012. - № 7. - С.10-15.

7. Генин, В.А. Оценка пространственного варьирования агрохимических показателей на отдельном поле / В.А. Генин, Н.В. Клебанович // Агрохимический вестник, 2018. - № 6. - С. 2-7.

8. Александрова, Л.Н. Лабораторно-практические занятия по почвоведению / Л.Н. Александрова, О.А. Найденова - 3-е изд. перераб. и доп. Л.: Колос, 1976. - 280 с.

9. Доспехов, Б.А. Методика полевого опыта (с основами стат. обработки результатов исследования) / Б.А. Доспехов: 5-е изд. доп. и перераб. - М.: Агропромиздат, 1985. - С.271356.

УДК631.434 (470.32)

\title{
ПРОСТРАНСТВЕННОЕ ВАРЬИРОВАНИЕ ПОКАЗАТЕЛЕЙ СТРУКТУРЫ ПОЧВЫ В СКЛОНОВОМ АГРОЛАНДШАФТЕ ЦЧР
}

\author{
Афонченко Н.В. \\ ФГБНУ «Курский ФАНЦ», г. Курск \\ E-mail:afonchienko53@mail.ru
}

\begin{abstract}
Резюме. В статье приводятся исследования на полигоне куполообразной формы, которые проводились в 2011-2013 годах и 2019-2021 годах. Исследованиями было установлено, что в среднем по экспозициям наибольшее количество агрегатов от 0,25 до 10 мм, коэффициент структурности и сумма водоустойчивых агрегатов отмечалось на плакоре и склонах северных экспозищий.
\end{abstract}

Ключевые слова: структура почвы, пространственное варьирование, склоновый агроландшафт.

Благоприятные агрофизические, агрохимические и биологические свойства являются важнейшими условиями, определяющими плодородие почв и получение высоких и стабильных урожаев. В процессе сельскохозяйственного использования плодородие склоновых земель претерпевает изменения, которые зависят от агроэкологических условий ландшафта [1,2]. Так, на эродированных землях Центральной лесостепи недобор продукции растениеводства ежегодно составляет в пересчете на зерно 12,2 млн. ц [3]. Наличие эродированных почв одна из основных причин неполного использования биоклиматических ресурсов. Под воздействием водной эрозии происходит ухудшение агрофизических, агрохимических и биологических свойств почвы [4,5]. Основу почвенного плодородия составляет гумус. В процессе эрозии почва теряет самый плодородный, 
гумусированный верхний слой. В результате эрозионных процессов происходит ухудшение структуры почвы. Водопрочность почвенной структуры может изменяться как в пространстве, так и во времени. Структура почвы динамична, её разрушение и восстановление зависит от различных факторов, правильное управление которыми позволяет поддерживать почву в необходимом структурном состоянии. Уменьшение количества водопрочных агрегатов создает условия для возникновения и развития процессов эрозии почв. Агрегаты, находящиеся на поверхности почвы, больше подвержены внешним воздействиям (механическая обработка, атмосферные осадки) и поэтому быстрее разрушаются. Разрушение почвенных агрегатов обуславливает заплывание почв с поверхности, особенно во влажное время. В сухое время на поверхности почв образуются плотные корки. Все это указывает на то, что только почвы, обладающие хорошей структурой, обладают и более благоприятными свойствами (по сравнению с бесструктурными почвами) для развития растений. Это выражается в следующем:

1. Структурные почвы меньше испаряют влаги, обладают большей водопроницаемостью и водоудерживающей способностью. Они больше накапливают влаги и более продуктивно её используют.

2. В структурных почвах создаются более благоприятные условия для микробиологических процессов и перевод питательных веществ из недоступной формы химических соединений в усвояемую (т.е. доступную для растений) форму.

3. Структурные почвы отличаются повышенной устойчивостью к эрозии и дефляции почв.

4. Структурные почвы требуют меньше затрат труда и средств на механическую обработку.

5. В структурных почвах создаются лучшие условия для прорастания сеМян.

Было установлено, что за десятилетний период времени в почвенном профиле в условиях склона $1-3^{0}$ происходит деградация структуры почвы до глубины 40см [7]. При проявлении эрозионных процессов происходит также и уплотнение почвенной массы в результате потери гумуса и илистой фракции гранулометрического состава - возрастает глыбистость, в целом снижается содержание водопрочных агрегатов, возрастает плотность сложения, снижается пористость агрегатов [8]. Л.Г. Смирновой и С.И. Тютюновым было установлено, что в слое почвы $0-10 \mathrm{~cm}$ на склоне $1-3^{0}$ плотность сложения почвы изменялась от 0,95 до $1,28 \Gamma / \mathrm{cm}^{3}$, а на склоне $3-5^{0}$ изменялась от 1,07 до $1,30^{0} \Gamma / \mathrm{cm}^{3}$ [9].

Создание и обеспечение нормального функционирования агроландшафтов является первоочередным вопросом в решении проблем повышения их продуктивности, устойчивости, биоразнообразия и предотвращения деградации почвы. В связи с эти необходима разработка систем поддержки принятия решений по оптимизации использования ресурсов в земледелии, основанных на оценке ресурсного потенциала природно-хозяйственных систем, анализа эффективности 
его использования, а также дальнейшего изучения пространственного варьирования агрофизических показателей в склоновых агроландшафтах ЦЧР.

Цель исследований - изучение пространственного варьирования структуры почвы в склоновом агроландшафте для разработки системы поддержки принятия решений по использованию природно-ресурсного потенциала в агролпншафтах ЦЧР.

Задачи исследований - провести исследования по изменению показателей структуры почвы (количество наиболее ценных агрегатов, коэффициент структурности, водопрочность и средневзвешенный диаметр водопрочных агрегатов) в склоновом агроландшафте.

Методы исследований. Объектом исследований является опыт на поле с куполообразной формой рельефа площадью 86 га. Исследования начали проводить в 2011-2013 годах на участке пашни на водоразделе и склонах северной экспозиции на площади 18.8 га на опытном поле ФГБНУ «Курский ФАНЦ» в Медвенском районе Курской области. Поверхность склона отличалась явно выраженной волнистостью. Высота территории над уровнем моря составляла 170-220 м. Были выбраны 5 микропрофилей. Почвы - чернозём типичный и выщелоченный различной степени смытости и намытости на лессовидных суглинках. Характер комплексности почвенного покрова меняется от вершины вниз по склону. В точках исследований с помощью GPS-приемника были определены координаты, проведена топографическая съёмка и картирование почв (рисунок 1). Средний уклон на склонах северных экспозиций составил более $6^{\circ}$. В 2018-2021 годах были продолжены исследования, но уже на всех экспозициях (водораздельное плато, северная, южная, восточная, западная, северовосточная, северо-западная, юго-восточная и юго-западная). Почвенные образцы для агрохимического анализа и структурно-агрегатного состава почвы из 0-20 см слоя почвы отбирались методом конверта. Содержание гумуса определяли по методу И.В. Тюрина в модификации Б.А. Никитина со спектрофотометрическим окончанием по Д.С. Орлову и Н.М. Гриндель. Структурно-агрегатный состав почвы (сухое и мокрое просеивание) проводили по методу Н.И. Саввинова. Плотность почвы определяли буровым методом по Н.А. Качинскому.

Результаты исследований. При изучении структурно-агрегатного состава почвы определялись следующие показатели (таблица 1) количество наиболее ценных агрегатов (размер от 0,25 до 10,0 мм), коэффициент структурности почвы, сумма водоустойчивых агрегатов (размер агрегатов > 0,25 мм), средневзвешенный диаметр водоустойчивых агрегатов в мм. В результате исследований было установлено, что коэффициент варьирования имел средние значения для таких показателей как количество наиболее ценных агрегатов, сумма водоустойчивых агрегатов и средневзвешенный диаметр водоустойчивых агрегатов.

Наибольший процент варьирования отмечался для коэффициента структурности почвы и составлял $28,5 \%$. 
Таблица 1 - Статистическая характеристика агрофизических показателей 2011 г.

\begin{tabular}{|c|c|c|c|c|}
\hline Показатели & $\begin{array}{c}\text { Количество } \\
\text { наиболее } \\
\text { ценных агрега- } \\
\text { тов, } \% \\
(0,25-10 \mathrm{mм})\end{array}$ & $\begin{array}{c}\text { Коэффи- } \\
\text { циент } \\
\text { структур- } \\
\text { ности }\end{array}$ & $\begin{array}{c}\text { Сумма водо- } \\
\text { устой- } \\
\text { чивых агрега- } \\
\text { тов } \\
>0,25 \mathrm{mM}, \%\end{array}$ & $\begin{array}{c}\text { Средневзвешен- } \\
\text { ный диаметр водо- } \\
\text { устойчивых агре- } \\
\text { гатов, мм }\end{array}$ \\
\hline Max & 84,5 & 5,6 & 62,4 & 0,430 \\
\hline Min & 66,7 & 2,0 & 45,0 & 0,256 \\
\hline Среднее & 76,6 & 3,4 & 55,1 & 0,354 \\
\hline $\mathrm{V} \%$ & 13,7 & 28,5 & 11,3 & 13,8 \\
\hline
\end{tabular}

$\mathrm{V}, \%$ - коэффициент варьирования.

В 2019-2021 годы были продолжены исследования на полигоне. Исследованиями было установлено, что в среднем по экспозициям (таблица 2) наибольшее количество агрегатов размером от 0,25 до 10 мм (наиболее ценные агрегаты), коэффициент структурности почвы и сумма водоустойчивых агрегатов было на плакоре и склонах северных экспозиций. Коэффициент структурности наименьшим был на склоне южной, западной и юго-восточной экспозициях. Наименьшее количество водоустойчивых агрегатов отмечалось на склоне юговосточной, южной и восточной экспозициях и было ниже, чем на плакоре на 12,$3 ; 8,7$ и 7,8 \%. Средневзвешенный диаметр водоустойчивых агрегатов в среднем наибольшим был на слоне северной экспозиции и составлял 0.457 мм и был выше, чем на плакоре на 0.030 мм. В среднем за 2019-2021 годы наибольшее варьирование отмечалось по таким показателям как коэффициент структурности почвы и сумма водоустойчивых агрегатов.

\section{Таблица 2 - Агрофизические показатели почвы за 2019-2021 годы}

\begin{tabular}{|l|c|c|c|c|}
\hline Экспозиция & $\begin{array}{c}\text { Количество } \\
\text { наиболее } \\
\text { ценных агрега- } \\
\text { тов, \% } \\
(0,25-10 \text { мм })\end{array}$ & $\begin{array}{c}\text { Коэффи- } \\
\text { циент } \\
\text { структур- } \\
\text { ности }\end{array}$ & $\begin{array}{c}\text { Сумма водо- } \\
\text { устой- } \\
\text { чивых агрегатов } \\
>0,25 \text { мм, \% }\end{array}$ & $\begin{array}{c}\text { Средневзве- } \\
\text { шенный диаметр } \\
\text { водоустойчивых } \\
\text { агрегатов, мм }\end{array}$ \\
\hline Плакор & 73,7 & 3,1 & 57,7 & 0,427 \\
\hline Северная & 72,2 & 2,7 & 57,6 & 0,457 \\
\hline Южная & 66,9 & 2,2 & 49,0 & 0,441 \\
\hline Восточная & 69,6 & 2,4 & 49,9 & 0,428 \\
\hline Западная & 67,4 & 2,2 & 51,2 & 0,413 \\
\hline Сев.-восточ. & 69,8 & 2,5 & 57,6 & 0,453 \\
\hline Сев.-запад. & 69,4 & 2,5 & 52,7 & 0,421 \\
\hline Юго-восточ. & 67,2 & 2,3 & 45,4 & 0,422 \\
\hline Юго-запад & 69,5 & 2,4 & 53,5 & 0,443 \\
\hline Мах & 81,6 & 4,3 & 70,3 & 0,681 \\
\hline Міп & 66,2 & 1,8 & 47,7 & 0,298 \\
\hline Среднее & 69,5 & 2,5 & 52,7 & 8,434 \\
\hline V, \% & 11,1 & 18,9 & 17,4 & \\
\hline
\end{tabular}

Библиографический список

1. Каштанов, А.Н. Агроэкология почв склонов /А.Н. Каштанов, В.Я. Явтушенко. - М. Колос: $1997 .-240$ с. 
2. Глазунов, Г.П. Оценка влияния морфометрических показателей рельефа на плодородие черноземных почв / Г.П. Глазунов, Н.В. Афонченко, В.В. Двойных // Достижения науки и техники в АПК .- 2020. - № 7 . - C. 10-18. - DOI: 10. 24411/ 0235-2451-2920-10702.

3. Чуян, Г.А. Пространственная изменчивость агрохимических свойств типичных черноземов в зависимости от степени смытости и экспозиции склонов / Г.А. Чуян, И.Г. Пыхтин, О.П. Тур, О.Н. Мирошниченко //Научно-техн. Бюлл. ВНИИЗПЭ. - Курск, 1976. - Вып. 4 (11). - C.17-21.

4. Чуян, Г.А. Агрохимические свойства типичного чернозема в зависимости от экспозиции склона / Г.А. Чуян, В.В. Ермаков, С.И. Чуян // Почвоведение, 1987. - № 12. - С. 39-46.

5. Фрид, А.С. Оценка плодородия (Гл.4) Научные основы предотвращения деградации почв (земель) сельскохозяйственных угодий России и формирование систем воспроизводства плодородия почв сельскохозяйственных угодий / А.С. Фрид, О.Г. Чуян.. И.С. Тютюнов, В.Д. Соловиченко // Коллективная монография. - М.: Почв. ин.-т. им. В.В. Докучаева Россельхозакадемии. 2013. - С.17-34. ISBN978-5 -8125-1887.

6. Иванов, Н.В. Природная и антропогенная эволюция почв (сравнительный анализ факторов) / Н.В. Иванов, Т.С. Луковская // Тезисы докладов междунар. конф. «Проблемы антропогенного почвообразования». - М.: 1997. - Т.1. - С. 49-53.

7. Смирнова, Л.Г. Различия физических свойств черноземов на склонах в ландшафтной системе земледелия / Л.Г. Смирнова, Л.Л. Новых, Е.А. Пелехоце // Почвоведение . - 2006. № 3. - С. 311-316.

8. Хазиев, Ф.Х. Антропогенная деградация плодородия черноземов Предуралья и проблемы его воспроизводства / Ф.Х Хазиев // Антропогенная эволюция черноземов: Тезисы докладов симпозиума. - Воронеж, 2000. - С. 247- 275.

9. Смирнова, Л.Г. Влияние элементов почвозащитного земледелия на плотность сложения эродированных черноземов / Л. Г. Смирнова, С.И. Тютюнов // Материалы Международной научной конференции, посвященной 100-летию со дня рождения основателя Воронежской школы почвоведения П.Г. Адерихина «Черноземы Центральной России: генезис, география, эволюция». - Воронеж, 2004. - С. 480-485.

УДК 631.8

\section{О МЕХАНИЗМЕ ВЛИЯНИЯ ГУМИНОВЫХ ВЕЩЕСТВ НА РОСТОВЫЕ ПРОЦЕССЫ РАСТЕНИЙ}

Безуглова О.С., Бесчетников В.В.

Южный федеральный университет, Ростов-на-Дону

E-mail: lola314@mail.ru

Резюме. В вегетационных опытах с песчаной культурой на полной питательной смеси изучалось влияние гуминовых удобрений на рост проростков озимой пшениць и гороха посевного. Установлено статистически достоверное положительное влияние гуматов на общий рост корневой системы растений, количество корневых волосков и их длину.

Abstract. In vegetation experiments with a sandy crop on a complete nutrient mixture, the effect of humic fertilizers on the growth of seedlings of winter wheat and seed peas was studied. A statistically significant positive effect of humates on the overall growth of the root system of plants, the number of root hairs and their length has been established.

Введение. Гуминовые удобрения при внесении их в почву, прежде всего, выполняют роль катализаторов биохимических процессов, что обусловлено их стимулирующим воздействием на почвенные микроорганизмы [1, 10-12]. Одновременно с ростом численности микроорганизмов усиливается ферментативная активность почвы, что увеличивает доступность питательных 
элементов почвы растениям [7, 8]. С другой стороны, для растений гуминовые вещества являются стимуляторами роста $[3,6]$. Обладая стимулирующим и адаптогенным действием на клеточном и субклеточном уровнях, они влияют на ростовые процессы растений, тем самым побуждая их к более активному потреблению элементов питания. Экспериментальное подтверждение этому получено в многочисленных лабораторных и полевых опытах с различными по происхождению гуминовыми препаратами на разных сельскохозяйственных культурах. Тем не менее, отсутствие полного понимания механизмов воздействия гуматов на почвенное плодородие, особенно при наиболее распространенном фолиарном использовании, препятствует более активному внедрению этого эффективного и экологически безопасного приема в практику растениеводства.

В настоящее время установлено, что фолиарная обработка посевов озимой пшеницы и многих других сельскохозяйственных культур сопровождается ростом активности микроорганизмов ризосферной зоны, что в свою очередь приводит к увеличению доступности элементов питания. На черноземах обыкновенных карбонатных это касается, прежде всего, подвижного фосфора, находящегося в этих почвах в первом минимуме. Однако под культурами с высокой потребностью калия (подсолнечник, картофель) подобное действие было отмечено и для обменного калия, а при определенном сочетании погодных условий наблюдалось и в отношении подвижных форм азота [2].

Корневые системы растений в значительной степени влияют на обстановку в корнеобитаемом слое почвы. В ходе своей жизнедеятельности растения постоянно воздействуют на почву, активно изменяя ее состав и свойства непосредственно через корневые выделения и опосредованно через обитающую в ризосфере микрофлору, изменяя тем самым интенсивность биохимических процессов в ней [5]. Состав и интенсивность корневых выделений определяется видовой и сортовой спецификой растений, их фазой развития, составом и свойствами корнеобитаемой среды, а также зависят от различных внешних воздействий на растения, влияющих на его физиологию [9]. Под влиянием обработок гуминовым препаратом растения, вероятно, более активно, в соответствии с возросшими потребностями в элементах питания регулируют процессы их мобилизации. Однако прямых доказательств этого факта до настоящего времени не обнародовано.

Цель данного исследования состояла в изучении реакции растительных организмов на обработку гуминовыми препаратами.

Объекты и методы исследования. В качестве исследуемых гуминовых удобрений использовали:

- Лигногумат марки «АМ» калийный - гуминовый препарат производства российской компании ООО «Лигногумат», получаемый путём переработки лигносодержащего растительного сырья - лигносульфоната - побочного продукта при производстве целлюлозы; 
- Life Force Humate Balance - гуминовое удобрение, производимое международной компанией ООО «Лайф Форс Групп», получаемое из леонардита (бурого угля).

Удобрения вносили всоответствии с рекомендациями производителя и с учетом концентрации в них действующего вещества, что составило на контейнер с 800 г почвы 0,12 г для лигногумата и 0,23 г для Humate Balance.

Исследования вели на следующих культурах:

- пшеница обыкновенная (Triticum aestivum, L.) сорта «Донэко» - озимый, полуинтенсивный, среднеранний, умеренно рослый сорт, полученный в ФГБНУ «ДЗНИИСХ» и рекомендованный для выращивания в Ростовской и Волгоградской областях, Республике Калмыкия. Год включения в реестр 2010;

- горох посевной (Pisum sativum L.) сорта «Первенец», полученного в ФГБНУ ВИР им. Н.И. Вавилова и рекомендованного для выращивания на территории большинства регионов Российской Федерации. Год включения в реестр - 2002.

Был выбран гидропонный метод выращивания растений, в качестве субстрата использовали промытый от ила и прокалённый речной песок. В качестве питательного раствора использовалась питательная смесь Прянишникова. Схема опыта включала по 3 варианта для каждого вида растений: 1. Контроль (без удобрений), 2. Лигногумат AM, 3. Life Force Humate Balance. Опыт проводили в 3-кратной повторности.

Через 2 недели (14 суток) проводили замер морфометрических показателей, таких как: длина корней и побегов; а также производили отбор фрагментов корней в зоне всасывания для проведения микроскопического анализа корневых волосков и подсчёта их длины и количества. Для световой микроскопии использовали микроскоп Микмед-6 производства фирмы ЛОМО (Россия). Съёмка фотографий проводилась при увеличении 40 крат.

Результаты морфометрических показателей были обработаны методами математической статистики [4].

Результаты и обсуждение. Морфометрические наблюдения показали, что гуминовые удобрения оказывают положительное влияние на развитие проростков обеих культур (таблица 1).

Причем эффективность Humate Balance была выше на проростках пшеницы, а лигногумата - на горохе. Если сравнивать по выраженности реакции, то заметно активнее реагировала корневая система, чем надземная часть, что возможно обусловлено стадией развития растений. Статистическая обработка результатов исследования показала, что разница показателей с контролем статистически достоверна: величина критерия Стьюдента колебалась в пределах 2,2-6,7, при стандартном критическом значении равном 2,01(для данной выборки и уровня значимости $\mathrm{p}<0,05)$. 
Таблица 1 - Влияние гуминовых удобрений на морфометрические параметры проростков озимой пшеницы (Triticum aestivum, L.) сорта «Донэко» и гороха посевного (Pisum sativum L.) сорта «Первенец»

\begin{tabular}{|c|c|c|c|c|c|}
\hline \multirow[b]{2}{*}{ Вариант } & \multicolumn{2}{|c|}{ Корни } & \multicolumn{2}{|c|}{ Побег } & \multirow[b]{2}{*}{$\begin{array}{c}\text { Среднее из показа- } \\
\text { телей (корень + по- } \\
\text { бег), \% }\end{array}$} \\
\hline & $\begin{array}{c}\text { М (сред- } \\
\text { нее по ва- } \\
\text { рианту), } \\
\text { см }\end{array}$ & $\begin{array}{l}\text { В сравне- } \\
\text { нии с кон- } \\
\text { тролем, \% }\end{array}$ & $\begin{array}{c}\text { М (сред- } \\
\text { нее по ва- } \\
\text { рианту), } \\
\text { см }\end{array}$ & $\begin{array}{l}\text { В сравне- } \\
\text { нии с кон- } \\
\text { тролем, \% }\end{array}$ & \\
\hline \multicolumn{6}{|c|}{ Озимая пшеница } \\
\hline Контроль & 12.0 & 100.0 & 22.6 & 100.0 & 100.0 \\
\hline Лигногумат AM & 15.2 & 126.7 & 28.4 & 125.7 & 126.0 \\
\hline Humate Balance & 17.1 & 142.5 & 30.4 & 134.5 & 137.3 \\
\hline \multicolumn{6}{|c|}{ Горох посевной } \\
\hline Контроль & 7.8 & 100.0 & 15.0 & 100.0 & 100.0 \\
\hline Лигногумат АМ & 9.6 & 123.1 & 17.9 & 119.3 & 120.6 \\
\hline Humate Balance & 8.8 & 112.8 & 17.1 & 114.0 & 113.6 \\
\hline
\end{tabular}

Гуминовые удобрения влияли и на развитие корневых волосков. В таблице 2 приведены результаты микроморфометрических измерений корней озимой пшеницы и гороха посевного в зоне всасывания.

Таблица 2 - Влияние гуминовых удобрений на морфометрические параметры корневых волосков проростков озимой пшеницы (Triticum aestivum, L.) сорта «Донэко» и гороха посевного (Pisum sativum L.) сорта «Первенец»

\begin{tabular}{|c|c|c|c|c|c|c|}
\hline \multirow{2}{*}{ № } & \multirow{2}{*}{ Вариант } & \multicolumn{2}{|c|}{$\begin{array}{c}\text { Средняя длина корне- } \\
\text { вых волосков }\end{array}$} & \multirow{2}{*}{$\begin{array}{c}\text { Отношение } \\
\text { длины корне- } \\
\text { вых волосков к } \\
\text { толщине корня }\end{array}$} & \multicolumn{2}{|c|}{$\begin{array}{c}\text { Количество корневых } \\
\text { волосков }\end{array}$} \\
\hline & & $\begin{array}{c}\text { Абсол. } \\
\text { значение, } \\
\text { мкм }\end{array}$ & $\begin{array}{l}\text { \% от кон- } \\
\text { троля }\end{array}$ & & $\begin{array}{c}\text { Абсол. } \\
\text { значение, } \\
\text { ед/мм² }\end{array}$ & $\begin{array}{l}\% \text { от кон- } \\
\text { троля }\end{array}$ \\
\hline \multicolumn{7}{|c|}{ Озимая пшеница } \\
\hline 1 & Контроль & 479 & 100.00 & 1.03 & 75 & 100.00 \\
\hline 2 & Лигногумат AM & 636 & 132.78 & 1.04 & 80 & 106.67 \\
\hline 3 & Humate Balance & 614.7 & 128.33 & 1.26 & 107 & 142.67 \\
\hline \multicolumn{7}{|c|}{ Горох посевной } \\
\hline 4 & Контроль & 255.6 & 100.00 & 0.21 & 28 & 100.00 \\
\hline 5 & Лигногумат AM & 355.4 & 139.05 & 0.51 & 57 & 203.57 \\
\hline 6 & Humate Balance & 336.4 & 131.61 & 0.28 & 40 & 142.86 \\
\hline
\end{tabular}


Внесение в питательную смесь гуминовых удобрений, как у пшеницы, так и у гороха стимулирует рост новых корневых волосков, увеличивается их средняя длина и отношение длины к толщине корня. Корневые волоски, являясь выростами наружной ткани корня - эпиблемы, обеспечивают увеличение площади поверхности корня в сотни раз и формируют так называемую зону всасывания. Наилучшие результаты показал Лигногумат марки AM, обеспечивший более, чем двукратную прибавку количества корневых волосков на горохе (203,7 \% от контроля). Результаты по вариантам с озимой пшеницей были не такими яркими, тем не менее, и эта культура положительно отзывалась на внесение гуминовых удобрений, однако Humate Balance обеспечил больший прирост количества корневых волосков, в то время как средняя длина их была ниже.

Заключение. Гуминовые удобрения оказали заметное стимулирующее действие на рост и развитие корневой системы в целом, а также на рост и количество корневых волосков на озимой пшенице и горохе посевном. Так как исследование вели на полной питательной смеси, прирост по сравнению с контролем корневых волосков свидетельствует о возросших потребностях растений и стимуляции ими всасывающего механизма. Следует также отметить, что эффективность гуминового препарата определяется как его природой, так и особенностями сельскохозяйственной культуры.

\section{Библиографический список}

1. Александрова И.В. О физиологической активности гумусовых веществ и продуктов метаболизма микроорганизмов// Органическое вещество целинных и освоенных почв. M.,1972. C.30-69.

2. Безуглова О.С., Полиенко Е.А., Горовцов А.В., Лыхман В.А. Влияние гуминовых препаратов на почвы и растения. Ростов-на-Дону - Таганрог: Изд-во Южного федерального университета, 2019. $154 \mathrm{c}$.

3. Горовая А.И., Орлов Д.С., Щербенко О.В. Гуминовые вещества. Строение, функции, механизм действия, протекторные свойства, экологическая роль. Киев: Наукова думка, $1995.302 \mathrm{c}$.

4. Доспехов, Б. А. Методика полевого опыта (с основами статистической обработки результатов исследований). М.: Агропромиздат, 1985.351 с.

5. Иванов В.П. Растительные выделения и их значение в жизни фитоценозов. М.: Наука, $1973.295 \mathrm{c}$.

6. Комаров А.А. Некоторые рассуждения о действии гуминовых препаратов на растения // Агрохимический вестник, № 6, 2009. С.28-29.

7. Полиенко Е.А., Безуглова О.С., Горовцов А.В., Лыхман В.А., Павлов П.Д. Применение гуминового препарата ВIO-Дон на посевах озимой пшеницы / // Достижения науки и техники АПК. 2016. Т. 30. № 2. С. 24-28.

8. Полиенко Е.А., НаимиО.И., Безуглова О.С. Влияние гуминового препарата ВІО-Дон на состав и динамику питательных элементов в системе «почва - растение» // Известия Оренбургского государственного аграрного университета. №5 (67). 2017. С.192-195. http://orensau.ru/images/stories/docs/izvestia/2017/12/Izvestia_5_67.pdf

9. Хомяков Ю.В. Роль корневых выделений растений в формировании биохимических свойств корнеобитаемой среды: автореф. дис. ... канд. биол. наук. Санкт-Петербург, 2009. $22 \mathrm{c}$. 
10. Arancon, N. Q., Edwards, C. A., \&Bierman, P. (2006). Influences of vermicomposts on field strawberries: Part 2. Effects on soil microbiological and chemical properties. Bioresource Technology, 97(6), 831-840.

11. Bezuglova, O.S., Gorovtsov, A.V., Polienko, E.A. Zinchenko V.E., Grinko A.V., Lykhman V.A., Dubinina M.N., Demidov A. Effect of humic preparation on winter wheat productivity and rhizosphere microbial community under herbicide-induced stress // J Soils Sediments (2019) Volume 19, Issue 6, June 2019: 2665-2675. https://doi.org/10.1007/s11368-018-02240-z

12. Visser, S. A. (1985). Effect of humic acids on numbers and activities of micro-organisms within physiological groups. OrganicGeochemistry, 8(1), 81-85.

\title{
УДК 631.8: $504.054: 574.24$
}

\section{ВЛИЯНИЕ ЗАГРЯЗНЕНИЯ МЕДЬЮ НА РОСТОВЫЕ ПРОЦЕССЫ РАСТЕНИЙ И РОЛЬ ГУМАТОВ В НЕЙТРАЛИЗАЦИИ СТРЕССА}

Бесчетников В.В., Безуглова О.С.

Южный федеральный университет, Академия биологии и биотехнологии

им. Д.И. Ивановского, Ростов-на-Дону, Россия

E-mail: beschetnikov@sfedu.ru

\begin{abstract}
Резюме. Исследовано влияние гуминовых удобрений на ткани корней и листовых пластин озимой пшеницы и гороха посевного в условиях повышенного содержания меди. Гуминовые удобрения снизили стресс от поллютанта и улучшили общце цฺитоморфометрические показатели корня и листовой пластинь.

Summary. The effect of humic fertilizers on the tissues of roots and leaf blades of winter wheat and pea in conditions of high copper content has been studied. Humic fertilizers reduced the stress from the pollutant and improved the overall cytomorphometric parameters of the root and leaf blade.
\end{abstract}

Медь является необходимым микроэлементом для растений [1]. Её ионы содержатся в составе всех тканей растений и участвуют во множестве важных физиологических процессов, таких как: фотосинтез, дыхание, синтез различных белков и углеводов, регулирование поступления воды, обмен азота и т.д. Однако, как и другие тяжёлые металлы (ТМ), медь в повышенных концентрациях способна вызывать окислительный стресс и оказывать серьёзное цитотоксическое воздействие [9], которое обычно проявляется в нарушении роста и развития растений, особенно на ранних стадиях [7].

Вероятность проявления подобного токсического эффекта на растения в настоящее время является достаточно высокой. Этому способствует широкое распространение данного металла и его соединений в различных отраслях промышленности, возрастающие выбросы его в окружающую среду. В связи с этим актуальным является поиск решений по снижению негативного воздействия высоких концентраций меди. Одним из способов нейтрализации стресса от повышенного содержания в среде ТМ, в том числе меди, может быть применение гуминовых веществ.

Данные соединения широко распространены в природе [8] и способны оказывать положительное влияние на растения в различных стрессовых условиях $[2,3,6]$, в том числе и при загрязнении почв ТМ $[4,10]$. Тем не менее, механизмы воздействия гуминовых веществ на растения в стрессовых 
условиях изучены недостаточно полно, особенно это касается изучения их влияния на развитие тканей органов растений.

Цель - изучение влияния гуминовых удобрений Лигногумат AM и Life Force Humate Balance на развитие тканей корней и листьев озимой пшеницы и гороха посевного в стрессовых условиях загрязнения среды медью.

Для этого был заложен вегетационный опыт на песчаной культуре с применением универсальной смеси Прянишникова. В качестве тест-объектов были использованы пророщенные семена озимой пшеницы (Triticum aestivum, L.) сорта «Донэко» и гороха посевного (Pisum sativum L.) сорта «Первенец» в количестве 8 шт/контейнер. Перед высевом семян в субстрат вносили гуминовые удобрения Лигногумат марки АМ и Life Force Humate Balance в дозе 0,12 и 0,23 г/контейнер, в соответствии с рекомендациями производителей. Для моделирования загрязнения медью был использован сульфат меди в концентрации 100 мг/кг в пересчёте на медь, что эквивалентно 33-кратному превышению подвижной меди в почве [5]. Итоговая схема опыта включала 4 варианта: 1. Контроль (без удобрений); 2. Cu 100 мг/кг; 3. Лигногумат АМ + Cu100 мг/кг; 4. Humate Balance + Cu 100 мг/кг. Опыт проводили в 3-кратной повторности.

После окончания опыта (14 суток) были отобраны фрагменты корней в зоне всасывания и листовых пластин для проведения микроскопического анализа. Фиксация постмортальных изменений проводилась растворами глутарового альдегида $(2,5 \%)$ и тетраоксида осмия (1\%) в натрий-фосфатном буфере $(\mathrm{pH}=7,3)$, для заливки в блоки использовали эпоксидную смолу Эпон-812. Подготовку полутонких срезов (300-700 нм) осуществляли на ультрамикротоме EM UC6 фирмы Leica (Германия), в качестве светооптического микроскопа использовали микроскоп Микмед-6 производства фирмы ЛОМО (Россия). Окрашивание срезов производилось водным раствором метиленового синего и толуидинового синего. Съёмка фотографий осуществлялась при увеличении 400 крат.

Результаты исследования. Корень растения является первым барьером на пути проникновения поллютантов из субстрата в растения. Одними из наиболее распространённых проявлений токсического эффекта от загрязнения ТМ являются деформация тканей корня и увеличение толщины его коры. Подобный эффект наблюдается и в нашем опыте (рисунок 1). Образец корня пшеницы, отобранный с варианта с внесением меди, обладает существенными деформациями центрального цилиндра и коры, которые выражаются в серьёзном искажении их формы и увеличением площади. В корне гороха деформации в основном оказался подвержен центральный цилиндр и прилегающие к нему клетки эндодермы. Также как для растений озимой пшеницы, так и для гороха можно отметить деформации слоя клеток эпиблемы, отвечающих за формирование корневых волосков.

Корни растений, выращиваемых на контроле и с применением Humate Balance, также обладают асимметрией корового слоя, однако клетки коры на данных вариантах имеют правильную, округлую форму и имеют схожий размер. Клетки эпиблемы хорошо различимы, плотно прилегают друг к другу и не 
имеют существенных деформаций. Наилучшая радиальная симметрия корня наблюдается при внесении Лигногумата АМ. Клетки эпиблемы, коры, а также тканей центрального цилиндра хорошо различимы, в своём большинстве обладают правильной формой и плотно прилегают друг к другу. Однако, на данном варианте отмечается увеличенное отношение площади сечения центрального цилиндра к площади сечения корового слоя (8.75).

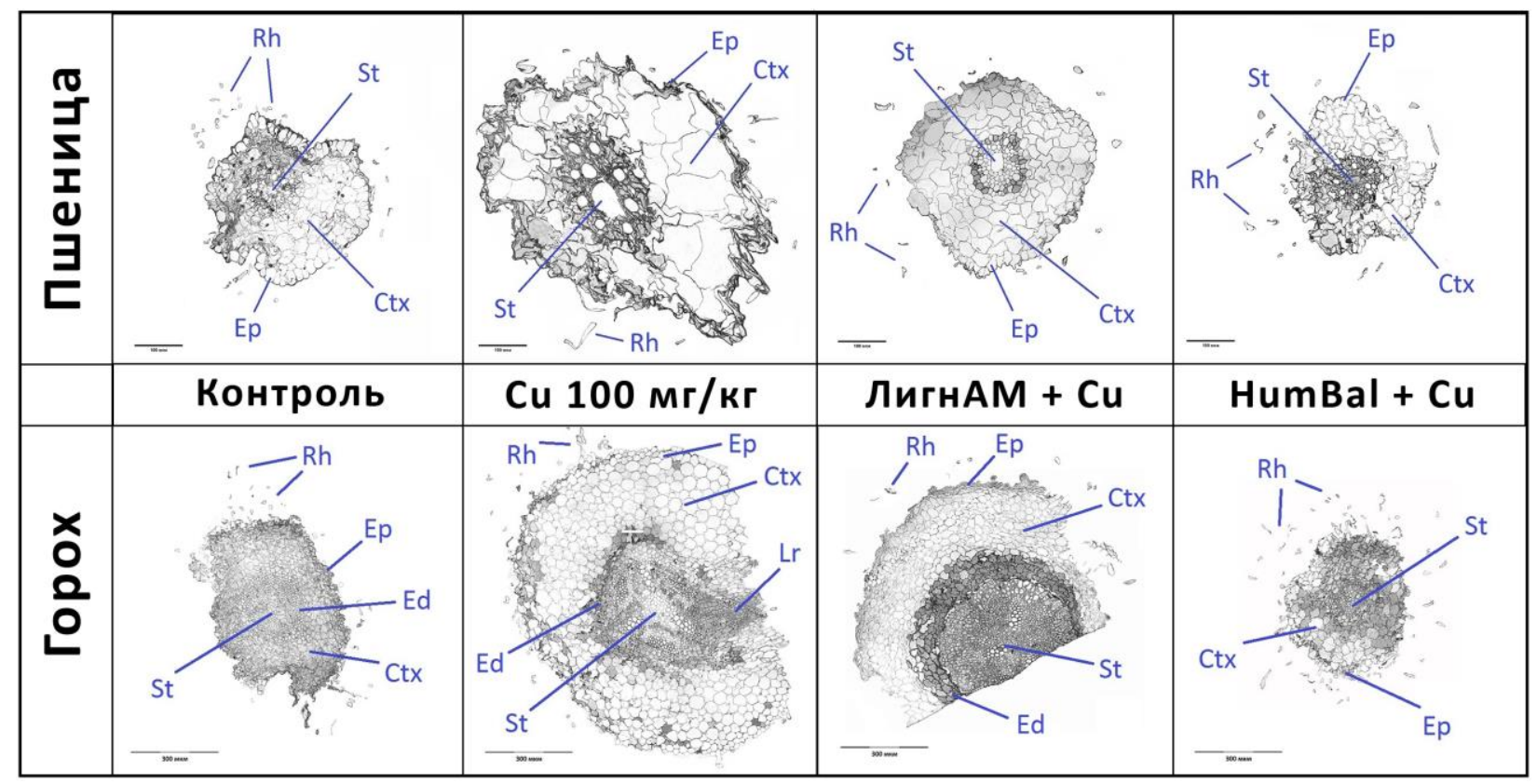

Рисунок 1 - Поперечные срезы корня озимой пшеницы и гороха посевного. $\mathbf{R h}$ - корневые волоски; Ep - эпиблема; Ctx - кора (кортекс); Ed - эндодерма; $\mathbf{S t}$ - центральный цилиндр (стела); $\mathbf{L r}$ - боковой корень. Масштабные отрезки: пшеница - 100 мкм, горох - 300 мкм.

Преодолев барьер «почва-корень» и попав внутрь растения, тяжёлые металлы способны перемещаться с восходящим током воды вверх по растениям к листьям. Как было упомянуто ранее, медь играет важную роль в фотосинтезе, который является основным источником углерода и энергии для растений. По этой причине необходимо рассматривать влияние её избыточного содержания в субстрате на внутреннюю организацию листьев.

При проведении микроскопического анализа срезов листовых пластин озимой пшеницы и гороха посевного серьёзных деформаций тканей и изменений строения для обоих растений на всех вариантах опыта обнаружено не было (рисунок 2). Ткани хорошо дифференцируются, у гороха прослеживается деление мезофилла на палисадную и губчатую паренхиму, характерное для двудольных растений. Клетки эпителия на всех вариантах не имеют повреждений и сложены плотным рядом. Однако у изученных листьев наблюдаются различия в размерах и количестве клеток хлоренхимы.

Так, например, среди листьев пшеницы наибольшая плотность хлоренхимы при наименьшей средней площади клеток отмечена для контроля, где данные показатели составили 453,8 мкм $^{2}$ и 2203,6 клетки/мм ${ }^{2}$ соответственно. Внесение меди приводит к увеличению средней площади клеток $\left(543,8\right.$ мкм $\left.^{2}\right)$ и, как следствие, снижению их плотности $(1838,8$ клеток/мм²). Наименьшее же 
количество клеток хлоренхимы на единицу площади наблюдается на варианте с внесением Humate Balance (1685 клеток/мм²) при наибольшей средней площади самих клеток $\left(610,9\right.$ мкм $\left.^{2}\right)$. Это может быть связано с проявлением ростостимулирующего действия данного гуминового удобрения на увеличение листовой пластины за счёт клеточного растяжения. При этом на варианте с внесением Лигногумата, на котором отмечено наибольшее количество пластид (12,5 шт/клетку), подобного эффекта не наблюдается, что может быть обусловлено различиями в химическом составе удобрений, причиной которым является различное сырьё и методы производства.

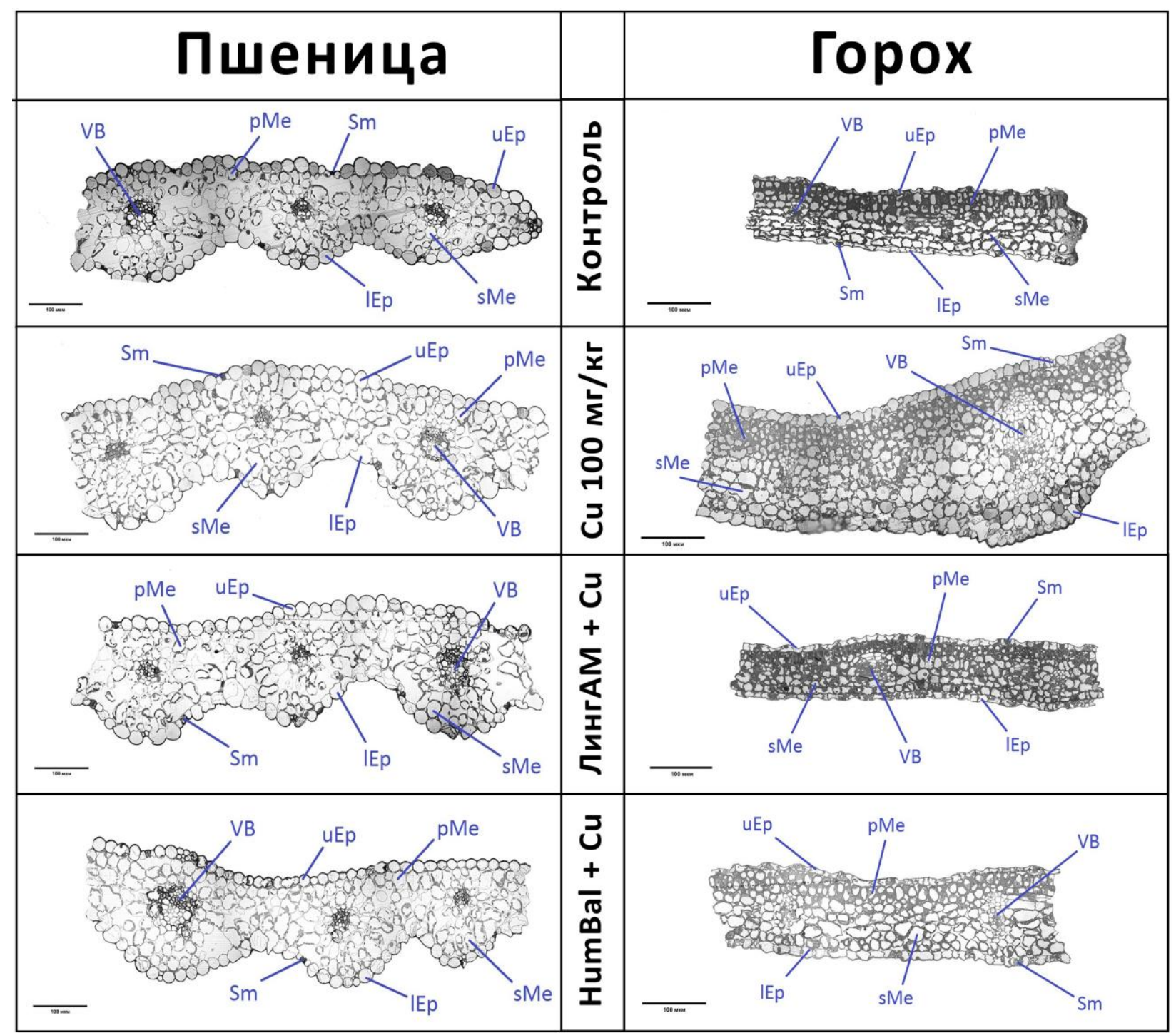

Рисунок 2 - Поперечные срезы листовой пластины озимой пшеницы и гороха посевного. $\mathbf{u E p}$ - верхний эпидермис; $\mathbf{I E p}$ - нижний эпидермис; $\mathbf{S m}$ - устьице (стома); $\mathbf{p M e ~ - ~ п а л и с а д н ы и ̆ ~ м е з о ф и л ; ~} \mathbf{s M e ~ - ~ г у б ч а т ы и ̆ ~ м е з о ф и л ; ~ V B - ~ п р о в о д я - ~}$ щий пучок. Масштабный отрезок - 100 мкм.

Изменение размеров клеток у гороха можно отметить только для губчатой паренхимы варианта с загрязнением. Такая особенность в совокупности с небольшим увеличением межклеточного пространства, скорее всего, является причиной наибольшей толщины листовой пластины у этого варианта и 
снижения параметра количества клеток хлоренхимы на единицу площади

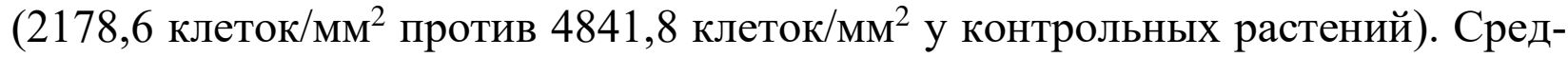
нее количество пластид в клетках хлоренхимы для всех вариантов лежит в пределах 9,5-10,7 единиц на клетку. Данный показатель немного снижен на варианте с внесением Лигногумата, но, стоит учитывать, что на данном варианте наблюдается наибольшая плотность хлоренхимы $(5114,7$ клеток/мм²) среди рассматриваемых вариантов.

Заключение. Основное негативное воздействие загрязнения субстрата медью приходится на корни растения: наблюдаются существенные деформации коры и центрального цилиндра, а также изменение формы клеток эпиблемы. Данный токсический эффект снижается при внесении в субстрат гуминовых удобрений. Листовые пластины растений оказались менее подвержены воздействию избыточного содержания меди в субстрате. Однако, на вариантах с гуминовыми удобрениями, кроме варианта с использованием Лигногумата

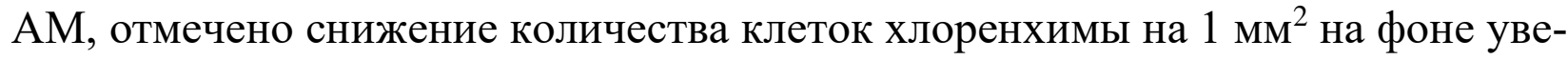
личения их средней площади по сравнению с контролем, вероятно обусловленное ростостимулирующей активностью гуматов.

\section{Библиографический список}

1. Кузнецов В. В., Дмитриева Г. А. Физиология растений. М.: Высшая школа, 2006. 742 c.

2. К Кыдралиева К. А. и др. Исследование адаптогенных свойств гуминовых препаратов по отношению к растительному покрову засоленных почв //Биодиагностика состояния природных и природно-техногенных систем. 2017. С. 172-173.

3. Нечаев Л. А. и др. Влияние применения гумата калия на продуктивность пивоваренного ячменя //Достижения науки и техники АПК, 2014. №. 6. С.33-35.

4. Перминова И. В. Анализ, классификация и прогноз свойств гумусовых кислот: дисс. ... док. хим. наук, М. МГУ им. М.В.Ломоносова, 2000. 359 с.

5. СанПиН 1.2.3685-21 «Гигиенические нормативы и требования к обеспечению безопасности и (или) безвредности для человека факторов среды обитания»: https://docs.cntd.ru/document/573500115.

6. Христева Л. А. Действие физиологически активных гуминовых кислот на растения при неблагоприятных внешних условиях //Гуминовые удобрения. Теория и практика их применения. 1973. Т. 4. С. 5-23.

7. Lewis S., Donkin M. E., Depledge M. H. Hsp70 expression in Enteromorphaintestinalis (Chlorophyta) exposed to environmental stressors //Aquatic Toxicology, 2001. T. 51 . №. 3. C. 277291.

8. Matilainen A. et al. An overview of the methods used in the characterisation of natural organic matter (NOM) in relation to drinking water treatment //Chemosphere, 2011. T. 83. №. 11. C. 1431-1442.

9. Stadtman E. R., Oliver C. N. Metal-catalyzed oxidation of proteins: physiological consequences //The Journal of biological chemistry (Print), 1991. T. 266. №. 4. C. 2005-2008.

10. Yates L. M., Von Wandruszka R. Decontamination of polluted water by treatment with a crude humic acid blend //Environmental science\& technology, 1999. T. 33. №. 12. C. 2076-2080. 


\title{
ВЛИЯНИЕ ПОСЛЕДЕЙСТВИЯ БИОУГЛЯ НА ПОТОКИ
} $\mathrm{N}_{2} \mathrm{O}$ И $\mathrm{NH}_{3}$ ИЗ ПОЧВ

\author{
Бовсун М. А. ${ }^{\mathbf{1}, 2}$, Нестеров В. В. ${ }^{3}$, Нестерова О. В. ${ }^{\mathbf{1}}$, \\ Брикманс А. В. ${ }^{1}$, Семаль В. А. ${ }^{4}$ \\ ${ }^{1}$ Дальневосточного федерального университета, Владивосток \\ E-mail: nesterova.ov@dvfu.ru, brikmans.av@dvfu.ru \\ ${ }^{2}$ Тихоокеанский океанологический институт им. Ильичева ДВО РАН, \\ г. Владивосток \\ E-mail: bovsun.mal@students.dvfu.ru \\ ${ }^{3}$ МАОУ «Лицей технический», г. Владивосток \\ E-mail:n.v2005@mail.ru \\ ${ }^{4}$ Федеральный научный центр биоразнообразия суши Восточной Азии ДВО \\ РАН, г. Владивосток \\ E-mail: semal.va@dvfu.ru
}

\begin{abstract}
Резюме. Оченено влияние древесного биоугля после одного года нахождения в почве на потоки $\mathrm{N}_{2} \mathrm{O}$ и $\mathrm{NH}_{3}$ в рамках полевого вегетационного опьта. За шесть месящев измерений кумулятивный поток $\mathrm{N}_{2} \mathrm{O}$ на участке с внесением 3 кг/м ${ }^{2}$ был снижен на $64 \%$ по сравнению с контролем. Кумулятивный поток $\mathrm{NH}_{3}$ на участке с внесением 3 кг/м ${ }^{2}$ биоугля увеличился на $50 \%$ по сравнению с контролем.
\end{abstract}

Ключевые слова: биоуголь, парниковые газы, закись азота, аммиак, эмиссия.

Summary. The influence of wood biochar after one year of being in the soil on the flow of $N 2 O$ and NH3 in the field vegetation experiment was evaluated. During six months of measurements, the cumulative flow of $\mathrm{N} 2 \mathrm{O}$ at the site with the addition of $3 \mathrm{~kg} / \mathrm{m} 2$ was reduced by $64 \%$ compared to the control. The cumulative NH3 flow at the site with the addition of $3 \mathrm{~kg} / \mathrm{m} 2$ of biochar increased by $50 \%$ compared to the control.

Key words: biochar, greenhouse gases, nitrous oxide, ammonia, emission.

Азот является важным элементом питания для растений (Oo et al. 2018) и имеет достаточно сложный круговорот в почвенной экосистеме. Основными процессами преобразования азота в почвах являются нитрификация, денитрификация, аммонификация. В результате этих процессов могут образовываться такие газы как $\mathrm{NO}_{2}, \mathrm{NO}, \mathrm{N}_{2} \mathrm{O}, \mathrm{N}_{2}$ и $\mathrm{NH}_{3}$. $\mathrm{N}_{2} \mathrm{O}$ является сильным парниковым газом (Oo et al. 2018, Jia J. Et al., 2012). Его глобальный коэффициент потепления может достигать 298 по сравнению с $\mathrm{CO}_{2}$. $\mathrm{NH}_{3}$ не является парниковым газом, поэтому данные газ не получил широкого интереса к исследованию, тем не менее он являете важным газом, так как его образование тесно связано с образованием $\mathrm{N}_{2} \mathrm{O}$.

На сегодняшний день биоуголь является одним из актуальных почвенных улучшателей, который может снижать потоки парниковых газов в том числе $\mathrm{N}_{2} \mathrm{O}$ и $\mathrm{NH}_{3}$ (Wang, 2019; Wu Zh., 2019; Liu, 2019).

В данной работе на основании полевого опыта было оценено влияние древесного биоугля после одного года пребывания в почве в двух дозах применения на потоки закиси азота $\left(\mathrm{N}_{2} \mathrm{O}\right)$ и аммиака $\left(\mathrm{NH}_{3}\right)$. 
Действие биоугля после одного года пребывания в почве (внесен был 15 июня 2018 года) на $\mathrm{N}_{2} \mathrm{O}$ и $\mathrm{NH}_{3}$ проводилось с июля по октябрь 2019 года (Bovsun et al 2021). Полевой опыт расположен на территории Приморской овощной опытной станции (с. Суражевка, Приморский край, Российская федерация $43.423110,132.313573)$. На опытном поле было выделено три участка площадью $21.6 \mathrm{~m}^{2}$, где вносился биоуголь в дозах 0 кг $/ \mathrm{M}^{2}(\mathrm{BC} 0), 1$ кг $/ \mathrm{M}^{2}(\mathrm{BC} 1 \mathrm{~kg})$, и $3 \mathrm{\kappa} г \mathrm{M}^{2}(\mathrm{BC} 3 \mathrm{~kg})$.

В исследовании использовался березовый (из Betula alba) биоуголь. Биоуголь был произведен методом медленного пиролиза при температуре от $360^{\circ} \mathrm{C}$ до $380^{\circ} \mathrm{C}$. Свойства биоугля до внесения в почву и после первого года внесения рассмотрены в Bovsun et al 2021.

Изучение проводилось на культуре сплошного сева - сое, которая была посажена 28 июля 2019 и собрана 10-12 октября 2019. Соя была использована как сидерат и после оценки биомассы оставлена на поле.

Почва на исследуемых участках классифицируется как Luvic Anthrosols и имеет среднесуглинистый гранулометрический состав

В полевых условиях в момент отбора почвенных образцов измерялась влажность почвы soil moisture sensor SM150 (Delta-T Devices Ltd, England) и температура почвы.

Территория Приморского края Российской Федерации характеризуется умеренным муссонным климатом. На изучаемой территории по данным многолетних измерений за период с апреля по октябрь средняя температура воздуха составляет $+14.5^{\circ} \mathrm{C}$, а количество осадков -584 мм. За период с апреля по октябрь 2019 года на исследуемой территории выпало 1032 мм осадков, что превышает среднемноголетнее значение на 448 мм. Согласно рисунку 1 видно, что причиной данного превышения показателей является аномальное выпадение осадков в августе (521 мм). По температурным характеристикам рассматриваемый временной промежуток не показал существенных отклонений от среднемноголетних значений температуры воздуха.

Почвенные потоки $\mathrm{N}_{2} \mathrm{O}$ и $\mathrm{NH}_{3}$ измерялись в лабораторных условиях при помощи лазерного газового анализатора Picarro G2508 (Picarro Inc., Santa Clara, CA, USA).

Почвенные образцы для измерения потоков $\mathrm{N}_{2} \mathrm{O}$ и $\mathrm{NH} 3$ отбирались в полевых условиях в алюминиевые бюксы объемом $78.5 \mathrm{~cm}^{3}$, закрывались крышкой и транспортировались в лабораторию. Бюксы (3 шт. участка) помещались в камеру газоанализатора и анализировались в течении 5 минут.

При измерении потока в лабораторных условиях измерялась температура воздуха и давление воздуха при помощи погодного преобразователя данных Vaisala Weather Transmitter WXT520 (Vaisala, Helsinki, Finland).

Потоки $\mathrm{N}_{2} \mathrm{O}$ и $\mathrm{NH}_{3}$ рассчитывались вручную с использованием линейной зависимости. Для оценки достоверности данных потока м использовали коэффициент детерминации $\mathrm{R}_{2}$.

Согласно данным полевой влажности почв (рис. 1) было выявлено снижение влажности почвы при внесении доз биоугля. Наибольшее различие 
показателей между контрольным участком и участками с внесением биоугля было отмечено в первый месяц измерения полевой влажности почв.

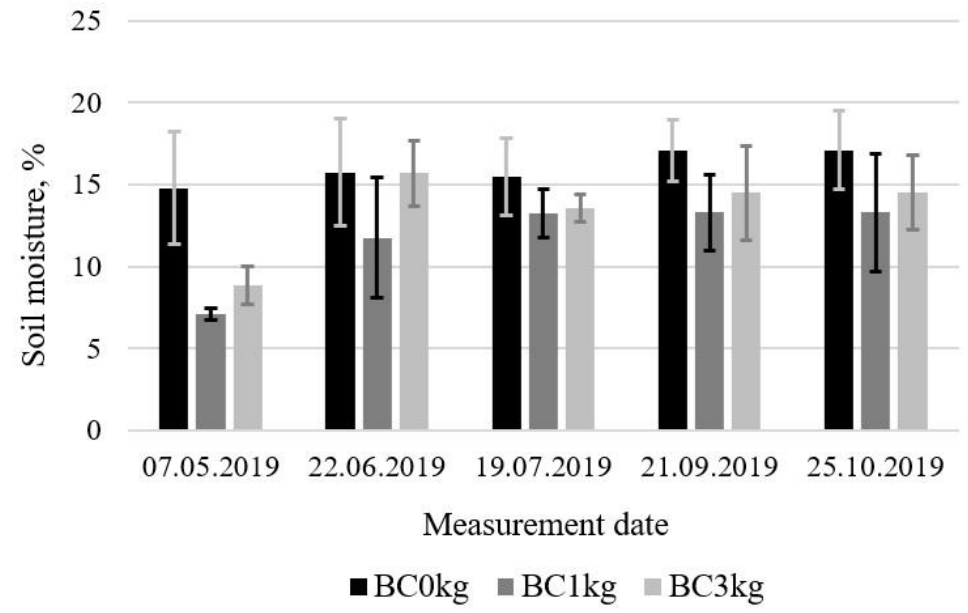

Рисунок 1 - Полевая влажность почвы на исследуемых участках за сезон 2019 года.

Согласно данным рисунка 2 температура почвы за период исследования не существенно отличалась во всех вариантах опыта. Температура почвы за весь период исследования коррелировала с температурой воздуха. Внесение биоугля не повлияло на значения температуры почвы.

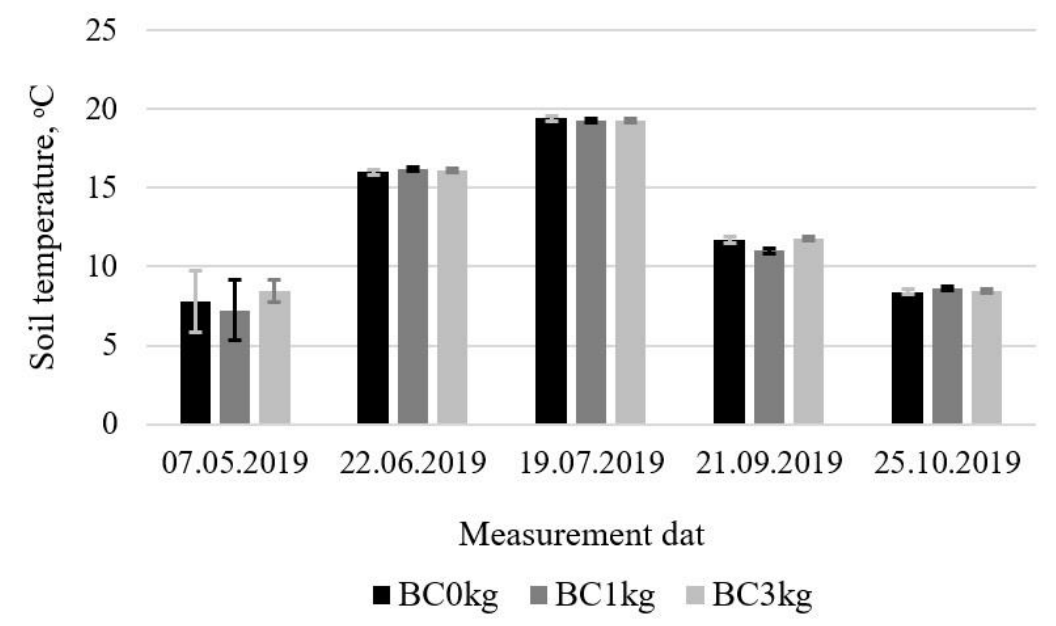

Рисунок 2 - Температура почвы на исследуемых участках за сезон 2019 года.

При рассмотрении кумулятивного потока $\mathrm{N}_{2} \mathrm{O}$ (рис. 5) отмечено снижение потока при применении биоугля. С мая по сентябрь наибольшее значение потока $\mathrm{N}_{2} \mathrm{O}$ показывал контрольный участок. Суммарный поток $\mathrm{N}_{2} \mathrm{O}$ на участке $\mathrm{c}$

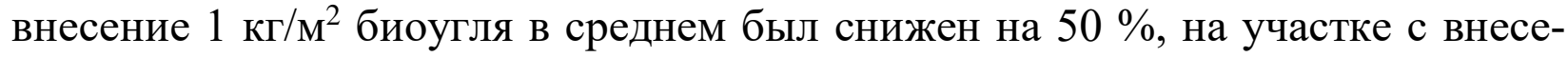
нием 3 кг $/ \mathrm{M}^{2}$ на $80 \%$. В октябре суммарный поток $\mathrm{N} 2 \mathrm{O}$ на участке с внесением 1 кг $\mathrm{M}^{2}$ биоугля стыл отрицательным (поглощение), на участке с внесением3

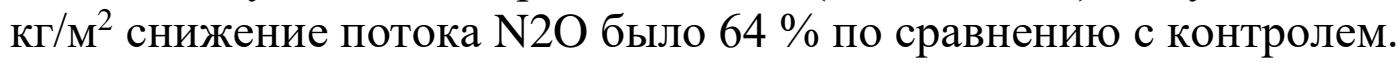




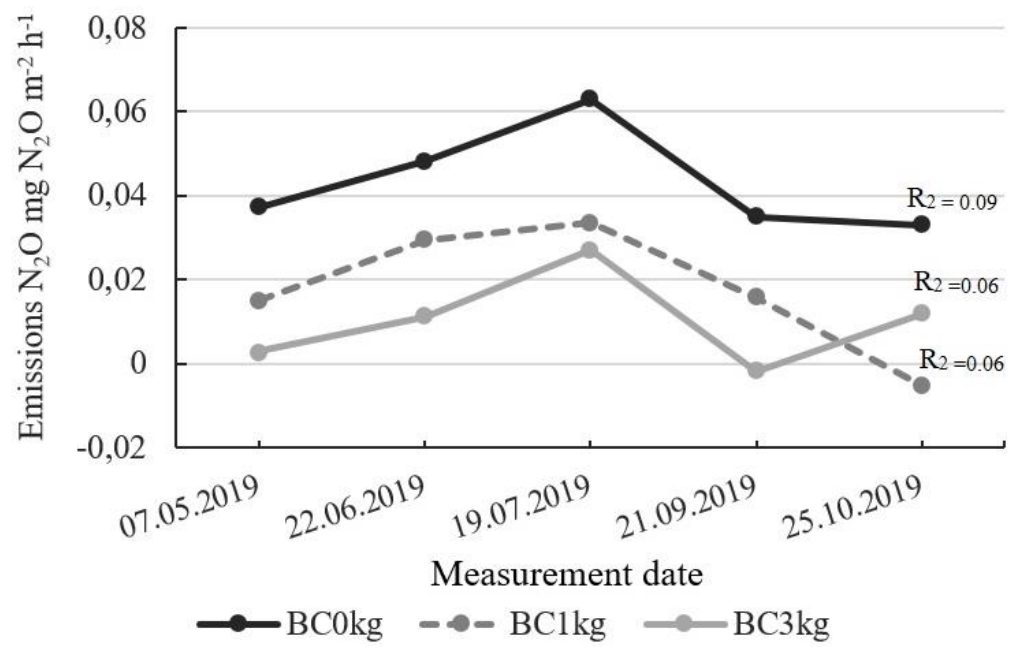

Рисунок 3 - Кумулятивные потоки $\mathrm{N}_{2} \mathrm{O}$ на исследуемых участках за сезон 2019 года.

При рассмотрении значений кумулятивного потока $\mathrm{NH}_{3}$ (рис. 4) найдено

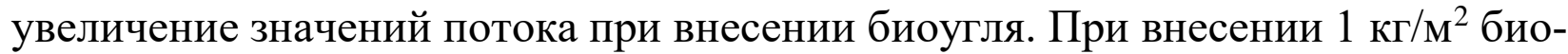
угля в начале периода измерения значения потока были равны значению потока на контрольном участке. К концу периода измерений поток $\mathrm{NH} 3$ на участке с внесение 1 кг/ $\mathrm{M}^{2}$ биоугля был увеличен на $27 \%$ по сравнению с контролем. На участке с внесением 3 кг/м² биоугля в начале периода измерений поток $\mathrm{NH}_{3}$ был выше значения потока на контрольном участке на 40 \%. К концу периода измерений значение потока $\mathrm{NH} 3$ на данном участке превышало на 50 \% поток на контрольном участке.

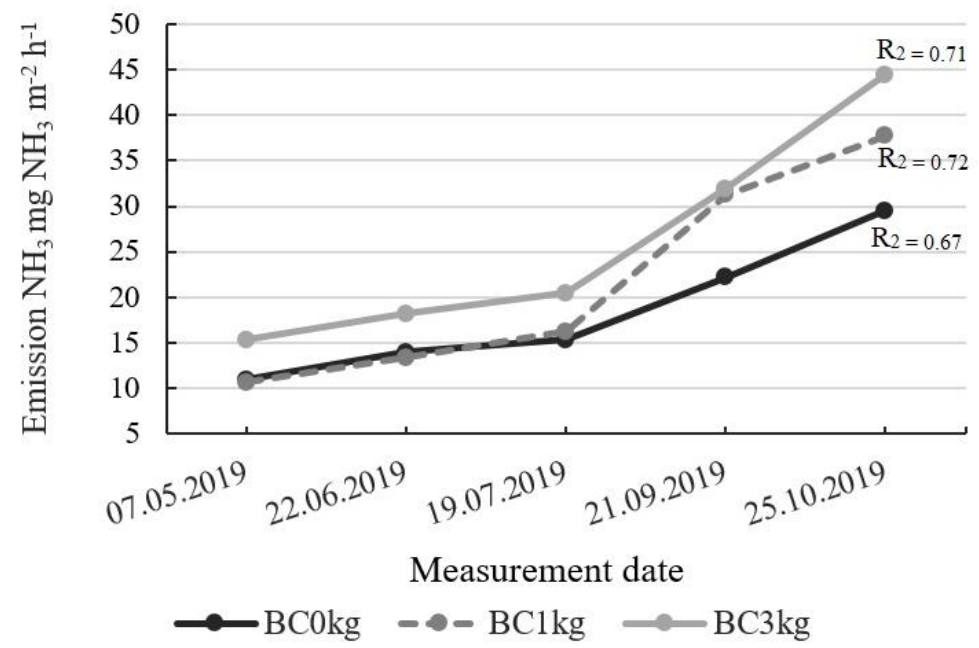

Рисунок 4 - Кумулятивные потоки $\mathrm{NH}_{3}$ на исследуемых участках за сезон 2019 года.

При рассмотрении кумулятивных потоков $\mathrm{N}_{2} \mathrm{O}$ и $\mathrm{NH}_{3}$ за период с мая по октябрь 2019 года были отмечены достоверные изменения в потоке газов при внесении биоугля. Кумулятивные потоки $\mathrm{N}_{2} \mathrm{O}$ снижались при внесении био-

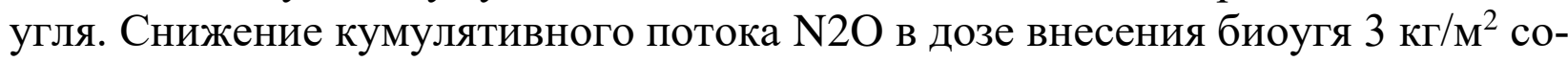
ставило 64 \% к концу периода измерений по сравнению с контролем. Кумулятивный поток $\mathrm{NH}_{3}$ при внесении биоугля увеличивался. Так при внесении 3 


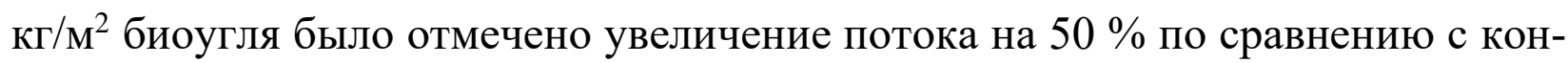
тролем.

\title{
Библиографический список
}

1. Oo A. Z., Sudo S., Win K. T., Shibata A., Gonai T. Influence of pruning waste biochar and oyster shell on $\mathrm{N}_{2} \mathrm{O}$ and $\mathrm{CO}_{2}$ emissions from Japanese pear orchard soil. Heliyon. 2018, 4, e00568. doi: 10.1016/j.heliyon.2018.e00568

2. Jia J., Li B., Chen Z., Xie Z., Xiong Z. Effects of biochar application on vegetable production and emissions of $\mathrm{N}_{2} \mathrm{O}$ and $\mathrm{CH}_{4}$. Soil Science and Plant Nutrition. 2012, 58:4, 503-509. DOI: 10.1080/00380768.2012.686436

3. Wang, C.; Shen, J.; Liu, J.; Qin, H.; Yuan, Q.; Fan, F.; Hu, Y.; Wang, J.;Wei, Y.; Wu, J. Microbial mechanisms in the reduction of $\mathrm{CH}_{4}$ emission from double rice cropping system amended by biochar: A four-year study. Soil Biol. Biochem. 2019, 135, 251-263. https://doi.org/10.1016/j.soilbio.2019.05.012

4. Wu, Z.; Zhang, X.; Dong, Y.; Li, B.; Xiong, Z. Biochar amendment reduced greenhouse gas intensities in the rice-wheat rotation system: Six-year field observation and meta-analysis. Agric. For. Meteorol. 2019, 278, 107625. https://doi.org/10.1016/j.agrformet.2019.107625

5. Liu, X., Li P., Ma J. Impact of biochar application on yield-scaled greenhouse gas intensity: A meta-analysis. Sciense of the total environmental. 2019. 656. 960-976.

6. Bovsun, M.A.; Castaldi, S.; Nesterova, O.V.; Semal, V.A.; Sakara, N.A.; Brikmans, A.V.; Khokhlova, A.I.; Karpenko, T.Y. Effect of Biochar on Soil $\mathrm{CO}_{2}$ Fluxes from Agricultural Field Experiments in Russian Far East. Agronomy. 2021, 11, 1559. https://doi.org/10.3390/agronomy 11081559

\section{УДК 631.67 (571.13) \\ ВЛИЯНИЕ ДЛИТЕЛЬНОГО СЕЛЬСКОХОЗЯЙСТВЕННОГО ИСПОЛЬЗОВАНИЯ НА ПОКАЗАТЕЛИ ПЛОДОРОДИЯ ОРОШАЕМОЙ ЛУГОВО-ЧЕРНОЗЕМНОЙ ПОЧВЫ \\ Бойко В.С. ${ }^{1}$, Тимохин А.Ю. ${ }^{1}$, Михайлов В.В. ${ }^{1}$ \\ ${ }^{1}$ ФГБНУ «Омский аграрный научный центр», г. Омск \\ E-mail: timokhin@anc55.ru.}

\begin{abstract}
Резюме.Определены показатели плодородия, катионно-анионный состав водной вытяжки орошаемой лугово-черноземной почвы в СПК «Пушкинский» лесостепной зоны Омской области. В результате исследований негативного влияния длительного орошения на показатели плодородия почвы не выявлено.
\end{abstract}

Ключевые слова: орошение, лугово-черноземная почва, Омская область.

Summary.The indicators of fertility, the cation-anionic composition of the water extract of the meadow-chernozem soil in the APC "Pushkinskiy" of the forest-steppe zone of the Omsk region were determined. According to the results of studies, no negative impact on the indicators of soil fertility during its long-term irrigation was revealed.

Key words: irrigation, meadow chernozem soil, Omsk region.

Обеспеченность России природными ресурсами позволяет производить сельскохозяйственную продукцию не только для внутреннего потребления, но и для экспорта в другие страны. Однако стабильность производства зерна в значительной степени зависит от погодных и климатических условий, преобладающих в конкретные годы, которые сильно различаются в разных сельскохозяйственных регионах [1-3].Увеличение производства продукции 
растениеводства осуществляется как за счет освоения новых земель, так и улучшения уже имеющихся на основе комплексной механизации, химизации и мелиорации [4-6].

На фоне отчётливой динамики повышения сумм эффективных температур ограниченный ресурс атмосферного увлажнения сопровождается ростом дефицитов влажности воздуха, что дополнительно снижает биоклиматический потенциал территории $[7,8]$. Оптимизация минерального питания и режим орошения оказывают существенное влияние на величину и ход формирования листовой поверхности и способствуют стабилизации производства сельскохозяйственной продукции $[9,10]$.

Важнейшей задачей орошаемого земледелия является обеспечение длительного эффективного использования пашни на основе формирования высоких урожаев, снижения затрат труда и средств (поливной воды, удобрений, пестицидов и др.) на единицу продукции, а также предотвращения отрицательного воздействия приемов интенсификации на природную среду $[11,12]$.

Цель исследований - определить показатели плодородия, катионно-анионный состав водной вытяжки лугово-черноземной почвывюжной лесостепи Омской области.

Работа выполнялась в СПК «Пушкинский» в южной лесостепной зоне Омской области на землях Пушкинской оросительной системы. Отбор грунтовой воды и почвенных образцов производился в июле 2018 г.

Объект исследований - орошаемая лугово-черноземная, среднемощная, среднегумусная, тяжелосуглинистая почва. В полученных образцах определяли: содержание подвижного фосфора и обменного калия (ГОСТ 26204-91), нитратов (ГОСТ 26488-85), органического вещества (ГОСТ 26213-91) иизмеряли значения рН (ГОСТ 26483-85). Все анализы проводили в ФГБУ «Центр агрохимической службы «Омский». В самой работе использовались методы маршрутного полевого исследования и лабораторные анализы.

Концентрация тяжелых металлов (свинец, кадмий, цинк) в почве СПК «Пушкинский» была в пределах ОДК (ориентировочно допустимых концентраций), что характеризует почвы как незагрязненные (СаНПиН 1.2.3685-21) (таблица 1).

Таблица 1 - Агрохимические свойства почв, СПК «Пушкинский»

\begin{tabular}{|c|c|c|c|c|c|c|c|c|c|}
\hline \multirow{2}{*}{ Поле } & \multirow{2}{*}{$\begin{array}{l}\text { Площадь, } \\
\text { га }\end{array}$} & \multirow{2}{*}{$\mathrm{pH}$} & \multirow{2}{*}{$\begin{array}{c}\text { Гумус, } \\
\%\end{array}$} & \multirow{2}{*}{$\begin{array}{c}\mathrm{N}-\mathrm{NO}_{3}, \mathrm{мг} / \mathrm{кг} \\
\text { почвы в слое } \\
0-0,4 \text { м }\end{array}$} & \multirow{2}{*}{$\begin{array}{c}\mathrm{P}_{2} \mathrm{O}_{5}, \mathrm{мг} / \mathrm{к} \\
\text { почвы в } \\
\text { слое } 0-0,2 \\
\text { м }\end{array}$} & \multirow{2}{*}{$\begin{array}{c}\mathrm{K}_{2} \mathrm{O}, \text { мг/кг } \\
\text { почвы в } \\
\text { слое } 0-0,2 \\
\text { м } \\
\end{array}$} & \multicolumn{3}{|c|}{$\begin{array}{c}\text { Тяжелые металлы, } \\
\text { мг/кг почвы }\end{array}$} \\
\hline & & & & & & & $\mathrm{Pb}$ & $\mathrm{Cd}$ & $\mathrm{Zn}$ \\
\hline 12 & 40 & $\begin{array}{c}\text { не } \\
\text { опр. }\end{array}$ & $\begin{array}{c}\text { не } \\
\text { опр. }\end{array}$ & 8,0 & 129 & 215 & не опр. & не опр. & не опр. \\
\hline 13 & 60 & $-/ /-$ & $-/ /-$ & 13,7 & 121 & 159 & $-/ /-$ & $-/ /-$ & $-/ /-$ \\
\hline 9 & 55 & $-/ /-$ & $-/ /-$ & 12,9 & 120 & 202 & $-/ /-$ & $-/ /-$ & $-/ /-$ \\
\hline 18 & 48 & $-/ /-$ & $-/ /-$ & 6,7 & 145 & 232 & $-/ /-$ & $-/ /-$ & $-/ /-$ \\
\hline 14 & 76 & $-/ /-$ & $-/ /-$ & 7,4 & 116 & 167 & $-/ /-$ & $-/ /-$ & $-/ /-$ \\
\hline 17 & 66 & $-/ /-$ & $-/ /-$ & 8,9 & 125 & 283 & $-/ /-$ & $-/ /-$ & $-/ /-$ \\
\hline 16 & 96 & 5,8 & 6,3 & 10,3 & 129 & 207 & 0,78 & 0,57 & 0,34 \\
\hline 21 & 108 & 6,5 & 6,3 & 4,8 & 117 & 247 & 0,72 & 0,045 & 0,35 \\
\hline
\end{tabular}


Результаты обследования показали, что почва орошаемых массивов СПК «Пушкинский» Омского района Омской области имеет нейтральную и близкую к нейтральной реакцию почвенной среды, благоприятную для возделывания всех основных сельскохозяйственных культур (таблица 1).

Содержание органического вещества среднее, подвижного фосфора - повышенное, обменного калия - высокое и очень высокое. Обеспеченность нитратным азотом - низкая и средняя, что говорит о дефиците минерального питания и необходимости применения минеральных удобрений.

Анализ катионно-анионного состава почвенного профиля орошаемых земель СПК «Пушкинский» выявил отсутствие засоления при нейтральной реакции среды (таблица 2). Концентрация анионов и катионов, в том числе и наиболее токсичных солей не достигает пороговых значений, при которых угнетаются культуры.

\section{Таблица 2 - Катионно-анионный состав водной вытяжки, СПК «Пуш- кино»}

\begin{tabular}{|l|c|c|c|c|c|c|c|c|}
\hline \multirow{2}{*}{\begin{tabular}{c} 
Наименование \\
\multicolumn{1}{c|}{ показателя }
\end{tabular}} & \multicolumn{9}{|c|}{ Слойпочвы, } \\
\cline { 2 - 10 } & $0,0-0,2$ & $0,2-0,4$ & $0,4-0,6$ & $0,6-0,8$ & $0,8-1,0$ & $1,0-1,2$ & $1,2-1,4$ & $1,4-1,8$ \\
\hline рН водный, ед. $\mathrm{pH}$ & 6,4 & 7,3 & 7,2 & 7,7 & 7,2 & 8,1 & 8,2 & 8,1 \\
\hline Плотный остаток, \% & $<0,1$ & $<0,1$ & $<0,1$ & $<0,1$ & $<0,1$ & 0,113 & 0,133 & 0,139 \\
\hline $\begin{array}{l}\text { Карбонат-ион, ммоль / } \\
100 \text { г }\end{array}$ & $<0,07$ & $<0,07$ & $<0,07$ & $<0,07$ & $<0,07$ & $<0,07$ & $<0,07$ & $<0,07$ \\
\hline $\begin{array}{l}\text { Бикарбонат-ион, ммоль } \\
\text { / 100 г }\end{array}$ & 0,25 & 0,56 & 0,56 & 0,56 & 0,56 & 1,05 & 0,86 & 0,79 \\
\hline $\begin{array}{l}\text { Хлорид-ион, ммоль / } \\
100 \text { г }\end{array}$ & 0,04 & 0,08 & 0,04 & 0,04 & 0,12 & 0,08 & 0,04 & 0,08 \\
\hline Кальций, ммоль / 100 г & $<0,5$ & $<0,5$ & $<0,5$ & $<0,5$ & $<0,5$ & $<0,5$ & $<0,5$ & $<0,5$ \\
\hline Магний, ммоль / 100 г & $<0,5$ & $<0,5$ & $<0,5$ & $<0,5$ & $<0,5$ & $<0,5$ & $<0,5$ & $<0,5$ \\
\hline Натрий, ммоль / 100 г & 0,50 & 0,85 & 0,75 & 0,85 & 1,00 & 1,05 & 1,30 & 1,30 \\
\hline $\begin{array}{l}\text { Сульфат-ион, ммоль / } \\
100 \text { г }\end{array}$ & 0,31 & 0,69 & 0,44 & 0,54 & 0,61 & 0,31 & 0,88 & 1,01 \\
\hline
\end{tabular}

Вода исследованных образцов грунтовых вод умеренно пресная, хорошего качества, ирригационный коэффициент - 37,2 (скважина 1) и 78,7 (скважина 2). Величина сухого остатка изменялась от 0,701 до 0,984 г/л, при $\mathrm{pH}-$ 7,9 (таблица 3).

Таблица 3 - Катионно-анионный состав грунтовой воды, Пушкинская ОС

\begin{tabular}{|c|c|c|c|c|c|c|c|c|}
\hline \multirow{2}{*}{$\begin{array}{c}\text { Обозначение } \\
\text { образца }\end{array}$} & \multirow{2}{*}{$\mathrm{pH}$} & \multirow{2}{*}{$\begin{array}{c}\text { Сухой } \\
\text { ост., } \\
\text { г/л }\end{array}$} & \multicolumn{6}{|c|}{$\frac{\text { ммоль/Л }}{\Gamma / л}$} \\
\hline & & & $\mathrm{HCO}_{3}^{-}$ & $\mathrm{Cl}^{-}$ & $\mathrm{Ca}^{2+}$ & $\mathrm{Mg}^{2+}$ & $\mathrm{Na}^{+}$ & $\mathrm{SO}_{4}{ }^{2}$ \\
\hline Скважина 1 & 7,9 & 0,984 & $\frac{8,78}{0,535}$ & $\frac{0,86}{0,030}$ & $\frac{3,60}{0,072}$ & $\frac{5,54}{0,066}$ & $\frac{4,30}{0,099}$ & $\frac{3,80}{0,182}$ \\
\hline Скважина 2 & 7,9 & 0,701 & $\frac{7,01}{0,428}$ & $\frac{0,39}{0,014}$ & $\frac{4,18}{0,084}$ & $\frac{3,02}{0,036}$ & $\frac{2,10}{0,048}$ & $\frac{1,90}{0,091}$ \\
\hline
\end{tabular}

В южной лесостепи проблема высокого уровня грунтовых вод стоит достаточно остро. В этом случае основой профилактики должен стать строго нормированный полив пресной оросительной водой из имеющихся водных источников (р. Иртыш и р. Омь). 
Длительное сельскохозяйственное использольвание орошаемой луговочерноземной почвы в СПК «Пушкинский» привело к снижению нитратного азота, тогда как другие показатели почвенного плодородия ( $\mathrm{pH}$, содержание подвижного фосфора, обменного калия, гумуса и тяжелых металлов) оставались в пределах нормы и обеспечивали благоприятное развитие выращиваемых культур. В тоже время засоления почвенного профиля не выявлено (концетрация натрия в почвенно-поглащающем комплексе $0,23-0,68$ \% от емкости катионного обмена). Таким образом в условиях орошения и высокого уровня грунтовых вод на юге Западной Сибири при нормированном поливе пресной водой, применении минеральных удобрений с учетом потребности растенийможно длительное время сохранять плодородие почвы, обеспечивая высокую урожайность сельскохозяйственных культур.

\section{Библиографический список}

1. Научные основы производства высококачественного зерна пшеницы: науч. издание. М.: ФГБНУ «Росинформагротех», 2018. - 396 с

2. Страшная А. И. Особенности засухи 2012 г. на Урале и в Западной Сибири и ее влиянии на урожайнось яровых зерновых культур / А. И. Страшная, Б. А. Бирман, О. В. Береза // Гидрометеорологические исследования и прогнозы. - 2018. - № 2.- С. 154-169.

3. Алтухов А.И. Проблема повышения качества пшеницы в стране требует комплексного решения / А.И. Алтухов, А.А. Завалин, Н.З. Милащенко, С.В. Трушкин //Вестник Курской государственной сельскохозяйственной академии. - 2020. - № 2. - С. 32-39.

4. Синяков Д. А. Об интенсификации сельского хозяйства в современных условиях / Д. А. Синяков // Актуальные вопросы экономических наук. - № 15-2. - 2010. - С. 214-219.

5. Цораева Э. Н. Изменение свойств почв при снижении воднойнагрузки: монография / Э. Н. Цораева. - Краснодар: КубГАУ,2020. - 186 с.

6. Гуляев Ю. А. Оценка современных биоклиматических ресурсов и перспектив роста урожайности в постцелинных регионах Урала и Западной Сибири / Ю. А. Гуляев // Таврический вестник аграрной науки. - № 4. - 2020. - С. 29-41.

7. Дубенок Н.Н. Системы двухстороннего регулирования водного режима осушаемых земель / Н.Н. Дубенок, К.Б. Шумакова, Р.В. Калиниченко, И.А. Гусейнов. - Москва: Российский государственный аграрный университет - МСХА им. К.А. Тимирязева, 2020. - 142 с.

8. Ермохин Ю. И. Интеграционная система почвенно-растительной диагностики как комплексный метод триединства развития агрохимии в настоящем и будущем: к 100-летию Омского государственного аграрного университета им. П. А. Столыпина и к 50-летию научнопедагогической школы кафедры агрохимии и почвоведения: в 2 т. / Ю. И. Ермохин. - Омск, 2020. - T. 1. -314 c.

9. Cutting-edge research in agricultural sciences. - London: B P International, 2021. - 143 p.

10. Технология возделывания новых сортов гороха в Омской области: рекомендации. Омск, 2014. - 25 с.

11. Бойко В. С. Энергетическая оценка агротехнологии зернобобовых культур в орошаемых агроценозах / В.С. Бойко, А.Ю. Тимохин // Вестник Ульяновской государственной сельскохозяйственной академии. - № 4. - 2020. - С. 49-55.

12. Тимохин А.Ю. Зернобобовые культуры в системе орошаемого агроценоза: монография / А.Ю. Тимохин, В.С. Бойко. - Омск: ФГБНУ «Омский АНЦ», 2021. - 164 с. 


\title{
СОЗДАНИЕ КРУПНОМАСШТАБНОЙ ЦИФРОВОЙ ПОЧВЕННОЙ КАРТЫ РОСТОВСКОЙ ОБЛАСТИ
}

\author{
Болдырева В.Э. ${ }^{1}$, Жолудев Р.О. ${ }^{1}$, Кайдалова Н.В. ${ }^{2}$, Крупенина Е.Б. ${ }^{2}$, \\ Кучменко Е.В. ${ }^{1}$, Литвинов Ю.А. ${ }^{1}$, Меженков А.А. ${ }^{1}$, Минаева Е.Н. ${ }^{1}$ \\ ${ }^{1}$ ФГАОУ ВО «Южный федеральный университет, г. Ростов-на-Дону \\ ${ }^{2}$ ФГБУ ГЦАС «Ростовский», п. Рассвет, Ростовская обл. \\ E-mail: aotpo.nfhfolpc@yandex.ru
}

\begin{abstract}
Резюме. В настоящее время актуальным является вопрос использования архивной и актуальной почвенной информации для решения задач агроэкологической оченки, охрань и рачионального использования земельных ресурсов. Крупномасштабные почвенные карты содержат исчерпывающую информачию о почвенном покрове, что дает возможность успешно решать эти задачи.
\end{abstract}

Summary. Currently, the issue of using archival and relevant soil information to solve the problems of agroecological assessment, protection and rational use of land resources is relevant. Large-scale soil maps contain comprehensive information about the soil cover, which makes it possible to successfully solve these problems.

Крупномасштабные почвенные карты, как наиболее информативные заслуживают особого внимания, поскольку на основе этих данных могут решаться многие практические задачи: расчет кадастровой стоимости земель сельскохозяйственного назначения, агроэкологический мониторинг земель и т.д.

Для территории Ростовской области накоплен большой объем архивной информации о почвенном покрове: среднемасштабные почвенные карты (1:300 000 - 100 000), крупномасштабные почвенные карты и очерки $(1: 10000-1: 25$ 000), составленные НИИ ЮжГипрозем в период с 1954 по 1995 годы. Основную часть крупномасштабных картографических материалов составляют данные второго и третьего тура почвенных обследований, завешенных в 1970 - 80 годах [3].

Ростовская область - один из ведущих сельскохозяйственных регионов России. Она находится на юго-западе Европейской части России и занимает обширную территорию в речном бассейне Нижнего Дона. Согласно природносельскохозяйственному районированию земельного фонда России область преимущественно расположена в умеренном природно-сельскохозяйственном поясе, в двух зонах - степной зоне обыкновенных и южных черноземов и сухостепной зоне темно-каштановых и каштановых почв. В восточной части области сухостепная зона переходит в полупустынную, которая занимает $1.2 \%$ от общей территории области. Максимальная высота над уровнем моря составляет 253 м. С севера на территорию области заходит Среднерусская возвышенность, на западе вклинивается восточная часть Донецкого кряжа, в юго-восточной части возвышаются Сальско-Манычская гряда и Ергенинская возвышенность [1]. Площадь Ростовской области составляет более 10 млн. га. Сельскохозяйственные угодья занимают 8,2 млн га, пашня - 5,9 млн га, в том числе орошаемая 231 тыс. га. [5] 
Для оцифровки крупномасштабных почвенных карт была использована методика, разработанная на базе факультета почвоведения Московского государственного университета и кафедры почвоведения и оценки земельных ресурсов Южного федерального университета [2]. В процессе работы используется следующее программное обеспечение: Adobe Photoshop, Google Earth Pro, ArcGIS 10.2.

Первым и ответственным этапом векторизации является инвентаризация имеющейся почвенной информации.

Результатом инвентаризации является список картографических данных с указанием таких параметров, как масштаб, год создания топографической основы, год почвенного обследования, год составления почвенного очерка и его комплектация.

Согласно схеме хозяйств Ростовской области (1963), на территории Ростовской области насчитывалось порядка 1000 хозяйств - колхозов, совхозов, подсобных хозяйств и сортоиспытательных участков. В настоящий момент, на базе ФГБУ ГЦАС «Ростовский» и кафедре почвоведения ЮФУ удалось собрать 617 крупномасштабных почвенных карт и сопутствующих материалов, выполненных за указанный период (1954-1995 гг.) [3].

Эффективное использование архивных материалов возможно, только в случае структурирования семантической составляющей карт и создания на их основе цифровых картографических материалов [2].

Для создания списка-классификатора почв названия почвенных выделов, представленные в легендах почвенных карт, разбиваются на составные элементы, т.е. выполняется процедура дизагрегации.

Под дизагрегацией нами понимается разделение почвенных наименований на таксономические единицы без потери связи между ними. В рамках работ по формированию списка-классификатора почв наименования почв на всех таксономических уровнях приводились в соответствии с классификацией и диагностикой почв СССР 1977 г., в случае отсутствия аналогов указывались региональные (местные) наименования почв [3]. Гранулометрический состав почвенных выделов представлен по классификации Качинского Н.А. Почвообразующие и подстилающие породы включают наименования в соответствии с картой почвообразующих пород Ростовской области под ред. Клименко 1977 г. и списком почв Ростовской области НИИ ЮжГипрозем (1988).

В связи со сложностью исходных картографических материалов и низким качеством сканированных изображений перед выполнением геореференсации в пакете программ ArcGIS была выполнена предварительная привязка в программе Google Earth [2].

В качестве ортофотоплана для привязки почвенной карты, были использованы актуальные спутниковые снимки ESRI Imagery с пространственным разрешением 0,6-15 м/пиксель, которые доступны в приложении ArcGIS 10.2 [6].

Векторизация почвенной карты представляет собой выделение почвенных контуров в виде полигонов по геореференсированной почвенной карте с 
возможной корректировкой некоторых объектов (лесных массивов, населенных пунктов, русел рек и т.д.) по космическому снимку. Предварительно в векторном слое создана шапка таблицы атрибутов согласно установленному локальному стандарту. После векторизации была проведена проверка качества векторизации почвенной карты на отсутствие ошибок топологии и геометрии.

Атрибутивная информация векторной почвенной карты внесена согласно легенде почвенной карты, либо по экспликации в очерке почвенного обследования (при отсутствии легенды).

Поскольку векторизация крупномасштабных почвенных карт проводилась отдельно по хозяйствам, необходимо было произвести сведение границ смежных хозяйств для корректной работы с единым слоем в дальнейшем. Сведение границ может проводиться как при помощи инструментов ArcMap (разбиение полигонов, удаление части полигона, автозавершение полигона и т.д.) либо вручную (в режиме редактирования) при выполнении сведения на сложных участках (например, по руслу реки) либо при корректировке границы.

Результатом векторизации является цифровая почвенная карта, составленная из 581 карты хозяйств Ростовской области в масштабе от 1:10000 до 1:25000. Наиболее хорошо крупномасштабными почвенными картами закрываются Зерноградский, Заветинский, Матвеево-Курганский, Неклиновский и некоторые другие районы. Очень слабо закрываются почвенными картами Орловский и Азовский районы, где отсутствует более половины хозяйств.

Оцифрованные крупномасштабные почвенные карты являются частью почвенной базы данных ФБГУ ГЦАС «Ростовский». Они используются при составлении отчетов о мониторинге состояния плодородия земель сельскохозяйственного назначения Ростовской области, а также в работе веб-приложений («Расчет нормативной урожайности сельскохозяйственных культур», «Почвенная карта Ростовской области»).

\section{Библиографический список}

1. Безуглова О.С., Хырхырова М.М. Почвы Ростовской области: учебное пособие / Ростов-на-Дону: Изд-во ЮФУ, 2008. - 352 с.

2. Голозубов О.М., Литвинов Ю.А., Колесникова В.М. Методическое пособие «Векторизация крупномасштабных почвенных карт». Электронная версия. М. 2020. - 72 с.

3. Литвинов Ю.А. Инвентаризация, гармонизация и анализ разнородных почвенно-географических данных для целей агроэкологического мониторинга (на примере ростовской области) / диссертация на соискание ученой степени кандидата биологических наук, Москва, 2018. - 230 с.

4. Меженков А.А., Карюк И.Н. Описание цифрового реестра почв ростовской области / Сборник трудов конференции «V Вильямсовские чтения - «Генетическая и агрономическая оценка почв»»)/ Москва, 2020.

5. Официальный портал Правительства Ростовской области / сельское хозяйство и АПК (https://www.donland.ru/activity/193/) (06.09.2021)

6. Снимки высокого и сверхвысокого разрешения на территорию России и СНГ (https://blogs.esri-cis.ru/2020/06/11/imagery-basemap/) (06.09.2021) 
УДК 631.445 .4

\title{
ОСОБЕННОСТИ РАЗВИТИЯ ПОЧВЕННОЙ МИКРОФЛОРЫ ПРИ ИСПОЛЬЗОВАНИИ ПОБОЧНОЙ ПРОДУКЦИИ НА УДОБРЕНИЕ
}

Брескина Г.М.

ФГБНУ «Курский федеральный аграрный научный центр», г. Курск

E-mail: breskina-galina@yandex.ru

\begin{abstract}
Резюме. Проведены исследования по выявлению эффективности использования побочной продукиии культур на удобрение в условиях зернопропашного севооборота: "сахарная свекла - ячмень - горох - озимая пшеница» проводились на черноземе типичном Курской области. Получены положсительные результаты по увеличению содержания углерода микробной биомассы по фону внесения побочной продукиии культур севооборота в качестве удобрения в сочетании со средними дозами ( $N_{170} P_{210} K_{210}$ за севооборот) минеральных удобрений и одинарной дозой извести - 50кг/на $1 \mathrm{~m}$ соломьл.
\end{abstract}

Последние 20 - 30 лет в России активно ведутся исследования по изучению экологически безопасных способов поддержанию и восстановлению органического вещества почвы. Основным источником органического вещества почвы является негумифицированное вещество, растительного или животного происхождения. Однако, в агроэкосистемах нарушается равновесие между поступающим органическим вещество и выносимым, с полей в виде урожая. Эта проблему можно было решить путем применения навоза, но из-за реформ в конце 90 -х родов прошлого столетия резко сократилось поголовье крупного рогатого скота, что привело к дефициту подстилочного навоза. В настоящее время на 1 га посева вносят 1,1 - 1,2 т органических удобрений в переводе на подстилочный навоз, что составляет не более 12-15 \% обеспеченности [1]. В связи с этим альтернативным источником пополнения органического вещества почвы могут являться растительные послеуборочные остатки: солома злаковых, стебли подсолнечника и кукурузы.

Различные подходы к использованию земель сельскохозяйственного назначения первоначально отражаются на биологических параметрах плодородия, а именно, биологической активности почв [2].

Пожнивно-корневые остатки оцениваются как важный ресурс для поддержания плодородия почв и сохранения устойчивости агроэкосистем $[3,4,5$,$] и$ служат основным доступным энергетическим материалом источником углерода и биогенных элементов, поэтому являются основным фактором, регулирующим микробиологическую деятельность в почвах $[6,7,8$,

Регулярное внесении соломы зерновых и зернобобовых культур в сочетании со средними дозами минеральных удобрений способствовало активизации почвенно-микробиологических процессов, поддержанию стабильного и более высокого уровня биологических показателей почвы, приближенного к залежным почвам с травянистым фитоценозом [9].

Состояние микробной микрофлоры почвы зависит от многих факторов реакции среды, запасов качественного состава органического вещества, физических свойств почвы, биологии произрастающих на данном угодье 
растительных сообществ, степени окультуренности пахотных почв. На активность микробиологических процессов влияют агрометеорологические условия вегетационного периода, особенно влагообеспеченность почвы [10].

Наиболее активное разложение соломы идет в верхнем слое (0-3 cм), о чем свидетельствует ее связь с целлюлозолитическими микроорганизмами. В зависимости от глубины заделки соломы основной вклад в минерализационные процессы (выделение $\mathrm{CO}_{2}$ ) вносят разные группы микроорганизмов [11].

Цель работы заключалась в оценке биологического состояния чернозема типичного при использовании побочной продукции сельскохозяйственных культур зернопропашного севооборота на удобрение при разных уровнях удобренности (внесение различных доз минеральных удобрений и извести).

Исследования по изучению содержания углерода микробной биомассы и целлюлозолитической активности чернозема типичного были проведены в полевом опыте, расположенный в опытном хозяйстве ФГБНУ «Курский федеральный научный центр» Медвенского района Курской области на водораздельном плато. Почвенный покров участка представлен черноземом типичным малогумусным тяжелосуглинистым на карбонатном лессовидном суглинке. Содержание гумуса - 5,34-5,56 \%, обменно-поглощенного кальция - 26,0-28,6 мг-экв на 100 г. почвы. Реакция среды нейтральная или близкая к нейтральной: $\mathrm{pH}$ водн. составляет $-6,6-7,5$, а $\mathrm{pH}$ солевой $-6,1-7,2$.

Влияние различных доз минеральных удобрений и извести на фоне использования побочной продукции в качестве органического удобрения изучалось в севообороте «сахарная свекла - ячмень - горох - озимая пшеница». Полнофакторная схема опыта включала 3 уровня доз извести $(0,1,2)$ и 4 уровня доз минеральных удобрений $(0,1,2,3)$. Те же дозы минеральных удобрений и извести изучались параллельно и на фоне внесения растительных остатков. Одинарная доза минеральных удобрений под сахарную свеклу $-\mathrm{N}_{90} \mathrm{P}_{90} \mathrm{~K}_{90}$, ячмень и озимую пшеницу $-\mathrm{N}_{40} \mathrm{P}_{40} \mathrm{~K}_{40}$, горох $-\mathrm{P}_{40} \mathrm{~K}_{40}$. Одинарная доза извести0,15 т/га. Количество используемой на удобрение побочной продукции (соломы и ботвы) строго дозировалось по 2 т/га сухого органического вещества по3 т/га соломы и 15 т/га ботвы. Таким образом, сочетанию с одинарными и двойными дозами извести соответствовали соотношения 50/10 и 100/20 кг извести на одну тонну соломы/ ботвы. Площадь делянок $-20 \mathrm{~m}^{2}$. Повторность 4$\mathrm{x}$ кратная. Определение микробной биомассы (МБ) проводили в свежих почвенных образцах - регидратационным методом [12]. Экспериментальные данные обработаны методами дисперсионного и корреляционно-регрессионного анализов с использованием программных средств Microsoft office EXCEL.

Использованием соломы злаковых под сахарную свеклу как органического удобрения с различными дозами минеральных удобрений и известняковой муки показало, что наибольшая МБ во все сроки исследований была при внесении низкой дозы извести (50 кг на 1 т соломы) как отдельно, так и совместно со средней дозой минеральных удобрений $-\mathrm{N}_{90} \mathrm{P}_{90} \mathrm{~K}_{90}$, что наглядно демонстрируют данные таблицы 1. 
На вариантах с внесением повышенных $\mathrm{N}_{180} \mathrm{P}_{180} \mathrm{~K}_{180}$ и высоких $\mathrm{N}_{270} \mathrm{P}_{270} \mathrm{~K}_{270}$ доз минеральных удобрений количество МБ снижалось не только по фону без извести, но и при внесении их с известью в дозе и 50 и 100 кг/т соломы. Это свидетельствует о том, что при интенсификации процесса поверхностного компостирования соломы озимой пшеницы необходимо создавать благоприятные условия для развития микроорганизмов, участвующих в процессе трансформации энергии органического вещества, ограничиваясь средними дозами минеральных удобрений с низкой дозой извести.

В период кущения ячменя, содержание микробной биомассы при использовании растительных остатков сахарной свеклы как органических удобрений было практически выше на всех вариантах внесения минеральных удобрений и извести, чем на тех же вариантах, но без ботвы сахарной свеклы на - 40-240 мг на 1 кг почвы или на 4,5-33,0 \% по фону извести и на 3,0-17,3 \% - по фону без извести. Так как лето было жарким и сухим, то к периоду уборки ячменя количество микробной биомассы в почве заметно уменьшилось и на фоне растительных остатков с известью (с 728-967 до 393-528 мг/кг), и на фоне без извести (с 697-884 до 333-499 мг/кг). Но закономерность оставалась такой же: по фону ботвы сахарной свеклы содержание МБ практически по всем удобренным вариантам с известью было выше на 11,3-20,8 \%, а по фонам без извести - на 10,3-14,3 \% по сравнению с фоном без растительных остатков. Это говорит о полезности растительных остатков для живых микроорганизмов, несмотря на значительную антропогенную нагрузку на почву (сельскохозяйственная техника и минеральные удобрения).

Определение содержания МБ в период созревания гороха и его уборки показало, что интенсивность и направленность продукционного процесса при использовании соломы ячменя в качестве органического удобрения была значительно выше на всех вариантах внесения минеральных удобрений и извести, нежели без внесения соломы. Это превышение в период созревания гороха было максимальным при поверхностном компостировании соломы с фосфорно-калийными удобрениями в дозе по 40 кг д.в. с известью в дозе 50 кг/т (73,6 и 76,8 \% соответственно).

В период же уборки гороха максимальное содержание МБ было при внесении минеральных, фосфорно-калийных удобрений без извести и превышало фон без соломы на 59,0-73,9 \%. По остальным фонам удобрений и извести увеличение микробной биомассы колебалось, но по всем вариантам оно было выраженным. В период уборки отмечено практически одинаковое содержание микробной биомассы по всем фонам фосфорно-калийных удобрений и обеим дозам извести с соломой ячменя (616-685 и 693-655 мг/кг почвы). Это связано с тем, что горох является культурой, которая хорошо отзывается на внесение кальцийсодержащих соединений, а также хорошо использует кальций почвы, подтягивая его к поверхности.

В период вегетации озимой пшеницы по гороху содержание МБ по фонам растительных остатков, минеральных удобрений и извести на отдельных вариантах было более низким, нежели по фонам минеральных удобрений и извести 
без соломы (вар. $4,5,8,10,12$ ). Причем, снижение содержания микробной биомассы было неодинаковым и колебалось от 14 до 71 мг/кг (от 1,9 до 9,4 \%), и закономерность какая-либо отсутствовала, что может быть связано с резкими изменениями погоды (колебания температуры воздуха составляли до $20^{\circ} \mathrm{C}$ при отсутствии осадков). Но к периоду уборки развитие микробной биомассы стабилизировалось, улучшились условия увлажнения, и солома гороха стала энергетическим материалом для микрофлоры, что и отразилось на содержании микробной биомассы. По фону соломы гороха оно стало выше на всех вариантах минеральных удобрений и извести по сравнению с фоном без соломы.

Для формирования урожая озимой пшеницы, вероятно, большое влияние оказало содержание микробной биомассы в период вегетации. Поэтому и урожайность озимой пшеницы на вариантах внесения минеральных удобрений по фону соломы с известью в дозе 100 кг/т была несколько выше урожайности по тем же фонам минеральных удобрений и извести без соломы.

При оценке величин МБ под разными культурами и в разные сроки ( в среднем по опыту) просматриваются следующие закономерности: 1) величины содержания МБ под культурами в целом зависят от качества внесенных под них растительных остатков (соломы ячменя, гороха и озимой пшеницы); 2) содержание МБ по уборке культур и его различия между сроками отбора сопряжены с погодными условиями учетного периода, оцененные в данном случае гидротермическим коэффициентом по Селянинову. Например, в 2007 году засушливые условия вегетационного периода ячменя ГТК $=0,95$, обусловили снижение микробной биомассы к уборке культуры в 2 раза (рис. 1).

Характер влияния агрохимических факторов (растительные остатки, известь и минеральные удобрения) на содержание микробной биомассы в почве в посевах зерновых культур зернопропашного севооборота был аналогичным. При этом поверхностное компостирование растительных остатков (ПК РО) повышало содержание микробной биомассы (МБ) по вегетации культур в среднем на 50 мг/кг (8\%), а по уборке на 100 мг/кг (19\%).

Сочетание известкования с минеральными удобрениями повышало МБ во время вегетации культур на 100 мг/кг (15\%), как по фону внесения побочной продукции на удобрение, так и без нее. По уборке культур положительный эффект от сочетания известкования с минеральными удобрениями, как по фону ПК РО, так и без него показатель МБ составлял уже 200 мг/кг (40-50 \%). При этом характер нелинейной зависимости указывает на то, что по фону ПК РО повышенные дозы минеральных удобрений не имеют депрессирующего действия на МБ, как в случае без внесения растительных остатков.

По дисперсионному анализу данных за три года с зерновыми культурами (ячмень, горох, озимая пшеница) установлено, что наибольший эффект в варьирование содержания МБ в почве оказал срок отбора, а влияние культуры и удобрений было примерно равным (рис.). 


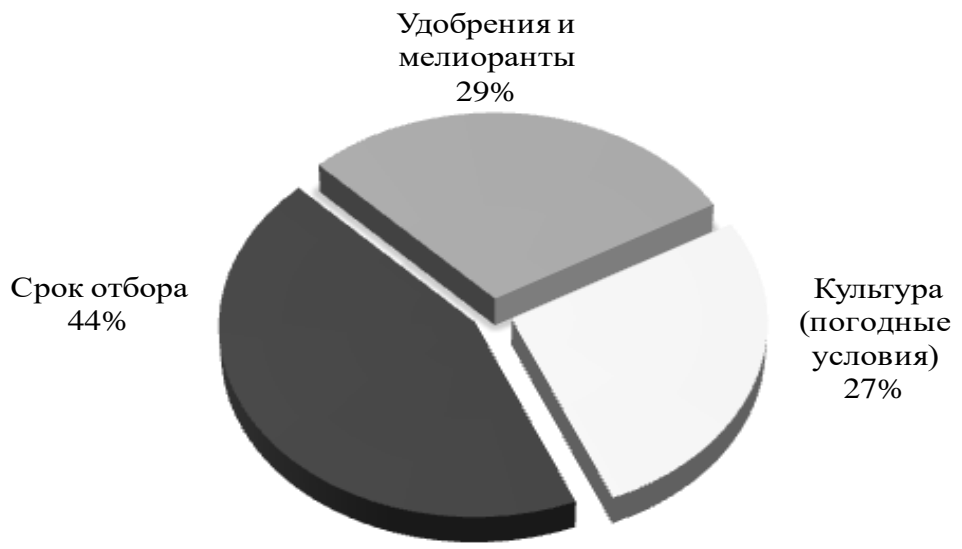

Рисунок - Доля вклада агрогенных факторов в варьирование содержания микробной биомассы в черноземе типичном

Таким образом, внесение побочной продукции с минеральными удобрениями снимало отрицательное влияние повышенных и высоких доз минеральных удобрений на показатели биологического качества почвы: возрастало содержание микробной биомассы в среднем на 8-19 \% в зависимости от доз минеральных удобрений.

Отсюда следует, что растительные остатки способствуют максимальному улучшению биологических свойств почвы (увеличение содержания микробной массы, интенсивности целлюлозолитической активности) только при внесении средних доз $\left(\mathrm{N}_{170} \mathrm{P}_{210} \mathrm{~K}_{210}\right.$ за севооборот) минеральных удобрений в сочетании с низкой дозой извести (50 кг на 1 т соломы и 10 кг на 1 т ботвы).

\section{Библиографический список}

1. Сельское хозяйство России. М.: МСХ РФ, 2014. 48c.

2. Полякова Н. В., Платонычева Ю.Н., Володина Е.Н. Содержание гумуса и биологическая активность пахотных темно-серых лесных почв / / Материалы международной научнопрактической конференции. Агрохимия и экология: история и современность. - Нижний Новгород.: 2008. - С.79.

3. Коновалов Н.Д., коновалов С.Н. Побочная продукция урожая как источник восполнения плодородия черноземов Тамбовской области // Агрохимия. 2007. №8. С. 5-10.

4. Назарюк В.М., Калимуллина Ф.Р. Влияние удобрений и растительных остатков на плодородие почвы, продуктивность и химический состав зерновых культур // Агрохимия. 2010. №6. С. 18-27.

5. Серая Т.М., Богатырева Е.Н., Бирюкова О.М., Мезенцева Е.Г. Высвобождение элементов питания при заделке соломы в дерново-подзолистые почвы в зависимости от ее видового состава и удобрения азотом // Агрохимия. 2013. №3. С. 52-59.

6. Аристовская Т.В. Микробиологические аспекты плодородия почв // Почвоведение. 1988. №9. С. 53-69.

7. Туев Н.А. Микробиологические процессы гумусообразования, М., Агропромиздат, 1989. - 108c.

8. Семенов В.М., Ходжаева А.К. Агроэкологические процессы растительных остатков в почве // Агрохимия. 2006. №7. С. 63-81.

9. Русакова И.В. Влияние длительного применения соломы и минеральных удобрений на биологические свойства дерново-подзолистой почвы // Агрохимия. 2017. №8. С. 16-24.

10. Юмашев Х.С., Захарова И.А. Микробиологическая активность выщелоченного чернозема при различных способах утилизации соломы // Плодородие. 2018. №2. С. 33-35.

11. Благодатский С. А., Благодатская Е.В., Горбенко А.Ю., Панников Н.С. 
Регидратационный метод определения биомассы микроорганизмов почвы // Почвоведение. 1987. №4. С. 64-71.

УДК 632.07:632.95.028

\title{
ВИДОВОЙ СОСТАВ И ЧИСЛЕННОСТЬ ОСНОВНЫХ ФИТОФАГОВ И ЭНТОМОФАГОВ НА ОПЫТНЫХ ПОЛЯХ КУРСКОГО ФАНЦ В СТАЦИОНАРНОМ ОПЫТЕ
}

\author{
Вавин В.Г. \\ ФГБНУ «Курский ФАНЦ», г. Курск \\ E-mail:vavin_vg@mail.ru
}

\begin{abstract}
Резюме. Представлены результаты фитосанитарного мониторинга по изучению биоразнообразия, видового состава и распространения вредителей и полезной энтомофауны в севообороте. На озимой пшенице выявлено 34 вида фитофагов, принадлежаших к 12 семействам и 8 основным видов энтомофагов, принадлежащих к 5 семействам.
\end{abstract}

Ключевые слова: вредители, энтомофаги, видовой состав, мониторинг, севооборот.

Современные технологии возделывания сельскохозяйственных культур в системе мероприятий по уходу за посевами обязательно предусматривает комплекс мероприятий, направленных на снижение численности вредных организмов. Превалирующим методом борьбы остается химический, хотя и имеет ряд негативных последствий влияния на окружающую природную среду и качество растениеводческой продукции.

Разработке любых мероприятий по борьбе с вредителями должны предшествовать энтомологические исследования по выявлению видового состава как фитофагов, так и полезной энтомофауны, который в существенной степени отличается по зонам возделывания зерновых, а также зависит от погодных условий [1].

Видовой состав энтомофауны складывается на основе местной фауны агроценоза и прилегающих к нему биотопов, за счет ближних и дальних мигрантов с мест зимовки и очагов акклиматизации. Существенное влияние на формирование энтомофауны посевов оказывает предшествующая культура и севооборот в целом.

В Курской области зерновые повреждают более 100 вредителей [2]. Многие из них могут нанести существенный вред посевам в благоприятные для них годы массового размножения.

В этой связи исследование видового состава и численности основных фитофагов, как и их природных врагов - энтомофагов являются весьма актуальными.

Методика исследований. Исследования видового состава фитофагов и связанной с ними полезной энтомофауны проводились с 2000 года и проводятся до сегодняшнего времени на опытных участках стационарного полевого опыта в севообороте по изучению сочетания биологических и антропогенных факторов воспроизводства плодородия почв на пашне Медвенского района Курской области. Фенологические наблюдения за развитием насекомых проводились по методике Б.В. Добровольского (1969). 
Учеты перезимовавших вредителей проводились путем почвенных раскопок в слое 0-25 см с помощью лопаты с извлечением насекомых вручную методом просеивания. Размер пробной площадки $0,0625 \mathrm{~m}^{2}(0,25$ х 0,25 м). Пробы почвы отбирались по диагонали поля из расчета 8 проб с 1 га с последующим пересчетом на $1 \mathrm{~m}^{2}$.

Результаты исследований. Численность многоядных личинок вредных представителей энтомофауны в почве под посевами различных культур севооборота по результатам весеннего обследования 2021 года в сравнении с аналогичным осенним обследованием 2020 года представлены в таблицах 1-3.

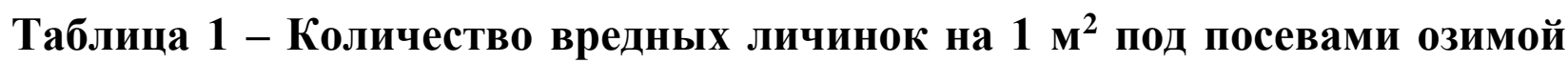
пшеницы и ячменя в слое почвы 0-25 см

\begin{tabular}{|c|c|c|c|c|c|c|}
\hline \multirow[b]{2}{*}{$\begin{array}{l}\text { Вредитель } \\
\text { (личинка) }\end{array}$} & \multicolumn{3}{|c|}{ Озимая пшеница } & \multicolumn{3}{|c|}{ Ячмень } \\
\hline & $\begin{array}{c}2020 г . \\
\text { (осень) }\end{array}$ & $\begin{array}{l}\text { 2021г. } \\
\text { (весна) }\end{array}$ & среднее & $\begin{array}{l}2020 \text { г. } \\
\text { (осень) }\end{array}$ & $\begin{array}{l}2021 \text { г. } \\
\text { (весна) }\end{array}$ & среднее \\
\hline Щелкуны & 5,4 & 3,3 & 4,35 & 4,4 & 5,3 & 4,85 \\
\hline Хлебная жужелица & 1,1 & 1,0 & 1,05 & 1,5 & 0,7 & 1,2 \\
\hline Майский жук & 0,8 & 1,0 & 0,9 & 0,3 & 1,3 & 0,8 \\
\hline Совки (зерновая, серая) & 3,3 & 2,7 & 3,0 & 0,9 & 2,0 & 1,45 \\
\hline Всего: & 10,6 & 8,0 & 9,3 & 7,1 & 9,3 & 8,2 \\
\hline
\end{tabular}

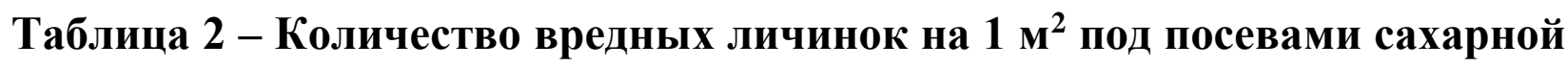
свеклы и на пару в слое почвы 0-25 см

\begin{tabular}{|l|c|c|c|c|c|c|}
\hline \multirow{2}{*}{\begin{tabular}{c}
\multirow{2}{*}{$\begin{array}{c}\text { Вредитель } \\
\text { (личинка) }\end{array}$} \\
\cline { 2 - 7 }
\end{tabular}} & $\begin{array}{c}|c| \\
\text { 2020г. } \\
\text { (осень) }\end{array}$ & $\begin{array}{c}2021 \text { г. } \\
\text { (весна) }\end{array}$ & среднее & $\begin{array}{c}2020 \text { г. } \\
\text { (осень) }\end{array}$ & $\begin{array}{c}2021 \text { г. } \\
\text { (весна) }\end{array}$ & среднее \\
\hline Щелкуны & 5,1 & 3,3 & 4,2 & 4,8 & 4,0 & 4,4 \\
\hline Хлебная жужелица & 0,96 & 0,7 & 0,8 & 1,1 & 0,7 & 0,9 \\
\hline Майский жук & 1,0 & 0,7 & 0,85 & 0,5 & 0,7 & 0,6 \\
\hline Совки (зерновая, серая) & 2,1 & 2,0 & 2,05 & 1,8 & 2,0 & 1,9 \\
\hline Всего: & 9,1 & 6,7 & 7,9 & 8,2 & 7,4 & 5,6 \\
\hline
\end{tabular}

Таблица 3 - Количество вредных личинок на 1 м $^{2}$ на полях, предназначенных под посев кукурузы и подсолнечника в слое почвы 0-25 cм

\begin{tabular}{|c|c|c|c|c|c|c|}
\hline \multirow[b]{2}{*}{$\begin{array}{l}\text { Вредитель } \\
\text { (личинка) }\end{array}$} & \multicolumn{3}{|c|}{ Кукуруза } & \multicolumn{3}{|c|}{ Подсолнечник } \\
\hline & $\begin{array}{l}2020 \text { г. } \\
\text { (осень) }\end{array}$ & $\begin{array}{l}2021 \text { г. } \\
\text { (весна) }\end{array}$ & среднее & $\begin{array}{l}2020 \text { г. } \\
\text { (осень) }\end{array}$ & $\begin{array}{c}2021 \text { г } \\
\text { (весна) }\end{array}$ & среднее \\
\hline Щелкуны & 2,8 & 3,4 & 3,3 & 3,1 & 2,7 & 2,9 \\
\hline Хлебная жужелица & 1,0 & 0,8 & 0,9 & 1,7 & 2,0 & 1,85 \\
\hline Майский жук & 0,5 & 0,1 & 0,3 & 0,2 & 0,3 & 0,25 \\
\hline Совки (зерновая, серая) & 1,3 & 1,8 & 1,5 & 1,9 & 0,9 & 1,4 \\
\hline Всего: & 5,6 & 6,1 & 5,85 & 6,9 & 5,9 & 6,4 \\
\hline
\end{tabular}

Таким образом, в пересчете на 1 га площади под посевами среднее общее содержание личинок фитофагов составляет:

оз. пшеница - 93000 особей;

ячмень - 82000 особей;

сахарная свекла - 79000 особей; 
кукуруза - 58500 особей;

подсолнечник - 64000 особей;

пар - 56000 особей.

Кроме того, следует учесть и большое количество полезных почвообитающих организмов: дождевые черви, мокрицы, ложноскорпионы, энхитреи, нематоды, ногохвостки, продуры, коллемболы, улитки, сороконожки и многих других, составляющих биоразнообразие агроценоза [2].

В целом в результате наших многолетних учетов и наблюдений, на 1 га агроценоза опытного участка в среднем приходится: 0,3-0,5 кг птиц; 2-3 кг грызунов и насекомоядных млекопитающих, около 300 кг членистоногих [3, 4].

Результаты исследований видового состава вредителей и энтомофагов озимой пшеницы и их встречаемости обобщены в таблице 4.

Таблица 4 - Видовой состав вредителей, энтомофагов и болезней озимой пшеницы в стационарном опыте

\begin{tabular}{|c|c|c|c|}
\hline \multirow[t]{2}{*}{ Вид } & \multicolumn{3}{|c|}{$\begin{array}{c}\text { Частота встречаемости в годы } \\
\text { исследований }\end{array}$} \\
\hline & 2019 & 2020 & 2021 \\
\hline 1 & 2 & 3 & 4 \\
\hline \multicolumn{4}{|l|}{ Фитофаги } \\
\hline Клоп-черепашка (Eurygaster integriceps) & ++ & ++ & ++ \\
\hline Элия остроголовая (Aelia acuminata) & - & - & + \\
\hline Пьявица красногрудая (Lema melanopus) & ++ & ++ & ++ \\
\hline Пьявица синяя (Lema lichensis) & - & - & ++ \\
\hline Блошка хлебная полосатая (Phyllotreta vittula) & ++ & ++ & ++ \\
\hline Хлебная обыкн. жужелица (Zabrus gibbus) & + & + & + \\
\hline Щелкун посевной (Agriotes sputators) & ++ & ++ & ++ \\
\hline Щелкун темный (Agriotes obscurus) & + & + & + \\
\hline Жук-кузька (Anisoplia austriaca) & + & + & + \\
\hline Злаковая тля (Schizaphis graminum) & ++ & ++ & ++ \\
\hline Пшеничный трипс (Haplothrips tritici) & ++ & ++ & ++ \\
\hline Хлебный пилильщик (Cephus pygmaeus) & ++ & ++ & ++ \\
\hline Овсяная шведская муха (Oscinella frit) & + & + & + \\
\hline Ячменная шведская муха (Oscinella pusilla) & + & ++ & + \\
\hline Гессенская муха (Mayetiola destructor) & + & + & + \\
\hline Опомиза пшеничная (Opomyza florum) & ++ & + & + \\
\hline Пшеничная муха (Fhorbia floralis) & + & + & + \\
\hline Озимая совка (Agrotis segetum) & + & + & + \\
\hline \multicolumn{4}{|l|}{ Энтомофаги } \\
\hline Кокцинелла семиточечная (Coccinella septempunctata) & ++ & ++ & ++ \\
\hline $\begin{array}{l}\text { Разноцветная азиатская божья коровка (Harmonia } \\
\text { axyridis) }\end{array}$ & - & - & + \\
\hline Златоглазка (Chrysoperla carnea) & ++ & ++ & ++ \\
\hline Мухи - журчалки (Syrphidae) & ++ & ++ & ++ \\
\hline Мухи - фазии (Tachinidae) & + & + & + \\
\hline Теленомус (Telenomus chloropus) & + & + & + \\
\hline Трихограмма (Trichogramma evanescens) & + & + & + \\
\hline
\end{tabular}


Из таблицы можно выявить наиболее массовые виды, которые могут повлиять на развитие фитосанитарной ситуации [5].

Выводы. На основании проведенного мониторинга на территории стационарного опытного участка по изучению оптимального сочетания биологических и антропогенных факторов воспроизводства плодородия почв на пашне в севообороте было выявлено на озимой пшенице 34 вида фитофагов, относящихся к 12 семействам, 8 основным видов энтомофагов, принадлежащих к 5 семействам.

Наибольшая численность почвообитающих личинок многоядных вредителей отмечено под озимой пшеницей и ячменем.

\section{Библиографический список}

1. Гринько А.В. Видовой состав основных фитофагов озимой пшеницы в приазовской зоне Ростовской области // Международный журнал гуманитарных и естественных наук, 2018. - № 3. - С. 124-127.

2. Бессомницина Е.П. Динамика населения беспозвоночных животных под воздействием антропогенных факторов // Биологическое разнообразие животных Сибири: материалы научной конференции. - Томск, 1998. - 124 с.

3. Акименко А.С., Вавин В.Г. К вопросу эффективного использования ресурсного потенциала агроценоза // Почвозащитное земледелие в России: Сб. материалов всерос. науч.практ. конф. - Курск: ВНИИЗиЗПЭ, 2015. - С. 60-62.

4. База данных структуры посевных площадей и системы севооборотов для автоматизированного проектирования адаптивно-ландшафтных систем земледелия в Центральном Черноземье / Г.Н. Черкасов [и др.]. - Курск, 2013. - 54 с.

5. Новожилов К.В. Сборник методических рекомендаций по защите растений. - СПб, 1998. $-306 \mathrm{c}$.

УДК 631.434(470.325)

КАЧЕСТВО СТРУКТУРЫ ЛУГОВО-ЧЕРНОЗЕМНЫХ ПОЧВ ПРИ ДЛИТЕЛЬНОМ СЕЛЬСКОХОЗЯЙСТВЕННОМ ИСПОЛЬЗОВАНИИ

Волошенко И.В., Новых Л.Л.

Белгородский государственный национальный исследовательский

университет, Белгород, РФ

E-mail:novykh@bsu.edu.ru

Резюме. Изучены структурно-агрегатный состав и водопрочность структуры лугово-черноземных почв, возникиих в результате вторичного гидроморфизма. Установлен противоречивый характер оценок степени деградации почвы по результатам «сухого» и «мокрого» просеивания почв.

Summary. The structural-aggregate composition and waterproofness of the structure of meadowchernozem soils that arose as a result of secondary hydromorphism are studied. The contradictory nature of assessments of the degree of soil degradation based on the results of «dry» and "wet» sifting of soils was determined.

Введение. Одним из видов агрогенной деградации почв является физическая деградация. Она проявляется, в первую очередь, в деградации структуры. Данное сообщение посвящено лугово-черноземным почвам. По информации «Единого государственного реестра почвенных ресурсов России» (ЕГРПР) [3] 
их площадь на территории Белгородской области составляет около 1 \%. Лугово-черноземные почвы относятся к полугидроморфным почвам, которые развиваются в условиях периодического избыточного увлажнения. В последней четверти XX века значительно вырос интерес к различным аспектам изучения и использования гидроморфных почв в связи с обострением проблемы избыточного увлажнения почв в ряде регионов России [1].

В одной из своих работ [2] мы рассматривали проявление вторичного гидроморфизма на территории Белгородской области в почвах опытного участка ФГНБУ «Белгородский НИИСХ». Вторичный гидроморфизм почв сильнее выражен в нижней части склона в связи с более близким залеганием грунтовых вод.

Цель исследования - изучение особенностей структуры лугово-черноземных почв опытного участка и определение степени ее деградации.

Материалы и методы. Объект исследования - лугово-черноземные почвы на территории опытного участка ФГНБУ «Белгородский НИИСХ», pacположенного в Белгородском районе (Белгородская область). В научных целях участок функционирует с 1991 г. Точное время начала земледельческого освоения данного участка установить не удалось. Можно утверждать, что в первой половине XX в. территория уже использовалась в сельскохозяйственном производстве. В настоящее время на изученных лугово-черноземных почвах применяется зональная система земледелия. Для выявления степени деградации структуры пахотных почв была изучена также целинная лугово-черноземная почва, которая размещена в аналогичных условиях рельефа на склоне балки долины р. Ерик, на расстоянии около 2 км от границы опыта.

Сравнение профилей исследуемых почв показывает, что обе почвы являются маломощными, что соответствует их размещению на слонах крутизной 3$5^{\circ}$. Признаки оглеения прослеживаются в целинном варианте в почвообразующей породе $(\mathrm{Cg})$ с глубины 52 см и в пахотном варианте в горизонте $\mathrm{BCg}$ и $\mathrm{Cg}$ с глубины 45 см. Эти признаки проявляются в зеленовытых тонах окраски и наличии ржавых железистых новообразований.

Для характеристики качества структуры исследуемых почв и степени ее деградации были использованы следующие показатели:

1) содержание глыб (Г), т.е. фракции размером > 10 мм, \%;

2) содержание пыли (П), т.е. фракции размером < 0,25 мм;

3) содержание агрономически ценных фракций (АЦФ), т.е. суммы фракций размером от 0,25 до 10 мм, \%;

4) суммарная водопрочность $(\mathrm{CB})$ - сумма фракций размером $>0,25$ мм, \%, определяемых при «мокром» просеивании почвы;

5) критерий АФИ, определяемый по формуле:

$$
A \Phi И=\frac{1-0,25 \text { мокрое }}{1-0,25 \text { сухое }} \times 100 \%
$$

6) наиболее ценная часть агрегатов (НЦЧА) - содержание агрегатов размером от 1 до 3 мм, \%.

Определение структурно-агрегатного состава почв и водоустойчивости структуры проводили по методике Саввинова. 
Результаты и их обсуждение. Основные показатели, характеризующие структурно-агрегатный состав и водопрочность структуры исследуемых почв, приведены в таблице 1. Таблица дополнена сведениями о среднем значении показателей в профилях почв и степени варьирования признаков.

\section{Таблица 1 - Основные показатели структуры исследуемых почв}

\begin{tabular}{|c|c|c|c|c|c|c|c|}
\hline Горизонт & Глубина, см & $\Gamma, \%$ & $\Pi, \%$ & $A Ц Ф, \%$ & $C B, \%$ & $A Ф И, \%$ & НЦЧА,\% \\
\hline \multicolumn{7}{|c|}{ Целина } \\
\hline А & $5-29$ & 38 & 7 & 55 & 73 & 393 & 18 \\
\hline AВ & $29-39$ & 28 & 3 & 69 & 57 & 425 & 32 \\
\hline В & $39-52$ & 24 & 6 & 70 & 60 & 464 & 24 \\
\hline Сgса & $52-\downarrow$ & 11 & 3 & 86 & 60 & 400 & 35 \\
\hline Среднее для профиля & 25 & 5 & 70 & 63 & 420 & 27 \\
\hline V, \% & 44 & 43 & 18 & 11 & 8 & 28 \\
\hline \multicolumn{7}{|c|}{ Пашня } \\
\hline Ар & $0-10$ & 16 & 8 & 76 & 30 & 150 & 32 \\
\hline Aрр & $10-30$ & 54 & 2 & 44 & 57 & 600 & 15 \\
\hline В & $30-45$ & 54 & 2 & 44 & 58 & 883 & 15 \\
\hline ВСg & $45-60$ & 24 & 13 & 63 & 69 & 260 & 27 \\
\hline Сg & $60-\downarrow$ & 39 & 12 & 49 & 26 & 266 & 15 \\
\hline Среднее для профиля & 37 & 7 & 55 & 48 & 432 & 21 \\
\hline V, \% & 46 & 71 & 25 & 39 & 70 & 39 \\
\hline
\end{tabular}

Примечание: $V$ - коэффициент вариации

Следует подчеркнуть, что лишь для содержания глыб варьирование показателей в профилях почв практически одинаково. Для всех остальных параметров варьирование в пахотной почве выше, что соответствует существующим представлениям о нарастании неоднородности свойств почв при антропогенном воздействии.

Приведенные данные показывают, что по структурно-агрегатному составу почвы значительно отличаются друг от друга. В общем и целом пахотная почва имеет более высокую глыбистость, но меньшее содержание АЦФ и НЦЧА, что свидетельствует о проявлении процессов деградации структуры.

На основе опубликованной информации [4-8] была проведена оценка качества структуры пахотных горизонтов исследуемых почв (табл. 2).

Приведенные данные говорят о том, что система оценок несовершенна и требует улучшения. Например, по водопрочности структуры пахотная почва имеет неудовлетворительную, удовлетворительную или хорошую оценку разброс оценок очень большой. Полагаем, что оценка степени деградации почв по содержанию отдельных фракций структурно-агрегатного состава (глыб, АЦФ, суммарной водопрочности) является некорректной, так как неизвестно, является ли наблюдаемый уровень содержания фракций следствием деградации почвы или исходным генетическим свойством. 
Таблица 2 - Оценка состояния параметров структуры верхних горизонтов исследуемых почв

\begin{tabular}{|c|c|c|c|c|}
\hline \multirow{3}{*}{$\begin{array}{l}\text { № } \\
\Pi / \Pi\end{array}$} & \multirow{3}{*}{$\begin{array}{l}\text { Оцениваемый } \\
\text { параметр }\end{array}$} & \multicolumn{3}{|c|}{ Оценка } \\
\hline & & \multirow{2}{*}{$\begin{array}{c}\text { Целинная } \\
\text { почва, гори- } \\
\text { зонт А } \\
\end{array}$} & \multicolumn{2}{|c|}{ Пахотная } \\
\hline & & & Ap & App \\
\hline 1. & $\begin{array}{l}\text { Содержание } А Ц Ф \text { (по Долгову } \\
\text { и Бахтину) (по [7]) }\end{array}$ & Удовл. & Хорошая & Удовл. \\
\hline 2. & $\begin{array}{l}\text { Водопрочность структуры (по } \\
\text { Долгову и Бахтину) (по [7]) }\end{array}$ & Отличная & Неудовл. & Хорошая \\
\hline 3. & $\begin{array}{l}\text { Водопрочность структуры (по } \\
\text { Кузнецовой) (по [7]) }\end{array}$ & Отличная & Удовл. & Хорошая \\
\hline 4. & $\begin{array}{l}\text { Водопрочность структуры (по } \\
\text { критерию АФИ) (по [7]) }\end{array}$ & Хорошая & Хорошая & $\begin{array}{c}\text { Очень хоро- } \\
\text { шая }\end{array}$ \\
\hline 5. & $\begin{array}{l}\text { Степень деградации по содер- } \\
\text { жанию глыб (по [5]) }\end{array}$ & $\begin{array}{lr}\text { Сильное } & \text { пре- } \\
\text { вышение } & \text { от } \\
\text { оптимума } & \\
\end{array}$ & $\begin{array}{l}\text { Слабое сниже- } \\
\text { ние от опти- } \\
\text { мума }\end{array}$ & $\begin{array}{l}\text { Сильное пре- } \\
\text { вышение от } \\
\text { оптимума }\end{array}$ \\
\hline 6. & $\begin{array}{l}\text { Степень деградации по содер- } \\
\text { жанию АЦФ (по [5]) }\end{array}$ & $\begin{array}{l}\text { Сильное сни- } \\
\text { жение от опти- } \\
\text { мума }\end{array}$ & Оптимум & $\begin{array}{l}\text { Сильное сни- } \\
\text { жение от оп- } \\
\text { тимума }\end{array}$ \\
\hline 7. & $\begin{array}{l}\text { Степень деградации по } C B \text { (по } \\
\text { [5] }\end{array}$ & $\begin{array}{l}\text { Слабое превы- } \\
\text { шение от опти- } \\
\text { мума }\end{array}$ & $\begin{array}{l}\text { Сильное сни- } \\
\text { жение от опти- } \\
\text { мума }\end{array}$ & $\begin{array}{l}\text { Слабое сниже- } \\
\text { ние от опти- } \\
\text { мума }\end{array}$ \\
\hline 8. & $\begin{array}{l}\text { Степень деградации по содер- } \\
\text { жанию глыб (по [6]) }\end{array}$ & $\begin{array}{l}\text { Деградация } \\
\text { слабая }\end{array}$ & Недеградир. & $\begin{array}{l}\text { Деградация } \\
\text { сильная }\end{array}$ \\
\hline 9. & $\begin{array}{l}\text { Степень деградации по содер- } \\
\text { жанию АЦФ (по [6]) }\end{array}$ & $\begin{array}{l}\text { Деградация } \\
\text { средняя }\end{array}$ & Недеградир. & $\begin{array}{l}\text { Деградация } \\
\text { сильная }\end{array}$ \\
\hline 10. & $\begin{array}{l}\text { Степень деградации по содер- } \\
\text { жанию глыб (по [8]) }\end{array}$ & $\begin{array}{l}\text { Средняя } \\
\text { балла) }\end{array}$ & $\begin{array}{l}\text { Слабая (2 } \\
\text { балла) }\end{array}$ & $\begin{array}{l}\text { Сильная (4 } \\
\text { балла) }\end{array}$ \\
\hline
\end{tabular}

В связи с этим было проведено сравнение свойств пахотного и подпахотного горизонтов с целинным вариантом таких почв (табл. 3).

Таблица 3 - Определение степени деградации пахотной почвы (по [4])

\begin{tabular}{|l|l|l|l|l|}
\hline $\begin{array}{l}\text { Слой } \\
\text { почвы, }\end{array}$ & $\begin{array}{l}\text { Уменьшение } \\
\text { содержания } \\
\text { АЦФ, } \%\end{array}$ & $\begin{array}{l}\text { Степень дегра- } \\
\text { дации } \\
\text { структуры }\end{array}$ & $\begin{array}{l}\text { Уменьшение } \\
\text { СВ, \% }\end{array}$ & $\begin{array}{l}\text { Степень деградации } \\
\text { водопрочности }\end{array}$ \\
\hline $0-20$ & Нет & Отсутствует & 40 & Сильная \\
\hline $0-10$ & Нет & Отсутствует & 59 & Катастрофическая \\
\hline $10-20$ & 20 & Слабая & 22 & Умеренная \\
\hline
\end{tabular}

Для лугово-черноземной почвы при оценке в целом слоя 0-20 см деградация структурно-агрегатного состава не фиксируется, но при этом наблюдается сильная деградация водопрочности структуры. Если рассмотреть пахотный и подпахотный горизонты отдельно (слои 0-10 и 10-20 см), то в «плужной подошве» (горизонте Арр) обнаруживается слабая деградация структуры почвы и умеренная деградация водопрочности. В слое 0-10 см на фоне отсутствия деградации структурно-агрегатного состава проявляется катастрофическая деградация водопрочности структуры. 
Заключение. Вследствие регулярных обработок верхнего горизонта почвы удается бороться с нарастанием ее глыбистости в пахотном горизонте, но водопрочность структуры при этом снижается так, что подтверждается наличие ярко выраженной деградации почвы.

\title{
Библиографический список
}

1. Авдеева Т.Н. История исследования гидроморфных почв Центрально-Черноземного экономического района России // Почвы России: вчера, сегодня, завтра: сб. статей по материалам Bсерос. с междунар. участием науч. конф., посвящ. Году экологии и 90-летию со дня рождения проф. В.В. Тюлина (5 окт. 2017 г.) / отв. за вып. А.М. Прокашев. - Киров: ВятГУ, 2017. - c. 14-23.

2. Вторичный гидроморфизм как актуальное направление трансформации черноземов / Л.Л. Новых, Е.А. Пелехоце, Л.Г. Смирнова [и др.] // Научные ведомости БелГУ. Сер. Естественные науки, 2016. - № 25 (246). - Вып. 37. - С. 94-102.

3. Единый государственный реестр почвенных ресурсов России. - М., 2019 [Электронный ресурc]. - URL: http://egrpr.esoil.ru (дата обращения: 08.05.2021).

4. Медведев В.В. Физическая деградация черноземов. Диагностика. Причины. Следствия. Предупреждение. - Харьков: Изд-во «Городская типография», 2013. - 324 с.

5. Методические рекомендации по проведению комплексного мониторинга плодородия почв земель сельскохозяйственного назначения / под ред. Л.М. Державина, Д.С. Булгакова. - М.: ФГНУ «Росинформагротех», 2003. - 240 с.

6. Проблемы деградации и восстановления продуктивности земель сельскохозяйственного назначения в России / под ред. А.В. Гордеева, Г.А. Романенко. - М.: Росинформагротех, 2008. $-67 \mathrm{c}$.

7. Теории и методы физики почв: коллективная монография / под ред. Е.В. Шеина и Л.О. Карпачевского. - М.: «Гриф и К», 2007. - 616 с.

8. Assessing the Degree of Physical Degradation and Suitability of Chernozems for the Minimization of Basic Tillage /T.A. Trofimova, S.I. Korzhov, V.A. Gulevskii [et al] // Eurasian Soil, 2018. - № 51. - P. 1080-1085.

\section{УДК 631.459.2.57}

\section{ИЗУЧЕНИЕ РАВНОМЕРНОСТИ РАСПРЕДЕЛЕНИЯ КАПЕЛЬ ДОЖДЯ ПО ПЛОЩАДИ ДОЖДЕВАНИЯ ПДУ}

\author{
Вытовтов В.А. \\ ФГБНУ «Курский ФАНЦ», г. Курск \\ E-mail:v.a.vitovtov@mail.ru
}

Резюме. Проведена оиенка равномерности оромения стоковых площзадок портативной дождевальной установкой (ПДУ) при: 1.ПДУ находится в состоянии покоя, 2. ПДУ раскачивается, 3. ПДУ равномерно вращается с отиентрированной спиралью Архимеда, 4 ПДУ вращается и принудительно раскачивается. Полученные результаты предназначены для использования в дальнейших работах с иелью повышения качества дождевания.

Ключевые слова: дождевальная установка, спираль Архимеда, приводной механизм, раскачивающее устройство.

Summary. An assessment of the uniformity of irrigation of runoff sites with a portable sprinkler (PDU) was carried out when: 1. The remote control is at rest, 2. The remote control is swinging, 3. The remote control rotates uniformly with a centered Archimedes spiral, 4 the remote control rotates and forcibly swings. The results obtained are intended for use in further work in order to improve the quality of sprinkling.

Key words: sprinkler, Archimedes spiral, drive mechanism, swinging device. 
Применение дождевальных установок позволяет проводить искусственное дождевание с заданной интенсивностью и продолжительностью, получать необходимую информацию при изучении почвенных эрозионных процессов в более короткие сроки, по сравнению с натурными наблюдениями.

Первоначально, сконструированная во Всероссийском научно-исследовательском институте земледелия и защиты почв от эрозии портативная дождевальная установка (ПДУ) и почвенные монолиты, имели прямоугольную форму. Каплеобразователи крепили на горизонтальной панели в шахматном порядке с определенным интервалом. При работе без раскачивания капли воды, образованные каплеобразователями, выбивали под собой углубления. Поэтому при дождевании дождевальную установку слегка раскачивали. Однако после вывешивания над монолитом, при раскачивании, ПДУ постоянно пыталась вращаться, что уменьшало орошаемую площадь и равномерность дождевания. Чтобы эффективно использовать возможность вращения перешли к круглой форме дождевателя и монолита. После проведенных экспериментов, лучшим способом закрепления каплеобразователей на круглой горизонтальной пластиковой панели был принят способ закрепления по спирали Архимеда с одинаковым шагом. У спирали Архимеда расстояние между соседними линиями одинаково, а при равном шаге по ней, каждый каплеобразователь орошает примерно одинаковую площадь. Первоначально дождевальную установку вывешивали на шнуре, который после закручивания самораскручивался.

Затем в лабораторных условиях для обеспечения равномерного вращения применили электропривод. Когда центр спирали Архимеда совпадает с осью вращения ПДУ, вращаясь, каждый ее каплеобразователь движется по своей, отличной от других окружности, и орошает свое кольцо. При отсутствии центровки над некоторыми кольцами могут выстраиваться по несколько каплеобразователей, в то время как рядом остаются неохваченные участки. Это приводило к образованию кольцевых углублений на поверхности почвы, выбиваемых, идущими по одной траектории каплями. $[1,2]$. Для их устранения нами было разработано и изготовлено автоматическое раскачивающее устройство. Эксплуатация этого устройства значительно упростила и улучшила качество дождевания. Однако остался вопрос, насколько эффективно было использовано данное расположение каплеобразователей.

Для создания искусственного дождя с заданным размером капель была разработана ПДУ (рис.1), состоящая из рамы, ёмкости для воды, поплавковой системы с резиновой грушей и дождевателя с горизонтальной панелью $[3,4]$. Дождеватель включает последовательно закрепленные на ниппеле толстую гибкую трубку, втулку и пучок тонких гибких трубок. Тонкие гибкие трубки, равные по длине и с одинаковой пропускной способностью, верхними концами закреплены во втулке, а нижними - на горизонтальной панели по спирали Архимеда. 


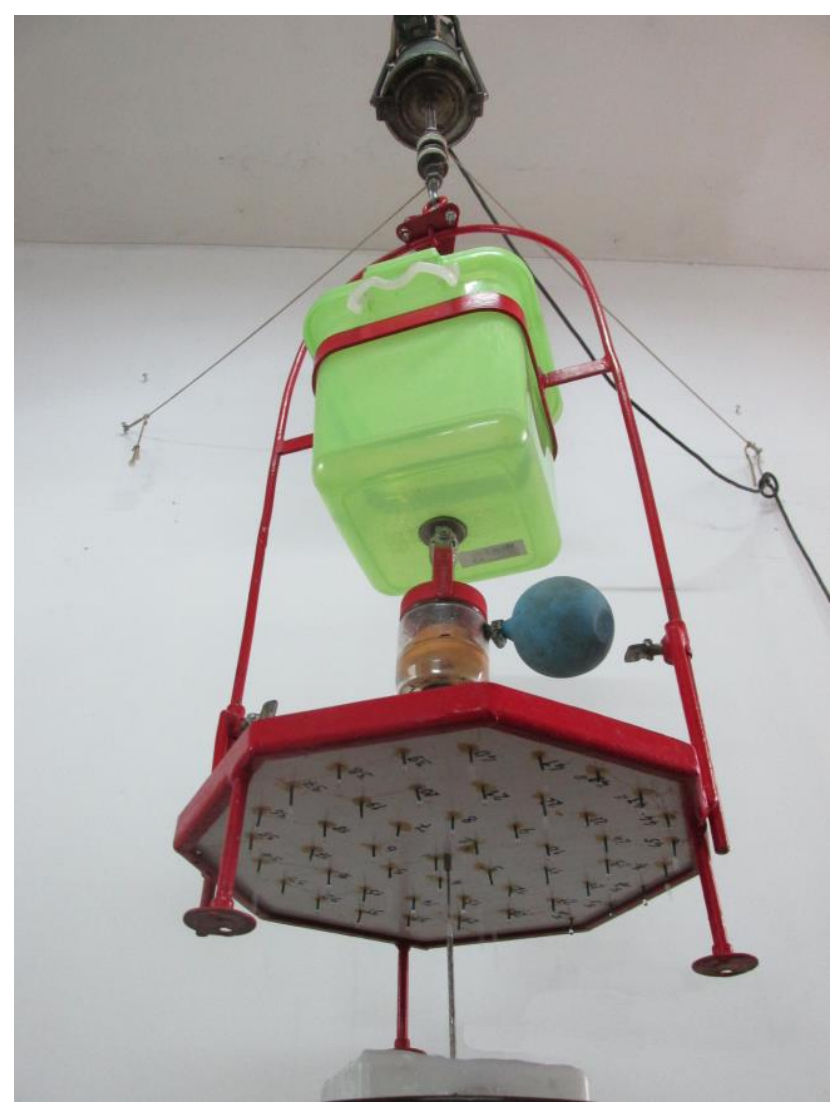

Рисунок 1 - Портативная дождевальная установка

Цель данной работы - сравнительная оценка различных факторов на качество распределения капель искусственного по орошаемой поверхности.

Для достижения цели была изготовлена круглая кассета с рядами квадратных пластмассовых ячеек (рис.2). Восемьдесят шесть пластмассовых ячеек с размерами 20-20-14 мм на круглом основании устанавливали рядами. В дождеобразователе в центре спирали Архимеда закреплена вертикальная металлическая ось (рис.3).

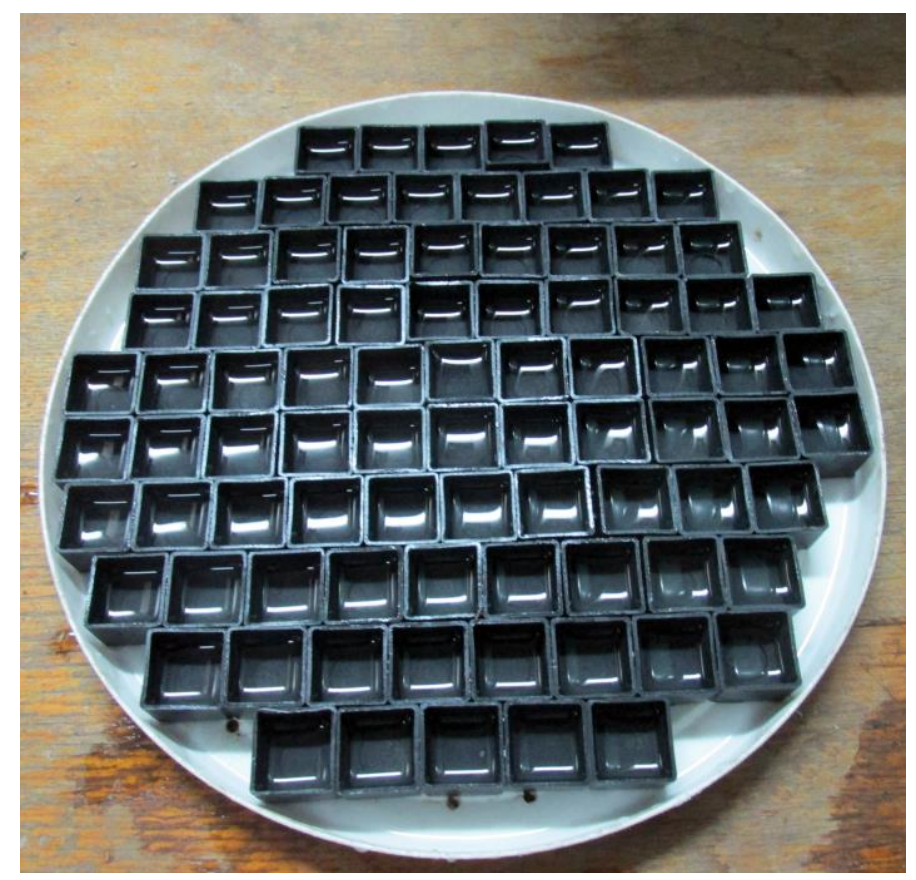

Рисунок 2 - Общий вид кассеты с наполненными ячейками 
При настройках под осью устанавливали вертикальный заостренный палец. Включив электропривод, не раскачивающей в стороны ПДУ, наблюдали изменение расстояния между осями, стационарно установленного пальца, и металлической оси, которое характеризует качество центровки.

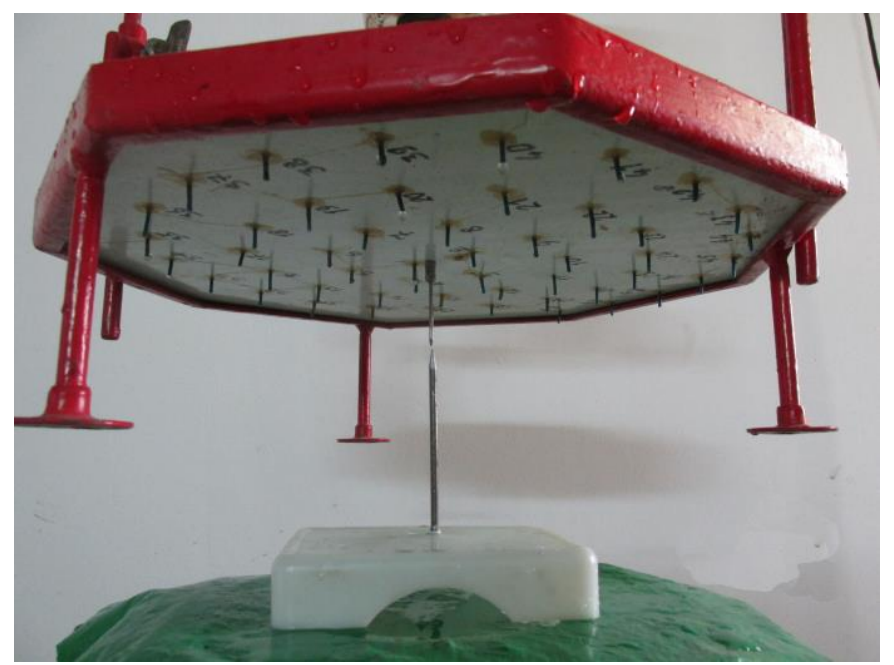

Рисунок 3 - Заостренный палец и вертикальная металлическая ось

Изменяли данное расстояние стяжками на подвесном узле: меняя длину стяжек, мы перемещаем центр подвески и ось вращения в горизонтальной плоскости в ту или иную сторону.

Ранее было выявлено, что центровка спирали Архимеда зависит от количества воды, находящейся в емкости. Поэтому вся дальнейшая работа проводилась с заданным объемом воды, находящейся в емкости и с минимальным отклонением центра спирали Архимеда от оси вращения ПДУ. Для уменьшения разброса капель из ячеек, сократили до 8 см. высоту их падения установкой вертикальной подставки под дождевальную установку. Первоначально определили базовое качество дождевания без вращения и раскачивания. Для этого запустили в рабочий режим неподвижную ПДУ. На подставку под центр дождевателя подвели центр кассеты с пустыми ячейками и отсекли время. Через 1мин. 30 сек., когда первые ячейки наполнились водой, кассету достали и поочередно взвесили все ячейки. Для удобства при расчетах данные разбили по интервалам через 1 г. После статистической обработки получили коэффициент вариации равномерности распределения искусственного дождя по орошаемой площади, который отображен в первом столбце представленной диаграммы на рис. 4.

На втором варианте повторили все действия, но только дождевальную установку раскачивали с максимально возможной амплитудой в 5 см. Первые ячейки наполнились в таком режиме уже через 2,5 мин. Через полторы минуты ячейки взвесили, провели статистическую обработку и результаты представлены во втором столбце графика на рис. 4.

На третьем варианте изучали равномерность орошения при включенном механизме принудительного вращения с максимальным приближением центра спирали Архимеда и центра вращения ПДУ. Вследствие того, что качество распределения капель воды по площади орошения заметно выросло, первые ячейки 
набрались только через 3,5 мин. Ячейки взвесили, обработали, и результаты представлены в третьем столбце на рис. 4.

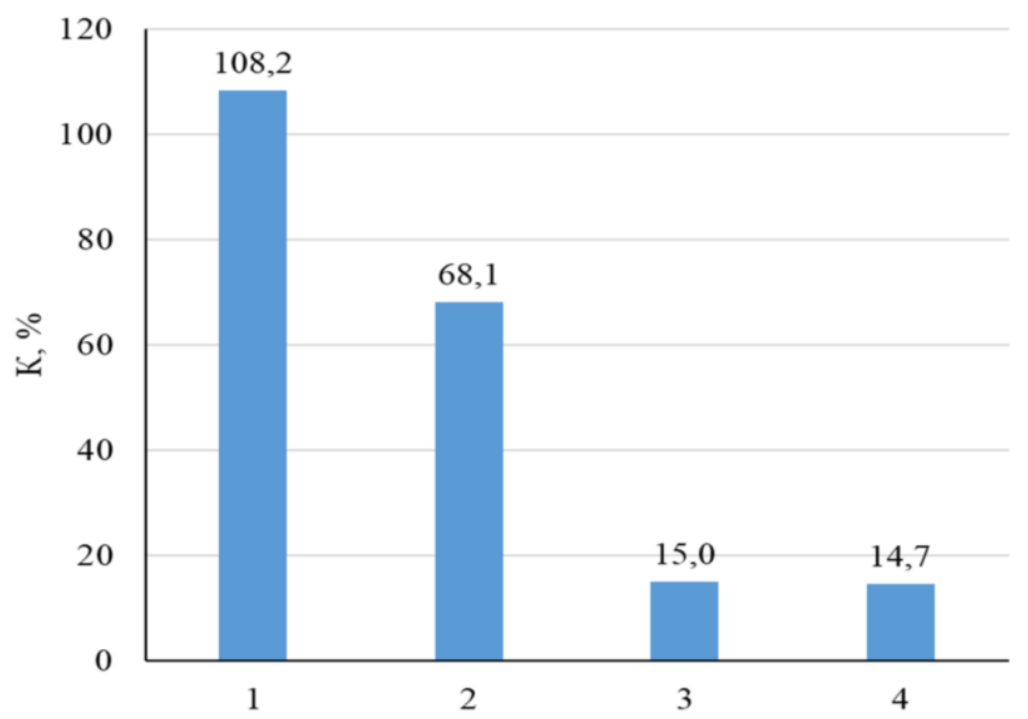

Рисунок 4 - Коэффициент вариации распределения искусственного дождя по орошаемой площади по вариантам:

1. ПДУ находится в состоянии покоя, 2. ПДУ раскачивается, 3. ПДУ равномерно вращается с отцентрированной спиралью Архимеда, 4. С отцентрированной спиралью Архимеда ПДУ вращается и принудительно раскачивается.

На четвертом варианте дополнительно включили раскачивающее устройство, которое перемещало дождевальную установку в двух плоскостях. Время наполнения первых ячеек осталось прежним - 3,5 мин., а качество дождевания представлено в четвертом столбце диаграммы на рис. 4.

Выводы: Самая низкая равномерность с коэффициентом вариации, превышающим 100\%, получена при дождевании покоящейся ПДУ. При небольшом покачивании в пределах 5 см коэффициент вариации уменьшился до 70\%. На равномерность распределения капель дождя сильно влияет центровка спирали Архимеда, коэффициент вариации уменьшился до 15\%. Однако, установлено, что центровка спирали Архимеда может незначительно изменяться при изменении количества воды в емкости, что происходит при длительном дождевании. Это приводит к небольшому падению равномерности орошения. Слабое раскачивание уменьшает это падение.

Проделанная работа показала необходимость в нахождении способа принудительной устойчивой центровки спирали Архимеда, при котором отпадет необходимость в принудительной раскачке ПДУ.

\section{Библиографический список}

1. Вытовтов В.А. Качество искусственного дождя портативной дождевальной установки и его улучшение // Агроэкологические проблемы почвоведения и земледелия / Сб. конф. МОО «Курской отделение об-ва почвоведов им. В.В. Докучаева. Курск, 24-25 апреля 2020 г. Курск: ФГБНУ Курский ФАНЦ, 2019. - С. 85-88.

2. Вытовтов В.А. Характеристики искусственного дождя при разной температуре // Актуальные проблемы почвоведения, экологии и земледелия / Сб. конф. МОО «Курской отделение об-ва почвоведов им. В.В. Докучаева. Курск, 28-29 мая 2020 г. Курск: ФГБНУ Курский ФАНЦ, 2020. - С. 82-85. 
3. Патент на изобретение 2519789 РФ: МПК А01G 25/09 Портативная лабораторно-полевая дождевальная установка / Вытовтов В.А., Сухановский Ю.П., Санжарова С.И., Прущик А.В., Соловьева Ю.А.; заявитель и патентообладатель ГНУ ВНИИЗиЗПЭ РАСХН - № 2012145695/13; заявл. 25.10.2012, опубл. 20.06.2014, бюл. № 17.

4. Патент на полезную модель 184625 РФ: МПК А01G 25/00 Портативная лабораторнополевая дождевальная установка / Вытовтов В.А., Сухановский Ю.П., Прущик А.В.; заявитель и патентообладатель Федеральное государственное бюджетное научное учреждение "Курский научно-исследовательский институт агропромышленного производства" - № 2018112099; заявл. 03.04.2018, опубл. 01.11.2018, бюл. № 31.

\section{УДК 631.51.011}

\section{БИОЭНЕРГЕТИЧЕСКАЯ ЭФФЕКТИВНОСТЬ ВЫРАЩИВАНИЯ ОДНОЛЕТНИХ ТРАВ ПРИ МИНИМАЛИЗАЦИИ ОБРАБОТКИ ПОЧВЫ}

Гармашов B.M., Нужная Н.А., Говоров В.Н., Крячкова М.П., Паутова В.С. «Воронежский ФАНЦ им. В.В. Докучаева», Каменная Степь, Россия, E-mail: garmashov.63@mail.ru

Резюме. Исследованиями, проведенными в почвенно-климатических условиях юго-востока ЦЧР с иелью выявления эффективности минимализачии обработки почвы под однолетние травы установлено, что минимализачия обработки почвы, несмотря на снижение затрат на ее проведение, не обеспечивает повышения энергетической эффективности производства однолетних трав из-за снижения выхода валовой энергии с урожаем. Наибольший энергетический эффект при выращивании однолетних трав (горохо-овсяной смеси) на зеленый корм обеспечивается при отвальной обработке почвы на глубину 20-22 см.

Summary. Studies conducted in the soil and climatic conditions of the south-east of the CDR in order to identify the effectiveness of minimizing soil cultivation for annual grasses have found that minimizing soil cultivation, despite reducing the cost of its implementation, does not increase the energy efficiency of annual grass production due to a decrease in the yield of gross energy with the harvest. The greatest energy effect when growing annual grasses (pea-oat mixture) for green feed is provided by dump tillage to a depth of $20-22 \mathrm{~cm}$.

В настоящее время одним из важнейших направлений в развитии сельскохозяйственного производства является ресурсосбережение. На сегодня проблемы энергетики становятся ключевыми в экономике $[1,2]$. Поэтому в современном земледелии одной из ведущих тенденций является минимализация в обработке почвы вплоть до полного отказа от последней, так как именно обработка почвы является наиболее энергозатратной операцией в технологии выращивания сельскохозяйственных культур [3-6]. Однако, как показывает практика, применение минимальных обработок в различных почвенно-климатических условиях распространения черноземных почв и под культуры с различными биологическими особенностями часто приводит к противоречивым результатам как по отношению к урожайности и показателям почвенного плодородия, так и биоэнергетической эффективности [7-11]. Все это обусловливает необходимость расширения и углубления исследований в поиске наиболее 
оптимальных способов и систем обработки почвы в современном земледелии региона, а с целью более объективной оценки технологий и технологических процессов проводить не только натуральную, но и биоэнергетическую их оценку. В связи с этим целью исследований было выявить наиболее эффективные с энергетической точки зрения приемы обработки почвы под однолетние травы.

Условия материалы и методы. Исследования проводились ФГБНУ «Воронежский ФАНЦ им. В.В. Докучаева» в стационарном опыте по разработке наиболее эффективных приемов и систем обработки почвы в севообороте, обеспечивающих воспроизводство плодородия почвы и высокую продуктивность выращиваемых культур. Исследования проводились на черноземе обыкновенном с благоприятными физико-механическими и агрохимическими показателями. Изучаемые обработки почвы представлены в таблице 1.

Результаты и их обсуждение. Обработка почвы является одним из главных агроприемов в возделывании сельскохозяйственных культур и, по мнению многих исследователей, одним из наиболее затратных, как по энергетическим ресурсам, так и по трудовым [3-8]. Достичь снижения ресурсо- и энергоёмкости при производстве сельскохозяйственной продукции можно либо путем снижения энергозатрат на единицу продукции при фиксированном уровне продуктивности, либо посредством опережающего прироста продукции к приросту энергозатрат.

Результаты расчета биоэнергетической эффективности выращивания однолетних трав (горохо-овсяной смеси) при различных способах и глубине основной обработки почвы показали, что наибольшие совокупные затраты энергии на гектар при выращивании однолетних трав на зеленый корм складываются по вспашке на глубину 20-22 и 25-27 см (различия между данными вариантами составляли не более 1 \%) (табл.).

Таблица 1 - Энергетическая эффективность выращивания однолетних трав (горох + овес) на зеленую массу при различных приемах основной обработки почвы, среднее за 2018-2020 гг.

\begin{tabular}{|c|c|c|c|c|c|c|c|}
\hline \multirow{2}{*}{ Показатель } & \multirow[t]{2}{*}{$\Phi{ }^{*}$} & \multicolumn{3}{|c|}{ Вспашка на глубину } & \multirow{2}{*}{\begin{tabular}{|c|} 
Безотвальная \\
обработка на \\
$14-16 \mathrm{~cm}$
\end{tabular}} & \multirow{2}{*}{$\begin{array}{c}\text { Поверхност- } \\
\text { ная обработка } \\
\text { на 6-8 см }\end{array}$} & \multirow{2}{*}{$\begin{array}{l}\text { Нуле- } \\
\text { вая об- } \\
\text { работка }\end{array}$} \\
\hline & & $20-22 \mathrm{~cm}$ & $25-27 \mathrm{~cm}$ & $14-16 \mathrm{~cm}$ & & & \\
\hline \multirow{2}{*}{$\begin{array}{l}\text { Выход энергии с } \\
\text { урожаем, ГДж/га }\end{array}$} & $\mathrm{a}$ & 63,1 & 65,2 & 61,8 & 59,9 & 56,8 & 36,6 \\
\hline & 6 & 75,4 & 75,3 & 72,9 & 71,1 & 70,8 & 42,7 \\
\hline \multirow{2}{*}{$\begin{array}{l}\text { Затраты техно- } \\
\text { генной энергии, } \\
\text { ГДж/га }\end{array}$} & $\mathrm{a}$ & 24,8 & 25,1 & 24,6 & 23,9 & 23,5 & 20,7 \\
\hline & 6 & 30,4 & 30,4 & 29,8 & 29,5 & 29,3 & 24,7 \\
\hline \multirow{2}{*}{$\begin{array}{l}\text { Приращение } \\
\text { энергии, ГДж/га }\end{array}$} & $\mathrm{a}$ & 38,3 & 40,1 & 37,2 & 36,0 & 33,3 & 15,9 \\
\hline & 6 & 45,0 & 44,9 & 43,1 & 42,6 & 41,5 & 18,0 \\
\hline \multirow{2}{*}{$\begin{array}{l}\text { Коэффициент } \\
\text { энергетической } \\
\text { эффективности }\end{array}$} & $\mathrm{a}$ & 2,54 & 2,60 & 2,51 & 2,51 & 2,41 & 1,77 \\
\hline & $\sigma$ & 2,48 & 2,47 & 2,44 & 2,45 & 2,42 & 1,73 \\
\hline
\end{tabular}

Фон*а - без удобрений; б - $\mathrm{N}_{60} \mathrm{P}_{60} \mathrm{~K}_{60}$ 
На этих же вариантах было получено и набольшее количество валовой энергии в урожае - 63,1-65,2 ГДж/га на неудобренном фоне и 75,3-75,4 ГДж/га - на удобренном (табл.).

При снижении интенсивности обработки почвы - минимализации, наряду с уменьшением общих энергетических затрат на выращивание однолетних трав отмечалось и снижение выхода обменной энергии с урожаем. Затраты энергии в зависимости от обработки почвы на неудобренном фоне снижались относительно вспашки на 20-22 см: на 1,04 \% при вспашке на 14-16 см - 5,3 \% при поверхностная обработке, а ее выход с урожаем зеленой массы на 2,1-10,0 \%. Приращение энергии также уступало вариантам вспаханным на 20-22 и 2527 см на 2,8-13,1\%.

Одним из наиболее важных показателей агроэнергетической оценки при производстве сельскохозяйственных культур является коэффициент энергетической эффективности, характеризующийся выходом обменной энергии на единицу совокупных энергетических затрат. Расчеты показали, что выращивание однолетних трав на зеленую массу во все годы исследования было энергетически эффективно на всех вариантах опыта, включая нулевую обработку почвы, коэффициент энергетической эффективности (Кэ) был выше 1. Но при этом было отмечено, что наиболее эффективным было выращивание горохоовсяной смеси по вспашке на глубину 20-22 и 25-27 см (Кэ - 2,54-2,60 на неудобренном фоне и 2,47-2,48 на удобренном). Несмотря на самые высокие затраты совокупной энергии, на данных вариантах опыта выход энергии с урожаем обеспечивал не только их полную компенсацию, но и обеспечивал максимальное ее приращение - 38-40 ГДж/га на неудобренном фоне и 45 ГДж/га на удобренном.

Снижение интенсивности обработки почвы сопровождалось пропорциональным снижением и затрат энергии, и ее выхода с урожаем зеленой массы. В результате, несмотря на общее снижение энергетических показателей выращивания однолетних трав в условиях минимализации обработки почвы, по показателю энергетической эффективности (отношению количества образованной энергии к вложенной) данные варианты находились практически на одном уровне. Вариация коэффициента энергетической эффективности между низкозатратными вариантами обработки почвы составила 2,41-2,51 ед на неудобренном фоне и 2,41-2,45 на удобренном.

В условиях технологии нулевой обработки почвы общие затраты энергии при выращивании однолетних трав на зеленую массу были наименьшими и составили 21-25 ГДж/га, что на 16,6-19,0 \% было меньше, чем по вспашке на глубину 20-22 см. В тоже время общее количество валовой энергии, накопленной в урожае горохо-овсяной смеси на варианте со вспашкой, значительно (на 41,943,4 \%) превосходило ее количество на нулевой обработке почвы.

Расчеты показали, что содержание энергии в урожае однолетних трав на варианте с нулевой обработкой почвы в меньшей степени покрывало энергетические затраты, связанные с их производством. Коэффициент энергетической 
эффективности на данном варианте составил лишь 1,73-1,78 единиц, против 2,48-2,54 по вспашке на глубину 20-22 см.

В целом следует заметить, что при выращивании травосмеси горох + овес на зеленую массу наибольший энергетический эффект обеспечивается по вспашке на глубину 20-22 см. Минимализация обработки почвы, несмотря на снижение затрат на ее проведение, не обеспечивала повышения энергетической эффективности производства однолетних трав из-за снижения выхода валовой энергии с урожаем зеленой массы. Коэффициент энергетической эффективности на всех обрабатываемых вариантах находился практически на одном уровне (на неудобренном фоне вариация Кэ составила 2,41-2,60 ед., на удобренном - 2,41-2,48) с тенденцией его снижения на вариантах с минимизацией обработки почвы.

Технология нулевой обработки почвы хоть и обеспечивала наименьшие затраты энергии и положительный энергетический баланс при возделывании однолетних трав, но по показателю энергетической эффективности (Кэ - 1,73-1,77) существенно уступала всем обрабатываемым вариантам.

Заключение. Наибольший энергетический эффект при выращивании однолетних трав (горохо-овсяной смеси) на зеленый корм обеспечивается по вспашке на глубину 20-22 см. Минимализация обработки почвы несмотря на снижение затрат на ее проведение не обеспечивает повышения энергетической эффективности производства однолетних трав из-за снижения выхода валовой энергии с урожаем.

\section{Библиографиеский список}

1. Меренкова, И.Н. Взаимосвязь между ресурсной обеспеченностью сельских территорий и устойчивостью сельскохозяйственных организаций / И.Н. Меренкова, И.И. Новикова // Микроэкономика, 2012. - № 5. - С. 73-77.

2. Закшевский, В.Г. Обеспечение эффективности развития малых форм хозяйствования / В.Г. Закшевский, Ю.Н. Губин, Е.В. Юров // Финансы. Экономика. Стратегия, 2013. - № 6. C. 9-13.

3. Саранин, К.И. Система обработки дерново-подзолистых почв в интенсивном земледелии / К.И. Саранин, Н.А. Старовойтов // Ресурсосберегающие системы обработки почвы / Под ред. И.П. Макарова. - М., 1990. - С. 20-32.

4. Власенко, А.Н. Экономические аспекты минимализации основной обработки почвы / А.Н. Власенко, И.Н. Шарков, Л.Н. Иодко // Земледелие, 2006. - № 4. - С. 18-20.

5. Гармашов, В.М. Агро- биоэнергетическая эффективность возделывания подсолнечника при различных способах обработки почвы / В.М. Гармашов, Е.В. Гармашова // Зерновое хозяйство, 2008. - № 3. - С. 4-7.;

6. Максютов, Н.А. Ресурсосберегающие приемы в земледелии / Н.А. Максютов, В.М. Жданов, В.П. Захаров, В.С. Лактионов // Земледелие, 2006. - № 6. - С. 33-34. 260.

7. Котлярова, Е.Г. Экономическая и энергетическая эффективность возделывания гороха на зерно / Е.Г. Котлярова, С.М. Лубенцов // Земледелие, 2013. - № 8. - С. 34-35.

8. Турусов В.И., Гармашов В.М. Влияние способов обработки на плодородие чернозема обыкновенного и урожайность ячменя в условиях юго-востока ЦЧР // Достижения науки и техники АПК, 2019. - Т. 33. - № 12. - С. 20-25.

9. Акчурин Р.Л. Продуктивность зерновых и зернобобовых культур при различных способах обработки почвы / Р. Л. Акчурин, И. О. Ченышев, Р. К. Нафиков и др. // Достижения науки и техники АПК, 2019. - Т. 33. - № 8. - С. 14-17. 
10. Трофимова Т.А., Коржов С.И., Гулевский В.А., Образцов В.Н. Оценка степени физической деградации и пригодности черноземов к минимализации основной обработки почвы // Почвоведение, 2018. - Т. 51. - № 9. - С. 1080-1085.

11. Королев В.А., Громовик А.И., Боронтов О.К. Изменение основных показателей плодородия чернозема выщелоченного при разных способах основной обработки // Почвоведение, 2016. - Т. 49. - № 1. - С. 95-101.

\title{
ОЦЕНКА СОДЕРЖАНИЯ ЗАПАСОВ ПРОДУКТИВНОЙ ВЛАГИ В УСЛОВИЯХ СКЛОНОВОГО АГРОЛАНДШАФТА
}

\author{
Глазунов Г.П. \\ ФГБНУ «Курский ФАНЦ», г. Курск \\ E-mail: gennadij-glazunov@yandex.ru
}

\begin{abstract}
Резюме. В статье приводятся исследования по оченке содержания запасов продуктивной влаги в условиях склонового агроландшафта. Показаны особенности варьирования в пахотном слое почвы запасов продуктивной влаги. Подтверждены результаты прогнозирования распределения запасов почвенной влаги в зависимости от морфометрических параметров рельефа. Выявлены наиболее влагообеспеченные участки агроландмафта в зависимости от местоположения в рельефе.
\end{abstract}

Ключевые слова: почва, запасы продуктивной влаги, варьирование, склоновый агроландшафт.

Почвенные ресурсы имеют ценное значение для сельского хозяйства. Проблемой для устойчивого использования и управления ими является пространственная неоднородность почвенного покрова, что затрудняет прогнозирование нелинейных взаимосвязей между различными почвенными процессами.

Неоспоримо большое и разностороннее влияние на параметры почвенного плодородия оказывает рельеф. Особенности рельефа определяют агрохимические показатели почвы, содержание в ней макро- и микроэлементов. Развитие и степень эрозионных процессов в первую очередь зависит от его строения. Сложный неоднородный рельеф может сказываться не только на неравномерности распределения выпадающих осадков, но и на интенсивности поверхностного стока. [1]. Различные гидрологические особенности, освещенность, радиационный и тепловой баланс, интенсивность биологических, химических, физических и других процессов в почве, определяемых строением рельефа, создают пестроту плодородия почвы [2]. Значительная пространственная неоднородность плодородия почв может наблюдаться даже в пределах одного поля, что создает разные условия для роста сельскохозяйственных культур и требует дифференцированного подхода к технологиям их возделывания. [3]. Неоднозначное влияние на плодородие почв полярных склонов оказывает и антропогенное воздействие, в результате которого происходит ухудшение плодородия почв и деградация почвенного покрова. Особую актуальность приобретают исследования, направленные на оценку закономерностей пространственного варьирования плодородия почв в агроландшафтах областей Центрального Черноземья, характеризующихся повышенной сложностью и контрастностью [4]. 
Для выявления неоднородности почвенного плодородия необходимо почвенное обследование территории. Это долгий, трудоемкий и затратный процесс. Однако в связи с развитием использования цифровых технологий (DSM - digital soil mapping) появляется возможность облегчить и ускорить не только процесс создания современных интерактивных почвенных карт, но и выполнять комплексную оценку параметров почвенного плодородия с учетом морфометрических характеристик склоновых агроландшафтов. Цифровые методы картирования позволяют обработать сразу большой объем информации.

Несмотря на то, что вопросам изучения пространственной неоднородности черноземных почв и агроэкологической оценке земель в склоновых агроландшафтах посвящено много работ $[5,6]$ они остаются ещё недостаточно изученными. В связи с этим, особую актуальность приобретают исследования, направленные на оценку закономерностей пространственного варьирования плодородия черноземов в агроландшафтах областей Центрального Черноземья и разработку методов комплексной агроэкологической оценки пахотных земель для адаптивно-ландшафтных систем земледелия, учитывающих почвенно-экологические условия территорий землепользования и специализацию сельскохозяйственного производства, а быстрое нарастание цифровизации сельскохозяйственного производства предполагает осуществление такой оценки с применением цифровых и геоинформационных технологий $[7,8]$.

Целью исследований является оценка содержания запасов продуктивной влаги в условиях склонового агроландшафта для разработки системы поддержки принятия решений по использованию природно-ресурсного потенциала в агроландшафтах ЦЧР.

Методика проведения исследований Исследования выполняются на базе лаборатории агрохимии и геоинформационных систем с использованием описательного, профильного, морфологического, картографического, статистического, сравнительно-аналитического методов анализа, экосистемного подхода и ГИС-технологий на основе современных методик с использованием программных средств Microsoft Office, QGIS 3.8.3., Surfer 14.0., OziExplorer, SAS Planet, Grid и геодезического оборудования. Применение ГИС-технологий проводилось с использованием разработок отечественных, зарубежных авторов и авторского подхода.

Объектом исследований являются черноземные почвы различной степени смытости и выщелоченности в агроландшафте с куполообразной формой рельефа, а также взаимосвязи между морфометрическими параметрами рельефа и содержания запасов продуктивной влаги.

Исследования проводились на территории Курского федерального аграрного научного центра (Медвенский район, Курская область), на производственном участке с куполообразной формой рельефа с площадью в 86 га.

Оценку содержания запасов продуктивной влаги в посевах озимой пшеницы на черноземах разной степени эродированности проводили с использованием ГИС-технологий и авторского подхода. Пробы отбирали из слоя почвы $0 \ldots 100 \mathrm{~cm}$ с предварительным наложением координатной сетки в 
компьютерных программах SASPlanet, Grid, OziExplorer с размером ячейки 50x50 м. Было выделено 26 трансект через каждые 50 м, проходящих через весь полигон и ориентированных с севера на юг, на каждой трансекте были отмечены точки опробования через 50 м. Для анализа выбирали трансекты, охватывающие различные элементы рельефа. На основе данных, полученных в результате полевых и лабораторных исследований, были созданы цифровые карты топографический индекс влажности (TWI) и распределение запасов продуктивной влаги в границах полигона.

Результаты исследований. На основе массива данных, полученных в результате инструментальной топографической съемки полигона, была создана цифровая модель рельефа. Основные морфометрические характеристики полигона исследования - уклон и экспозиции склонов полигона исследования.

На территории полигона под покровом озимой пшеницы были проведены исследования почвы для изучения пространственного распределения запасов продуктивной влаги в $0 \ldots 100$ см слое почвы.

Для прогнозирования распределения запасов почвенной влаги в зависимости от морфометрических параметров рельефа в программе QGIS была построена картограмма на основе определения топографического индекса влажности (Topographic Wetness Index, TWI), характеризующая участки с предрасположенностью к избыточному увлажнению. Топографический индекс влажности определяли по формуле, заложенной в алгоритм программы:

TWI $=\operatorname{Ln}(\alpha / \tan \beta)$

При анализе полученных данных установлено, что наиболее влагообеспеченными могут быть участки полигона северо-восточной и северо-западной экспозиций с индексом влажности $>10,4$ (рис. 1). Это согласуется с прогнозом интенсивного стока.

В дальнейшем почва на территории полигона была исследована под покровом озимой пшеницы для изучения пространственного распределения запасов продуктивной влаги в $0 \ldots 100$ см слое почвы в начале и конце вегетации культуры. В весенний период в $0 . .30$ см слое почвы величина этого показателя изменялись от 36,7 мм (южная экспозиция) до 48,5 мм (северо-западная экспозиция). В $0 \ldots 100$ см слое почвы запасы продуктивной влаги по трансекте О варьировали от 123,3 мм до 142,7 мм. При этом изменения имели характер кривой. В точке О-3, расположенной в нижней части склона северной экспозиции, содержалось наименьшее количество влаги (123,3 мм), в точке O-11, находящейся ближе к плакору, оно возрастало (142,7 мм), а затем к точке O-21, расположенной на южной экспозиции полигона, снижалось (127,1 мм). 


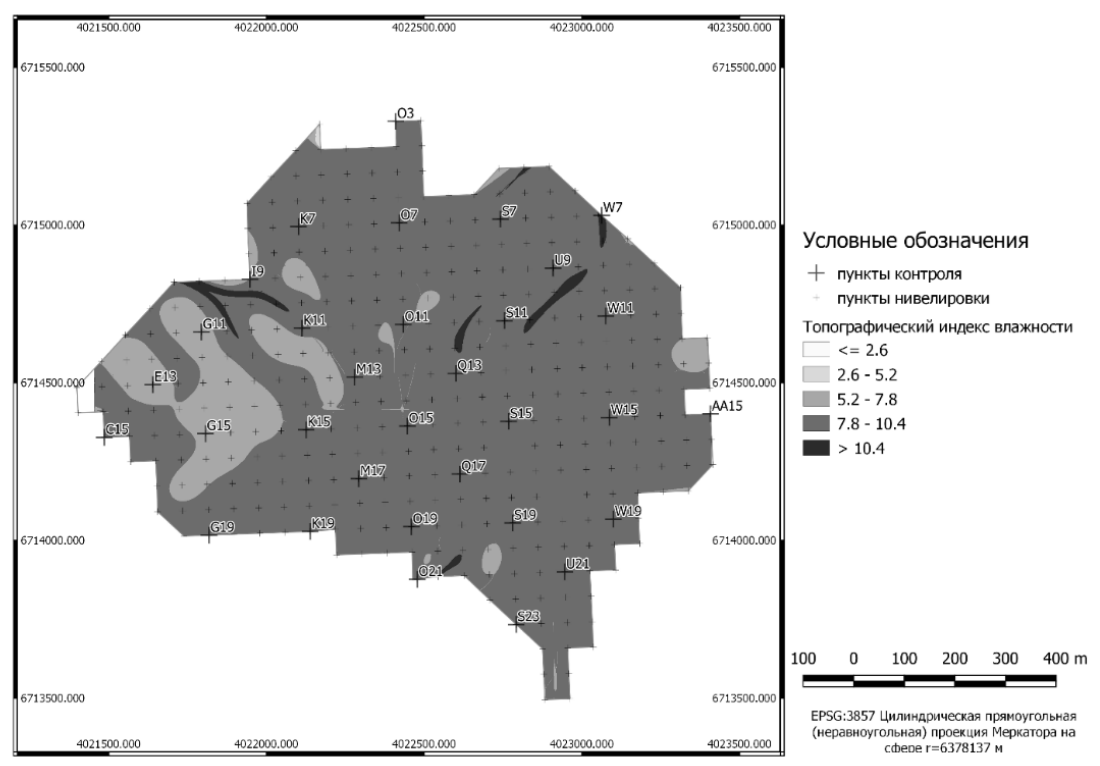

Рисунок 1 - Топографический индекс влажности (TWI) в границах полигона.

На трансекте $\mathrm{S}$ наибольшую величину этого показателя отмечали в нижних точках на склоне северной экспозиции - 149,1 и 149,8 мм, далее по трансекте от водораздельной до нижней части склона южной экспозиции она уменьшалась до 127,3 мм, а в самой нижней точке S-23 составляла 147,5 мм. Таким образом, запасы продуктивной влаги по трансекте О в $0 \ldots 100$ см слое почвы были удовлетворительными в нижних частях склона северной и южной экспозиции и хорошими - ближе к водоразделу и на водоразделе. По трансекте $\mathrm{S}$ хорошие запасы влаги отмечали на склоне северной экспозиции до водораздельной части склона и в самой нижней точке южной экспозиции, удовлетворительные - на склоне южной экспозиции. Наибольшее количество продуктивной влаги отмечали в точках U-9 - 158,0 мм (северо-восточная экспозиция) и I-9 - 157,9 мм (северо-западная экспозиция), что соответствует уровню «хорошее». Наименьшее количество продуктивной влаги отмечали в точках $\mathrm{G}-15$ (116,0 мм, западная экспозиция) и W-19 (115,9 мм, юго-восточная экспозиция), где оно оценивается как «удовлетворительное». Результаты проведенной статистической обработки (табл.) свидетельствуют, что запасы продуктивной влаги в почве характеризовались низким коэффициент вариации от 7,02 до 8,16 , а их качественная оценка изменялась от хорошей до удовлетворительной.

Таблица - Оценка содержания запасов продуктивной влаги в 0...100 см слое в посевах озимой пшеницы

\begin{tabular}{|c|c|c|c|c|}
\hline \multirow[t]{2}{*}{ Параметр } & \multicolumn{3}{|c|}{$\begin{array}{l}\text { Запасы продуктивной влаги по } \\
\text { слоям почвы, мм }\end{array}$} & \multirow{2}{*}{$\begin{array}{l}\text { Качественная оценка запасов продук- } \\
\text { тивной влаги }\end{array}$} \\
\hline & $0-30 \mathrm{~cm}$ & $0-50 \mathrm{~cm}$ & $0-100 \mathrm{~cm}$ & \\
\hline Max & 49,5 & 85,2 & 158 & хорошая \\
\hline Min & 36,7 & 60,7 & 115,9 & удовлетворительная \\
\hline$X$ & 43 & 74 & 134 & хорошая \\
\hline $\mathrm{Sd}$ & 3,19 & 5,18 & 10,93 & \\
\hline $\mathrm{V}, \%$ & 7,37 & 7,02 & 8,16 & \\
\hline
\end{tabular}


Запасы влаги в 0-100 см слое почвы наибольшими отмечались на склоне северо-восточной экспозиции и оценивались как хорошие [8]. На склонах других экспозиций запасы продуктивной влаги оценивались как удовлетворительные.

На рисунке 2 видно, что распределение запасов продуктивной влаги в 0 100 см слое чернозёмных почв в зависимости от местоположения в рельефе совпадает с картограммой топографического индекса влажности. Наибольшие запасы продуктивной влаги отмечали на вогнутых формах рельефа на водосбоpax. В почвенных образцах, отобранных на водоразделах её содержание соответствовало удовлетворительному уровню.

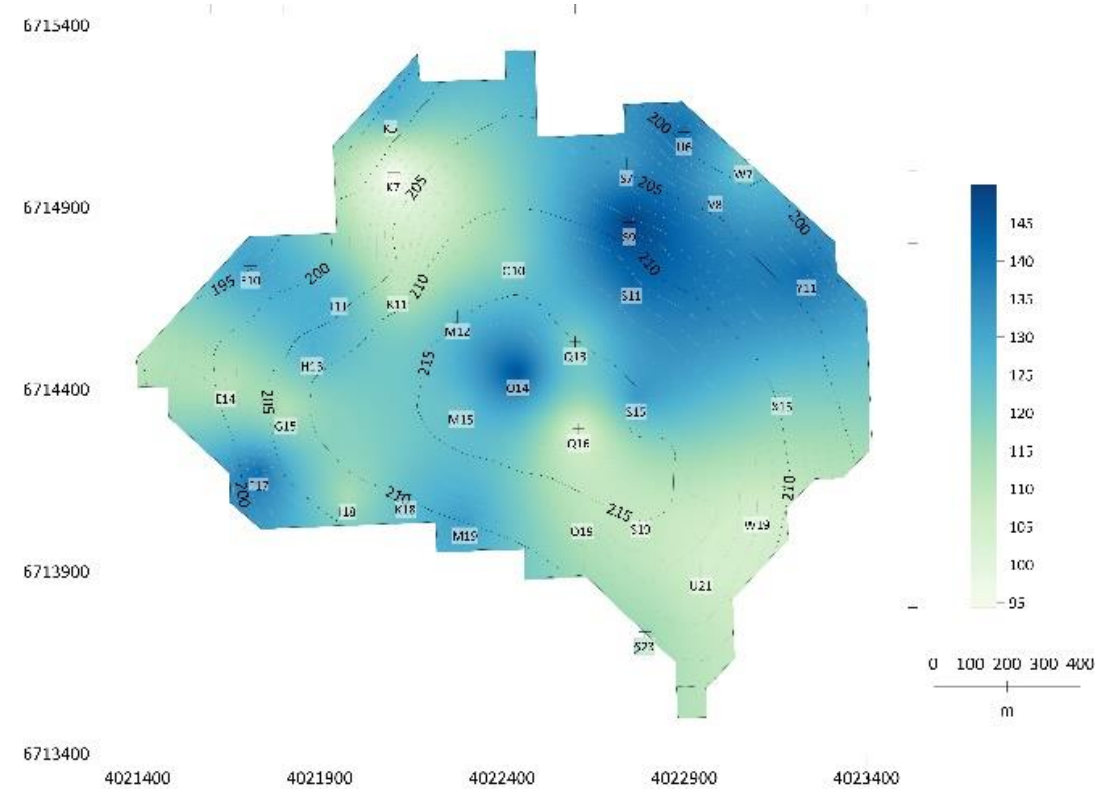

Рисунок 2 - Распределение запасов продуктивной влаги в 0-100 см слое чернозёмных почв

Выводы. В результате проведенных комплексных исследования на полигоне опытного поля Курского ФАНЦ (Медвенский район, Курская область) с куполообразной формой рельефа с использованием цифровых и ГИСтехнологий, показаны особенности варьирования в пахотном слое почвы запасов продуктивной влаги. Подтверждены результаты прогнозирования распределения запасов почвенной влаги в зависимости от морфометрических параметров рельефа. Наиболее влагообеспеченными могут быть участки полигона северо-западной и северо-восточной экспозиций с индексом влажности $>10,4$.

Полученные результаты необходимы для разработки системы поддержки принятия решений по использованию природно-ресурсного потенциала в агроландшафтах ЦЧР.

\section{Библиографический список}

1. Самсонова В.П., Кротов Д.Г., Лаврешова Е.Ю. Пространственная изменчивость агрохимических свойств сельскохозяйственных угодий Брянской области. Агрохимия, 2017. № 7. - С. 11-18.

2. Ширинян М.Х. Влияние рельефа агроландшафта на плодородие почвы и эффективность удобрений / М.Х. Ширинян, В.М. Кильдюшкин, Г.М. Лесовая // Проблемы агрохимии и экологии, 2009. - № 2. - С. 14-17. 
3. Кирюшин, В.И. Экологические основы проектирования сельскохозяйственных ландшафтов / В.И. Кирюшин // СПБ: ОО «Квадро», 2018. - 568c.

4. Чуян Н.А., Чуян О.Г., Брескина Г.М. Агрофизические показатели чернозема типичного в условиях использования побочной продукции на удобрение при разных уровнях удобренности // Достижения науки и техники АПК, 2013. - № 2. - С. 3-5.

5. Лукин, С.В. Применение геоинформационных систем для агроэкологического мониторинга сельскохозяйственных земель / С.В. Лукин, И.Г. Костин, Е.С. Малышева //Агрохимический вестник, 2019. - № 4. - С. 8-13.

6. Глазунов Г.П., Афонченко Н.В., Двойных В.В. Оценка влияния морфометрических показателей рельефа на плодородие черноземных почв // Достижения науки и техники АПК, 2020. - Т. 34. - № 7. - С. 10-18. DOI: 10.24411/0235-2451-2020-10702

7. Карманов И.И., Булгаков Д.С. Методика почвенно-агроклиматической оценки пахотных земель для кадастра. М.: Изд-во ООО «АПР», 2012. - 121с.

8. Вадюнина А.Ф., Корчагина 3.А. Методы исследования физических свойств почв. - М.: Агропромиздат, 1986. - С.53-78.

\title{
УДК 631.5 \\ НАУЧНО-МЕТОДОЛОГИЧЕСКИЕ ОСНОВЫ ЦИФРОВОЙ ОПТИМИЗАЦИИ АГРОТЕХНОЛОГИЙ
}

\author{
Гуреев И.И. \\ ФГБНУ «Курский ФАНЦ», г. Курск \\ E-mail: gureev06@mail.ru
}

Резюме. Предложено стациионарные значения функции параметра оптимизаџии агротехнологий определять после их иифрового моделирования совместно с дополнительными условиями в виде уравнений связи, используя метод неопределённых множителей Лагранжа. Эффективность разработанных научно-методических основ показана на примере оптимизации удобрения озимой пшениць.

Summary. It is proposed to determine the stationary values of the function of the optimization parameter of agricultural technologies after their digital modeling together with additional conditions in the form of communication equations using the method of indefinite Lagrange multipliers. The effectiveness of the developed scientific and methodological foundations is shown on the example of the optimization of winter wheat fertilization.

Ключевые слова: научно-методологические основы, земледелие, ичирровая оптимизация, математическое моделирование, метод Лагранжа.

Keywords: scientific and methodological foundations, agriculture, digital optimization, mathematical modeling, Lagrange method.

Введение. Достоверность и оперативность оптимизации агротехнологий существенно возрастают с применением математического моделирования и цифровых методов. Помимо повышения точности оптимизации, моделирование позволяет выявить синергию факторов в различных сельскохозяйственных технологических процессах [1].

Для каждого элемента агротехнологии построение оптимизационной математической модели (физической, эмпирической) начинается, прежде всего, с формулировки параметров оптимизации, т.е. критериев, по которым оценивается эффективность. 
Содержание параметров оптимизации определяется решаемыми задачами. На практике редко встречаются задачи, где единственный критерий оценки однозначно диктуется целевой направленностью. Исследовательский процесс в земледелии характеризуется, как правило, несколькими параметрами оптимизации, раскрывающими разные, часто противоположные его стороны [2].

Например, интенсификация агротехнологий, наряду с повышением урожайности сельскохозяйственных культур, одновременно сопряжена с необходимостью минимизации общих затрат. Но постановка задачи достижения максимального эффекта при минимальных затратах в научном плане нереальна. Поэтому многокритериальную задачу сводят к однокритериальной выделением главного параметра оптимизации, обратив его в максимум (минимум).

На все остальные параметры накладывают ограничения, требуя, чтобы они были не меньше (больше) заданных значений. Так, формулировка параметра оптимизации может содержать максимизацию урожайности при ограничении до определённого уровня затрат. Методика решения подобных задач хорошо формализована в области линейных взаимосвязей параметров оптимизации с факторами (линейное программирование), где ограничения, налагаемые на элементы решения, имеют вид линейных равенств или неравенств относительно не взаимосвязанных между собой факторов [3].

Иногда используется другой менее точный подход построения функции желательности Харрингтона, характеризующей совокупность нескольких параметров оптимизации [4]. Однако функция желательности имеет недостаток. Шкала соотношений между ней и параметрами оптимизации строится на основе субъективной оценки исследователя к отдельным оптимизируемым компонентам, т.е. присутствует небезошибочный человеческий фактор.

Цель исследований. Создание научно-методологических основ цифровой оптимизации агротехнологий.

Условия материалы и методы. Особенности нового методологического подхода поясним на конкретных примерах. Предположим, исследуют влияние на энергоёмкость и качественные показатели отвальной вспашки факторов ширины захвата плуга и рабочей скорости агрегата. За основной параметр оптимизации принимают энергоёмкость приёма и по экспериментальным данным строят эмпирическую модель её зависимости от факторов. Остальные параметры оптимизации, определяющие качество вспашки (крошение обрабатываемого пласта, степень заделки в почву пожнивных остатков и др.) принимают за ограничения. Варьируя факторами, минимизируют энергоёмкость вспашки при солюдении ограничений по параметрам качества.

Таким образом, одна из основных задач оптимизации производственных ресурсов в земледелии связана с определением экстремальных (максимальных или минимальных) значений алгебраических функций (1):

$$
Y=Y\left(X_{1}, X_{2}, \ldots X_{n}\right) \text {; }
$$


где $Y$ - параметр оптимизации;

$X_{1}, X_{2}, \ldots X_{n}$ - переменные факторы в количестве $n$, под которыми понимают величины, воздействующие на исследуемый процесс и принимающие в некоторый момент определённые дискретные значения.

Математическое условие для определения экстремальных значений параметра оптимизации характеризуется частной производной функции $Y$ по каждому из оптимизируемых факторов с последующим приравниванием нулю (2):

$$
\begin{aligned}
& \frac{d Y}{d X_{1}}=0 ; \\
& \frac{d Y}{d X_{2}}=0 ; \\
& \cdots \\
& \frac{d Y}{d X_{n}}=0 .
\end{aligned}
$$

Точки $X_{n}$, полученные в результате решения системы уравнений (2), называются стационарными точками функции $Y$ и являются оптимальными значениями факторов.

Однако во многих задачах земледелия по определению стационарных точек фукции $Y$ между переменными $X_{n}$ существуют взаимосвязи, которые изложенной выше методикой не учитываются.

К примеру, исследуют влияние на урожайность озимой пшеницы и качественные показатели зерна (массовая доля белка, число падения, натура и др.) факторов в виде элементов минерального питания. Требуется определить значения факторов, соответствующие максимальной урожайности зерна требуемого качества.

Но в данном случае значимое влияние на урожайность зерна оказывает как количество вносимых элементов питания, так и соотношение между ними, т.е. элементы питания взаимосвязаны. Поэтому математически точно оптимизация будет осуществлена, если стационарные значения функции $Y=Y\left(X_{1}, X_{2}, \ldots X_{n}\right)$ определять с учётом связи $\varphi=\varphi\left(X_{1}, X_{2}, \ldots X_{n}\right)=0$.

Решение таких задач упрощается использованием метода неопределённых множителей Лагранжа, согласно которому необходимое условие стационарности функции $Y$ находят при условии (3):

$$
\begin{aligned}
& \frac{d \Phi}{d X_{1}}=0 ; \\
& \frac{d \Phi}{d X_{2}}=0 ; \\
& \frac{d \Phi}{d X_{n}}=0 ;
\end{aligned}
$$


где $\Phi\left(X_{1}, X_{2}, \ldots X_{n}\right)=Y\left(X_{1}, X_{2}, \ldots X_{n}\right)+\lambda \varphi\left(X_{1}, X_{2}, \ldots X_{n}\right)$;

$\lambda$ - множитель Лагранжа. В алгебраических задачах он постоянен и не несёт информационной ценности, но определение его значительно проще, чем исключение неизвестной через уравнение связи [3].

Если возвратиться к приведенному выше примеру, то при оптимизации питания озимой пшеницы количество уравнений связи должно соответствовать количеству $m$ оцениваемых качественных показателей зерна культуры. Тогда:

$$
\Phi\left(X_{1}, X_{2}, \ldots X_{n}\right)=Y\left(X_{1}, X_{2}, \ldots X_{n}\right)+\sum_{i=1}^{m} \lambda_{i} \varphi_{i}\left(X_{1}, X_{2}, \ldots X_{n}\right) ;
$$

где $i=0, \ldots m, n>m$.

Оптимизируемые факторы $X_{n}$ и множители $\lambda_{i}$ находят решением системы $n+m$ уравнений (3) и (4).

Результаты и обсуждение. Важнейшая задача агротехнологий состоит в обеспечении растений сельскохозяйственных культур в достаточном количестве необходимыми элементами питания. Удобрение мощный рычаг управления продуктивностью культур при одновременном снижении потерь почвы и питательных веществ в ней [5]. Нормы вносимых удобрений должны соответствовать потребности растений в питательных веществах, что определяется множеством факторов. Это вид культуры, погодноклиматические условия, содержание подвижных элементов питания в почве и её агрофизические свойства, агротехника возделывания культуры и многое другое $[6,7]$.

Существует большое количество способов расчёта норм внесения удобрений. Но самым надёжным и достоверным для конкретных условий является способ полевого опыта с удобрениями.

Рассмотрим модельный пример с озимой пшеницей. Предположим, что в результате полевого опыта получены уравнения регрессии по влиянию на

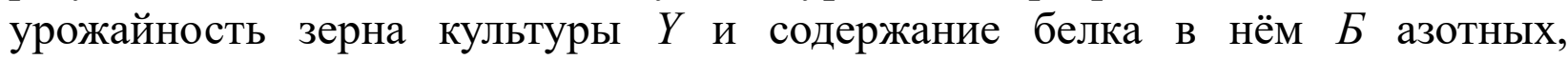
фосфорных и калийных удобрений. За основной параметр оптимизации принимаем урожайность $Y$, а уравнение содержания белка в зерне $\bar{B}$ используем в качестве связи $\varphi$ :

$$
\begin{aligned}
& Y=4,21-9,5 X_{1}+41,3 X_{2}+51,6 X_{3}-14,8 X_{1} X_{3}, \mathrm{~T} / \text { га; } \\
& \varphi=5-9,7+15,3 X_{1}-38,4 X_{2}-61,1 X_{3}-72,8 X_{1} X_{2}=0, \% ; \\
\text { где } & \text { факторы, соответственно, азотные, фосфорные и калийные } \\
X_{1}, X_{2}, X_{3} & \text { удобрения, т/га. }
\end{aligned}
$$

Поставим задачу получения максимальной урожайности зерна озимой пшеницы 3-его класса. Согласно ГОСТ 9353-2016, у такой пшеницы массовая доля белка в пересчёте на сухое вещество должна быть не менее $B=12 \%$. Следовательно, условию (3) и (4) стационарности функции урожайности озимой пшеницы соответствует система четырёх уравнений: 


$$
\begin{aligned}
& 5-9,7+15,3 X_{1}-38,4 X_{2}-61,1 X_{3}-72,8 X_{1} X_{2}=0 ; \\
& -9,5-14,8 X_{3}-\lambda\left(72,8 X_{2}-15,3\right)=0 ; \\
& 41,3-\lambda\left(72,8 X_{1}+38,4\right)=0 ; \\
& 51,6-14,8 X_{1}-\lambda 61,1=0 .
\end{aligned}
$$

Данная система уравнений решена численным методом: $X_{l}=0,181$ т/га; $X_{2}=0,033$ т $/$ га; $X_{3}=0,055$ т $/$ га; $\lambda=0,8$.

Подставляя полученные значения факторов в уравнение урожайности культуры, получим $Y=6,55$ т/га. Таким образом, обозначенная величина урожайности зерна озимой пшеницы 3-его класса является оптимальной при расходовании выше приведенных доз минеральных удобрений.

Вывод. Предложены научно-методологические основы оптимизации агротехнологий применением метода неопределённых множителей Лагранжа. Это позволило повысить точность оптимизации в исследовательских задачах вследствие определения оптимальных значений ресурсов совместно с дополнительными условиями в виде уравнений связи оптимизируемых параметров.

\section{Библиографический список}

1. Cillis D. Modeling soil organic carbon and carbon dioxide emissions in different tillage systems supported by precision agriculture technologies under current climatic conditions / D._Cillis, A. Pezzuolo, F. Marinello, L. Sartori, B. Maestrini // Soil \& Tillage Research. - 2018. - T. 183. C. 51-59.

2. Лихацевич А.П. Анализ результатов агрономических опытов с использованием обобщённой математической модели // Весці Нацыянальнай акадэміі навук Беларусі. Серыя аграрных навук. - 2017. - № 2. - С. 68-81.

3. Ганичев А.В., Ганичева А.В. Математическое программирование: учеб. пособие. Тверь: Тверской государственный технический университет, 2017. - 88 с.

4. Гуреев И.И. Результаты испытаний комбинированного орудия для посева зерновых культур // Инновационно-технологические основы развития земледелия: Сб. докладов Всерос. науч.-практ. конф. - Курск: ВНИИЗиЗПЭ, 2006. - С. 98-102.

5. Bindraban P.S., Dimkpa C., Nagarajan L. et al. Revisiting fertilizers and fertilization strategies for improved nutrient uptake by plants // Biology and Fertility of Soils. -2015. -V. 51. - No 8. - Pp. 897-911.

6. Bindraban P.S, van der Velde M., Ye L., et al., 2012. Assessing the impact of soil degradation on food production. Curr Opin Environ Sust 4:478-488.

7. Ding W., Xu X., He P., et al., 2018. Improving yield and nitrogen use efficiency through alternative fertilization options for rice in China: a meta-analysis. Field Crops Research, vol. 227, pp.11-18.

8. Гуреев И.И. Современные технологии возделывания и уборки сахарной свёклы. Практическое руководство / Изд. 2-е, перераб. и доп. - М.: Печатный Город, 2011. - 256 с. 


\title{
ЦЕЛЛЮЛОЗОРАЗЛАГАЮЩАЯ АКТИВНОСТЬ ПОЧВЫ КАК ОДИН ИЗ ПОКАЗАТЕЛЕЙ ЕЁ БИОЛОГИЧЕСКОЙ АКТИВНОСТИ
}

\author{
Двойных В.В. \\ ФГБНУ «Курский ФАНЦ», г. Курск \\ E-mail: viktoria.dvoinyh@yandex.ru
}

\begin{abstract}
Резюме. Важно выявить наиболее информативные и доступные показатели биологической активности почвы для оценки агротехнических приемов при воздельвании сельскохозяйственных культур. Показатели биологической активности почвы необходимы для характеристики ее как биологической системы и оценки степени ее изменения под влиянием антропогенного воздействия.

Resume. It is important to identify the most informative and accessible indicators of the biological activity of the soil for assessing agrotechnical techniques in the cultivation of agricultural crops. Indicators of the biological activity of the soil are necessary to characterize it as a biological system and to assess the degree of its change under the influence of anthropogenic impact.
\end{abstract}

Целлюлозолитическая активность является одним из показателей биологической активности, а определение степени распада ткани в почве позволяет дать более точную оценку ее активности [1]. Изучение жизнедеятельности целлюлозолитической микрофлоры является информативным параметром биомониторинга почв агроландшафтов. Целлюлоза-наиболее распрастраненное углеродное соединение, синтез которого в маштабах биосферы занимает первое место: более $50 \%$ от всего синтезируемого органического вещества [2]. В почвах любого типа, формирующихся в различных климатических условиях, существуют виды микроорганизмов, которые доводят расщепление клетчатки до конца, образуя углекислоту и воду при условии достаточного количества азота и минеральных элементов, необходимых для обмена веществ. Процесс разложения органического вещества является важным неотъемлемым звеном мирового биогеохимического круговорота элементов, во многом определяет плодородие почв. Скорость разложения целлюлозы влияет на скорость разложения органики в целом. Данный показатель можно рассматривать как количественную меру почвенного плодородия, а чистую целлюлозу можно рассматривать как модельный субстрат для разложения, на фоне которого можно определить действие факторов внешней среды и изучить свойства почвы. В настоящее время, в рамках контроля за состоянием окружающей среды и оценки воздействия на неё, особое место занимает биологический мониторинг - контроль состояния окружающей природной среды с помощью живых организмов. При проведении биомониторинга и биодиагностики почв ведущими являются показатели биологической активности, под которой подразумевают интенсивность протекающих в ней биологических процессов. Биологическая активность почвы обусловлена суммарным содержанием в почве определенного запаса ферментов, как выделенных в процессе жизнедеятельности растений и микроорганизмов, так и аккумулированных почвой после разрушения отмерших клеток. Биологическая активность почв характеризует размеры и 
направление процессов превращения веществ и энергии в экосистемах суши, интенсивность переработки органических веществ и разрушения минералов [3, $4,5]$.

К широко используемым показателям биологической активности почв относится оценка скорости разложения клетчатки целлюлозоразрушающими микроорганизмами (целлюлозолитическая активность почв). Это один из немногих интегральных показателей интенсивности микробиологических процессов непосредственно в природных условиях. Метод оценки биологической активности по целлюлозолитической активности имеет свои преимущества: он прост, дает сравнимые результаты и отражает тонкие изменения почвенных условий (таких, например, как влажность, степень окультуренности), динамику почвенных процессов и различия в почвах в связи с их использованием. Метод широко применяется для решения не только почвенно-генетических, но и разнообразных практических задач.

Биологическую активность почвы оценивают по интегральным показателям, которые могут быть использованы при тестировании состояния почв. При загрязнении почв небольшими количествами органических соединений может наблюдаться возрастание некоторых показателей биологической активности, так как более интенсивно развиваются группы микроорганизмов, участвующих в переработке дополнительных субстратов (фенолов, углеводородов). При загрязнениях тяжелыми металлами, оксидами серы, большими количествами различных органических веществ преобладает токсический эффект, вследствие чего биологическая активность подавляется. Степень разложения ткани широко используется как показатель биологической активности почвы и позволяет судить о наличии в ней минерального азота и мобилизационных возможностях почвы в отношении этого элемента.

На полигоне опытного поля Курского федерального аграрного научного центра (Медвенский район, Курская область) были проведены исследования биологической активности почвы. Полигон расположен на территории европейской части России в пределах Средне-Русской возвышенности на высоте 190-217 м над уровнем моря, у истока реки Млодать. Средний уклон составляет $2,23^{\circ}$. Почва опытного участка представлена черноземами различной степени смытости. Заложен опыт на производственном участке с куполообразной формой рельефа с выраженной волнистостью, площадью в 86га.

В 2021 году в первом сроке закладки на склонах всех экспозиций наблюдалось снижение биологической активности почвы. Неблагоприятный температурный режим месяца отличался не только большей величиной атмосферных осадков, но и сравнительно низкими температурами атмосферного воздуха. Сложившиеся погодные условия оказывали угнетающее действие на активность почвенной микрофлоры, что способствовало снижению биологической активности почвы. В первый срок доля утраченного полотна в почве в течение 30 суток в среднем составила не более 0,003\%. Во второй срок закладки доля утраченного полотна составила в среднем 0,007\% так как наиболее активные аэробные целлюлозоразрушающие бактерии запускают процесс органического 
распада в поверхностном слое почвы. Интенсивность разложения целлюлозы была слабее по сравнению с предыдущим годом. Слабая интенсивность разложения целлюлозы в 2021 году определена неблагоприятными погодными условиями.

\section{Таблица - Статистические параметры интенсивности разложения} тканей (РТ) по первому и второму срокам закладки (2020 г.- 2021г.)

\begin{tabular}{|c|c|c|c|}
\hline Разложение & Среднее & Минимум & Максим. \\
\hline \multicolumn{4}{|c|}{$2020 \Gamma$} \\
\hline PT1 , \% & 46,8 & 7,8 & 82,2 \\
\hline ИРТ1 & 0,014 & 0,002 & 0,027 \\
\hline PT2, $\%$ & 38,2 & 7,1 & 83,1 \\
\hline ИРТ2 & 0,013 & 0,002 & 0,028 \\
\hline \multicolumn{4}{|c|}{$2021 \Gamma$} \\
\hline PT1 , \% & 10,0 & 2,4 & 29,3 \\
\hline ИРТ1 & 0,003 & 0,0008 & 0,011 \\
\hline PT2, \% & 16,0 & 3,5 & 60,8 \\
\hline ИРТ2 & 0,007 & 0,001 & 0,030 \\
\hline
\end{tabular}

Примечание: РТ-разложение ткани; ИРТ- интенсивность разложения ткани; 1, 2- сроки.

Выводы. Оценка биологической активности почвы может быть использована как предварительные исследования почвенных процессов с последующим их учетом при закладке полевых опытов. Целлюлозолитическая активность является важным показателем интенсивности деструкционных процессов в почве. Интенсивность разложения целлюлозы в почве определяется совместным действием нескольких факторов: погодными условиями, характером растительного покрова, объемом органического вещества, поступающего в почву, типом почв, её физическими свойствами, химическим составом. Биологическую активность почвы нельзя оценивать по одному-двум параметрам, должен отслеживаться комплекс показателей. К сожалению, до настоящего времени не существует устоявшейся общепринятой унифицированной системы оценки биологических свойств почвы, на основе которой можно было бы составить некую шкалу, подобно шкале для оценки физических и химических свойств почвы, хотя необходимость создания такой системы признает большинство специалистов.

\section{Библиографический список}

1. Востров И. С. Определение биологической активности почвы различными методами [Текст] / И. С. Востров, А. Н. Петрова // Микробиология. - Т.30. - Вып. 4. - 1961. - С. 12-15. 2. Зинченко М.К., Зинченко С.И., Федулова И.Д. Численность и активность целлюлозолитической микрофлоры в агроценозах серой лесной почвы. Коллективная монография. под редакцией В.В. Окоркова. Иваново, 2019. -102 с.

3. Звягинцев Д.Г. Биология почв / Д.Г. Звягинцев, И.П. Бабьева, Г.М. Зенова. - М.: МГУ, 2005. $-445 \mathrm{c}$.

4. Казеев К.Ш. Биологическая диагностика и индикация почв: методология и методы исследований / К.Ш. Козеев, С.И. Колесников, В.Ф. Вальков. - Ростов н/Д: Изд-во РГУ, 2003. $-216 \mathrm{c}$.

5. Коваленко М.В. Биологические показатели и плодородие почвы // Актуальные вопросы агрономической науки в XXI веке. - Самара, 2004. - С. 424-430. 
УДК 631.854

\title{
БИОДИАГНОСТИКА ЭКОЛОГИЧЕСКОГО СОСТОЯНИЯ ЧЕРНОЗЕМОВ ЦЧР \\ Девятова Т.А., Горбунова Ю.С. \\ Воронежский государственный университет, г. Воронеж \\ E-mail:devyatova@bio.vsu.ru, gorbunova.vsu@mail.ru
}

\begin{abstract}
Резюме. Выявлены региональные закономерности пространственно-временной динамики черноземов в условиях ЦЧР, разработаны критерии оценки воздействия хозяйственной деятельности на почвенный покров региона и региональная система почвенно-экологического мониторинга.

Summary. The regional regularities of the spatial and temporal dynamics of chernozems in the conditions of the CDR are revealed, criteria for assessing the impact of economic activity on the soil cover of the region and the regional system of soil and environmental monitoring are developed.
\end{abstract}

Универсальным методом биологической индикации антропогенной деградации черноземов является комплексный метод с применением интегрального показателя биологического состояния (ИПБС) по Ацци (Ацци, 1959), основанный на гибком наборе микробиологических и биохимических методов анализа - адаптированных к условиям конкретного типа агроландшафта и доминирующего фактора антропогенной нагрузки. Использование районированного ИПБС (РИПБС) позволяет систематизировать имеющуюся информацию по биологической индикации различных вариантов антропогенной деградации черноземов ЦЧР в условиях разных типов ландшафта.

Объекты и методы исследования. При изучении агрогенной динамики чернозёмов объектами послужили почвы длительных стационарных опытов с различными вариантами удобрения (Рамонь, Каменная степь, Стрелецкая степь, Агроуниверситет) севооборотов и приёмов обработки почвы, а также почвы ключевых участков в наиболее представительных ландшафтах ЦЧР.

Для сравнения изучались почвы «эталонных» участков, расположенных, как правило, на охраняемых территориях, являющихся тестовыми участками фонового экологического мониторинга. К ним относятся участки целинных степей (Каменной, Хрипунской, Стрелецкой) и залежные участки, приуроченные к ключам (Девятова и др., 2004; Девятова, Крамарева, 2004).

Результаты исследования.

1 этап: обобщение результатов комплексного мониторинга экологического состояния чернозёмов ЦЧР по фондовым материалам.

2 этап: выбраны ключевые участки и «эталонные» объекты, в различных ландшафтах, что позволило оценить природное разнообразие почв в пределах региона и типы их деградации.

3 этап: проводились разносторонние лабораторно-аналитические исследования. 
4 этап: проводились исследования по анализу основных интервалов варьирования ОДП нормального состояния чернозёмов и ряда их экологических регламентов: пороговой и критической величины параметров.

5 этап: выявлялись региональные закономерности пространственно-временной динамики черноземов в условиях ЦЧР, разрабатывались критерии оценки воздействия хозяйственной деятельности на почвенный покров региона и региональная система почвенно-экологического мониторинга.

Лабораторные исследования свойств почв проводили общепринятыми методами (Аринушкина, 1983). Интегральный показатель биологического состояния (ИПБС) рассчитывался по формуле: ИПБС $=Б_{\mathrm{cp}}\left(\mathrm{Б}_{\text {мах.cp. }} \cdot 100 \%\right)$, где $\mathrm{b}_{\mathrm{cp} .}=\left(\mathrm{Б}_{1}+\mathrm{Б}_{2}+\mathrm{Б}_{3}+\ldots \mathrm{Б}_{\mathrm{n}}\right) / \mathrm{n}$, где Б1 - относительный показатель Б1=(Бф/Бмах $)$ • $100 \%$.

ИПБС зональных подтипов черноземов снижается в ряду: чернозем типичный > чернозем выщелоченный > чернозем обыкновенный $>$ чернозем южный > чернозем оподзоленный (табл. 1). Максимум ИПБС отмечен для чернозема типичного (94-100\%). У других подтипов черноземов ИПБС равен 51-90\% от чернозема типичного. Минимальные значения отмечены для чернозема южного (51\%). Отмеченные закономерности обнаруживаются в основном при сравнительной оценке ферментативной активности пахотных черноземов одного региона близких по своему генезису и свойствам.

Причем уровень ферментативной активности этих почв может зависеть от множества факторов, которые, как правило, полностью учесть невозможно (общее количество и форма внесенных удобрений, уровень агротехники, набор культур и т.д.). Выявлены корреляционные связи между ферментативной активностью и количеством подвижных соединений фосфора и азота $(\mathrm{r}=0,67)$ и содержанием гумуса $(\mathrm{r}=0,94)$.

Таблица 1 - Общая относительная биологическая активность
черноземов ЦЧР, \% от тах
\begin{tabular}{|c|c|c|c|c|c|c|c|}
\hline Почва & $П$ & У & $\Phi$ & И & К & Д & ИПБС \\
\hline Чернозем оподзоленный & 50 & 34 & 33 & 46 & 71 & 71 & 51 \\
\hline Чернозем выщелоченный & 78 & 82 & 81 & 73 & 77 & 81 & 79 \\
\hline Чернозем типичный & 95 & 96 & 99 & 90 & 90 & 95 & 94 \\
\hline Чернозем обыкновенный & 73 & 86 & 89 & 75 & 87 & 74 & 79 \\
\hline Чернозем южный & 49 & 36 & 81 & 47 & 85 & 86 & 73 \\
\hline
\end{tabular}

Примечание: П - Протеаза, У - Уреаза, Ф - Фосфатаза, И - Инвертаза, К - Каталаза, Д Дегидрогеназа

Заключение. Следовательно, можно полагать, что накопление в почвах гумуса, азотсодержащих органических соединений и соответствующее повышение ферментативной активности представляет единый процесс, протекающий в определенных биоклиматических условиях.

Степень техногенной деградации черноземов и переходных к ним почв ЦЧР может быть определена как по показателям ферментативной активности, так и по интегральному показателю биологического состояния. С нарастанием степени загрязнения зафиксировано существенное снижение активности 
основных видов ферментативных процессов (до 80\% от фона - при высоком уровне техногенного загрязнения).

\title{
Библиографический список
}

1. Аринушкина Е.В. Руководство по химическому анализу почв / Аринушкина. - М.: МГУ, 1983. - 487 с.

2. Ацци Д. Сельскохозяйственная экология / Д. Ацци. - М., 1959. - 479 с.

3. Девятова Т.А. Ферментативная активность как показатель изменения состояния черноземов при длительном сельскохозяйственном использовании / Т.А. Девятова, Т.Н. Крамарева, Н.В. Стороженко и др. // Агроэкологическая оптимизация земледелия. - Курск, 2004. - C. 420-423.

4. Девятова Т.А. Функционально-экологическое состояние почв г. Воронежа / Т.А. Девятова, Т.Н. Крамарева, Н.В. Стороженко и др. // Современные проблемы загрязнения почв. - М., 2004. - С. 203-206.

5. Хазиев Ф.Х. Методы почвенной энзимологии / Ф.Х. Хазиев. - М.: Наука, 1990. - 189 c.

\section{УДК 631.82}

\section{ВЛИЯНИЕ РАЗЛИЧНЫХ ТЕХНОЛОГИЙ ВОЗДЕЛЫВАНИЯ ЯРОВОЙ ПШЕНИЦЫ НА ФОРМИРОВАНИЕ ПЛОЩАДИ ЛИСТОВОЙ ПОВЕРХНОСТИ}

\author{
Дериглазова Г.М.
}

ФГБНУ «Курский федеральный аграрный научный центр», г. Курск, Россия E-mail: g_deriglazova@mail.ru

Резюме. В статье анализируются исследования по изучению особенностей формирования листовой поверхности яровой пшеницы в зависимости от технологии воздельвания в условиях черноземных почв Курской области. Выявлены сопряженные связи площади листовой поверхности с элементами технологий.

Ключевые слова: яровая пшеница, площадь листовой поверхности, экстенсивная технология, интенсивная технология, биотехнология, экологоресурсосберегающая технология.

Summary. The article analyzes the research on the study of the peculiarities of the formation of the leaf surface of spring wheat, depending on the cultivation technology in the conditions of chernozem soils of the Kursk region. The conjugate relations of the sheet surface area with the elements of technologies are revealed.

Key words: spring wheat, leaf surface area, extensive technology, intensive technology, biotechnology, eco-resource-saving technology.

Урожайность сельскохозяйственных культур формируется за счет фотосинтетической деятельности растений. Листовому аппарату и его ассимиляционной площади принадлежит большая задача - сформировать в течение вегетации растений главный генеративный орган - колос, наполненный полноценным зерном $[1,2]$. Сложные процессы роста и развития растений зависят от поглотительной способности каждой клетки зеленого листа и превращения энергии солнца в энергию дальнейшего роста и развития растения [3-5].

Фотосинтетический процесс, протекающий в листьях, а так же в стеблях и в других зелёных органах растений синтезирует в клетках до 90-95\% 
органических соединений [4]. Около $80 \%$ в создании урожая пшеницы принадлежит листьям [6].

Таким образом, вопрос развития листовой поверхности яровой пшеницы остается мало изученным и требует дальнейшего исследования.

Целью работы являлось - изучение особенностей формирования листовой поверхности яровой пшеницы в зависимости от технологии возделывания в условиях черноземных почв Курской области.

Исследования проводились в 2021 году в многолетнем полевом стационарном опыте лаборатории технологий возделывания полевых культур и агроэкологической оценки земель в 9-польном полевом севообороте. Чередование культур в севообороте: 1) клевер, 2) озимая пшеница, 3) сахарная свекла, 4) яровая пшеница, 5) горох, 6) озимая рожь, 7) гречиха, 8) овес, 9) ячмень + клевер. Сорт яровой мягкой пшеницы - Дарья. Почва опытного участка - чернозем типичный. Повторность опыта - трехкратная. Расположение делянок систематическое, размер посевной делянки - 189 м² $^{2}(5.4$ х 35 м), учетная площадь - 100 м $^{2}$ (4 м х 25 м). Схема опыта и содержание вариантов представлены в таблице 1 .

\section{Таблица 1 - Схема опыта и содержание вариантов}

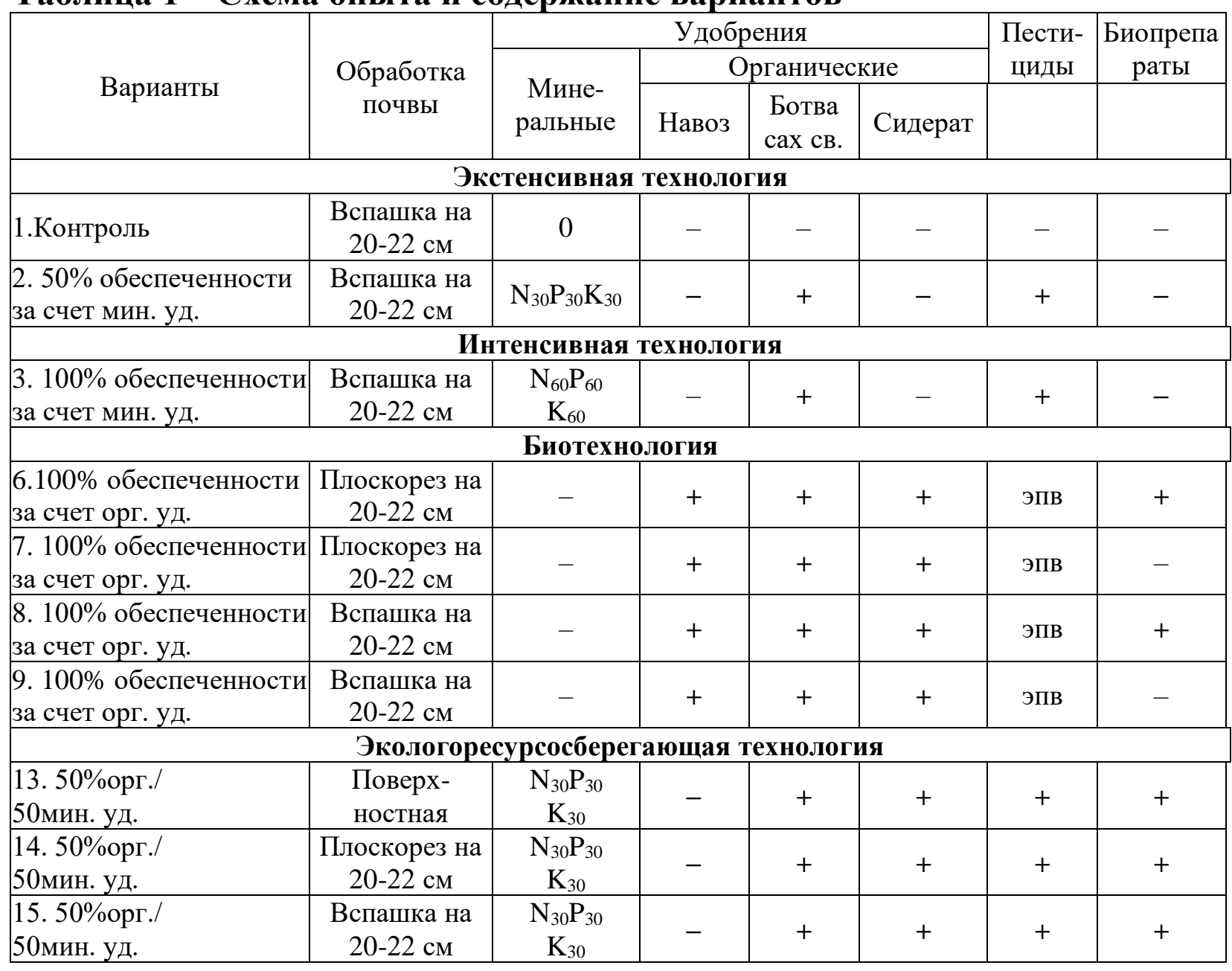

Площадь листьев яровой пшеницы определялась методом промеров для зерновых культур. Математическая обработка экспериментальных данных 
проведена по Б.А. Доспехову, статистический анализ данных - с помощью программ MicrosoftOfficeExcel.

Площадь листьев как одного растения, так и площадь посева листовой поверхности на гектаре посева яровой пшеницы существенно изменялась под воздействием исследуемых технологий и фаз развития.

Установлено, что площадь листьев одного растения яровой пшеницы в фазе полных всходов при развитии трех листьев (фаза Z 13) в зависимости от вариантов опыта варьировала в широких пределах (от 3,41 до 5,12 см²) (рис. 1).

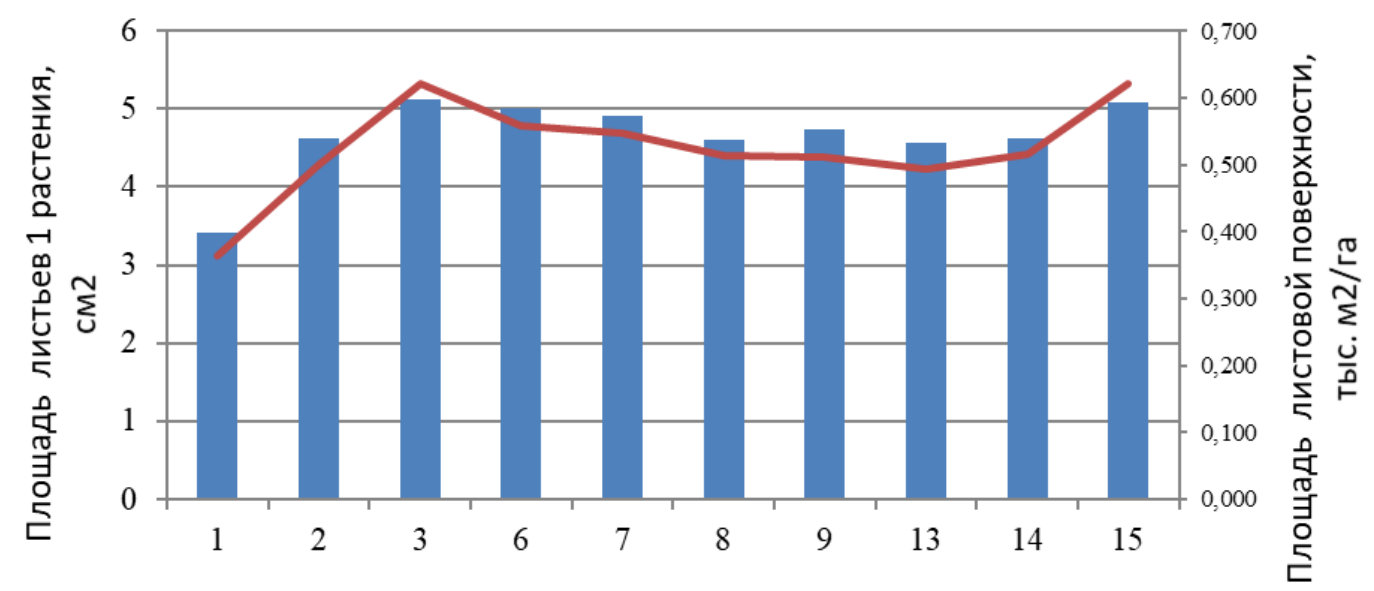

Площадь листьев 1 растения, см2 一 Площадь листовой поверхности, тыс. м2 /га

Рисунок 1 - Площадь листовой поверхности яровой пшеницы при различных технологиях возделывания в фазе Z 13

Она существенно изменялась от внесенных удобрений, которые способствовали активизации ростовых функций листьев. Поэтому площадь листовой поверхности одного растения в удобренных вариантах формировалась в целом быстрее, чем в контроле. Наибольшее повышение показателя в опыте, в сравнении с контролем, наблюдалось в вариантах при возделывании по вспашке по интенсивной технологии при $100 \%$ обеспеченности минеральными удобрениями и по экологоресурсосберегающей технологии при обеспечении $50 \%$ за счет органических и 50\% за счет минеральных удобрений. В данных вариантах показатель увеличился на $1,71 \mathrm{~cm}^{2}$ и 1,68 cм². Таким образом, превышение площадь листовой поверхности одного растения составило около $50 \%$ по сравнению с контролем.

Площадь листовой поверхности на гектаре посева напрямую связана с площадью каждого листа и густотой стояния растений. Большая площадь листьев пшеницы отмечалась при возделывании по вспашке при возделывании по интенсивной и экологоресурсосберегающей технологиям $(0,621$ и 0,620 тыс. $\mathrm{M}^{2} /$ га соответственно). Превышение по сравнению с контролем здесь составило $70 \%$. Листья на данных вариантах отличались большой длиной и шириной, а также посевы выделялись высокой густотой стояния посевов. На остальных вариантах опыта площадь листовой поверхности была выше по сравнению с контрольным вариантом на 35-53\%

Анализируя площадь листьев с одного растения в фазе середины кущения культуры можно отметить, что наибольшее значение показателя было 
достигнуто по вспашке при возделывании по экологоресурсосберегающей технологии - 14,21 см² (рис. 2). Так же большой показатель был достигнут при интенсивной технологии возделывания (3 вариант $-13,64 \mathrm{~cm}^{2}$ ) и по вспашке при возделывании по биотехнологии со $100 \%$ обеспеченностью за счет органических удобрений (9 вариант - 13,13 см²). Таким образом, вспашка обеспечила максимальную площадь ассимиляции одного растения яровой пшеницы в фазу полного кущения.

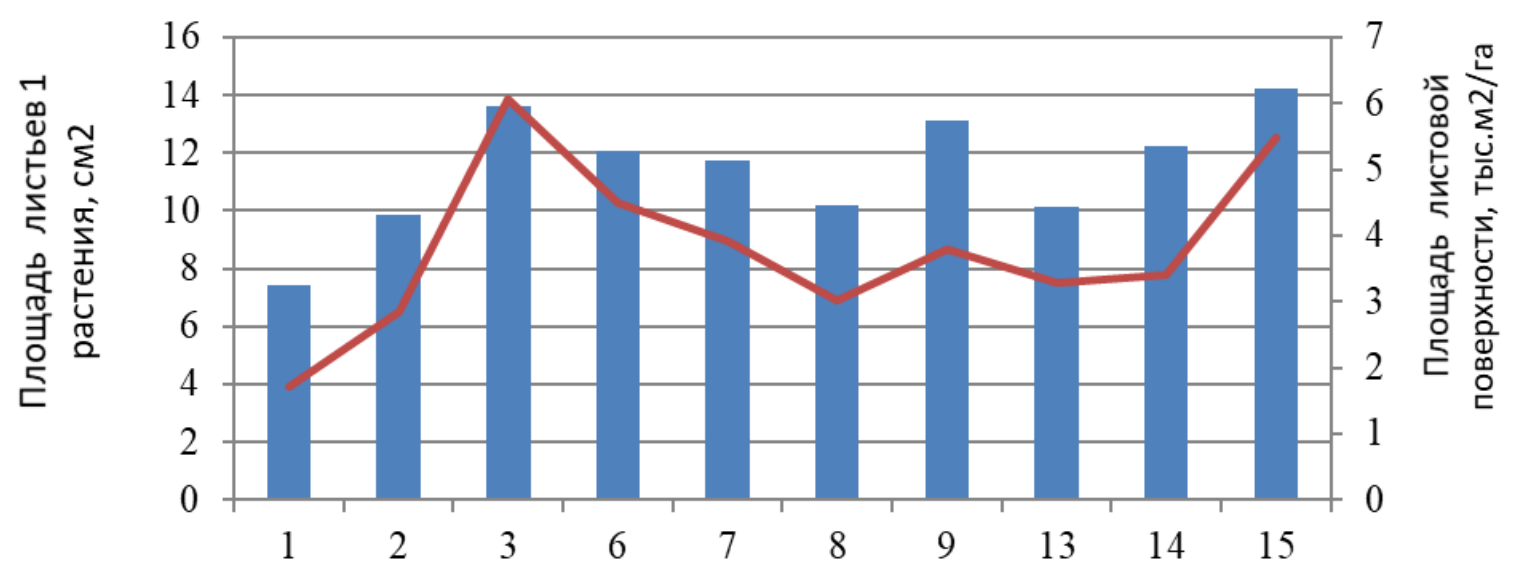

Площадь листьев 1 растения, см2 - Площадь листовой поверхности, тыс. м2 /га

Рисунок 2 - Площадь листовой поверхности яровой пшеницы при различных технологиях возделывания в фазе полного кущения

Площадь ассимиляции листовой поверхности на гектаре посевов варьировала в больших пределах по сравнению с фазой всходов и изменялась от 1,717

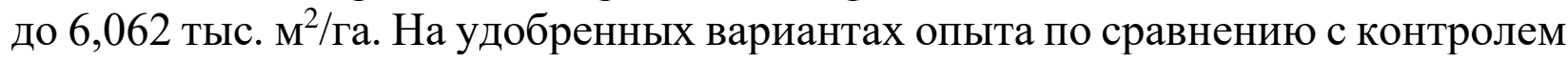
увеличение площади листовой поверхности на гектаре посевов составило от 0,6 до 2,5 раза.

В фазе середины колошения (Z 55) происходило максимальное увеличение площади ассимиляции яровой пшеницы (рис. 3).

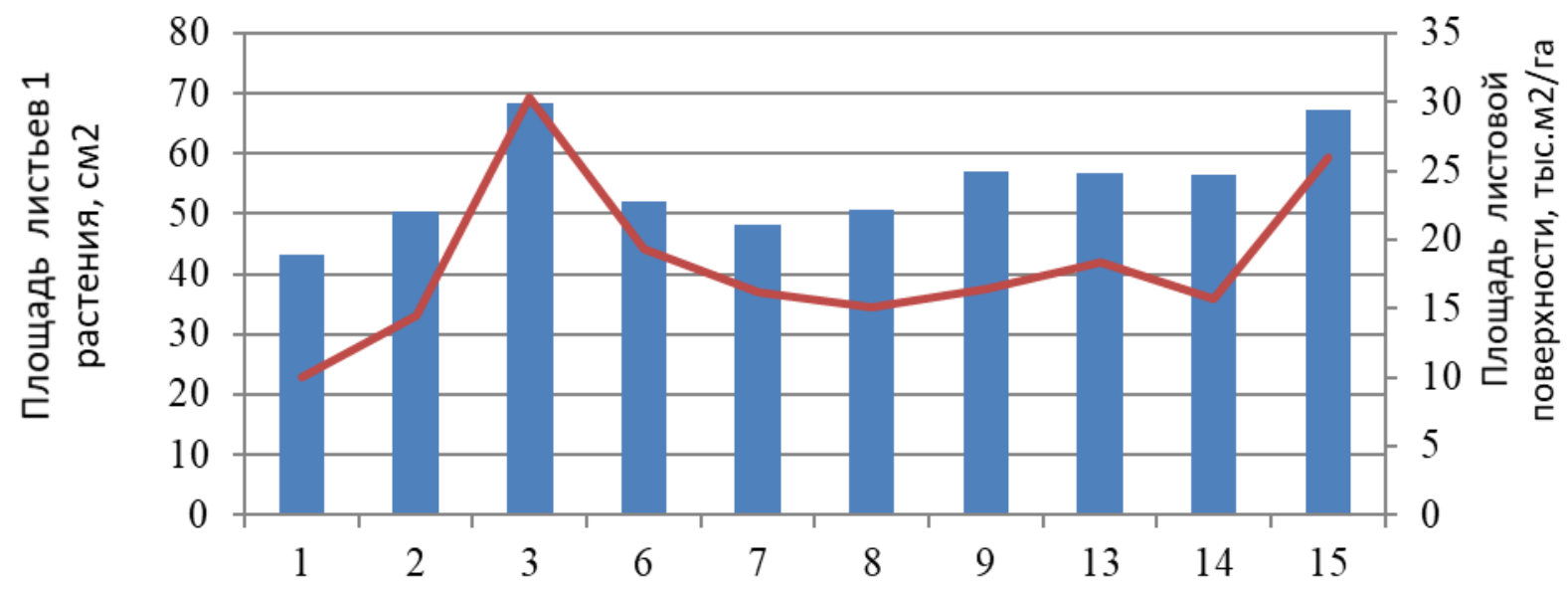

Площадь листьев 1 растения, см2 一лощадь листовой поверхности, тыс. м2 /га

Рисунок 3 - Площадь листовой поверхности яровой пшеницы при различных технологиях возделывания в фазе Z 55 
Площадь листьев одного растения при колошении яровой пшеницы изменялась от 43,2 до $68,3 \mathrm{~cm}^{2}$. Прибавка от внесения удобрений составила от 5,1 до $25,1 \mathrm{~cm}^{2}$ или $11,9-58,2 \%$. Самым большим значением показателя выделялся третий (возделывание по вспашке по интенсивной технологии) вариант. Несколько ниже были показатели при ресурсосберегающей технологии по вспашке.

Максимальная площадь листовой поверхности за вегетационный период культуры варьировала в зависимости от вариантов опыта от 9,99 до 30,35 тыс. $\mathrm{m}^{2} /$ га. Несомненное преимущество оставалось за интенсивной и ресурсосберегающей технологией возделывания яровой пшеницы.

Таким образом, интенсивная и ресурсосберегающая технологии возделывания яровой пшеницы обеспечивали формирование наибольшей площади листовой поверхности на всех фазах роста культуры.

Анализ сопряженных данных элементов технологий и исследуемых показателей позволил выявить высокую прямую связь площади листовой поверхности с внесением минеральных удобрений при колошении культуры $(\mathrm{r}=0,74)$, умеренную при всходах $(\mathrm{r}=0,48)$ и заметную при кущении $(\mathrm{r}=0,54)$. Внесение ботвы сахарной свеклы положительно сказывалось на всех фазах развития культуры. Это воздействие снижалось от всходов к колошению, о чем свидетельствует высокая, заметная и умеренная корреляционная связь $(\mathrm{r}=0,77$ при всходах; 0,57 при кущении; 0,46 при колошении). Применение сидератов имело прямую умеренную связь на площадь листовой поверхности одного растения при всходах и кущении культуры ( $\mathrm{r}=0,40$ и 0,38 соответственно).

\begin{abstract}
Работа выполнена в рамках государственного задания ФГБНУ «Курский федеральный аграрный научный центр» по теме № 0632-2019-0010 «Разработать научно-обоснованные параметры построения систем земледелия и агротехнологий нового поколения с целью производства заданного количества и качества сельскохозяйственной продукции, сохранения и воспроизводства почвенного плодородия».
\end{abstract}

\title{
Библиографический список
}

1. Ничипорович А.А. Фотосинтетическая деятельность растений в посевах / А.А. Ничипорович, А.Е. Строганова, С.Н. Чмора, М.П. Власова. М.: Изд-воАНСССР, 1961. 211с

2. Бегишев А.Н. Работа листьев разных сельскохозяйственных растений в полевых условиях / А.Н. Бегишев // Тр. Ин-та физиологии растений им. К.А. Тимирязева АНСССР. - 1983. - Т. 8, вып. 1. - С. 229-263.

3. A. Balykin, L. G. Shashkarov, G. A. Mefodyev, V. G. Semenov Leaves area of spring wheat plants depending on preseeding treatment of seeds and varieties// bulletin of national academy of sciences of the republic of Kazakhstan ISSN 1991-3494 Volume 2, Number 384 (2020), 70-75.

4. Кумаков В.А. Физиологическое обоснование моделей сортов пшеницы - М.: Колос, 1985. $-270 \mathrm{c}$.

5. Galina Deriglazova, Tatiana Gavrilova Formation of the leaf surface area of spring wheat in various cultivation technologies// BIO Web Conf. Volume 32, 02004 (2021) III International Scientific and Practical Conference "Problems and Prospects of Scientific and Innovative Support of the Agro-Industrial Complex of the Regions" 2021

6. Стрижова Ф.М., Ожогина Л.В. Формирование площади листовой поверхности сортами яровой пшеницы // Вестник Алтайского государственного аграрного университета, 2005. № 4 (20) - C. 16-20. 


\title{
РОСТ И РАЗВИТИЕ ЯРОВОЙ ПШЕНИЦЫ ПРИ РАЗЛИЧНЫХ ТЕХНОЛОГИЯХ ВОЗДЕЛЫВАНИЯ
}

\author{
Дериглазова Г.М.
}

ФГБНУ «Курский федеральный аграрный научный центр», г. Курск, Россия E-mail: g_deriglazova@mail.ru

Резюме. В статье анализируются исследования по изучению влияния различных технологий воздельввания на рост и развитие яровой пшеницы в условиях черноземных почв Курской области. Выявлены сопряженные связи исследуемых показателей с элементами технологий.

Ключевые слова: яровая пшеница, высота растений, кустистость, экстенсивная технология, интенсивная технология, биотехнология, экологоресурсосберегающая технология.

Resume. The article analyzes studies on the influence of various cultivation technologies on the growth and development of spring wheat in the conditions of chernozem soils of the Kursk region. The conjugate relations of the studied indicators with the elements of technologies are revealed.

Key words: spring wheat, plant height, bushiness, extensive technology, intensive technology, biotechnology, eco-resource-saving technology.

Вопросы роста и развития яровой пшеницы при различных технологиях возделывания имеет большое значение для сельскохозяйственного производства $[1,2]$. Их анализ позволяет выявить влияние внешних условий и уровень технологии не только на конечный результат, но и на его слагаемые. Изучение основных физиологических процессов, таких как роста и развития яровой пшеницы, является актуальной задачей науки [3-6].

Целью работы являлось - изучение роста и развития яровой пшеницы в зависимости от технологии возделывания в условиях черноземных почв Курской области.

Исследования проводились в 2021 году в многолетнем полевом стационарном опыте лаборатории технологий возделывания полевых культур и агроэкологической оценки земель в 9-польном полевом севообороте. Чередование культур в севообороте: 1) клевер, 2) озимая пшеница, 3) сахарная свекла, 4) яровая пшенииа, 5) горох, 6) озимая рожь, 7) гречиха, 8) овес, 9) ячмень + клевер. Сорт яровой мягкой пшеницы - Дарья. Почва опытного участка - чернозем типичный. Повторность опыта - трехкратная. Расположение делянок систематическое, размер посевной делянки - 189 м $^{2}(5.4$ х 35 м), учетная площадь

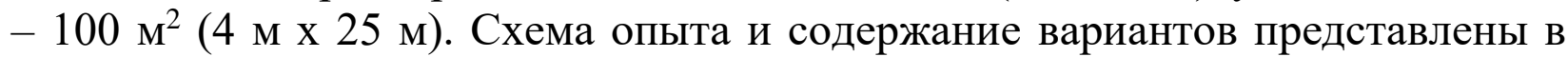
таблице 1 .

Математическая обработка экспериментальных данных проведена по Б.А. Доспехову [7], статистический анализ данных - с помощью программ МicrosoftOfficeExcel и STATGRAP.2_1. 
Таблица 1 - Схема опыта и содержание вариантов

\begin{tabular}{|c|c|c|c|c|c|c|c|}
\hline \multirow{3}{*}{ Варианты } & \multirow{3}{*}{$\begin{array}{c}\text { Обработка } \\
\text { почвы }\end{array}$} & \multicolumn{4}{|c|}{ Удобрения } & \multirow{3}{*}{$\begin{array}{c}\text { Пести- } \\
\text { циды }\end{array}$} & \multirow{3}{*}{$\begin{array}{c}\text { Биопрепа } \\
\text { раты }\end{array}$} \\
\hline & & \multirow{2}{*}{$\begin{array}{c}\text { Мине- } \\
\text { ральные }\end{array}$} & \multicolumn{3}{|c|}{ Органические } & & \\
\hline & & & Навоз & $\begin{array}{l}\text { Ботва } \\
\text { сах св. }\end{array}$ & Сидерат & & \\
\hline \multicolumn{8}{|c|}{ Экстенсивная технология } \\
\hline 1.Контроль & $\begin{array}{c}\text { Вспашка на } \\
20-22 \text { см }\end{array}$ & 0 & - & - & - & - & - \\
\hline $\begin{array}{l}2.50 \% \\
\text { обеспеченности } \\
\text { за счет мин. уд. }\end{array}$ & $\begin{array}{c}\text { Вспашка на } \\
20-22 \text { см }\end{array}$ & $\mathrm{N}_{30} \mathrm{P}_{30} \mathrm{~K}_{30}$ & - & + & - & + & - \\
\hline \multicolumn{8}{|c|}{ Интенсивная технология } \\
\hline $\begin{array}{l}3.100 \% \\
\text { обеспеченности } \\
\text { за счет мин. уд. }\end{array}$ & $\begin{array}{c}\text { Вспашка на } \\
20-22 \text { см }\end{array}$ & $\begin{array}{c}\mathrm{N}_{60} \mathrm{P}_{60} \\
\mathrm{~K}_{60}\end{array}$ & - & + & - & + & - \\
\hline \multicolumn{8}{|c|}{ Биотехнология } \\
\hline $\begin{array}{l}6.100 \% \\
\text { обеспеченности } \\
\text { за счет орг. уд. }\end{array}$ & $\begin{array}{c}\text { Плоскорез } \\
\text { на 20-22 см }\end{array}$ & - & + & + & + & эпв & + \\
\hline $\begin{array}{l}7.100 \% \\
\text { обеспеченности } \\
\text { за счет орг. уд. }\end{array}$ & $\begin{array}{c}\text { Плоскорез } \\
\text { на 20-22 см }\end{array}$ & - & + & + & + & эпв & - \\
\hline $\begin{array}{l}8.100 \% \\
\text { обеспеченности } \\
\text { за счет орг. уд. }\end{array}$ & $\begin{array}{c}\text { Вспашка на } \\
\text { 20-22 см }\end{array}$ & - & + & + & + & эпв & + \\
\hline $\begin{array}{l}9.100 \% \\
\text { обеспеченности } \\
\text { за счет орг. уд. }\end{array}$ & $\begin{array}{c}\text { Вспашка на } \\
20-22 \text { см }\end{array}$ & - & + & + & + & эпв & - \\
\hline \multicolumn{8}{|c|}{ Экологоресурсосберегающая технология } \\
\hline $\begin{array}{l}13.50 \% \text { орг./ } \\
50 \text { мин. уд. }\end{array}$ & $\begin{array}{l}\text { Поверх- } \\
\text { ностная }\end{array}$ & $\begin{array}{c}\mathrm{N}_{30} \mathrm{P}_{30} \\
\mathrm{~K}_{30}\end{array}$ & - & + & + & + & + \\
\hline $\begin{array}{l}\text { 14. } 50 \% \text { орг./ } \\
\text { 50мин. уд. }\end{array}$ & $\begin{array}{c}\text { Плоскорез } \\
\text { на 20-22 см }\end{array}$ & $\begin{array}{c}\mathrm{N}_{30} \mathrm{P}_{30} \\
\mathrm{~K}_{30}\end{array}$ & - & + & + & + & + \\
\hline $\begin{array}{l}\text { 15. 50\%орг./ } \\
50 \text { мин. уд. }\end{array}$ & $\begin{array}{c}\text { Вспашка на } \\
20-22 \text { см }\end{array}$ & $\begin{array}{c}\mathrm{N}_{30} \mathrm{P}_{30} \\
\mathrm{~K}_{30}\end{array}$ & - & + & + & + & + \\
\hline
\end{tabular}

Число взошедших растений яровой пшеницы в погодных условиях 2021

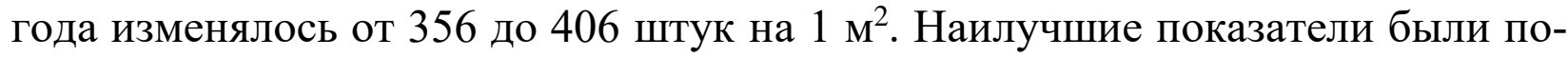
лучены при применении вспашки по экологоресурсосберегающей и интенсивной технологии (406 и 404 шт./м²).

Таблица 2 - Число взошедших растений на 1 м $^{2}$

\begin{tabular}{|c|c|c|}
\hline Вариант & Число взошедших растений на $1 \mathrm{~m}^{2}$, шт. & + /- \\
\hline 1 & 356 & 4 \\
\hline 2 & 360 & 48 \\
\hline 3 & 404 & 16 \\
\hline 6 & 372 & 15 \\
\hline 7 & 371 & 16 \\
\hline 9 & 372 & 4 \\
\hline 13 & 360 & 4 \\
\hline 14 & 360 & 16 \\
\hline 15 & 372 & 50 \\
\hline
\end{tabular}


В пределах одного сорта высота растений определяется агрометеорологическими условиями, плодородием почвы и агротехникой возделывания сельскохозяйственной культуры. На высоту растений могут оказывать влияние повреждения их сельскохозяйственными вредителями и болезнями. Высокорослые растения, как правило, формируют больший урожай, в том числе хозяйственно ценной его части. В годы с хорошо сформировавшимся стеблестоем растения пшеницы имеют крупный колос с большим количеством крупных зерен. Низкорослые посевы, как правило, формируют урожай более низкого качества $[1,2]$.

Высота яровой пшеницы при массовом появлении всходов варьировала от 15,8 см на контрольном варианте, до 22,1 на варианте по интенсивной технологии возделывания (рис. 1). Высокой высотой растения отмечались и при возделывании по вспашке при экологоресурсосберегающей технологии (15 вариант) $(20,0$ см).

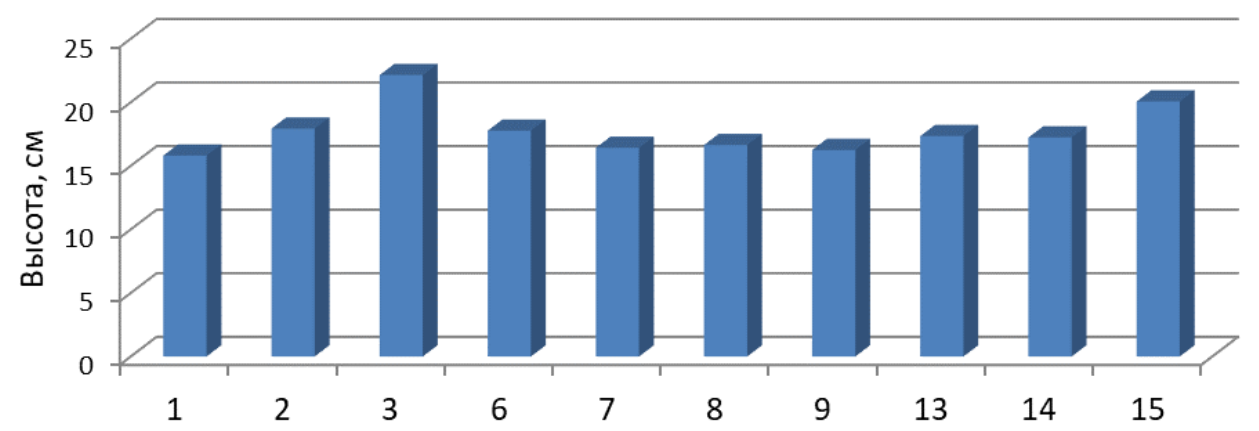

Рисунок 1 - Высота растений при полных всходах яровой пшеницы, см

Средняя продуктивная кустистость яровой пшеницы колеблется от 1,2 до 2,5 шт. Факторы, определяющие продуктивную кустистость пшеницы, следующие: срок посева (при запаздывании с посевом кустистость уменьшается), запас влаги, азотистых и других питательных веществ в почве, площадь питания растений, глубина нахождения узла кущения [5].

Густота стояния растений в фазу полного кущения в зависимости от технологии возделывания изменялась за счет кустистости растений, которая варьировала от 1,3 (на контрольном варианте) до 2,2 шт. (на 3 варианте) (рис. 2).

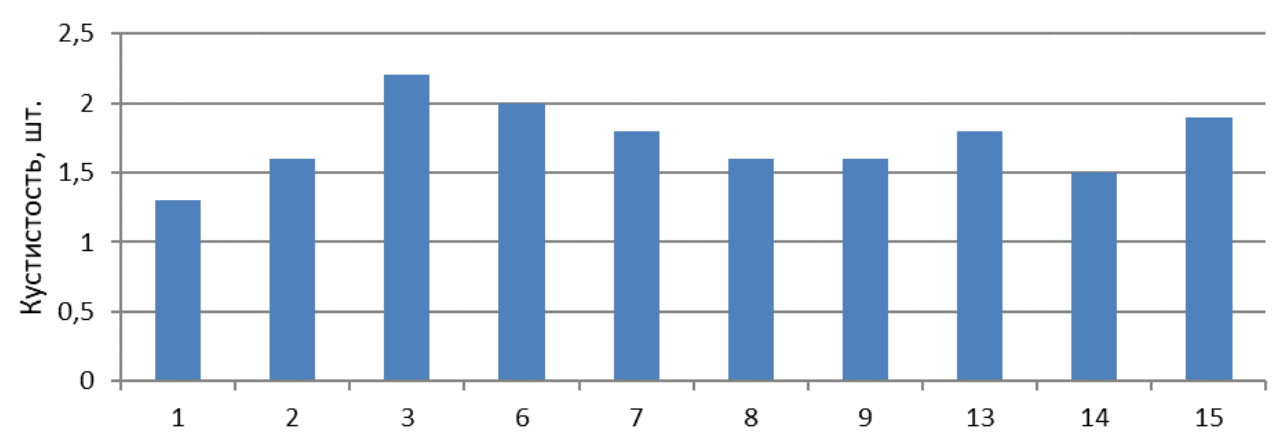

Рисунок 2 - Кустистость яровой пшеницы

Наибольший сырой и сухой вес 10 растений при кущении яровой пшеницы был отмечен при возделывании по вспашке при интенсивной, биотехнологии и экологоресурсосберегающей технологии. Сухой вес растений 
увеличивался при внесении удобрений на 0,15-1,45 г. или на 17-170\%

Под воздействием внесения удобрений показатели структуры урожая в фазу полной спелости, такие как: длина колоса, количество зерен в колосе, вес зерна, вес соломы, масса 1000 зерен, достоверно возрастали по сравнению с контролем (табл. 3).

Таблица 3 - Структура урожая яровой пшеницы

\begin{tabular}{|c|c|c|c|c|c|c|}
\hline Вариант & $\begin{array}{c}\text { Длина ко- } \\
\text { лоса, см }\end{array}$ & $\begin{array}{l}\text { Кол-во, зе- } \\
\text { рен в ко- } \\
\text { лосе, шт. }\end{array}$ & $\begin{array}{c}\text { Вес зерна, } \\
\Gamma / \mathbf{M}^{2} .\end{array}$ & 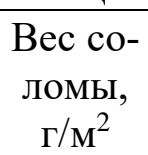 & $\begin{array}{c}\text { Соотношени- } \\
\text { евеса зерна к } \\
\text { соломе }\end{array}$ & $\begin{array}{c}\text { Macca } \\
1000 \text { зе- } \\
\text { рен, г. }\end{array}$ \\
\hline 1 & 7,1 & 25,7 & 18,36 & 15,3 & 1,2 & 31,41 \\
\hline 2 & 7,8 & 30,2 & 21,57 & 18,0 & 1,2 & 32,25 \\
\hline 3 & 8,4 & 36,0 & 25,71 & 18,4 & 1,4 & 37,63 \\
\hline 6 & 8,1 & 31,6 & 22,57 & 18,8 & 1,2 & 34,22 \\
\hline 7 & 8,2 & 31,9 & 22,79 & 19,0 & 1,2 & 31,52 \\
\hline 8 & 8,0 & 30,8 & 22,00 & 20,0 & 1,1 & 31,74 \\
\hline 9 & 8,3 & 32,5 & 23,21 & 16,6 & 1,4 & 36,89 \\
\hline 13 & 7,5 & 26,3 & 18,79 & 17,1 & 1,1 & 32,12 \\
\hline 14 & 7,5 & 26,2 & 18,71 & 14,4 & 1,3 & 33,24 \\
\hline 15 & 8,4 & 35,1 & 25,00 & 17,9 & 1,4 & 37,56 \\
\hline $\mathrm{HCP}_{05}$ & 0,3 & 2,1 & 1,84 & 1,2 & 0,1 & 2,64 \\
\hline
\end{tabular}

Проанализировав сопряженность данных, выяснено, что применения минеральных удобрений способствовало активизации роста и развития яровой пшеницы в течение всего вегетационного периода. Так, внесение минеральных удобрений имело высокую корреляционную связь с высотой растений $(\mathrm{r}=0,84)$, заметную связь с числом взошедших растений, кустистостью, весом сухих растений $(\mathrm{r}=0,60 ; 0,50 ; 0,50$ соответственно) и умеренную с массой 1000 зерен $(\mathrm{r}=0,45)$. Внесение органических удобрений положительно повлияло на длину колоса и вес соломы (r=0,43; 0,52 соответственно). Замена плоскорезной поверхностной обработки почвы на вспашку увеличивало сухой вес растений при кущении культуры, количество зерен в колосе, вес зерна и массу 1000 зерен ( $\mathrm{r}=0,50 ; 0,47 ; 0,48 ; 0,37$ соответственно).

Работа выполнена в рамках государственного задания ФГБНУ «Курский федеральный аграрный научный центр» по теме№ 0632-2019-0010 «Разработать научно-обоснованные параметры построения систем земледелия и агротехнологий нового поколения с целью производства заданного количества и качества сельскохозяйственной продукции, сохранения и воспроизводства почвенного плодородия».

\section{Библиографический список}

1. Кумаков В.А. Физиология яровой пшеницы / В.А. Кумаков. М.: Колос, 1980. - 207 с.

2. Федоров Н.И. Продуктивность пшеницы / Н.И. Федоров. Саратов: Приволж. кн. издво, 1980. $-176 \mathrm{c}$.

3. G M Deriglazova Monitoring of spring wheat cultivation under the climatic conditions of Kursk Region //IOP Conference Series: Earth and Environmental Science 666 (2021) 052059, doi:10.1088/1755-1315/666/5/052059

4. Бойко Н.И., Паркина О.В., Пискарев В.В. Формирование массы зерна с колоса у сортообразцов пшеницы мягкой яровой (TriticumaestivumL.) в контрастных метеоусловиях лесостепи Приобья // Достижения науки т техники АПК, 2019. - №12. - С. 43-47 
5. Оленин О А Яровая пшеница, земледелие и геополитика //Пермский аграрный вестник, 2016. - №2 (14). - С. 72-81

6. Комарова С.П., Хижникова Т.Г., Ожогина Л.В. Рост, развитие и продуктивность яровой пшеницы сортов отечественной и зарубежной селекции // Вестник АГАУ, 2003. - № 2. - С. 92-95.

7. Доспехов Б.А. Методика полевого опыта / Б. А. Доспехов. М.: Колос, 1979. - 416 с.

УДК 631.51 .01

\title{
ВЛИЯНИЕ ОСНОВНОЙ ОБРАБОТКИ ПОЧВЫ НА УРОЖАЙНОСТЬ И КАЧЕСТВО ПРОДУКЦИИ ЗЕРНОВОГО СЕВООБОРОТА
}

\author{
Дубовик Д.В. ${ }^{1}$, Дубовик Е.В. ${ }^{1}$, Морозов А.Н. ${ }^{1}$
}

${ }^{1}$ ФГБНУ «Курский федеральный аграрный научный центр», г. Курск

E-mail: kurskfarc@mail.ru

Резюме. В условиях Курской области изучено влияние различных приемов основной обработки почвы на урожайность и качество зерна культур севооборота. Установлено, что наиболее высокая урожайность зерна озимой пшеницы, гороха и ярового ячменя формируется при вспашке, а сои - при прямом посеве. Качество зерна озимой пшеницы и гороха было наиболее высоким при использовании отвальной обработки, ярового ячменя и сои - при комбинированной обработке почвы.

Ключевые слова: озимая пшеница, горох, яровой ячмень, соя, вспашка, комбинированная, поверхностная обработка, прямой посев.

Summary. In the conditions of the Kursk region, the influence of various methods of basic tillage on the yield and quality of grain of crop rotation crops was studied. It is established that the highest grain yield of winter wheat, peas and spring barley is formed during plowing, and soybeans-during direct sowing. The quality of winter wheat and pea grain was the highest when using dump processing, spring barley and soy-with combined tillage.

Key words: winter wheat, peas, spring barley, soy, plowing, combined tillage, surface tillage, no-till.

Введение. Одна из основных задач современного сельскохозяйственного производства - снижение затрат на выращивание растениеводческой продукции при получении запланированного количества продукции заданного качества. Для этого требуется разработка инновационных технологий возделывания сельскохозяйственных культур, предусматривающих энерго- и ресурсосбережение [1]. При этом одним из наиболее энергетически затратных элементов агротехнологий возделывания сельскохозяйственных культур является обработка почвы [2]. В настоящее время применяется довольно широкий набор приемов обработки почвы: от глубокой отвальной вспашки до крайней степени минимизации - прямого посева. [3, 4].

При минимизации обработки почвы отмечаются как положительные, так и отрицательные последствия. Так, при прямом посеве происходит накопление влаги в почве за счет мульчирующего слоя пожнивных остатков, отмечается снижение проявления эрозионных процессов $[5,6]$. Отмечается изменение агрофизических свойств почвы как в лучшую, так и в худшую стороны (переуплотнение, увеличение количества крупных почвенных агрегатов >10 мм) [6, 7]. При минимизации обработки почвы отмечается изменение азотного и углеродного режимов почвы [8]. Все эти факторы оказывают непосредственное влияние на урожайность возделываемых в севооборотах культур и качество 
получаемой продукции.

Целью работы являлось изучение влияние приемов основной обработки почвы на урожайность и качество продукции культур зернового севооборота.

Условия материалы и методы. Исследования проведены в полевом стационарном опыте ФГБНУ «Курский федеральный аграрный научный центр» (Курская область, Курский район, п. Черемушки) в 2019-2020 гг. в четырехпольном зерновом севообороте. Севооборот развёрнут в пространстве и времени, со следующим чередованием культур: горох - озимая пшеница - соя яровой ячмень.

Схема опыта включала следующие варианты: вспашка с оборотом пласта (20-22 см); комбинированная обработка (дискование 8-10 см + чизель 20-22 см); поверхностная обработка (дискование 8-10 см); прямой посев (технология No-till). Прямой посев осуществлялся, без обработки почвы, сеялкой прямого посева Дон 114. Приемы обработки почвы применялись систематически с 2015 г. для каждого варианта.

Варианты в полевом опыте размещались систематически в один ярус. Площадь посевной делянки $6000 \mathrm{~m}^{2}(60 \times 100)$, повторность трехкратная.

Почва опытного участка - чернозем типичный мощный тяжелосуглинистый, со средним содержанием гумуса в пахотном слое $-5,1 \%$, высоким содержанием подвижного фосфора и обменного калия (по Чирикову) - 192 мг/кг и 133 мг/кг почвы, соответственно. Реакция почвенной среды слабо кислая $\left(\mathrm{pH}_{\mathrm{KCl}} 5,3\right)$.

Урожайность культур зернового севооборота учитывали комбайном Сампо-500 методом сплошного учета, поделяночно с пересчетом на стандартную влажность и $100 \%$ чистоту. Статистическая обработка полученных данных проводилась с использованием программ Microsoft Excel, Statistica, методами дисперсионного и корреляционного анализов.

Результаты и обсуждение. Используемые приемы основной обработки почвы оказали существенное влияние на изменение урожайности зерна гороха. Так, наибольшая урожайность была получена при возделывании гороха по вспашке - 2,20 т/га (табл. 1). При переходе на комбинированную обработку почвы по сравнению со вспашкой урожайность снизилась на 0,47 т/га, поверхностную на 0,60 т/га, прямой посев - 0,51 т/га. Как видно наибольшее снижение урожайности гороха произошло при использовании поверхностной обработки.

Наиболее высокая урожайность зерна озимой пшеницы (4,40 т/га) была получена при ее возделывании по вспашке. При применении комбинированной обработки почвы по сравнению со вспашкой урожайность снизилась на 0,40 т/га, поверхностной - на 0,65 т/га, прямого посева - 1,14 т/га.

В отличие от других изучаемых культур севооборота наибольшая урожайность зерна сои была получена при прямом посеве $(2,14$ т/га). В варианте с вспашкой урожайность сои уступала прямому посеву на 0,19 т/га, по комбинированной обработке - на 0,39 т/га, поверхностной обработке $-0,48$ т/га. Относительно вспашки урожайность сои при комбинированной обработке была достоверно ниже на 0,20 т/га, при поверхностной обработке на 0,29 т/га. 
Таблица 1 - Урожайность культур зернового севооборота

\begin{tabular}{|l|c|c|c|c|}
\hline \multirow{2}{*}{$\begin{array}{c}\text { Приемы основной обра- } \\
\text { ботки почвы }\end{array}$} & \multicolumn{4}{|c|}{ Урожайность, т/га } \\
\cline { 2 - 5 } & Горох & $\begin{array}{c}\text { Озимая пше- } \\
\text { ница }\end{array}$ & Соя & $\begin{array}{c}\text { Яровой } \\
\text { ячмень }\end{array}$ \\
\hline Вспашка & 2,20 & 4,40 & 1,95 & 3,78 \\
\hline Комбинированная & 1,73 & 4,00 & 1,75 & 3,02 \\
\hline Поверхностная & 1,60 & 3,75 & 1,66 & 2,78 \\
\hline Прямой посев & 1,69 & 3,26 & 2,14 & 2,49 \\
\hline $\mathrm{HCP}_{05}$ & 0,30 & 0,6 & 0,13 & 0,23 \\
\hline
\end{tabular}

Самая высокая урожайность ячменя отмечалась при использовании в качестве приема основной обработки почвы вспашки. При комбинированной обработке почвы урожайность ячменя по сравнению со вспашкой снизилась на 0,76 т/га, поверхностной - на 1,00 т/га, прямом посеве - на 1,29 т/га.

Изучаемые приемы основной обработки почвы оказали влияние на качество зерна культур севооборота. Так, применение вспашки способствовало повышению натуры зерна гороха на 15,1-18,0 г/л и увеличению в нем содержания белка на 0,7-0,9\% по сравнению с остальными приемами основной обработки почвы (табл. 2). При минимизации обработки почвы содержание белка в зерне существенно не различалось и составляло 21,3-21,5\%. Масса 1000 зерен гороха также была более высокой при вспашке - 149,2 г. При этом наименьшая масса 1000 зерен отмечалась при прямом посеве $(138,7$ г), что было обусловлено уменьшением их размера.

Таблица 2 - Влияние основной обработки почвы на качество зерна гороха

\begin{tabular}{|l|c|c|c|}
\hline $\begin{array}{c}\text { Приемы основной обработки } \\
\text { почвы }\end{array}$ & Натура, г/л & $\begin{array}{c}\text { Содержание } \\
\text { белка, \% }\end{array}$ & $\begin{array}{c}\text { Масса 1000 зе- } \\
\text { рен, г }\end{array}$ \\
\hline Вспашка & 806,7 & 22,2 & 149,2 \\
\hline Комбинированная & 788,7 & 21,5 & 141,4 \\
\hline Поверхностная & 792,2 & 21,3 & 145,7 \\
\hline Прямой посев & 791,6 & 21,3 & 138,7 \\
\hline $\mathrm{HCP}_{05}$ & 1,1 & 0,4 & 0,4 \\
\hline
\end{tabular}

Наилучшие показатели качества зерна озимой пшеницы были получены в варианте с применением вспашки: натура зерна была выше на 4,4-9,0 г/л, содержание белка в зерне на 0,5-1,4\%, масса 1000 зерен на 1,4-1,9 г, чем на прочих изучаемых приемах обработки почвы (табл. 3). При минимизации основной обработки почвы физические показатели качества зерна (натура зерна и масса 1000 зерен) существенно не различались.

Таблица 3 - Влияние основной обработки почвы на качество зерна озимой пшеницы

\begin{tabular}{|l|c|c|c|}
\hline $\begin{array}{c}\text { Приемы основной обработки } \\
\text { почвы }\end{array}$ & Натура, г/л & $\begin{array}{c}\text { Содержание } \\
\text { белка, } \%\end{array}$ & $\begin{array}{c}\text { Масса } 1000 \text { зе- } \\
\text { рен, г }\end{array}$ \\
\hline Вспашка & 815,1 & 12,6 & 43,8 \\
\hline Комбинированная & 810,7 & 11,8 & 42,4 \\
\hline Поверхностная & 810,9 & 12,1 & 41,9 \\
\hline Прямой посев & 806,1 & 11,2 & 42,3 \\
\hline $\mathrm{HCP}_{05}$ & 2,2 & 0,3 & 0,3 \\
\hline
\end{tabular}


Изучаемые способы основной обработки почвы оказали влияние на качество зерна сои. Наибольшая натура зерна формировалась при поверхностной обработке - 748,6 г/л, и была выше на 4,4-8,6 г/л по отношению к другим способам основной обработки почвы (табл. 4). Наиболее высокое количество белка в зерне сои отмечалось при применении комбинированной и поверхностной обработок почвы (35,0-34,7\%), а наименьшее при прямом посеве и вспашке $(33,8-34,1 \%)$. Очевидно, это обусловлено обратной корреляционной связью между урожайностью зерна и количеством белка в нем $(\mathrm{r}=-0,91)$. При этом масса 1000 зерен сои была наиболее высокой при посеве по вспашке, а наименьшей при поверхностной обработке.

\section{Таблица 4 - Влияние основной обработки почвы на качество зерна сои}

\begin{tabular}{|c|c|c|c|}
\hline $\begin{array}{c}\text { Приемы основной обработки } \\
\text { почвы }\end{array}$ & Натура, г/л & $\begin{array}{l}\text { Содержание } \\
\text { белка, \% }\end{array}$ & $\begin{array}{l}\text { Macca } 1000 \text { зе- } \\
\text { рен, Г }\end{array}$ \\
\hline Вспашка & 744,2 & 34,1 & 106,2 \\
\hline Комбинированная & 744,1 & 35,0 & 105,3 \\
\hline Поверхностная & 748,6 & 34,7 & 94,5 \\
\hline Прямой посев & 740,0 & 33,8 & 96,4 \\
\hline $\mathrm{HCP}_{05}$ & 2,6 & 0,7 & 1,1 \\
\hline
\end{tabular}

Определение физических показателей качества зерна ярового ячменя показало, что наибольшая натура зерна формировалась на поверхностной обработке, а масса 1000 зерен - по вспашке (табл. 5). При применении прямого посева натура зерна ярового ячменя была достоверно ниже на 54,8-57,8 г/л, чем на других изучаемых приемах обработки, которые между собой существенно не различались. Это связано с формированием менее выполненного зерна ячменя при прямом посеве, что подтверждается меньшей на 0,6-1,9 г массой 1000 зерен в этом варианте по сравнению с другими изучаемыми приемами основной обработки. В тоже время при прямом посеве содержание белка в зерне ячменя было существенно выше на 1,0\% по сравнению со вспашкой, на $0,6 \%$ - с комбинированной обработкой и на $1,3 \%$ - с поверхностной обработкой.

\section{Таблица 5 - Влияние основной обработки почвы на качество зерна яро-} вого ячменя

\begin{tabular}{|l|c|c|c|}
\hline $\begin{array}{l}\text { Приемы основной обработки } \\
\text { почвы }\end{array}$ & Натура, г/л & $\begin{array}{c}\text { Содержание } \\
\text { белка, \% }\end{array}$ & $\begin{array}{c}\text { Масса } 1000 \text { зе- } \\
\text { рен, г }\end{array}$ \\
\hline Вспашка & 605,6 & 13,1 & 40,0 \\
\hline Комбинированная & 603,4 & 13,5 & 39,4 \\
\hline Поверхностная & 606,4 & 12,8 & 38,8 \\
\hline Прямой посев & 548,6 & 14,1 & 38,1 \\
\hline $\mathrm{HCP}_{05}$ & 2,6 & 0,3 & 0,3 \\
\hline
\end{tabular}

Заключение. В результате исследований установлено, что наиболее высокая урожайность зерна озимой пшеницы, гороха и ярового ячменя формируется при использовании в качестве способа основной обработки почвы вспашки. При минимизации обработки почвы происходит снижение урожайности данных культур. Наиболее высокая урожайность сои была получена в варианте с применением технологии прямого посева. Качество зерна озимой 
пшеницы и гороха было наиболее высоким при использовании вспашки, сои и ярового ячменя - комбинированной обработки почвы.

\title{
Библиографический список
}

1. Кирюшин В.И. Экологизация земледелия и технологическая политика. - М.: МСХА, 2000. -473 c.

2. Кирюшин В.И. Проблема минимизации обработки почвы: перспективы развития и задачи исследований // Земледелие. 2013. № 7. С. 3-6.

3. Дридигер В.К., Невечеря А.Ф., Токарев И.Д. и др. Экономическая эффективность технологии No-till в засушливой зоне Ставропольского края // Земледелие. 2017. №3. 16-19.

4. Fernandez R., Frasier I., Noellemeyer E. et al. Soil quality and productivity under zero tillage and grazing on Mollisols in Argentina - A long-term study // Geoderma Regional. 2017. V. 11. P. 44-52.

5. Белолюбцев А.И. Роль мульчирующей обработки и минимизации в адаптации эрозионно опасных агроландшафтов к климатическим изменениям // Известия ТСХА. 2011. № 2. C. 103-112.

6. Komissarov M.A., Klik A. The impact of No-till, conservation, and conventional tillage systems on erosion and soil properties in Lower Austria // Eurasian Soil Science. 2020. T. 53. №4. C. 503-511.

7. Влияние приемов основной обработки почвы в севообороте на динамику влажности и агрофизические свойства чернозема выщелоченного / В.Н. Романов, В.К. Ивченко, И.О. Ильченко и др. // Достижения науки и техники АПК. 2018. №5. С. 32-34.

8. Malhi S.S., Nyborg M., Goddard T., Puurveen D. Long-term tillage, straw management and $\mathrm{N}$ fertilization effects on quantity and quality of organic $\mathrm{C}$ and $\mathrm{N}$ in a Black Chernozem soil // Nutr. Cycl. Agroecosyst. 2011. №. 90. P. 227-241.

\section{УДК 633.11«24»:631.582:631.8}

\section{ВЛИЯНИЕ СЕВООБОРОТА И МИНЕРАЛЬНЫХ УДОБРЕНИЙ НА КАЧЕСТВЕННЫЕ ПОКАЗАТЕЛИ ПРОДОВОЛЬСТВЕННОГО ЗЕРНА ОЗИМОЙ ПШЕНИЦЫ}

\author{
Дудкина Т.А.
}

ФГБНУ «Курский ФАНЦ», г. Курск

E-mail: dt5dt@mail.ru

\begin{abstract}
Резюме: Показано, что севооборот и минеральные удобрения влияют не только на количество зерна, но и на его качество. Наибольшая масса 1000 зёрен была в севообороте с сидеральным паром, натура зерна - в севообороте с чёрным паром, а содержание крахмала севообороте с занятым паром. Первые два показателя с увеличением нормы внесения удобрений возрастали.
\end{abstract}

Ключевые слова: севооборот, минеральные удобрения, озимая пшеница, масса 1000 зёрен, натура зерна, содержание крахмала в зерне.

\section{INFLUENCE OF CROP ROTATION AND MINERAL FERTILIZERS FOR QUALITATIVE INDICATORS OF WINTER WHEAT FOOD GRAIN \\ Dudkina T.A. \\ FSBSI «Kursk FARC», Kursk}

Summary. It is shown that crop rotation and mineral fertilizers influence not only the amount of grain, but also its quality. Maximumweight of 1000 grains was in the crop rotation with green manured fallow, natural weight of the grain was in the crop rotation with black fallow, and the 
starch content was in the crop rotation with cropped fallow. The first two indicators increased with an increase in the rate of fertilization.

Keywords: crop rotation, mineral fertilizers, winter wheat, 1000 grain weight, grain natural weight, starch content in grain.

В Центрально-Чернозёмной зоне озимая пшеница наряду с яровым ячменём составляет основу производства продовольственного зерна. Эта культура является одним из важнейших источников получения растительного белка. Эта культура относится к числу наиболее ценных и высокоурожайных зерновых культур. По урожайности в условиях Курской области она в абсолютном большинстве лет превосходила яровую пшеницу и рожь.

Велико агротехническое значение озимой пшеницы, являющейся превосходным предшественником для большинства полевых культур. При этом сама озимая пшеница весьма требовательна к севообороту [1].

К числу важнейших факторов, обеспечивающих получение высоких урожаев сельскохозяйственных культур, относится внесение минеральных удобрений. Известно, что наибольшая урожайность культур севооборота достигается при применении интенсивных технологий. Уровень интенсивности в значительной мере определяется тем, насколько культурные растения обеспечиваются питательными веществами, необходимыми для их роста и развития. Для этого требуется, прежде всего, оптимизация минерального питания растений.

От чередования культур в севообороте и от внесения минеральных удобрений зависит не только количество произведенной продукции, но и его качество $[2,3,4]$.

В 2018-2020 годах в опыте по биологизации земледелия Курского ФАНЦ (с. Панино Медвенского района Курской области) проведены исследования по влиянию севооборота и минеральных удобрений на качественные показатели продовольственного зерна мягкой озимой пшеницы сорта Синтетик селекции Белгородского ФАНЦ. Обработка экспериментальных данных проводилась методами математической статистики [5] при использовании программных средств Microsoft Office Excel, Statistika 6.0.

Почва опытного участка - чернозём типичный, тяжелосуглинистый, среднемощный с содержанием гумуса 4,8-5,0 \%.

Опыт заложен по полнофакторной схеме. Расположение вариантов систематическое, повторность трёхкратная.

Чередование сельскохозяйственных культур в изучавшихся севооборотах следующее: 1) зернопаропропашной - чёрный пар, озимая пшеница, сахарная свёкла, кукуруза на силос, ячмень; 2) зернопаропропашной с сидеральным паром - сидеральный пар (горох), озимая пшеница, сахарная свёкла, кукуруза на силос, ячмень; 3) плодосменный - занятый пар (кормовые бобы), озимая пшеница, подсолнечник, соя, ячмень.

Сидеральную массу заделывали в почву двукратной обработкой дисковой бороной. Технология возделывания культур общепринятая.

Предусматривалось четыре уровня варьирования применения 
минеральных удобрений: без удобрений, NPK-30, NPK-40, NPK-52 д.в. на 1 гектар севооборотной площади.

В среднем по фонам удобренности самые высокие значения урожайности в 2018-2020 годах были получены в зернопаропропашном севообороте с чёрным и сидеральным паром. Существенно ниже был этот показатель в плодосменном севообороте. Эти данные показывают, что в звеньях с чёрным и сидеральным паром создавались лучшие почвенные и фитосанитарные условия для выращивания озимой пшеницы. Повышение уровня удобренности в результате применения минеральных удобрений сопровождалось ростом урожайности культуры.

Из экспериментальных материалов, представленных на рисунке 1, видно, что наибольшая масса 1000 зёрен озимой пшеницы сорта Синтетик в среднем за три года исследований была при её возделывании в зернопаропропашном севообороте с сидеральным паром - 47,9 г. Ниже и на одном уровне был этот показатель в двух других севооборотах $-47,3$ г.

Масcа 1000 зёрен, г

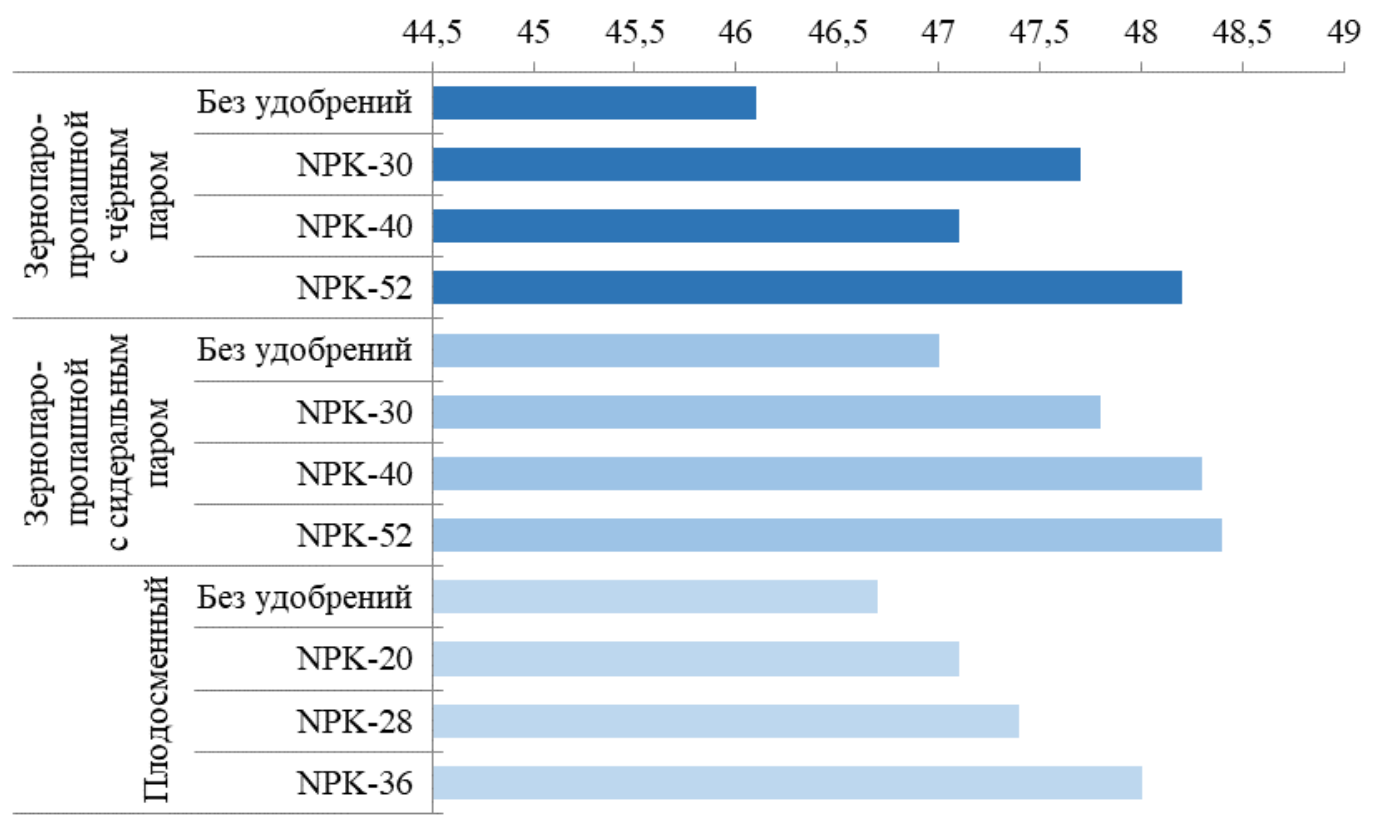

Рисунок 1 - Влияние севооборота и минеральных удобрений на массу 1000 зёрен озимой пшеницы, г (2018-2020 гг.)

Важным показателем, характеризующим качество зерна озимой пшеницы, является натура зерна. Более высокая натура зерна была в севообороте с чёрным паром - 838 г (рис. 2), несколько ниже - в сидеральном севообороте - 836 г. Плодосменный севооборот уступал двум другим севооборотам по рассматриваемому показателю. Во всех вариантах опыта, согласно классификации, зерно являлось высоконатурным.

Определение содержания крахмала в зерне озимой пшеницы сорта Синтетик проводилось на анализаторе зерна Инфратек-1243. Анализ данных, полученных в 2018-2020 годах, показал, что наибольшей крахмалистостью в среднем по фонам удобренности выделялось зерно озимой пшеницы в 
плодосменном севообороте при её выращивании по занятому пару - 66,7\% (рис. 3). Ниже всего этот показатель был в севообороте с сидеральным паром 65,7\%. Среднее положение занимал севооборот с чёрным паром.

Рассматриваемые показатели, за исключением крахмала в зерне, повышались с увеличением нормы внесения минеральных удобрений. Что касается накопления в зерне крахмала, то наиболее интенсивно оно проходило на фоне без удобрений. По мере увеличения удобренности этот показатель снижался, что особенно было заметно в плодосменном севообороте.

Крахмал (на сухое вещество), \%

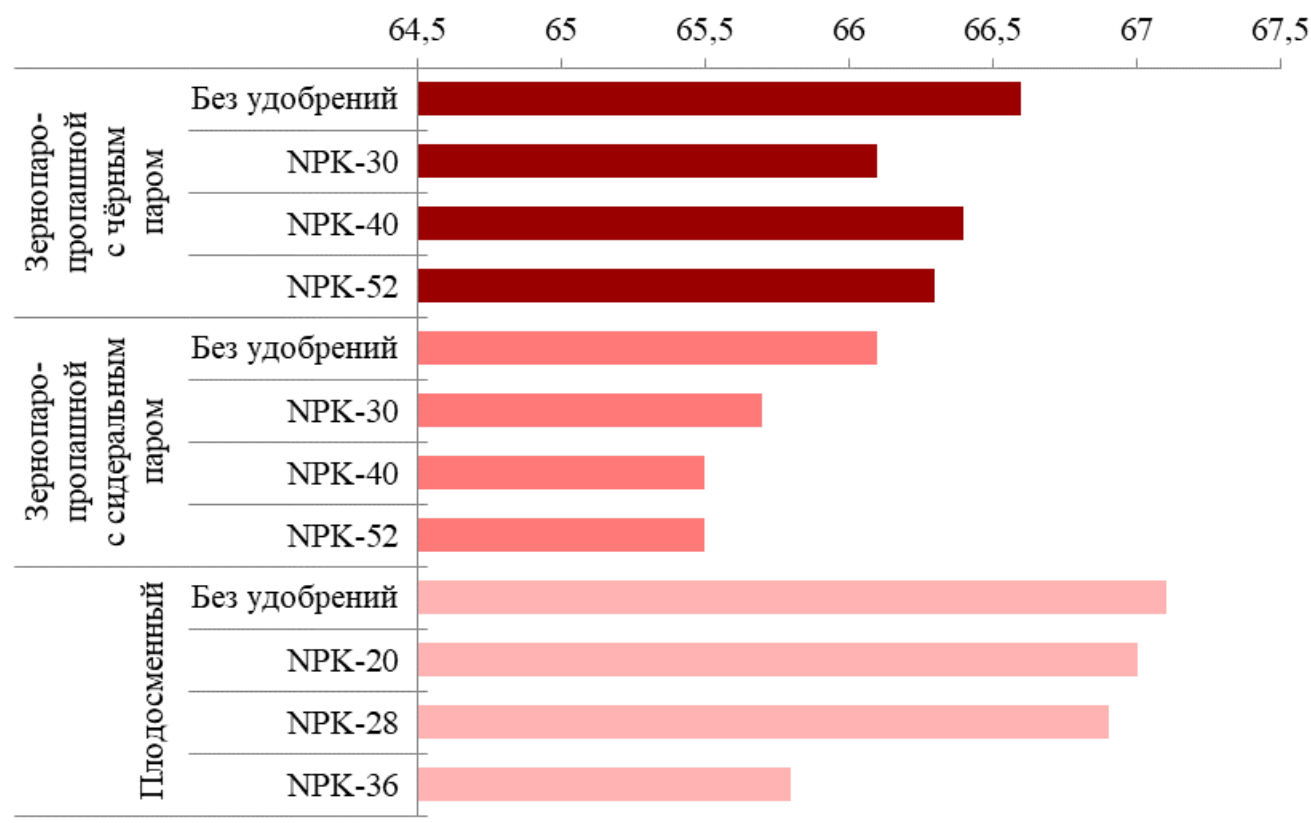

Рисунок 2 - Влияние севооборота и минеральных удобрений на содержание крахмала в зерне озимой пшеницы, \% (2018-2020 гг.) Натура зерна, г

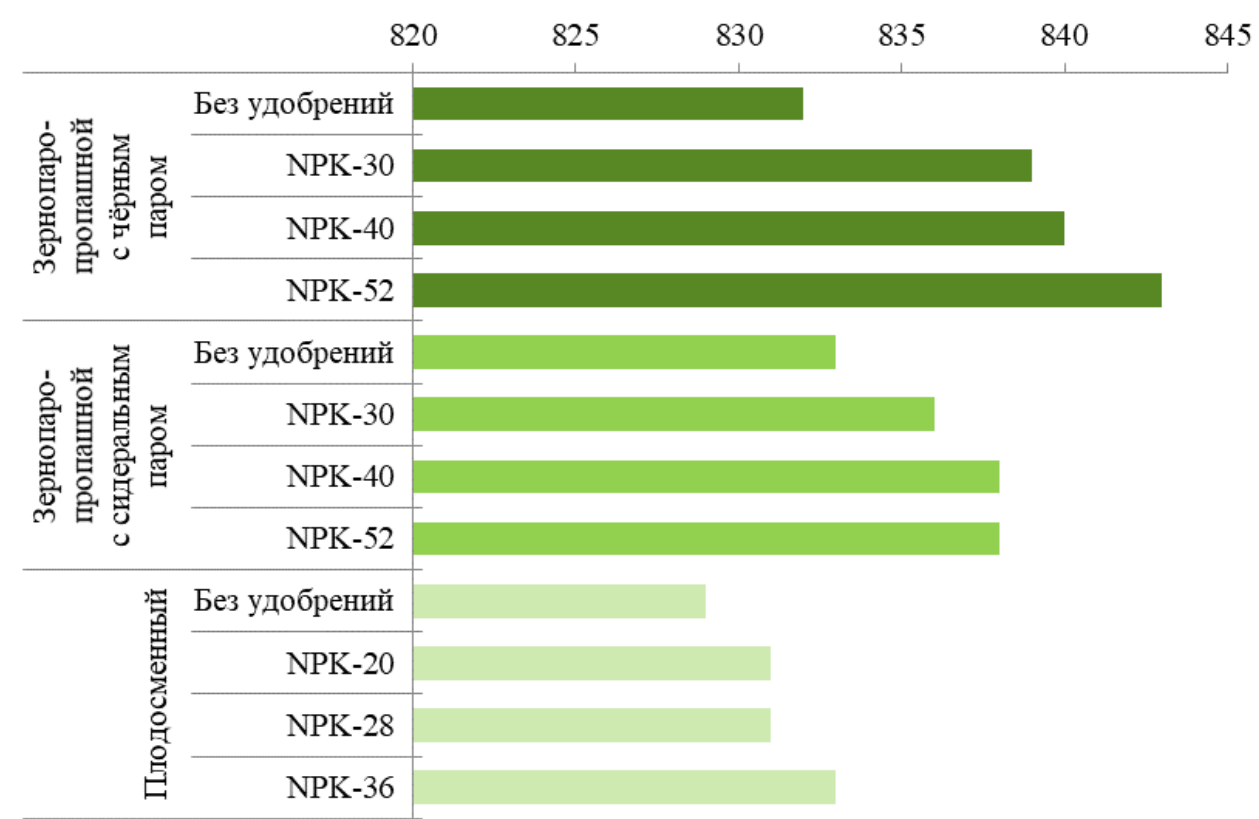

Рисунок 3 - Влияние севооборота и минеральных удобрений на натуру зерна озимой пшеницы, г (2018-2020 гг.) 


\section{Библиографический список}

1. Рекомендации по возделыванию озимой пшеницы в Курской области /А.Ю. Айдиев, В.М. Дудкин, И.В. Дудкин и др. - Курск, 2010. - 32 с.

2. Долгополова Н.В. Последействие удобрений в севообороте на урожай и качество зерна яровой пшеницы // Инновации в научно-техническом обеспечении агропромышленного комплекса России. Сб. Всероссийской (национальной) науч.-практ. конф. - Курск, 2020. C. 60-64.

3. Труфанова А.Ю., Долгополова Н.В. Влияние предшественников в севообороте на урожай и качество озимой пшеницы // Молодежная наука - развитию агропромышленного комплекса. Сб. Всероссийской (национальной) науч.-практ. конф. студентов, аспирантов и молодых ученых. Курск, 2020. - С. 43-47.

4. Дериглазова Г.М. Влияние природных и антропогенных факторов на урожай и качество зерна ярового ячменя // Земледелие, 2012. - № 6. - С. 43-45.

5. Доспехов Б.А. Методика полевого опыта. - М.: Колос, 1985. - 416 с.

УДК 631.434(470.62)

ПЕДОЭКОЛОГИЧЕСКИЕ ОСОБЕННОСТИ РИСОВЫХ ПОЧВ: УЯЗВИМОСТЬ СТРУКТУРЫ

Елисеева Н.В. ${ }^{1}$, Слюсаренко Э.Е. ${ }^{2}$, Тешева С.А. ${ }^{3}$

${ }^{1}$ Академия маркетинга и социально-информационных технологий - ИМСИТ, Краснодар, РФ

${ }^{2}$ Филиал Адыгейского государственного университета, Белореченск (Краснодарский край), РФ

${ }^{3}$ ФГБНУ «Федеральный научный центр риса», Краснодар, РФ

E-mail:envves@mail.ru

Резюме. Изучены структурно-агрегатный состав и водопрочность структуры рисовой почвы. Установлены низкое качество структуры и уровень ее уязвимости, который изменяется от повышенной угрозы разрушения структуры водой до очень высокой.

Summary. The structural-aggregate composition and waterproofness of the rice soil structure were studied. The low quality of the structure and the level of its vulnerability were identified, which varies from an increased threat of destruction of the structure by water to a very high one.

Введение. В предыдущей работе подобной тематики мы рассматривали педоэкологические особенности слитых черноземов [4]. Было установлено, что весь почвенный профиль и почвообразующая порода характеризуются повышенной угрозой разрушения структуры под действием воды. В последней четверти XX века значительно вырос интерес к различным аспектам изучения и использования гидроморфных почв в связи с обострением проблемы избыточного увлажнения почв в ряде регионов России [1].

Согласно информации «Единого государственного реестра почвенных ресурсов России» (ЕГРПР) [2], Краснодарский край имеет разнообразный почвенный покров: среди почв лидируют по распространению черноземы, общая площадь которых составляет $56,5 \%$, в том числе более $40 \%$ - это черноземы южные и обыкновенные. В то же время более $17 \%$ площади края занимают полугидроморфные и гидроморфные почвы. Рисоводческая отрасль является важной частью агропромышленного комплекса Краснодарского края: валовой 
сбор риса на Кубани составляет более $80 \%$ от общероссийского [5]. С начала $\mathrm{XX}$ века в рисосеянии начали активно использовать гидроморфные почвы.

В классификационной системе, применяемой в ЕГРПР, нет рисовых почв, заявленных в названии статьи, что требует пояснений приводимой терминологии. Известно, что технология возделывания риса предусматривает содержание поля в определенные периоды под слоем воды. Это приводит к значительным изменениям окислительно-восстановительных условий в почве и, соответственно, к трансформации физических, химических, биологических свойств почв. В таких измененных условиях почвообразовательный процесс направлен на сближение и объединение почв различной типовой принадлежности, что делает возможным их объединение в один тип рисовых почв [5].

Цель исследования - изучение особенностей структуры рисовых почв и определение ее уязвимости.

Материалы и методы. Объектами исследования послужили почвы на территории рисовой оросительной системы (пос. Белозерный, Краснодарский край). Рисовая оросительная система расположена в стародельтовом агроландшафтном районе Краснодарского края, функционирует с 1937 г.

Лугово-черноземная рисовая почва имеет следующий перечень горизонтов: Ap, App, AB, B1, B2g, Cg. Оглеение разной степени выражено по всему профилю, но явные признаки фиксируются в нижней части профиля (горизонты В2g и $\mathrm{Cg}$ ).

Традиционными показателями, используемыми для характеристики структуры, являются содержание глыб $(\Gamma)$, пыли $(\Pi)$, агрономически ценных фракций $(A Ц \Phi)$, коэффициент структурности $(K c)$, содержание водопрочных агрегатов размером $>0,25$ мм (суммарная водопрочность, $C B$ ), коэффициент водоустойчивости агрегатов $(K \varepsilon)$. Для характеристики распределения агрегатов по размерам с помощью одного параметра часто используют средневзвешенный диаметр агрегатов (CBД) и средневзвешенный диаметр водопрочных агрегатов (СВДв).

Для расчета показателей используют следующие формулы:

$$
\begin{aligned}
К_{\mathrm{c}} & =\text { АЦФ/(Г+П) } \\
К_{\mathrm{B}} & =\mathrm{CB} / \sum>0,25
\end{aligned}
$$

где $\sum>0,25$ мм - сумма фракций диаметром более 0,25 мм, \%, определяемая в ходе «сухого» просеивания почвы.

Для характеристики угрозы разрушения почвенной структуры водой некоторыми авторами предлагается использовать коэффициент уязвимости структуры - Ky. Этот показатель для обобщенной характеристики почвенных фракций использован в работе [3]. Формула для расчета коэффициента уязвимости структуры имеет следующий вид: 


$$
K y=\frac{C В Д}{C В Д в}
$$

Расшифровка использованных обозначений приведена выше.

Результаты и их обсуждение. На основании результатов определения структурно-агрегатного состава почв и водопрочности структуры нами были рассчитаны показатели для исследуемой рисовой почвы. Результаты приведены в таблице.

Таблица - Основные показатели, характеризующие структурноагрегатный состав и водопрочность структуры исследуемой рисовой почвы

\begin{tabular}{|c|c|c|c|c|c|c|}
\hline Горизонт & $\begin{array}{c}\text { Глубина, } \\
\text { см }\end{array}$ & $\Gamma, \%$ & $A Ц \Phi, \%$ & $\kappa c$ & $C B, \%$ & Кв \\
\hline $\mathrm{Ap}$ & $0-20$ & 49 & 50 & 1,00 & 80 & 0,80 \\
\hline $\mathrm{App}$ & $20-40$ & 50 & 49 & 1,00 & 82 & 0,98 \\
\hline $\mathrm{AB}$ & $40-77$ & 60 & 49 & 0,80 & 87 & 0,90 \\
\hline $\mathrm{B} 1$ & $77-100$ & 70 & 29 & 0,41 & 84 & 0,90 \\
\hline $\mathrm{B} 2 \mathrm{~g}$ & $100-130$ & 84 & 15 & 0,18 & 85 & 0,73 \\
\hline $\mathrm{Cg}$ & $130-\downarrow$ & 84 & 14 & 0,16 & 84 & 0,87 \\
\hline
\end{tabular}

На рисунке 1 представлено профильное распределение коэффициентов структурности и водоустойчивости в исследуемой почве.

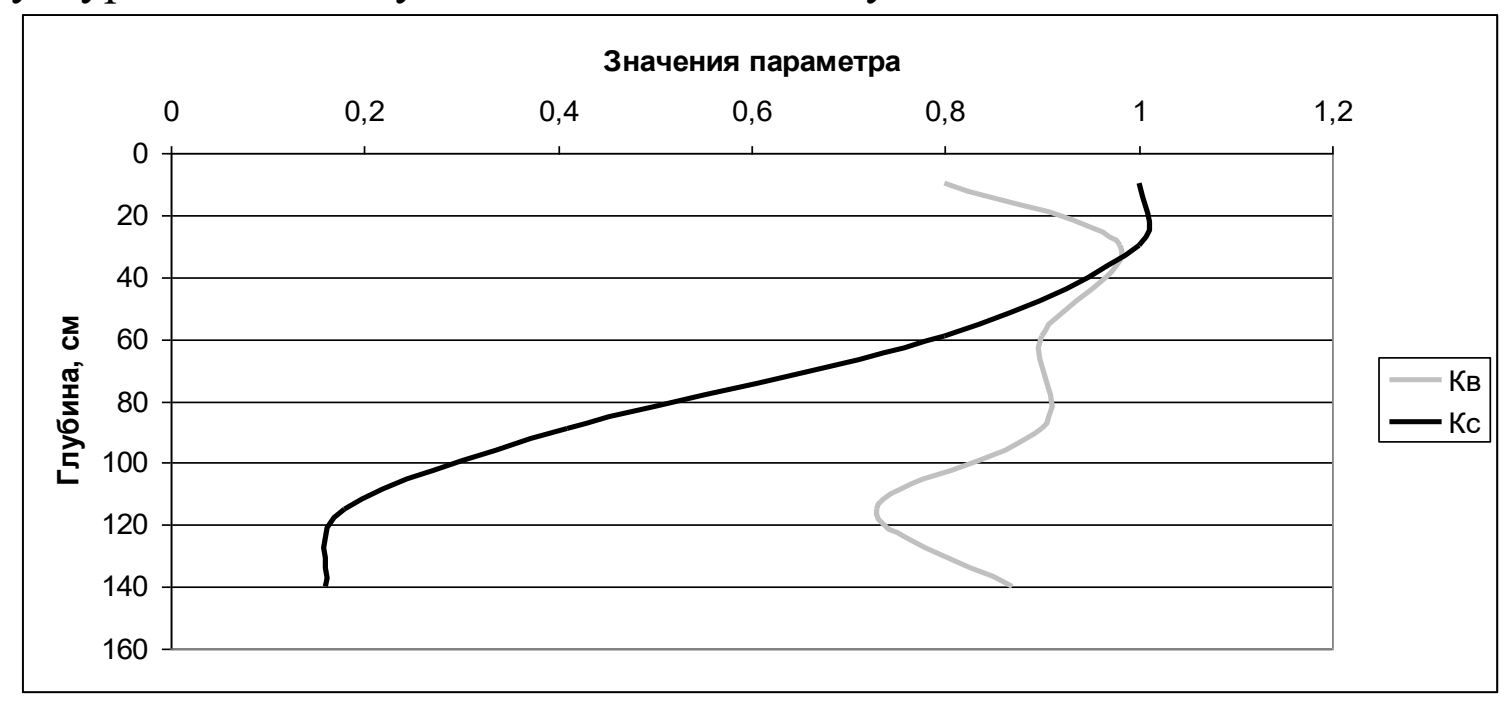

Рисунок 1 - Уровень коэффициентов структурности и водоустойчивости в профиле исследуемой почвы

По классификации Е.В. Шеина [7], качество структуры при сухом просеивании в верхних горизонтах Ар, Аpp, АВ удовлетворительное. В переходной части профиля и породе качество структуры неудовлетворительное, т.к. $K c<$ 0,67 . Оценка водопрочности структуры по $C B$, проведенная по классификации И.В. Кузнецовой [7], показывает, что она - избыточно высокая. Водоустойчивость структуры всех генетических горизонтов близка: $\kappa_{6}=0,80-0,87$.

Расчеты средневзвешенных диаметров частиц в генетических горизонтах почвы показали, что CВД при сухом просеивании изменяется от 9,4 мм в верхних горизонтах Ар и Арр до 13,3 мм в горизонтах В2g и Сg, составляя, в среднем для профиля, 11,3 мм при варьировании показателя $16 \%$. Для 
интерпретации представленных значений, следует вспомнить, что наиболее ценной почвенной структурой считается зернистая (от 5 до 0,25 мм), поэтому можно утверждать, что исследуемая почва имеет низкое качество структуры за счет высокого содержания крупных фракций.

Анализ СВДв показал, что этот параметр изменяется от 0,9 мм в горизонте B2g до 1,8 мм в почвообразующей породе, составляя, в среднем по профилю, 1,3 мм при варьировании $26 \%$.

На рисунке 2 показано профильное распределение трех показателей СВД, СВДв и Ку.

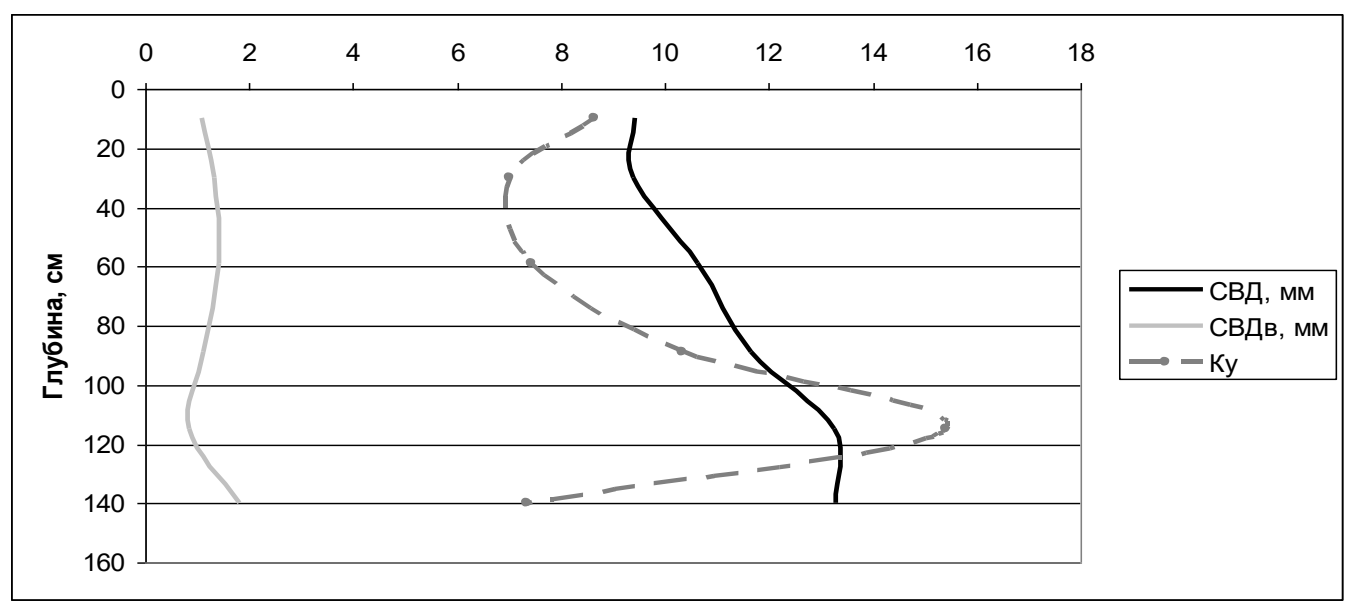

Рисунок 2 - Профильное распределение $C B Д, C B Д в$ и $K y$ в исследуемой почве

Распределение $C В Д$ в рисовой почве близко к регрессивно-элювиальному типу, а распределение $C В Д в-к$ недифференцированному типу. Профильное распределение коэффициента уязвимости структуры имеет сложный характер, который можно обозначить как регрессивно-аккумулятивный - прогрессивно грунтово-аккумулятивный. Изменение показателя наблюдается от 7,0 в горизонте Арр до 15,4 в горизонте В2g, составляя, в среднем 9,4 при варьировании $34 \%$.

Ранее при изучении уязвимости структуры слитых черноземов мы проводили оценку по критериям, предложенным для черноземов в работе [3], т.е. деление всей совокупности полученных значений $К y$ проводили на 3 группы с низкой угрозой разрушения структуры водой, повышенной и очень высокой. Дальнейшие исследования показали, что интервал показателя для почв с повышенной угрозой разрушения структуры очень широкий, поэтому мы рекомендуем разделить его на два интервала с повышенной и высокой угрозой разрушения структуры. Таким образом, для оценки уязвимости структуры предлагается следующая актуализированная шкала:

1) $K y<4$ - низкая угроза разрушения почвенной структуры водой;

2) $4 \leq K y<7-$ повышенная угроза разрушения почвенной структуры водой;

3) $7 \leq K y<10$ - высокая угроза разрушения почвенной структуры водой;

4) $K y \geq 10$ - очень высокая угроза разрушения почвенной структуры водой. 
Оценивая по предложенной шкале рисовую почву, приходим к выводу, что в горизонтах Ap, App, AB, Сg наблюдается повышенная угроза разрушения почвенной структуры водой, а в горизонтах В1 и В2g такая угроза очень высокая.

\title{
Библиографический список:
}

1. Авдеева Т.Н. История исследования гидроморфных почв Центрально-Черноземного экономического района России // Почвы России: вчера, сегодня, завтра: сб. статей по материалам Всерос. с междунар. участием науч. конф., посвящ. Году экологии и 90 -летию со дня рождения проф. В.В. Тюлина (5 окт. 2017 г.) / отв. за вып. А.М. Прокашев. - Киров: ВятГУ, 2017. - С. 14-23.

2. Единый государственный реестр почвенных ресурсов России. - М., 2019 [Электронный pecypc]. - URL: http://egrpr.esoil.ru (дата обращения: 08.05.2021).

3. Новых Л.Л., Хачатрян В.С., Пелехоце Е.А. Перспективные показатели для интерпретации результатов определения структурного состояния почв: уязвимость структуры // Якаевские чтения 2017 «Современные научные исследования: исторический опыт и инновации»: сб. материалов Междунар. науч.-практ. конф., г. Краснодар, 10-11 февраля 2017 г. Краснодар: ИМСИТ, 2017. - С. 88-93.

4. Педоэкологические особенности слитых черноземов: уязвимость структуры / Н.В. Елисеева, Л.Л. Новых, И.В. Волошенко, Э.Е. Слюсаренко // Проблемы природопользования и экологическая ситуация в Европейской России и на сопредельных территориях: материалы VIII Междунар. науч. конф., Белгород, 22-25 окт. 2019 г. / под ред. М.А. Польшиной. Белгород: ИД «Белгород» НИУ «БелГУ», 2019. - С. 214-218.

5. Пищенко Д.А., Гаркуша С.В., Тешева С.А. Эффективность выращивания риса в Краснодарском крае // Масличные культуры. - 2020. - Вып. 3 (183). - С. 103-106.

6. Сидоренко А.В., Елисеева Н.В. Свойства лугово-черноземных почв Кубани под культурой риса //Вестник Оренбургского государственного университета. - 2011. - № 12 (131). - С. 143-145.

7. Теории и методы физики почв: коллективная монография / под ред. Е.В. Шеина и Л.О. Карпачевского. - М.: «Гриф и К», 2007. - 616 с.

\section{ОЦЕНКА СОРТОВ ОЗИМОЙ ТВЕРДОЙ ПШЕНИЦЫ В ПИТОМНИКЕ КОНКУРСНОГО СОРТОИСПЫТАНИЯ}

\author{
Емельянова А.А., Логвинова Е.В. \\ ФГБНУ «Курский федеральный аграрный научный центр» \\ E-mail:em3lianjwa.a@yandex.ru, e.logv1nova@yandex.ru
}

\begin{abstract}
Резюме. В ФГБНУ «Курский Федеральный аграрный научный центр» совместно с ведущиии селекиентрами РФ ведется работа по изучению сортов твердой озимой пшеницы на предмет экологической пластичности и наличию хозяйственно-ценных признаков при воздельввании в условиях Центрально-Черноземного региона (Курской области). На данном этапе исследований изучены и дана оченка сортам озимой твердой пшеницы, из которых были вылделены наиболее перспективные. За годы исследований метеоусловия складывались разнообразно. Неблагоприятные факторы внешней среды позволили лучше оценить уровень адаптивности изучаемых сортов к абиострессам. В связи с этим важной задачей совместной селекции является повышение экологической устойчивости, способности обеспечивать выссокую стабильную урожайность в почвенно-климатических условиях Курской области. Ключевые слова: озимая твердая пшеница, селекция, сорт, линия, урожай, структура, перезимовка, полегание, адаптивность, качество зерна, оченка.
\end{abstract}


Введение. Селекция озимой твердой пшеницы ведет свое начало с первой половины XX века. Первые сорта были зарегистрированы в Государственном реестре селекционных достижений только лишь в 50-х годах прошлого столетия. В данный момент районировано 28 сортов озимой твердой пшеницы.

Расширение ареала возделывания озимой твердой пшеницы, несомненно, могло бы улучшить ситуацию по обеспечению внутреннего рынка страны. Ежегодный сбор зерна твердой пшеницы составляет около 700 тыс. тонн. Твердая пшеница по своей значимости занимает второе место после мягкой пшеницы, поскольку ее зерно - особо ценное сырье для производства высококачественных макаронных изделий, круп, диетического питания, спагетти. $[1,2]$.

Озимая твердая пшеница имеет ряд преимуществ по сравнению с яровой формой; во-первых, более развитая корневая система и раннее созревание, что позволяет лучше переносить засуху за счет использования осенне-зимних осадков, во-вторых, высокая продуктивность.

Основным направлением на ближайшую перспективу следует признать селекцию на широкую адаптацию, основанную на придании сортам морозостойкости, засухоустойчивости, устойчивости к полеганию. Эффективность от внедрения новых адаптивных сортов, как правило, превышает все другие агроприемы и не требует больших материальных затрат. В настоящее время сорт стал тем фактором, без которого невозможно осуществлять внедрение научнотехнического прогресса в сельское хозяйство и добиться эффективного развития производства и экономической стабильности [3]. Цель исследований заключалась в изучении и выделении перспективного селекционного материала озимой твердой пшеницы экологически пластичного, высокопродуктивного, устойчивого к биотическим и абиотическим стрессам в почвенно-климатических условиях Центрально-Черноземной зоны (Курская область) для дальнейшей селекционной работы.

Материалы и методы. Материалом исследования являлись сорта озимой твердой пшеницы селекции ФГБНУ «Национального центра зерна им. П.П. Лукьяненко», ФГБНУ и ФГБНУ «Федерального научного центра «Донской».

В лаборатории экологической селекции Курского ФАНЦ посевы размещались на полях специального селекционного севооборота. Предшественник черный пар.

Научные исследования проводились на базе лабораторий экологической селекции и семеноводства по методике Государственного сортоиспытания сельскохозяйственных культур с использованием статистических методов «Методика полевого опыта» Б.А. Доспехова $[4,5,6]$.

В конкурсном сортоиспытании посев культур проводился на делянках площадью $10 \mathrm{~m}^{2}$, повторность шестикратная. Норма высева 5млн. всхожих зерен на 1га. Расположение делянок в первом ярусе систематическое, для удобства демонстрации опытов, в остальных рендамизированное. Способ посева сплошной рядовой, селекционной, порционной сеялкой СКС-6-10.

На опытах проводились: фенологические наблюдения по фазам (всходы, кущение, колошение, молочная спелость, восковая спелость, полная спелость), 
учет густоты стояния растений по всходам и перед уборкой, учет поражения болезнями: мучнистой росой и бурой ржавчиной. Проводилась бальная оценка состояния посевов по всходам и перед уборкой, устойчивости к полеганию, выравненности стеблестоя, продуктивности колоса. После уборки селекционных делянок проводился учет урожая, в лабораторных условиях анализировались растения по элементам структуры урожая, (высота растений, число растений, число стеблей, число продуктивных стеблей, общая кустистость, продуктивная кустистость, масса 1000 зерен, длина главного колоса, число зерен в главном колосе, вес зерна с одного растения), выравненность и оценка выполненности зерна. Анализ качества зерна проводился при помощи анализатора Инфратек 1241.

Результаты. Экологическая пластичность новых сортов, их устойчивость к лимитирующим факторам внешней среды и способность формировать высокие урожаи - приоритетное направление в селекции. Выбор лучших сортов сельскохозяйственных культур является наиболее дешевым, доступным и быстрым способом повышения урожайности и валовых сборов зерна [7].

За годы исследований погодные условия в период вегетации растений складывались разнообразно, что позволило лучше оценить способность изучаемых сортов и линий приспосабливаться к неблагоприятным факторам внешней среды. Более подробно они приведены далее и в таблице 1 .

Таблица 1 - Метеорологические условия вегетационного периода (по данным метеопункта «Петрин» Курской области, 2018-2020гг.)

\begin{tabular}{|l|l|c|c|c|c|c|c|}
\hline \multicolumn{2}{|c|}{ Показатель } & $\begin{array}{c}\text { Сен- } \\
\text { тябрь }\end{array}$ & $\begin{array}{c}\text { Ок- } \\
\text { тябрь }\end{array}$ & Апрель & Май & Июнь & Июль \\
\hline \multirow{2}{*}{$\begin{array}{l}\text { Температура } \\
\text { воздуха, }{ }^{\circ} \mathrm{C}\end{array}$} & $\begin{array}{l}\text { Средняя } \\
\text { за месяц }\end{array}$ & 13,7 & 7,6 & 7,2 & 14,0 & 21,0 & 19,8 \\
\cline { 2 - 8 } & $\begin{array}{l}\text { Отклоне- } \\
\text { ние } \\
\text { от нормы }\end{array}$ & $+1,3$ & 1,2 & $+1,0$ & $+2,1$ & $+3,7$ & $+1,2$ \\
\hline \multirow{2}{*}{ Осадки, мм } & $\begin{array}{l}\text { Сумма } \\
\text { за месяц }\end{array}$ & 25,8 & 34,4 & 22,1 & 78,2 & 35,4 & 62,8 \\
\hline $\begin{array}{l}\text { Процент от } \\
\text { нормы }\end{array}$ & 58,7 & 82,2 & 64,0 & 156,4 & 60,0 & 88,5 \\
\hline $\begin{array}{l}\text { Гидротермический коэф- } \\
\text { фициент (ГТК) }\end{array}$ & 0,42 & - & - & 1,78 & 0,57 & 1,02 \\
\hline
\end{tabular}

Озимая твердая пшеница более уязвима к негативным воздействиям среды в зимний период, что является основной проблемой в нашем регионе с суровыми условиями перезимовки озимых культур в отличие от более южных регионов. На рисунке 1 представлен уровень перезимовки, выделенных сортов за 2018-2021гг. 


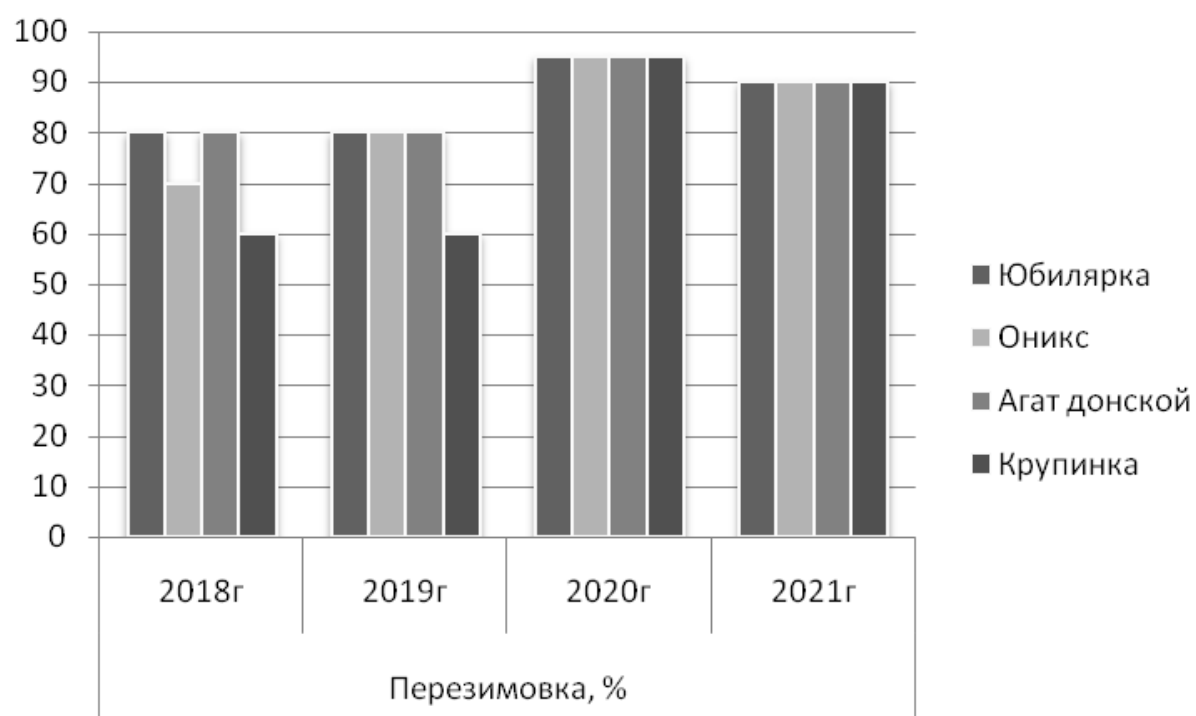

Рисунок 1 - Уровень перезимовки сортов озимой твердой пшеницы (2018-2021 гг.)

В настоящее время по Центрально-Черноземному региону нет допущенных к возделыванию сортов озимой твердой пшеницы, что объясняет отсутствие стандарта в опыте.

Урожайность у выделенных сортов озимой твердой пшеницы, в питомнике конкурсного сортоиспытания, в среднем за годы исследования была примерно на одном уровне и составляла 51,6-56,0 ц/га. В зависимости от агрометеорологических условий, вегетационного периода урожайность растений колебалась от 37,2 ц/га до 72,5 ц/га.

Таблица 2 - Урожайность зерна озимой твердой пшеницы (2018-2020гг.)

\begin{tabular}{|c|c|c|c|c|}
\hline \multirow{2}{*}{ Сорт, линия } & \multicolumn{4}{|c|}{ Урожайность, ц/га } \\
\cline { 2 - 5 } & 2018 г. & 2019 г. & 2020 г. & средняя \\
\hline Юбилярка & 47,5 & 51,4 & 64,7 & 54,5 \\
\hline Оникс & 51,0 & 42,8 & 68,0 & 53,9 \\
\hline Агат донской & 53,2 & 45,3 & 69,5 & 56,0 \\
\hline Крупинка & 37,2 & 45,3 & 72,5 & 51,6 \\
\hline НСР $_{05}$ & 1,5 & 0,9 & 1,8 & - \\
\hline
\end{tabular}

На основании проведенного структурного анализа сортов и линий озимой твердой пшеницы, мы можем судить о наличии хозяйственно-ценных признаков у выделенных сортообразцов. Исходя из массы 1000 зерен от 45,1 до 51,9 г, в среднем за 2018-2020 гг., можно сделать вывод, что сорта и линия озимой твердой пшеницы имеют достаточно крупное, выполненное зерно таблица 3.

Так же можно отметить способность растений формировать хорошо озерненный колос 38-41 зерен в среднем. Большую роль в формировании урожая играет продуктивная кустистость, так как компенсирует потерю растений, в том числе и из-за неблагоприятных воздействий внешней среды. 


\section{Таблица 3 - Структурный анализ озимой твердой пшеницы}

(2018-2020гг.)

\begin{tabular}{|c|c|c|c|c|c|c|}
\hline \multirow{2}{*}{ Сорт, линия } & \multirow{2}{*}{\begin{tabular}{c} 
Высота \\
растений, \\
\cline { 5 - 7 }
\end{tabular}} & \multicolumn{2}{|c|}{ Кустистость } & \multicolumn{2}{|c|}{ Анализ колоса } & Масса \\
\cline { 5 - 7 } & общая & $\begin{array}{c}\text { продук- } \\
\text { тивная }\end{array}$ & длина, см & $\begin{array}{c}\text { число зе- } \\
\text { рен, шт }\end{array}$ & $\begin{array}{c}1000 \\
\text { зерен, г }\end{array}$ \\
\hline Юбилярка & 94,0 & 4,2 & 3,5 & 6,5 & 39 & 49,9 \\
\hline Оникс & 86,7 & 3,5 & 2,7 & 6,0 & 41 & 45,2 \\
\hline Агат донской & 95,7 & 3,6 & 3,0 & 5,0 & 38 & 46,6 \\
\hline Крупинка & 87,8 & 4,0 & 3,4 & 6,0 & 39 & 51,9 \\
\hline
\end{tabular}

Выводы. Увеличение производства зерна твердой пшеницы является одной из важных и пока что нерешенных проблем. Выделенные сорта озимой твердой пшеницы хорошо проявили себя по основным хозяйственным ценным признакам (урожайность, элементы структуры урожая) и уровню адаптивности представляют интерес для дальнейшей селекционной работы.

\section{Библиографический список}

1. Мудрова А.А. Результативность использования исходного материала при селекции сортов пшеницы твердой озимой в условиях Кубани / А.А. Мудрова, А.С. Яновский // Зерновое хозяйство России, 2016. - №1 (43). - С. 24-27.

2. Коммерческие сорта озимой твердой пшеницы и особенности их семеноводства / Н.Е. Самофалова, Н.П. Иличкина, М.А. Авраменко, О.А. Дубинина, Т.Г. Дерова // Зерновое хозяйство России, 2016. - №6 (48). - С. 42-47.

3. Гриб С.И. Научная кооперация по селекции яровой пшеницы для условий Беларуси и Нечерноземья России. // Весці Нац. акад. навук Беларуси. Сер. аграр. Навук, 2013. - №3. C. 35-39.

4. Методика Государственного сортоиспытания сельскохозяйственных культур. - вып. 2. - М., 1989. - 197c.

5. Методические указания ВИР. - Л. 1977. - 53 с.

6. Доспехов Б.А. Методика полевого опыта (с основами статистической обработки результатов исследований). - М.: Колос, 1979. - 416 с.

7. Кильчевский А.В., Хотылева Л.В. Экологическая селекция растений. Мн.: Тэхналогія, 1997. - 372 c.

УДК 631.432.2/445.25/633.14

\section{ОСОБЕННОСТИ ИСПОЛЬЗОВАНИЯ ВЛАГИ ОЗИМОЙ РОЖЬЮ В АГРОСИСТЕМАХ ОПОЛЬНОЙ ЗОНЫ}

Зинченко С.И., Рыжова Л.Е.

Верхневолжский федеральный аграрный научный центр, г. Суздаль.

E-mail: zinchenkosergei@mail.ru

Резюме. На серой лесной почве Владимирского ополья проведено изучение влияния приемов основной обработки на содержание продуктивной влаги при воздельввании озимой ржи в зернотравяном севообороте. Содержание продуктивной влаги изучали в слоях 0-30,0-50,50100 и $0-100 \mathrm{~cm}$.

Summary. On the gray forest soil of the Vladimir Opole, the influence of basic processing techniques on the content of productive moisture during the cultivation of winter rye in the grain-grass crop rotation was studied. The content of productive moisture was studied in layers 0-30,0-50, 50100 and $0-100 \mathrm{~cm}$. 
Исследования проводились в стационарном полевом опыте по изучению приемов основной обработки в зернотравяном севообороте (овес + мн. травы (клевер+тимофеевка) - клевер первого года пользования с тимофеевкой - клевер второго года пользования с тимофеевкой - озимая рожь - яровая пшеница - ячмень) на поле, где возделывалась озимая рожь после трав второго года пользования (клевер+тимофеевка).

Наблюдения за запасами продуктивной влаги проводили на глубину одного метра (ГОСТ 28268 - 89) в течение 132 дня в первый год и 143 дня во второй год возделывания озимой ржи [1].

Рассмотрение использования запасов продуктивной влаги и атмосферных осадков в первый год возделывания озимой ржи в период от скашивания трав второго года пользования до посева культуры показало, что вероятно из-за систематической обработки поверхности почвы с целью уничтожения растительности происходит активное испарение влаги с открытой поверхности агросистем, поэтому вероятно в слое 0-30 см на всех вариантах отмечается потеря продуктивной влаги от 37,2-45,0 мм (рис. 1).

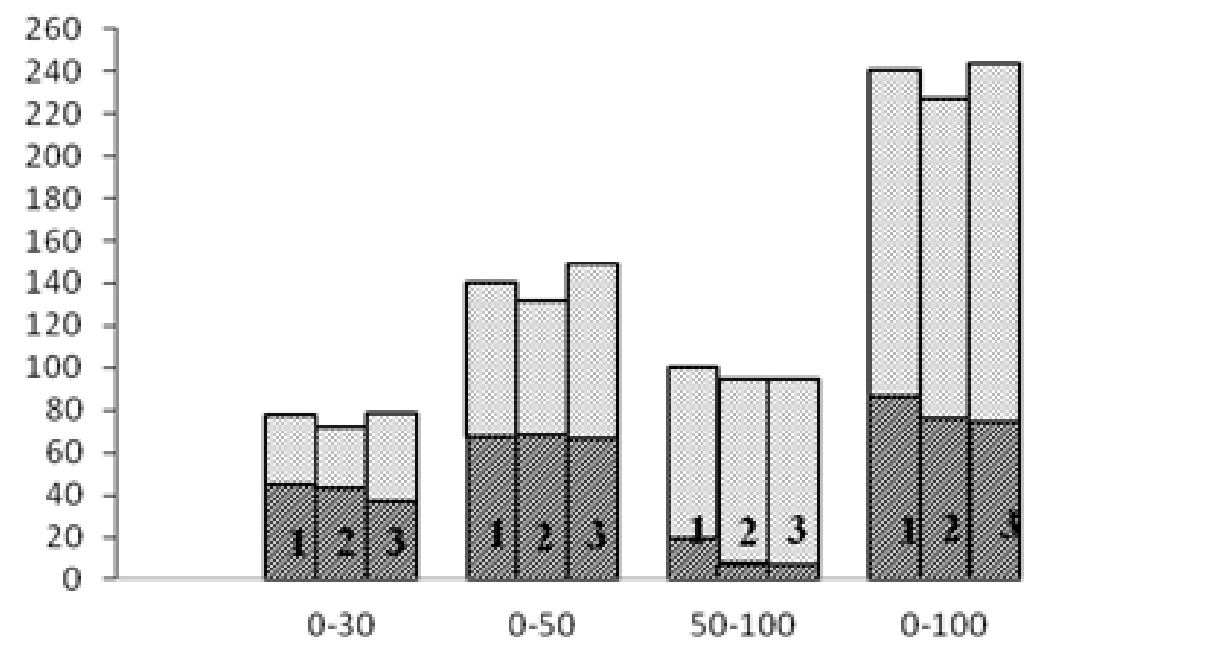

1 - ежегодная безотвальная на 6-8 см; 2 - ежегодная безотвальная на 20-22 см; 3 - ежегодная отвальная на 20-22 см - запасы влаги в слое почвы, мм;

Рисунок 1 - Распределение запасов продуктивной влаги в метровом слое почвы от уборки трав многолетних трав (клевер + тимофеевка) второго года пользования к посеву озимой ржи, мм

При этом тренд к более интенсивным потерям влаги из этого слоя отмечен на вариантах с безотвальной обработкой на 6-8 и 20-22 см - 43,6-45,0 мм.

С увеличением глубины изучаемого профиля почвы до 0-50 см потери влаги вероятно за счет капиллярного подтягивания в более верхние слои почвы увеличиваются на 14,9-18,0 \%.

С углублением изучаемого слоя до 50-100 потери продуктивной влаги в сравнении со слоем 0-50 см резко снижаются на 11,4-29,0\%. Наиболее интенсивно потери влаги происходят на варианте с рыхлением на 6-8 см - 19,6 мм.

В целом в слое почвы 0-100 см запасы продуктивной влаги во всех агросистемах снижаются на 74,9-87,0 мм, и несмотря на то, что в этот период 
выпало 155,2 мм, вероятно, потеря продуктивной влаги происходит за счет ее испарения с поверхности поля.

После посева озимой ржи и до ухода в зиму основное количество продуктивной влаги в этот период в агросистемах накапливается в слое 0-30 см - 30,542,8 мм (рис. 2). В слое 0-50 см этот показатель был на уровне $33,4-52,3$ мм. В слое 50-100 см агросистем количество влаги увеличивалось только на 1,7-12,6 MM.

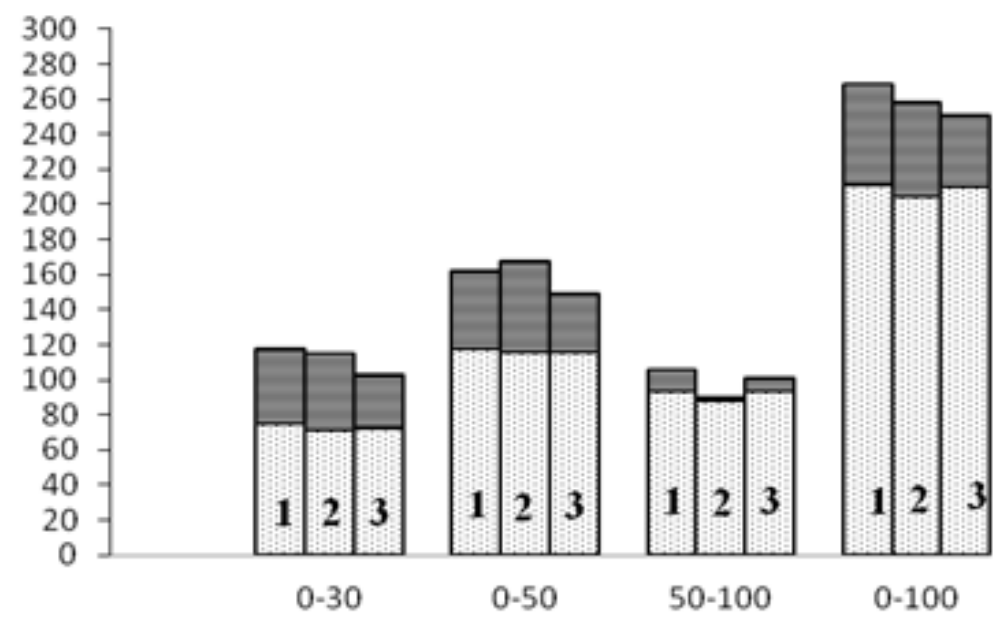

1 - ежегодная безотвальная на 6-8 см; 2 - ежегодная безотвальная на 20-22 см; 3 - ежегодная отвальная на 20-22 см - запасы влаги в слое почвы, мм;

- приход влаги в слое почвы, мм.

Рисунк 2 - Распределение запасов продуктивной влаги в метровом слое почвы от посева озимой ржи к уходу в зиму, мм

В целом к концу наблюдений в агросистемах в слое 0-100 см дополнительно накапливается от 40,7 до 57,2 мм и в основном это происходило в верхнем слое - 0-30 см.

Рассматривая динамику продуктивной влаги под озимой рожью, нельзя не отметить и период от ухода в зиму до возобновления весенней вегетации культуры. В этот период по утверждению отдельных исследований озимая рожь продолжает свое развитие $[2,3,4]$.

На рисунке 3 отмечено распределение запасов продуктивной влаги в метровом слое в этот период.

В этот период расход продуктивной влаги из слоя 0-30 см идет, вероятно, в основном за счет ее испарения из почвы в ранневесенний период от 42,4 до 49,2 мм. Из слоя 0-50 см расход продуктивной влаги увеличивается на 11,6$38,4 \%$. И по вариантам опыта составил 54,5-63,8 мм.

С увеличением глубины изучаемого слоя до 50-100 см потеря запасов влаги по вариантам опыта снижается до 4,1-24,3 мм. В агросистемах он разный наиболее высокие потери влаги наблюдаются в агросистеме с безотвальной обработкой на 6-8 cм.

А запасы влаги в этом слое были на уровне 69,3-77,1 мм $\left(\mathrm{HCP}_{05}=17,1 \mathrm{mм}\right)$. В целом в метровом слое почвы за изучаемый период в агросистемах запасы продуктивной влаги снижаются на 71,5-79,2 мм, а ее запасы составляют 126,6 $-138,4$ мм $\left(\mathrm{HCP}_{05}=18,3 \mathrm{mм}\right)$. 


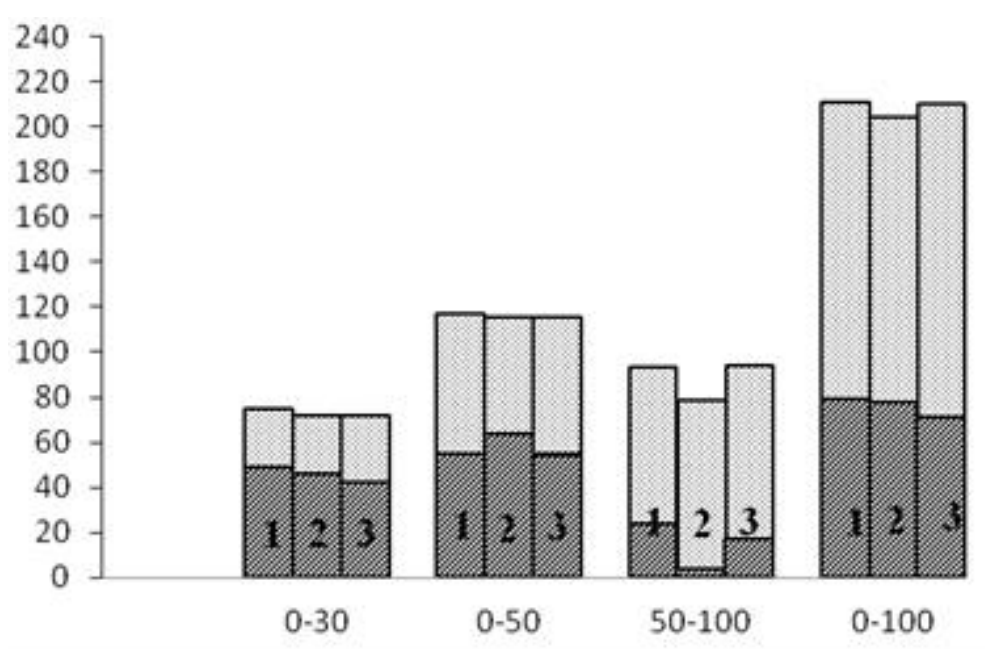

1 - ежегодная безотвальная на 6-8 cм; 2 - ежегодная безотвальная на 20-22 см; 3 - ежегодная отвальная на 20-22 см - запасы влаги в слое почвы, мм;

Рисунок 3 - Распределение запасов продуктивной влаги в метровом слое почвы от ухода в зиму до возобновлений весенней вегетации озимой ржи, мм

С возобновлением весенне вегетации озимой ржи потери продуктивной влаги из почвы в сравнении с предыдущим периодом из слоя 0-30 см снижаются в 2,9-14,5 раза вероятно за счет использования в основном атмосферных осадков и снижения испарения с поверхности почвы за счет покрытия ее рожью (рис. 4).

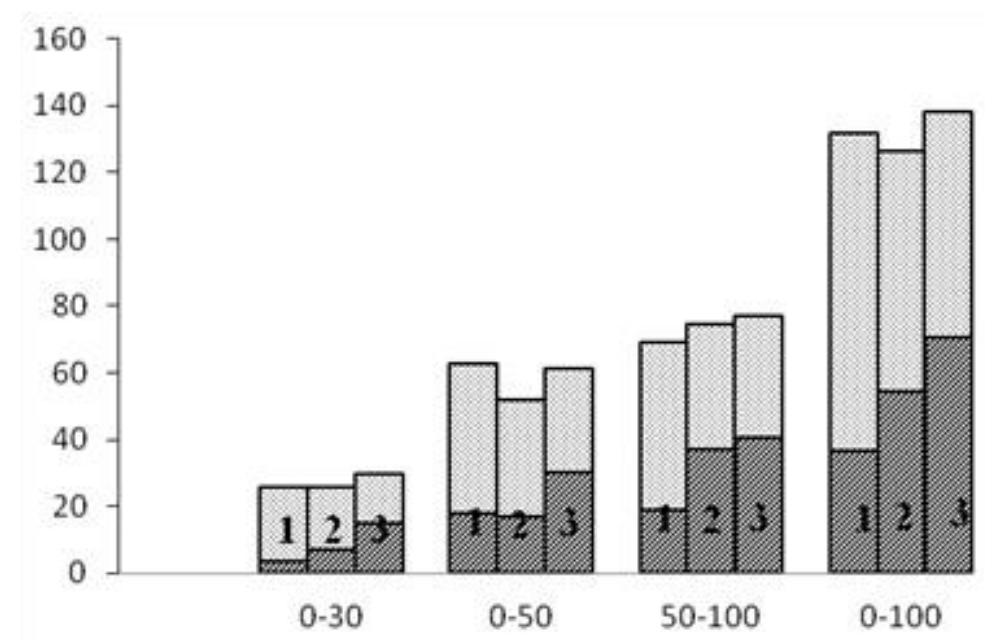

1 - ежегодная безотвальная на 6-8 см; 2 - ежегодная безотвальная на 20-22 см; 3 - ежегодная отвальная на 20-22 см - запасы влаги в слое почвы, мм;

Рисунок 4 - Распределение запасов продуктивной влаги в метровом слое почвы от возобновлений весенней вегетации озимой ржи до колошения, мм

В связи с тем, что к колошению корневая система озимой ржи проникает во второй полуметр метрового слоя почвы и из-за высокой потребности культуры во влаги в этот период наблюдаем более высокое потребление продуктивной влаги из слоя 50-100 см, чем из слоя 0-50 см на 1,2-20,1 мм. Высокое количество продуктивной влаги здесь расходуется на вариантах с рыхлением на 20-22 см 37,1-40,5 мм. 
В слое 0-100 см запасы продуктивной влаги были на уровне 67,8-95,1 мм $\left(\mathrm{HCP}_{05}=23,1 \mathrm{мm}\right)$. Наиболее высокие запасы отмечаются на варианте с безотвальной обработкой на 6-8 см, наименьшие на вспашке - 67,8 мм.

Если в слоях 0-30, 0-50 и 50-100 см, в период от колошения до созревания озимой ржи, запасы продуктивной влаги в агроэкосистемах были на одном уровне, то в слое 0-100 см наиболее высокие запасы отмечаются на вариантах с безотвальной обработкой 105,7-116,1 мм $\left(\mathrm{HCP}_{05}=20,2\right.$ мм), наименьшие на вспашке - 81,1 мм (рис. 5).

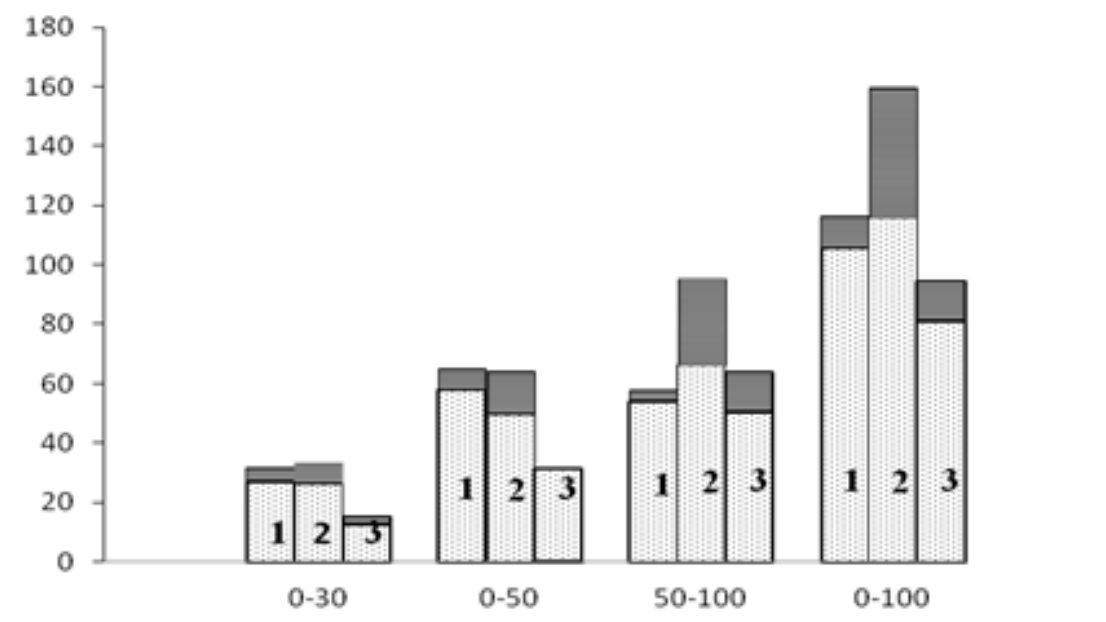

1 - ежегодная безотвальная на 6-8 см; 2 - ежегодная безотвальная на 20-22 см; 3 - ежегодная отвальная на 20-22 см - запасы влаги в слое почвы, мм; - приход влаги в слое почвы, мм.

Рисунок 5 - Распределение запасов продуктивной влаги в метровом слое почвы от колошения до полной спелости озимой ржи, мм

К уходу в зиму после выпадения 131,2 мм атмосферных осадков запасы продуктивной влаги в агросистемах в целом в изучаемых слоях выравниваются и в слое 0-100 см они были на уровне 140,6-143,1 мм $\left(\mathrm{HCP}_{05}=25,1\right.$ мм) (рис.6). Наиболее активное накопление продуктивной влаги происходит в этот период в слоях 0-30 и 0-50 см.

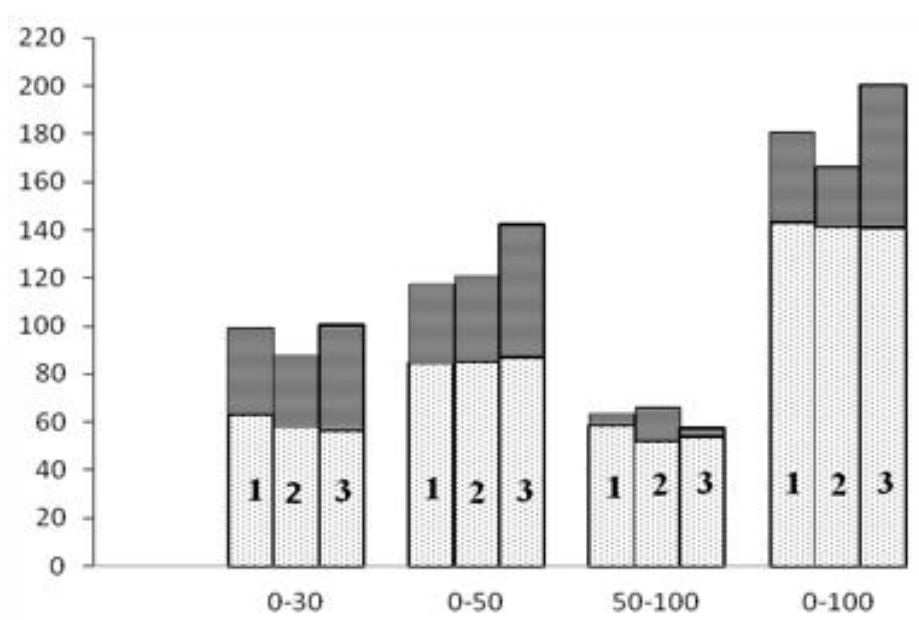

1 - ежегодная безотвальная на 6-8 cм; 2 - ежегодная безотвальная на 20-22 см; 3 - ежегодная отвальная на 20-22 см - запасы влаги в слое почвы, мм; - приход влаги в слое почвы, мм.

Рисунок 6 - Распределение запасов продуктивной влаги в метровом слое почвы от уборки озимой ржи до ухода в зиму, мм 
Важной величиной в определении эффективности технологий при формировании урожая сельскохозяйственных культур является расход влаги на формирование единицы продукции - коэффициент водопотребления (КВ).

Однако коэффициент водопотребления будет зависеть от слоя почвы, который мы возьмем для изучения [5].

Если мы возьмём слой в 0-30 см, то КВ составит от 130,0 до 154,0 мм/т. Наименее низкие показатели КВ будут на вариантах с безотвальным рыхлением на 6-8 и 20-22 см - 130,0-132,3 мм/т. В слое 0-50 см он будет в интервале от 132,3 до 164,8 мм/т. А в слое $0-100$ см от 144,0 до 174,0 мм/т.

Таким, образом наименьшие затраты продуктивной влаги на формировании 1 тонны зерна (при нормальной технологии возделывании) озимой ржи затрачиваются на варианте с безотвальной обработкой на 6-8 и 20-22 см - 144,0$145,1 \mathrm{~mm} / \mathrm{T}$.

\section{Выводы.}

1. Содержание запасов продуктивной влаги озимой ржи в агросистемах зависит от периода ее возделывания: при паровании использование влаги происходит в основном из слоя 0-50 см, использование ее из слоя 50-100 см в сравнении со слоем 0-50 см снижается на 11,4-29,0 \%; после посева происходит ее увеличение в основном в слое 0-30 см на 74,8-74,9\% от общего количества, в слое 50-100 см - на 4,1-22,0\% мм; от ухода в зиму до возобновления весенней вегетации расход продуктивной влаги в агросистемах снижается, в метровом слое почвы он увеличивается от слоя почвы 0-30 см к слою 0-50 см на 11,6$38,4 \%$. В слое 50-100 см потеря запасов влаги по вариантам опыта снижается до 4,1-24,3 мм; с возобновлением весенней вегетации использование продуктивной влаги из почвы в сравнении с предыдущим периодом из слоя 0-30 см снижаются в 2,9-14,5 раза, из слоя 0-50 см - на 26,6-55,2\%. Наиболее высокие запасы отмечаются на варианте с безотвальной обработкой на 6-8 см, наименьшие на вспашке - 67,8 мм; в период от колошения до созревания в слоях почвы 0-30, 0-50 и 50-100 см запасы продуктивной влаги в агросистемах были на одном уровне, в слое 0-100 см высокие запасы продуктивной влаги отмечаются на вариантах с безотвальной обработкой $105,7-116,1$ мм $\left(\mathrm{HCP}_{05}=20,2\right.$ мм), наименьшие на вспашке - 81,1 мм.

2. Высокие затраты продуктивной влаги на формировании 1 тонны зерна (при нормальной технологии возделывании) озимой ржи затрачиваются на варианте с безотвальной обработкой на 6-8 и 20-22 см - 144,0-145,1 мм/т.

\section{Библиографический список}

1. ГОСТ 28268-89. Почвы. Методы определения влажности, максимальной гигроскопической влажности и влажности устойчивого завядания растений. М., 1989.

2. Иванов А.Л. Задачи современного земледелия // Владимирский земледелец, 2003. - № 3. - C. $2-8$.

3. Корневые системы и продуктивность сельскохозяйственных растений / А.С. Устименко, П.В. Данильяук, А.Т. Гвоздиковская, Изд.: Урожай, 1975. - 368с.

4. Тиунов А.Н., Глухих К.А., Хорьков О.А., Шернин А.И. М. Рожь. Колос, 1972. - 352 с. 
5. Зинченко С.И. Характеристика отдельных физических и почвенно-гидрологических свойств метрового профиля серой лесной почвы // Владимирский земледелец, 2018. - №1 (83). - C. 2-5.

УДК 631.433 .53

\title{
ПЛОЩАДНЫЕ ПОКАЗАТЕЛИ ЭМИССИИ СО2 ИЗ ПОЧВЫ РАЗЛИЧНЫХ БИОТОПОВ МЕДВЕНСКОГО РАЙОНА КУРСКОЙ ОБЛАСТИ
}

\author{
Золотухин А.Н. ${ }^{1,2}$, Суховеева О.Э. ${ }^{2}$, Карелин Д.В. ${ }^{2}$ \\ ${ }^{1}$ Всероссийский НИИ земледелия и защиты почв от эрозии - структурное \\ подразделение ФГБНУ "Курский ФАНЦ», г. Курск \\ E-mail: alipijj@rambler.ru \\ ${ }^{2}$ Институт географии РАН, г. Москва
}

\begin{abstract}
Резюме. В статье приведена оценка площзадных показателей почвенной эмиссии $\mathrm{CO}_{2} \mathrm{paз-}$ личных биотопов Медвенского р-на Курской области.
\end{abstract}

Ключевые слова: углеродный баланс, эмиссия $\mathrm{CO}_{2}$, площадные показатели.

Введение. Углеродный баланс различных сообществ является важнейшим интегральным показателем их состояния и функционирования в зависимости от внешних и внутренних факторов - естественных и антропогенных. Значимым компонентом исследований углеродного баланса являются постоянные наблюдения за состоянием ключевых экосистем изучаемого ландшафта. В черноземной лесостепной зоне количественные показатели эмиссии $\mathrm{CO}_{2}$ из почвы природных экосистем, залежей и активно эксплуатируемых пашен под различными сельскохозяйственными культурами значимо отличаются друг от друга. В качестве основной причины этого выступает многообразие характерных времен реализации различных деградационных и восстановительных процессов [5].

Динамика наземного покрова является одним из трех глобальных индикаторов достижения нейтрального баланса деградации земель (НБДЗ), наряду с динамикой продуктивности земель и динамикой запасов органического вещества в почве [3]. Поэтому оценка площадных показателей эмиссии $\mathrm{CO}_{2}$ из почвы является необходимой для применения и адаптации концепции нейтрального баланса деградации земель (НБДЗ - состояние земель, когда количество здоровых и продуктивных земельных ресурсов, необходимое для поддержания жизненно важных экосистемных услуг, остается стабильным или увеличивается в определенных масштабах времени и пространства).

Материалы и методы. На территории Курской биосферной станции (КБС) (Медвенский р-н, Курской обл.) и в ее окрестностях с апреля по октябрь 2017-2020 гг. проводились постоянные полевые измерения почвенной эмиссии $\mathrm{CO}_{2}$.

Объекты исследования включали в себя различные типы биотопов: климаксные сообщества (75-летняя некосимая восстановленная перисто-ковыльная степь и ясеневый лес возрастом более 50 лет), залежи (зарастающая, на 
2020 г. 4-летняя залежь с рудеральной растительностью, а также две с измененным землепользованием), пашни (озимая пшеница, яровой ячмень, соя, подсолнечник и другие). Измерения проводились портативными инфракрасными газоанализаторами AZ 77535 методом закрытых камер [2].

В окрестностях КБС было задействовано девять площадок наблюдения с десятью вкопанными камерами на каждой из них. За весь период наблюдений (2017-2020 гг.) было произведено более 320 измерений (т.е. более 2170 единичных). Точки были заложены 26 апреля 2017 (KBS6 и KBS7 в 2019 г.).

Для оценки площадных показателей почвенной эмиссии $\mathrm{CO}_{2}$ использовали космические снимки Maxar Technologies высокого разрешения от

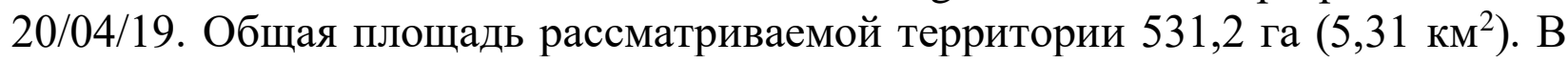
расчет не брали дороги, территории хозяйственных объектов, лесозащитные полосы. Всего было выделено 11 участков, по типам землепользования и характеру растительного покрова (рис. 1).

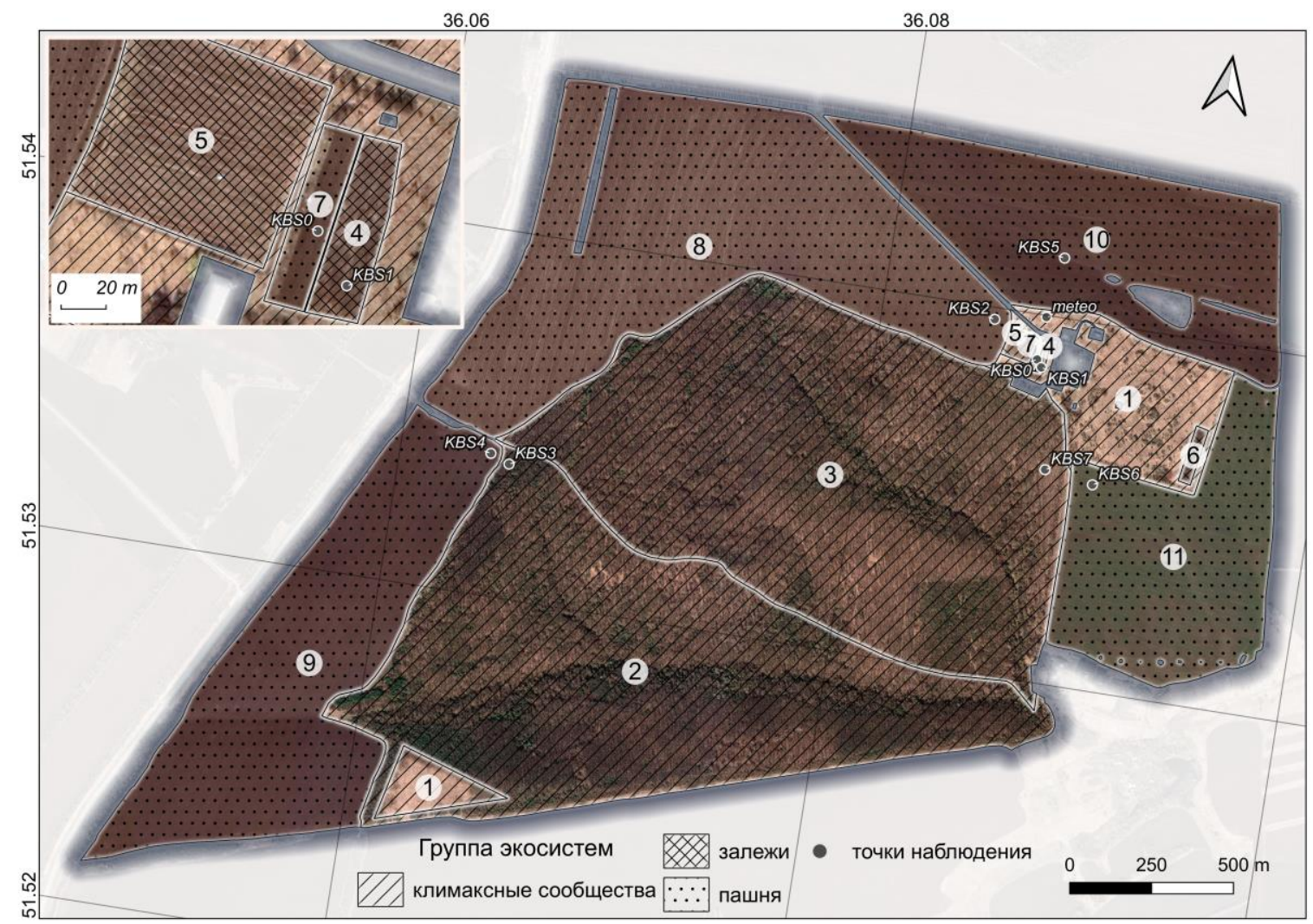

Рисунок 1 - Схема рассматриваемого участка площадью 531,2 га (цифры соответствуют номерам выделов, символами KBS обозначено расположение точек измерения)

\section{Климаксные сообщества:}

1. Восстановленная перистоковыльная степь. Некосимая более 70 лет залежь в районе метеостанции КБС (N 51.53999 Е 36.08757) является, по сути, уже около-климаксным, т. е. относительно устойчивым фитоценозом. Растительный покров представлен лугово-степными видами, среди которых преобладает ковыль перистый (Stipa pennata) [1]. 
2. Ясеневый лес - возраст деревьев более 50 лет. Юго-западная часть леса Сборная Дача (N 51.533973 Е 36.06556). В составе насаждений и подлеска преобладают: ясень пенсильванский (Fraxinus pennsylvanica) (высота 1-го яруса 22-25 м.), бересклет европейский (Euonymus europaeus), вяз голый (Ulmus glabra), клён ясенелистный, или американский (Acer negundo), черёмуха обыкновенная (Padus avium). Высота подлеска до 8 м.

3. Кленово-дубовый лес - (N 51.535519 Е 36.088293). Северо-западная часть леса Сборная Дача. Древостой: дуб черешчатый (Quercus robur), клен остролистный (Acer platanoides), черёмуха обыкновенная (Padus avium) и др.

Залежи:

4. Молодая (1-4-летняя) залежь - (N 51.53860 Е 36.08736) характеризуется активными процессами зарастания (бурьянистая растительность). Площадь оставлена под залежь в 2016 г. до этого ее занимали посевы ячменя. Растительный покров представляют: пырей ползучий (Elytrigia repens), бодяк щетинистый (Cirsium setosum), молочай (Euphorbia virgata), латук (Lactuca serriola), полынь обыкновенная (Artemisia vulgaris), чертополох колючий (Carduus acanthoides) и др. [1].

5. Участок (N 51.539031 Е 36.086468) периодически используется для посадки зерновых. В 2017-2019 гг. оставлен под залежь, в 2020 - пар.

6. Выдел (N 51.536715 Е 36.094532) залежь, в 2019 году площадь оставлена под пар, в 2020 г. - озимая пшеница.

Поля с ежегодной распашкой:

7. Ежегодная пашня-огород. Основная культура картофель (N 51.53862 Е 36.08704).

8. Участок со слабо выраженной эрозией (N 51.53907 Е 36.08495).

9. Поле к юго-западу от ясеневого леса (N 51.53399 Е 36.06425).

10. Поле к северу от метеостанции КБС (N 51.54173 Е 36.08662).

11. Поле к востоку от кленово-дубового леса (N 51.535695 Е 36.090457$)$.

Севообороты на исследуемых пахотных участках указаны в табл. 1.

Таблица 1 - Ротация с.-х. культур на объектах исследования

\begin{tabular}{|c|l|l|l|l|}
\hline Выдел & \multicolumn{1}{|c|}{2017} & \multicolumn{1}{|c|}{2018} & \multicolumn{1}{|c|}{2020} \\
\hline 5 & Залежь & Залежь & Залежь & Пар \\
6 & Залежь & Залежь & Пар & Пшеница озимая \\
7 & Картофель & Картофель & Картофель & Картофель \\
8 & Ячмень яровой & Кукуруза & Соя & Соя \\
9 & Подсолнечник & Пшеница озимая & Соя & Соя \\
10 & Пшеница озимая & Соя & Подсолнечник & Ячмень яровой \\
11 & - & - & Пшеница озимая & Подсолнечник \\
\hline
\end{tabular}

Наблюдения на территории леса «Сборная дача» проводились в двух точках на юго-западе (преимущественно ясень) и северо-востоке (преимущественно клен и дуб). Поэтому на данной схеме лес представлен двумя выделами (2 и 3), граница между которыми проведена по старой просеке.

Выделы 5 и 6 представляют собой залежные площади, возвращаемые в сельскохозяйственный оборот. Эмиссия для этих участков рассчитана с учетом 
изменений, происходящих в характере их землепользования.

Для расчета среднегодовой эмиссии (т $\mathrm{C}^{-1} \mathrm{a}^{-1}$ год $\left.{ }^{-1}\right)$ необходимо учитывать дыхание холодного периода (ноябрь-апрель), которое в лесостепной зоне в среднем составляет 25\% от суммарного годового потока [4]. Данные, полученные при измерениях в теплый период, принимались за 75\%.

Результаты. Полученные за четыре года наблюдений полевые данные являются основой для пространственной и площадной оценки почвенной эмиссии $\mathrm{CO}_{2}$ на экспериментальных участках КБС (табл. 2).

\section{Таблица 2 - Пространственные и площадные показатели почвенной эмиссии СО2 на экспериментальных участках КБС}

\begin{tabular}{|c|c|c|c|c|c|}
\hline $\begin{array}{c}\text { Группа } \\
\text { экосистем }\end{array}$ & Тип экосистемы & 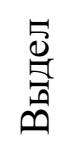 & $\mathrm{S}$, га & $\begin{array}{c}\text { Наблюдаемый } \\
\text { средний поток } \\
\text { т С га }{ }^{-1} \text { год }\end{array}$ & $\begin{array}{c}\text { Средний суммар- } \\
\text { ный поток с выдела, } \\
\text { т С год }{ }^{-1}\end{array}$ \\
\hline \multirow{5}{*}{$\begin{array}{c}\text { Климакс- } \\
\text { ные }\end{array}$} & Лесостепь & 1 & 24,70 & $10,496 \pm 0,717$ & $259,251 \pm 17,705$ \\
\hline & Ясеневый лес & 2 & 121,56 & $8,723 \pm 0,781$ & $1060,392 \pm 94,914$ \\
\hline & Кленовый лес & 3 & 130,44 & $11,354 \pm 1,824$ & $1480,964 \pm 237,923$ \\
\hline & Всего & & 276,70 & & 2800,607 \\
\hline & Залежь & 4 & 0,18 & $16,307 \pm 1,267$ & $2,935 \pm 0,228$ \\
\hline & Залежь/пар & 5 & 0,80 & $14,726 \pm 1,28$ & $11,781 \pm 1,024$ \\
\hline \multirow[t]{4}{*}{ Залежи } & Залежь/пар/оз.пш. & 6 & 0,69 & $14,246 \pm 1,344$ & $9,83 \pm 0,927$ \\
\hline & Всего & & 1,67 & & 24,546 \\
\hline & & 7 & 0,15 & $6,963 \pm 0,614$ & $1,044 \pm 0,092$ \\
\hline & & 8 & 90,68 & $7,168 \pm 0,666$ & $649,994 \pm 60,357$ \\
\hline \multirow[t]{4}{*}{ Пашни } & С.-х. культуры & 9 & 65,15 & $10,074 \pm 1,216$ & $656,295 \pm 79,222$ \\
\hline & & 10 & 53,88 & $11,93 \pm 1,318$ & $642,767 \pm 71,035$ \\
\hline & & 11 & 42,97 & $6,483 \pm 1,299$ & $278,583 \pm 55,827$ \\
\hline & Всего & & 252,83 & & 2228,683 \\
\hline Итого & & & 531,20 & 118,470 & 5053,836 \\
\hline
\end{tabular}

Доля $\mathrm{CO}_{2}$, выделяемого из почвы каждого типа экосистем в атмосферу, прямо пропорциональна их площади. Климаксные сообщества, занимающие почти половину площади участка $(52,1 \%)$, дают более половины потока углерода $(55,4 \%)$. На долю пашен приходится $47,6 \%$ площади и $44,1 \%$ совокупной эмиссии $\mathrm{CO}_{2}$. На долю залежных земель $-0,3 \%$ и $0,5 \%$, соответственно.

Суммарный годовой поток $\mathrm{CO}_{2}$ из почвы рассматриваемого участка площадью 531,2 га составил 5053,836 т С год ${ }^{-1}$.

В таблице 3 представлен вклад каждой сельскохозяйственной культуры в почвенную эмиссию $\mathrm{CO}_{2}$ с участка за 4 года, с учетом ее присутствия и отсутствия.

Наибольшую интенсивность почвенного дыхания демонстрируют посевы сои $10,986 \pm 2,695$ т С га ${ }^{-1}$ год ${ }^{-1}$ и посевы пшеницы $10,155 \pm 1,843$ т С га ${ }^{-1}$ год $^{-}$ 1 .

Средний суммарный поток с площади под соей составил 1003,943 \pm 246,323 т С год ${ }^{-1}$ (46,0\% от общего дыхания пашни) при занимаемой площади 91,39 га (39,5\%), под пшеницей 411,262 $\pm 74,636$ т С год ${ }^{-1}(18,9 \%)$ - площадь 40,50 га $(17,5 \%)$. 


Таблица 3 - Вклад сельскохозяйственных культур в суммарный поток с
рассматриваемого участка
\begin{tabular}{|l|l|l|l|}
\hline Культура & $\begin{array}{l}\text { Средняя занимаемая } \\
\text { культурой площадь в } \\
\text { год }\end{array}$ & $\begin{array}{l}\text { Наблюдаемый } \\
\text { средний поток т } \\
\text { га }^{-1} \text { год }^{-1}\end{array}$ & $\begin{array}{l}\text { Средний суммарный поток } \\
\text { с площади под культурой, } \\
\text { т С год }\end{array}$ \\
\hline Ячмень & 36,14 & $8,230 \pm 1,412$ & $297,418 \pm 51,044$ \\
Подсолнечник & 40,50 & $8,761 \pm 1,597$ & $354,828 \pm 64,693$ \\
Пшеница & 40,50 & $10,155 \pm 1,843$ & $411,262 \pm 74,636$ \\
Кукуруза & 22,67 & $4,843 \pm 0,890$ & $109,787 \pm 20,168$ \\
Соя & 91,39 & $10,986 \pm 2,695$ & $1003,943 \pm 246,323$ \\
Картофель & 0,15 & $6,901 \pm 1,268$ & $1,035 \pm 0,190$ \\
Итого & 231,35 & 49,875 & 2178,273 \\
\hline
\end{tabular}

Заключение. Постоянные наблюдения за состоянием ключевых экосистем изучаемого ландшафта являются значимым компонентом исследований углеродного баланса. При пространственном анализе эмиссии следует учитывать территориальную структуру землепользования. Такая оценка площадных характеристик конкретного участка может быть использована как компонент расчета НБДЗ. В статье на основе данных полевых измерений оценена почвенная эмиссия $\mathrm{CO}_{2}$ на участке площадью 531,2 га, где представлены пашни $(47,6 \%)$, климаксные сообщества $(52,1 \%)$ и небольшая доля залежных земель $(0,3 \%)$. Среднегодовой поток $\mathrm{CO}_{2}$ из почвы рассматриваемого участка составил 118,5 т С га ${ }^{-1}$ год ${ }^{-1}$, а совокупный $-5053,8$ т С год ${ }^{-1}$. Наибольший вклад в эмиссию $\mathrm{CO}_{2}$ среди сельскохозяйственных культур на рассматриваемом участке за 4 года внесли посевы сои $(46,0 \%)$ и пшеницы $(18,9 \%)$.

\section{Библиографический список}

1. Золотухин Н.И., Золотухин А.Н. О растительности залежей Курской биосферной станции Института географии РАН. Флора и растительность Центрального Черноземья - ... [Текст]: материалы межрегиональной научной конференции, посвященной 50-летию музея природы Центрально-Черноземного гос. природного биосферного заповедника им. проф. В. В. Алехина; [ред. кол. О. В. Рыжков (отв. ред.) и др.]. - Курск: - ИП Бабкина Г.П., 2021. -. C. 120-124.

2. Карелин Д.В., Замолодчиков Д.Г., Краев Г.Н. Методическое руководство по анализу эмиссий углерода из почв поселений в тундре. - М.: Изд-во ЦЭПЛ РАН, 2015. - 64 с.

3. Карелин Д.В., Суховеева О.Э., Золотухин А.Н., Лунин В.Н., Куст Г.С. Современные исследования и мониторинг углеродного баланса на Курской биосферной станции Института географии РАН в рамках концепции нейтрального баланса деградации земель // Вопросы географии, серия Человек и биосфера, - М.: Медиа-ПРЕСС, 2021. - Т. 152, С. 253-280.

4. Курганова И.Н. Эмиссия и баланс диоксида углерода в наземных экосистемах России. - Автореф. дис. ... д-ра биол. наук: 03.00.27, 03.00.16. - Пущино.: ИФХиБПП РАН, 2010. $48 \mathrm{c}$.

5. Лобковский В. А., Куст Г. С., Андреева О. В. Методические подходы к установлению базовой линии для мониторинга индикаторов нейтрального баланса деградации земель в России // Проблемы региональной экологии, 2019. - №4. URL: https://cyberleninka.ru/article/n/metodicheskie-podhody-k-ustanovleniyu-bazovoy-linii-dlyamonitoringa-indikatorov-neytralnogo-balansa-degradatsii-zemel-v-rossii (дата обращения: 05.08.2021).) 


\title{
УДК $631.43(571.63)$
}

\section{БАЗОВЫЕ ФИЗИЧЕСКИЕ И ФИЗИКО-ХИМИЧЕСКИЕ ПОКАЗАТЕЛИ АГРОПОЧВ СПУСТЯ МЕСЯЦ ПОСЛЕ ВНЕСЕНИЯ БИОУГЛЯ}

\author{
Иванкова А.И. ${ }^{1}$, Козлова А.А. ${ }^{1}$, Гилев А.М. ${ }^{1}$,
} Брикманс А.В. ${ }^{1}$, Нестерова О.В. ${ }^{1}$,

${ }^{1}$ ФГАОУ ВО Дальневосточный федеральный университет, г. Владивосток

E-mail: creativewriter1903@ gmail.com

Резюме. Впервые для агропочв юга Приморского края на примере агротемногумусовых подбелов с дренажной системой и без нее, рассматривается влияние биоугля, через месяи после

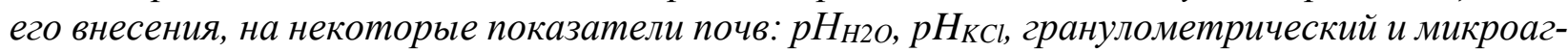
регатный состав, показатели оченки качества структуры почвы - Кд, Ка, Кс, ППС.

Ключевые слова: биоуголь, агропочвы, гранулометрический состав, водопрочность агрегатов, оченка качества структуры.

Summary. In Luvic Anthrosols with a drainage system and without it, was studed the effect of biochar on some soil parameters: $\mathrm{pH} 2 \mathrm{O}, \mathrm{pHKCl}$, granulometric and microaggregate composition, for assessing the quality of the soil structure after one month iapplication in the south of Primorsky region.

Key words: biochar, agrosoils, particle size distribution, water resistance of aggregates, assessment of the quality of the structure.

В условиях интенсивного земледелия почвы испытывают на себе сильную антропогенную нагрузку, подвергаясь сильному механическому воздействию. В муссонном типе климата Приморского края эта проблема стоит очень остро: тяжелый гранулометрический состав, плохие водно-воздушные свойства в совокупности с влиянием механического воздействия на агропочвы приводят к ухудшению условий роста и развития растений, что может снижать урожай. Внесение биоугля изменяет физические свойства почвы, такие как текстура, структура, распределение размеров пор и плотность, водоудерживающая способность, рост растений [1].

Объект исследования - агротемногумусовые подбелы Приморской овощной опытной станции ВНИИО. С 2020 г. в качестве мелиоранта для улучшения физических свойств почв был внесен биоуголь, произведенный из древесных

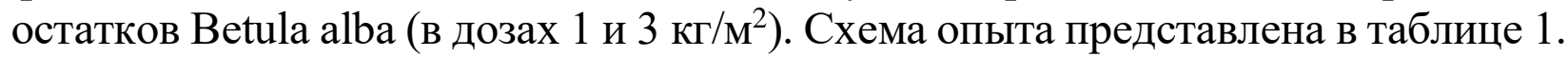

Таблица 1 - Схема полевого опыта

\begin{tabular}{|c|c|c|c|c|c|c|}
\hline \multirow[t]{2}{*}{ Год } & \multicolumn{3}{|c|}{ Участок без дренажа почвы } & \multicolumn{3}{|c|}{ Участок с дренажом почвы } \\
\hline & $\begin{array}{c}\text { биоуголь } \\
0 \text { кг/м }{ }^{2}\end{array}$ & $\begin{array}{c}\text { биоуголь } \\
1 \text { кг/м }{ }^{2}\end{array}$ & $\begin{array}{c}\text { биоуголь } \\
3 \text { кг/м }\end{array}$ & $\begin{array}{c}\text { биоуголь } \\
3 \text { кг/м² }\end{array}$ & $\begin{array}{c}\text { биоуголь } \\
1 \text { кг/м }{ }^{2}\end{array}$ & $\begin{array}{c}\text { биоуголь } \\
0 \text { кг/м }{ }^{2}\end{array}$ \\
\hline 2020 & свекла & свекла & свекла & свекла & свекла & свекла \\
\hline
\end{tabular}

Исследования показали, что через месяц после внесения биоугля (табл. 2) в агропочвы на участке с дренажной системой и дозой биоугля 3 кг $/ \mathrm{M}^{2}$ значения $\mathrm{pH}_{\text {H2O }}$ составило 5,95, с применением биоугля в дозе 1 кг значение $\mathrm{pH}_{\text {н2о соста- }}$ вил 6,78 , тогда как на контрольном участке без внесения биоугля значение $\mathrm{pH}_{\text {H2о }}$ составило 5,98. На участке без дренажа наблюдались более заметные изменения $\mathrm{pH}_{\mathrm{H} 2 \mathrm{O}}$. При внесении биоугля в дозах 1 и 3 кг $/ \mathrm{M}^{2}$ видно, что биоуголь 
способен поддерживать рН среды смещая значения в сторону нейтральной. Подобная тенденция наблюдается и для $\mathrm{pH}_{\mathrm{KCl}}$. На поле без дренажа с внесением биоугля в дозах 1 и 3 кг значения $\mathrm{pH}_{\mathrm{KCl}}$ смещаются в сторону слабокислой реакции среды, а в варианте без внесения биоугля этот показатель варьирует от среднекислой среды до слабокислой реакции среды.

\section{Таблица 2 - Свойства агропочв}

\begin{tabular}{|c|c|c|c|c|c|c|c|c|}
\hline \multirow{2}{*}{ Свойства } & \multicolumn{2}{|c|}{$\begin{array}{c}\text { Кислотно-основ- } \\
\text { ные свойства аг- } \\
\text { ропочв }\end{array}$} & \multirow[t]{2}{*}{$\begin{array}{l}\text { Гранулометри- } \\
\text { ческий состав }\end{array}$} & \multirow{2}{*}{$\begin{array}{c}\text { Водопроч- } \\
\text { ность агре- } \\
\text { гатов в стоя- } \\
\text { чей воде, \% }\end{array}$} & \multicolumn{4}{|c|}{$\begin{array}{l}\text { Оценка качества } \\
\text { структуры почвы }\end{array}$} \\
\hline & $\mathrm{pH}_{\mathrm{H} 2 \mathrm{O}}$ & $\mathrm{pH}_{\mathrm{KCl}}$ & & & Кд & Kc & $\mathrm{Ka}$ & ППС \\
\hline Др К & 5,98 & 5,22 & Глина средняя & 20,3 & 4 & 96 & 90 & 24 \\
\hline Др 1 кг & 6,78 & 4,84 & Глина легкая & 20,5 & 4 & 96 & 90 & 24 \\
\hline Др 3 кг & 5,95 & 5,22 & Глина легкая & 19,5 & 4 & 85 & 86 & 21 \\
\hline Бдр К & 6,38 & 5,55 & Глина легкая & 12,4 & 4 & 96 & 90 & 24 \\
\hline Бдр 1 кг & 6,46 & 5,88 & Глина легкая & 22,6 & 9 & 79 & 75 & 9 \\
\hline Бдр 3 кг & 6,63 & 6,03 & Глина легкая & 22,7 & 5 & 72 & 70 & 14 \\
\hline
\end{tabular}

Анализируя данные по гранулометрическому составу агропочв было установлено, что почвы на участке с дренажной системой (табл.2), где биоуголь не вносился (контроль), гранулометрический состав является глиной средней (сумма фракций $>0,01$ составила $35 \%$ ). При внесении 1 кг биоугля/м² гранулометрический состав стал легче - глиной лёгкой (сумма фракций $>0,01$ составила 36\%). При внесении биоугля в дозе 3 кг/ $\mathrm{m}^{2}$ гранулометрический состав остался неизменным (глина лёгкая), однако сумма фракций $>0,01$ составила уже $41 \%$. Гранулометрический состав почв на бездренажной системе в контрольном варианте в ходе анализа был определён как глина лёгкая, сумма фракций $>0,01$ составила $38 \%$. При внесении как 1 , так и 3 кг $/ \mathrm{M}^{2}$ биоугля, гранулометрический состав почв остался неизменным - глиной лёгкой, сумма фракций $>0,0143 \%$ и $46 \%$ соответственно.

Данные микроагрегатного анализа показали, что во всех вариантах опыта минимум частиц пришлось на фракцию ила (1-2 \%), максимум частиц содержится во фракции мелкого песка (34-47 \%).

На основе гранулометрического и микроагрегатного анализов были рассчитаны коэффициенты структурности (Кс), дисперсности (Кд), агрегированности (Ка) и показатель противоэрозионной стойкости (ППС). Коэффициент дисперсности (табл. 2) во всех вариантах опыта показал высокую водопрочность. Коэффициент структурности варьировал незначительно от 72\% до 96\%, что показал удовлетворительную оценку способности агропочв к оструктуриванию. Коэффициент агрегированности показал в целом высокую способность агропочв образовывать агрегаты. Показатель противоэрозионной стойкости показал средние и высокие значения для агропочв всех вариантов опыта и составляет от 9 до $24 \%$.

Также был проведен анализ водопрочности агрегатов в стоячей воде. Исследования показали, что агропочвы во всех вариантах опыта дренажной системы обладают показателем водопрочности около $20 \%$, однако в системе без 
дренажа в варианте с контролем водопрочность агрегатов показал значения в $12 \%$, а с применением биоугля в дозе 1 и 3 кг/ $\mathrm{M}^{2}-22 \%$.

Таким образом исследования показали, что при использовании биоугля в дозе 1 и 3 кг/м² через месяц после внесения наблюдается смещение реакции среды в сторону нейтральной на поле с бездренажной системой. Гранулометрический состав почв через месяц после внесения биоугля в целом изменился незначительно и остался глиной легкой. Коэффициенты оценки качества структуры почв показали высокие значения во всех вариантах опыта. Таким образом заметные изменения через месяц после применения биоугля наблюдаются только в изменении кислотно-щелочных свойствах.

\section{Библиографический список}

1. Попова, А. Д. Применение биоугля как мелиоранта и его влияние на изменение физических свойств агропочв юга Приморского края / А.Д. Попова, В. А. Семаль, А. В. Брикманс, О. В. Нестерова, Ю. А. Колесникова, М. А. Бовсун // Вестник Алтайского государственного аграрного университета. - 2019. - №6. - С. 57-63.

\section{УДК 631.92: 633.854.78 \\ ОЦЕНКА ТЕРРИТОРИИ ЦЧР ДЛЯ ПРОИЗВОДСТВА ПОДСОЛНЕЧНИКА}

Караулова Л.Н.

ФГБНУ «Курский ФАНЦ» - ВНИИ земледелия и защиты почв от эрозии, г. Курск, РФ

E-mail: karaulovaln@gmail.com

Резюме. Большой размах колебаний урожайности подсолнечника в годы исследований характерен для всех областей ЦЧР. Установлено, что основной причиной значительного снижения урожсайности подсолнечника в южных районах чаще всего является дефицит влаги, в северных районах ЦЧР урожай определяет теплообеспеченность. На рост урожайности подсолнечника в большей мере повлияло повышение культуры земледелия, выраженное через повышение доз вносимых удобрений. Наиболее значимый вклад в урожайность на территории ЦЧР вносит фосфорное питание. В иелом оценивая устойчивость получения урожая подсолнечника воздельввемого в условиях ЦЧР следует отметить, что регион можно отнести к зоне нормативной устойчивости получения урожая; коэффициент устойчивости составляет 90-98\%.

Ключевые слова: подсолнечник, тепло-влагообеспеченность, минеральные удобрения, коэффициент устойчивости, индекс корреляции.

Summary. A large scale of fluctuations in the yield of sunflower in the years of research is characteristic of all areas of the CDR. It has been established that the main reason for a significant decrease in sunflower yield in the southern regions is most often a lack of moisture, in the northern regions of the CDR, the yield determines the heat supply. The increase in the yield of sunflower was largely influenced by the increase in the culture of agriculture, expressed through an increase in the doses of fertilizers applied. The most significant contribution to the yield on the territory of the CDR is made by phosphorus nutrition. In general, assessing the stability of obtaining a sunflower crop cultivated in the conditions of the Central Asian Republic, it should be noted that the region can be attributed to the zone of normative stability of obtaining a crop; the stability coefficient is $90-98 \%$.

Key words: sunflower, heat and moisture availability, mineral fertilizers, stability coefficient, correlation index. 
Подсолнечник, выращиваемый на маслосемя для хозяйств ЦЧР, сравнительно новая культура, однако, хорошо зарекомендовавшая себя на полях. И в последнее десятилетие она становится все более популярной среди производителей.

Изменение климатических условий, селекционная работа - все это позволило расширить ареал возделывания подсолнечника. Расширению зоны возделывания способствует и стабильный многолетний спрос на внутреннем рынке. Благодаря этому регулярно увеличиваются посевные площади под данную культуру, в том числе и в северной части Центрально-черноземного региона.

Целью исследований являлось оценить территорию ЦЧР по климатическим, агрохимическим условиям и показателю устойчивости производства подсолнечника на маслосемя.

Объектом для научно-теоретических исследований являлись взаимосвязи между урожайностью подсолнечника в районах ЦЧР, агроклиматическими показателями и агрохимическими свойствами почв за период 2011-2020гг.

Сформированные базы по ЦЧР включают 5 областей: 21 район Белгородской области, 32 района Воронежской области, 28 районов Курской области, 18 районов Липецкой области и 23 района Тамбовской области.

Следует отметить, что значительный рост посевных площадей в последние годы связан не только с ростом урожайности, обусловленной внедрением новых более урожайных сортов и гибридов подсолнечника, но и в значительной степени с увеличением теплообеспеченности территорий. По данным Вильфанд Р.М., Страшной А.И. и др. [1, 2] установлено, что северная граница сумм температур, необходимых для созревания большинства сортов подсолнечника, в ЦФО существенно продвинулась к северу и проходит по южным районам Брянской области, центральным районам Орловской, Тульской и Рязанской областей.

Нами были проанализированы фактические данные урожайности подсолнечника и наблюдений гидрометеостанций в годы с различными агрометеорологическими условиями за период 2011- 2020 гг. В результате проведенного анализа оказалось, что суммы активных температур за вегетационный период подсолнечника в Белгородской и Воронежской областях варьировали от $2150^{\circ} \mathrm{C}$ до $2799^{\circ} \mathrm{C}$, на остальной территории ЦЧР (Курской, Липецкой и Тамбовской области) суммы температур колебались в основном от $2012^{\circ} \mathrm{C}$ до $2531^{\circ} \mathrm{C}$.

Проведенный анализ условий увлажнения и термический режим по месяцам вегетационного периода подсолнечника выявил, что положительное влияние термического режима на урожайность в наибольшей степени проявилось в период всходов, а также созревания. Коэффициенты корреляции урожайности со средней температурой за май и июле составляли 0,3-0,4. Значительное влияние температуры воздуха в мае на урожайность объясняется тем, что термический режим определяет скорость и дружность появления всходов, так как увлажнение в этот период преимущественно достаточное. 
В июне коэффициент корреляции был отрицательным и выражен весьма слабо $(\mathrm{r}=0,2)$, столь слабые связи Макляк Е.Н. [3] объясняет тем, что значения изучаемого фактора находятся в основном вблизи оптимальных величин для этого периода.

Влияние режима увлажнения было выявлено только в период июль - август, коэффициент корреляции был отрицательным, его значение составило 0,3. Слабое влияние условий увлажнения может быть связано с физиологическими особенностями строения корневой системы подсолнечника, его способностью получать влагу из более глубоких слоев почвы.

В таких условиях изменчивость урожайности увеличивается, что нашло отражение в зависимости урожайности от сумм осадков и температур, приводимых в таблице 1 .

Таблица 1 - Урожайность подсолнечника в зависимости от тепловлагообеспеченности (2011-2020гг)

\begin{tabular}{|c|c|c|c|c|}
\hline Осадки, мм & $\mathrm{T},{ }^{\circ} \mathrm{C}$ & $\dot{\mathrm{X}} \pm \mathrm{Sd}$ & $\underset{\max )}{\operatorname{Lim}(\min }-$ & $\mathrm{V}, \%$ \\
\hline \multirow{6}{*}{$<200$} & $<2200$ & $18,3 \pm 6,5$ & $4,0-28,7$ & 35 \\
\hline & $2200-2300$ & $21,8 \pm 5,9$ & $10,0-33,0$ & 27 \\
\hline & $2300-2400$ & $22,6 \pm 4,8$ & $12,9-34,0$ & 21 \\
\hline & $2400-2500$ & $23,9 \pm 5,0$ & $14,9-38,3$ & 21 \\
\hline & $2500-2600$ & $23,8 \pm 4,3$ & $16,4-30,2$ & 18 \\
\hline & $>2600$ & $13,8 \pm 6,3$ & $5,0-26,5$ & 46 \\
\hline \multirow{6}{*}{$200-250$} & $<2200$ & $23,8 \pm 4,6$ & $17,4-32,0$ & 19 \\
\hline & $2200-2300$ & $24,6 \pm 5,4$ & $13,9-33,0$ & 22 \\
\hline & $2300-2400$ & $23,9 \pm 6,8$ & $12,0-33,3$ & 28 \\
\hline & $2400-2500$ & $24,2 \pm 4,7$ & $15,6-34,4$ & 19 \\
\hline & $2500-2600$ & $22,4 \pm 3,8$ & $16,1-27,2$ & 17 \\
\hline & $>2600$ & $16,9 \pm 4,7$ & $13,4-24,5$ & 28 \\
\hline \multirow{6}{*}{$250-300$} & $<2200$ & $22,9 \pm 3,2$ & $19,2-24,8$ & 14 \\
\hline & $2200-2300$ & $25,8 \pm 5,6$ & $17,6-33,8$ & 22 \\
\hline & $2300-2400$ & $25,5 \pm 5,9$ & $13,8-32,4$ & 23 \\
\hline & $2400-2500$ & $22,6 \pm 3,7$ & $18,0-31,3$ & 16 \\
\hline & $2500-2600$ & $23,6 \pm 4,5$ & $18,1-29,7$ & 19 \\
\hline & $>2600$ & & & \\
\hline \multirow{6}{*}{$>300$} & $<2200$ & $16,4 \pm 0,1$ & $15,3-16,5$ & 1 \\
\hline & $2200-2300$ & $27,4 \pm 11,4$ & $18,8-40,3$ & 41 \\
\hline & $2300-2400$ & $22,6 \pm 4,7$ & $15,0-30,2$ & 21 \\
\hline & $2400-2500$ & $21,7 \pm 5,1$ & $15,9-29,7$ & 24 \\
\hline & $2500-2600$ & $22,2 \pm 4,5$ & $19,1-25,4$ & 20 \\
\hline & $>2600$ & & & \\
\hline
\end{tabular}

Большой размах колебаний урожайности в годы исследований характерен для всех областей. Следует отметить, что в южных районах с недостаточным и неустойчивым увлажнением основной причиной значительного снижения урожайности подсолнечника чаще всего является дефицит влаги, в северных районах ЦЧР урожай определяет теплообеспеченность периода вегетации. 
Результаты проведенных исследований выявили не только влияние погоды (термического режима и увлажнения территории на урожайность подсолнечника), но и значительное влияние культуры земледелия, о чем свидетельствуют коэффициенты детерминации $\left(\mathrm{R}^{2}\right)$ в уравнениях регрессии.

Проведенный анализ временных рядов средней районной урожайности подсолнечника показал значительный ее рост за счет повышения культуры земледелия, который выражается через повышение доз вносимых удобрений и вполне удовлетворительно аппроксимируется уравнениями регрессии, имеющими следующий вид:

Белгородская область

$$
\mathrm{Уp}=14,61+0,0009 * \mathrm{MУ} * \text { КОП }+0,0006 * \mathrm{P}_{2} \mathrm{O}_{5} * \text { КОП } 2, \mathrm{R}^{2}=47
$$

Воронежская область

Курская область

$$
\mathrm{Y} p=15,52+0,0008 * \mathrm{MУ} * \text { КОП }+0,98 * \text { Гумус, } \mathrm{R}^{2}=42
$$

$$
\mathrm{У} p=7,51+0,037 * \mathrm{MУ}-0,086 * \mathrm{P}_{2} \mathrm{O}_{5}, \mathrm{R}^{2}=47 \text {, где }
$$

Ур - урожайность подсолнечника, ц/га

МУ - внесение минеральных удобрений, ц/га

КОП - климатически обеспеченная продуктивность, ц. з.е./га

$\mathrm{P}_{2} \mathrm{O}_{5}$, Гумус - содержание в почве фосфора и гумуса, мг/100 г и \% соответственно.

Подсолнечник, обладая мощной корневой системой и надземной массой, на протяжении всей вегетации предъявляет повышенные требования к наличию в почве доступных форм питательных веществ. В период вегетации подсолнечник сильнее всего нуждается в фосфорном питании, что нашло отражение в уравнениях регрессии. Повышение фосфорного питания способствует увеличению количества зачатков в соцветии, что ведет к повышению урожайности.

Оценивая в целом пригодность районов областей ЦЧР для выращивания подсолнечника, рассчитывался коэффициент устойчивости получения урожая (рис. 1). Коэффициент устойчивости (Ку) и индекс корреляции (Jr) рассчитывали по методу Суслова С.А, Громовой И.В [4] и Кайякиной М.С. [5].

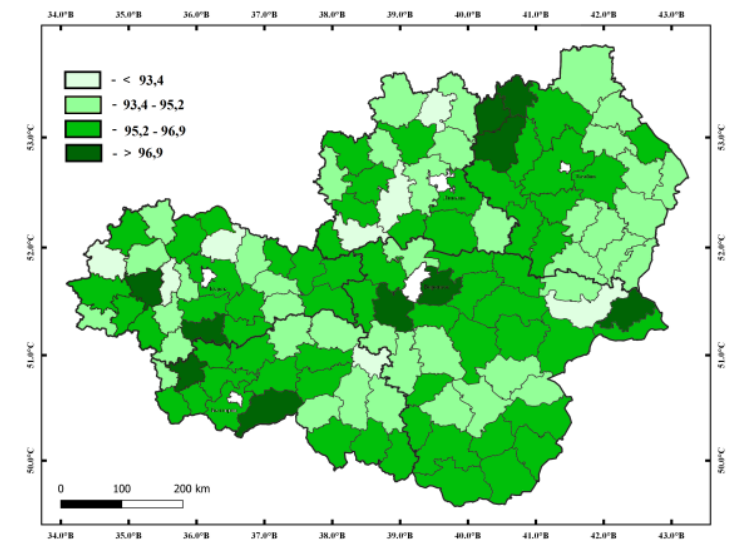

a)

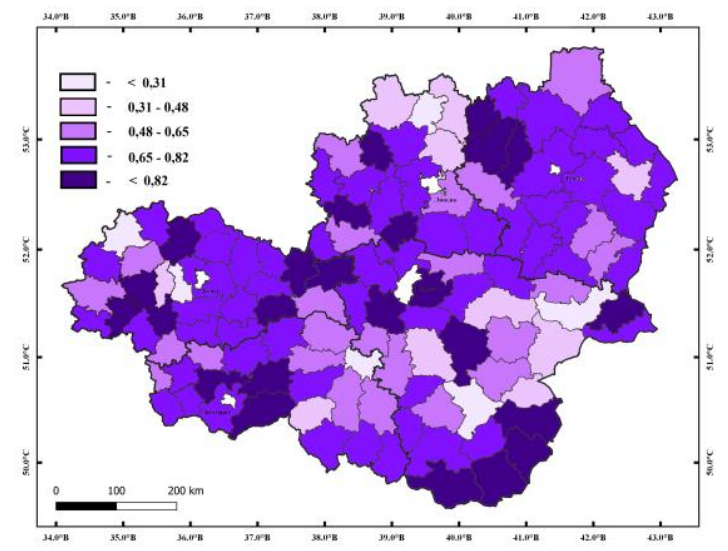

б)

Рисунок 1 - Коэффициент устойчивости урожайности подсолнечника (a) и индекс корреляции (б) 
Интерпретация коэффициента устойчивости такова: чем больше значение Ку, тем ниже колеблемость динамического ряда относительно тренда и выше его устойчивость.

По аналогии с коэффициентом вариации предлагается градация значений показателей устойчивости: Ку $>0,9$ принять за норматив устойчивости, Ку 0,9 - 0,8 считать допустимой, при Ку 0,8 - 0,6 речь должна идти о неустойчивом развитии явления или процесса, при Ку 0,6 - 0,4 считать вариацию показателя крайне неустойчивой, а при $\mathrm{K}$ у $<0,4$ - считать недопустимой [4].

Индекс корреляции (Jr) показывает степень сопряженности колебаний исследуемых показателей с совокупностью факторов, повышающих ее во времени. То есть, чем больше этот коэффициент, тем сильнее урожайность зависит от уровня агротехники, а не от случайных метеорологических факторов. Приближение индекса корреляции к 1 означает большую устойчивость изменения уровней динамического ряда.

В целом оценивая устойчивость получения урожая подсолнечника, возделываемого в условиях ЦЧР, следует отметить, что регион можно отнести к зоне нормативной устойчивости получения урожая коэффициент устойчивости составляет 91-97\% в Белгородской области, 93-97\% в Воронежской, 90-97\% в Курской, 92-97\% в Липецкой и 94-98\% в Тамбовской области. При этом сильнее урожайность зависит от уровня агротехники при возделывании в Тамбовской области $(\mathrm{Jr}=0,5-1,0)$, в Белгородской, Воронежской, Курской и Липецкой областях в среднем индекс корреляции равен 0,6-0,7 ед. с варьированием по районам от 0,1 до 1,0 .

В Белгородской области районы с наибольшим показателем индекса корреляции $(0,9$ ед) - Корочанский и Шебекинский, в Воронежской - Аннинский, Бобровский, Каменский, Нижнедевицкий, Панинский, Терновский ( $\mathrm{Jr}=0,9-$ $1,0)$, в Курской - Касторенский, Льговский, Фатежский $(\mathrm{Jr}=0,9-1,0)$, в Липецкой области - Краснинский, Хлевенский $(\mathrm{Jr}=0,9)$, в Тамбовской - Мичуринский, Первомайский $(\mathrm{Jr}=0,9-1,0)$.

$\mathrm{B}$ меньшей степени урожайность зависит от уровня агротехники в Красненском и Яковлевском районах Белгородской области $(\mathrm{Jr}=0,2-0,4)$. В Воронежской области определены районы с низким коэффициентом корреляции это Воробьевский, Новоусманский, Острогожский $(\mathrm{Jr}=0,2-0,3)$, в Курской области - Дмитриевский, Курчатовский, Октябрьский $(\mathrm{Jr}=0,1-0,3)$, в Липецкой области - Данковский, Лев-Толстовский, Чаплыгинский $(\mathrm{Jr}=0,2-0,4)$ и Тамбовской - Кирсановский, Уваровский $(\mathrm{Jr}=0,5)$.

\section{Выводы:}

1. Суммы активных температур за вегетационный период подсолнечника в Белгородской и Воронежской областях варьировали от $2150^{\circ} \mathrm{C}$ до $2799^{\circ} \mathrm{C}$, на остальной территории ЦЧР (Курской, Липецкой и Тамбовской области) суммы температур колебались в основном от $2012^{\circ} \mathrm{C}$ до $2531^{\circ} \mathrm{C}$.

2. Гидротермический режим по месяцам вегетационного периода подсолнечника выявил, что положительное влияние на урожайность термического режима в наибольшей степени проявилось в период всходов, а также 
созревания. Коэффициенты корреляции урожайности со средней температурой за май и июль составляли $0,3-0,4$. Влияние режима увлажнения было выявлено только в период июль - август, коэффициент корреляции был отрицательным его значение составило -0,3.

3. Анализ временных рядов средней районной урожайности подсолнечника показал значительный ее рост за счет повышения культуры земледелия. Подсолнечник на протяжении всей вегетации предъявляет повышенные требования к наличию в почве доступных форм питательных веществ, сильнее всего зависимость проявилась от доз минеральных удобрений и повышенного содержания фосфора в почве.

4. Регион можно отнести к зоне нормативной устойчивости получения урожая, коэффициент устойчивости составляет 91-97\% в Белгородской области, 93-97\% в Воронежской, 90-97\% в Курской, 92-97\% в Липецкой и 94-98\% в Тамбовской области.

5. Урожайность в большей мере определяет уровень агротехники в Тамбовской области $(\mathrm{Jr}=0,5-1,0)$, в Белгородской, Воронежской, Курской Липецкой областях в среднем индекс корреляции равен 0,6-0,7 ед.

\title{
Библиографический список
}

1. Страшная А.И., Береза О.В., Кланг П.С. Агрометеорологические условия и прогнозирование урожайности семян подсолнечника в Центральном федеральном округе // Гидрометеорологические исследования и прогнозы, 2019. - №3(373). - С. 121-138.

2. Вильфанд Р.М., Страшная А.И., Береза О.В. О динамике агроклиматических показателей условий сева, зимовки и формирования урожая основных зерновых культур // Труды гидрометцентра России, 2016. - Вып. 360. - С.45-78.

3. Макляк Е.Н., Кириченко В.В. Реакция гибридов подсолнечника разных групп спелости на температурный режим периода вегетации // Масличниые культуры. Науч.-тех. Бюл. ВНИИМК, 2016. - Вып. 4 (168). - С. 36-44.

4. Суслов С.А., Громова И.В. Методика региональной оценки экономической устойчивости сельскохозяйственного производства // Вестник НГИЭИ, 2012. - №5. - С. 100-114.

5. Кайякина М.С. Статистические методы изучения урожайности (на примере совхоза Ленинградской области). - Л., 1969. - 106 с.

УДК: 631.8

\section{ВЛИЯНИЕ ГУМИНОВОГО ПРЕПАРАТА НА СТРУКТУРУ ЧЕРНОЗЕМА ОБЫКНОВЕННОГО ПОД ГОРОХОМ}

Карташев С.С., Безуглова О.С.

Южный федеральный университет, Ростов-на-Дону

E-mail: semyonrus357@gmail.com

\begin{abstract}
Резюме. Приведены результаты изучения структурного состояния чернозема обыкновенного карбонатного при использовании гуминового препарата в баковых смесях с гербицидами на посевах гороха. Под влиянием гуминового препарата в чернозёме обыкновенном карбонатном наблюдается повышение коэффициентов структурности и водопрочности. Установлено снижение гльбистой фракиии и увеличение суммарного количества агрономически иенных агрегатов.

Summary. The results of studying the structural state of Calcic Chernozem using a humic preparation in tank mixtures with herbicides on pea crops are presented. In ordinary carbonate
\end{abstract}


chernozem, an increase in the coefficients of structure and water resistance is observed. A decrease in the blocky fraction and an increase in the total amount of agronomically valuable aggregates were found.

Введение. Одной из составляющих биологического земледелия является использование гуминовых препаратов и удобрений. Компоненты почвенного органического вещества, такие как молекулы гуминовых кислот и полисахариды, повышают стабильность агрегатов за счет связывания минеральных частиц в агрегаты и снижают их подверженность эрозии ветром или водой. В свою очередь, образование стабильных агрегатов усиливает физическую защиту почвенного органического вещества от микробного разложения [1]. Благоприятное влияние увеличения концентрации почвенного органического вещества на повышение структурной стабильности почвы отмечалось в научной литературе $[9,10]$

Горох, как предшественник, значительно снижает себестоимость выращивания озимой пшеницы, потому что оставляет с соломой и растительными остатками определенное количество азота, фосфора и калия. Именно поэтому горох является одним из лучших предшественников для большинства культур севооборота и ценным сидеральным удобрением [5].

Объекты исследования. Объектами исследований являются сельскохозяйственная культура (горох, сорт Альянс, оригинатор сорта ФГБНУ ФРАНЦ), уровни минерального питания растений, гуминовый препарат ВІО-Дон.

Исследования проводились на стационаре агрохимии и защиты растений ФГБНУ ФРАНЦ на чернозёме обыкновенном карбонатном.

В опыте изучали средний фон удобрений и контроль (без удобрений); стандартная система химической защиты растений и контроль (без гербицидов), а также гуминовый препарат ВІО-Дон. Данный препарат разбавляли до оптимальной концентрации $0,001 \%$, и в составе баковой смеси с гербицидом и инсектицидом производили обработку растений. Для гербицидных обработок при выращивании гороха рекомендован препарат Гезагард, КС (500 г/л прометрина), относящийся к классу триазинов. В качестве инсектицида использовали Би-58 Новый [6]. Дополнительное внесение гуминового препарата в баковую смесь снижает стрессовую нагрузку, прибавка к урожайности бобовых культур увеличивается до 30 \% [8]. Обработка баковой смесью была проведена в фазу формирования бобов. После сбора урожая был произведён отбор почвенных образцов [3].

В качестве удобрения использовали азофоску (16:16:16), удобрение вносилось при посеве, 250 кг / га в физическом весе (N40P40K40).

Методы исследования. Определение структурного состояния почвы проводили методом Н.И. Саввинова [2]. Состоит он из двух частей: фракционирование почвы на ситах в воздушно-сухом состоянии (сухое просеивание) и фракционирование на ситах в воде (мокрое просеивание). По данным сухого просеивания рассчитывают коэффициент структурности. При мокром просеивании определяется водопрочность агрегатов. 
Результаты и обсуждение. Структурное состояние почвы является важным фактором почвенного плодородия.

Данные сухого просеивания представлены в таблице 1. Необходимо отметить, что применение препарата ВIO-Дон вызывает положительную тенденцию в структурообразовательной динамике. Наблюдается снижение доли глыбистой фракции и увеличение суммарного количества агрономически ценных агрегатов. Также можно отметить, что почвы не были подвержены сильной деградации. Об этом свидетельствует низкое суммарное содержание глыбистых фракций на контроле.

Таблица 1 - Усредненные значения распределение почвенных агрегатов (\%) по фракциям в чернозёме обыкновенном карбонатном без внесения минеральных удобрений

\begin{tabular}{|c|c|c|c|c|c|c|c|c|c|}
\hline $\begin{array}{c}\text { Размер агре- } \\
\text { гатов (мм) }\end{array}$ & $>10$ & $10-7$ & $7-5$ & $5-3$ & $3-2$ & $2-1$ & $1-0,5$ & $\begin{array}{c}0,5- \\
0,25\end{array}$ & $<0,25$ \\
\hline Контроль & 17,83 & 3,99 & 4,31 & 6,16 & 2,39 & 15,58 & 25,70 & 14,80 & 9,24 \\
\hline $\begin{array}{c}\text { Контроль + } \\
\text { ВІО-Дон }\end{array}$ & 14,23 & 3,66 & 3,45 & 5,82 & 2,22 & 15,73 & 27,24 & 16,56 & 11,10 \\
\hline ХимС3 & 12,26 & 4,31 & 5,94 & 7,84 & 2,91 & 17,11 & 24,45 & 14,72 & 10,47 \\
\hline $\begin{array}{c}\text { ХимС3 + } \\
\text { ВІО-Дон }\end{array}$ & 12,30 & 4,10 & 4,63 & 6,94 & 2,74 & 16,76 & 26,52 & 15,13 & 10,88 \\
\hline
\end{tabular}

Такую же тенденцию можно наблюдать и на участке с внесением в почву минерального удобрения.

Согласно классификации Саввинова, по содержанию агрономически ценных структурных фракций на всех вариантах состояние структуры можно оценить как хорошее.

Классическим показателем состояния структуры служит коэффициент структурности, рассчитываемый как отношение количества агрономически ценных агрегатов, к агрономически неценным. Для сухого просеивания за агрономически ценные агрегаты принимают фракции 7-5; 5-3; 3-2; 2-1; 1-0,5; $0,5-0,25$. Агрегаты размером $>7$ и $<0,25$ относятся к агрономически неценным. Результаты по определению коэффициента структурности в ходе полевого эксперимента, представлены на рис. 1.

Результаты сухого просеивания свидетельствуют, что применение гуминового препарата ВІО-Дон благоприятно сказывается на структурности почвы. Это заметно на варианте без применения химической системы защиты растений. В варианте с применением химической системы защиты значимое влияние гумата на структурность почвы не выявлено. Так как образцы были отобраны после сбора урожая, высокий коэффициент структурности почвы на контрольном участке свидетельствует о положительном воздействии гороха на физические свойства почвы.

На вариантах с применением удобрения прослеживается такая же тенденция зависимости физических свойств почвы от гуминовых препаратов. 


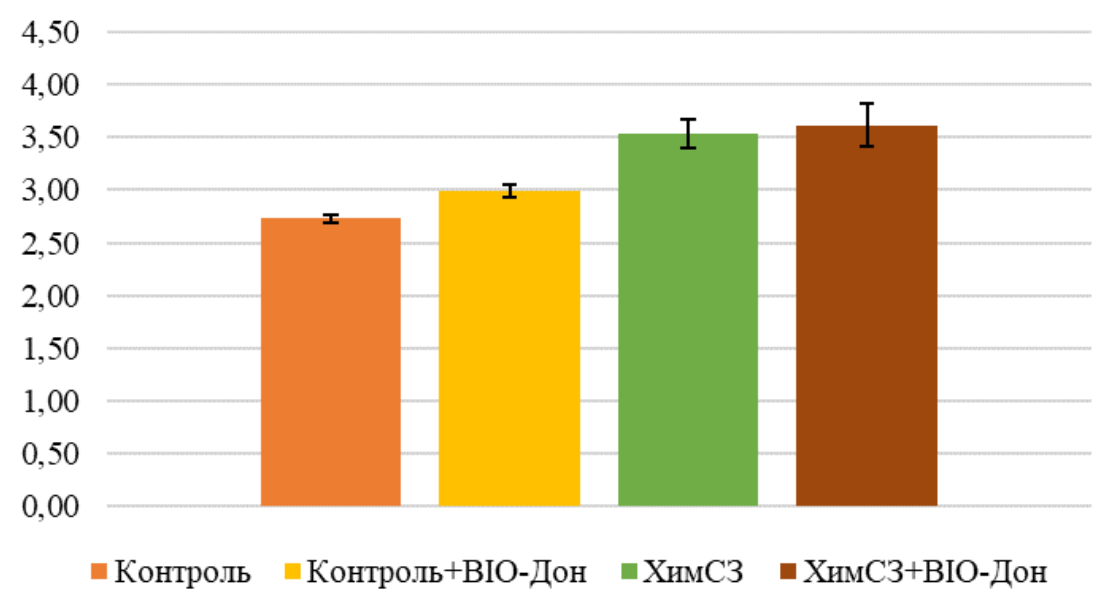

Рисунок $1-$ Усреднённое значение коэффициента структурности в чернозёме обыкновенном карбонатном по вариантам опыта без применения минеральных удобрений

Агрегатное состояние во всех случаях можно оценить, как отличное.

Результаты мокрого просеивания показывают, что применение гуминовых препаратов положительно сказывается и на водоустойчивости структуры. Почвенное органическое вещество способствует образованию агрономически ценной водопрочной структуры почвы и, соответственно, созданию благоприятных водно-воздушных свойств для растений [4].

Данные мокрого просеивания представлены в таблице 2. По результатам мокрого просеивания применение гуминового препарата ВIO-Дон также увеличивает количество агрономически ценных водопрочных агрегатов. Данная тенденция наблюдается на всех вариантах опыта.

По классификации Саввинова содержание ценных структурных фракций на трёх из четырёх вариантов опыта оценивается как неудовлетворительное по водоустойчивости. Это, вероятно, обуславливается повышенной карбонатностью чернозема обыкновенного.

Таблица 2 - Усредненные значения процентного содержания водопрочных фракций в чернозёме обыкновенном карбонатном без внесения минеральных удобрений

\begin{tabular}{|c|c|c|c|c|c|c|}
\hline Размер агрегатов (мм) & $5-3$ & $3-2$ & $2-1$ & $1-0,5$ & $0,5-0,25$ & $<0,25$ \\
\hline Контроль & 0,46 & 0,20 & 1,59 & 6,38 & 26,76 & 64,60 \\
\hline Контроль + ВІО-Дон & 0,43 & 0,10 & 1,29 & 6,93 & 35,06 & 56,19 \\
\hline ХимС3 & 0,32 & 0,20 & 1,56 & 6,22 & 25,28 & 66,42 \\
\hline ХимС3 + ВІО-Дон & 0,45 & 0,18 & 1,24 & 5,96 & 22,79 & 69,38 \\
\hline
\end{tabular}

При внесении гуминового препарата на контрольном варианте наблюдается качественное изменение состояния структуры: по количеству водопрочных агрегатов водоустойчивость структуры оценивается как удовлетворительная (рис.2). Однако на варианте с баковой смесью такого эффекта не обнаружено.

На участках с минеральным фоном наблюдается аналогичное увеличение суммарного количества агрономически ценных водопрочных агрегатов. 


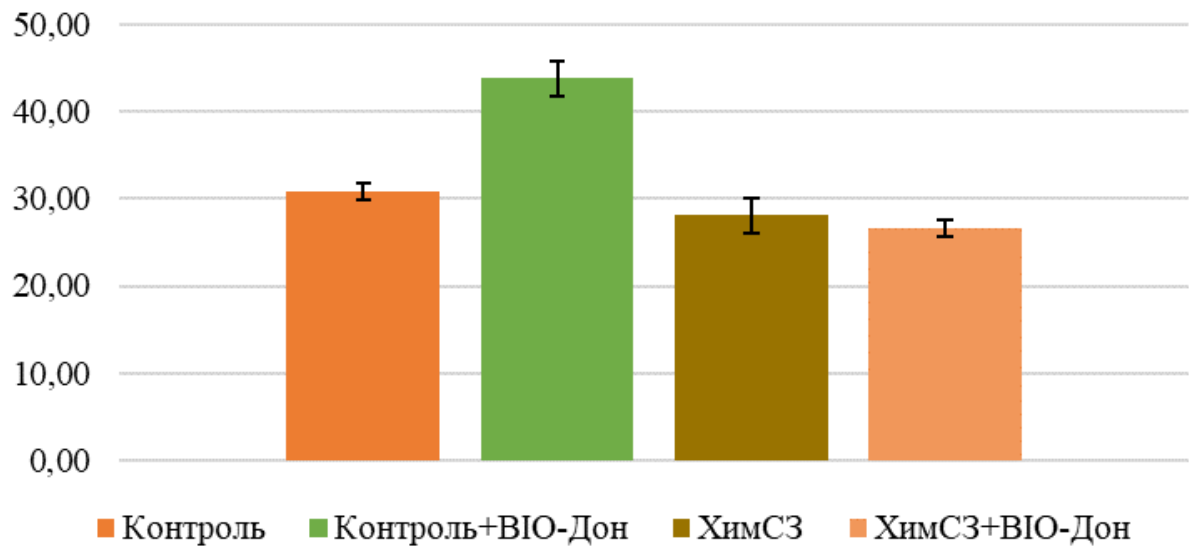

Рисунок $2-$ Усреднённое значение коэффициента водопрочности в чернозёме обыкновенном карбонатном по вариантам опыта без применения минеральных удобрений

По классификации Саввинова при добавлении в баковую смесь гуминового препарата как на вариантах без удобрений, так и при внесении удобрений водопрочность структуры возрастает и меняется ее оценка от неудовлетворительной до удовлетворительной. Если использовать для оценки классификацию Кузнецовой, то водопрочность структуры изменяется от удовлетворительной до хорошей.

Выводы. Результаты исследования свидетельствуют о благоприятном воздействии гуминового препарата при его добавлении в баковую смесь с пестицидами на структурное состояние почвы под горохом. В чернозёме обыкновенном карбонатном наблюдается повышение коэффициентов структурности и водопрочности за счет снижения доли глыбистой фракции и увеличения суммарного количества агрономически ценных агрегатов

\section{Библиографический список}

1. Безуглова О.С., Полиенко Е.А., Горовцов А.В., Лыхман В.А. Влияние гуминовых препаратов на почвы и растения. Ростов-на-Дону - Таганрог: Изд-во Южного федерального университета, 2019. $154 \mathrm{c}$.

2. Вадюнина А. Ф., Корчагина 3. А. Методы определения физических свойств почв и грунтов. М.: Высшая школа, 1961. С. 416.

3. ГОСТ 29269-91: Почвы. Общее требование к проведению анализов. https://docs.cntd.ru/document/1200023560 (дата обращения: 7.09.2021)

4. Ковда В. А. Биогеохимия почвенного покрова. М.: Наука, 1985. 264 с.

5. Нідзельський В.А. Динаміка росту гороху залежно від погодних умов року // Науковий вісник нубіп України. Серія: Агрономія, 2015. № 210-1. С. 67-74

6. Полиенко Е.А., Безуглова О.С., Патрикеев Е.С., Горовцов А.В., Лыхман В.А., Наими О.И., Дубинина М.Н., Поволоцкая Ю.С. Влияние гуминовых веществ на динамику элементов питания при сочетании с системами защиты нута // Агрохимический вестник, 2020. №5. C. 52-57. DOI: $10.24411 / 1029-2551-2020-10069$

7. Шаповал О. А., Можарова И. П., Коршунов А. А. Регуляторы роста растений в агротехнологиях // Защита и карантин растений, 2014. №6. С. 16-20.

8. Якименко О. С. Применение гуминовых продуктов в РФ: результаты полевых опытов (обзор литературы) //Живые и биокосные системы, 2016. №. 18. С. 1-12. https://www.jbks.ru/archive/issue-18/article-4 
9. Bronick C.J., Lal R. Soil structure and management. A review // Geoderma, 2005. № 124. P. $3-22$.

10. Hati K.M., Swarup A., Dwivedi A., Misra A., Bandyopadhyay K. Changes in soil physical properties and organic carbon status at the topsoil horizon of a vertisol of Central India after 28 years of continuous cropping, fertilization and manuring // Agric. Ecosyst. Environ., 2007. №119. P.127-134.

УДК: $631.51: 633.11$

\section{ВЛИЯНИЕ РАЗЛИЧНЫХ СИСТЕМ ОСНОВНОЙ ОБРАБОТКИ НА АГРОФИЗИЧЕСКИЕ ПОКАЗАТЕЛИ ЧЕРНОЗЕМА ВЫЩЕЛОЧЕННОГО ДЕГРАДИРОВАННОГО И УРОЖАЙНОСТЬ ОЗИМОЙ ПШЕНИЦЫ НА КУБАНИ}

Кильдюшкин В.М., Животовская Е.Г.

ФГБНУ «Национальный Центр Зерна им. П.П. Лукьяненко»

Россия, 350012, г. Краснодар-12, Центральная усадьба

КНИИСХ им. П.П. Лукьяненко

E-mail: k.agrotehnologia@yandex.ru

Резюме: изучение основных агрофизических свойств чернозема выщелоченного деградированного показало, что лучшие условия для формирования высокой урожайности озимой пшеницы складывается при традчционной и разуплотняющей обработок почвы.

Ключевые слова: обработка почвы, агрофизика почвы, урожайность озимой пшениць Summary: the study of the main agrophysical properties of leached degraded chernozem has shown that the best conditions for the formation of high yields of winter wheat are formed with traditional and decompression tillage.

Key words: tillage, soil agrophysics, winter wheat yield

Обработка почвы является основным элементом при разработке ресурсосберегающих технологий возделывания полевых культур. От нее зависят агрофизические, агрохимические и биологические свойства почвы, которые во многом определяют развитие и величину продуктивности возделываемых сельскохозяйственных культур.

В НЦЗ им. П.П. Лукьяненко с 2008 года ведутся исследования по разработке ресурсосберегающих технологий, сохранение почвенного плодородия и получение высокой урожайности полевых культур высокого качества.

Почва стационарного участка - чернозем выщелоченный сверхмощный деградированный. Содержание гумуса в пахотном горизонте - 3,4 \% (по Тюрину), подвижного фосфора - 46-50 и обменного калия 360-400 мг/кг (по Мачигину). Исследования проводились в 6-ти польном зернопропашном севообороте со следующим чередованием культур: озимая пшеница - соя - озимая пшеница - подсолнечник - озимая пшеница - кукуруза на зерно; В опыте изучалось три способа основной обработки почвы:

1. Традиционный (вспашка на глубину 25-27 см под пропашные культуры + минимальная на глубину 10-12 см под зерновые колосовые);

2. Разуплотняющий (чизелевание на глубину 35-38 см + минимальная обработка на 10-12 см под зерновые колосовые); 
3. Минимальный (бессменная обработка на глубину 10-12 см под все культуры севооборота);

Исследования проводились на 3 уровнях минерального питания: 1- без удобрений (контроль), 2 - средний фон - $\mathrm{N}_{102} \mathrm{P}_{20} \mathrm{~K}_{10}, 3$ - повышенный фон $\mathrm{N}_{132} \mathrm{P}_{30} \mathrm{~K}_{30}$;

Изучение водного баланса под озимой пшеницей по предшественнику кукуруза на зерно в среднем за 2015-2020 годы показала, что наибольшие запасы продуктивной влаги в слое 0-100 см в весенний период при возобновлении ранневесенней вегетации растений отмечены на традиционной обработке 164,2 мм и разуплотняющей 152,9 мм по сравнению с минимальной обработкой 136,4 мм. К уборке запасы продуктивной влаги значительно снизились, но закономерность осталась прежней. Что касается водопотребления, то наиболее эффективно влага использовалась при традиционной обработке с коэффициентом водопотребления на тонну зерна $546 \mathrm{~m}^{3}$ по сравнению с разуплотняющей и бессменной минимальной - 600 и $643 \mathrm{~m}^{3}$ соответственно. Одним из основных характеристик физических свойств почвы является плотность ее сложения. Определение данного показателя (весной) под озимой пшеницей показало, что наиболее благоприятное сложение почвы для роста и развития растений складывалось в слоях 0-20 и 20-40 см на традиционной и разуплотняющей обработ-

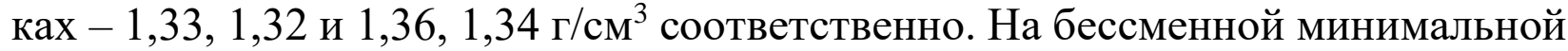
обработке отмечалась более высокая плотность по всему профилю почвы: в

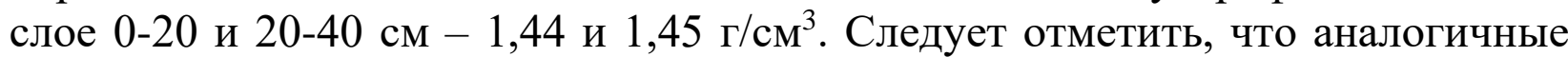
результаты были получены и другими исследователями [1]. Одним из важных показателей агрофизики на черноземах является порозность почвы, так на традиционной и разуплотняющей обработках порозность была близкой по значению - 54 и $55 \%$ в слое $0-20$ см и $50,51 \%$ в слое $20-40$ см, соответственно. На бессменной минимальной обработке наблюдалось снижение порозности по всем исследуемым слоям до 46 и 48 \% соответственно. Результаты наблюдений за агрегатным составом в пахотном слое почвы показали, что при традиционной и разуплотняющей обработках они были близкими по значению - 64 и 65 , а при бессменной минимальной отмечалось большее количество агрономически ценных агрегатов почвы - 74 \%, однако в слое 20-40 см увеличение отмечалось их на традиционной и разуплотняющей обработках и уменьшение на поверхностной - 68, 69, 65 \% соответственно. Данные результаты подтверждаются и другими авторами [2].

Анализ полученной урожайности озимой пшеницы в среднем за 6 лет показал, что наибольшую прибавку урожайности по всем вариантам обработки почвы дали варианты с использованием минеральных удобрений, таблица 1

Варианты с традиционной и разуплотняющей обработками почвы показали наибольшую урожайность - 6,1 и 6,0 ц/га, однако достоверной разности между ними не было. Наименьшая урожайность по всем фонам минерального питания была получена на бессменной минимальной обработке - 5,5 т/га. 
Таблица 1 - Урожайность озимой пшеницы (т/га) в 6-ти польном зернопропашном севообороте в зависимости от способов основной обработки почвы и удобрений, (среднее 2015-2020 гг.)

\begin{tabular}{|l|c|c|c|c|}
\hline \multirow{2}{*}{$\begin{array}{c}\text { Способ обработки } \\
\text { почвы }\end{array}$} & $\begin{array}{c}\text { Без удобрений } \\
\text { (контроль) }\end{array}$ & $\mathrm{N}_{102} \mathrm{P}_{20} \mathrm{~K}_{10}$ & $\mathrm{~N}_{132} \mathrm{P}_{30} \mathrm{~K}_{30}$ & $\begin{array}{c}\text { Среднее по } \\
\text { обработкам }\end{array}$ \\
\hline Традиционный & 3,9 & 6,9 & 7,5 & 6,1 \\
\hline Разуплотняющий & 3,8 & 6,8 & 7,4 & 6,0 \\
\hline Минимальный & 3,5 & 6,2 & 6,8 & 5,5 \\
\hline $\begin{array}{l}\text { Среднее по фону ми- } \\
\text { нерального питания }\end{array}$ & 3,7 & 6,6 & 7,2 & - \\
\hline \multicolumn{5}{|c|}{$\mathrm{HCP}_{05},-0,2$ т/га } \\
\hline
\end{tabular}

Таким образом изучение агрофизических свойств чернозема выщелоченного малогумусного деградированного показало, что лучшие условия для роста и развития растений были получены традиционной и разуплотняющей обработках почвы. Соответственно здесь же на фоне минерального питания была получена максимальная урожайность от 6,8 до 7,5 т/га.

\section{Библиографический список}

1. Уваров Г.И. Регулирование плотности почвы в современных технологиях возделывания культур /Г.И.Уваров, В.Д. Соловинченко, М.В. Бондаренко //Ресурсосберегающие технологии земледелия: сб. докл. Международной науч. пр. конф. / Курск, 2005 - С. 345-348.

2. Коротеев В.И. Влияние систем основной обработки на агрегатный состав темно-серых почв / В.И. Коротеев, Н.П. Масютенко, Л.А. Нечаев, В.И. Селихов //Ресурсосберегающие технологии земледелия: сб. докл. Международной науч. пр. конф. - Курск, 2000. - С. $262-$ 264.

УДК 631.45.631.153.3651.95.

\section{ПРОДУКТИВНОСТЬ БИНАРНЫХ И ПОЛИВИДОВЫХ ТРАВОСМЕСЕЙ С ИСПОЛЬЗОВАНИЕМ ВИКИ ОЗИМОЙ И ПЕЛЮШКИ}

Крамаренко В.Я.

ФГБНУ «Челябинский НИИСХ», Челябинск

E-mail: chniisx2@mail.ru

Резюме. Установлено, что для создания высокопродуктивных бинарных и поливидовых посевов бобово-злаковых травосмесей для производства зерносенажа в северной лесостепи Южного Урала могут быть использованы не только горох посевной и вика яровая, но и новые малораспространенные виды бобовых трав - пелюшка и вика озимая.

Ключевые слова: бинарный посев, поливидовой посев, кормовая продуктивность, кормопротеиновые единиць.

Summary. It has been established that for the creation of highly productive binary and multi-species crops of legume-cereal mixtures for the production of grain silage in the northern forest-steppe of the Southern Urals, not only plant peas and spring vetch can be used, but also new rare types of legumes - pelushka and winter vetch.

Key words: binary sowing, multi-species sowing, fodder productivity, fodder protein units 
Основой увеличения производства продукции животноводства является создание достаточных запасов всех видов кормов. При этом важно улучшать их качество за счет расширения смешанных посевов. Возделывание новых видов и сортов высокобелковых однолетних культур позволяет получать высокачественные корма, богатые протеином, аминокислотами и минеральными солями.

Устойчивость кормопроизводства от неблагоприятных метеорологических условий достигается на основе совершенствования структуры посевных площадей в направлении увеличения удельного веса ассортимента наиболее продуктивных засухоустойчивых кормовых культур. Видовой состав важнейших кормовых культур для возделывания определяется и корректируется полевыми опытами научно-исследовательских учреждений по природно-климатическим зонам РФ [1].

В последние годы в научных исследованиях большое внимание уделяется вопросам повышения плодородия почвы на основе создания севооборотов с посевами бобовых культур. По мнению В.В. Вавилова, Г.С. Посыпанова (1978), Н.А.Зеленского и др. (2010), севообороты с бобовыми культурами должны преобладать. Это связано с тем, что бобовые культуры являются восстановителями почвенного плодородия, поскольку обогащают почву азотом за счет клубеньковых бактерий [2,3].

Современные биологи считают, что повышение биологической производительности земли связано с освоением вместо широко распространенных монокультур (только злаковые или только бобовые и т.п.) возделывание бинарных или поливидовых посевов из двух и нескольких видов культур (Г.С. Посыпанов 1989) [4]. В смешанных посевах растения, имея различное расположение листьев, лучше используют солнечный свет и солнечную энергию.

Бинарные посевы обладают более высокой устойчивостью к стрессам, урожайностью, чем одновидовые посевы. В.Г. Бандилет (1988) отмечает, что составляющие компоненты травосмеси должны быть адаптированы не только к природно-климатическим условиям соответствующего региона, но и друг к другу [5]. В этом случае их взаимодействие приобретает характер синергизма.

Основными однолетними бобовыми культурами в бинарных и поливидовых травосмесях в лесостепи Южного Урала и Зауралья являются горох посевной и вика яровая. Ассортимент бобовых трав, предлагаемый учеными-аграрниками, может быть значительно расширен. Озимая вика для нашего региона является культурой новой и нуждается в изучении, а пелюшка (горох полевой) известна давно, но незаслуженно пока не получила широко распространения.

Целью исследований - создание высокопродуктивных бинарных и поливидовых бобово-злаковых травостоев для производства зерносенажа с использованием новых и малораспространенных бобовых трав.

Наши исследования проводили в условиях северной лесостепи области, которая характеризуется следующими метеорологическими показателями. Для неё характерен умеренно теплый и достаточно влажный вегетационный период. Сумма положительных температур за десятиградусный период равняется 
в среднем $2200-2300{ }^{\circ} \mathrm{C}$. Продолжительность периода активной вегетации растений составляет 120-130 дней. Осадков за вегетационный период выпадает около 271 мм, ГТК по Селянинову соответствует 1,4.

Экспериментальные данные получены в полевом опыте, который закладывался в период 2019-2020 гг., на черноземе выщелоченном тяжелосуглинистом. В опыте использовали семена районированных сортов кормовых культур: овес - Атлет, горох посевной Аксайский усатый 55, подсолнечник Сибирский 97, просо Быстрое, Суданская трава Юбилейная 90, вика яровая Юбилейная 110. Пелюшка (горох полевой) и вика озимая использовались не сортовые. Исходная норма высева овса в чистом виде - 5 млн. шт. всхожих семян на 1 га, в смеси: овса $-2,2$ млн., гороха и пелюшки $-0,7$ млн., вики озимой $-1,2$ млн., подсолнечника - 0,12 млн. шт. Остальные кормовые культуры были посеяны в чистом виде, исходя из принятых в регионе норм посева.

Полевые опыты закладывались по пару. Минеральные удобрения не применялись. Повторность в опыте - трехкратная. Общая площадь делянки $10-$

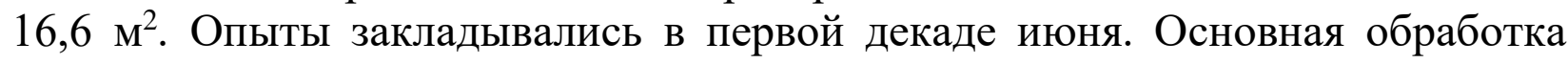
почвы отвальная.

Учет урожайности зеленой массы трав определяли методом учетных площадок рамкой со стороной 50 см. Выход абсолютно-сухого вещества устанавливался по пробным снопам, взятым перед уборкой урожая на двух несмежных повторностях каждого варианта. Урожайные данные обработаны методом дисперсионного анализа по Б.А. Доспехову (1985) [6].

Однолетние травы убирались в фазу молочно-восковой спелости зерна. Питательная ценность растительной массы кормовых растений рассчитывалась в кормовых и кормопротеиновых единицах на основании полного зоотехнического анализа, который выполнялся испытательной лабораторией Челябинского НИИСХ.

За годы исследований метеорологические условия отличались засушливостью. Сумма осадков за вегетационный период (май-август) 2019 года составила 189 мм, в 2020 году - 232 мм при норме 271 мм. ГТК равнялся 1,0.

Результаты исследований. Величина урожая надземной массы является наиболее важным показателем посевов однолетних трав и травосмесей (табл.).

Анализ полученных данных в бинарных посевах показал, что жизненные ресурсы в засушливые годы наиболее полно использовали горох с пелюшкой, формируя в среднем 17,6 т/га зеленой массы. В поливидовых посевах наиболее высокий сбор зеленой массы получен на варианте: овес + пелюшка +подсолнечник $-26,6$ т/га.

Более объективным показателем продуктивности посевов является сбор сухого вещества. В среднем за два года его максимальный выход с единицы площади обеспечила поливидовая травосмесь, состоящая тоже из овса, пелюшки и подсолнечника $-7,1$ т/га. Бинарные травосмеси по сухой массе не имели преимуществ по сравнению с горохо-овсом (контроль). 
Таблица - Параметры однолетних кормовых культур при уборке в фазу молочно-восковой спелости, в среднем за 2019- 2020 гг.

\begin{tabular}{|c|c|c|c|c|c|c|}
\hline \multirow{3}{*}{ Культура, смесь } & \multicolumn{2}{|c|}{$\begin{array}{c}\text { Урожайность, } \\
\text { т/га }\end{array}$} & \multicolumn{4}{|c|}{ Продуктивность } \\
\hline & \multirow[b]{2}{*}{$\begin{array}{c}\text { зеле- } \\
\text { ная } \\
\text { масса }\end{array}$} & \multirow[b]{2}{*}{$\begin{array}{l}\text { сухая } \\
\text { масса }\end{array}$} & \multirow[b]{2}{*}{$\begin{array}{c}\text { сбор } \\
\text { корм. } \\
\text { ед., т/га }\end{array}$} & \multicolumn{2}{|c|}{ переваримый протеин } & \multirow{2}{*}{$\begin{array}{c}\text { сбор кор- } \\
\text { мопротеи- } \\
\text { новых еди- } \\
\text { ниц, т/га }\end{array}$} \\
\hline & & & & $\begin{array}{c}\text { сбор с } 1 \\
\text { га, т/га }\end{array}$ & $\begin{array}{c}\text { содержа- } \\
\text { ние в } 1 \\
\text { корм. ед., г }\end{array}$ & \\
\hline $\begin{array}{l}\text { Овес + горох (кон- } \\
\text { троль) }\end{array}$ & 13,4 & 4,5 & 5,6 & 0,57 & 102 & 10,3 \\
\hline Овес + пелюшка & 17,6 & 4,3 & 5,2 & 0,56 & 108 & 10,6 \\
\hline Овес + вика озимая & 15,2 & 4,0 & 6,1 & 0,75 & 123 & 7,2 \\
\hline Овес + вика яровая & 16,3 & 4,8 & 5,8 & 0,66 & 114 & 6,3 \\
\hline $\begin{array}{l}\text { Овес + горох +под- } \\
\text { солнечник }\end{array}$ & 17,2 & 5,3 & 7,4 & 0,72 & 97 & 6,9 \\
\hline $\begin{array}{l}\text { Овес +пелюшка + } \\
\text { подсолнечник }\end{array}$ & 26,6 & 7,1 & 9,1 & 1,03 & 113 & 9,7 \\
\hline $\begin{array}{l}\text { Овес + вика озимая + } \\
\text { подсолнечник }\end{array}$ & 21,1 & 5,3 & 6,7 & 0,79 & 118 & 7,5 \\
\hline $\begin{array}{l}\text { Овес + вика яро- } \\
\text { вая+подсолнечник }\end{array}$ & 17,6 & 5,0 & 6,5 & 0,54 & 83 & 5,1 \\
\hline Овес & 15,0 & 5,7 & 6,8 & 0,40 & 59 & 3,9 \\
\hline Просо & 10,4 & 3,7 & 4,6 & 0,34 & 74 & 3,2 \\
\hline Суданская трава & 16,4 & 4,9 & 4,7 & 0,37 & 79 & 3,5 \\
\hline $\mathrm{HCP}_{05}$ & 0,74 & 0,40 & & & & \\
\hline
\end{tabular}

По выходу питательных веществ с единицы площади преимущество также остается за вышеназванной тройной травосмесью - 9,1т/га кормовых единиц и 1,03 т/га переваримого протеина.

В оценке кормов особое значение имеет обеспеченность кормовой единицы переваримым протеином. По этому показателю на первое место вышла бинарная травосмесь: овес с викой озимой - 123 г переваримого протеина на 1 корм. ед., затем поливидовая травосмесь: овес + вика озимая + подсолнечник 118 г и овес с пелюшкой и подсолнечником - 113 г.

У бинарной травосмеси - овес с викой яровой также повышенная обеспеченность кормовой единицы переваримым протеином - 114 г, но она существенно уступает по сбору КПЕ вышеперечисленным вариантам. Вика озимая в травосмеси до самой уборки на зерносенаж находится в фазе цветения, так как относится к озимым культурам и сохраняет высокое кормовое достоинство травосмеси в целом.

Пелюшка относится к индетерминантным растениями и тоже повышает качество корма за счет продолжительного периода вегетации до самой уборки силосной массы.

Самая низкая обеспеченность кормовой единицы переваримым протеином, не отвечающая зоотехническим нормам, получена на чистых посевах проса, суданской травы и, особенно, овса. Чтобы устранить этот недостаток 
такие культуры нуждаются в посевах на кормовые цели в смеси с бобовыми травами.

По сбору КПЕ наиболее высокие и близкие показатели получены при возделывании овса с пелюшкой - 10,6 т, овса с горохом - 10,3 т и поливидовой травосмеси: овес + пелюшка + подсолнечник - 9,7 т/га. Сборы КПЕ бинарной смеси вики озимой и овса была ниже, и составил 7,2 т/га, а поливидовой смеси вики озимой с овсом и подсолнечником - 7,5 т/га, но превышали травосмеси с участием вики яровой.

На основе полученных данных можно сделать вывод, что бинарные и поливидовые травосмеси с участием пелюшки, озимой вики являются высокопродуктивными и могут быть рекомендованы для посева на зерносенаж в северной лесостепи области.

\title{
Библиографический список
}

1. Крутиховский В.К. Кормодобывание на черноземе в лесостепи в Зауралье, (переиздание). - ГУП «Куртамышская типография», 2008. - 122 с.

2. Вавилов П.П. Бобовые, азот и проблема белка /П.П. Вавилов, Г.С. Посыпанов //Вестник с.-х. науки. - № 9.- С.24-30.

3. Зеленский Н.А. Бинарные посевы озимой пшеницы на эродированных черноземах Ростовской области //Н.А. Зеленский, А.П. Авдеенко, Е.П. Луганцев, Г.В. Мокриков. - П. Персиановский, 2010. - 190 с.

4. Посыпанов Г.С. Факторы, определяющие эффективность азотфиксации бобовыми культурами /Г.С. Посыпанов //Биологический азот в сельском хозяйстве СССР. - М.: Наука, 1989. - С. 37-39.

5. Бандилет В.Г. Эффективность смесей на засоренных посевах / В.Г. Бандилет, В.В. Швыдкий // Кормовые культуры, 1988. - № 4. - С. 37.

6. Доспехов Б.А. Методика полевого опыта (с основами статистической обработки результатов исследований) / Б.А. Доспехов // 5-е изд., доп. и перераб. - М.: Агропромиздат, 1985. -351

УДК 631.46:631.417.2:631.445.4

\section{ВЛИЯНИЕ БИОПРЕПАРАТОВ НА СОДЕРЖАНИЕ И СОСТАВ ПОДВИЖНЫХ ГУМУСОВЫХ ВЕЩЕСТВ В ЧЕРНОЗЁМЕ ТИПИЧНОМ В ПОСЕВАХ ЯРОВОГО ЯЧМЕНЯ}

\author{
Кузнецов А.В., Припутнева М.А. \\ ФГБНУ «Курский ФАНЦ» г. Курск \\ E-mail: kuzneczov.1983@mail.ru
}

\begin{abstract}
Резюме. Установлено, что агробиотехнология с совместным применением биопрепаратов Грибофит и Имуназот и азотных удобрений в посевах ячменя, приводит к появлению стойкой тенденџии к увеличению содержания 0-20 см слое чернозёма типичного подвижных гумусовых веществ и подвижных гуминовых кислот, что свидетельствует об улучшении качественного состава подвижных гумусовых веществ.

Ключевые слова: биопрепараты, Имуназот, Грибофит, подвижные гумусовые вещества, подвижные гуминовые кислоты, подвижные фульвокислоты, яровой ячмень, чернозём типичный.
\end{abstract}


В настоящее время в РФ вследствие сокращения внесения органических удобрений (навоза и др.) происходит значительное снижение содержания органического вещества в почве. В результате происходит ухудшение плодородия и экологического состояния почвы. Поэтому все чаще для восстановления плодородия почвы применяют биологические способы, одним из которых является заделка в почву пожнивных остатков, обработанных биодеструкторами (комплексные микробные препараты, ускоряющие разложение растительных остатков) $[1,2]$.

В результате трансформации свежего органического вещества, поступающего в почву, образуются подвижные гумусовые вещества - лабильная наиболее трансформируемая и обогащенная азотом часть гумусовых веществ, которая является ближайшим источником питательных элементов для сельскохозяйственных культур [3]. Следовательно, от количества (по массе) поступающих в почву послеуборочных остатков и интенсивности их гумификации зависит и содержание в почве подвижных гумусовых веществ $[3,4,5]$.

В настоящее время, хотя уже проведены многочисленные исследования влияния совместного использования заделки в почву пожнивных растительных остатков и минеральных удобрений на урожайность сельскохозяйственных культур и плодородие почвы $[6,7,8]$, недостаточно изученным остается вопрос о влиянии биопрепаратов-фунгицидов-ростостимуляторов-деструкторов на содержание и состав подвижных гумусовых веществ.

Объекты и методы. Исследования проводились на опытном поле ВНИИЗиЗПЭ - структурного подразделения ФГБНУ «Курский ФАНЦ» (Курская область Медвенский район, п. Панино) на склоне северной экспозиции крутизной до $3^{\circ}$ в научно-производственном опыте общей площадью 1,5 га в посевах ярового ячменя (сорт Суздалец). Технология возделывания ярового ячменя является общепринятой в регионе. Предшественником ячменя был подсолнечник.

Опыт заложен в соответствие с общепринятыми методиками в трехкратной повторности, площадь делянки $240 \mathrm{~m}^{2}$ (6 м х 40 м). Варианты полевого опыта: Вариант 1 (контроль) - измельченные растительные остатки ячменя без обработки биопрепаратами. Вариант 2 - измельчённые растительные остатки ячменя $+\mathrm{N}_{10}$ на 1 т соломы. Вариант 3 - обработка семян, почвы перед посевом, посевов 2 раза в течение вегетации + после уборки урожая обработка измельченных растительных остатков ячменя биопрепаратами (Грибофитом (5 л/га) + Имуназотом (3 л/га) (агробиотехнология 1)). Вариант 4 - агротехнология $1+\mathrm{N}_{10}$ на 1 т соломы (агробиотехнология 2).

В опыте исследуются биопрепараты - Грибофит и Имуназот. Грибофит это экологически безопасный биофунгицид, ростостимулятор, фосфатмобилизатор и биодеструктор. Препарат содержит споры и мицелий гриба Trichoderma, а также, продуцируемые грибом в процессе производственного культивирования, биологически активные вещества (антибиотики, ферменты, витамины, фитогормоны). Имуназот - биологический фунгицид, ростостимулятор, фосфатмобилизатор контактного и системного действия, на основе 
ризосферных бактерий Pseudomonas. Антифунгальная (противогрибковая) и бактерицидная (уничтожение колоний патогенных бактерий) активность бактерий обусловлена синтезированием антибиотиков - производных феназина и пирролнитрина.

Объект исследования - чернозём типичный слабосмытый тяжелосуглинистый.

Для изучения содержания и состава подвижных гумусовых веществ отбор смешанных почвенных образцов проводили по диагонали делянок из 5 точек буром по глубинам 0-10 см и 10-20 см весной до посева, перед заделкой растительных остатков (после уборки урожая) и через 46 суток после заделки растительных остатков в почву.

Количественный и качественный состав подвижных гумусовых веществ, извлекаемых 0,1 н. раствором $\mathrm{NaOH}$ из недекальцинированных почв черноземного типа, определяли по методу И.В. Тюрина в модификации Почвенного института им. В.В. Докучаева [3].

На рисунке 1 представлены результаты исследования содержания и состава углерода подвижных гумусовых веществ $\left(\mathrm{C}_{\text {Пгв }}\right)$ в $0-20$ см слое чернозёма типичного перед посевом ячменя.

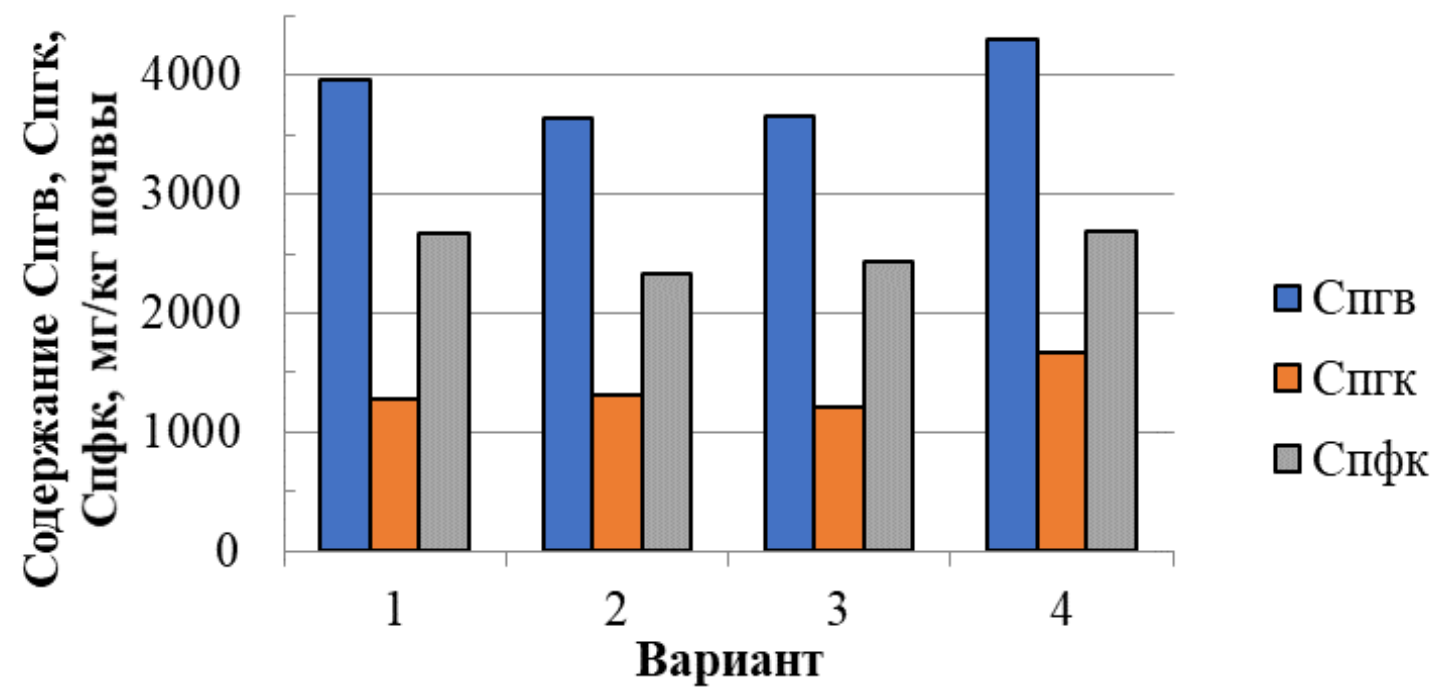

Рисунок 1 - Содержание и состав подвижных гумусовых веществ в 0-20 см слое чернозема типичного перед посевом ярового ячменя 5.04.19.

Из представленных на рисунке данных видно, что весной в слое 0-20 см чернозёма типичного на варианте 4 (агробиотехнология 2) отмечается максимальное содержание ПГВ и ПГК соответственно 4300 мг/кг почвы и 1700 мг/кг почвы. Вероятно, в весенний период это связано как с большим количеством (по массе) поступивших ранее растительных остатков подсолнечника, так и с увеличением интенсивности процесса их гумификации в результате применения биопрепаратов и азотных удобрений.

После уборки ячменя в слое $0-20$ см чернозёма типичного несколько повышенное содержание $\mathrm{C}_{\text {Пгв }}$ отмечается на вариантах 3 и 4 с применением биопрепаратов Грибофит и Имуназот. Это произошло за счёт более высокого 
содержания ПГК и ПФК на вариантах с биопрепаратами. Вероятно, данная тенденция является результатом совместного применения биопрепаратов (Грибофит и Имуназот) которые способствуют ускорению процессов гумификации и тем самым способствуют накоплению ПГВ в почве.

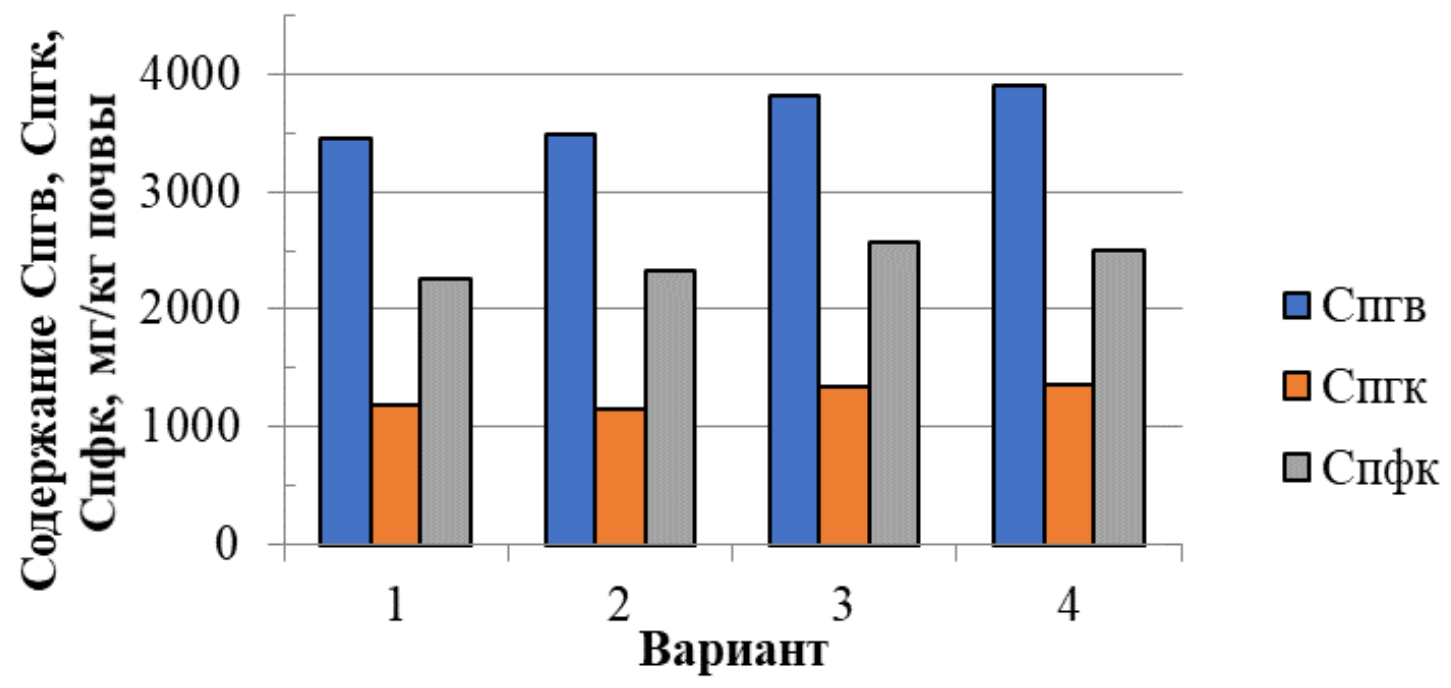

Рисунок 2 - Содержание и состав подвижных гумусовых веществ в 0-20 см слое чернозема типичного после уборки ярового ячменя 5.08.19

Схожая картина наблюдалась через 46 суток после заделки пожнивных растительных остатков ячменя (рис. 3 ).

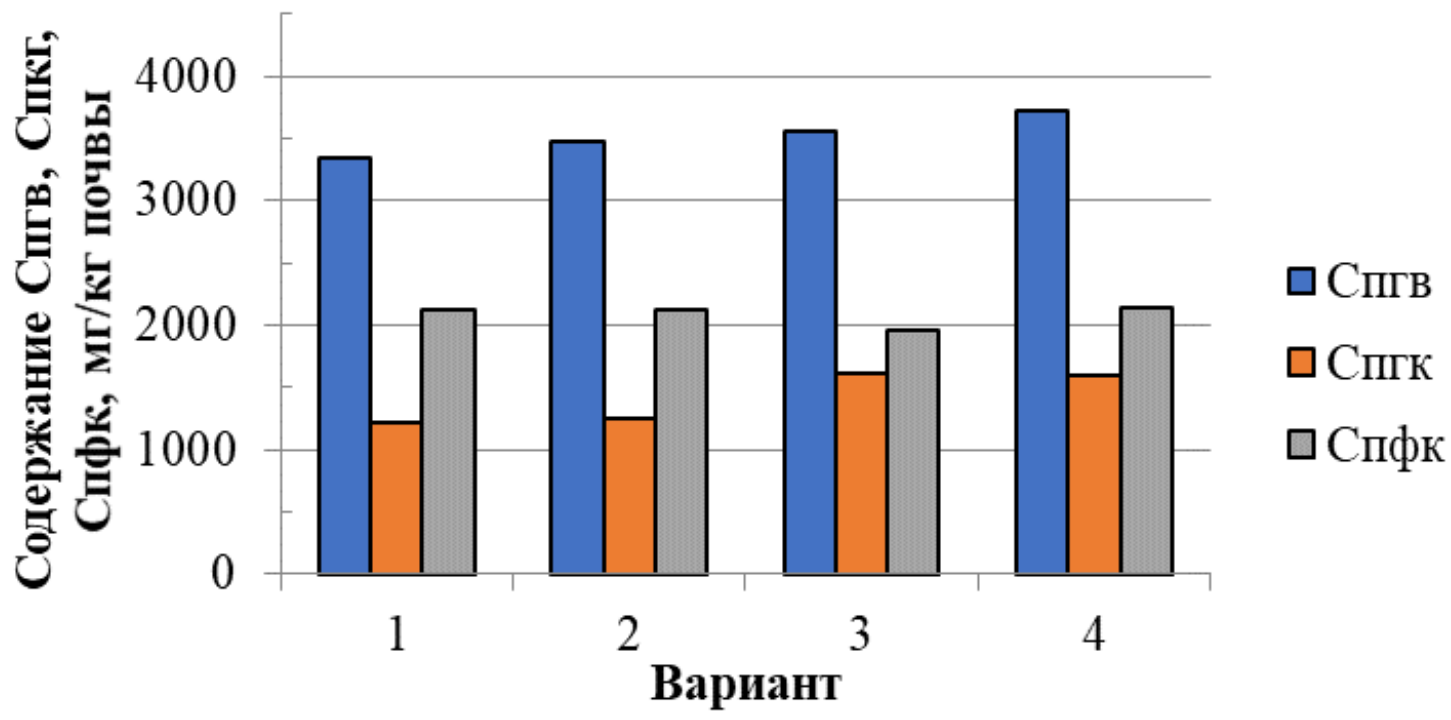

Рисунок 3 - Содержание и состав подвижных гумусовых веществ в 0-20 см слое чернозема типичного через 46 суток после заделки растительных остатков ярового ячменя 15.10 .19

Так, в слое 0-20 см чернозёма типичного на варианте 4 (биопрепараты + $\mathrm{N}_{10}$ на 1 т пожнивных остатков) и варианте 3 (биопрепараты) через 46 суток после заделки растительных остатков ячменя отмечается максимальное содержание ПГВ и ПГК, соответственно, в 1,1 и 1,3 раза больше, чем на контроле. При этом содержание ПФК было примерно одинаковым. Вероятно, это обусловлено совместным действием биопрепаратов (Грибофит и Имуназот) и 
азотных удобрений, которые ускоряют процессы гумификации пожнивных растительных остатков и образования ПГВ и ПГК.

Таким образом, в посевах ячменя агробиотехнология-2 с совместным применением биопрепаратов Грибофит и Имуназот и азотных удобрений способствует появлению стойкой тенденции к увеличению содержания в 0-20 см слое чернозёма типичного ПГВ и ПГК, следовательно, к улучшению их качественного состава.

\section{Библиографический список}

1. Кирюшин, В.И. Экологические основы земледелия / В.И. Кирюшин. - М.: Колос, 1996. -367 c.

2. Тихонович И.А., Кожемяков А.П., Чеботарь В.К. и др. Биопрепараты в сельском хозяйстве (Методология и практика применения микроорганизмов в растениеводстве и кормопроизводстве). - М.: Россельхозакадемия, 2005. - 154 с.

3. Рекомендации для исследования баланса и трансформации органического вещества при сельскохозяйственном использовании и интенсивном окультуривании почв: Методические рекомендации / Сост. К.В. Дьяконова. - М.: ВАСХНИЛ. Почвенный институт им. В.В. Докучаева, 1984. - 96 с.

4. Дедов, А.В. Трансформация послеуборочных остатков и содержание в почве подвижных гумусовых веществ / А.В. Дедов, Н.И. Придворев, Е.В. Морозова // Агрохимия. - 2001. - №11. - С. 26-33.

5. Ганжара, Н.Ф. Баланс гумуса в почвах и пути его регулирования / Н.Ф. Ганжара // Земледелие. - 1986. - № 10. - С. 7-9.

6. Болотских, Г.А. Особенности трансформации органического вещества чернозёма типичного при различных формах сельскохозяйственного использования земель / Г.А. Болотских // Автореферат дисс. на соиск. уч. ст. канд. с.-х. наук. - Курск, 2001. - 27 с.

7. Мамонтов В.Г., Афанасьев Р.А., Родионова Л.П., Быканова О.М. К вопросу о лабильном органическом веществе почв // Плодородие. - 2008. - №2 . - С. 20-22.

8. Масютенко Н.П., Юринская В.Ф. Методические рекомендации по регулированию гумусного состояния черноземных почв Курской области. - Курск, 1990. - 50 с.

УДК 631. 6.02 (478)

\section{ЗАЩИТА ПОЧВ ОТ ЭРОЗИИ В БАССЕЙНЕ РЕКИ БЭЛЦАТА} РЕСПУБЛИКИ МОЛДОВА

Кухарук Е.С. ${ }^{1}$, Корман Ю.Х. ${ }^{2}$, Кухарук Р.А. ${ }^{3}$

${ }^{1}$ Международная ассоциация хранителей реки Eco-TIRAS, Молдова,

${ }^{2}$ Государственны Аграрный Университет Молдовы,

${ }^{3}$ Институт Почвоведения, Агрохимии и Охраны Почв им. «Н. Димо», Кишинёв

E-mail: ecostrategii@yahoo.com; iu.corman@uasm.md; sarasvaty7@gmail.com.

Резюме. в статье рассматриваются площзади эродированных почв в бассейне реки Бэлцата за два периода исследований почвенного покрова, по данным Земельного Кадастра Молдовы 2005 и 2021 годов. На исследуемой территории уделяется внимание лесному фонду для прогноза развития прочессов эрозии и их последствий, предотвращения деградации и опустынивания почвенного покрова.

Summary. The article examines the areas of eroded soils in the Baltata River basin for two periods of soil cover studies, according to the data of the Land Cadastre of the Republic of Moldova 2005 
and 2021. In the study area, attention is paid to the forest fund to predict the development of erosion processes and their consequences, to prevent degradation and desertification of the soil cover.

Река Бэлцата - правый приток Днестра, площадь бассейна 153,9 км², протяжённость с северо-запада на юго-восток 27,5 км. ширина 7,7 км. Эта территория характеризуется большим разнообразием почвенного покрова, с абсолютными высотами от 16 до 219 м (в среднем 120 м). Уклоны поверхности от 0 до 170 м, но наиболее частые от 20 до 50 м (Фото 1).

Карта масштабом М 1:11000 была составлена на основе контура гидрографического бассейна и орто-фотоплана. На ней отображена цифровая модель местности, лесные насаждения и водные ресурсы. Вершины склонов покрыты лесной растительностью и это представляет красивые пейзажи, которые, при понижении местности, сменяются лугами с большим разнообразием травяной растительности. На склонах распаханные участки используются под различные сельскохозяйственные культуры, сады и виноградники.

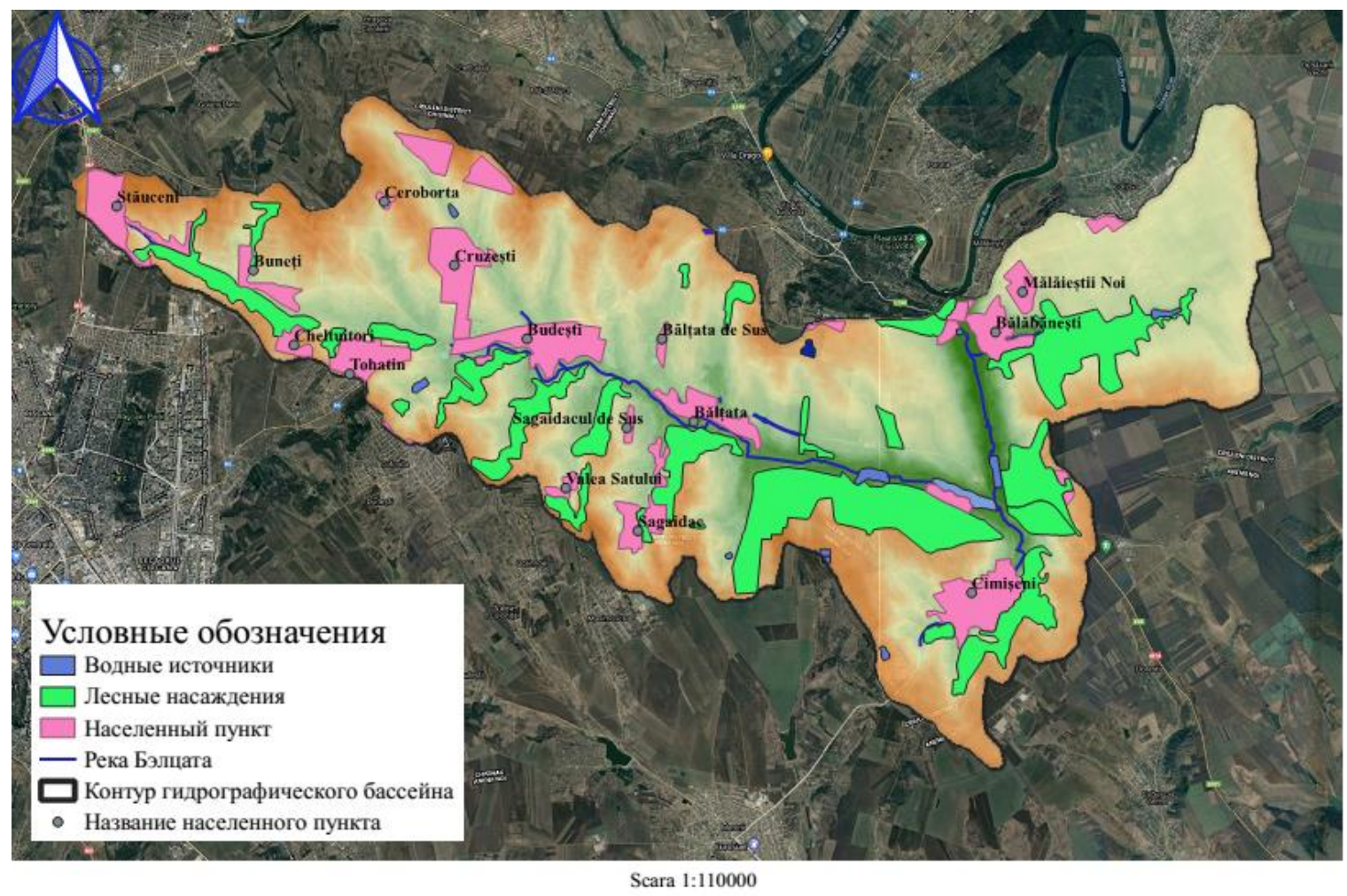

Фото 1 - Бассейн реки Бэлцата на основе данных 2021 года (М 1:110000)

Без соблюдения противоэрозионных мероприятий, на распаханных почвах склонов, наблюдаем смыв почвенного покрова, который приводит к снижению урожайности сельскохозяйственных культур.

По данным Земельного Кадастра Республики Молдова на 2021 год, всего эродированных почв в бассейне реки Бэлцата 4507 га (Таблица 1) [1,2].

За сравнительно небольшой промежуток времени в 16 лет, площадь эродированных почв увеличилась на 251 га.

Необходимость разделения почв по степени эродированности - одно из условий для дальнейшего плана организационных действий по сохранению 
почвенного плодородия, лесонасаждений, сохранения флоры и фауны, уменьшения стока воды и минимализации эрозионных процессов.

На рассматриваемой территории находятся 2905 га слабоэродированных почв, 1382 га среднеэродированных и 389 га сильноэродированных почв. Средний балл бонитета варьирует от 67 до 74.

\section{Таблица 1 - Состояние эродированных почв и лесного фонда в бассейне реки Бэлцата}

\begin{tabular}{|c|c|c|c|c|c|c|c|}
\hline \multirow{3}{*}{$\begin{array}{c}\text { Название административно- } \\
\text { территориальных единиц }\end{array}$} & \multirow{3}{*}{$\begin{array}{l}\text { Всего зе- } \\
\text { мель } \\
\text { исследо- } \\
\text { ванных } \\
\text { (га) }\end{array}$} & \multirow{3}{*}{$\begin{array}{c}\text { Средний } \\
\text { балл бо- } \\
\text { нитета } \\
\text { (баллы) }\end{array}$} & \multirow{2}{*}{$\begin{array}{c}\text { Всего } \\
\text { эроди- } \\
\text { рован- } \\
\text { ных зе- } \\
\text { мель }\end{array}$} & \multicolumn{3}{|c|}{ Эродированные } & \multirow{3}{*}{$\begin{array}{c}\text { Лесной } \\
\text { фонд } \\
\text { (га) }\end{array}$} \\
\hline & & & & Слабо- & Средне- & Сильно- & \\
\hline & & & \multicolumn{4}{|c|}{ (га) } & \\
\hline \multicolumn{8}{|l|}{ на 1 января 2021} \\
\hline Криулень, ком. Бэлцата & 2925 & 60 & 861 & 648 & 150 & 63 & 1040 \\
\hline $\begin{array}{l}\text { Криулень, ком. Бэлэб- } \\
\text { энешть }\end{array}$ & 4191 & 74 & 603 & 356 & 165 & 82 & 648 \\
\hline $\begin{array}{l}\text { Криулень, село Чими- } \\
\text { шень }\end{array}$ & 3305 & 73 & 684 & 546 & 125 & 13 & 432 \\
\hline $\begin{array}{l}\text { Мун. Кишинэу, ком. Бу- } \\
\text { дешть }\end{array}$ & 2839 & 68 & 931 & 479 & 319 & 133 & 236 \\
\hline $\begin{array}{l}\text { Мун. Кишинэу, ком. То- } \\
\text { хатин }\end{array}$ & 1519 & 74 & 238 & 121 & 111 & 6 & 199 \\
\hline $\begin{array}{l}\text { Мун. Кишинэу, ком. Кру- } \\
\text { зешть }\end{array}$ & 1214 & 67 & 402 & 190 & 163 & 49 & 433 \\
\hline $\begin{array}{l}\text { Мун. Кишинэу, ком. } \\
\text { Стаучень }\end{array}$ & 2745 & 71 & 788 & 507 & 192 & 89 & 227 \\
\hline Всего: & 18737 & 70 & 4507 & 2847 & 1225 & 435 & 3215 \\
\hline \multicolumn{8}{|l|}{ на 1 января 2005} \\
\hline Криулень, ком. Бэлцата & 2925 & 58 & 737 & 541 & 119 & 77 & 931 \\
\hline $\begin{array}{l}\text { Криулень, ком. Бэлэб- } \\
\text { энешть }\end{array}$ & 4191 & 75 & 437 & 350 & 73 & 14 & 682 \\
\hline $\begin{array}{l}\text { Криулень, село Чими- } \\
\text { шень }\end{array}$ & 3305 & 71 & 699 & 571 & 115 & 13 & 411 \\
\hline $\begin{array}{l}\text { Мун. Кишинэу, ком. Бу- } \\
\text { дешть }\end{array}$ & 2839 & 71 & 834 & 452 & 296 & 86 & 264 \\
\hline $\begin{array}{l}\text { Мун. Кишинэу, ком. То- } \\
\text { хатин }\end{array}$ & 1519 & 77 & 269 & 138 & 92 & 39 & 208 \\
\hline $\begin{array}{l}\text { Мун. Кишинэу, ком. Кру- } \\
\text { зешть }\end{array}$ & 1214 & 75 & 295 & 225 & 53 & 17 & 3 \\
\hline $\begin{array}{l}\text { Мун. Кишинэу, ком. } \\
\text { Стаучень }\end{array}$ & 2745 & 73 & 985 & 648 & 194 & 143 & 213 \\
\hline Всего: & 18738 & 71 & 4256 & 2925 & 1382 & 389 & 2712 \\
\hline
\end{tabular}

Настораживает тот факт, что на территории бассейна реки Бэлцата более 63\% слабоэродированных почв. При несоблюдении противоэрозионных мероприятий, слабоэродированные почвы переходят в разряд среднеэродированных, а это означает потерю плодородия и уменьшение урожайности сельхозкультур до 50\% [3]. Уменьшение гумуса в среднеэродированных почвах, в условиях засушливых летних периодах, приводит к гибели урожая сельхозпродукции. 
В недалеком будущем, эродированные почвы будут составлять более $24 \%$, а это означает, что сельские хозяйства будут недополучать урожай, ухудшится финансовое положение жителей, возрастет бедность и обнищание населения этой территории. Вот почему так важно знать ситуацию почвенного покрова территории, которую исследуешь, для правильного менеджмента и сохранения экосистем.

За 16 лет площадь лесного фонда увеличилась за счёт сильноэродированных почв, которые выводят из сельскохозяйственного оборота под облесение.

Для сохранения влаги в почве и минимализации эрозионных процессов на склоновых пространствах, нужно проводить посадку лесных противоэрозионных насаждений. Лесные защитные противоэрозионные полосы играют водорегулирующую, снегораспределительную и почвозащитную роль [4]. Для этого рекомендуется высаживать водорегулирующие (противоэрозионные) лесные полосы, которые способны изменять поверхностный сток, а значит, сохранять почву от размыва и смыва. Под влиянием лесных насаждений сокращается непродуктивное испарение влаги с поверхности почвы. Повышается продуктивность транспирации, что в конечном итоге улучшает обеспеченность почвы влагой.

На склонах лесополосы любого назначения размещают параллельно горизонталям, и только на ровных участках лесные полосы располагают поперёк направления господствующих ветров, иначе они могут стать местом концентрации стока и развития линейной эрозии [4].

Правильная организация территории является важнейшим, но не единственным организационно-хозяйственным мероприятием. К этой группе можно отнести также мероприятия, направленные на ограничение степени хозяйственного освоения территории, интенсивности её использования. Сюда относятся: запрещение или ограничение рубки леса, распашки земель, выпаса скота на наиболее эрозионно опасных участках, сохранение, при освоении новых земель, участков леса и лугов противоэрозионного назначения, особенно в речных долинах и балках, на крутых приречных и прибалочных склонах, в крупных водоотводящих ложбинах.

Проблема охраны и экологического оздоровления в бассейне реки Бэлцата Молдовы входит в задачи проекта BS963 «Protecting streams for a clean Black Sea by reducing sediment and litter pollution with joint innovative monitoring and control tools and nature-based practices» на 2020-2021 годы программы Черного моря (сокращённое название «Protect-Streams-4 Sea»).

Настоящая работа выполнена в рамках проекта BSB963 Программы Чёрного моря Европейского Союза.

This publication has been produced with the fi nancial assistance of the European Union (BSB963 Project of the EU Black Sea Regional Operational Programme, 2014-2020). The contents of this publication are the sole responsibility of its authors and can in no way be taken to reflect the views of the European Union. 


\title{
Выводы
}

1. При изучении состояния почвенного покрова в бассейне реки Бэлцата, главное внимание обращено на склоново-эрозионную ситуацию: выделено более $29 \%$ всех деградированных почв.

2. Слабоэродированные почвы занимают $15 \%$, в которых усиливается химическая, физическая и биологическая деградация почв.

3. Сильнодеградированные почвы составляют $2 \%$, которые нуждаются в конкретных мероприятиях по лесонасаждениям.

4. Всего сельскохозяйственных земель 18738 га. Качественное состояние почв даёт их группировка на классы по уровню плодородия: в III и IV классах включены почвы с бонитетом 51-70 баллов - эти почвы требуют мероприятия по сохранению и повышению плодородия, которые расположены в бассейне реки Бэлцата.

\section{Библиографический список}

1. Cadastru Funciar al Republicii Moldova, Chișinău, 2021. - P. 969.

2. Cadastru Funciar al Republicii Moldova, Chișinău, 2005. - P. 942.

3. Гид по сохранению и рациональному использованию влаги почв / Кухарук Е., Руснак В., Корман Ю. и др. Кишинёв: Print-Caro, 2015. - С. 24, 186

4. Кузнецов М.С., Глазунов Г.П. Эрозия и охрана почв. М.: Юрайт, 2019. - С. 252-261.

\section{УДК 631. 811.98; 633.8}

\section{ОЦЕНКА ЭФФЕКТИВНОСТИ ПРИМЕНЕНИЯ КОМПЛЕКСНЫХ УДОБРЕНИЙ С МИКРОЭЛЕМЕНТАМИ НА ПОСЕВАХ СОИ В УСЛОВИЯХ КУРСКОЙ ОБЛАСТИ}

\author{
Лазарев В.И., Минченко Ж.Н. \\ ФГБНУ «Курский ФАНЦ», г. Курск \\ E-mail:vla190353@yandex.ru
}

\begin{abstract}
Резюме. В статье представлены результаты исследований, свидетельствующие о высокой эффективности применения комплексных удобрений с микроэлементами на посевах сои при воздельвании её в условиях черноземных почв Курской области. Установлено, что двукратная обработка посевов в фазах 2-го и 6-го тройчатого листа $(1,5 \mathrm{\pi} / 2$ а) в сочетании с обработкой семян $(1,5 \mathrm{n} / \mathrm{m})$ способствовала повышению урожайности сои на 0,34-0,40 m/2а, или 15,2-17,9\%, содержанию белка в зерне на 2,28-3,09\%, жира на 2,06-2,92 \%, в сравнение с контролем.
\end{abstract}

Ключевые слов: комплексные удобрения с микроэлементами, соя, чернозём типичный, урожайность, качество зерна.

Summary. The article presents the results of research indicating the high efficiency of the use of complex fertilizers with trace elements on soybean crops when it is cultivated in the conditions of chernozem soils of the Kursk region. It was found that double treatment of crops in the phases of the 2 nd and 6th triple leaf $(1.5 \mathrm{l} / \mathrm{ha})$ in combination with seed treatment $(1.5 \mathrm{l} / \mathrm{t})$ contributed to an increase in soybean yield by 0.34-0.40 t/ha, or 15.2-17.9\%, protein content in grain by 2.28-3.09, fat by 2.06-2.92, compared with the control.

Keywords: complex fertilizers with trace elements, soy, typical chernozem, yield, grain quality. 
Введение. Посевные площади сои в Курской области значительно увеличиваются с каждым годом [1]. Так площади посева сои в области за последние годы составляли: в 2017 г. - 173 тыс. га, в 2018 г. - 216 тыс. га, в 2019 г. - 281тыс. га, а в 2020 г. площадь её посевов составила 265 тыс. га. Это составляет $3,7 \%$ от площадей посевов в Российской Федерации. Средняя урожайность сои в Курской области колебалась от - 17,0 ц/га в 2017 г., до 20,9 ц/га в 2020 году. Валовой сбор сои в эти годы и составил: в 2017 г. - 290909 т, в 2020 г. - 553600 т соответственно. Во многих районах области (Суджанский, Беловский, Льговский) уровень урожайности сои превышает среднеобластное значение и доходит до - 29,7 ц/га. Это свидетельствует о неполном использовании потенциальных возможностей этой культуры [2].

Получение высоких и стабильных урожаев высококачественного зерна сои в настоящее время обусловлено комплексом агротехнических приёмов применяемых технологий возделывания, требующих существенного изменения в сторону экологизации и ресурсосбережения [3]. Основой этих технологий служит использовании биологических средств защиты растений, микробиологических препаратов, регуляторов роста и комплексных микроэлементных удобрений $[4,5]$. Несмотря на то, что микроэлементы поглощаются соей в не больших количествах, их роль не менее важна, а недостаток приводит к значительному замедлению темпов роста, нарушению важных биологических процессов в организме растения и снижению урожайности [6].

В условиях средней и низкой обеспеченности почв Курской области подвижными формами микроэлементов, существует необходимость в использовании микроэлементных удобрений на просевах сои $[7,8]$. Научно обоснованный подход в системе удобрения способен снизить химическую нагрузку на грунт, уменьшить расходы энергоресурсов, получить в результате высокий урожай зерна.

Материалы и методы. В 2018-2020 гг. в стационарном опыте лаборатории технологий возделывания полевых культур и агроэкологической оценки земель ФГБНУ «Курский ФАНЦ» проводились исследования по изучению эффективности использования микроэлементных удобрений на посевах сои. Объектом исследований служили комплексные удобрения с микроэлементами: МикроФид Комплекс, МикроФид Цинк и МикроФид Бор.

Опытный участок представлен черноземом типичным мощным тяжелосуглинистым. Содержание гумуса в пахотном слое (по Тюрину) - 6,1 \% , подвижного фосфора (по Чирикову) - 15,6 мг/100 г почвы, обменного калия (по Масловой) - 11,3 мг/100 г почвы по Масловой, $\mathrm{pH}$ - 6,5. Почва опытного участка относится к среднеобеспеченной по содержанию подвижных форм бора - 0,34 мг/кг, меди - 0,30 мг/кг, цинка - 0,32 мг/кг, магния - 4,50 мгэкв./100 г.

Сою размещали в зернопаровом севообороте со следующим чередованием культур: чистый пар, озимая пшеница, соя, яровая пшеница. Обработку семян водным раствором микроэлементных удобрений проводили за 1 день до посева ранцевым опрыскивателем (расход рабочего раствора - 15 л/т). Обработку 
растений сои в фазах 2-го и 6-го тройчатого листа также проводили ранцевым опрыскивателем (расход рабочего раствора - 250 л/га). Варианты в полевом опыте располагались систематически, в 3-х кратной повторности. Общая площадь опытной делянки - $200 \mathrm{~m}^{2}$, учетной делянки - $100 \mathrm{~m}^{2}$. Способ посева рядовой. Норма высева сои - 0,6 млн всхожих зерен/га.

Результаты и обсуждение. В результате проведенных исследований установлено, что обработка семян сои комплексными микроэлементными удобрениями способствовала стимулированию и активизации начальных ростовых процессов в зерне, увеличивала полевую всхожесть семян. Так в вариантах с обработкой семян сои удобрениями МикроФид Комплекс, МикроФид Цинк и МикроФид Бор полевая всхожесть семян увеличилась на 3,8, 4,5, 5,2 \%, в сравнении с контрольным вариантом.

Наблюдения показали, что предпосевная обработка семян (1,5 л/т) в сочетании с 2-х кратной обработкой посевов $(1,5$ л/га) в фазах 2-го и 6-го тройчатого листа микроэлементными удобрениями, способствовала стимулированию иммунной системы растений, лучшему росту и развитию, образованию мощной вегетативной массы и корневой системы, а также формированию лучшей структуры урожая сои. Так, с использованием удобрений МикроФид Комплекс и МикроФид Цинк количество бобов с одного растения составило 25,125,5 шт., озерненность боба - 2,3-2,3 шт., масса зерна с одного растения - 6,97,1 г, масса 1000 зерен - 129,3-130,4. Величина этих показателей в контрольном варианте составила -20,9 шт., 2,2 шт., 6,2 г, масса 1000 зерен - 118,8 г, соответственно.

В варианте с обработкой семян и двукратной обработкой посевов сои микроэлементным удобрением МикроФид Бор были получены наиболее высокие показатели структуры урожая: количество бобов с одного растения - 26,8 шт., озернённость боба - 2,4 шт., масса зерна с одного растения - 7,8 г, масса 1000 зерен - 130,7 г.

Установлено, что обработка семян и посевов микроэлементными удобрениями, как элемент технологии возделывания сои, существенно увеличивает урожайность и влияет на улучшение качества зерна сои (табл.1).

В среднем за годы исследований анализ урожайных данных, полученных в опыте свидетельствует о том, что максимальная прибавка урожая сои была получена в варианте опыта с обработкой семян и посевов в фазах 2-го и 6-го тройчатого листа удобрением МикроФид Бор, урожайность увеличилась, в сравнении с контрольным вариантом на - 0,40 т/га или 17,8\%. В вариантах, с использованием препаратов МикроФид Комплекс и МикроФид Цинк, прибавка урожайности была несколько ниже и составила $-0,34-0,37$ т/га или $15,2-16,5 \%$.

Использование удобрений с микроэлементами положительно сказывалось и на качестве зерна. Так, обработка семян и посевов в фазах 2-го и 6-го тройчатого листа препаратом МикроФид Бор повышала содержание белка в зерне на $-3,09 \%$, жира на - 2,92\%. Применение препаратов МикроФид Комплекс и МикроФид Цинк при аналогичных способах использования 
способствовало увеличению содержания белка в зерне на - 2,28-2,82\%, жира на $-2,06-2,41 \%$.

Таблица 1 - Влияние микроэлементных удобрений на урожайность и качество зерна сои (2018-2020 гг.)

\begin{tabular}{|c|c|c|c|c|c|c|}
\hline Варианты & $\begin{array}{l}\text { Урожайн } \\
\text { ость, } \\
\text { т/га }\end{array}$ & $\begin{array}{l}\text { Прибав } \\
\text {-ка, } \\
\text { т/га }\end{array}$ & $\begin{array}{c}\text { Белок, } \\
\%\end{array}$ & $\begin{array}{c}\text { Жир, } \\
\%\end{array}$ & $\begin{array}{l}\text { Клетча } \\
\text { тка, } \\
\%\end{array}$ & $\begin{array}{c}\text { Зола, } \\
\%\end{array}$ \\
\hline $\begin{array}{l}\text { 1. Контроль (без обработок } \\
\text { препаратами) }\end{array}$ & 2,24 & - & 27,03 & 24,36 & 6,18 & 6,31 \\
\hline $\begin{array}{l}\text { 2. МикроФид Комплекс }(1,5 \text { л/т) } \\
\text { обработка семян, + обработка } \\
\text { посевов }(1,5 \text { л/га) в фазах 2-го и } \\
6 \text {-го тройчатого листа }\end{array}$ & 2,58 & $+0,34$ & 29,31 & 26,42 & 5,87 & 6,04 \\
\hline $\begin{array}{l}\text { 3. МикроФид Цинк (1,5 л/т) об- } \\
\text { работка семян, + обработка по- } \\
\text { севов }(1,5 \text { л/га) в фазах 2-го и 6- } \\
\text { го тройчатого листа }\end{array}$ & 2,61 & $+0,37$ & 29,85 & 26,77 & 5,89 & 5,98 \\
\hline $\begin{array}{l}\text { 4. МикроФид Бор }(1,5 \text { л/т) обра- } \\
\text { ботка семян, + обработка посе- } \\
\text { вов }(1,5 \text { л/га) в фазах 2-го и 6-го } \\
\text { тройчатого листа }\end{array}$ & 2,64 & $+0,40$ & 30,12 & 27,28 & 5,94 & 6,01 \\
\hline $\mathrm{HCP}_{05}$ & \multicolumn{2}{|l|}{0,11} & & & & \\
\hline
\end{tabular}

В результате анализа полученных экспериментальных данных установлено, что наиболее экономически эффективным при возделывании сои было применение комплексного микроэлементного удобрения МикроФид Бор. Обработка семян $(1,5$ л/т) в сочетании с двукратной обработкой посевов $(1,5$ л/га) повышала урожайность сои на - 0,40 т/га, на сумму 10000 руб./г, уровень рентабельности на $-26,5 \%$, способствовала снижению себестоимости 1 т зерна на 132,9 руб. Сумма условно чистого дохода составила - 8761,2 руб./га. Экономическая эффективность использования удобрений с микроэлементами МикроФид Комплекс и МикроФид Цинк при обработке семян и посевов в фазах 2-го 6-го тройчатого листа была несколько ниже. Прибавка урожайности составила 0,34-0,37 т/га, на сумму 8500-9250 руб./га. Уровень рентабельности вырос на - 22,7-24,9 \%, при снижении себестоимости 1 т зерна на 115,6-125,6 руб. Сумма условно чистого дохода составила - 7446,6-8134,8 руб./га, соответственно.

Заключение. Проведенные исследования показали высокую эффективность использования комплексных удобрений с микроэлементами марки МикроФид при возделывании сои в условиях Курской области. Так, предпосевная обработка семян и двукратная обработка посевов сои в фазах 2-го и 6-го тройчатого листа увеличивала урожайность сои на 0,34-0,40 т/га, или на 15,2$17,9 \%$, содержание белка зерне на 2,28-3,09 \%, жира на 2,06-2,92 \%, в сравнении с контрольным вариантом. Наиболее высокие экономические 
показатели при возделывании сои, обеспечивало применение удобрения МикроФид Бор: стоимость валовой продукции увеличилась на 10000 руб./га, величина условно чистого дохода на $-87612,0$ руб./га, уровень рентабельности на $-26,5 \%$, себестоимости 1 т зерна снизилась на 132,9 руб. Экономические показатели эффективности применения микроэлементных удобрений МикроФид Комплекс и МикроФид Цинк при таких же способах внесения были ниже эффективности микроэлементного удобрения МикроФид Бор. Стоимость валовой продукции от их применения увеличивалась на 8500-9250 руб./га, величина условно чистого дохода - на 7446,6-8134,8 руб./га, уровень рентабельности - на 22,7-24,9 \%, при снижении себестоимости 1 т зерна на 115,6-125,6 руб.

\title{
Библиографический список
}

1. Матушанская Е.Е., Золотарева Е.Л. Анализ объемов и эффективности производства сои в курской области. Вестник Курской государственной сельскохозяйственной академии, 2015. - № 7. - С. 83-86.

2. Лазарев В.И., Башкатов А.Я., Минченко Ж.Н. Эффективность микроэлементных удобрений при возделывании сои сорта Казачка в условиях Курской области. Земледелие, 2018. - № 2. - С. 34-36.

3. Милащенко Н.3., Трушкин С.В. К проблеме освоения инновационных технологий. Плодородие, 2011. - № 3. - С. 50-52.

4. Бэлл Р.В., Дэлл Б. Роль микроэлементов в устойчивом производстве продовольствия, кормов, волокна и биоэнергии (М.: Международный институт питания растений, 2017).

5. Board J.B, Soybean Yield Formation: What Controls It and How It Can Be Improved, Soybean Physiology and Biochemistry, ( Prof. Hany El-Shemy (Ed.) / J.E.Board, C.S. Kahlon, 2011).

6. Спицына С.Ф., Томаровский А.А., Оствальд Г.В., Третьяков М.Е. Эффективность применения микроудобрений под сою. Вестник Алтайского государственного аграрного университета, 2015. - 8. - 43-47.

7. Лазарев В.И., Айдиев А.Я., Золотарева И.А., и др. Эффективность микроэлементных удобрений в условиях Курской области. Монография (Курск: Изд-во Курской ГСХА, 2013. 8. Пироженко В.В., Цыганков Д.Н., Мирошниченко О.Н. Мониторинг состояния плодородия пахотных почв Курской области. Достижения науки и техники АПК, 2019. - № 4. C. $12-13$.

\section{УДК 631.81:631.421}

\section{ЭФФЕКТИВНОСТЬ НОВЫХ ФОРМ ЖИДКИХ АЗОТНЫХ УДОБРЕНИЙ НА ПОСЕВАХ ОЗИМОЙ ПШЕНИЦЫ В УСЛОВИЯХ КУРСКОЙ ОБЛАСТИ}

Лазарев В.И., Минченко Ж.Н.

ФГБНУ «Курский ФАНЦ», г. Курск

Email:vla190353@yandex.ru

\begin{abstract}
Резюме. Представлены результаты исследований по изучению эффективности жидкого азотного удобрения КАС-32 на посевах озимой пшенищь в условиях черноземных почв Курской области. Установлено, что двукратная обработка посевов препаратом КАС-32 в фазе кущения в дозе N30 и фазе начало выхода в трубку в дозе N15 повышала урожайность озимой пшенищы на 8,7 и/га или 19,4\%, содержание сырой клейковины в зерне на 2,4\%, использование КАС-32 на посевах озимой пшенищь было экономически выгодно.
\end{abstract}


Ключевые слов: озимая пшеница, жидкое азотное удобрений КАС-32, аммиачная селитра, урожайность, структура урожая, содержание клейковины, экономическая эффективность.

Summary. The results of studies on the effectiveness of liquid nitrogen fertilizer CAS-32 on winter wheat crops in the conditions of chernozem soils of the Kursk region are presented. It was found that two-time treatment of crops with CAS-32 in the tillering phase at a dose of N30 and the beginning of the release into the tube at a dose of N15 increased the yield of winter wheat by 8.7 c/ha or $19.4 \%$, the content of raw gluten in grain by $2.4 \%$, the use of CAS-32 on winter wheat crops was economically profitable.

Keywords: winter wheat, liquid nitrogen fertilizer CAS-32, ammonium nitrate, yield, crop structure, gluten content, economic efficiency.

Введение. Обеспечение сельскохозяйственных культур доступными формами азота, является одной из основных проблем современного земледелия Центрально Черноземного региона. Хотя мировое потребление азота в настоящее время достигло огромных размеров, азот все еще остается наиболее недостающим элементом минерального питания, лимитирующим получение высоких и стабильных урожаев сельскохозяйственных культур $[1,2]$.

Пахотные почвы Курской области сильно нуждаются во внесении азотных удобрений: свыше 70\% их площадей имеют среднюю и ниже средней обеспеченность подвижными формами азота. По данным ФГУ КАС «Курская» потребность земледелия области в азотных удобрениях составляет 28580 тонн д.в. В этих условиях особое значение приобретает максимальное использование всех видов органических и минеральных удобрений, содержащих азот [3]. Выбор удобрения из имеющегося в продаже ассортимента должен сводиться к определению такой формы, применение которой обойдется дешевле по сравнению с другими, и при этом обеспечит получение максимально возможной прибавки урожая стоимостью, превышающей затраты на использование данного удобрения [4].

В последнее время ассортимент предлагаемых сельхозтоваропроизво-дителям средств химизации значительно расширился, в том числе и за счет выпуска таких качественно новых форм азотных удобрений, как КАС (карбамидно-аммиачная смесь). КАС - это жидкое азотное удобрение, содержащее сразу три формы азота - нитратную, аммонийную и амидную. Эффективность этого удобрения обоснована рядом преимуществ перед уже имеющимися твердыми азотными удобрениями. В случае их использования обеспечивается полная механизация процессов хранения, транспортировки и внесения в почву, в сравнении с твердыми формами азотных удобрений $[5,6]$.

Однако, эффективность этого удобрения во многом зависит от почвенноклиматических условий, в связи с чем возникает настоятельная необходимость в изучении параметров применения жидкого азотного удобрения КАС-32 в различные периоды вегетации озимой пшеницы влияния его на урожайность и качество зерна в условиях черноземных почв Курской области.

Методика. Изучение эффективности использования карбамидноаммиачного удобрения (КАС-32) проводилось в 2018-2020 годах в опыте отдела земледелия ФГБНУ «Курский ФАНЦ» в севообороте со следующим чередованием 
культур: 1. Чистый пар; 2. Озимая пшеница; 3. Гречиха; 4. Яровая пшеница. Изучалась эффективность применения препарата КАС-32 при обработке посевов озимой пшеницы в фазе кущения в дозе N30-60 и фазе выхода в трубку в дозе N15-30 в сравнении с использованием гранулированной аммиачной селитры в те же сроки и в тех же дозах.

Почва опытного участка представлена черноземом типичным мощным тяжелосуглинистым. Содержание гумуса в пахотном слое составляет 6,0-6,2\%, подвижного фосфора (по Чирикову) - 10,1-14,5, обменного калия (по Масловой) - 16,8-19,0 мг/100 г почвы. Реакция почвенной среды нейтральная (рН 6,8$7,0)$.

Фон минерального питания в контрольном и изучаемых вариантах $\mathrm{N}_{30} \mathrm{P}_{30} \mathrm{~K}_{30}$ с осени под основную обработку почвы. Сорт озимой пшеницы - Ермак. Норма посева -5 млн. всхожих зерен на гектар. Способ посева - рядовой (сеялкой СН-16). Глубина заделки семян - 4-5 см.

Обработка посевов озимой пшеницы препаратом КАС-32 в фазе кущения и фазе выход в трубку проводилась ранцевым опрыскивателем в соответствии со схемой опыта.

За период исследований проводились следующие наблюдения, учеты и анализы: фенологические наблюдения по «Методике государственного сортоиспытания сельскохозяйственных культур» (1996); густота насаждений - путем подсчета всех растений на учетных площадках; содержание сырой клейковины стандартным методом (И.Е. Казаков, 1967), натура зерна (ГОСТ-1084076), масса 1000 зерен (ГОСТ-10842-76).

Уборка и учет урожая проводилась самоходным комбайном «Сампо» прямым комбайнированием. Для обработки экспериментальных данных применялся дисперсионный метод математического анализа [7].

Результаты и их обсуждение. Наблюдения за ростом и развитием озимой пшеницы показали, что обработка посевов азотными удобрениями (аммиачная селитра, КАС-32) способствовала удлинению периода активной вегетации растений, фаза колошения наступила на 1-2 дня раньше, а спелость зерна - на 2-3 дня позже, чем в контрольном варианрте. Разницы в наступлении фенологических фаз развития озимой пшеницы в вариантах с различными видами азотных удобрений - не наблюдалось.

Установлено, что обработка посевов жидким азотным удобрением КАС32 вызвала появление на листьях озимой пшеницы ожогов (некротических пятен). Степень повреждения листьев зависела от фазы развития растений, дозы удобрения и, особенно, погодных условий в период внесения препарата КАС32. Так, несение жидкого азотного удобрения КАС-32 в период кущения и ранневесеннего отрастания (первая подкормка), когда температура воздуха не превышала 5-7 ${ }^{\circ} \mathrm{C}$, практически не приводила к ожогам растений даже при дозе внесения КАС $\mathrm{N}_{60}$. При проведении второй подкормки в фазе начало выхода в трубку, когда температура воздуха составляла $16-18{ }^{\circ} \mathrm{C}$, обработка посевов препаратом КАС-32 в дозе N15-30 вызывала ожоги листьев, не смотря на то, что удобрение КАС-32 разбавлялось водой в соотношении 1:2. Некротические 
пятна на растениях озимой пшеницы появлялись на второй день после обработки посевов, поражались кончики листьев озимой пшеницы, степень поражения составляла 15-20\%. В таком состоянии растения находились в течение 8-9 дней. На 9-10 день ожоги проходили растения полностью оправлялись от ожогов.

Обработка посевов жидким азотным удобрением КАС-32оказывала положительное влияние на структуру урожая озимой пшеницы. Так, ранневесенняя подкормка озимой пшеницы препаратом КАС-32 дозе N30 повышала количество продуктивных стеблей - на 29 шт./м² (504 шт./м², в контрольном варианте - 475 шт./ м²), озерненность колоса - на 1 зерно (26 шт., в контрольном варианте 25 шт.), массу 1000 зерен на 2,6 г. (45,2 г, в контрольном варианте 42,6 г.), натуру зерна на 16 г/л (681 г/л, в контрольном варианте 665 г/л). С увеличением дозы внесения КАС-32 до N60 показатели структуры урожая озимой пшеницы повышались: количество продуктивных стеблей на 1 шт./м², озерненность колоса на 1 шт., масса 1000 зерен на 0,1 г., натура зерна на 5 г/л, в сравнении с внесением КАС-32 в дозе N30 (табл. 3).

В варианте с двукратной обработкой посевов озимой пшеницы жидким азотным удобрением КАС-32 в фазе кущения в дозе N30 и фазе начало выхода в трубку в дозе $\mathrm{N}_{15}$ количество продуктивных стеблей повышалось на 3 шт./ м $^{2}$, озерненность колоса - на 2 шт., масса 1000 зерен на 1,4 г, натура зерна на 12 г/л, в сравнении с обработкой посевов озимой пшеницы в фазе кущения в дозе $\mathrm{N}_{30}$. Увеличение дозы подкормки КАС-32 до $\mathrm{N}_{60}$ в фазе кущения и до $\mathrm{N}_{30}$ в фазе начало выхода в трубку не приводило к повышению показателей структуры урожая озимой пшеницы, в сравнении с внесением КАС-32 в дозе N30. Это связано с отрицательным влиянием повышенных доз препарата КАС-32 (обжог листьев озимой пшеницы).

Ранневесенняя подкормка озимой пшеницы аммиачной селитрой в дозе

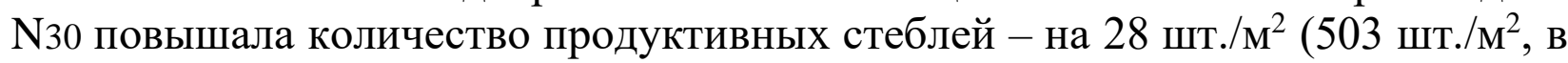
контрольном варианте - 475 шт./м²), озерненность колоса - на 1 зерно (26 шт, в контрольном варианте 25 шт.), массу 1000 зерен на 1,8 г.(44,4 г), натуру зерна на -2 г.

Более высокие показатели структуры урожая в вариантах с исполь-зованием жидкого азотного удобрения КАС-32 обеспечили более высокую урожайность озимой пшеницы (табл. 1).

Так, ранневесенняя подкормка озимой пшеницы препаратом КАС-32 дозе $\mathrm{N}_{30}$ повышала урожайность озимой пшеницы на 5,9 ц/га или 13,2\%. С увеличение дозы внесения КАС-32 до N60 урожайность озимой пшеницы повышалась на 6,3 ц/га или $14,1 \%$.

Двукратная обработка посевов жидким азотным удобрением КАС-32 в фазе кущения в дозе N30 и фазе начало выхода в трубку в дозе N15 повышала урожайность озимой пшеницы на 8,7 ц/га или 19,4\%. Увеличение дозы подкормки КАС-32 до $\mathrm{N}_{60}$ в фазе кущения и до N30 в фазе начало выхода в трубку приводило к снижению урожайности озимой пшеницы на 0,6 ц/га. Это связано 
с отрицательным влиянием повышенных доз препарата КАС-32 (обжог листьев озимой пшеницы).

Таблица 1 - Влияние жидкого азотного удобрения КАС-32 на урожайность и качество зерна озимой пшеницы, 2018-2020 гг.

\begin{tabular}{|c|c|c|c|c|}
\hline \multirow[b]{2}{*}{ Варианты } & \multicolumn{2}{|c|}{ Урожайность } & \multicolumn{2}{|c|}{$\begin{array}{l}\text { Содержание } \\
\text { клейковины }\end{array}$} \\
\hline & ц/га & $\begin{array}{c}\text { +- к } \\
\text { контро- } \\
\text { лю, ц/га }\end{array}$ & $\%$ & $\begin{array}{c}+- \text { к } \\
\text { контро- } \\
\text { лю, \% }\end{array}$ \\
\hline 1. Контроль, без удобрений & 44,8 & - & 22,4 & - \\
\hline 2. Ранневесенняя подкормка Ам. селитра $\left(\mathrm{N}_{30}\right)$ & 49,4 & 4,6 & 23,1 & 0,7 \\
\hline 3. Ранневесенняя подкормка КАС-32 $\left(\mathrm{N}_{30}\right)$ & 50,7 & 5,9 & 22,9 & 0,5 \\
\hline 3. Ранневесенняя подкормка КАС-32 ( $\left.\mathrm{N}_{60}\right)$ & 51,1 & 6,3 & 23,5 & 1,1 \\
\hline $\begin{array}{l}\text { 5. Ранневесенняя подкормка Ам. селитра }\left(\mathrm{N}_{30}\right) \\
\text { + подкормка в фазе выхода в трубку } \mathrm{N}_{30}\end{array}$ & 52,0 & 7,2 & 25,0 & 2,6 \\
\hline $\begin{array}{l}\text { 6. Ранневесенняя подкормка КАС-32 }\left(\mathrm{N}_{30}\right)+ \\
\text { подкормка в фазе выхода в трубку } \mathrm{N}_{15}\end{array}$ & 53,5 & 8,7 & 24,8 & 2,4 \\
\hline $\begin{array}{l}\text { 7. Ранневесенняя подкормка КАС-32 }\left(\mathrm{N}_{60}\right)+ \\
\text { подкормка в фазе выхода в трубку } \mathrm{N}_{30}\end{array}$ & 52,9 & 8,1 & 25,3 & 2,9 \\
\hline $\mathrm{HCP}_{05}$ & & 1,86 & & 0,80 \\
\hline
\end{tabular}

Эффективность двукратной обработки посевов озимой пшеницы аммиачной селитрой в фазе кущения в дозе $\mathrm{N}_{30}$ и фазе начало выхода в трубку в дозе N30 была несколько ниже. Прибавка урожая озимой пшеницы в этом варианте составила 7,2 ц/га или $16,1 \%$ в сравнении с контролем.

Обработка посевов озимой пшеницы различными видами азотных удобрений обеспечивала существенное повышение содержания сырой клейковины в зерне озимой пшеницы. При этом эффективность различных видов азотных удобрений (аммиачной селитры и КАС-32) была практически одинакова. Так, использование аммиачной селитры для подкормки озимой пшеницы в фазе кущения в дозе $\mathrm{N}_{30}$ и фазе начало выхода в трубку в дозе $\mathrm{N}_{30}$ увеличивало содержание сырой клейковины в зерне на 2,6\%, а жидкого азотного удобрения КАС32 в тех же дозах - на 2,4\%. С повышением дозы внесения КАС-32 до $\mathrm{N}_{60}$ при ранневесенней подкормке и до $\mathrm{N}_{30}$ при подкормке в фазе начало выхода в трубку содержание сырой клейковины в зерне озимой пшеницы повышалось на $2,9 \%$.

Расчеты экономической эффективности показали, что использование жидкого азотного удобрения КАС-32 на посевах озимой пшеницы было экономически выгодно. Наиболее высокий условно чистый доход (4693,9 руб./га) 
был получен в варианте с двукратной обработкой посевов препаратом КАС-32 в фазе кущения в дозе $\mathrm{N}_{30}$ и фазе начало выхода в трубку в дозе $\mathrm{N}_{15}$. Увеличение дозы внесения жидкого азотного удобрения при ранневесенней подкормке до $\mathrm{N}_{60}$ и до $\mathrm{N}_{30}$ при подкормке в фазе начало выхода в трубку приводило к снижению величина условно чистого дохода на 2073,3 руб. (2620,6 руб./га). При обработке посевов озимой пшеницы аммиачной селитрой в фазе кущения и фазе начало выхода в трубку в дозе $\mathrm{N}_{30}$ величина условно чистого дохода составила 3596,0 руб./га, т.е. использование препарата удобрения КАС-32 на посевах озимой пшеницы было экономически выгоднее, чем аммиачной селитры.

Заключение. Результаты проведенных испытаний установлено, что двукратная обработка посевов удобрением КАС-32 в фазе кущения в дозе $\mathrm{N}_{30}$ и фазе начало выхода в трубку в дозе $\mathrm{N}_{15}$ повышала урожайность озимой пшеницы на 8,7 ц/га или 19,4\%, содержание сырой клейковины в зерне на 2,4\%. Увеличение дозы подкормки КАС-32 до $\mathrm{N}_{60}$ в фазе кущения и до $\mathrm{N}_{30}$ в фазе начало выхода в трубку увеличивало урожайность озимой пшеницы на 8,1 ц/га или $18,1 \%$, содержание сырой клейковины в зерне на $2,9 \%$. Снижение урожайности озимой пшеницы в этом варианте (на 0,6 ц/га) связано с отрицательным влиянием повышенных доз препарата КАС-32 (обжог листьев озимой пшеницы). Наиболее высокий условно чистый доход (4693,9 руб./га) был получен в варианте с двукратной обработкой посевов препаратом КАС-32 в фазе кущения в дозе $\mathrm{N}_{30}$ и фазе начало выхода в трубку в дозе $\mathrm{N}_{15}$. Увеличение дозы внесения жидкого азотного удобрения при ранневесенней подкормке до $\mathrm{N}_{60}$ и до $\mathrm{N}_{30}$ при подкормке в фазе начало выхода в трубку приводило к снижению величина условно чистого дохода на 2073,3 руб./га.

\section{Библиографический список}

1. Минеев В.Г. Агрохимия и экологические проблемы современного земледелия / В.Г. Минеев // Экологические функции агрохимии в современном земледелии. М.: ВНИИА, 2008. C. 5-8.

2. Соловиченко В.Д., Тютюнов С.И., Уваров Г.И. Воспроизводство плодородия почв и рост продуктивности сельскохозяйственных культур Центрально-Черноземного региона. - Белгород: Отчий край, 2011. - 255 с.

3. Лазарев В.И., Золотарева И.А., Хижняков А.Н. Эффективность влияния отдельных видов минеральных удобрений и их сочетаний на продуктивность культур зернопропашного севооборота // Вестник Курской ГСХА. Курск, 2014. - №3. - С. 58-59.

4. Применение карбамид-аммиачной смеси под основные сельскохозяйственные культуры: рекомендации / Ф.Н. Леонов [и др.]; под общ. ред. Ф.Н. Леонова. - Минск, 2004. - 12 с.

5. Дудкина Е. Карбамидно-аммиачная смесь (КАС) / Е. Дудкина // Агроном, 2013. - № 1 (лютий). - С. 20-22.

6. Пасічник Н. А. Застосування КАС для підживлення пшениці озимої на лучно-чорноземному карбонатному грунті / Н. А. Пасічник, I. У. Марчук // Вісн. ХНАУ, 2013. - № 1. - С. 140-143. - (Сер. Агрохімія). КАС

7. Доспехов Б.А. Методика полевого опыта. - М., Агропромиздат, 1985. - 351 с. 
УДК 631.471

\title{
БАЗА ДАННЫХ ЛИМИТИРУЮЩИХ УРОЖАЙ ФАКТОРОВ СЕЛЬСКОХОЗЯЙСТВЕННЫХ КУЛЬТУР ДЛЯ ПОЧВЕННЫХ ИНФОРМАЦИОННЫХ СИСТЕМ
}

\author{
Лапа В.В., Матыченков Д.В., Азаренок Т.Н., \\ Матыченкова О.В., Дыдышко С.В.
}

РУП «Институт почвоведения и агрохимии», Минск, Республика Беларусь E-mail:odm@brissa.by

\begin{abstract}
Резюме. Статья посвящена созданию базы данных лимитирующих урожай сельскохозяйственных культур факторов. На ее основе производится установление лимитирующих урожай факторов для каждого элементарного участка по каждой культуре.

Summary. The article is devoted to the creation of a database of factors limiting the yield of agricultural crops. On its basis, the establishment of factors limiting the yield is made for each elementary plot for each crop.
\end{abstract}

Современный подход к управлению продуктивностью сельскохозяйственных культур имеет комплексный характер и должен формироваться по принципам, которые учитывают особенности фотосинтеза, морфогенеза и минерального питания, и обеспечивают управления ими. Первоочередной задачей такого подхода является максимальное нивелирование препятствующих факторов сближения биологического потенциала культуры (сорта) с фактическим. Основная цель формирования агротехнологий, основанных на интегрированном применении средств химизации, заключается в последовательном преодолении факторов, лимитирующих урожайность сельскохозяйственной культуры и качества продукции. Лимитирующими факторами следует называть такие факторы, которые ограничивают развитие организмов из-за недостатка или их избытка по сравнению с потребностью (оптимальным содержанием).

Получение планируемых урожаев сельскохозяйственных культур в значительной мере обусловливается уровнем обеспеченности растений элементами питания. В этой связи первостепенной задачей системы удобрения является оптимизация питания растений при минимальных затратах удобрений. Высокая их эффективность может быть достигнута лишь в том случае, когда внесение элементов питания, лимитирующих рост и развитие растений, полностью компенсирует дефицит питательных веществ в почве и соответствует нуждаемости в них растений.

Важнейшими фактором, определяющим и, в конечном счете, плодородие почв, является ее классификационная принадлежность, определяемая рядом соподчиненных свойств: типовая принадлежность почв, гранулометрический состав, подстилание. Еще одним фактором, влияющим на достижение максимальной урожайности сельскохозяйственных культур, является режим увлажнения почв. Как дефицит влаги, так и ее переизбыток часто являются лимитирующими факторами повышения урожайности и должны учитываться при формировании системы удобрений как севооборота, так и отдельных культур. Повышенная кислотность также является лимитирующим фактором 
получения высоких урожаев сельскохозяйственных культур. Большинство почв луговых земель Беларуси имеет от природы кислую реакцию почвенной среды, что часто является лимитирующим фактором в повышении продуктивности сенокосов и пастбищ. Хотя травянистая растительность способствует развитию дернового почвообразовательного процесса, ведущего к накоплению щелочноземельных металлов в корнеобитаемом слое, но процессы выщелачивания преобладают над процессами аккумуляции. Единственным коренным приемом оптимизации кислотности почв является их известкование.

Практика показывает, что прибавка урожая от улучшения одного фактора, обычно лимитирующего урожаи, бывает большей, если одновременно улучшается и другой лимитирующий фактор. Так, максимальной прибавки от азота можно добиться только, если культуры получают фосфор, калий и воду в достаточных количествах.

По обобщенным данным, именно по фитосанитарным причинам при размещении по плохим предшественникам урожайность пшеницы и тритикале снижается до 40\%, ячменя - до 30\%, озимой ржи - до 15\% и овса - до 10\% [1]. Особенно сильно реагируют на нарушение севооборота бобовые культуры. Только химическими средствами далеко не удается решить проблему борьбы с болезнями, вредителями и сорняками. Увеличение уровня удобрений, повышение степени окультуренности почвы и применение полной химической защиты растений не снижает роли севооборота в повышении урожайности сельскохозяйственных культур. Поэтому так важен и выбор предшественника в севооборотах.

Почвы республики характеризуются большой пестротой по уровню плодородия. Большие различия между полями наблюдаются по типам почв, гранулометрическому составу, степени увлажнения, эродированности, закамененности, агрохимическим показателям, удаленности от производственных центров и другим показателям. Поэтому при планировании системы использования земли, оптимизации структуры посевных площадей и системы севооборотов следует учитывать особенности каждого рабочего участка (поля).

Для учета максимально возможного количества факторов, лимитирующих производительность возделываемых культур, в основу базы данных положена информация об агропроизводственных группировках почв [2]. Кроме общей агропроизводственной группировки почв республики по пригодности под сельскохозяйственные культуры, большое значение в современных условиях имеют частные (специализированные) группировки для каждой из культур с учетом их индивидуальных требований к почвенным условиям. В этих группировках для конкретной сельскохозяйственной культуры в каждой степени пригодности приводится перечень классификационных единиц почв с учетом типовой принадлежности, степени и режима увлажнения, гранулометрического состава почвообразующих и подстилающих пород, агроэкологического состояния, которые по своим показателям и производительной способности соответствуют той или иной группе пригодности почв. Такие группировки почв разработаны под наиболее требовательные к почвенным условиям культуры, 
возделываемые в республике: озимую пшеницу, озимое тритикале, яровую пшеницу, ячмень, лен, сахарную свеклу, озимый рапс. Используя данные частных агропроизводственных группировок, регламенты возделывания сельскохозяйственных культур, различные рекомендации, нормативы и справочники, были созданы базы данных лимитирующих урожай факторов для следующих культур: озимая пшеница (табл. 1), озимое тритикале, озимая рожь, яровая пшеница, ячмень, лен, сахарная свекла, озимый рапс, люцерна, кукуруза на зерно, кукуруза на зеленую массу, картофель, лен долгунец.

Таблица 1 - База данных лимитирующих урожай факторов для озимой пшеницы

\begin{tabular}{|c|c|c|c|c|c|c|c|c|c|c|c|c|c|c|c|}
\hline \multirow{2}{*}{ Факторы } & \multicolumn{15}{|c|}{ Значение лимитирующего фактора } \\
\hline & \multicolumn{2}{|c|}{ Оптимальное } & \multicolumn{5}{|c|}{ Пригодное } & \multicolumn{4}{|c|}{ Допустимое } & \multicolumn{4}{|c|}{ Недопустимое } \\
\hline 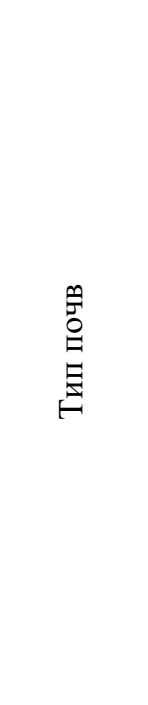 & 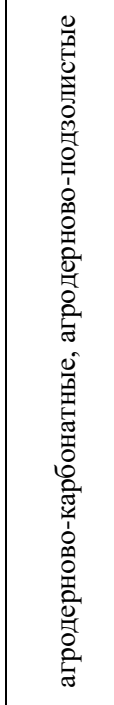 & 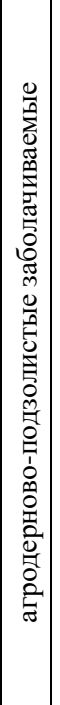 & 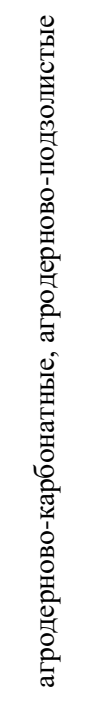 & 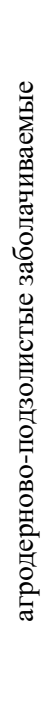 & 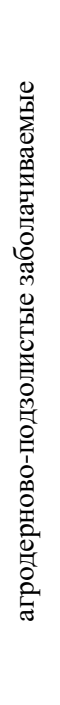 & 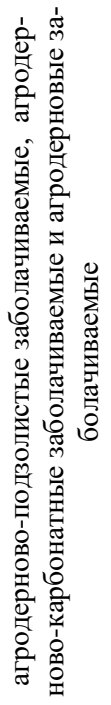 & 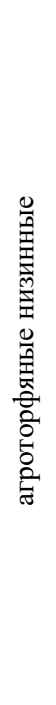 & 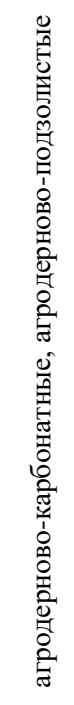 & 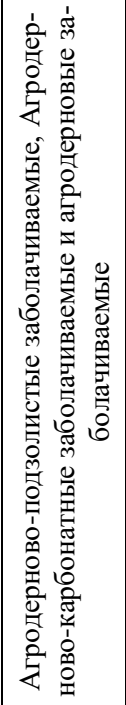 & 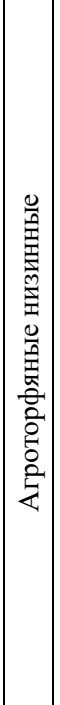 & 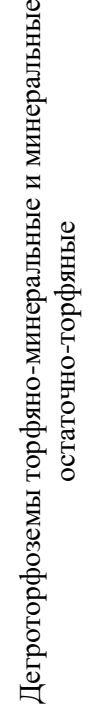 & 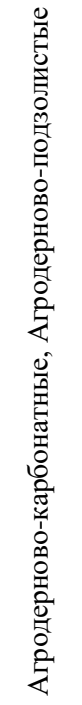 & 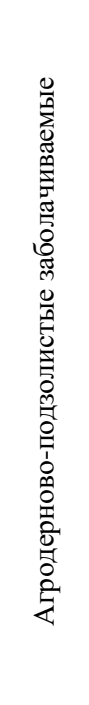 & 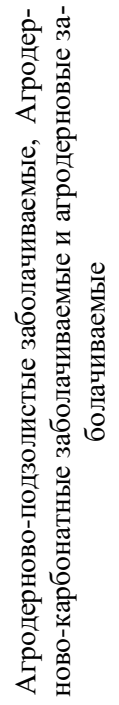 & 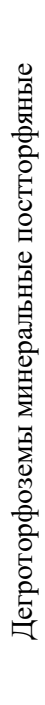 \\
\hline 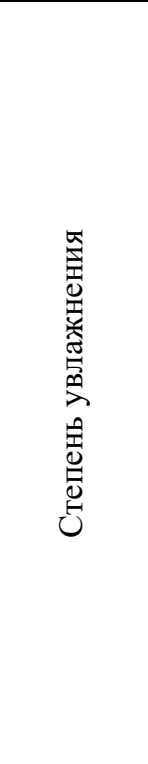 & 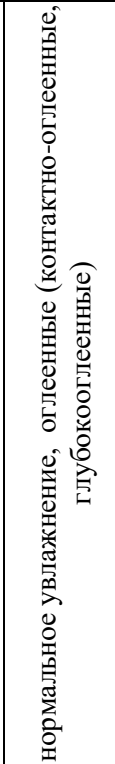 & 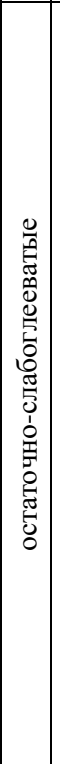 & 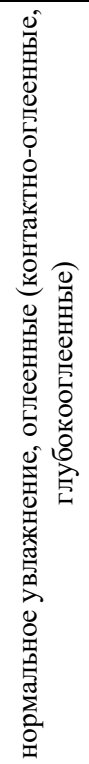 & 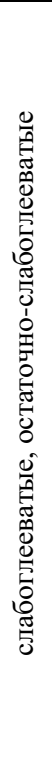 & 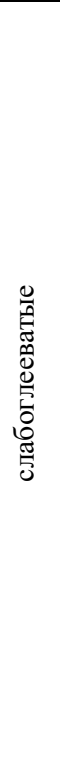 & 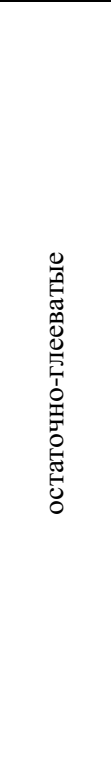 & 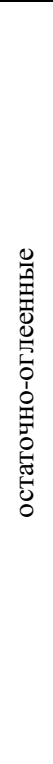 & 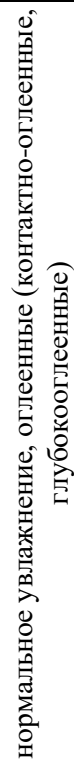 & 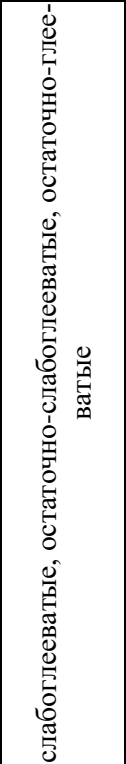 & 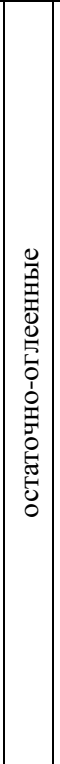 & 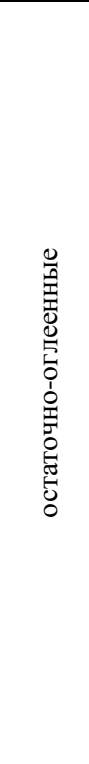 & 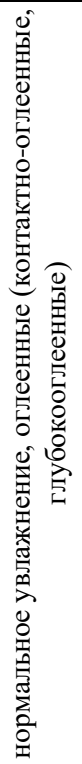 & 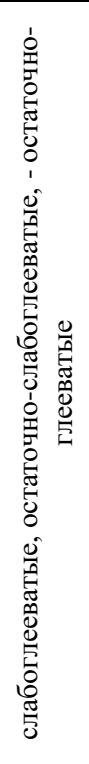 & 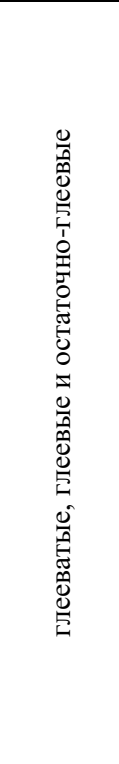 & 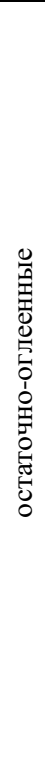 \\
\hline
\end{tabular}




\begin{tabular}{|c|c|c|c|c|c|c|c|c|c|c|c|}
\hline 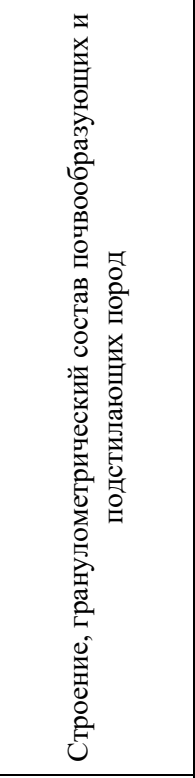 & 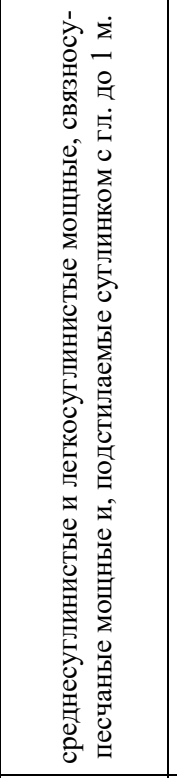 & 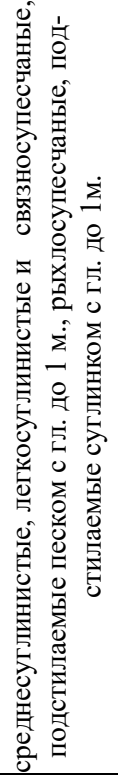 & 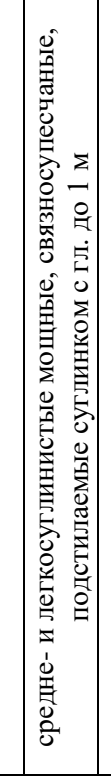 & 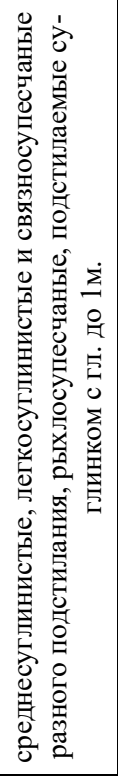 & $\begin{array}{l}\Sigma \\
\Sigma \\
n \\
0 \\
0 \\
0 \\
0 \\
0 \\
0 \\
0 \\
0 \\
0 \\
0 \\
0 \\
0 \\
0 \\
z\end{array}$ & 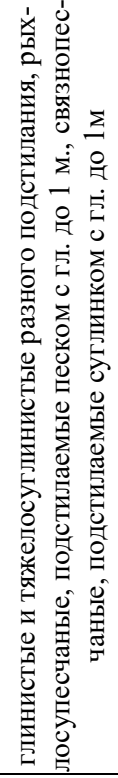 & 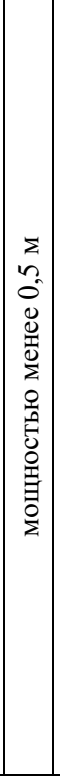 & 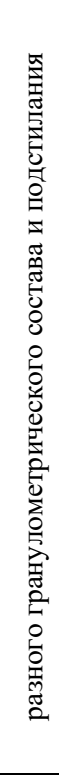 & 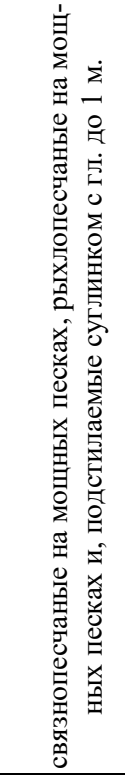 & 罷 & 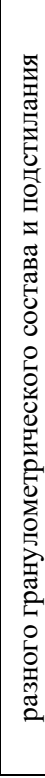 \\
\hline $\begin{array}{c}\text { Эродирован- } \\
\text { ность }\end{array}$ & Отсутствует & \multicolumn{4}{|c|}{ слабая } & \multicolumn{3}{|c|}{ средняя } & \multicolumn{3}{|c|}{ сильная и очень сильная } \\
\hline Диапазон pH & $6,01-7,00$ & \multicolumn{4}{|c|}{$\begin{array}{l}5,81-6,00 \\
7,01-7,50\end{array}$} & \multicolumn{3}{|c|}{$\begin{array}{l}5,50-5,80 \\
7,51-8,00\end{array}$} & \multicolumn{3}{|c|}{$\begin{array}{l}<5,50 \\
>8,00 \\
\end{array}$} \\
\hline $\begin{array}{c}\text { Содержание } \\
\text { гумуса, \% }\end{array}$ & $>1,8$ & \multicolumn{4}{|c|}{$>1,8$} & \multicolumn{3}{|c|}{$>1,8$} & \multicolumn{3}{|c|}{$<1,8$} \\
\hline $\begin{array}{c}\text { Содержание } \\
\text { фосфора, мг/кг } \\
\text { почвы } \\
\end{array}$ & $>300$ & \multicolumn{4}{|c|}{$201-300$} & \multicolumn{3}{|c|}{$151-200$} & \multicolumn{3}{|c|}{$<150$} \\
\hline $\begin{array}{c}\text { Содержание } \\
\text { калия, мг/кг } \\
\text { почвы } \\
\end{array}$ & $>300$ & \multicolumn{4}{|c|}{$201-300$} & \multicolumn{3}{|c|}{$151-200$} & \multicolumn{3}{|c|}{$<150$} \\
\hline 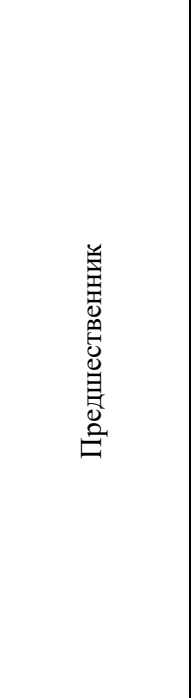 & 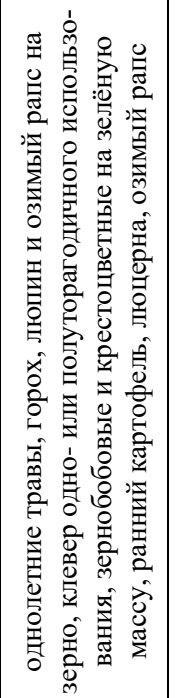 & \multicolumn{4}{|c|}{ 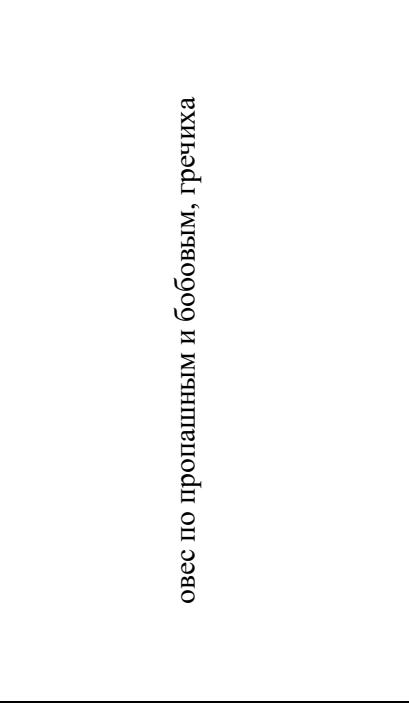 } & \multicolumn{3}{|c|}{ 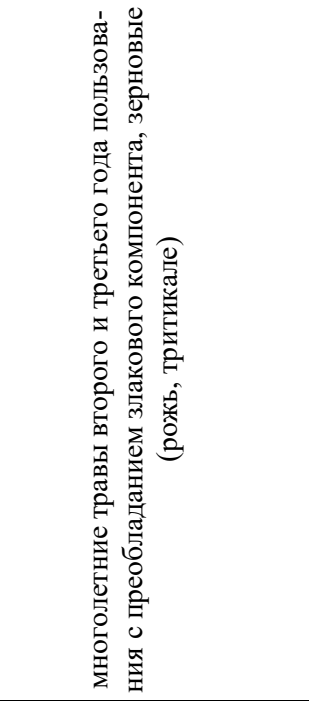 } & \multicolumn{3}{|c|}{ 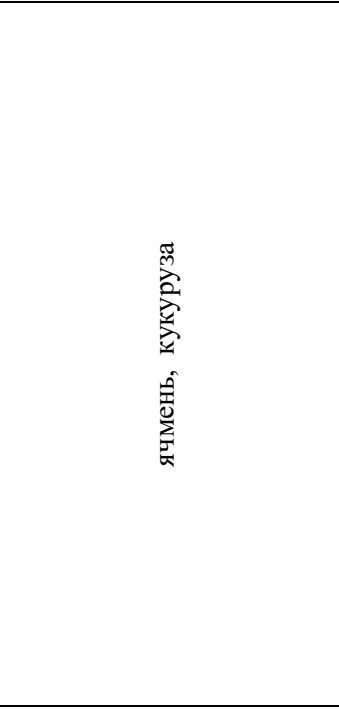 } \\
\hline
\end{tabular}

В самой базе данный значение типа почв, увлажнения, гранулометрического состава и подстилания представлены в виде кодировки согласно «Номенклатурного списка почв Беларуси» [3], являющегося отраслевым стандартом цифровой почвенной картографии Беларуси. Следует отметить также, что базы данных могут быть пополнены информацией о дополнительных факторах, влияющих на урожайность сельскохозяйственных культур - содержание микроэлементов, содержание кальция, и т.д.

Исходя из классификационной принадлежности почвенного покрова, а также факторов, лимитирующих урожайность возделываемой культуры, 
производится присвоение почвенному контуру цифровой почвенной карты то или иное значение самого фактора. То есть лимитирующим может быть не только один, но и целая совокупность факторов. Здесь следует различать те факторы, которые могут быть изменены в процессе окультуривания почвенного покрова, и те, которые являются перманентными, то есть постоянными и не могут быть изменены в обозримом будущем. К таким относится типовая принадлежность почв, характер и гранулометрический состав как подстилающих пород, так и самих почв. Следующей является задача установление влияния факторов для данной сельскохозяйственной культуры для всего элементарного участка. Используя геостатистический метод объединения контуров на основе идентичности заданного параметра, в конечном итоге присваивается значение лимитирующего фактора в целом конкретного рабочего участка. Для этого используются методы статистической обработки нечисловых данных [4]. Таким образом производится установление лимитирующих урожай факторов для каждого элементарного участка по каждой культуре.

Полученные результаты исследований явятся составной частью многоцелевой оценки пригодности почвенного покрова для возделывания сельскохозяйственных культур с учетом его потенциального плодородия и выявление лимитирующих урожай факторов для каждой возделываемой культуры и элементарного участка.

\section{Библиографический список}

1. Земледелие / П.И. Никончик [и др.]; под ред. П. И. Никончика. - Минск: ИВЦ Минфина, 2014. - $584 \mathrm{c.}$

2. Лапа В.В., Цытрон Г.С., Шибут Л.И. Пригодность почв Республики Беларусь для возделывания отдельных сельскохозяйственных культур: рекомендации. - Минск, 2011 - 65 с.

3. Смеян, Н.И. Номенклатурный список почв Беларуси (для целей крупномасштабного картографирования) / Смеян Н.И. [и др.]. - Минск, 2003. - 43 с.

4. Почвенно-информационные системы в агропочвоведении / В.В. Лапа [и др.] // Земледелие и защита растений, 2018. - №2 (117). - С. 9-12.

УДК. 631.111 .1

\section{ИЗУЧЕНИЕ УСТОЙЧИВОСТИ К ПОЛЕГАНИЮ СОРТООБРАЗЦОВ ОЗИМОЙ ТРИТИКАЛЕ В КОНКУРСНОМ СОРТОИСПЫТАНИИ ФГБНУ «КУРСКИЙ ФАНЦ»}

Логвинова Е.В., Емельянова А.А.

ФГБНУ «Курский федеральный аграрный научный центр»

E-mail: logvinova.e78@mail.ru,emeiyanova.a87@mail.ru

Резюме. В статье изложены результаты исследования за 2018-2020 г2. сортообразиов озимой тритикале в конкурсном сортоиспытании ФГБНУ «Курский ФАНЦ». При исследовании сортообразиов озимой тритикале особое внимание уделялось сортам и линиям, проявившим себя как устойчивых к полеганию во время колошения, перед уборкой и их урожайности.

Ключевые слова: селекция, линия, озимая тритикале, полегание, устойчивость, урожай, высота растений. 
В современных системах земледелия и адаптивной селекции известно, что одним из направлений является создание сортов с высоким уровнем адаптивных свойств, способных давать стабильно высокие урожаи зерна в постоянно изменяющихся агроклиматических условиях. Роль культуры тритикале в увеличении производства зерна постоянно возрастает. (1) Поэтому создание высокоурожайных сортов обязательно включает в себя оценку устойчивости к полеганию.

Полегание - один из главных факторов, влияющих на урожайность озимой тритикале, качество зерна и содержание в нем питательных веществ. При полегании понижается устойчивость растений к болезням, формируется щуплое зерно, возникают проблемы с уборкой урожая. Полегание тритикале в предуборочный и уборочный периоды, сопровождающиеся неблагоприятными погодными условиями и частым выпадением дождей, влечет за собой прорастание зерна на корню и значительным снижением хлебопекарного и комбикормового качества. Формирование мелкого зерна с низкой массой 1000 зерен в результате нарушения транспортировки ассимилянтов в колос - частое явление при полегании, наступившем до налива зерна. Потери зерна на полегающих посевах тритикале составляет в среднем от 30-65\% [2]. Полегание посевов на стадиях колошения, молочной, восковой, полной спелости зерна приводит к снижению урожайности до $20 \%$ соответственно. Даже кратковременное полегание растений вызывает потери урожая [3].

Важнейший морфологический признак, связанный с устойчивостью к полеганию - это высота растений. Основным направлением для снижения риска возникновения полегания стало выведение сортов, несущих гены короткостебельности [4].

Цель исследований - изучить выделенные в конкурсном сортоиспытании сортообразцы озимой тритикале, характеризующиеся высокой адаптивностью к абиотическим и биотическим факторам среды почвенно-климатических условий Курской области.

Материал, методы и условия проведения исследований. Материалом исследования являются сорта и линии озимой тритикале. Исследования проводились на базе экологической селекции ФГБНУ «Курский ФАНЦ». Методика проведения исследований общепринятая в селекционном процессе с использованием статистических методов «Методика полевого опыта» Б.А. Доспехова $[5,6]$.

Изучаемый материал выращивали на полях специального селекционного севооборота по технической агротехники региона. Предшественник чистый пар. Почва опытного участка представлена черноземом типичным. Учетная площадь делянки $10 \mathrm{~m}^{2}$, повторность опыта 6-ти кратная, норма высева 4 млн. всхожих семян на 1 га. Расположение делянок в первом ярусе систематическая, для удобства демонстрации опыта, в остальных - рендомизированное. Способ посева сплошной рядовой. Сеялка - СКС 6-10, ширина междурядий 15 см.

В опытах проводились фенологические наблюдения по фазам развития растений. Велся учет густоты стояния по всходам и перед уборкой, учет 
поражения болезнями (мучнистая роса, бурая ржавчина). А также проводилась бальная оценка состояния посевов по всходам, после перезимовки и перед уборкой, учитывалась устойчивость к полеганию в фазы колошения и полной спелости. В лабораторных условиях растения анализировались по элементам структуры урожая, выполненности и выравненности зерна.

Погодные условия отличались между собой не только температурным режимом в процессе вегетации растений, но количеством выпавших осадков.

Результаты исследования. Исследования (2018-2020 гг.) были направлены на комплексную оценку сортообразцов озимой тритикале в конкурсном сортоиспытании. Полегание является одним из самых серьезных недостатков тритикале. Оно приводит к резкому снижению урожайности зерна, а также его качества вследствие преждевременного прорастания зерна в колосе. (4) Поэтому в лаборатории экологической селекции ФГБНУ «Курского ФАНЦ» при изучении сортов озимой тритикале обязательно включает в себя оценку устойчивости к полеганию. Полегание наблюдалась во все годы исследований, однако сорта проявили себя к нему по-разному (Таблица 1).

Таблица 1 - Устойчивость к полеганию растений выделенных сортообразцов озимой тритикале, балл

\begin{tabular}{|l|c|c|c|c|c|c|c|c|}
\hline \multirow{2}{*}{ Сорт, линия } & \multicolumn{2}{|c|}{2018 г. } & \multicolumn{2}{c|}{2019 г. } & \multicolumn{2}{c|}{2020 г. } & \multicolumn{2}{c|}{ Среднее } \\
\cline { 2 - 9 } & $\begin{array}{c}\text { в пе- } \\
\text { риод } \\
\text { коло- } \\
\text { шения }\end{array}$ & $\begin{array}{c}\text { перед } \\
\text { убор- } \\
\text { кой }\end{array}$ & $\begin{array}{c}\text { в пе- } \\
\text { риод } \\
\text { ко- } \\
\text { лоше- } \\
\text { ния }\end{array}$ & $\begin{array}{c}\text { перед } \\
\text { убор- } \\
\text { кой }\end{array}$ & $\begin{array}{c}\text { в пе- } \\
\text { риод } \\
\text { ко- } \\
\text { лоше- } \\
\text { ния }\end{array}$ & $\begin{array}{c}\text { перед } \\
\text { убор- } \\
\text { кой } \\
\text { риод } \\
\text { ко- } \\
\text { лоше- } \\
\text { ния }\end{array}$ & $\begin{array}{c}\text { перед } \\
\text { убор- } \\
\text { кой }\end{array}$ \\
\hline Тальва 100 ст. & 4,5 & 4,0 & 4,0 & 4,0 & 4,0 & 3,0 & 4,2 & 3,7 \\
\hline Атаман Платов & 5,0 & 5,0 & 5,0 & 5,0 & 5,0 & 5,0 & 5,0 & 5,0 \\
\hline Гектор & 5,0 & 4,5 & 4,5 & 4,0 & 5,0 & 5,0 & 4,7 & 4,5 \\
\hline Валентин 90 & 5,0 & 4,0 & 5,0 & 4,0 & 4,5 & 4,0 & 4,7 & 4,0 \\
\hline Трудяга & 5,0 & 4,5 & 4,5 & 4,0 & 4,5 & 4,0 & 4,7 & 4,2 \\
\hline Богуслав & 5,0 & 5,0 & 5,0 & 5,0 & 5,0 & 5,0 & 5,0 & 5,0 \\
\hline Каприз & 5,0 & 5,0 & 4,5 & 4,5 & 5,0 & 5,0 & 4,8 & 4,8 \\
\hline $3461 / 16$ & 5,0 & 4,5 & 5,0 & 4,0 & 5,0 & 5,0 & 5,0 & 4,5 \\
\hline $11-11$ Т41-7 & 5,0 & 5,0 & 5,0 & 5,0 & 5,0 & 5,0 & 5,0 & 5,0 \\
\hline $11-131$ Т11-15 & 5,0 & 4,5 & 5,0 & 4,5 & 5,0 & 5,0 & 5,0 & 4,7 \\
\hline
\end{tabular}

На фоне неблагоприятных погодных условий, в период созревания устойчивость к полеганию сохранили практически все изучаемые сорта и линии в конкурсном сортоиспытании. Также выделенные сорта и линии характеризуются высоким уровнем зимостойкости и устойчивостью к основным листовым болезням.

Высота растений играет немаловажную роль в формировании урожая. Полегание растений в нашей зоне, когда происходят катаклизмы, напрямую зависит от высоты растений. Поэтому селекционеры акцентируют внимание на создание низкорослых и среднерослых сортов (2). В таблице 2 представлены сорта и сортообразцы с различной высотой растений. 
Таблица 2 - Высота, вегетационный период растений и урожай озимой тритикале (среднее за 2018-2020 гг.)

\begin{tabular}{|l|c|c|c|}
\hline \multicolumn{1}{|c|}{ Сорт, линия, } & $\begin{array}{c}\text { Вегетационный пе- } \\
\text { риод, дней }\end{array}$ & $\begin{array}{c}\text { Высота растений, } \\
\text { см }\end{array}$ & Урожайность, ц/га \\
\hline Тальва 100, ст. & 296 & 148 & 72,0 \\
\hline Атаман Платов & 296 & 102 & 94,9 \\
\hline Гектор & 298 & 107 & 91,5 \\
\hline Валентин 90 & 298 & 117 & 78,6 \\
\hline Трудяга & 300 & 119 & 82,2 \\
\hline Богуслав & 303 & 104 & 76,9 \\
\hline Каприз & 295 & 112 & 87,3 \\
\hline $3461 / 16$ & 297 & 97 & 84,3 \\
\hline $11-11$ Т41-7 & 300 & 99 & 80,7 \\
\hline $11-131$ Т11-15 & 298 & 106 & 84,8 \\
\hline
\end{tabular}

Вегетационный период выделенных сортообразцов составил от 296 до 303 дней. Высота растений колебалась от 97 до $148 \mathrm{~cm}$, урожайность в среднем по годам составила 72,0-94,9 ц/га.

Таким образом, степень устойчивости к полеганию растений зависит от многих внешних и внутренних факторов. Для снижения риска возникновения полегания необходимо учитывать не только анатомо-морфологические и физиологические особенности сорта, такие как длина, толщина и упругость стебля, длина междоузлий, сопротивляемости к горизонтальным нагрузкам и др., но и климатические особенности регионов, на территории которых культивируются сортообразцы. Следует отметить, что тритикале, в отличие от других зерновых культур, более стрессовынослива как в отношении погодных условий, так и почв.

\section{Библиографический список}

1. Грабовец, А.И. Тритикале / А.И. Грабовец, А.В. Крохмаль. - Ростов-на-Дону: ООО «Издательство «Юг», 2018. - 440 с.

2. Емельянова А.А., Логвинова Е.В., Новикова В.Т. Результаты экологического испытания сортообразцов, номеров озимого тритикале/ Тритикале Материалы 8-й Международной научно-пра5тической конференции «Тритикале и стабилизация производства зерна, кормов и продуктов их переработки» 7 июня 2018 года восьмой выпуск Ростов-на-Дону, 2018. C.56-60.

3. Медведев А.М., Васютин А.С., Медведева Л.М. Изучение мирового генофона озимой тритикале в Московской области //Аграрный вестник Юго-Востока. - 2014. - №1-2. - С.3437.

4. Ворончихина И.Н., Ворончихин В.В., Пыльнев В.В., Рубец В.С. Изучение устойчивости сортообразцов озимой тритикале к полеганию в условиях Центрального региона Нечерноземной зоны России/ Тритикале Материалы секции тритикале ОСХН РАН он-лайн «Селекция, генетика, агротехника и технология переработки сырья» 9 июня 2020 года выпуск 9 Ростов-на-Дону, 2021. - С. 97-101.

5. Методика Государственного сортоиспытания сельскохозяйственных культур. - Вып.2. - M., 1989.

6. Доспехов Б.А. Методика полевого опыта. - М.: Агропромиздат, 1985. -351 с. 
УДК 631.559: 633.11«324»: 631.582: 631.82

\title{
УРОЖАЙНОСТЬ И КАЧЕСТВО ЗЕРНА ОЗИМОЙ ПШЕНИЦЫ В СЕВООБОРОТАХ ЦЧР ПРИ РАЗНОМ УРОВНЕ МИНЕРАЛЬНОГО ПИТАНИЯ
}

\author{
Лукьянов В.А. \\ ФГБНУ «Курский ФАНЦ», г. Курск \\ E-mail: lukyanov27@mail.ru
}

\begin{abstract}
Резюме. В условиях Центрально-Чернозёмного региона изучено влияние разных видов севооборотов и трёх уровней минерального питания на урожайность и качество зерна озимой пшеницы. В зернопаропропашном севообороте была получена наибольшая урожайность зерна, которая изменялась в зависимости от применяемых доз минеральных удобрений. Показатели качества зерна озимой пшеницы варьировались неоднозначно, однако, их улучшение наблюдалось с дозой минеральных удобрений $N_{40} P_{80} K_{80}$.
\end{abstract}

Ключевые слова: озимая пшенииа, гидротермические условия, севообороты, минеральные удобрения, агротехнологии.

Summary. In the conditions of the Central Chernozem region, the influence of different types of crop rotations and three levels of mineral nutrition on the yield and quality of winter wheat grain was studied. In the grain-fallow-row crop rotation, the highest grain yield was obtained, which varied depending on the applied doses of mineral fertilizers. The indicators of the quality of winter wheat grain varied ambiguously, however, their improvement was observed with a dose of mineral fertilizers $\mathrm{N}_{40} \mathrm{P}_{80} \mathrm{~K}_{80}$.

Key words: winter wheat, hydrothermal conditions, crop rotations, mineral fertilizers, agricultural technologies.

Введение. Урожайность зерна озимой пшеницы в нашей стране из года в год увеличивается благодаря многим факторам, но особое место занимает интенсификации агротехнологий и их оптимизация. Вместе с этим, следует отметить важность комплексных научных исследований, без которых невозможно совершенствование традиционных способов возделывания сельскохозяйственных культур.

В список важнейших элементов современного земледелия входят системы севооборотов и удобрений, эффективное использование которых позволяет не только увеличить урожайность и качество зерна озимой пшеницы, но и сохранить плодородие почв. Системы севооборотов позволяют рационально использовать площади пашни, с их помощью можно стабилизировать запасы органического вещества в почве, сохранить влагу, спланировать надёжную защиту от вредителей и болезней, реализовать биологический потенциал ценных полевых культур [1, 2, 3].

С биологической точки зрения, период использования легкодоступных минеральных форм азота, фосфора, калия и микроэлементов намного меньше, чем послеуборочных корневых и пожнивных остатков, поэтому, если рассматривать минеральные формы удобрений как фактор увеличения урожайности, то по сравнению с севооборотами, удобрения преобладают над ними. Тем не менее, прибавка от правильно смоделированных севооборотов может быть значительной $[4,5]$. С другой стороны, увеличение урожайности в отдельных 
случаях приводит к снижению показателей качества продукции, что может быть связано с особенностями сорта или дефицитом определённых питательных веществ $[6,7,8]$.

Цель исследований - определение влияния севооборотов и доз минеральных удобрений на урожайность и качество зерна озимой пшеницы в условиях Центрально-Чернозёмного региона.

Методика исследований. Исследования проводились в 2015-2020 гг. в стационарном многофакторном полевом опыте ФГБНУ «Курский ФАНЦ». Схема опыта включала: фактор А - зернопаропропашной (озимая пшеницакукуруза на зелёный корм - ячмень - чистый пар), зернотравянопропашной (озимая пшеница - кукуруза на зелёный корм - ячмень + многолетние травы многолетние травы первого года), зернотравяной (озимая пшеница - ячмень + многолетние травы - многолетние травы первого года - многолетние травы второго года; фактор В - уровень минерального питания (без удобрений,

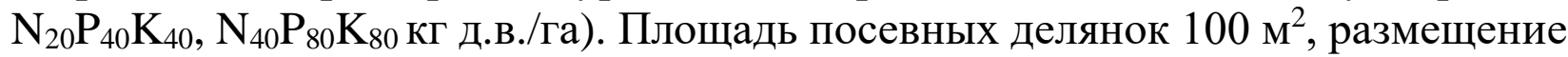
вариантов рандомизированное. Сорт озимой пшеницы «Синтетик», норма высева семян 5 млн шт./га. Почвенный покров представлен чернозёмом типичным среднесуглинистым, агрохимические показатели которого (в слое 0-20 см) имели следующие характеристики: $\mathrm{pH}$ - 5,33, гумус 5,05 \%, щёлочно-гидролизуемый азот 16,16 мг/100 г, подвижный фосфор 10,73 мг/100 г, обменный калий $8,73 \mathrm{мг} / 100$ г.

Результаты и обсуждение. Метеорологические условия в периоды проведения исследований были оптимальными для роста и развития озимой пшеницы, однако, в некоторые месяцы отмечалось недостаточное количество осадков (рисунок 1). Гидротермический коэффициент за период её вегетации в 2015-2016 гг. составил 1,28, а в 2019-2020 гг. он практически не изменился 1,29 . В августе 2015 г. (в период посева озимой пшеницы) отмечено незначительно количество осадков $(Г Т К=0,05)$, но уже в сентябре количество осадков увеличилось и ГТК составил $1,74$.

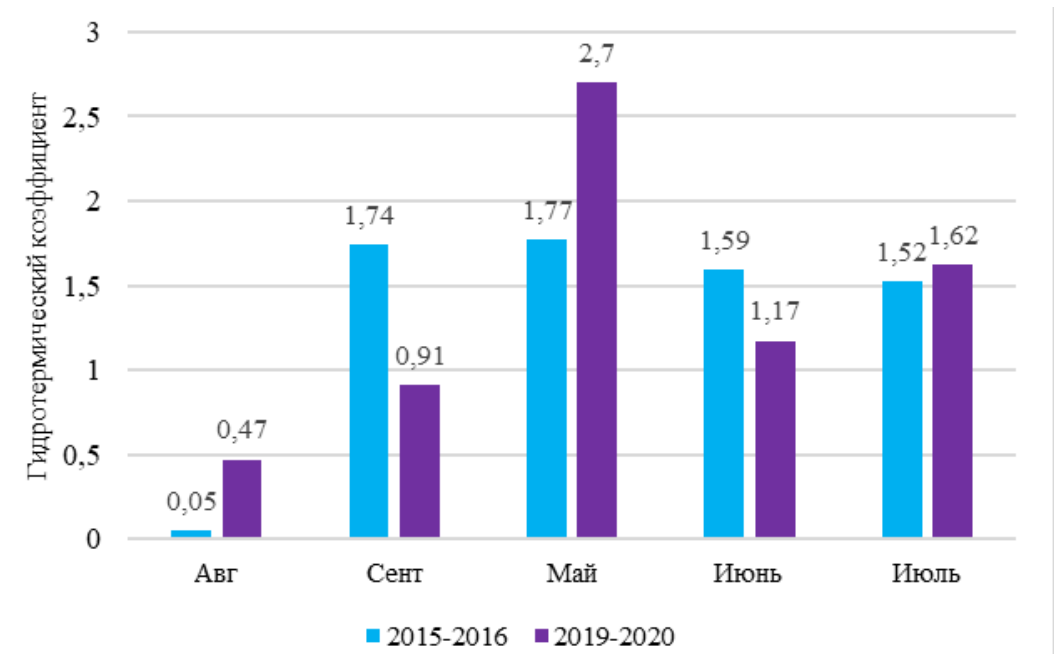

Рисунок 1 - Гидротермический режим в периоды проведения исследований

С весны 2016 года гидротермический режим характеризовался как достаточно и избыточно влажный. В августе-сентябре 2019 г., по сравнению с 2015 
г., количество осадков было меньше (ГТК $=0,47$ и 0,91 соответственно). В весенне-летний период 2020 г., выпавших осадков было больше и гидротермический режим изменялся от слабо засушливого до избыточно влажного.

При сравнительной оценке эффективности севооборотов (фактор А) и доз минеральных удобрений (фактор В) показаны значимые различия $\left(\mathrm{F}_{\phi}>\mathrm{F}_{05}\right)$ между исходными вариантами исследований, однако, в условиях ЦентральноЧернозёмного региона, минеральные удобрения оказали большее влияние на урожайность зерна озимой пшеницы по сравнению с севооборотами (таблица 1).

В зернопаропропашном севообороте была получена наибольшая урожайность зерна, которая изменялась по уровню минерального питания от 2,79 до 4,63 т/га и в среднем составила 3,86 т/га. Следующим севооборотом по величине урожайности следовал зернотравянопропашной, в котором урожайность составила в среднем 3,51 т/га. Самая низкая урожайность отмечена в зернотравяном севообороте - 3,22 т/га.

\section{Таблица 1 - Урожайность зерна озимой пшеницы с применением разных доз минеральных удобрений в изучаемых севооборотах}

\begin{tabular}{|c|c|c|c|c|}
\hline \multirow{2}{*}{$\begin{array}{c}\text { Севообороты } \\
\text { (фактор А) }\end{array}$} & \multirow{2}{*}{$\begin{array}{l}\text { Удобрения } \\
\text { (фактор В) }\end{array}$} & \multirow{2}{*}{$\begin{array}{c}\text { Урожайность, } \\
\text { т/га } \\
\end{array}$} & \multicolumn{2}{|c|}{ Прибавка, \pm т/га } \\
\hline & & & севооборот & удобрения \\
\hline \multirow{4}{*}{$\begin{array}{l}\text { Зернопаро- } \\
\text { пропашной }\end{array}$} & 0 & 2,79 & - & - \\
\hline & $\mathrm{N}_{20} \mathrm{P}_{40} \mathrm{~K}_{40}$ & 4,17 & - & $+1,38$ \\
\hline & $\mathrm{N}_{40} \mathrm{P}_{80} \mathrm{~K}_{80}$ & 4,63 & - & $+1,84$ \\
\hline & средняя & 3,86 & - & - \\
\hline \multirow{4}{*}{$\begin{array}{l}\text { Зернотравяно-про- } \\
\text { пашной }\end{array}$} & 0 & 2,61 & $-0,18$ & - \\
\hline & $\mathrm{N}_{20} \mathrm{P}_{40} \mathrm{~K}_{40}$ & 3,63 & $-0,54$ & $+1,02$ \\
\hline & $\mathrm{N}_{40} \mathrm{P}_{80} \mathrm{~K}_{80}$ & 4,28 & $-0,35$ & $+1,67$ \\
\hline & средняя & 3,51 & - & - \\
\hline \multirow[t]{4}{*}{ Зернотравяной } & 0 & 2,38 & $-0,41$ & - \\
\hline & $\mathrm{N}_{20} \mathrm{P}_{40} \mathrm{~K}_{40}$ & 3,46 & $-0,71$ & $+1,08$ \\
\hline & $\mathrm{N}_{40} \mathrm{P}_{80} \mathrm{~K}_{80}$ & 3,82 & $-0,81$ & $+1,44$ \\
\hline & средняя & 3,22 & - & - \\
\hline \multirow[t]{4}{*}{ Средняя } & 0 & 2,59 & - & - \\
\hline & $\mathrm{N}_{20} \mathrm{P}_{40} \mathrm{~K}_{40}$ & 3,75 & - & - \\
\hline & $\mathrm{N}_{40} \mathrm{P}_{80} \mathrm{~K}_{80}$ & 4,24 & - & - \\
\hline & средняя & 3,53 & - & - \\
\hline $\mathrm{HCP}_{05}$ & $\mathrm{~A}(\mathrm{~B}) / \mathrm{AB}$ & \multicolumn{3}{|c|}{$0,29 / 0,51$} \\
\hline
\end{tabular}

Минеральные удобрения в дозе $\mathrm{N}_{20} \mathrm{P}_{40} \mathrm{~K}_{40}$ кг д.в./га способствовали увеличению урожайности в зернопаропропашном севообороте на 1,38 т/га, в зернотравянопропашном на 1,02 т/га и в зернотравяном на 1,08 т/га. Увеличение дозы минеральных удобрений в 2 раза позволило повысить урожай зерна озимой пшеницы относительно контрольных вариантов в зернопаропропашном севообороте на 1,84 т/га, в зернотравянопропашном на 1,67 т/га, в зернотравяном на 1,44 т/га. Максимальная урожайность озимой пшеницы получена в зернопаропропашном севообороте с дозой минеральных удобрений $\mathrm{N}_{40} \mathrm{P}_{80} \mathrm{~K}_{80}$ $(4,63$ т/га). Следует отметить, что в вариантах без применения минеральных 
форм удобрений урожайность озимой пшеницы была значительно ниже и изменялась по севооборотам от 2,38 до 2,79 т/га.

Изучаемые виды севооборотов и уровни минерального питания позволили оказать влияние на массу 1000 зёрен, натуру зерна, содержание белка и клейковины в зерне озимой пшеницы (таблица 2). Отсутствие минеральных удобрений сопровождалось самыми низкими показателями качества во всех севооборотах. Исходя из полученных данных, наиболее интересным с точки зрения качественных показателей зерна озимой пшеницы был зернопаропропашной севооборот. В зернотравяном севообороте отмечено снижение массы 1000 зёрен, белка и клейковины.

\section{Таблица 2 - Качество зерна озимой пшеницы в зависимости от севооборо- тов и доз минеральных удобрений}

\begin{tabular}{|c|c|c|c|c|c|}
\hline $\begin{array}{c}\text { Севообороты } \\
\text { (фактор А) }\end{array}$ & $\begin{array}{c}\text { Удобрения } \\
\text { (фактор В) }\end{array}$ & $\begin{array}{c}\mathrm{M}_{1000} \text { зёрен, } \\
\Gamma\end{array}$ & $\begin{array}{c}\text { Натура } \\
\text { зерна, г/л }\end{array}$ & $\begin{array}{c}\text { Белок, } \\
\%\end{array}$ & $\begin{array}{c}\text { Клейковина, } \\
\%\end{array}$ \\
\hline \multirow{2}{*}{$\begin{array}{c}\text { Зернопаро-про- } \\
\text { пашной }\end{array}$} & 0 & 42,34 & 732 & 12,4 & 21,6 \\
\cline { 2 - 6 } & $\mathrm{N}_{20} \mathrm{P}_{40} \mathrm{~K}_{40}$ & 42,37 & 735 & 12,9 & 24,2 \\
\cline { 2 - 6 } & $\mathrm{N}_{40} \mathrm{P}_{80} \mathrm{~K}_{80}$ & 42,92 & 745 & 13,1 & 24,8 \\
\hline \multirow{3}{*}{$\begin{array}{c}\text { Зернотравяно- } \\
\text { пропашной }\end{array}$} & 0 & 41,19 & 731 & 11,5 & 19,3 \\
\cline { 2 - 6 } & $\mathrm{N}_{20} \mathrm{P}_{40} \mathrm{~K}_{40}$ & 42,07 & 729 & 13,1 & 23,1 \\
\cline { 2 - 6 } & $\mathrm{N}_{40} \mathrm{P}_{80} \mathrm{~K}_{80}$ & 41,97 & 736 & 13,5 & 24,5 \\
\hline \multirow{3}{*}{ Зернотравяной } & 0 & 40,96 & 727 & 12,8 & 22,6 \\
\cline { 2 - 6 } & $\mathrm{N}_{20} \mathrm{P}_{40} \mathrm{~K}_{40}$ & 41,16 & 736 & 13,3 & 23,6 \\
\cline { 2 - 6 } & $\mathrm{N}_{40} \mathrm{P}_{80} \mathrm{~K}_{80}$ & 41,83 & 742 & 13,3 & 23,3 \\
\hline $\mathrm{HCР}_{05}$ & $\mathrm{~A}(\mathrm{~B}) / \mathrm{AB}$ & $0,59 / 1,01$ & $7 / 13$ & $1,0 / 1,7$ & $2,6 / 4,5$ \\
\hline
\end{tabular}

Уровень минерального питания $\mathrm{N}_{20} \mathrm{P}_{40} \mathrm{~K}_{40}$ положительно влиял на качественные показатели зерна озимой пшеницы, но статистически значимые различия по массе 1000 зёрен наблюдались только в зернотравянопропашном севообороте, по натуре зерна в зернотравяном, по содержанию белка в зернотравянопропашном, по содержанию клейковины в зернопаропропашном и зернотравянопропашном севооборотах. Увеличение минеральных удобрений до $\mathrm{N}_{40} \mathrm{P}_{80} \mathrm{~K}_{80}$ способствовало существенному изменению массы 1000 зёрен в зернотравянопропашном и зернотравяном севооборотах, натуры зерна только в зернопаропропашном, клейковины в зернопаропропашном и зернотравянопропашном, белка в зернотравянопропашном севообороте.

Выводы. При сравнительной оценке влияния севооборотов и доз минеральных удобрений в условиях Центрально-Чернозёмного региона установлены значимые различия $\left(\mathrm{F}_{\phi}>\mathrm{F}_{05}\right)$ по обоим факторам эксперимента, однако, минеральные удобрения (фактор В) оказали большее влияние на урожайность зерна озимой пшеницы по сравнению с севооборотами. В зернопаропропашном севообороте была получена наибольшая урожайность зерна, которая изменялась от 2,79 до 4,63 т/га в зависимости от уровня минерального питания. Использование разных севооборотов и доз минеральных удобрений позволило оказать влияние на качественные показатели зерна озимой пшеницы, но статистически существенное влияние отмечено только в определённых вариантах опыта. 
Полученные результаты исследований будут использованы для корректировки имеющихся, а также для разработки новых технологий в адаптивноландшафтной системе земледелия Центрально-Чернозёмного региона.

Исследования проведены по теме государственного задания № 06322019-0015.

\title{
Библиографический список
}

1. Esaulko A.N., Salenko E.A., Lobankova O.Yu., Golosnoy E.V., Gromova N.V. Optimization of mineral nutrition of winter wheat in leached chernozem conditions // Research Journal of Pharmaceutical, Biological and Chemical Sciences, 2018. - T. 9. - № 4. - C. 565-570.

2. Воронин, А.Н. Влияние структуры севооборота, способа основной обработки почвы и удобрений на продуктивность озимой пшеницы в Центрально-Черноземном регионе / А.Н. Воронин, В.В. Никитин, В.Д. Соловиченко, В.И. Мельников // Агрохимия, 2016. - № 5. - С. $21-27$.

3. Турусов В.И., Гармашов В.М., Богатых О.А., Балюнова Е.А. Роль предшественников пшеницы озимой в севообороте в условиях ЦЧЗ // Аграрная наука, 2017. - № 11-12. - С. 1011.

4. Babulicova, M. The influence of fertilization and crop rotation on the winter wheat production // Plant Soil Environ, 2014. - 60 (7). - P. 297-302.

5. Дзанагов С.Х., Лазаров Т.К., Калоев Б.С., Кубатиева З.А., Калагова Р.В. Влияние длительного применения удобрений на показатели роста, урожайность и качество зерна озимой пшеницы // Агрохимия, 2019. - № 4. - C. 31-38. DOI: 10.1134/S0002188119020066.

6. Гостев А.В. Условия формирования зерна высокого качества в высокопродуктивных ресурсосберегающих агротехнологиях ЦЧР // Земледелие, 2019. - № 6. - С. 16-20.

7. Турусов В.И., Богатых О.А., Дронова Н.В., Балюнова Е.А., Говорова О.В. Влияние предшественников на продуктивность и качество озимой пшеницы в севооборотах в Центральном Черноземье // Центральный научный вестник, 2019. - Т. 4. - № 3 (68). - С. 17-19.

8. Pushkareva V.I., Goleva G.G., Vashchenko T.G., Fedulova T.P., Golev A.D., Ivannikov V.A. Assessment of ecological properties of winter wheat seeds // B сборнике: IOP Conference Series: Earth and Environmental Science. 6th International Conference on Agriproducts Processing and Farming, 2020. - C. 012031.

\section{УДК 631.8:633.34:631.434}

\section{ВЛИЯНИЕ ОБРАБОТКИ БИОПРЕПАРАТАМИ ПОБОЧНОЙ ПРОДУКЦИИ СОИ НА СТРУКТУРНО-АГРЕГАТНЫЙ СОСТАВ ЧЕРНОЗЕМА ТИПИЧНОГО СЛАБОЭРОДИРОВАННОГО}

\author{
Масютенко М.Н. \\ ФГБНУ «Курский ФАНЦ», г. Курск, Россия
}

\begin{abstract}
Резюме. В статье показано положсительное влияние обработки вносимых в почву измельченных растительных остатков сои биопрепаратами Грибофит (5 $\mathrm{\pi} / 2 a)+$ Имуназот (3 л/га) на структурное состояние чернозема типичного слабоэродированного: повышается количество агрономически иченных фракиий 2-1 и коэффиџиент структурности.
\end{abstract}

Важную роль в плодородии почв играет её структурное состояние. Водоустойчивость и механическая прочность почвы влияют на её водный, воздушный и тепловой режимы [1]. Однако современные интенсивные технологии возделывания сельскохозяйственных культур, сочетающие в себе многократную за сезон механическую обработку почвы, частое использование пестицидов, высоких доз минеральных удобрений, приводят к ее обесструктуриванию, 
обеднению микробиоты и сдвигу видового состава в сторону фитопатогенных форм. По данным Богатырёвой Е.В. [2] внесение соломоразлагающих биопрепаратов значительно увеличило водопрочность микроструктуры и степень агрегатности почвы (по Качинскому). Существуют и другие отдельные работы, свидетельствующие о влиянии биопрепаратов на водно-физические свойства и структурное состояние почвы [3].

Поэтому изучение влияния обработки биопрепаратами измельченной побочной продукции сои на структурно-агрегатный состав черноземных почв актуально и является целью исследований.

Исследования проводили на опытном поле в стационарном полевом опыте с биопрепаратами ФГБНУ «Курский ФАНЦ» (с. Панино Медвенского р-на Курской обл.) в черноземе типичном слабосмытом при возделывании сои. После уборки измельченную побочную продукцию сои обрабатывали биопрепаратами и заделывали в почву дисковыми боронами на глубину 10-12 см. Варианты опыта представлены в таблицах. В опыте использовали аммиачную селитру, а в качестве биопрепаратов - Грибофит и Имуназот. Грибофит - это биологический препарат, содержащий споры и мицелий гриба Trichoderma и биологически активные вещества, он активно разлагает клетчатку и подавляет развитие фитопатогенов. Имуназот - это биологический препарат, содержащий ризосферные бактерии Pseudomonas, обладает антимикробным и ростостимулирующим действием.

Определение структурно-агрегатного состава почвы проводился по методу Н.И. Саввинова - сухое и мокрое просеивание [4]. Образцы почвы для определения структурно-агрегатного состава были отобраны в слоях 0-10, 1020 см в период уборки урожая сои и через 67 дней после заделки растительных остатков в почву в 3-х кратной повторности. Результаты исследования были обработаны статистическими методами анализа (Доспехов, 1987) с использованием Excel.

При анализе структурно-агрегатного состава (сухое просеивание) почвы на 67 день после разложения внесенной в почву измельченной соломы сои (рис.1) установлено преобладание в агрономически ценных агрегатах чернозема типичного слабосмытого фракции 2-1 мм в слое 0-10 см, особенно на вариантах с биопрепаратами (26,5-27,2 \%). Также значительное количество в структурно-агрегатном составе составляют крупные агрегаты размером $>10$ мм $(22,0-23,3 \%)$.

Отмечена тенденция увеличения количества агрономически ценных агрегатов на вариантах с биопрепаратами (табл.1). Обработка растительных остатков сои биопрепаратами и внесение её в почву значимо повлияло на увеличение количества агрегатов размером 2-1 мм в слое 0-10 см, а в слое почвы 10-20 см наблюдается увеличение количества агрегатов размером 1-0,25мм. На вариантах с биопрепаратами отмечается тенденция к увеличению коэффициента структурности. 
Таблица 1 - Показатели структурного состояния почвы чернозема типичного слабосмытого на опыте с биопрепаратами после разложения внесенных в почву измельченной надземной части сои на 67 день

\begin{tabular}{|c|c|c|c|}
\hline Вариант & $\begin{array}{c}\text { Глубина, } \\
\text { см }\end{array}$ & $\begin{array}{l}\text { Коэффициент } \\
\text { структурности }\end{array}$ & $\begin{array}{c}\text { Агрономически } \\
\text { ценные агрегаты } \\
10-0,25 \text { мм, \% }\end{array}$ \\
\hline \multirow{2}{*}{$\begin{array}{l}\text { 1. Контроль - измельченные остатки сои без об- } \\
\text { работки }\end{array}$} & $0-10$ & 3,0 & 75,2 \\
\hline & $10-20$ & 2,8 & 73,5 \\
\hline \multirow[b]{2}{*}{ 2. Измельченные остатки сои $+\mathrm{N}_{10}$ кг д.в./т } & $0-10$ & 2,9 & 74,4 \\
\hline & $10-20$ & 3,4 & 77,2 \\
\hline \multirow[b]{2}{*}{$\begin{array}{l}\text { 3. Обработка семян биопрепаратами + обработка } \\
\text { биопрепаратами почвы перед посевом + обра- } \\
\text { ботка биопрепаратами посевов } 2 \text { раза в течение } \\
\text { вегетации (кущение, через } 2 \text { недели - после вы- } \\
\text { хода в трубку)+ после уборки урожая обработка } \\
\text { измельченных остатков сои Грибофитом }(5 \text { л/га) } \\
\text { + Имуназотом (3 л/га) (агробиотехнология-1) }\end{array}$} & $0-10$ & 3,2 & 76,3 \\
\hline & $10-20$ & 3,3 & 76,9 \\
\hline \multirow[b]{2}{*}{$\begin{array}{l}\text { 4. Обработка семян биопрепаратами + обработка } \\
\text { биопрепаратами почвы перед посевом + обра- } \\
\text { ботка биопрепаратами посевов } 2 \text { раза в течение } \\
\text { вегетации (кущение, через } 2 \text { недели - после вы- } \\
\text { хода в трубку) + после уборки урожая обработка } \\
\text { измельченной измельченных остатков сои Гри- } \\
\text { бофитом (5 л/га) + Имуназотом ( } 3 \text { л/га) + } \mathrm{N}_{10} \text { кг } \\
\text { д.в. на } 1 \text { т побочной продукции (агробиотехноло- } \\
\text { гия- } 2)\end{array}$} & $0-10$ & 3,2 & 76,0 \\
\hline & $10-20$ & 2,9 & 74,7 \\
\hline
\end{tabular}

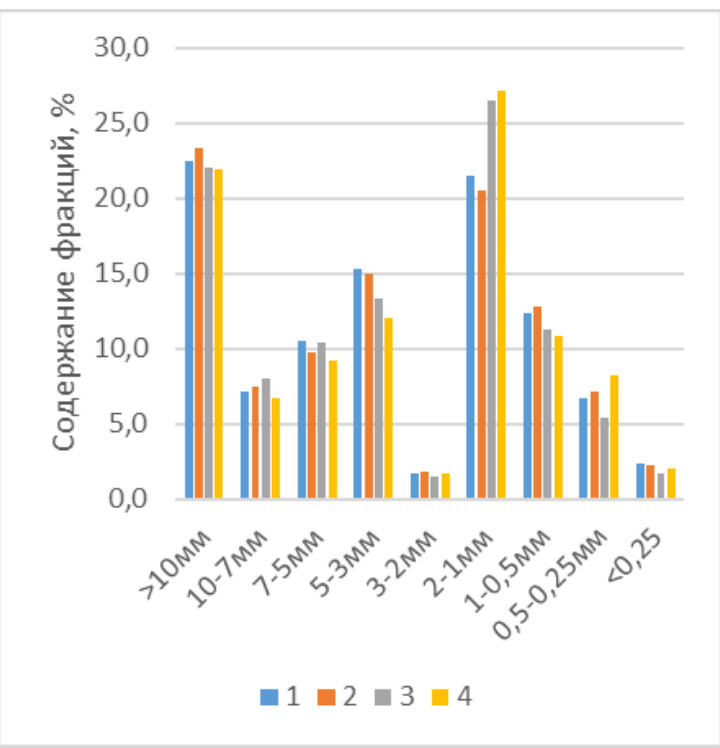

A

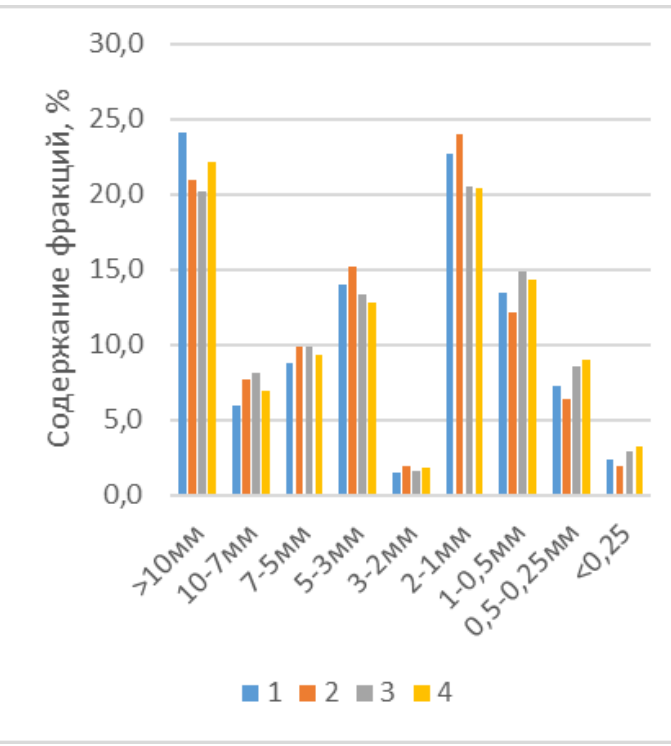

Б

Рисунок 1 - Структурно-агрегатный состав (сухое просеивание) чернозема типичного слабосмытого на опыте с биопрепаратами (А - в слое 0-10 см, Б - в слое 10-20 см) после разложения внесенных в почву измельченной надземной части сои на 67 день (Варианты указаны в таблице 1)

В составе водоустойчивых и неводоустойчивых агрегатов после мокрого просеивания (рис.2,3) в слое 0-10 см и 10-20 см было установлено преобладание неводоустойчивых фракций $<0,25$ мм на всех вариантах опыта до внесения и после заделки в почву растительных остатков сои. Причем на вариантах с 
биопрепаратами до внесения растительных остатков сои их было на 11-16\% меньше, а после заделки и разложения на - 21-25\%, чем на контроле.

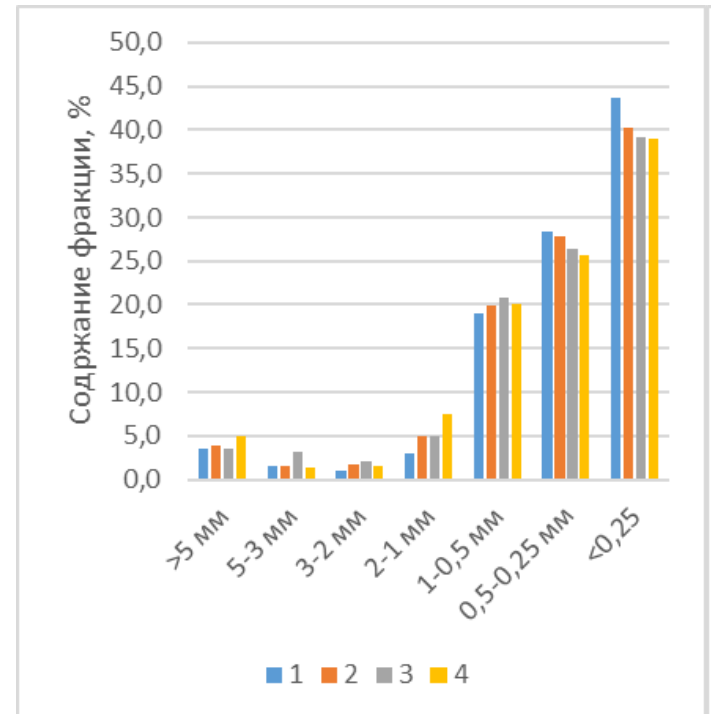

A

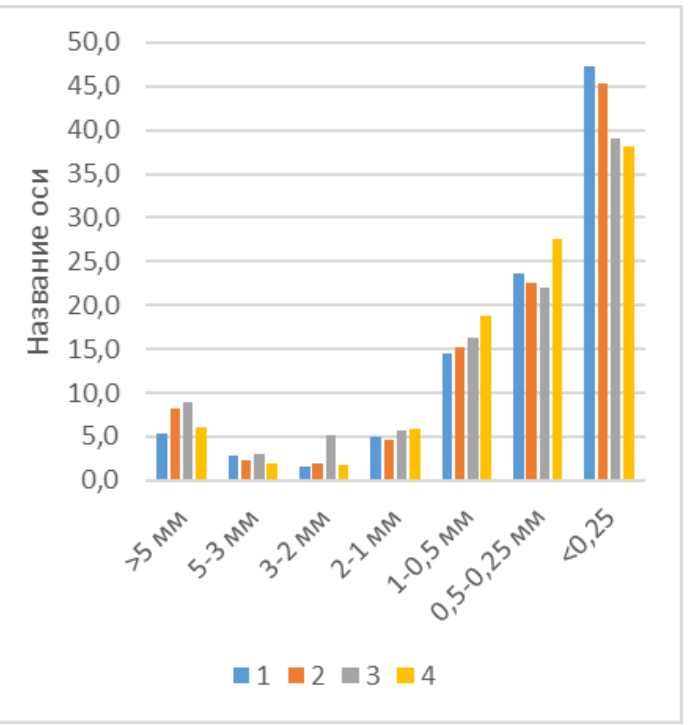

Б

Рисунок 2 - Усредненное значение процентного содержания водопрочных и неводопрочных фракций чернозема типичного слабосмытого в слое 0-10 см: А - до внесения, Б - через 67 дней после заделки внесенных в почву растительных остатков сои (Варианты указаны в таблице 1)

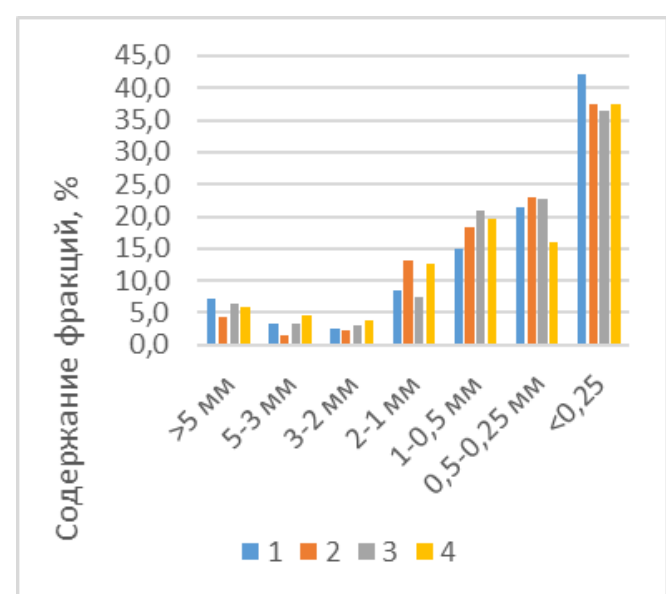

A

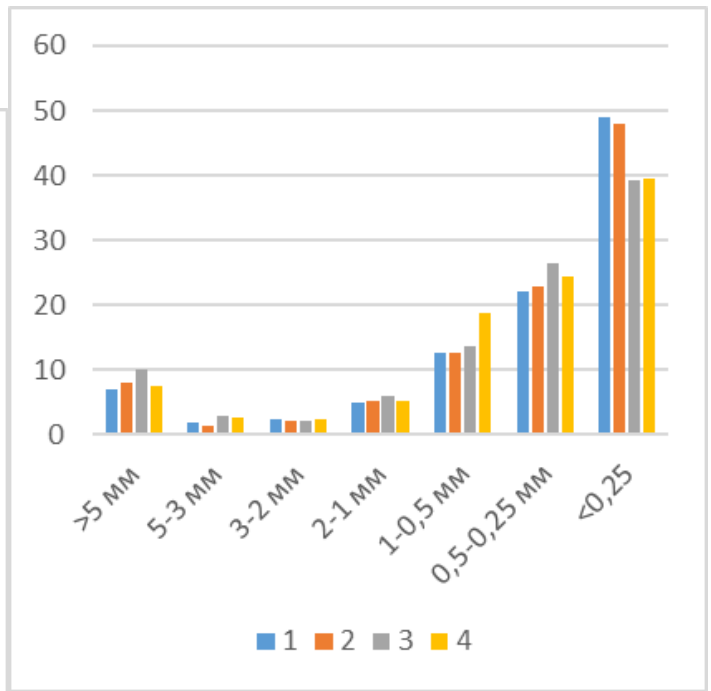

Б

Рисунок 3 - Усредненное значение процентного содержания водопрочных и неводопрочных фракций чернозема типичного слабосмытого в слое 10-20 см:

А - до внесения, Б - через 67 дней после заделки внесенных в почву растительных остатков сои (Варианты указаны в таблице 1)

Через 67 дней после заделки внесенных в почву растительных остатков сои и их частичного разложения в слое $0-10$ и 10-20 см отмечается увеличение количества водопрочных агрегатов $>5 \mathrm{Mm}$, особенно на вариантах с биопрепаратами в 1,2-2,6 раза, отмечается снижение фракций 1-0,5мм и 0,5-0,25 мм. А также четко проявляется тенденция к повышению содержания водоустойчивых агрегатов 0,5-0,25 мм на вариантах с биопрепаратами. 
Оценка водоустойчивости почвенной структуры была проведена по суммарному количеству агрегатов $>0,25$ мм при мокром просеивании (\%) (табл.2) по Кузнецовой И.В. По содержанию водопрочных агрегатов на вариантах опыта состояние почвы в слое 0-10 см и 10-20 см до внесения растительных остатков сои на контроле и на варианте 2 с азотом оценивается как хорошее, а на вариантах с биопрепаратами как отличное. После заделки внесенных в почву растительных остатков сои через 67 дней на вариантах опыта при использовании биопрепаратов отмечается отличная водоустойчивость почвы, на остальных хорошая. Однако следует отметить, что значения на контроле и на варианте 2 несколько снизились. Вероятно, это связано с большим сроком экспозиции, гидротермическими условиями. На варианте с биопрепаратами сумма водопрочных агрегатов в слое $0-10$ см и в слое $10-20$ см на $14-17 \%$ и на $15-19 \%$ больше, чем на контроле.

\section{Таблица 2 - Оценка водоустойчивости почвенной структуры чернозема типичного слабоэродированного}

\begin{tabular}{|c|c|c|c|c|c|}
\hline \multirow{3}{*}{ Вариант } & \multirow{3}{*}{$\begin{array}{l}\text { Глу- } \\
\text { бина, } \\
\text { см }\end{array}$} & \multicolumn{4}{|c|}{ Сумма водопрочных агрегатов } \\
\hline & & \multicolumn{2}{|c|}{$\begin{array}{c}\text { до внесения } \\
\text { растительных } \\
\text { остатков сои } \\
\text { в почву }\end{array}$} & \multicolumn{2}{|c|}{$\begin{array}{l}\text { через } 67 \text { дней после } \\
\text { заделки внесенных в } \\
\text { почву растительных } \\
\text { остатков сои }\end{array}$} \\
\hline & & $\%$ & Оценка & $\%$ & Оценка \\
\hline \multirow{2}{*}{$\begin{array}{l}\text { 1. Контроль - измельченные } \\
\text { остатки сои без обработки }\end{array}$} & $0-10$ & $56 \pm 1,5$ & хорошая & $53 \pm 1,4$ & хорошая \\
\hline & $10-20$ & $58 \pm 0,7$ & хорошая & $52 \pm 0,6$ & хорошая \\
\hline \multirow{2}{*}{$\begin{array}{l}\text { 2. Измельченные остатки сои } \\
+\mathrm{N}_{10} \text { кг д.в./T }\end{array}$} & $0-10$ & $60 \pm 1,2$ & хорошая & $55 \pm 1,0$ & хорошая \\
\hline & $10-20$ & $63 \pm 0,9$ & отличная & $52 \pm 0,8$ & хорошая \\
\hline \multirow{2}{*}{$\begin{array}{l}\text { 3. Обработка семян биопрепара- } \\
\text { тами + обработка биопрепаратами } \\
\text { почвы перед посевом + обработка } \\
\text { биопрепаратами посевов } 2 \text { раза в } \\
\text { течение вегетации (кущение, через } \\
2 \text { недели - после выхода в трубку)+ } \\
\text { после уборки урожая обработка из- } \\
\text { мельченных остатков сои Гри- } \\
\text { бофитом (5 л/га) + Имуназотом (3 } \\
\text { л/га) (агробиотехнология- } 1)\end{array}$} & $0-10$ & $61 \pm 1,3$ & отличная & $61 \pm 1,3$ & отличная \\
\hline & $10-20$ & $64 \pm 0,7$ & отличная & $61 \pm 0,8$ & отличная \\
\hline \multirow[b]{2}{*}{$\begin{array}{l}\text { 4. Обработка семян биопрепара- } \\
\text { тами + обработка биопрепаратами } \\
\text { почвы перед посевом + обработка } \\
\text { биопрепаратами посевов } 2 \text { раза в } \\
\text { течение вегетации (кущение, че- } \\
\text { рез } 2 \text { недели - после выхода в } \\
\text { трубку) + после уборки урожая } \\
\text { обработка измельченной измель- } \\
\text { ченных остатков сои Грибофитом } \\
(5 \text { л/га) + Имуназотом (3 л/га) + } \\
\mathrm{N}_{10} \text { кг д.в. на } 1 \text { т побочной продук- } \\
\text { ции (агробиотехнология-2) }\end{array}$} & $0-10$ & $61 \pm 1,2$ & отличная & $62 \pm 1,4$ & отличная \\
\hline & $10-20$ & $63 \pm 0,6$ & отличная & $61 \pm 0,6$ & отличная \\
\hline
\end{tabular}

$$
\pm- \text { стандартное отклонение }
$$


Таким образом, полученные данные по сухому просеиванию свидетельствуют о положительном влиянии на структурное состояние чернозема типичного вносимых в почву растительных остатков сои и, особенно, растительных остатков, обработанных микробиологическими препаратами, за счет повышения агрономически ценных фракций 2-1 мм в слое $0-10$ см и 1-0,25мм в слое $10-20$ см и снижения фракций $<0,25$ мм, отмечена тенденция к увеличению коэффициента структурности.

Биопрепараты Грибофит (5 л/га) + Имуназот (3 л/га) также способствовали повышению количества водоустойчивых агрегатов. Таким образом, заделка растительных остатков в почву с применением биопрепаратов способствует улучшению структурно-агрегатного состояния чернозема типичного слабоэродированного, повышению их водоустойчивости.

\section{Библиографический список}

1. Теории и методы физики почв: коллективная монография / Под ред. Е. В. Шеина, Л. О. Карпачевского. М.: Гриф и К, 2007. - 616 с.

2. Богатырёва Е.В. Эффективность соломоразлагающих биопрепаратов в зоне неустойчивого увлажнения Ставропольского края // Достижение науки и техники АПК, 2014. - № 9. - C. 31-33.

3. Jensen E.S., Ambus P. Prospects for manipulating crop residues to control nitrogen mineralization-immobilisation in soil // K. Skogs-o. Lantbrakad. Tidskr, 2000. - V. 139. - I.8, - P. 25-42. 4. Вадюнина А. Ф., Корчагина 3. А. Методы исследования физических свойств почвы. М.: Агропромиздат, 1986. -416 с.

УДК 631.45

\section{ПРОБЛЕМЫ И ПЕРСПЕКТИВЫ СОХРАНЕНИЯ И ПОВЫШЕНИЯ ПЛОДОРОДИЯ ПОЧВ}

Масютенко Н.П.

ФГБНУ «Курский ФАНЦ», г. Курск, Россия

Глупый выращивает сорняки, умный - культуру, мудрый возделывает почву. Китайская пословица

По имеющимся оценкам, 95\% того, что мы едим, прямо или косвенно производится на наших почвах. Наши почвы являются основой для сельского хозяйства и средой, где произрастают практически все растения, которые используются для производства пищевых продуктов.

Почвы обладают бесценным даром, уникальным свойством - плодородием. Плодородие - это способность почвы удовлетворять потребность растений и обеспечивать условия для их нормальной жизнедеятельности, включая достаточное количество питательных веществ в подвижной форме, возможность трансформации их в почвенный запас и обратно, водный, воздушный и тепловой режимы, устойчивость к неблагоприятным факторам, супрессивность, буферность, пригодность для использования современных технологий возделывания культур. 
Американские ученые Larson W.E., Pierce F.J. определяют качество nочвы как набор физических, химических и биологических свойств, которые обеспечивают среду для роста растений и разложения вредных веществ [1]. Качество почвы - это характеристика свойств и состава почвы, определяющая ее плодородие. Термин «качество» означает степень соответствия совокупности присущих характеристик требованиям.

Осуществление продукционного процесса и формирование урожая возделываемых сельскохозяйственных культур определяются

- запасом и качеством органического вещества, гумуса,

- запасами и мобильностью макро- и микроэлементов минерального питания растений,

- комплексом режимов (водным, тепловым, воздушным) и параметров почвы, т.е. плодородием почвы.

Плодородие почвы не является единственным фактором урожая, помимо него на урожайность культур влияют биологические особенности растений, климат, агротехника и т.п. Однако при прочих равных условиях, оно будет определять продуктивность культур.

При анализе современного состояния плодородия черноземных почв. выделяются следующие основные проблемы.

Первая проблема. В большинстве почв России отмечается снижение содержания гумуса, ухудшение его качества, дегумификация, отрицательный баланс гумуса в почвах.

В процессе сельскохозяйственного использования в черноземных пахотных почвах ЦЧР по сравнению с целинными (рис.1) наблюдается снижение:

содержания гумуса на 25-50\%, подвижных гумусовых веществ на 30-50\%,

негумифицированного органического вещества в 2-4,5 раза в зависимости от степени эродированности и местоположения в рельефе.
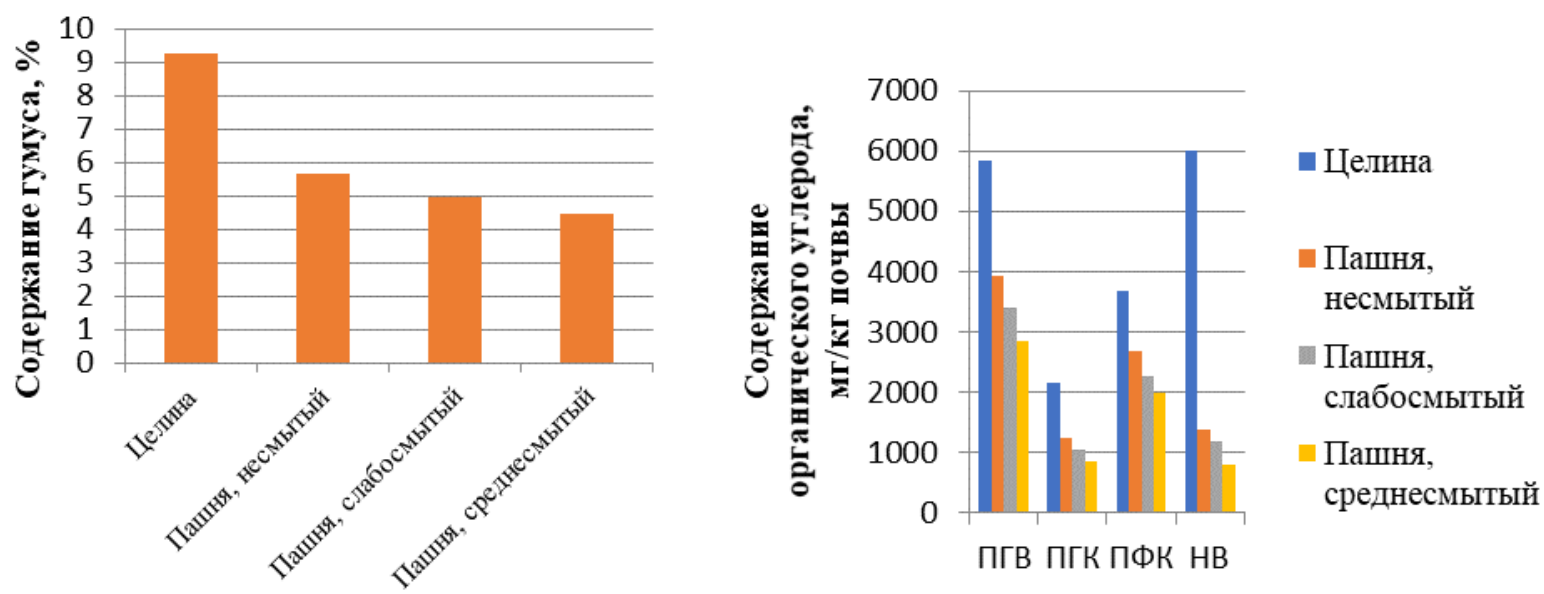

Рисунок 1 - Изменение содержания органического вещества и его состава в черноземе типичном в зависимости от использования и степени эродированности в слое $0-25 \mathrm{~cm}$ 
Например, по данным Статистического ежегодника Курской области за 2018 год [2], Краткого статистического сборника. Курская область в цифрах. 2019 [3] с 2005 по 2018 год внесение органических удобрений на 1 га посева сельскохозяйственных культур в Курской области составляло 0,19-0,42 т, что соответствует 2,7-6,0 \% от требуемого количества в год. Даже под пропашную культуру - сахарную свеклу, которая способствует усиленной минерализации почвенного гумуса, вносят недопустимо малые количества органических удобрений 0,1-0,6 т/га, только в 2005 году внесли 2,1 т/га.

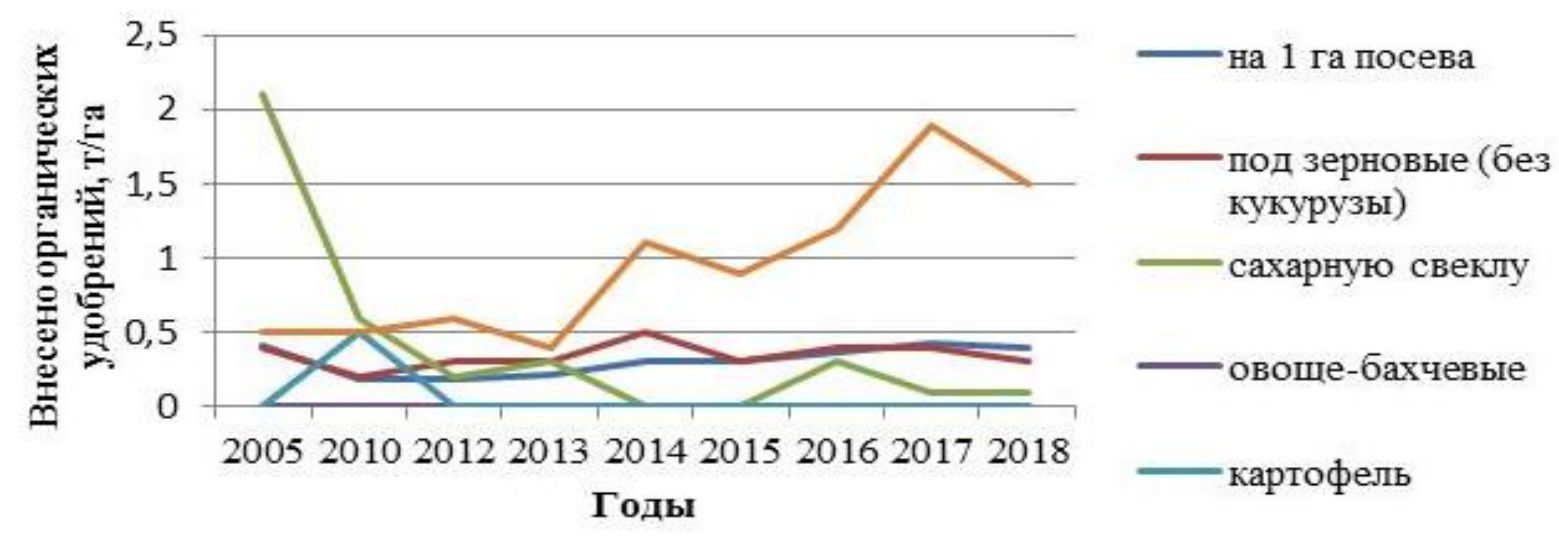

Рисунок 2 - Внесение органических удобрений под посевы сельскохозяйственных культур в Курской области в 2005-2018 гг.

Вторая проблема. В большинстве почв России снижаются запасы основных питательных элементов в почвах, т.к. баланс элементов минерального питания растений в земледелии и кормопроизводстве России много лет отрицательный, а соотношение азота, фосфора и калия далеко от оптимального и научно обоснованного. Рост урожаев и качества продукции (высокое содержание белка и клейковины) всегда сопровождаются увеличением выноса $\mathrm{N}, \mathrm{P}, \mathrm{K}$. Средний объем применения минеральных удобрений (д.в.) в год за пятилетний период, рассчитанный д.т.н. ф-та почвоведения МГУ Д.М. Хомяковым [4] с использованием данных Росстата составлял в 2001-2005гг. - 1,4 млн. т; в 20062010 гг. $-1,8$ млн. т; 2011-2015 гг. - 1,9 млн. т; 2016-2020гг. $-2,6$ млн. т. В то же время со 100 млн. т зерновых колосовых выносится в год $\mathrm{N}-3,0$ млн. т, Р 1,2 млн. т, $\mathrm{K}-2,3$ млн. т, то есть в 2,5 раза больше.

Третья проблема. В стране продолжается увеличение доли и площади кислых пахотных почв. Они выявляются уже в южных регионах страны, при этом снижается эффективность агротехнологий, качество урожаев. Это связано с применением физиологически кислых минеральных удобрений; выпадением кислых атмосферных осадков, стимулирующим отчуждение из пахотного слоя почвы кальция и магния за счет внутрипрофильной миграции (вымывания) и выноса с урожаями; уменьшением темпов известкования почв; тем, что рост урожаев и качества продукции всегда сопровождаются увеличением выноса $\mathrm{Ca}, \mathrm{Mg}$. Со 100 млн. т зерновых колосовых выносится в год Са - до 1 млн. т, $\mathrm{Mg}-0,8$ млн. т. На 1 га в среднем необходимо вносить 6-9 т известковых материалов с периодичностью 5-7 лет. 
Четвертая проблема. В стране продолжает увеличиваться доля и площади эродированных почв. В целом по стране в составе эродированных сельскохозяйственных угодий средне- и сильноэродированные почвы занимают 26\%. В течение последних 20 лет темпы прироста эродированных и дефлированных почв достигли 6-7\% каждые 5 лет. Наиболее подвержены эрозии и дефляции сельскохозяйственные угодья (в т.ч. и пашня) в Поволжском, СевероКавказском, Центрально-Черноземном и Уральском районах. В результате эрозии и дефляции почв недобор урожая на пашне достигает 36\%, на других угодьях - до $47 \%$.

Эти проблемы почв возникли не вчера, и не одно десятилетие назад. Угроза почвам от эрозии существовала всегда, но особенно остро она встала в связи с интенсификацией земледелия, необходимостью получения большего количества сельскохозяйственной продукции. Наиболее опасными в эрозионном отношении являются территории следующих Федеральных округов: Приволжский - 50,0\%, Южный - 16,0\%, Центральный - 13,0\%. На серых лесных почвах и черноземах в лесостепных районах наблюдается эрозия талыми и ливневыми водами весной и летом. По данным Государственного национального доклада о состоянии и использовании земель в Российской Федерации в 2015 г. (2016) наиболее опасными в эрозионном в дефляционноопасном отношении являются территории следующих Федеральных округов: Сибирский - 43,0\%, Южный - 30,0 \%, Северо-Кавказский - 14,0\%, Приволжский - 9,0\%.

Ухудшение состояния почвенных ресурсов - общемировая тенденция. Как отмечается в докладе Продовольственной и сельскохозяйственной организации объединенных наций (FAO) «Состояние почвенных ресурсов мира», разработанном Межправительственной группой экспертов FAO, в которую входят около 200 почвоведов из 60 стран мира. Состояние почв в мире резко ухудшается вследствие эрозии, снижения содержания питательных веществ в почвах, потери органического углерода, заиления почв и других угроз.

Как видим, эрозия почв стоит на первом месте среди глобальных проблем. Основным выводом доклада звучит то, что в мире эрозия уносит от 25 до 40 млрд. тонн верхнего слоя почвы ежегодно, значительно снижает урожайность сельскохозяйственных культур. Ежегодные потери производства зерновых вследствие эрозии составляют до 7,6 млн. тонн ежегодно. Без принятия мер по снижению эрозии к 2050 г. потери зерна могут составлять более 253 млн.т, что эквивалентно 1,5 млн. км² сельскохозяйственных угодий, и равняется площади всей пахотной земли такой страны, как Индия.

Основными причинами возникших проблем является то, что

1. в почву не поступает достаточного количества органических и минеральных удобрений, чтобы обеспечить бездефицитные балансы углерода, азота и питательных элементов,

2. не вносят необходимого количества известковых материалов для нейтрализации кислотности почвы.

3. противоэрозионные мероприятия не проводятся или проводят в недостаточном объеме. 
В результате деградация почв с каждым годом усиливается, плодородие падает, продолжается тенденция эксплуатации плодородия отечественных почв за счет будущих поколений граждан страны, т.к. в почву не поступает достаточного количества органических и минеральных удобрений, известковых материалов. Как отмечает Д.М. Хомяков (2021), в настоящее время большая часть урожая сельскохозяйственных культур формируется за счет мобилизации запасов почвенного плодородия без адекватной компенсации выносимых элементов питания, превышающих в целом ряде случаев уровень их внесения с удобрениями в 4-5 раз, что приводит к отрицательному балансу питательных веществ и гумуса и создает условия для усиления деградационных процессов. Считается, что способность почв постоянно предоставлять «природно-ресурсный» кредит, как это происходит на протяжении последних 30-ти лет, пока еще до конца не исчерпана. Но настанет момент, когда деградация почв станет необратимой на значительных площадях.

В случае сохранения действующего подхода, не соответствующего принципам устойчивого развития, пределы роста отрасли будут обусловлены ежегодно уменьшающимся потенциалом плодородия российских почв. Оценка ситуации в данной сфере была дана на заседании и в решении Президиума Совета законодателей РФ при Федеральном Собрании РФ 18.12.2020 «О мерах по обеспечению плодородия земель сельскохозяйственного назначения». «В Стратегии национальной безопасности Российской Федерации, утвержденной Указом Президента РФ от 31.12.2015 № 683, предусмотрено, что обеспечение продовольственной безопасности осуществляется, в том числе, за счет повышения плодородия почв, предотвращения истощения и сокращения площадей сельскохозяйственных земель и пахотных угодий. При этом сохранение, восстановление и повышение плодородия почв земель сельскохозяйственного назначения являются составляющими развития и совершенствования агропромышленного комплекса Российской Федерации.

В такой ситуации необходимо целенаправленное управление плодородием пахотных почв. При управлении необходимо учитывать фактическое состояние плодородия на каждом конкретном поле, поэтому требуется его оценка и периодический контроль. Основой сохранения (воспроизводства) и управления плодородием почв являются:

1. Поддержание бездефицитного баланса гумуса.

2. Обеспечение баланса питательных элементов на заданном уровне с учетом планируемых урожаев.

3. Химическая мелиорация (регулирование кислотности почвы).

4. Обеспечение агрофизического состояния почвы благоприятного для возделывания сельскохозяйственных культур.

5. Поддержание биологического состояния почвы, обеспечивающего уравновешенность процессов минерализации и гумификации органического вещества и благоприятные условия для возделывания сельскохозяйственных культур. 
Предлагается система мер для сохранения плодородия почв и почвенных ресурсов (табл.1)

\title{
Таблица 1 - Система мер для улучшения сохранения почв и почвенных ресурсов
}

\author{
I Меры для сохранения содержания гумуса в почве \\ 1. Внесение органических удобрений \\ 2. Внесение растительных остатков (побочной продукции) с азотными удобрениями \\ 3. Севообороты и возделывание в севообороте многолетних трав \\ 4. Применение почвозащитных обработок почвы: \\ мелкая безотвальная (на глубину 12-15 см) \\ поверхностная (до 12 см) \\ нулевая
}

II Меры для сохранения «здоровья» почвы

1.Внесение гуминовых препаратов и биопрепаратов

2.Использование сидеральных культур, многолетних бобовых трав

III Меры для обеспечения баланса питательных элементов и снижения кислотности почвы

1.Внесение комплексных минеральных удобрений

2. Снижение кислотности почвы за счет внесения Са-содержащих веществ

IV Мероприятия по накоплению влаги в почве

Введение чистых паров, ранняя глубокая зябь, прикатывание и своевременное боронование почвы; поконтурная обработка почвы на склонах; осеннее бороздование; лункование и щелевание почв, снегозадержание (посев кулис, защитные лесные полосы, уплотнение снега и создание снежных валиков и др.), создание искусственных водоемов в балках, оврагах, малых реках и т.п.

1.Обработка почвы поперек склона

2.Посадка лесополос

3.Укрепление склонов

4. Проведение других противоэрозионных мероприятий

VI Проведение агрохимического обследования почвы

1 раз в 5 лет для осуществления контроля за плодородием и качеством почвы для разработки проектов системы мер для воспроизводства и улучшения плодородия почв и сохранения почвенных ресурсов каждого поля конкретного хозяйства, в т.ч., проектирования противоэрозионных мероприятий и корректировки их во времени.

Для каждого поля необходимо рассчитать научно обоснованные дозы внесения органических и минеральных удобрений, потребность в мелиорантах с учетом фактического состояния плодородия почвы, вида и планируемых урожаев возделываемых культур.

Для сохранения и повышения плодородия почв необходимо иметь современную инновационную Систему управления плодородием почв в хозяйстве, направленную на его улучшение, на 5-7 лет или более долгосрочную перспективу и на каждый конкретный год подробно с учетом состояния плодородия почвы и планов по возделываемым культурам, их планируемой урожайности. Необходим паспорт плодородия каждого поля, контроль и оценка плодородия почвы на поле не реже раз в 5 лет. 
Сохранение и воспроизводство плодородия различных типов почв являются важным условием эффективного и устойчивого развития агропромышленного комплекса, стабильности производства сельскохозяйственной продукции.

\title{
Библиографический список
}

1. Larson W.E., Pierce F.J. Conservation and enhancement of soil quality // Evaluation for Sustainable Land Management in the Developing World / Ed. Dumansky, J. Proceedings of the International Workshop, Chiang Rai, Thailand. Technical papers. V. 2. Bangkok: International Board for Soil Research and Management, 1991. P. 175-203.

2. Статистический ежегодник Курской области. 2018: Стат. сб. / Курскстат. - С25 Курск, 2018 - С.221-223.

3. Курская область в цифрах. 2019: Краткий статистический сборник / Территориальный орган Федеральной службы государственной статистики по Курской области. - Курск, 2019. - C.50-51.

4. Хомяков Д.М. Значение почвенных ресурсов в стратегии устойчивого развития АПК // Агроэкологические проблемы почвоведения и земледелия. Сборник докладов XVI международной научно-практической конференции Курского отделения МОО «Общество почвоведов имени В.В. Докучаева, посвященной 175-летию со дня рождения В.В. Докучаева. Г. Курск, 28-29 апреля 2021г. Курск: ФГБНУ «Курский ФАНЦ», 2021. - С.471-476.

УДК: $63: 631.8$

\section{ДИНАМИКА МИКРОЭЛЕМЕНТОВ В ПОЧВАХ КУРСКОЙ ОБЛАСТИ И ФАКТОРЫ, ВЛИЯЮЩИЕ НА ИХ СОДЕРЖАНИЕ \\ Митрохина О.А. \\ ФГБНУ «Курский ФАНЦ», Курск \\ E-mail: mitrokhina1977@mail.ru}

\begin{abstract}
Резюме. В статье представлен материал по содержанию и динамики подвижных микроэлементов (медь, цинк, марганеи, бор) за 10 туров обследования. Представлены корреляционные зависимости содержания микроэлементов в почвах от погодных условий и агрохимических показателей в почвах Курской области.
\end{abstract}

Ключевые слова: микроэлементы, медь, бор, марганец, иинк, Курская область, содержание.

Summary. The article presents the material on the content and dynamics of mobile trace elements (copper, zinc, manganese, boron) for 10 rounds of the survey. The correlation dependences of the content of trace elements in soils on weather conditions and agrochemical indicators in the soils of the Kursk region are presented. Keywords: trace elements, copper, boron, manganese, zinc, Kursk region, content.

Key words: trace elements, copper, boron, manganese, zinc, Kursk region, content.

Почва является основным средством и предметом труда в сельскохозяйственном производстве, источником жизни человека, его здоровья. Центрально-Чернозёмный регион (ЦЧР) Российской Федерации является важным аграрным районом страны с интенсивно развивающимся земледелием. Проблема сохранения и повышения плодородия почв, их охрана, экология, получение стабильно-высоких урожаев культур находится в центре внимания учёных-аграриев, работников сельскохозяйственного производства. 
Низкая культура земледелия, игнорирование научных подходов в использовании почв, недостаточное научное обоснование многих агротехнических приёмов наряду с негативными проявлениями погодных условий приводит к деградационным процессам: смыву и размыву, потере содержания гумуса, мощности гумусового горизонта, элементов питания растений, повышению кислотности, осолонцеванию, резкому ухудшению агрофизических свойств. Всё это снижает уровень плодородия почв и, как следствие, урожайность сельскохозяйственных культур и качество продукции.

В Центрально-Чернозёмном регионе назрела острая необходимость более детального изучения современного состояния почвенного покрова, его структуры, районирования, а также типизации земель и обобщения результатов длительных полевых опытов по воспроизводству почвенного плодородия [1].

Помимо основных макроэлементов (азота, фосфора, калия) в почвах находятся микроэлементы. К ним относятся цинк, медь, марганец, бор, кобальт, молибден и др.). При достаточном количестве основных питательных веществ дефицит микроэлементов в почве приводит к существенному снижению урожайности сельскохозяйственных культур и ухудшению качества продукции [2]. В связи с ростом производства возникает необходимость функционирования почвенно-геохимического мониторинга различного уровня, составной частью которых должна быть база данных о содержании химических элементов в зональных почвах отдельных регионов [3-4].

Нами проведены исследования и проанализированы литературные данные определяющие режимы микроэлементного состояния почв Курской области и позволяющие осуществлять индивидуальную оценку и прогноз динамики их изменений с учетом ландшафтно-географических особенностей расположения, климатических условий и агротехнических факторов.

Изменение содержания микроэлементов в почвах Курской области можно анализировать с 4 тура обследования (1984-1989). Содержание меди в почвах области в этот период составляло 0,15 мг/кг - низкий уровень обеспеченности, содержание цинка так же было низким 0,63 мг/кг, марганца 39,56 мг/кг, что соответствует высокому уровню обеспеченности почв элементом, содержание бора было низким (рисунок 1).

К 10 туру обследования (2014-2016гг) уровень обеспеченности почв микроэлементами снизился в сравнении с исходными данными. Содержание меди снизилось на 26\%, содержание цинка возросло, но соответствует низкому уровню обеспеченности 0,72 мг/кг, содержание марганца существенно уменьшилось в почвах области на 81 \%, и отвечает низкому уровню содержания, содержание бора увеличивалось и соответствует среднему значению. 


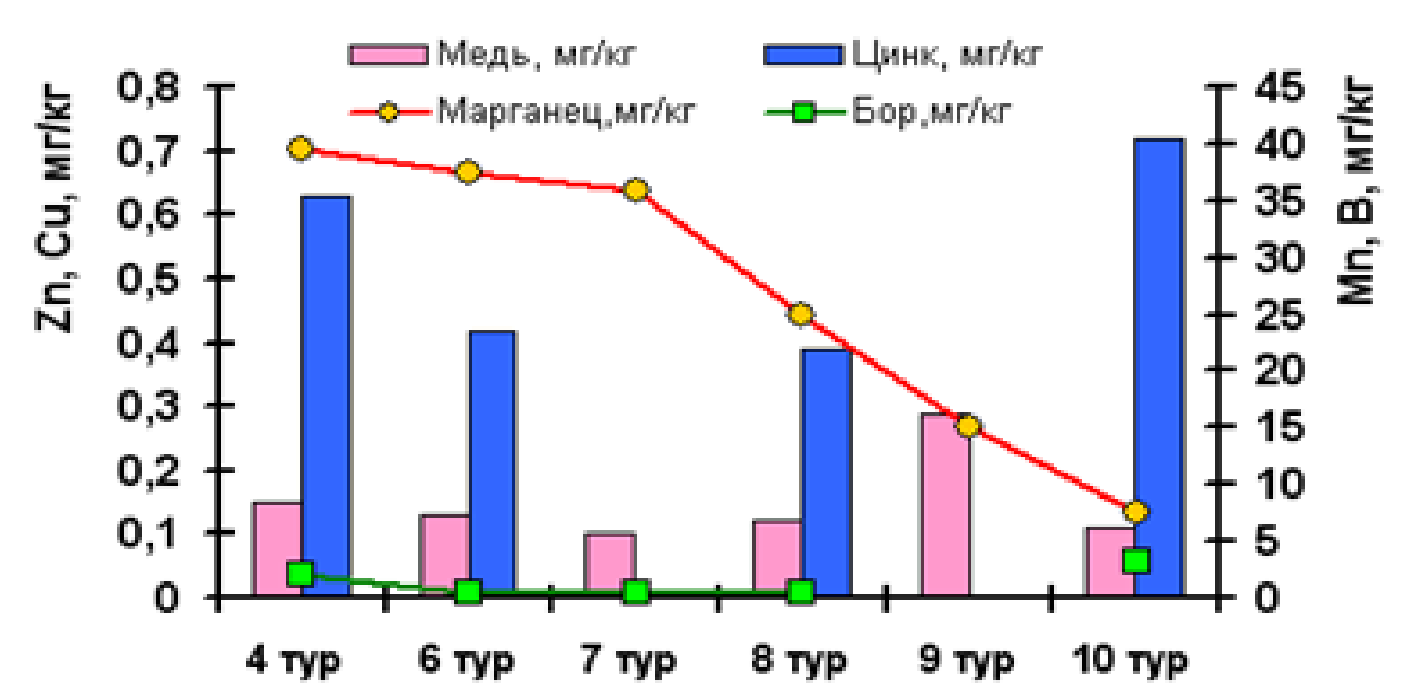

Рисунок 1 - Динамика микроэлементов в почвах Курской области, мг/кг

Полученный нами экспериментальный материал показал наличие тесной положительной связи между медью и суммой активных температур $\mathrm{r}=0,84$. Coдержание цинка имеет высокую обратную связь с данным показателем r=-0,88, марганец и бор характеризуются средней связью. Содержание цинка, марганца и бора имеет тесную обратную связь со средней температурой за год. Содержание меди характеризуется слабой прямой связью со средней температурой за год. Высокая положительная связь характерна для цинка и осадками более 10 мм r $=0,90$; отмечается высокая обратная связь коэффициента увлажнения и меди $\mathrm{r}=-0,82$; высокая обратная связь с марганцем $\mathrm{r}=-0,79$; средняя положительная связь с цинком (таблица 1).

Таблица 1 - Корреляционная зависимость содержания микроэлементов от погодных условий и агрохимических показателей в почвах Курской области

\begin{tabular}{|l|c|c|c|c|}
\hline \multicolumn{1}{|c|}{ Показатель } & $\mathrm{Cu}$ & $\mathrm{Zn}$ & $\mathrm{Mn}$ & $\mathrm{B}$ \\
\hline Сумма активных температур & 0,84 & $-0,88$ & $-0,49$ & $-0,62$ \\
\hline Средняя температура за год & 0,42 & $-0,91$ & $-0,98$ & $-0,86$ \\
\hline Сумма осадков за год & $-0,80$ & 0,41 & $-0,97$ & $-0,005$ \\
\hline Осадки более 10 мм & $-0,58$ & 0,90 & $-0,22$ & 0,39 \\
\hline ГТК & $-0,64$ & 0,89 & $-0,14$ & 0,43 \\
\hline Коэффициент увлажнения & $-0,82$ & 0,60 & $-0,79$ & 0,18 \\
\hline рН & 0,82 & 0,92 & 0,88 & 0,34 \\
\hline $\mathrm{K}_{2} \mathrm{O}$ & 0,28 & 0,82 & $-0,76$ & 0,84 \\
\hline $\mathrm{P}_{2} \mathrm{O}_{5}$ & $-0,08$ & $-0,39$ & $-0,21$ & $-0,36$ \\
\hline Запасы К & 0,91 & - & 0,82 & 0,48 \\
\hline Запасы Р & 0,62 & -1 & $-0,76$ & 0,98 \\
\hline Гумус & $-0,98$ & -1 & -1 & $-0,91$ \\
\hline
\end{tabular}

Агрохимические факторы оказывают неодинаковое действие и степень тесноты корреляционных связей на содержание подвижных микроэлементов. В почвах Курской области наблюдается тесная положительная корреляционная связь кислотности почвы с медью $\mathrm{r}=0,82$; цинком $\mathrm{r}=0,92$; марганцем $\mathrm{r}=0,88$ 
(таблица 1). С запасами калия тесно положительно коррелировало содержание меди $\mathrm{r}=0,91$ и марганца $\mathrm{r}=0,82$. Между содержанием гумуса и содержанием микроэлементов наблюдается тесная обратная связь. Причем с цинком и марганцем $\mathrm{r}=-1$, медью и бором $\mathrm{r}=-0,98 ; \mathrm{r}=-0,91$ соответственно. $\mathrm{C}$ запасами фосфора в почве и содержанием цинка имеется тесная обратная связь $\mathrm{r}=-1$; с марганцем связь высокая обратная $\mathrm{r}=-0,76$; с бором тесная положительная $\mathrm{r}=0,98$; с медью средняя положительная $\mathrm{r}=0,62$.

Выводы: Проведенные исследования указывают на то, что содержание подвижных форм микроэлементов за изучаемый нами период снижается. Содержание таких микроэлементов как цинк, медь, марганец соответствует низкому, бор среднее. Проведенный корреляционный анализ данных показал наличие высокой связи микроэлементов с погодными условиями и некоторыми агрохимическими показателями.

\title{
Библиографический список
}

1. Соловиченко В.Д. Почвенный покров Центрально-Черноземного региона и воспроизводство плодородия почв: Диссертация д-ра с.-х. наук. Белгород, 2011. - 280 с.

2. Лукин С.В. Микроэлементы в почвах ЦЧО // Земледелие, №6. - 2015. - С. 26-28.

3. Протасова Н.А., Щербаков А.П. // Микроэлементы Cr, V, Ni, Mn, Zn, Cu, Co, Ti, Zr, Ca, $\mathrm{Be}, \mathrm{Sr}, \mathrm{Ba}, \mathrm{B}, \mathrm{I}$, Мо в черноземах и серых лесных почвах Центрального Черноземья. - Воронеж: Воронеж гос. Ун-т, 2003. - 368 с.

4. Митрохина О.А. Влияние физико-химических свойств и микроэлементного состава чернозема типичного на урожайность и качество зерна озимой пшеницы / О.А. Митрохина // автореферат диссертации на соискание ученой степени кандидата с-х наук. Курск, 2009. $24 \mathrm{c}$.

УДК 911.53; 911.52;631.412

\section{ГЕТЕРОГЕННОСТЬ ЛАНДШАФТА КАК ОСНОВНОЙ ФАКТОР ПРОДУКТИВНОСТИ В ПРОСТРАНСТВЕ-ВРЕМЕНИ}

\author{
Несветаев М.Ю., Ларькин М.А., Губарев Д.И., Ефимова В.И. \\ ФГБНУ «ФАНЦ Юго-Востока» \\ E-mail: nesvetaev.m@yandex.ru
}

\begin{abstract}
Резюме. В статье выявлены агрохимические особенности почв и продуктивности типов фачий на опьтных полях ФГБНУ «ФАНЦ Юго-Востока». Продуктивность типов фаций, выраженная в урожайности яровой пшеницы, имеет высокую пространственно-временную устойчивость и изменяется от более высоких показателей на фациях слабопологих $и$ пологих склонов к низким на фаџиях ложбин и межложбинных водоразделов с максимальной урожайностью на водораздельных типах фаџий. Также выявлена тесная зависимость между содержанием основных элементов питания в почве (нитратный азот, подвижные фосфор, калий) и продуктивностью морфологических единии в пространстве и времени.
\end{abstract}

Ключевые слова: агроландшафт, типь фачий, ПТК, агрохимия.

Summary. The article reveals the agrochemical characteristics of soils and the productivity of facies types in the experimental fields of the FSBSO"FCAR of the South-East". The productivity of facies types, expressed in the yield of spring wheat, has a high spatial-temporal stability and changes from higher indicators on facies of slightly sloping and gentle slopes to low ones on facies 
of troughs and inter-valley watersheds with maximum productivity on watershed types of facies. A close relationship was also revealed between the content of the main nutrients in the soil (nitrate nitrogen, mobile phosphorus, potassium) and the productivity of morphological units in space and time.

Key words: agrolandscape, types of facies, NTC, agrochemistry.

Введение. В природе многообразие ландшафтно-морфологических условий упорядочено. Все природно-территориальные комплексы (ПТК) находятся в тесной вещественно-энергетической связи друг с другом. В этом плане ландшафт - континуален и не имеет четких границ. Дискретизация ландшафта, методически обоснованная русской школой ландшафтоведения - это плод человеческой мысли, направленный на выделение в ландшафте примерно однородных условий с целью прикладного использования знаний физической географии в сельском хозяйстве и не только $[1,3,4,5]$. Количество поступающей солнечной энергии, атмосферных осадков, химических элементов из вышележащих по рельефу комплексов на них также неизменно, как и неизменны горизонтальная и вертикальная миграция в них [2].

Нами проведена работа по исследованию морфоструктуры ландшафта, с целью определения влияния морфологических частей ландшафтной местности на продуктивность территории. При этом стояла задача выявить сохраняется ли влияние конкретных полигонов во времени и пространстве. Из всех возможных характеристик ПТК отобраны те, которые максимально точно характеризуют продуктивность агроценоза и позволяют уже сейчас достигнуть главной цели - построить пространственно-временную модель продуктивности ландшафта, благодаря которой можно оказывать воздействие на продуктивность посредством внесения минеральных удобрений.

Методика исследования. Определение нитратного азота $\left(\mathrm{N}-\mathrm{NO}_{3}\right)$ в почвенных образцах определялось потенциометрическим методом на иономере; подвижные формы фосфора и калия - в 1\% углеаммонийной вытяжке по Мачигину по ГОСТ 26205-91. Урожайность яровой пшеницы определяли методом линейных метров в трехкратной повторности. Перевод полученных агрохимических результатов и урожайности яровой пшеницы в биоэнергетические эквиваленты проведен по методике [6].

Результаты исследования. Результатом исследований стало создание ландшафтной карты опытных полей ФГБНУ «ФАНЦ Юго-Востока» г. Саратова. Была разработана схема опыта, согласно которой на доминантных и субдоминантных типах фаций данной местности в период 2018-2020 гг. проведен отбор почвенных образцов и учет урожайности яровой пшеницы. Каждый год отбор проб происходил на разных полях севооборотов в пределах данной местности. В результате полевых и камеральных работ была выявлена устойчивость суммарного содержания макроэлементов в почве и продуктивности типов фаций.

На рисунке 1 мы видим, что в 2018-2020 гг. продуктивность изменяется от высоких показателей на слабопологих и пологих склонах северной $(2,09$ и 2,03

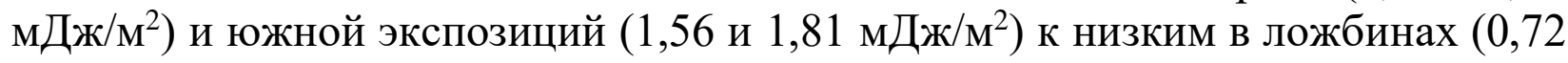


и 0,40 мДж/м ${ }^{2}$ ) с промежуточным положением межложбинных водоразделов $\left(1,85\right.$ и 1,59 мДж/м $\left.{ }^{2}\right)$ и с околомаксимальным на водораздельном типе фаций

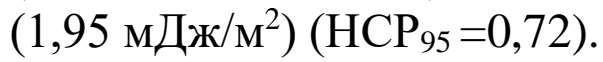

Была выявлена тесная зависимость между содержанием основных элементов питания в почве (нитратный азот, подвижные фосфор, калий) и продуктивностью морфологических единиц (рис.1).

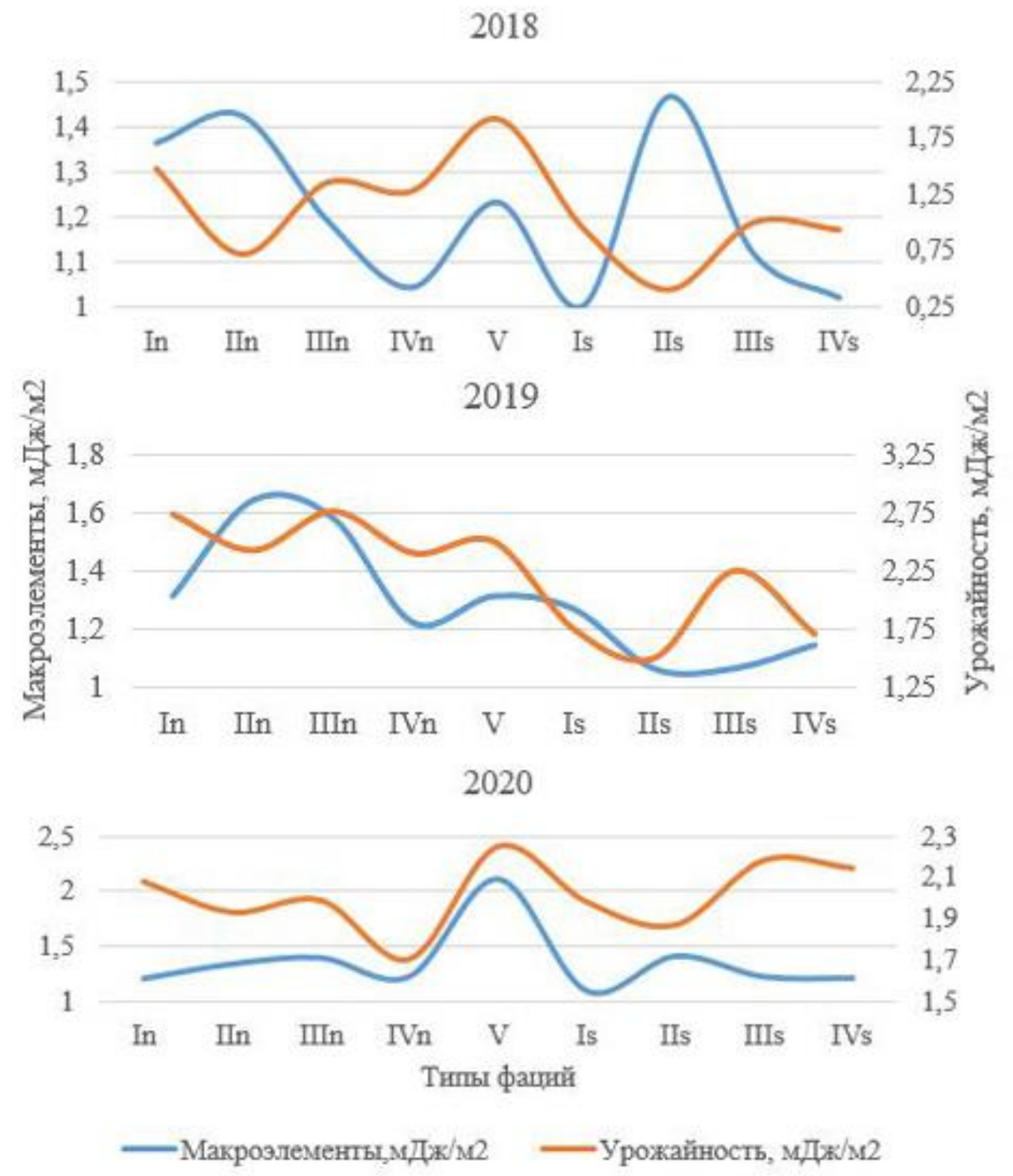

Рисунок 1 - Урожайность яровой пшеницы и суммарное содержание макроэлементов по типам фаций за 2018-2020 гг.

Примечания: In - слабопологие (1-3) вогнутые склоны северо-восточной экспозищии; II nслабопологие $\left(1-3^{\circ}\right)$ вогнутые склоны ложбин северо-восточной экспозищии; III $n$ - пологие $\left(3-5^{\circ}\right)$ вогнутые склоны северо-восточной экспозищии; IV $n$ - слабопологие $\left(1-3^{\circ}\right)$ склоны межложбинных водоразделов северо-восточной экспозищи. V-почти плоские $\left(0-1,5^{\circ}\right)$ выпуклье водораздельные пространства; Is - слабопологие (1-3) вогнутые склоны юго-западной экспозици; II $n$ - слабопологие (1-3 ${ }^{\circ}$ вогнутые склоны ложбин юго-западной экспозиции; III $n$ - пологие (3-5 ) вогнутые склоны юго-западной экспозиции; IV $n$ - слабопологие (1-3) склоны межложбинных водоразделов юго-западной экспозиции. 
Представленные на графиках данные свидетельствуют о том, с повышением урожайности яровой пшеницы уменьшается суммарное содержание макроэлементов в почве вследствие выноса растением питательных веществ. Исключения из этого правила повторяются на фациях водораздельной части ландшафта. Водоразделы, вследствие своего положения, способствующего стабильному функционированию системы при более равномерном содержании нитратного азота в почве за весь сезон (например, содержание нитратного азота в почвах фаций северного и южного склонов более нестабильно по сезону, имея коэффициенты вариации от весны к осени $26 \%$, в то время как на водоразделе только 1,5\%), имеют чаще всего максимальную урожайность. Это способствует тому, что вынос питательных веществ здесь компенсируется лучше, вследствие лучших условий для перегнивания пожнивно-корневых остатков. Все это вкупе с минимальной плоскостной эрозией стабилизирует содержание важнейших элементов плодородия.

Таким образом, одни и те же типы фаций, но на разных участках хозяйства устойчивы во времени в продуктивности и в содержании основных элементов питания растений.

Выводы. Проведенные исследования позволяют нам сделать следующие выводы:

- почвы типов фаций, вне зависимости от рода (почвы), отбираемые на протяжении 3 лет на разных полях, по суммарному количеству макроэлементов в них умеренно устойчивы в пространстве-времени;

-продуктивность типов фаций, выраженная в урожайности яровой пшеницы, имеет высокую пространственно-временную устойчивость и изменяется от более высоких показателей на фациях слабопологих и пологих склонов к низким на фациях ложбин и межложбинных водоразделов с промежуточным положением на водораздельных типах фаций;

-суммарное содержание макроэлементов в почве по уборке обратно пропорционально урожайности яровой пшеницы вследствие выноса культурой питательных веществ. Водораздельная часть, имея лучшие условия для сохранения и пополнения запасов элементов питания, не подчиняется этому правилу.

Полученные выводы дают право утверждать, что морфологические части ландшафта сохраняют свое влияние и значение на всей площади его (ландшафта) распространения. Более того, это влияние устойчиво во времени, что позволяет не только предсказать и смоделировать состояние ландшафта в будущем, но и наметить пути уменьшения влияния негативных факторов на сельскохозяйственное производство.

\section{Библиографический список}

1. Беручашвили Н.Л. Четыре измерения ландшафта. М.: Мысль, 1986. - 182 с., ил., карт. 2. Николаев В.А., Копыл И.В., Сысуев В.В. Природно-антропогенные ландшафты (сельскохозяйственные и лесохозяйственные): Учебное пособие. - М.: Географический факультет МГУ, 2008 г. $-160 \mathrm{c}$.

3. Николаев В. А. Ландшафтоведение. Семинарские и практические занятия. Изд. 2-е, перераб. и доп.-М.: Географический факультет МГУ, 2006. - 208 с. 
4. Солнцев Н.А. Учение о ландшафте (избранные труды). - М.: Изд-во Моск. ун-та, 2001. $-384 \mathrm{c}$.

5. Беручашвили Н.Л. Геофизика ландшафта: учеб. пособие для геогр. спец. вузов. - М.: Высш. шк., 1990. - 287 с.: ил.

6. Володин В.М., Еремина Р.Ф., Михайлова Н.Ф. Методика определения экологической емкости и биоэнергетического потенциала территории агроландшафта. Изд. Центр «ЮМЭКС». - Курск, 2000 - 31с.

\title{
УДК 633.16.321.631.526.32:631.529 \\ НОВЫЙ ПЕРСПЕКТИВНЫЙ СОРТ ЯРОВОГО ЯЧМЕНЯ ОМСКИЙ 102 ДЛЯ УСЛОВИЙ ОРГАНИЧЕСКОГО ЗЕМЛЕДЕЛИЯ
}

\author{
Николаев П.Н., Юсова О.А. \\ ФГБНУ «Омский АНЦ», г. Омск \\ E-mail:nikolaev@anc55.ru; yusova@anc55.ru
}

\begin{abstract}
Резюме. Представлена характеристика адаптивности нового сорта ячменя Омский 102 для условий органического земледелия Западной Сибири. Отмечена повышенная урожайность (+0,8 m/2а к st.), крупность зерна (+11,0 г к st.) и содержание крахмала (+1,0\% $\kappa$ st.). По содержанию белка и сырого жира данный сорт на уровне стандарта (12,1 и 1,8 \% соответственно).
\end{abstract}

Ключевые слова: ячмень (Hordeum Sativum J), сорт, урожайность, качество зерна, адаптивность.

Summary. The characteristic of adaptability of a new variety of barley Omsk 102 for the conditions of organic farming in Western Siberia is presented. There was an increased yield ( $+0.8 \mathrm{t} / \mathrm{ha}$ to St.), grain size $(+11.0 \mathrm{~g}$ to $\mathrm{St}$.) and starch content $(+1.0 \%$ to St.). In terms of protein and crude fat content, this grade is at the standard level (12.1 and 1.8\%, respectively).

Keywords: barley (Hordeum Sativum J), variety, yield, grain quality, adaptability.

Ячмень является важнейшей, универсальной и незаменимой по многообразному использованию зерновой культурой $[1,2]$.

На данный момент в Государственный реестр селекционных достижений, допущенных к использованию в Западной Сибири находятся 32 сорта из них: 11 сортов (34,4\%) созданных в ФГБНУ «Омский АНЦ»: Омский 90 (к-30721, medicum, пивоваренный 2000 г); Омский 91 (к-30918, nutans, пивоваренный, 2004 г.); Омский голозерный 1 (к-30919, nudum, 2004 г.); Омский 95 (к-31043, nutans, кормовой, 2007 г.); Омский голозерный 2 (к-31187, coeleste, 2008 г.); Омский 96 (к-30977, nutans, 2008 г.); Саша (к-31110, medicum, 2012 г.); Омский 99 (к-31230, pallidum, 2015 г.); Омский 100 (к-31336, medicum, 2019 г.); Омский голозерный 4 (к-31419, coeleste, 2020 г.).

Высокая изменчивость условий выращивания Западной Сибири обуславливает необходимость создания и распространения нового поколения сортов, обладающих высокой и стабильной продуктивностью.

Цель исследований - агробиологическая характеристика нового перспективного среднеспелого сорта ярового ячменя (Hordeum Sativum J) Омский 102, проходит государственное сортоиспытание по Уральскому (9), Западно-Сибирскому (10) и Восточно-Сибирскому (11) регионам. 
Оригинатор сорта ярового ячменя Омского 102 - ФГБНУ «Омский АНЦ». В качестве отцовской родительской формы выступал сорт Trumpf (Германия) полученный из ВИРа; материнская линия - Медикум 4584, полученная в Омском АНЦ и адаптированная к местным почвенно-климатическим условиям. В качестве источников скороспелости, засухоустойчивости и урожайности в схему гибридизации включены сорта Омский 86 , Донецкий 8 , Приишимский; в качестве источников повышенного качества зерна и устойчивости к головневым заболеваниям - сорта зарубежной селекции SMT 48076; Porvenir; Биомант).

Сорт Омский 102 разновидности nutans, относится к лесостепной экологической группе сортов, засухоустойчив, среднеспелый, от всходов до созревания 77-87 суток. Сорт высокорослый (85-100 см), соломина прочная, устойчив к полеганию. Колосья двурядные, пленчатые, остистые, соломенно-желтые, цилиндрической формы, средней длины, рыхлые. Переход цветочной чешуи в ость постепенный. Нервация цветочной чешуи сильно выражена. Ости длинные, зазубренные от основания, расположены вдоль колоса (параллельно колосу), соломенно-желтые, средней грубости, в отдельные годы могут быть слабо зазубрены вначале или в конце ости, с момента созревания, зазубрены на остях грубеют. Щетинка длинноволосистая. Зерно - желтое, пленчатое, полукруглое, крупное. Масса 1000 зерен варьирует от 54,0 до 57,0 г. (в среднем за три года составила 55,9 г., что на 11,0 г больше, чем у стандартного сорта Омский 95). Сыпучесть зерна при посеве хорошая.

В среднем за период исследований, содержание белка в зерне сортов ячменя составило 12,3\%; сырого жира - 2,0\%. Сорт Омский 102 по данным показателям на уровне стандарта (12,1 и 1,8 \% соответственно). Достоверных различий между сортами по данным показателям не выявлено. По содержанию крахмала в зерне новый сорт Омский 102 превышает стандарт $(+1,0 \%)$, но уступает последнему переданному сорту Омский 101 (-1,5\%). По показателю крупности зерна Омский 102 достоверно превышает стандартный сорт Омский 95 и Омский 101 (+11,0 и +2,3 г соответственно). В среднем за период исследований, урожайность исследуемых сортов ячменя составила 5,34 т/га, табл. 2. Наиболее урожайным годом можно считать 2020 г. (+0,15...3,15 т/га по отношению к прочим периодам исследованиям).

\section{Таблица 1 - Урожайность и качество зерна сорта Омский 102, в среднем за 2016-2020 гг.}

\begin{tabular}{|l|c|c|c|c|c|}
\hline \multicolumn{1}{|c|}{ Сорт } & $\begin{array}{c}\text { Урожайность, } \\
\text { т/га }\end{array}$ & $\begin{array}{c}\text { Содержание } \\
\text { белка, \% }\end{array}$ & $\begin{array}{c}\text { Содержание } \\
\text { сырого жира, } \\
\%\end{array}$ & $\begin{array}{c}\text { Содержание } \\
\text { крахмала, \% }\end{array}$ & $\begin{array}{c}\text { Масса 1000 } \\
\text { зерен, г }\end{array}$ \\
\hline Омский 95, st. & 4,84 & 12,6 & 2,1 & 54,7 & 44,9 \\
\hline Омский 101 & 5,55 & 12,3 & 2,2 & 57,2 & 53,2 \\
\hline Омский 102 & 5,64 & 12,1 & 1,8 & 55,7 & 55,9 \\
\hline$S_{\bar{x}}$ & 0,19 & 0,8 & 0,4 & 0,7 & 3,3 \\
\hline
\end{tabular}

Урожайность стандартного сорта Омский 95 составила 4,84 т/га (Lim. = 2,19...6,04 т/га). Новый перспективный сорт Омский 102 превышал стандарт в 
2018 и 2020 гг. $(+0,58$ и $+0,66$ т/га). В остальные периоды исследований урожайность данного сорта отмечена на уровне стандарта (3,76 и 6,63 т/га). За счет перечисленных особенностей, Омский 102 характеризовался повышенной урожайностью в среднем за период исследований $(0,8$ т/га) и по продуктивности относится к высокоурожайным в условиях Западной Сибири.

В среднем за период исследований, сорта ячменя характеризовались сбором белка на уровне 620,6 т/га, крахмала - 2,7 т/га и сырого жира - 101,2 т/га. Повышенная урожайность сорта Омский 102 способствовала превышению по выходу питательных веществ с единицы площади. Так, в среднем за период исследований, сбор белка нового сорта составил 655,95 кг/га (+98,9 кг/га к стандарту). Сбор сырого жира отмечен на уровне 98,05 кг/га (+7,06 кг/га к стандарту). Также Омский 102 характеризовался повышенным сбором крахмала $(3,03$ т/га), что достоверно превышает стандарт $(+0,6$ т/га) и сорт Омский 101 $(+0,35 \mathrm{~T} / \mathrm{гa})$.

Омский 102 достоверно превышал по уровню стабильности стандартный сорт Омский 95 (ИС = 26,2; Hom $=8,91 ; \mathrm{Sc}=17,82$, по Хангильдину В.В.) и отмечен на уровне сорта Омский 101.

Омский 102 достоверно превышает стандарт по относительной стабильности $\left(\mathrm{St}^{2}=0,96 ; \mathrm{A}=5,53\right.$, по Н.А. Соболеву) и на уровне сорта Омский 101 .

Омский 102 достоверно ниже стандарта по фактору стабильности (S.F.=1,78, по D. Lewis) и на уровне сорта Омский 101. Наблюдается достоверное превышение сортом Омский 102 стандарта по генотипическому эффекту ( $\varepsilon \mathrm{i}=0,30$, по D. Lewis), что на уровне сорта Омский 101.

Стандартный сорт Омский 95 относится к интенсивной группе $(И=79,4 \%)$, сорт Омский $102(И=52,3 \%)$ - к полуинтенсивной, сорт Омский 101 (И=49,0\%) - к интенсивной, по А.В. Головченко.

\section{Выводы}

1. Новый перспективный сорт Омский 102 характеризуется повышенной урожайностью (+0,8 т/га к st.) и крупностью зерна (+11,0 г к st.), в среднем за период исследований.

2. Сорт Омский 102 имеет повышенный сбор белка (+98,9 кг/га к st.), сырого жира (+7,06 кг/га к st.) и крахмала (+0,35 т/га к st.).

3. Сорт Омский 102 адаптивен для условий органического земледелия Западной Сибири и относится к полуинтенсивной группе.

\section{Библиографический список}

1. Сурин Н.А., Зобова Н.В., Ляхова Н.Е. Генетический потенциал и селекционная значимость ячменя Сибири // Вавиловский журнал генетики и селекции, 2014. - №2. - С. 378-386. 2. Николаев П. Н., Юсова О. А., Аниськов Н. И., Сафонова И. В. Агробиологическая характеристика многорядных голозерных сортов ячменя селекции Омского АНЦ // Труды по прикладной ботанике, генетике и селекции, 2019. - № 180 (1). - C. 37-43. DOI: 10.30901/2227-8834-2019-1-38-43. 


\title{
ЭФФЕКТИВНОСТЬ ВОЗДЕЛЫВАНИЯ ЯЧМЕНЯ ПРИ МИНИМИЗАЦИИ ОСНОВНОЙ ОБРАБОТКИ ПОЧВЫ В СЕВООБОРОТАХ ЦЧР
}

\author{
Нитченко Л.Б.
}

ФГБНУ «Курский ФАНЦ», г. Курск

E-mail: Nitchenko58@yandex.ru

\begin{abstract}
Резюме. Установлено, что урожайность ячменя выме в зернопаропропашном севообороте при отвальной обработке почвы и внесении удобрений в дозе $N_{60} P_{60} K_{60}$. Применение комбинированной и безотвальной основной обработки почвы в севооборотах способствовало снижению прямых затрат и себестоимости зерна, повышению прибыли и рентабельности при незначительном снижении урожайности ячменя.
\end{abstract}

Ключевые слова: ячмень, урожайность, натура зерна, севооборот, основная обработка почвы, минеральные удобрения, экономическая эффективность.

В сельскохозяйственном производстве при возделывании зерновых культур основной задачей является увеличение валовых сборов зерна при снижении производственных затрат. Наибольшему снижению производственных затрат и себестоимости, повышению прибыли и рентабельности способствует размещение ячменя по лучшим предшественникам, отказ от наиболее энергоёмкой основной обработки почвы вспашки и рациональное применение минеральных удобрений.

Для производства ярового ячменя 1-го класса качества культуру необходимо возделывать в зернопаропропашном севообороте на фоне повышенных доз минеральных удобрений [1]. Согласно исследованиям [2], размещение ярового ячменя в севообороте после кукурузы на силос повышало урожайность на 0,14-0,16 т/га, по сравнению с возделыванием после сахарной свеклы.

Наибольшая урожайность зерна ярового ячменя получена при посеве по вспашке. Минимизации обработки почвы приводила к уменьшению урожайности ячменя при комбинированной обработке на $19,9 \%$, при поверхностной - на 34,7 \%, при прямом посеве - на 29,7 \% [3].

Безотвальная и поверхностная обработки почвы в годы с типичными для зоны погодными условиями снижала урожайность ячменя, а в годы с количеством осадков выше средних многолетних значений различия в урожайности незначительные [4].

По мнению ученых [5], чтобы получать стабильную урожайность ячменя $(4,0-4,4$ т/га) в зернопропашном севообороте, рекомендуется применять минеральные удобрения в дозе $\mathrm{N}_{50} \mathrm{P}_{50} \mathrm{~K}_{50}$ с использованием энергосберегающих обработок почвы. Чистый доход при этом достигает 11221-13213 руб./га, а окупаемость 1 кг удобрений - 8,7-10,0 кг зерна.

Цель исследований - определение эффективности возделывания ячменя при минимизации основной обработки почвы в зернопаропропашном и зернотравянопропашном севооборотах ЦЧР. 
Материалы и методы исследований. В многофакторном полевом опыте ФГБНУ «Курский ФАНЦ» в 1986...2018 гг. в зернопаропропашном и зер-нотравянопропашном севооборотах изучали эффективность возделывания ячменя при минимизации основной обработки почвы.

Зернопаропропашной севооборот (ЗПП) включал следующие культуры: чистый пар - озимая пшеница (Triticum aestivum L.) - кукуруза (Zéa máys) на зелёный корм - ячмень (Hordeum vulgare). Зернотравянопропашной севооборот (ЗТП): многолетние травы (Onobrýchis arenária) - озимая пшеница (Triticum aestivum L.) - кукуруза (Zéa máys) на зелёный корм - ячмень (Hordeum vulgare) с подсевом многолетних трав (Onobrýchis arenária). Фактор «система основной обработки почвы в севооборотах» изучали на трёх уровнях: отвальная $(\mathrm{O})$, безотвальная (Б), комбинированная (К) (отвальная обработка под кукурузу и поверхностная под зерновые культуры). Отвальную и безотвальную обработки почвы проводили на глубину 20-22 см, поверхностную - на 10 см. Уровень минерального питания: без удобрений, $\mathrm{N}_{30} \mathrm{P}_{30} \mathrm{~K}_{30}, \mathrm{~N}_{60} \mathrm{P}_{60} \mathrm{~K}_{60}$ кг д.в./га. Площадь посевных делянок $100 \mathrm{~m}^{2}$. Учёт урожайности проводили методом прямой механизированной уборки. Почвы опытного участка представлены чернозёмом типичным среднесуглинистым.

Результаты исследования. Результаты многолетних исследований показали, что урожайность ячменя (таблица 1) в зернопаропропашном севообо-

Таблица 1 - Урожайность ячменя в зависимости от систем основной обработки почвы и доз минеральных удобрений в севооборотах (средняя $1986 . .2018$ гг.)

\begin{tabular}{|c|c|c|c|c|c|}
\hline \multirow[t]{2}{*}{ Севооборот (A) } & \multirow{2}{*}{$\begin{array}{c}\text { Система обработки } \\
\text { почвы (В) }\end{array}$} & \multicolumn{3}{|c|}{ Минеральные удобрения (C) } & \multirow[t]{2}{*}{ Средняя } \\
\hline & & $\begin{array}{c}\text { Без } \\
\text { удобре- } \\
\text { ний }\end{array}$ & $\mathrm{N}_{30} \mathrm{P}_{30} \mathrm{~K}_{30}$ & $\mathrm{~N}_{60} \mathrm{P}_{60} \mathrm{~K}_{60}$ & \\
\hline \multirow[t]{4}{*}{ Зернопаропропашной } & Отвальная & 3,15 & 3,54 & 3,71 & 3,47 \\
\hline & Комбинированная & 2,97 & 3,32 & 3,54 & 3,28 \\
\hline & Безотвальная & 3,11 & 3,38 & 3,48 & 3,32 \\
\hline & средняя & 3,08 & 3,41 & 3,58 & 3,36 \\
\hline \multirow[t]{4}{*}{ Зернотравянопропашной } & Отвальная & 2,93 & 3,41 & 3,57 & 3,30 \\
\hline & Комбинированная & 2,74 & 3,36 & 3,61 & 3,24 \\
\hline & Безотвальная & 2,69 & 3,34 & 3,62 & 3,22 \\
\hline & средняя & 2,79 & 3,37 & 3,60 & 3,25 \\
\hline \multirow[t]{4}{*}{ Средняя } & Отвальная & 3,04 & 3,48 & 3,64 & 3,39 \\
\hline & Комбинированная & 2,86 & 3,34 & 3,58 & 3,26 \\
\hline & Безотвальная & 2,90 & 3,36 & 3,55 & 3,27 \\
\hline & средняя & 2,93 & 3,39 & 3,59 & 3,30 \\
\hline $\mathrm{HCP}_{05}$ & & \multicolumn{4}{|c|}{$\begin{array}{l}A=0,11 ; B=0,14 ; C=0,14 ; A B=0,20 \\
A C=0,20 ; B C=0,24 ; A B C=0,34\end{array}$} \\
\hline
\end{tabular}

роте была выше в среднем на $0,11 \mathrm{~T} / г$, по сравнению с зернотравянопропашным севооборотом. Наибольшей урожайность ячменя получена в зернопаропропашном севооборот при отвальной обработке почвы - 3,15 т/га (вариант без удобрений $), \quad 3,54$ т/га $\left(\mathrm{N}_{30} \mathrm{P}_{30} \mathrm{~K}_{30}\right), \quad 3,71$ т/га $\left(\mathrm{N}_{60} \mathrm{P}_{60} \mathrm{~K}_{60}\right)$. Применение 
комбинированной и безотвальной обработок почвы способствовало снижению урожайности ячменя на 4,5-6,2 \%, по сравнению с аналогичными вариантами при отвальной обработке. В зернотравяно-пропашном севообороте снижение урожайности ячменя при комбинированной и безотвальной обработках почвы было достоверным (при $\mathrm{HCP}_{05}=0,14 \mathrm{~T} /$ га) в варианте без внесения удобрений. В удобренных вариантах различия в урожайности ячменя по обработкам почвы находились в пределах ошибки опыта. Внесение минеральных удобрений способствовало повышению урожайности ячменя в изучаемых севооборотах как при отвальной, так и при безотвальной и комбинированной обработках почвы. Прибавки урожайности ячменя в зернопаропропашном севообороте составили: 0,27-0,39 т/га при внесении $\mathrm{N}_{30} \mathrm{P}_{30} \mathrm{~K}_{30}$ и были больше при отвальной обработке почвы; 0,37-0,57 т/га при внесении $\mathrm{N}_{60} \mathrm{P}_{60} \mathrm{~K}_{60}$ и при отвальной и комбинированной обработках были практически равными. В зернотравянопропашном севообороте прибавки урожайности ячменя соответственно составили $0,48-0,65$ т/га, 0,64-0,93 т/га и были больше при безотвальной и комбинированной обработках почвы.

В результате проведенных исследований установлено, что натура зерна ячменя (рисунок 1) в зернопаропропашном севообороте в среднем составила 636 г/л, в зернотравянопропашном севообороте была выше на 6 г/л и составила 642 г/л. При минимизации обработки почвы и внесении минеральных удобрений наблюдалось повышение натуры зерна ячменя. Ориентировочный класс качества зерна ячменя, полученного в зернопаропропашном и зернотравянопропашном севооборотах - на продовольственные цели, согласно ГОСТ 28672$90[6]$.

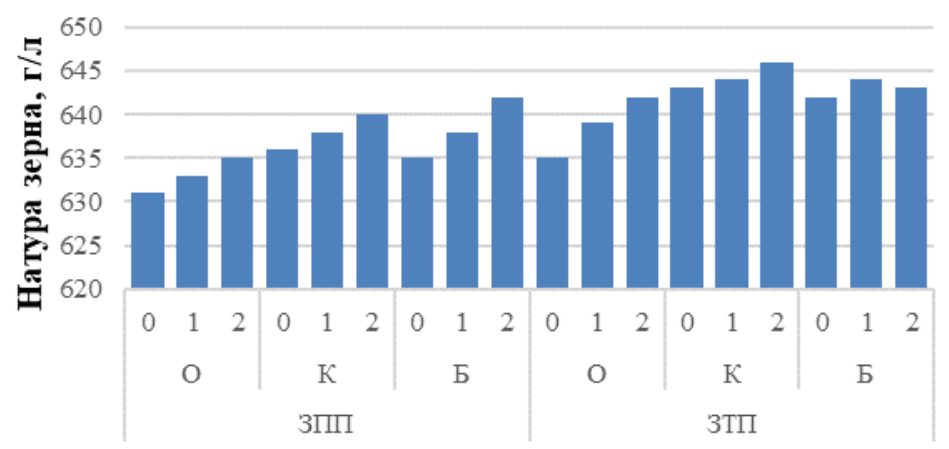

Рисунок 1 - Влияние систем основной обработки почвы и доз минеральных удобрении на натуру зерна ячменя в севооборотах

Результаты определения экономической эффективности (таблица 2) показали, что в зернопаропропашном севообороте при возделывании ячменя по отвальной обработке почвы себестоимость зерна составила 5,26 тыс. руб./т, рентабельность - 90,1\%. В зернотравянопропашном севообороте себестоимость зерна была выше - 5,66 тыс. руб./т, рентабельность ниже - 76,8 \%. Применение комбинированной и безотвальной обработок почвы в зернопаропропашном севообороте в вариантах без внесения минеральных удобрений способствовало снижению себестоимости зерна соответственно на 0,29 и 0,56 тыс. руб./т и повышению рентабельности на 10,5 и 22,6 \%, по сравнению с отвальной 
обработкой. Снижение себестоимости зерна ячменя в зернотравянопропашном севообороте при комбинированной обработке составило 0,26 тыс. руб./т, при безотвальной - 0,22 тыс. руб./т. Рентабельность была выше соответственно на 8,2 и 7,1\%. Прибыль более высокой была при безотвальной обработке почвы $-16,48$ тыс. руб./га.

\section{Таблица 2 - Экономическая эффективность возделывания ячменя в зависимости от систем основной обработки почвы и доз минеральных} удобрений в севооборотах

\begin{tabular}{|c|c|c|c|c|c|c|c|c|}
\hline \multirow[t]{2}{*}{$\begin{array}{c}\text { Система основной } \\
\text { обработки почвы }\end{array}$} & \multicolumn{2}{|c|}{$\begin{array}{c}\text { Урожайность, } \\
\text { т/га }\end{array}$} & \multicolumn{2}{|c|}{$\begin{array}{c}\text { Себесто- } \\
\text { имость, тыс. } \\
\text { руб./т }\end{array}$} & \multicolumn{2}{|c|}{$\begin{array}{c}\text { Прибыль, } \\
\text { тыс. руб./га }\end{array}$} & \multicolumn{2}{|c|}{$\begin{array}{c}\text { Рентабельность } \\
\%\end{array}$} \\
\hline & ЗПП & उТП & 3ПП & 3 उТ & ЗПП & उТП & ЗПП & 3 उТ \\
\hline \multicolumn{9}{|c|}{ Без удобрений } \\
\hline Отвальная & 3,15 & 2,93 & 5,26 & 5,66 & 14,93 & 12,73 & 90,1 & 76,8 \\
\hline Комбинированная & 2,97 & 2,74 & 4,97 & 5,40 & 14,89 & 12,59 & 100,6 & 85,0 \\
\hline Безотвальная & 3,11 & 2,69 & 4,70 & 5,44 & 16,48 & 12,28 & 112,7 & 83,9 \\
\hline \multicolumn{9}{|c|}{ Доза минеральных удобрений $\mathrm{N}_{30} \mathrm{P}_{30} \mathrm{~K}_{30}$} \\
\hline Отвальная & 3,54 & 3,41 & 5,23 & 5,42 & 16,90 & 15,60 & 91,4 & 84,3 \\
\hline Комбинированная & 3,32 & 3,36 & 5,03 & 4,97 & 16,48 & 16,88 & 98,6 & 101,0 \\
\hline Безотвальная & 3,38 & 3,34 & 4,90 & 4,96 & 17,24 & 16,84 & 104,2 & 101,8 \\
\hline \multicolumn{9}{|c|}{ Доза минеральных удобрений $\mathrm{N}_{60} \mathrm{P}_{60} \mathrm{~K}_{60}$} \\
\hline Отвальная & 3,71 & 3,57 & 5,48 & 5,70 & 16,77 & 15,37 & 82,5 & 75,6 \\
\hline Комбинированная & 3,54 & 3,61 & 5,23 & 5,13 & 16,87 & 17,57 & 91,1 & 94,8 \\
\hline Безотвальная & 3,48 & 3,62 & 5,28 & 5,08 & 16,41 & 17,82 & 89,3 & 96,9 \\
\hline
\end{tabular}

В зернопаропропашном севообороте при дозе внесения минеральных удобрений $\mathrm{N}_{30} \mathrm{P}_{30} \mathrm{~K}_{30}$ более низкой себестоимость зерна ячменя была при безотвальной обработке почвы - 4,90 тыс. руб./т; прибыль при безотвальной обработке увеличилась на 0,34 тыс. руб./га, при комбинированной - уменьшилась на 0,42 тыс. руб./га, по сравнению с отвальной обработкой. Рентабельность при отвальной обработке почвы составила 91,4 \%, при безотвальной - 100,4 \%, при комбинированной - 98,6 \%. В зернотравянопропашном севообороте при дозе удобрений $\mathrm{N}_{30} \mathrm{P}_{30} \mathrm{~K}_{30}$ рентабельность при отвальной обработке почвы равнялась $84,3 \%$; при комбинированной и безотвальной обработках почвы она была практически равной и составила соответственно 101,0 и 101,8 \%.

В зернопаропропашном севообороте при дозе внесения минеральных удобрений $\mathrm{N}_{60} \mathrm{P}_{60} \mathrm{~K}_{60}$ себестоимость зерна ячменя была ниже при комбинированной обработке почвы - 5,23 тыс. руб./т; прибыль при безотвальной обработке уменьшилась на 0,36 тыс. руб./га, при комбинированной обработке - увеличилась на 0,10 тыс. руб./га. Рентабельность самой высокой была при комбинированной обработке почвы - 91,1\%. В зернотравянопропашном севообороте при дозе удобрений $\mathrm{N}_{30} \mathrm{P}_{30} \mathrm{~K}_{30}$ себестоимость зерна ячменя была ниже $(5,08$ тыс. руб./т), а рентабельность выше (96,9 \%) при безотвальной обработке почвы. При отвальной обработке почвы рентабельность равнялась 75,6 \%; при комбинированной 94,8 \%. 
Выводы. Результаты исследований показали, что урожайность ячменя выше в зернопаропропашном севообороте при отвальной обработке почвы и внесении удобрений в дозе $\mathrm{N}_{60} \mathrm{P}_{60} \mathrm{~K}_{60}$. Зернотравянопропашной севооборот уступал по урожайности зернопаропропашному. Применение комбинированной и безотвальной основной обработки почвы в севооборотах способствовало снижению прямых затрат и себестоимости зерна, повышению прибыли и рентабельности, при незначительном снижении урожайности ячменя, по сравнению с отвальной обработкой. Прибавки урожайности ячменя в зернопаропропашном севообороте при внесении $\mathrm{N}_{30} \mathrm{P}_{30} \mathrm{~K}_{30}$ были больше при отвальной обработке почвы; при внесении $\mathrm{N}_{60} \mathrm{P}_{60} \mathrm{~K}_{60}$ - при отвальной и комбинированной обработках были практически равными. В зернотравянопропашном севообороте прибавки урожайности ячменя были больше при безотвальной и комбинированной обработках почвы.

\title{
Библиографический список
}

1. Гостев А.В. Условия формирования зерна высокого качества в высокопродуктивных ресурсосберегающих агротехнологиях ЦЧР // Земледелие, 2019. - № 6. - С. 16-20.

2. Лазарев В.И. Эффективность возделывания яровых зерновых культур в различных видах полевых севооборотов в почвенно-климатических условиях Курской области // Международный сельскохозяйственный журнал, 2020. - № 5 (377). - С. 17-19.

3. Дубовик Д.В. Эффективность приёмов основной обработки почвы под яровой ячмень на чернозёмах Курской области // Земледелие, 2021. - № 2. - С. 44-48.

4. Турусов В.И., Корнилов И.М. Обработка почвы под ячмень на различных элементах агроландшафта // Земледелие, 2013. - №1. - С. 19-20.

5. Самыкин В.Н., Соловиченко В.Д., Логвинов И.В., Мартаков Г.М. Экономическая оценка интенсивных технологий возделывания ячменя в зернопропашном севообороте // Земледелие, 2013. - № 5. - С. 25-26.

6. Межгосударственный стандарт. ГОСТ 28672-90. «Ячмень. Требования при заготовках и поставках». М.: Стандартинформ, 2010. - 86 с.

УДК $631.871: 631.434 .6$

\section{ВЛИЯНИЕ БИОПРЕПАРАТОВ НА СТРУКТУРНО-АГРЕГАТНЫЙ СОСТАВ ЧЕРНОЗЕМА ТИПИЧНОГО СЛАБОСМЫТОГО В ПОСЕВАХ КОРМОВЫХ БОБОВ}

\author{
Окунева А.А. \\ ФГБНУ «Курский ФАНЦ», г. Курск \\ E-mail: ok.anan@yandex.ru
}

\begin{abstract}
Резюме. В статье представлены результаты исследования влияния биопрепаратов совместно с внесением растительных остатков и азота, на структурно-агрегатный состав чернозема типичного слабосмытого при воздельвании бобовых культур. Отмечается повымение суммы агрономически ценной фракции и улучшение водопрочности структуры почвы.
\end{abstract}

В настоящее время характерной чертой ведения сельского хозяйства является интенсификация агротехнического воздействия на почвенный покров земель сельхоз назначения [1]. Постоянный вынос органического вещества, нерациональное использование минеральных удобрений, а также интенсивная 
обработка сельскохозяйственной техникой приводят к обесструктуриванию пахотных почв и являются причинами ухудшения почвенного плодородия.

Кроме активной механической обработки широко распространено использование препаратов и удобрений химической природы. Средства химизации являются приоритетными факторами воздействия на агроэкосистему в сельскохозяйственных ландшафтах [2]. Они бесспорно необходимы для поддержания роста и развития возделываемых культур, однако, к побочным эффектам можно отнести отрицательное воздействие на агромикробоценоз. Основные функциональные группы почвенных микроорганизмов - грибы, бактерии и актиномицеты - это активные участники процессов структурообразования, формирования водопрочных агрегатов, разложения органического вещества [3]. Альтернативным решением по улучшению экологического состояния почвенной экосистемы является=применение биологических препаратов на основе микроорганизмов.

На территории опытного поля Курского ФАНЦ (Курская область, Медвенский район) были проведены исследования, направленные на изучение влияния биологических препаратов на структурно-агрегатный состав чернозема типичного слабосмытого при возделывании бобовых культур. В качестве биопрепаратов использовали «Грибофит» на основе микроскопического гриба вида Trichoderma viride и «Имуназот», в основе культуры бактерии вида Pseudomonas chloraraphis. Первый препарат является микробиологическим фунгицидом и деструктором, используется для санации почвы, второй - оказывает ростостимулирующее действие и подавляет рост фитопатогенных микроорганизмов.

Опыт заложен в 4-х вариантах:

Вариант 1 (контроль) - измельченные растительные остатки кормовых бобов без обработки биопрепаратами.

Вариант 2 - измельченные растительные остатки кормовых бобов с внесением азотных удобрений в дозе $\mathrm{N}_{10}$ д.в. на 1 т растительных остатков.

Вариант 3 - полная обработка биопрепаратами семян, почвы перед посевом, двукратная обработка при вегетации и после уборки урожая растительных остатков кормовых бобов «Грибофитом» в дозе 5 л/га и «Имуназотом» - 3 л/га.

Вариант 4 - полная обработка биопрепаратами семян, почвы перед посевом, двукратная обработка при вегетации и после уборки урожая растительных остатков кормовых бобов «Грибофитом» в дозе 5 л/га и «Имуназотом» - 3 л/га, а также внесение азотных удобрений в дозе $\mathrm{N}_{10}$ д.в. на 1 т растительных остатков.

Отбор почвенных образцов проводился на стационарном полевом опыте с применением биопрепаратов в слоях 0-10, 10-20 см на 4-х вариантах в 3-х кратной повторности. Подготовка почвенных образцов и определение структурноагрегатного состава почвы проводились по методу Н.И. Саввинова - сухое и мокрое просеивание (Вадюнина, Корчагина, 1986). Результаты исследования были обработаны статистическими методами анализа (Доспехов, 1987). 
На рисунке 1 представлены данные по процентному содержанию фракций почвенных водопрочных и неводопрочных почвенных агрегатов в образцах, отобранных на глубине $0-10$ см.

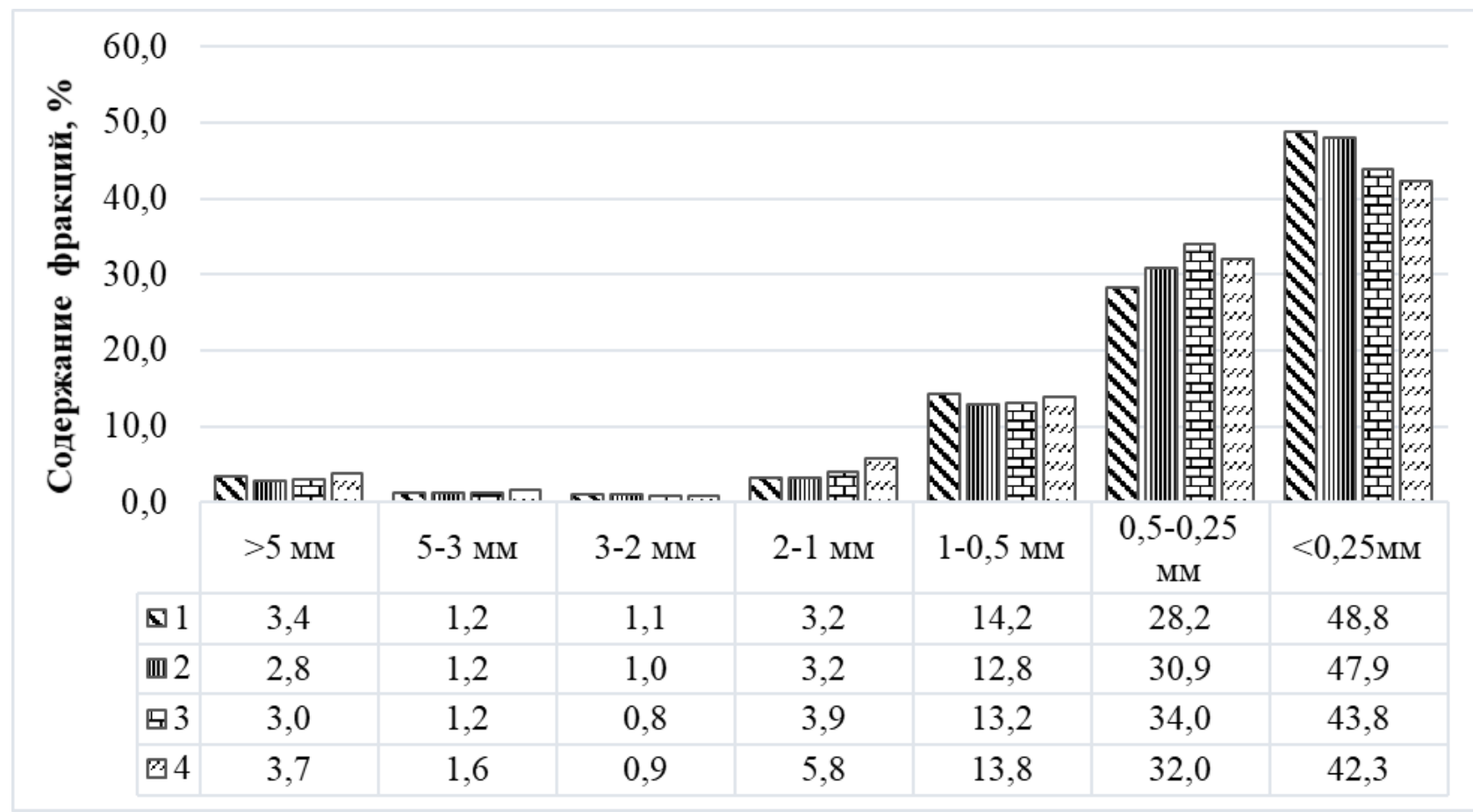

Рисунок 1 - Структурно-агрегатный состав (мокрое просеивание) чернозема типичного слабосмытого на опыте с биопрепаратами после

разложения внесенных в почву измельченной надземной части растений кормовых бобов (на 80 день) в слое 0-10 см

Выявлено, что содержание неводопрочной фракции $<0,25$ мм снижается от 1-ого варианта опыта (контроль) к 4-ому. Обратная тенденция, т.е. тенденция к увеличению, прослеживается по фракции размером 2-1 мм, которая является наиболее агрономически ценной. Это свидетельствует о положительном влиянии обработки биопрепаратами растительных остатков кормовых бобов на структурно-агрегатный состав почвы. Стоит обратить внимание, что процентное содержание фракции 0,5-0,25 мм в 3-м варианте (с внесением только биопрепаратов) опыта принимает максимальные значения, по сравнению с остальными. Аналогичные данные получены при анализе результатов процентного содержания фракций почвенных образцов, отобранных на глубине 10-20 см (рис. 2).

Тенденция к снижению объема неводопрочных агрегатов ( $<0,25$ мм) от 1ого к 4-ому варианту сохраняется и здесь. Аналогично наблюдается увеличение содержания агрономически ценных агрегатов 2-1 мм от контрольного к варианту совместного использования биопрепаратов с минеральными удобрениями. Стоит отметить синхронное увеличение содержания фракции 0,5-0,25 мм в 2,3 и 4-м вариантах опыта по сравнению с контрольным. Происходит уменьшение показателей от контрольного варианта к опытным на размерности $>5$ мм. В целом, динамика улучшения структурного состава почвы сохраняется на 
всех исследуемых глубинах в вариантах опыта с применением биологических препаратов.

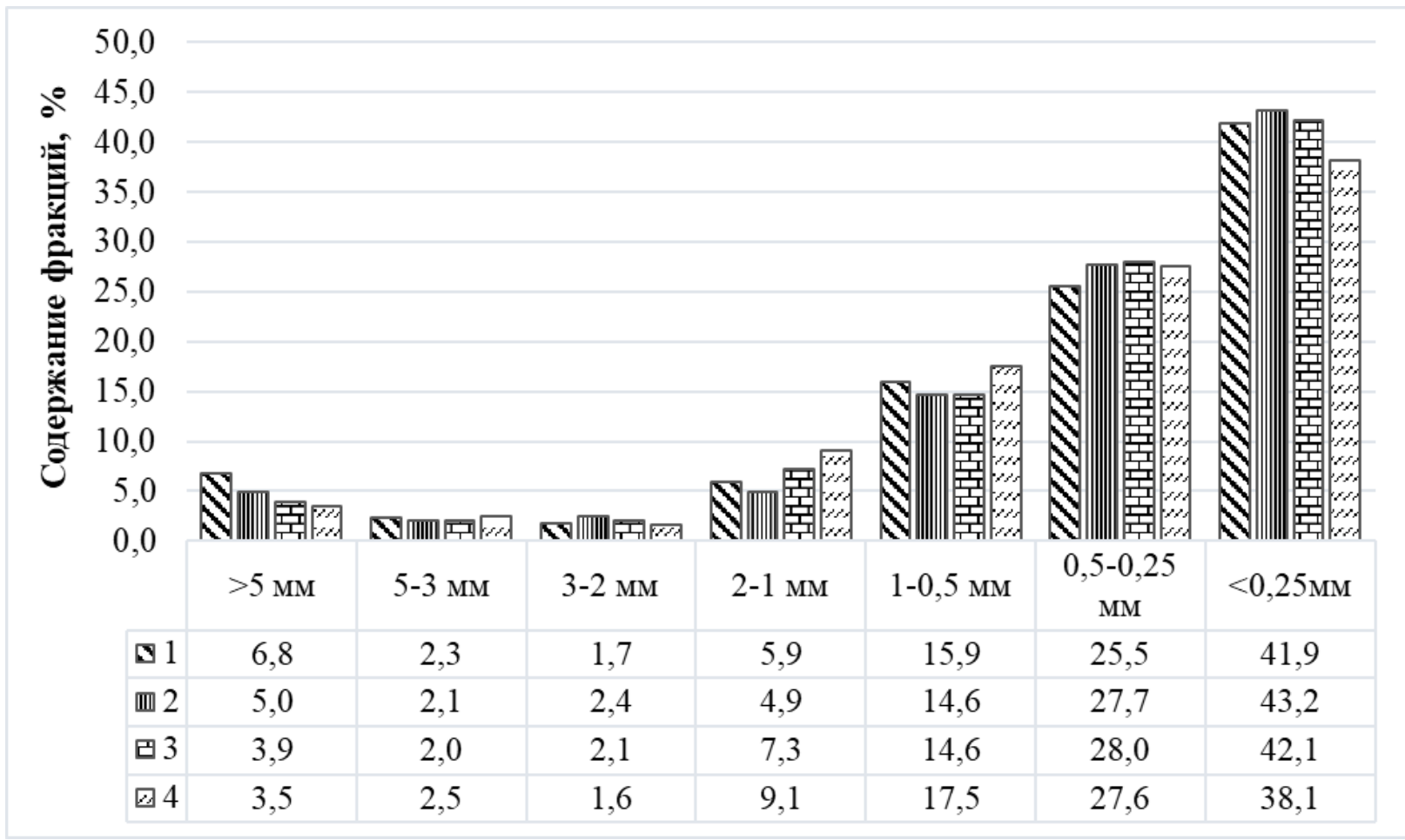

Рисунок 2 - Структурно-агрегатный состав (мокрое просеивание) чернозема типичного слабосмытого на опыте с биопрепаратами после

разложения внесенных в почву измельченной надземной части растений кормовых бобов (на 80 день) в слое 10-20 см

Следует отметить, что минимальные значения показателя количества водопрочных агрегатов $>0,25$ мм отмечаются в контрольном варианте опыта (без внесения минеральных удобрений и биопрепаратов), как на глубине 0-10 см, так и 10-20 мм, и, соответственно, равны 51,2 и 58,1 (табл.1). Максимальные значения показателя фиксируются в 4-м варианте опыта, где производилось внесение биологических препаратов. Данные по этому варианту составляют на глубине 0-10 мм 57,7\%, а на глубине 10-20 мм - 61,9\%, что выше контрольных значений на $11,3 \%$ и 6,1\%, соответственно.

При анализе данных по количеству водопрочных агрегатов можно заметить тенденцию к увеличению данного показателя по вариантам от 1 к 4. Причем на такое положительное изменение содержания водопрочных агрегатов оказывают влияние именно применение в вариантах 3 и 4 биологических препаратов «Грибофит» и «Имуназот». При оценке водопрочности структуры почвы в исследуемых образцах полученные данные можно интерпретировать как «хорошая» во всех вариантах опыта, кроме 4-ого. Здесь на глубине 10-20 см структуру можно охарактеризовать как «отличная», что является подтверждением эффективного использования минеральных удобрений и биопрепаратов (табл. 1). 
Таблица 1 - Водопрочность чернозема типичного слабосмытого на опыте с биопрепаратами после разложения внесенной в почву измельченной надземной части кормовых бобов

\begin{tabular}{|c|c|c|c|}
\hline \hline \multirow{2}{*}{ Вариант } & $\begin{array}{c}\text { Глубина, } \\
\text { см }\end{array}$ & $\begin{array}{c}\text { Количество водопрочных агрегатов } \\
>0,25 \mathrm{Mm}\end{array}$ & $\begin{array}{c}\text { Оценка водопрочности } \\
\text { структуры почвы }\end{array}$ \\
\hline \hline \multirow{2}{*}{1} & $0-10$ & 51,2 & хорошая \\
\cline { 2 - 4 } 2 & $10-20$ & 58,1 & хорошая \\
\hline \hline \multirow{2}{*}{3} & $0-10$ & 52,1 & хорошая \\
\cline { 2 - 4 } & $10-20$ & 56,8 & хорошая \\
\hline \hline \multirow{2}{*}{4} & $0-10$ & 56,2 & хорошая \\
\hline \hline & $10-20$ & 57,9 & хорошая \\
\hline \hline
\end{tabular}

Таким образом, на основе полученных результатов по структурно-агрегатному составу методом мокрого просеивания (по Н.В. Саввинову) чернозема типичного слабосмытого на опыте с биопрепаратами после разложения внесенной в почву измельченной надземной части кормовых бобов можно сделать вывод об эффективности применения используемых биологических препаратов «Имуназот» и «Грибофит». Это подтверждается положительными результатами по увеличению суммы водопрочных агрегатов по сравнению с контролем, улучшением водопрочности структуры почвы до «отличной» в варианте с использованием минеральных удобрений и биопрепаратов и снижением содержания неводопрочных агрегатов.

\section{Библиографиеский список}

1. Несмеянова, М. А. Структурно-агрегатный состав и водопрочность почвы под влиянием многолетних бобовых трав / М. А. Несмеянова // Пермский аграрный вестник №1. 2015. - № 9. - С. 50-55.

2. Негативные последствия при внесении минеральных удобрений под полевые культуры и пути их устранения / В. Яичкин, А. Косых, И. Сотникова, А. Бекмухамедова. // Известия оренбургского государственного аграрного университета. - 2010. - № 2 (26). - С. 53 54.

3. Дубовик, Е. В. Влияние биопрепаратов на структурно-агрегатный состав чернозема типичного слабоэродированного / Е. В. Дубовик, Н. П. Масютенко // Международный сельскохозяйственный журнал. - 2020. - № 5. - С. 56-60. 
УДК: 519.24:631.8

\section{ИСПОЛЬЗОВАНИЕ МАТЕМАТИЧЕСКОГО МОДЕЛИРОВАНИЯ ПРИ ОПРЕДЕЛЕНИИ ОПТИМАЛЬНЫХ ДОЗ УДОБРЕНИЯ ПОД СЕЛЬСКОХОЗЯЙСТВЕННЫЕ КУЛЬТУРЫ}

Осипов Ю.Ф., Новикова А.А., Шаповалова Е.В., Шевченко А.А. ФГБНУ «Национальный центр зерна имени П.П. Лукьяненко», г. Краснодар E-mail: Yurii.osipov.36@mail.ru; Ana.nov@mail.ru; Eudjahe3009@mail.ru; Allafedorova1996@gmail.com

Резюме. В данной работе ведется обсуждение причин низкой эффективности удобрений в РФ. Для ее увеличения предлагается использовать методы системного анализа и математического моделирования. Применение авторами математического моделирования при расчете оптимальных доз удобрений (на примере азотных подкормок) показало его высокую эффективность: окупаемость $2^{x}$ азотных подкормок (в сумме) составила: 29 (на озимом ячмене) и 22 (на озимой пшениче) кг зерна/кг д.в. удобрений; при этом достигнута высокая урожайность ( 90 ич/га) и получено зерно хорошего качества.

Ключевые слова: математическое моделирование, расчет оптимальных доз удобрений, азотные подкормки озимых колосовых культур, урожайность, окупаемость азотных подкормок.

Summary. In this paper discusses the reasons for the low efficiency of fertilizers in the Russian Federation. To increase it, it is proposed to use the methods of system analysis and mathematical modeling. The use of mathematical modeling by the authors in calculating of optimal doses of fertilizers (for example, nitrogen fertilizing) showed of it high efficiency: the payback of 2 nitrogen fertilizing (in total) was: 29 (for winter barley) and 22 (for winter wheat) $\mathrm{kg}$ grain / $\mathrm{kg}$ a.i. fertilizers; at the same time, a high yield was achieved $(\sim 90 \mathrm{c} / \mathrm{ha})$ and good quality grain was obtained. Key words: mathematical modeling, calculation of optimal doses of fertilizers, nitrogen fertilization of winter crops, yield, recoupment of nitrogen fertilization.

В среднем, в Российской Федерации эффективность использования удобрений очень низка [1], что связано со многими факторами, но главное, на наш взгляд, с отсутствием системного подхода к решению вопроса об определении оптимальных доз удобрений. Существующие методики давно устарели, в частности, потому, что нацелены не на повышение урожайности сельскохозяйственных культур, а только на снижение дефицита в почве того или иного элемента без количественного учета взаимодействий в системе почва - растение - АФЦ (агрофитоценоз) - удобрения - погода.

Иначе говоря, мы имеем перед собой многокомпонентную систему, с которой функционально связано формирование продуктивности АФЦ культуры и, в конечном итоге, ее урожайность. Решить эту задачу возможно только при условии:

1 - использования результатов многолетних данных многофакторных научных опытов;

2 - системного анализа этой информации [2];

3 - создания математических моделей (для отдельных культур и этапов вегетации) связи урожайности с наиболее существенными факторами системы, в том числе: исходным уровнем эффективного плодородия почвы, дозами основного удобрения и подкормок, состоянием АФЦ и т.д.; уравнения рассчитываются с 
помощью специальной программы ${ }^{*}$ «Пошаговый множественный нелинейный регрессионный анализ»

4 - с помощью другой специальной программы (усовершенствованный метод Хука-Дживса) $)^{* *) 1}$ осуществляется поиск оптимального уровня аргументов (доз удобрений) по заданной функции (урожайности) с учетом уровня сопутствующих факторов.

Используя эти подходы, нами было разработано и запатентовано два способа определения оптимальных доз азотных подкормок для озимых колосовых культур [3]: - для первой (ранневесенней) азотной подкормки, которая включает в себя следующие показатели: индекс предшественника (определяется статистически на основе многолетней информации об урожайности культуры на том или ином предшественнике), содержание в почве (рано весной): в слое 0-20 см - N-NO и N-NH $_{4}$ мГ/кг (ГОСТ-26951-86; ГОСТ 26489-85), а в слое 20$40 \mathrm{~cm}-\mathrm{P}_{2} \mathrm{O}_{5}$ и $\mathrm{K}_{2} \mathrm{O}$ мг/кг (по Мачигину, ГОСТ26205-91), густоту агрофитоценоза, (количество стеблей ( $>2 \mathrm{~cm}$ ) на $1 \mathrm{M}^{2}$ посева в начале весенней вегетации) и сумму осадков (мм) за осенне-зимний период(сентябрь-февраль) текущего с.х. года (по данным Гидрометеослужбы ).

Для расчета дозы второй азотной подкормки [на V-VI этапе органогенеза, по Куперман (4)]использовали следующие факторы: дозу внесенной 1й азотной подкормки в кг д.в./га, накопленную сырую биомассу АФЦ $\left(г / \mathrm{M}^{2}\right)$, содержание в ней азота (\%), содержание в почве (рано весной): $\mathrm{N}-\mathrm{NH}_{4}$ (слой 0-20 см), $\mathrm{P}_{2} \mathrm{O}_{5}$ и $\mathrm{K}_{2} \mathrm{O}$ (слой 20-40 см) мг/кг, среднесуточную температуру воздуха в марте месяце текущего года $\left(\mathrm{C}^{\circ}\right)$.

Каждый из вышеописанных способов имеет свою математическую модель, описывающую взаимосвязь в системе: урожайность - почва - удобрения - состояние АФЦ, причем для каждой культуры рассчитана своя математическая модель (в патентах представлены другие модели, где функцией (у) являются рассчитываемые дозы подкормок).

Проверку эффективности предлагаемых методов расчета оптимальной дозы удобрений проводили на озимом ячмене в 2018-2019 с.-х. году [совместно с отделом селекции и семеноводства ячменя (3)] и - в 2020-2021 с.-х. году на озимой пшенице.

Погодные условия в эти годы были различными. В 2018-2019 с.-х. году, при благоприятных условиях в зимний период, весенне-летний период отличался недостаточным количеством осадков и высокими среднесуточными температурами, что снизило урожайность озимого ячменя. 2020-2021 с.-х. год выделился избыточным количеством осадков в весенне-летний период (при благоприятных условиях зимовки), что, напротив, способствовало увеличению урожайности озимой пшеницы.

$\mathbf{1}{ }^{*}$ и $^{* *)}$ - программы созданы в лаборатории био-мат. методов в КНИИСХ им. П.П. Лукьяненко, г. Краснодар. 
Исследования проводили в центральной зоне Краснодарского края в НЦЗ им. П.П. Лукьяненко в многофакторных опытах. Предшественниками были: для озимого ячменя - подсолнечник; для озимой пшеницы - соя. Опыты закладывали в пятикратной повторности; площадь делянки: для озимого ячменя $10 \mathrm{~m}^{2}$, для озимой пшеницы - $20 \mathrm{~m}^{2}$. Почва - чернозем сверхмощный малогумусный выщелоченный. Для посева использовали перспективные сорта селекции НЦЗ им. П.П. Лукьяненко: по озимому ячменю - сорт Серп, по озимой пшенице - сорт Адель. Сроки посева: в октябре месяце, близкие к оптимальным. Агротехника - принятая для зоны возделывания.

Исходное эффективное плодородие почвы, под опытами, было различным, в частности, перед посевом озимого ячменя (после подсолнечника) содержание азота нитратов (по агрохимическим критериям) было низким (5,9 мг/кг); фосфора - очень высоким (65 мг/кг), калия - высоким (450 мг/кг); а в почве после сои (перед посевом озимой пшеницы) - содержание азота нитратов было также низким (4,1мг/кг); а фосфора и калия - повышенным (44 и 330 мг/кг соответственно).

Расчеты доз удобрений (основного и подкормок) производились по программе «Поиск аргументов по заданной функции**)», где аргументами выступали искомые дозы удобрений, а функцией - планируемая урожайность культуры. При этом использовались математические модели (нелинейные уравнения, рассчитанные нами на основании многолетних многофакторных опытов) описывающие связь урожайности с исходным эффективным плодородием почвы, дозами вносимых удобрений, состоянием АФЦ и рядом других, существенных для формирования урожая, факторов.

Как следует из результатов исследований (табл. 1), как по озимому ячменю, так и по озимой пшенице получена высокая урожайность ( 90 ц/га) близкая к планируемому уровню. При этом, получено зерно хорошего качества. Для озимого ячменя, как фуражной культуры, важно высокое содержание белка в зерне $(\sim 11 \%)$, при этом, зерно озимой пшеницы (несмотря на ее высокую урожайность в опыте) соответствует III классу и является продовольственным (табл. 1).

Таблица 1 - Урожайность и качество зерна озимых колосовых культур в связи с системой удобрений, разработанной с применением методов математического моделирования, 2019 и 2021 с.-х. годы

\begin{tabular}{|c|c|c|c|c|c|c|c|c|}
\hline \multirow{3}{*}{$\begin{array}{l}\mathrm{N} \\
\mathrm{N}\end{array}$} & \multirow{3}{*}{$\begin{array}{c}\text { Культура/ } \\
\text { сорт }\end{array}$} & \multicolumn{3}{|c|}{$\begin{array}{c}\text { Внесено удобрений, } \\
\text { кг д.в./га }\end{array}$} & \multicolumn{2}{|c|}{ Урожайность, ц/га } & \multicolumn{2}{|c|}{ Качество зерна } \\
\hline & & \multirow{2}{*}{ Основное } & \multicolumn{2}{|c|}{ Подкормки } & \multirow{2}{*}{ План. } & \multirow{2}{*}{ Факт. } & \multirow{2}{*}{$\begin{array}{c}\text { Содержание } \\
\text { белка, \% }\end{array}$} & \multirow{2}{*}{$\begin{array}{l}\text { Класс } \\
\text { зерна }\end{array}$} \\
\hline & & & $1^{\text {凡 }}$ & $2^{\text {r }}$ & & & & \\
\hline 1 & $\begin{array}{l}\text { Оз. ячмень } \\
\text { Серп }\end{array}$ & $\mathrm{N}_{20} \mathrm{P}_{0} \mathrm{~K}_{105}$ & $\mathrm{~N}_{30}$ & $\mathrm{~N}_{45}$ & 90 & 87.8 & 10.8 & - \\
\hline 2 & $\begin{array}{l}\text { О3. пшеница } \\
\text { Адель }\end{array}$ & $\mathrm{N}_{20} \mathrm{P}_{50} \mathrm{~K}_{110}$ & $\mathrm{~N}_{70}$ & $\mathrm{~N}_{56}$ & 80 & 90.3 & 13.0 & III \\
\hline
\end{tabular}

Расчет эффективности азотных подкормок (табл. 2 и 3 ) на обеих культурах показал их высокую окупаемость (>20 кг зерна/ кг д.в. удобрений). 
Таблица 2 - Расчет окупаемости весенних азотных подкормок озимого ячменя, 2019 г

\begin{tabular}{|c|c|c|c|c|c|c|}
\hline \multirow{2}{*}{ Сорт } & \multirow{2}{*}{ Bap. } & \multicolumn{2}{|c|}{$\begin{array}{c}\text { Внесено удобрений, } \\
\text { кг д.в./га }\end{array}$} & \multirow{2}{*}{$\begin{array}{c}\text { Урожай- } \\
\text { ность, } \\
\text { ц/га }\end{array}$} & \multirow{2}{*}{$\begin{array}{c}\text { Прирост } \\
\text { урожайно- } \\
\text { сти, ц/га }\end{array}$} & \multirow{2}{*}{$\begin{array}{l}\text { Окупаемость } \\
\text { подкормок, кг } \\
\text { зерна/кг азота }\end{array}$} \\
\hline & & $\begin{array}{l}\text { Основное } \\
\text { удобрение }\end{array}$ & Подкормки & & & \\
\hline \multirow{3}{*}{ Серп } & $1-\mathrm{St}$ & $\mathrm{N}_{20} \mathrm{P}_{0} \mathrm{~K}_{105}$ & - & 65,9 & - & - \\
\hline & 2 & $\mathrm{~N}_{20} \mathrm{P}_{0} \mathrm{~K}_{105}$ & $1^{x}-30$ & 73,9 & 8,0 & 26,7 \\
\hline & 3 & $\mathrm{~N}_{20} \mathrm{P}_{0} \mathrm{~K}_{105}$ & $2^{n}-45$ & 87,8 & 13,9 & 30,9 \\
\hline $\begin{array}{l}\text { В сред- } \\
\text { нем }\end{array}$ & $2+3$ & $\mathrm{~N}_{20} \mathrm{P}_{0} \mathrm{~K}_{105}$ & $\sum 75$ & - & 21,9 & 29,2 \\
\hline
\end{tabular}

$\mathrm{P} \%=3,6$

$\mathrm{HCP}_{(0,95)}=4,4 \mathrm{~L} / \mathrm{ra}$

Таблица 3 - Расчет окупаемости весенних азотных подкормок озимой пшеницы, 2021 г

\begin{tabular}{|c|c|c|c|c|c|c|}
\hline \multirow[b]{2}{*}{ Сорт } & \multirow[b]{2}{*}{ Bap. } & \multicolumn{2}{|c|}{$\begin{array}{c}\text { Внесено удобрений, } \\
\text { кг д.в./га }\end{array}$} & \multirow{2}{*}{$\begin{array}{l}\text { Урожай- } \\
\text { ность, } \\
\text { ц/га }\end{array}$} & \multirow{2}{*}{$\begin{array}{l}\text { Прирост } \\
\text { урожайно- } \\
\text { сти, ц/га }\end{array}$} & \multirow{2}{*}{$\begin{array}{l}\text { Окупаемость } \\
\text { подкормок, кг } \\
\text { зерна/кг азота }\end{array}$} \\
\hline & & $\begin{array}{l}\text { Основное } \\
\text { удобрение }\end{array}$ & Подкормки & & & \\
\hline \multirow{3}{*}{ Адель } & $1-\mathrm{St}$ & $\mathrm{N}_{20} \mathrm{P}_{50} \mathrm{~K}_{110}$ & - & 63,1 & - & - \\
\hline & 2 & $\mathrm{~N}_{20} \mathrm{P}_{50} \mathrm{~K}_{110}$ & $1^{\text {s }}-70$ & 79,2 & 16,1 & 23,0 \\
\hline & 3 & $\mathrm{~N}_{20} \mathrm{P}_{50} \mathrm{~K}_{110}$ & $2^{x}-56$ & 90,3 & 11,1 & 19,8 \\
\hline $\begin{array}{l}\text { В сред- } \\
\text { нем }\end{array}$ & $2+3$ & $\mathrm{~N}_{20} \mathrm{P}_{50} \mathrm{~K}_{110}$ & $\sum 126$ & - & 27,2 & 21,6 \\
\hline
\end{tabular}

$\mathrm{P} \%=4,5$

$\mathrm{HCP}_{(0,95)}=6,0 ц / г \mathrm{a}$

В заключение следует отметить, что использование обширной информации об исходном уровне эффективного плодородия почвы, состояния АФЦ с.х. культуры на отдельных этапах ее вегетации, планируемой урожайности и математических моделей (уравнений), отражающих взаимодействие факторов в этой системе, при математическом моделировании, позволяет определить оптимальные дозы удобрений с высокой точностью, что и является основой их высокой окупаемости.

\section{Выводы}

1. Для использования математического моделирования при определении оптимальных доз удобрений необходимо иметь обширную базу данных и специальные методы системного анализа, позволяющие строить математические модели.

2. Использование математического моделирования для расчета доз удобрений под озимые колосовые культуры позволяет более точно определить их оптимальное количество для получения запланированной урожайности и зерна хорошего качества.

3. Использование новых, основанных на математическом моделировании, способов расчета оптимальных доз весенних подкормок озимых колосовых культур позволяет существенно снизить расход удобрений, а, следовательно, и затрат на получение 1 ц сельскохозяйственной продукции. 
4. Применение новых методов расчета оптимальных доз удобрений существенно повышает окупаемость удобрений.

\section{Библиографический список}

1. Алейнов Д.П. А готово ли наше сельское хозяйство использовать минеральные удобрения? // Экономика сельскохозяйственных и перерабатывающих предприятий, 2009. - №1. - C. 6-11

2. Доспехов Б.А. Методика полевого опыта (с основами статистической обработки результатов исследования)/ Б.А. Доспехов, 5 издание., дополненное и переработанное. - М.: Агропромиздат, 1985. - $351 \mathrm{c.}$

3. Осипов Ю.Ф., Каленич В.И., Новикова А.А., Алиференко Ю.С., Шаповалова Е.В., Кузнецова Т.Е., Серкин Н.В. Новые способы расчета доз азотных подкормок озимых колосовых культур. // Плодородие, 2021. - №2. - С. 21-25. DOI: 10.25680/S19948603.2021.119.06 Куперман Ф.М., Дворянкин Ф.А., Ржанова Е.И., Ростовцева Е.Л. Этапы формирования органов плодоношения злаков, І. изд.-во МГУ, 1955 г.

УДК 631.417

\section{ОЦЕНКА СВЯЗИ ПЛОТНОСТИ ПОЧВЫ С ПОКАЗАТЕЛЯМИ ПЛОДОРОДИЯ ЧЕРНОЗЕМА ТИПИЧНОГО}

Панкова Т.И.

ФГБНУ «Курский федеральный аграрный научный центр», г. Курск

E-mail: pankova-ti@mail.ru

Резюме. Выявлена и количественно оценена взаимосвязь между плотностью почвы и основными показателями плодородия почвы на пашне под озимой пшеницей. Установлена высокая связь с содержанием в почве водопрочных агрегатов, обменных оснований, лабильных гумусовых веществ значениями показателя рН солевого раствора почвы, диаметров сухих и водопрочных агрегатов.

При оценке плодородия почвы и разработке его моделей необходимо учитывать реально существующую взаимосвязь между почвенными свойствами. Взаимозависимость свойств - объективная реальность, которая должна стать предметом изучения. Это важно для углубления представлений об их важнейшем свойстве - плодородии, понимания особенностей его воспроизводства [1].

Физические свойства почвы в значительной степени определяют уровень плодородия почв. Один из важнейших его показателей - плотность почвы. Нельзя не учитывать влияние плотности почв на продуктивность и урожайность культурных растений, также внимательного отношения требует учет взаимосвязи ее с другими параметрами плодородия почвы. Агрофизические свойства почвы, в частности, ее плотность являются менее лабильными свойствами по сравнению с другими почвенными свойствами. Однако они также изменяются в зависимости от гранулометрического состава, содержания гумуса, структуры, количества внесенных органических и минеральных удобрений, влажности и других факторов.

На основе информационно-логического анализа в рамках анализируемой системы почва-растение нами выявлена и количественно оценена взаимосвязь между плотностью почвы и основными агрофизическими, агрохимическими 
показателями чернозема типичного, а также с показателями его гумусного состояния на пашне под озимой пшеницей. Связь оценивали по следующей шкале [2]: коэффициент эффективности передачи информации (Кэ) > 0,25 связь очень высокая; 0,16-0,25 - связь высокая (тесная); 0,08- 0,15 - связь средняя; <0,08 - связь слабая (низкая).

В ходе наших исследований установлено, что плотность почвы тесно связана практически со всеми изученными физико-химическими свойствами: содержанием обменных оснований (суммой обменных оснований, обменным кальцием и обменным магнием) и со значением $\mathrm{pH}$ солевого раствора (Кэ= 0,24-0,16), и только с рН водного раствора - связь средняя (Кэ=0,15). Характер связи плотности почвы с изученными физико- химическими свойствами обратный, лишь с содержанием обменного магния в почве отмечена связь нелинейного произведения.

Связь содержания питательных элементов в почве на пашне под озимой пшеницей с плотностью почвы значительно ниже, чем со свойствами, определяющими характер почвенной среды: Кэ изменяются от 0,14 до 0,06, характер связи различный. Самая слабая связь плотности почвы отмечена с содержанием в ней подвижных фосфатов $($ Кэ=0,06), с остальными питательными элементами выявлена средняя связь. Так, связь плотности почвы с содержанием в почве подвижного калия и нитратного азота средняя и прямая (Кэ = 0,13-0,10), а с содержанием с аммонийного азота - связь также средняя, но характер связи - нелинейного произведения (Кэ =0,14).

В ходе исследования выявлена высокая взаимосвязь агрофизических свойств почвы между собой. Так, нами отмечена высокая и обратная связь плотности почвы с содержанием в ней водопрочных агрегатов и диаметром сухих и водопрочных агрегатов (Кэ=0,24-0,18).

Изучение взаимосвязи плотности почвы с органическим веществом почвы показало, что только между отдельными показателями гумусного состояния почвы и агрофизическими параметрами плодородия существует высокая связь. Так, нами установлена высокая и прямая связь между плотностью чернозема типичного и содержанием в почве только подвижных гумусовых веществ $($ Кэ=0,16). Связь остальных показателей гумусного состояния почвы с плотностью, по нашим данным, в 1,6-2,3 раза слабее, чем с подвижными гумусовыми веществами. Например, связь плотности почвы с содержанием в почве подвижных гуминовых кислот средняя и прямая (Кэ=0,12), а связь с содержанием подвижных фульвокислот - слабая $\left(\mathrm{Kэ}_{=}=0,04\right)$. Но во всех описанных случаях отмечена прямая связь. Нами отмечена низкая связь плотности почвы с содержанием в почве гумуса и негумифицированного органического вещества, коэффициенты эффективности передачи информации имеют невысокие значения $\left(\mathrm{K}_{\ni}=0,05-0,06\right)$.

Таким образом, входе исследований установлена высокая связь плотности почвы с отдельными показателями плодородия почвы: с содержанием в почве водопрочных агрегатов, обменных оснований, значением показателя рН солевого раствора почвы, значениями диаметров сухих и водопрочных агрегатов, а 
также с содержанием в почве лабильных гумусовых веществ. Отмечена тесная взаимосвязь между агрофизическими показателями плодородия, а также установлено, что среди остальных изученных показателей плодородия почвы наибольшее значение в формировании плотности почвы имеют физико-химические показатели плодородия почв.

\title{
Библиографический список
}

1. Семенов В.А. О разработке моделей плодородия почв // Модели плодородия почв и методы их разработки / Научные труды почвенного института им. В.В. Докучаева. - М., 1982. - С. 36-44.

2. Бурлакова Л.М. Комплексы параметров различных уровней почвенного плодородия и пути его управления в системе земледелия в Алтайском крае / Тезисы докладов к конференции. - Барнаул, 1983. - С. 92-96.

УДК 631.1:004

\section{ВЛИЯНИЕ УЗКИХ ВОДОРЕГУЛИРУЮЩИХ ЛЕСНЫХ ПОЛОС РАЗЛИЧНОЙ ПРОСТРАНСТВЕННОЙ ОРИЕНТАЦИИ НА РОСТ И РАЗВИТИЕ ГРЕЧИХИ}

\author{
Подлесных И.В.
}

\author{
ФГБНУ Курский Федеральный аграрный научный центр \\ Курский ФАНЦ, Курск \\ E-mail: podlesnich_igor@rambler.ru
}

\begin{abstract}
Резюме. Лесные полосы наравне с положительным влиянием на эрозионно-гидрологические показатели, предотвращение проявления дефляции и экологическую стабилизацию пахотных земель, формируют зону депрессии на разном расстоянии в зависимости от экспозиции склона, на котором они размещзаются. В зоне депрессии наблюдается сокращение количества растений на 1 м $^{2}$ и высота растений меньше, чем в межполосном пространстве в 3-5 раз, что сказывается на урожайности воздельваемых культур.
\end{abstract}

Ключевые слова: лесная полоса, депрессивная зона, микроклимат.

Узкие водорегулирующие лесные полосы, расположенные на склоне в лесостепной зоне, оказывают влияние на окружающие их полевые ценозы. Больше всего это проявляется в разнообразии микроклиматических показателей (температуре и влажности воздуха, освещенности), водном и ветровом режиме, снегораспределении, аккумуляции жидкого стока посредством перевода его во внутрипочвенный и защите почвы от дефляции, что в конечном итоге сказывается на повышение урожайности возделываемых культур, и улучшении экологической ситуации на окружающей территорией.

Но наряду с положительным влиянием лесных полос на прилегающие к ним агроландшафты, что отмечается в большом количестве исследований $[1$, $2,3,4,5]$ существует и отрицательное влияние на рост и развитие растений, а соответственно и урожайность сельскохозяйственных культур в депрессивной зоне вдоль лесной полосы.

Исследования проводили на опыте по контурно-мелиоративному земледелию ФГБНУ «Курский ФАНЦ», расположенному в Медвенском районе 
Курской области [6]. Почвы опыта представлены черноземом типичным и выщелоченным разной степени смытости [7].

Водорегулирующие лесные полосы, относительно которых проводились исследования, расположены вдоль одной горизонтали проходящей по южной, западной и северной экспозициям опытных водосборов. Год посадки полосы 1985, схема размещения Т-Т, расстояние между рядами деревьев 3 метра. В междурядье для усиления водопоглощения организована канава с валом по нижней опушке полосы [8].

Целью исследования являлось установление ширины депрессивной зоны вдоль лесных полос различной пространственной ориентации с целью выработки рекомендаций для сельскохозяйственных производителей растительной продукции по рациональному использованию её в производстве.

Исследования проводили в зоне влияния выше и ниже лесной полосы (ЛП) на расстоянии $5,10,25$ и 50 метров. Измеряли высоту растений и количество растений на $1 \mathrm{~m}^{2}$. Полученные данные обработали и в виде диаграмм представили ниже.

В 2021 году на опыте по контурно-мелиоративному земледелию в укороченном севообороте возделывалась гречиха сорта Деметра. Сев культуры был произведен в оптимальные сроки с 10 по 13 мая, через неделю 17 мая наблюдались выровненные полные всходы независимо от расположения относительно лесной полосы. Через 20 дней после полных всходов в фазу цветения было проведено исследование по определению депрессивной зоны вдоль лесных полос расположенных в средней части склонов северной южной и западной экспозиций, и её влияния на рост возделываемой культуры.

На рисунках 1, 2 и 3 показаны диаграммы, характеризующие количество растений на $1 \mathrm{~m}^{2}$ расположенных на разном расстоянии от лесной полосы. Как видно из рисунков в депрессивной зоне лесной полосы количество растений ниже, чем на расстоянии $2 \mathrm{H}$ как выше, так и ниже лесной полосы. Относительно лесной полосы, расположенной на южной экспозиции, наблюдается превышение 6\% вниз от ЛП и 9\% вверх от ЛП соответственно рисунок 1.

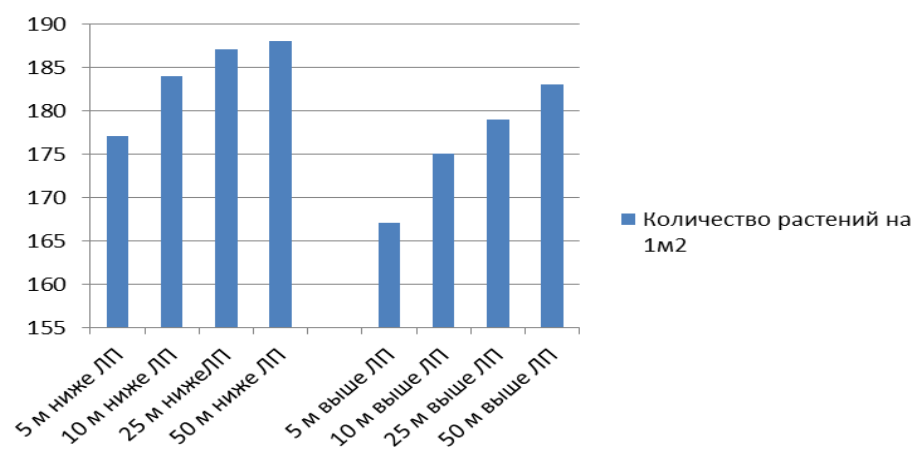

Рисунок 1 - Количество растений на $1 \mathrm{~m}^{2}$ на разном расстоянии от лесной полосы расположенной на склоне южной экспозиции

В депрессивной зоне лесной полосы расположенной на склоне северной экспозиции эти различия составили $9 \%$ и $3 \%$ соответственно, рисунок 2 a, а 
относительно лесной полосы, расположенной на нейтральной западной экспозиции $3 \%$ и $11 \%$ соответственно рисунок 2 .

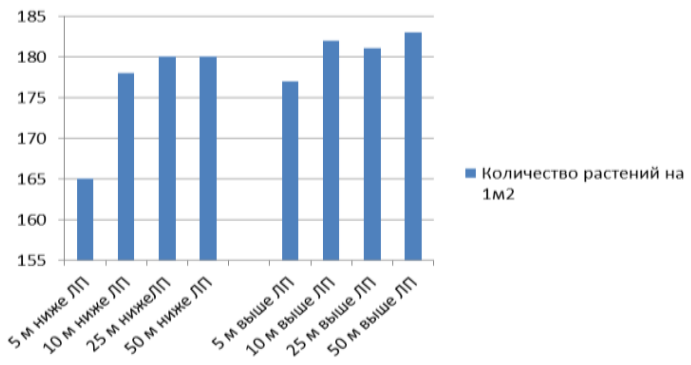

a

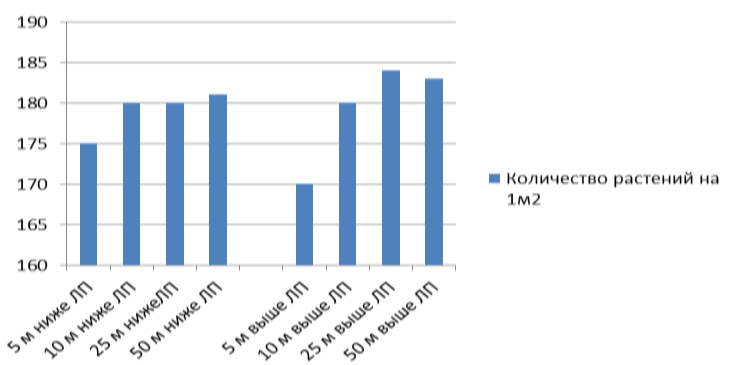

6

Рисунок 2 - Количество растений на $1 \mathrm{~m}^{2}$ на разном расстоянии от лесной полосы, расположенной на склоне а) северной экспозиции,

б) западной экспозиции

По нашему мнению, причина этого кроется в том, что на расстоянии 5-10 метров от лесной полосы в зимний период формировался снежный щлейф и влажность почвы к моменту сева была выше, чем на удалении от лесной полосы. Почва на основной площади пашни в межполосном пространстве была готовой к севу и ждать «дозревания» ее на территории вблизи лесной полосы не стали, что в итоге и привело к частичному снижению всхожести семян. Кроме того, на этом расстоянии от лесной полосы наблюдался недостаток солнечного света и тепла, что формировало неблагоприятные микроклиматические показатели для роста и развития свето и теплолюбивой культуры.

Аналогичное влияние депрессивной зоны сказывается и на рост растений. Вдоль лесной полосы располагающейся на склоне западной экспозиции наименьшая высота растений наблюдается на расстоянии 5 метров как вверх, так и вниз от лесной полосы рисунок 3.

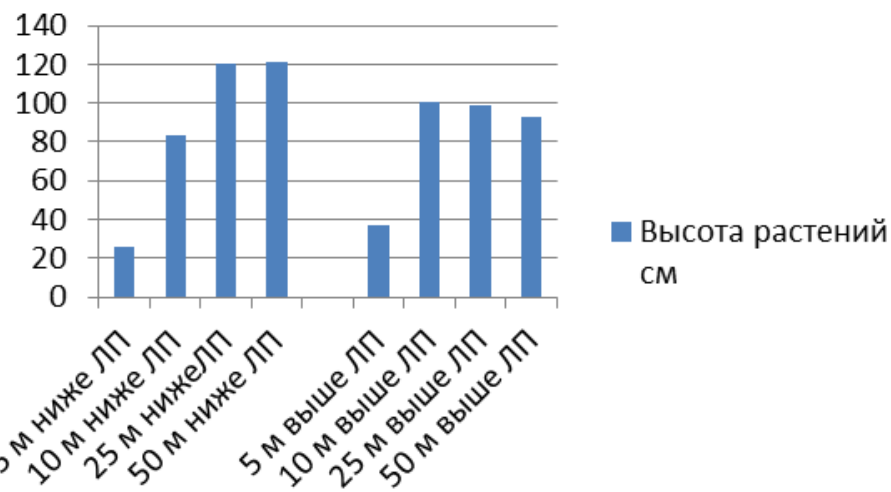

Рисунок 3 - Высота растений на разном расстоянии от лесной полосы расположенной на склоне западной экспозиции

Анализируя ширину депрессивной зоны вдоль лесных полос расположенных на склонах северной и южной экспозиций, рисунок 4, можно отметить, что она вдоль этих лесных полос имеет разную ширину. Так на склоне северной экспозиции ниже лесной полосы она простирается до 10 метров, а выше лесной полосы на 5метров. Вдоль же лесной полосы расположенной на склоне южной экспозиции все с точностью наоборот, выше лесной полосы зоны угнетения 
растений занимает расстояние до 10 метров от лесной полосы, а ниже депрессивная зона простирается на расстоянии до 5 метров.

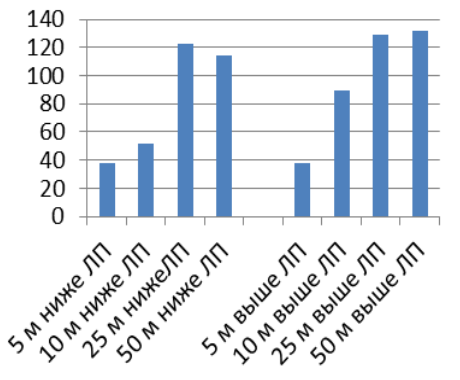

a

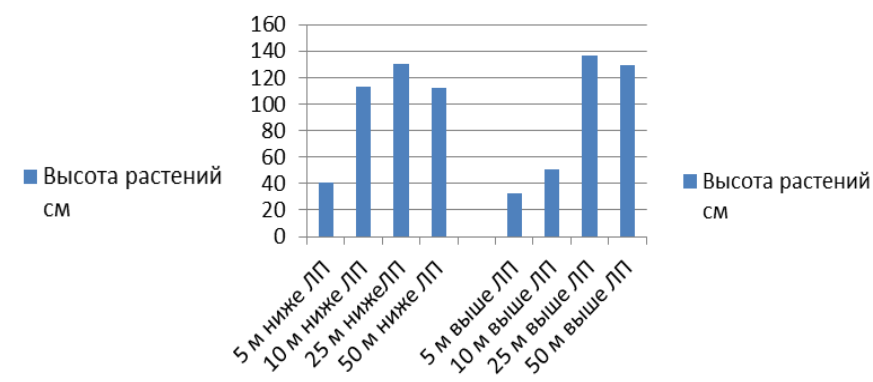

6

Рисунок 4 - Высота растений на разном расстоянии от лесной полосы, расположенной на склоне: а) северной экспозиции, б) южной экспозиции

По нашему мнению на это влияет недостаток тепла и света, если территория вдоль лесной полосы на склоне западной экспозиции освещается в течении дня относительно равномерно, то территория вниз от лесной полосы на склоне северной экспозиции и выше лесной полосы на склоне южной экспозиции большую часть дня находятся в тени из-за высоты деревьев лесной полосы, которая на сегодня составляет порядка 30 метров.

Проведя наши исследования, можно отметить, что вдоль узких лесных полос формируется депрессивная зона, в пределах которой возделываемые культуры испытывают недостаток тепла и света, что отрицательно сказывается на росте и развитии растений, а соответственно и в последствии на урожайности. В качестве рекомендации для аграриев можно предложить вдоль лесной полосы формировать зону с посевом многолетних трав, что будет, во-первых: способствовать дополнительному впитыванию вод и предотвращению смыва почв во время весеннего снеготаяния, во-вторых: дополнительная кормовая база для крупного рогатого скота и, в-третьих, будет способствовать экологической стабильности биоценозов лесной полосы.

\section{Библиографический список}

1. Полуэктов Е.В., Балакай Г.Т. Влияние защитных лесных полос на урожайность сельскохозяйственных культур // Экологические проблемы развития агроландшафтов и способы повышения их продуктивности. Сборник статей Международной научной экологической конференции. Краснодар, 27-29 марта 2018 года. Изд-во: Кубанский государственный аграрный университет имени И.Т. Трубилина, 2018. - С. 504-507

2. Михина Е.А., Михин В.И. Повышение полезащитными насаждениями продуктивности искусственных фитоценозов в условиях центральной лесостепи России// Актуальные направления научных исследований XXI века: теория и практика. - 2020. - № 1 (48). - Т. 8. - C. $109-113$

3. Тимерьянов А.Ш. Защитное действие лесных насаждений на свойства почв и урожайность сельскохозяйственных культур // Вестник РАСХН, 2011. - №6. - С. 28-30

4. Кулик К.Н., Степанов А.М. Полезащитные лесонасаждения и их роль в повышении продуктивности агроландшафтов // Вестник РАСХН, 2008. - № 1. - С. 21-23

5. Дубенок Н.Н., Танюкевич В.В., Бабошко О.И. Фитонасыщенность полезащитных лесных полос и их мелиоративное влияние на урожайность сельскохозяйственных культур // Вестник РАСХН, 2016. - № 1. - С. 27-30 
6. Подлесных И.В., Зарудная Т.Я. Узкая лесная полоса как фактор экологической стабилизации агроландшафтов // Актуальные проблемы экологии и охраны труда/ сборник статей IX Международной научно-практической конференции. Курск. Изд-во: Юго-Западный государственный университет. - Курск, 2017. - С. 176-180

7. Подлесных И.В., Зарудная Т.Я., Надеин С.В. Влияние распределения побочной продукции и листового опада на динамику содержания гумуса в черноземных почвах // Актуальные проблемы почвоведения, экологии и земледелия / Сборник докладов научно-практической конференции с Международным участием Курского отделения МОО "Общество почвоведов имени В.В. Докучаева". - Изд-тво: ВНИИЗиЗПЭ Россельхозакадемии. Курск, 2016. - С. 252-255

8. Подлесных И.В., Зарудная Т.Я., Надеин С.В. К усовершенствованию методики проектирования базовых элементов противоэрозионной организации территории в адаптивноландшафтном земледелии // Вестник Курской Государственной Сельскохозяйственной Академии, 2016. - № 7. - С. 57-82

УДК 631.51:631.43

\title{
ВЛИЯНИЕ ОСНОВНОЙ ОБРАБОТКИ НА СВОЙСТВА ПОЧВЫ ПРИ ВОЗДЕЛЫВАНИИ ГРЕЧИХИ
}

\author{
Прущик А.В. \\ ФГБНУ «Курский ФАНЦ», Курск \\ E-mail: model-erosion@mail.ru
}

\begin{abstract}
Резюме. Изучены агрофизические свойства почвы при воздельвании гречихи посевной по разным основным обработкам: вспашке и поверхностной обработке. Выявлены существенные различия в пахотном слое при различных обработках в весенний период. К кониу вегетачии различия в физических свойствах почвы несуществены. Для исключения влияния различных факторов необходимо продолжение исследований в этом направлении.
\end{abstract}

Ключевые слова: плотность почвы, структурно-агрегатный состав, водопрочность агрегатов, вспашка, поверхностная обработка.

Summary. Agrophysical properties of soil when cultivating buckwheat were studied according to various main treatments: plowing and surface treatment. Significant differences in the arable layer were revealed during various treatments in the spring. By the end of vegetation, differences in the physical properties of the soil are insignificant. To eliminate the influence of various factors, continued research in this direction is necessary.

Key words: soil density, structural-aggregate composition, water strength of aggregates, plowing, surface disking.

В результате длительной обработки почвы происходит разрушение зернистой структуры чернозема, которая отмечена на целинных участках степи. Вследствие механического воздействия на почву рабочих органов почвообрабатывающих орудий происходит распыление почвы или же проявляется обратный процесс - образование глыб [1-5].

Переуплотнение черноземов возникает при работе на поле орудий обработки и при движении тракторов. Переуплотненеие снижает водо- и воздухопроницаемость почвы, препятствует проникновению корней растений, что приводит к снижению урожайности сельскохозяйственных культур $[1,2]$.

Воздействие на влажную почву тяжелой техники привело к переуплотнению, которое сопровождается иссушением верхнего слоя, цементацией и 
растрескиванием пахотного слоя. Почвенная корка в несколько сотен раз снижает водопроницаемость почвы [6]. В комплексе переуплотнение и почвенная корка приводят к ухудшению условий для роста и развития возделываемых сельскохозяйственных культур.

Структура почвы также важный показатель, характеризующий ее плодородие. Способность почвы распадаться на агрегаты называют структурностью, а совокупность различных агрегатов - почвенной структурой. Для оценки структурного состояния почвы используют коэффициент структурности (КС) [1].

Коэффициент структурности представляет собой отношение количества агрономически ценных агрегатов (10-1 мм) к суммарному количеству пылеватых частиц и глыбистых агрегатов. Оптимальные значения величины КС для полевых культур в интервале 4,5-5,5 единиц. Падение КС ниже 4,5 единиц означает некоторую деградацию структуры, увеличение ее до 0,6-0,7 единиц наблюдается нередко и опасности для земеледелия не представляет [2, 7].

Следовательно, изменение физических свойств почвы, запасов гумуса в пахотном слое почвы [8] отражается неспосредственно на росте и разивтии сельскохозяйственных культур и на урожайности, в частности. Для изучения влияния основной обработки на свойства почвы был заложен эксперимент.

Экспериментальные участки расположены в Медвенском районе Курской обасти на плакорных частях водосборов.

В качестве основной обработки почвы изучены вспашка с оборотом пласта на глубину 20-22 см и поверхностная обработка дискатором - на 10-12 см. Весной почву перед посевом прокультивировали, в течение всей вегетации растений гречихи на обоих вариантах проводили одинаковые обработки.

Почва - агрочернозем миграционно-карбонатный (типичный), среднемощный, тяжелосуглинистый. Почвообразующие породы на территории экспериментального участка представлены лессовидными суглинками четвертичного возраста.

Влажность почвы определяли термостатно-весовым методом через 5 см на глубину до 1 м.

Плотность почвы от бирали почвенным буром-пробоотборником [9] на глубину до 1 м с шагом в 5 см.

Для определения структурно-агрегатного состава образцы почвы отбирали послойно: 0-10 и 10-20 см. Определение агрегатного состава почвы и водопрочности почвенных агрегатов проводили методом Н.И. Саввинова.

Определение водопрочности почвенных агрегатов в стоячей воде проводили по П.И. Андрианова в модификации Н.А. Качинского также в слое 0-10 и 10-20 cM.

На экспериментальных полях возделыванли гречиху посевную по агротехнологии, принятой для Курской области.

В начале вегетации гречихи посевной влажность почвы в слое $0-10$ см ниже, практически на 10\% по варианту со вспашкой, однако следующие 20 см превышает дискование. Влажность почвы ниже 30 см одинакова. К концу 
вегетации растений достоверной разницы по влажности между обработками не было отмечено.

При определении плотности почвы в начале вегетации растений (рис. 1) отмечено снижение этого показателя в слое 10-25 см на варианте со вспашкой. На глубине 50 см и ниже плотность почвы одинакова в пределах погрешности при разных обработках. В конце вегетации плотность была одинакова в пределах погрешности по всему метровому профилю, что объяснется низкой влажностью почвы.

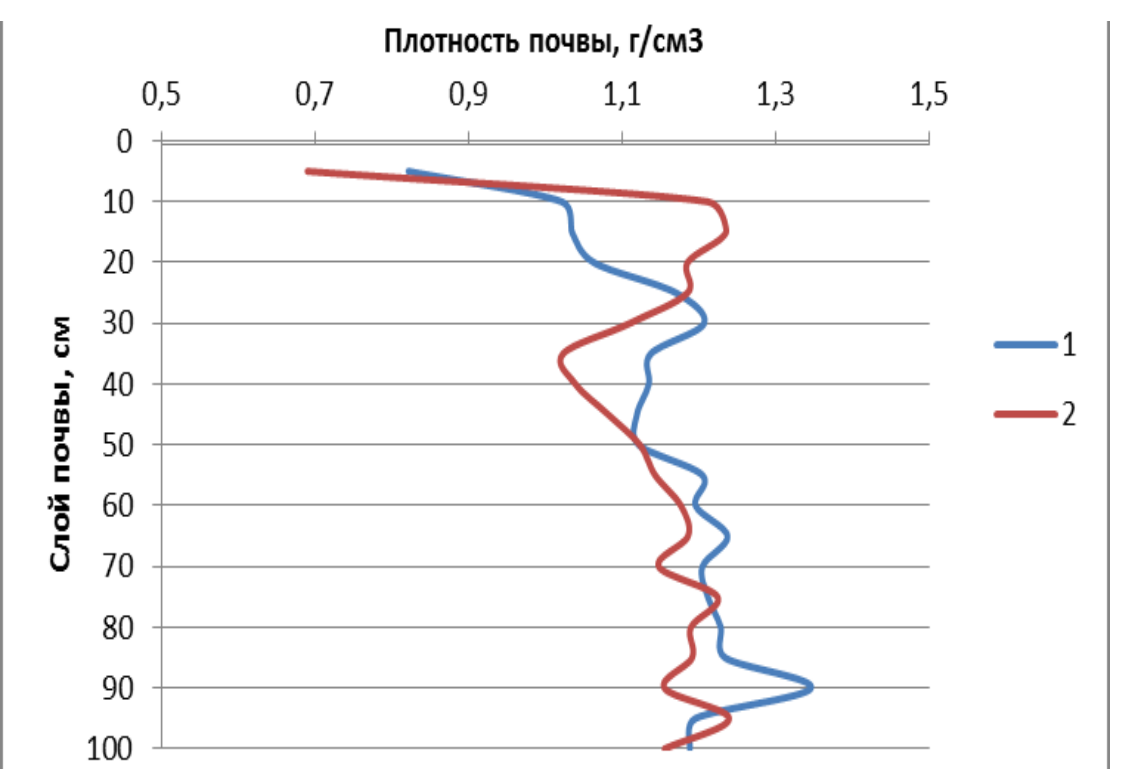

Рисунок 1 - Плотность почвы в начале вегетации растений

(1 - вспашка, 2 - дискование)

Порезультатам анализа структурно-агрегатного состояния почвы на полях с разной основной обработокой рассчитаны средневзвешенные диаметры агрегатов для сухой почвы и при мокром просеивании - для водопрочных агрегатов (рис. 2).

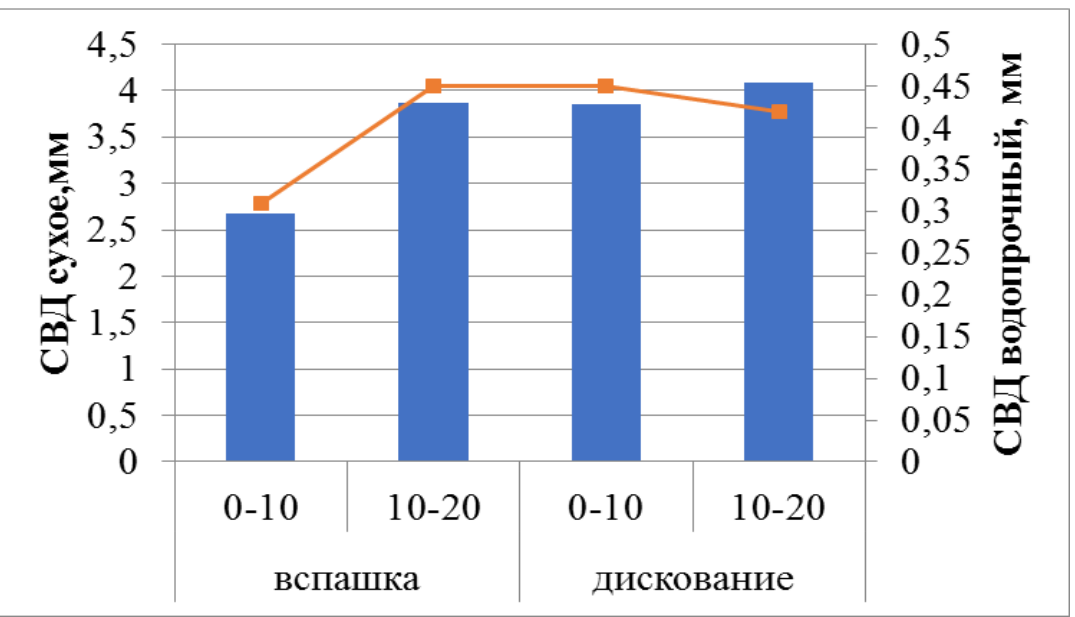

Рисунок 2 - Средневзвешенный диаметр при сухом и мокром просеивании

Отмечено уменьшение коэффициента водопрочности агрегатов в слое 010 см на варианте со вспашкой как при сухом просеивании, так и для водопрочных агрегатов. Такие результатаы получены и в начале и в конце вегетации 
растений. Средневзвешенные диамтеры как для сухой почвы, так и при определении водопрочных агрегатов для слоя 10-20 на вспашке и для слоя 0-20 на варианте при дисковании были одинаковы в пределах погрешности и превышали средневзвешенный диаметр 0-10 см на вспашке на 1,5 мм.

Результаты поределения коэффициента водопрочности агрегатов в стоячей воде представлены на рисунке 3.

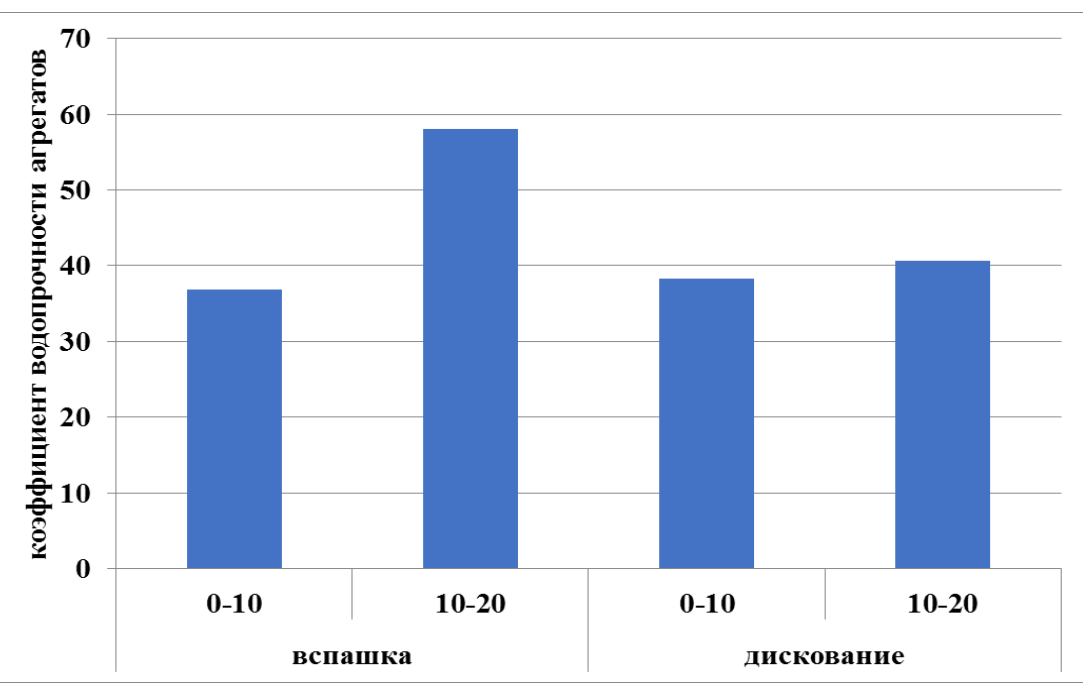

Рисунок 3 - Коэффициент водопрочности агрегатов

В слое 10-20 см на поле со вспашкой был достоверно получен более высокий коэффициент водопрочности. Чем выше коэффициент водопрочности, тем структура почвы более устойчива к воздействию воды.

Предварительно выявлена разница в агрофизических свойствах почвы при разных обработках, планируется продолжение исследований в этом направлении.

\section{Библиографический список}

1. Шеин Е.В., Гончаров В.М. Агрофизика. - М, 2019. - 184 с.

2. Крупеников И.А. Черноземы. Возникновение, совершенство, трагедия деградации, пути охраны и возрождения. Кишинев: Pontos, 2008. - 288 с.

3. Курганова И.Н., Лопес де Гереню В.О., Смоленцева Е.Н., Семенова М.П., Личко В.И., Смоленцев Б.А. Влияние типа землепользования на физические свойства черноземов лесостепной зоны Западной Сибири // Почвоведение, 2021. - № 9. - С. 1061-1075. https://doi.org/10.31857/S0032180X21090045.

4. Дубовик Д.В., Дубовик Е.В., Шумаков А.В., Ильин Б.С. Минимализация приемов основной обработки почвы под озимую пшеницу в Курской области // Международный сельскохозяйственный журнал, 2020. - № 6. - C.86-89. DOI: 10.24411/2587-6740-2020-16122.

5. Умарова А.Б., Бутылкина М.А. Сусленкова М.М. Александрова М.С. Ежелев 3.С., Хмелева М.В., Шхапацев А.К, Гасина А.И. Агрегатная структура естественных и пахотных почв разного генезиса: морфологические и реологические характеристики // Почвоведение, 2021. - № 9. - C. 1019-1032. https://doi.org/10.31857/S0032180X21090136

6. Сухановский Ю.П., Вытовтов В.А., Прущик А.В., Соловьева Ю.А., Санжарова С.И. Оценка впитывающей способности почвы с использованием портативной дождевальной установки. Бюллетень Почвенного института имени В.В. Докучаева. - 2015. - № 78. - С. 31 41. https://doi.org/10.19047/0136-1694-2015-78-31-41. 
7. Дубовик Е.В., Дубовик Д.В., Шумаков А.В. Влияние приемов основной обработки почвы на макроструктуру чернозема типичного // Почвоведение, 2021. - № 10. - С. 1195 1206. https://doi.org/10.31857/S0032180X21100051.

8. Сухановский Ю.П., Прущик А.В., Санжарова С.И. Зависимость урожайности зерновых и пропашных культур от запасов гумуса в черноземах и серых лесных почвах // Доклады PACXH, 2014. - № 4. - C.49-52.

9. Патент на изобретение 2657555 Рос. Федерации: МПК E02D 1/04 Почвенный бур-пробоотборник / Вытовтов В.А., Сухановский Ю.П., Прущик А.В., Салимгареева О.А.; заявитель и патентообладатель ФГБНУ ВНИИЗиЗПЭ - №2016152784; заявл. 30.12.2016, опубл. 14.06.2018, бюл. № 17.

\title{
УДК 631.452
}

\section{ВЫПАДЕНИЕ АТМОСФЕРНЫХ ОСАДКОВ ЗА ЛЕТНИЙ ПЕРИОД В ПОЧВЕННЫХ ПОДЗОНАХ СТЕПНОЙ ЗОНЫ, КАК ПОКАЗАТЕЛИ ЭКОНОМИЧЕСКИХ РИСКОВ}

\author{
Рыспеков Т.P.
}

Казахский национальный аграрный университет, г. Алматы, Казахстан E-mail: rispekov_t@mail.ru

Резюме. Колебания урожайности полей в почвенных подзонах степной зоны вызывают необходимость прогнозов вероятности неблагоприятных условий. Одним из значительно влияющих на это факторов связано с количеством выпадения атмосферных осадков в летний период. Автор приводит вероятности этих минимальных осадковза ряд лет.

Ключевые слова: атмосферные осадки, степная зона, минимальное количество осадков.

Summary.Fluctuations of thefields yield in the soil subzones of the steppe zone necessitate predictions of the probability of unfavorable conditions. One of the factors significantly influencing this is associated with the amount of atmospheric precipitation in the summer. One of the significantly influencing factors is related to the amount of precipitation in the summer period. The author gives the probabilities of these minimum precipitation for a number of years.

Key words: precipitation, steppe zone, minimum amount of precipitation.

Постоянный поиск материалов о рациональном использовании земель степной зоны Казахстана не приводит к удовлетворительным результатам. Урожаи полей часто отличаются по годам. Одним из факторов, влияющих на урожай сельскохозяйственных культур, является погода.

Осадки в эти периоды имеют большое значение для сельскохозяйственного производства, окружающей природы. Поэтому знать их возможную величину важно, но это очень сложно из-за их большой вариабельности. Даже величины среднегодовых осадков имеют большую вариабельность.

И.А. Васько [1] пишет, что за тридцать лет (1957-1986 гг.) в подзоне засушливых степей выпадает в среднем 347 мм осадков, с колебаниями по годам от 220 до 472 мм. Он приводит данные за летний период: в среднем выпадает 143 мм с колебаниями от 50 до 257 мм. А. Шамен [2] анализирует средние годовые суммы атмосферных осадков по данным 9 метеостанций за период 19861995 гг. За этот период наименышее количество осадков выпало в подзоне очень сухих степей (станция Аркалык) в 1988 г. - 200 мм, в подзоне умеренозасушливых степей (станция Костанай) максимально выпало осадков в 1990 г. 
- 476 мм, а наибольшее в умерено-влажной южной лесостепной зоне (станция Петропавловск) в 1994 г. - 594 мм (таблица).

Высокая вариабельность выпадения атмосферных осадков по срокам создает необходимость в особой их систематизации. Так в работе [3] автор пишет, что в подзоне южных черноземов (подзона засушливых степей) повторяемость засух до 5 лет из каждых 20, а в подзоне темно-каштановых почв (умеренно-сухая часть сухой степи) - 7 лет из каждых 20. Повторяемость засух в подзоне каштановых почв (очень сухая степь) [3] дает как 5 лет из 10. Авторы работы [4] различают увлажненный, типичный и засушливые годы. В своей работе к засушливым годам они относят - 1975, 1977, 1980, 1981, 1982, 1983 годы, к типичным по увлажнению годам они относят - 1968, 1971, 1973, 1974, 1976, а к увлажненным - 1969, 1970, 1972, 1978, 1979 годы. И в этой работе [4] нет определенных закономерностей в чередовании увлажненных, типичных и засушливых сроков по годам.

В работе [5] говорится, что среднегодовое количество осадков в Северном Казахстане от 250 до 350 мм, с большими отклонениями по годам. Они пишут, что максимум осадков в большинстве областей приходится на июль-август с проявлением в весеннее-летний период почвенных засух. О вариабельности количества выпадающих осадков по летним месяцам мы видим и в работе [6]. Они приводят количество осадков за летние месяцы (данные Шортандинской АМС). В среднем за период 1957-1985 гг. выпало осадков в июне - 40,6 мм, в июле - 59,6, в августе - 45,0. За период 1982-1985 гг. только в 1985 г. количество осадков приблизился к средней многолетней величине в июне $-42,3$ мм, а в другие годы и, особенно в июле и августе количество осадков было существенно ниже среднемноголетних [6].

Из-за высокой вариабельности выпадения атмосферных осадков [7] считает, что всякие связи летнего максимума осадков, позволяющие объективно и доступно для практиков определять их с достаточной заблаговременность и обеспеченностью, представляют значительный интерес.

М.Х. Байдал [7] приводит одну из таких связей это связь летнего максимума осадков с осадками второй половины зимы (январь-февраль). После значительных зимних осадков (по сравнению с их нормой) следует летний максимум, меньший по величине, чем после незначительных зимних осадков. Так, при зимних осадках более 20 мм летний максимум не превышает 70 мм и чаще всего равен 30-50 мм. Наоборот, после зимних осадков порядка 5-10 мм летний максимум большей частью превышает 70 мм и около одной трети случаев -80 мм [7].

Однако также важно предсказать возможность минимального количества осадков, чтобы определить вероятность возникновения засухи. Известно, что засуха - это естественное, обусловленное циркуляционными процессами в атмосфере явление природы, характеризующееся длительным отсутствием осадков (или значительным их сокращением по сравнению со средними многолетними нормами), повышенными температурами воздуха, почвы и ветрами. 
Для точного прогноза засухи необходимо знать большое количество переменных, которые позволили бы предсказать его заблаговременно. Мы провели анализ выпадения летних осадков по данным нескольких метеостанции за период 1986-2006 гг. Например, возьмем данные Аркалыкской МС. Здесь за изучаемый период максимальное количество осадков выпало за лето 2003 г. 220,5 мм, что превышает среднее многолетнее почти в 2 раза. В 1999 г. выпало - 164,12 мм, что также выше средних многолетних за этот период. Ровно половина лет (10) из этого периода составляет лето, когда средняя сумма осадков превысило среднюю многолетнюю величину - 87,00 мм.

Минимально дней с осадками летом было в 1997 г. - 7 суток, с суммой осадков 7,31 мм.Минимальное количество летних осадков выпадало (кроме «рекордного» 1997 г.) в 1991 г. - 19,79 мм и в 1989 г. - 31,12 мм. В 1998 г. примерно выпало такое же количество осадков, что и в 1989 г., т.е. $-31,79$ мм. Такое количество осадков вызывают атмосферные засухи и связанные с ними ситуации, которые выливаютсяв экономическиепотери.

Анализ выпадения осадков по летним месяцам показал, как динамику выпадения по дням и по количеству выпадающих осадков в определенные месяцы, так и сходство и различия между этими месяцами.

Максимальное количество осадков в июньские дни были в 1993 и 1999 гг. В эти годы выпало, соответственно, 80,05 и 110,17 мм атмосферных осадков. Сумма выпавших осадков составило 276,9 и $381,1 \%$ от среднего многолетнего за июньские осадки. Превышение выше среднего значения составляет всего 5 лет, 2 года можно считать равными средней многолетней величине, а остальные 14 лет были меньше средней величины.

Как мы видим по данным [2] наименьшее количество годовых осадков, в некоторые годы, могут оказаться ниже, по сравнению с максимальными за летний период в другие годы.Если сравнить выпавшее количество 220,5 мм осадков за лето 2003 г. в подзоне каштановых почв, то оно равно или превышает годовое количество осадков 1988, 1991гг. [2] и равно нижнему пределу годовых осадков подзоны засушливых степей [1]. Летние осадки 2003 г. являются рекордной величиной для этой подзоны. Они составляют $253,4 \%$ от средней многолетней величины.

Средние годовые суммы атмосферных осадков [2] по областям приведены в таблице. Так 1990 г. был наиболее многоводный, если учитывать по всем областям, а 1991 г. наоборот, маловодный.

Минимальное количество дней с осадками в июньские дни были в 1997 и 1991 гг. В эти годы выпало, соответственно, 0,5 и 4,32 мм атмосферных осадков. Максимум атмосферных осадков выпало в июле 2003 г. - 114,8 мм. Это составляет 391,67\% от среднего многолетнего за июльские осадки. Превышение выше среднего значения составляет 9 лет, а остальные 12 лет были меньше средней величины.

Минимальное количество осадков в июльские дни были в 1989, 1995 и 1997 гг. В эти годы выпало, соответственно, 6,73, 6,03 и 1,41 мм атмосферных осадков. 
Таблица - Средние годовые суммы атмосферных осадков по степной зоне Казахстана [2]

\begin{tabular}{|c|c|c|c|c|c|c|c|c|c|c|}
\hline \multirow{2}{*}{ Станция } & \multicolumn{10}{|c|}{ Год } \\
\cline { 2 - 10 } & 1988 & 1989 & 1990 & 1991 & 1992 & 1993 & 1994 & 1995 & Сумма & Сред. \\
\hline Петропавловск & 408 & 393 & 448 & 256 & 384 & 470 & 594 & 351 & 3304 & 413 \\
Костанай & 305 & 324 & 476 & 220 & 372 & 413 & 347 & 254 & 2711 & 339 \\
Кокшетау & 211 & 241 & 499 & 215 & 358 & 418 & 524 & 201 & 2667 & 334 \\
Аркалык & 200 & 361 & 347 & 226 & 323 & 441 & 327 & 245 & 2470 & 309 \\
Акмола & 255 & 314 & 409 & 233 & 336 & 342 & 385 & 262 & 2536 & 317 \\
Павлодар & 253 & 284 & 429 & 253 & 412 & 309 & 291 & 265 & 2496 & 312 \\
Уральск & 277 & 318 & 447 & 271 & 475 & 438 & 465 & 260 & 2951 & 369 \\
\hline
\end{tabular}

Максимум атмосферных осадков выпало в августе 2005 г. - 84,5 мм. Выпадение 84,5 мм осадков составляет $293,61 \%$ от среднего многолетнего за августовские осадки. Минимальное количество осадков в августовские дни были в 1997, 2003 и 2006 гг., тогда выпало 5,40, 25,2 и 18,1 мм осадков. Превышение осадков выше среднего августовского значения составляет 8 лет, а остальные 13 лет были меньше средней величины.

Данные средних летних месячных осадков на «Аркалыкской» метеостанции ниже, чем на «Шортандинской» в июне на $28,79 \%$ или 1,4 раза, в июле на $50,82 \%$ или в 2 раза, а в августе - на 36,04 или 1,6 раза. Эта разница является следствием расположения первой в подзоне очень сухих степей $\left(K_{2}\right)$, а второй - в подзоне засушливых степей $\left(Ч_{1}\right)$.

Мы полагаем, что с появлением неосваиваемых территорий появляется возможность манипулирования этими землями: для сохранения окружающей территории и почв; включения части земель во влажные годы с внесением основных норм удобрений под обработку; использования снегонакопительных и мульчирующих свойств растительных остатков неиспользуемых территорий; уменьшения территорий возделывания, в связи с погодными условиями степной зоны [8].

Проведенный нами анализ статистических данных по атмосферным осадкам на территории Северного Казахстана в летний период за ряд лет показывает необходимость их учета посуточно. Существующий подход к выпадающим осадкам как среднее за 10, 30-31 и 92 дня для территории Северного Казахстана сильно искажают реальную обстановку, и тем более прогноз урожая на будущее. Искажение прогноза вызывают как выпадение разного количества осадков за декаду, месяц, сезон, так и величины выпадающих осадков за эти периоды. Также важно для использования, при оценке вероятности погодных условий, осенние и весенние запасы влаги почвы. Показанноесравнение величин летних осадков с годовыми осадками в подзонах не говорит конкретно о прогнозе вероятных благоприятных или неблагоприятных для растений условий. Поэтому следует быть готовым кдвух или трехлетним засухам.

Таким образом, на территории Северного Казахстана в летний период необходимо учитывать вероятность не системных засушливых явлений из-за малого количества атмосферных осадков. Вероятность засухи вызывает необходимость увеличивать возможности построения разнообразных 
региональных моделей использования почв. Правильный прогноз атмосферной и почвенной засухи позволяют заранее оценить возможные экономические потери. При благоприятных условиях для роста и развития растений, следует учитывать затраты сбор урожая.

\title{
Библиографический список
}

1. Васько И.А. Зависимость урожайности яровой пшеницы от метеорологических факторов /Интенсификация почвозащитного земледелия в Северном Казахстане. - Целиноград, 1989. - С. 3-12.

2. Шамен А. Гидрометеорология и мониторинг природной среды Казахстана. - Алматы: Ғылым. 1996. - 293 с.

3. Семанова Е.И. Земельный фонд Казахской ССР и его качественная характеристика /Успехи почвоведения в Казахстане. - Алматы, 1975. - С. 36-48.

4. Ахметов К.А., Вольская Н.А., Канафин Б.К. Продуктивность зерновых культур в севообороте /К вопросам агротехники полевых культур в Северном Казахстане. - Целиноград, 1987. - С. 3-9.

5. Готовец А.Ф., Нестеренко А.М., Шевченко В.А., Миллер А.А. Интенсивные технологии возделывания яровой твердой пшеницы в Казахстане /К вопросам агротехники полевых культур в Северном Казахстане. - Целиноград, 1987. - С. 22-36.

6. Охинько И.П., Тотошин И.Ф. Динамика использования влаги и нитратов из почвенного профиля растениями яровой пшеницы и ячменя /К вопросам агротехники полевых культур в Северном Казахстане. - Целиноград, 1987. - С. 55-68.

7. М.Х. Байдал Колебания климата Кустанайской области в XX столетии. - Л.: Гидрометеоиздат, 1971. - 156 с.

8. Рыспеков Т.Р. Современные экологические и экономические аспекты изучения почвенно-растительных ресурсов на ландшафтах степной зоны Республики Казахстан / Сборник докладов Международной научно-практической конференции, посвященной 50-летию со дня основания ВНИИ земледелия и защиты почв от эрозии 9-11 сентября 2020 года. Курск. - С. 86-90.

\section{УДК 631.4}

\section{К ВОПРОСУ ОБ ИЗУЧЕНИИ ПЫЛЕВОЙ НАГРУЗКИ И ОСОБЕННОСТЕЙ АТМОСФЕРНЫХ МИКРОЧАСТИЦ В КУРСКОЙ ОБЛАСТИ}

\author{
Салимгареева О.А. \\ ФГБОУ ВО «МГУ им. М. В. Ломоносова», Москва \\ E-mail: tavtava@yandex.ru
}

\begin{abstract}
Резюме. При оценке пылевой нагрузки на территориях различного назначения в Курской области установлено, что заповедные участки Стрелецкой степи в конще лета, начале осени имеют минимальное количество выпадающих атмосферных микрочастии среди исследованных объектов. Согласно принятым для населенных пунктов категориям, выявлено, что пылевая нагрузка в этот период в Центральном районе города Курска и на поле опыта по контурно-мелиоративному земледелию (КМЗ) Курского ФАНЦ - низкая, в селе Любимовка на расстоянии 25 м от дороги, ведущей к Хлебоприемному предприятию (ХПП) высокая, в 1 м от дороги рядом с ХПП - очень высокая. Исследованы особенности состава и микростроения частии, выпадающих из атмосферного воздуха в районах различного природопользования.
\end{abstract}

Ключевые слова: пылеаэрозольные выпадения, тонкие фракции, микростроение частиц. 
Экологическая ситуация в регионах во многом определяется составом и содержанием атмосферных микрочастиц, особенностями пылевой нагрузки. При осаждении сухого пылеаэрозоля вблизи крупных магистралей атмосферные микрочастицы участвуют в формировании потоков веществ на всех стадиях, являясь как источником загрязнения почв, так и транзитной и депонирующей средой [3]. Плодородие и питательная ценность почвы при изменении ее химического состава из-за осаждения пыли могут ухудшаться [5]. В крупных городах проводится государственный мониторинг загрязнения атмосферного воздуха мелкодисперсными взвешенными частицами. Контролируется содержание в воздухе частиц с размерностью 1-2 и 2,5-10 мкм, оказывающих наиболее выраженное негативное влияние на здоровье человека, что позволяет судить об уровнях и степени загрязнения атмосферы мегаполисов. Состав твердых пылеаэрозольных выпадений в городских условиях достаточно хорошо изучен, особенно для придорожных территорий, где величина техногенной нагрузки особенно велика $[1,3]$. Однако вопросы пылевой нагрузки и состава пылеаэрозольных выпадений в заповедных условиях и вдали от городов, на наш взгляд, еще мало исследованы.

Целью работы явилась оценка пылевой нагрузки и особенностей атмосферных микрочастиц в Курской области, как в заповедных условиях, так и в сельской местности, и в городе.

Объекты и методы. Исследования были проведены:

- на четырех научных стационарах Стрелецкого участка территории Центрально-Черноземного государственного природного биосферного заповедника имени профессора В.В. Алехина (далее ЦЧГБЗ) разного режима заповедания: 1) абсолютно заповедный участок некосимой степи (НКС $\mathrm{N} \mathrm{51,5715360,} \mathrm{Е} \mathrm{36,0943290);} \mathrm{2)} \mathrm{степь,} \mathrm{косимая} \mathrm{ежегодно} \mathrm{(КС} \mathrm{-} \mathrm{N}$ 51,5712750, Е 36,0975650); 3) дубрава (N 51,5634830, Е 36,0864860); 4) бессменный пар (БП - N 51,5700920, Е 36,0895320);

- на поле опыта КМЗ «Курского ФАНЦ» (поле - N 51.522187 Е 36.037226);

- в г. Курске на крыше ВНИИ земледелия и защиты почв от эрозии (городN 51.763737, E 36.171733)

- в с. Любимовка Большесолдатского района Курской области в 1 м от дороги рядом с ХПП (1 м. от дор. - N 051.503079, Е 35.635955);

- в с. Любимовка Большесолдатского района Курской области в 25 м от дороги в 50 м от ХПП (25 м от дор. - N 51.503022, Е 35.635400);

Для сбора атмосферных микрочастиц был использован авторский метод сбора сухих атмосферных пылеаэрозолей, подобный ранее предложенному Прокофьевой [4].

Материал для исследования был собран путем непосредственного осаждения аэрозольных частиц из атмосферы в чашки Петри, помещенные в установку (рис.1). Экспонирование контейнеров осуществлялось в течение августа-сентября 2020 года. В чашках Петри накапливались твердые атмосферные выпадения. 

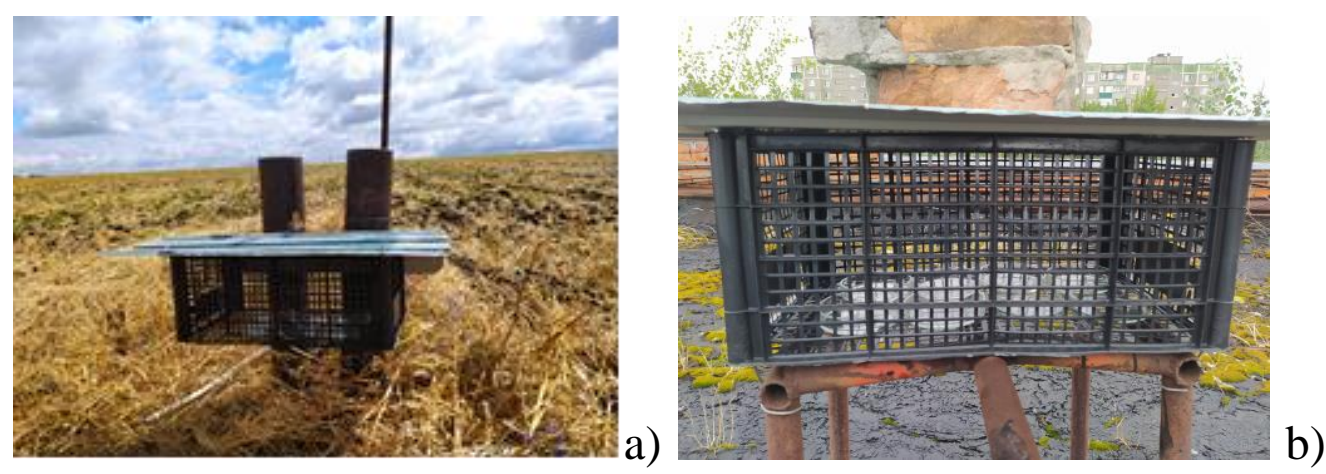

Рисунок 1 - Сбор образцов атмосферных микрочастиц

a) на поле опыта КМЗ; b) г. Курск, на крыше ВНИИ ЗиЗПЭ

По окончании эксперимента была вычислена пылевая нагрузка в кг/кв.км* сутки на участках исследования по формуле: $\mathrm{P}=\mathrm{Pa} /(\mathrm{S} * \mathrm{~T})$, где $\mathrm{Pa}-$ вес осажденной пыли; $\mathrm{S}$ - проективная площадь осаждения; T - временной интервал проведения эксперимента (сутки) [2].

Проведено исследование строения твердых выпадений от мезо- до субмикроуровня при помощи: бинокулярной лупы, поляризационного микроскопа, сканирующего электронного микроскопа (СЭМ). Субмикроскопические исследования были проведены с использованием СЭМ факультета почвоведения JEOL jsm 6060 A.

Все статистические расчеты были произведены при помощи программы STATISTICA 8.

Результаты и обсуждение. На всех из четырех исследованных участках территории ЦЧГБЗ были выявлены низкие значения пылевой нагрузки, в среднем от 64 до 28 кг/кв.км*сутки (рис. 2). Для дубравы характерны наименьшие значения и минимальная вариабельность суточной пылевой нагрузки, что обеспечивается хорошими протекторными свойствами листвы древесной растительности по отношению к атмосферным микрочастицам, отмечавшимися ранее [6].

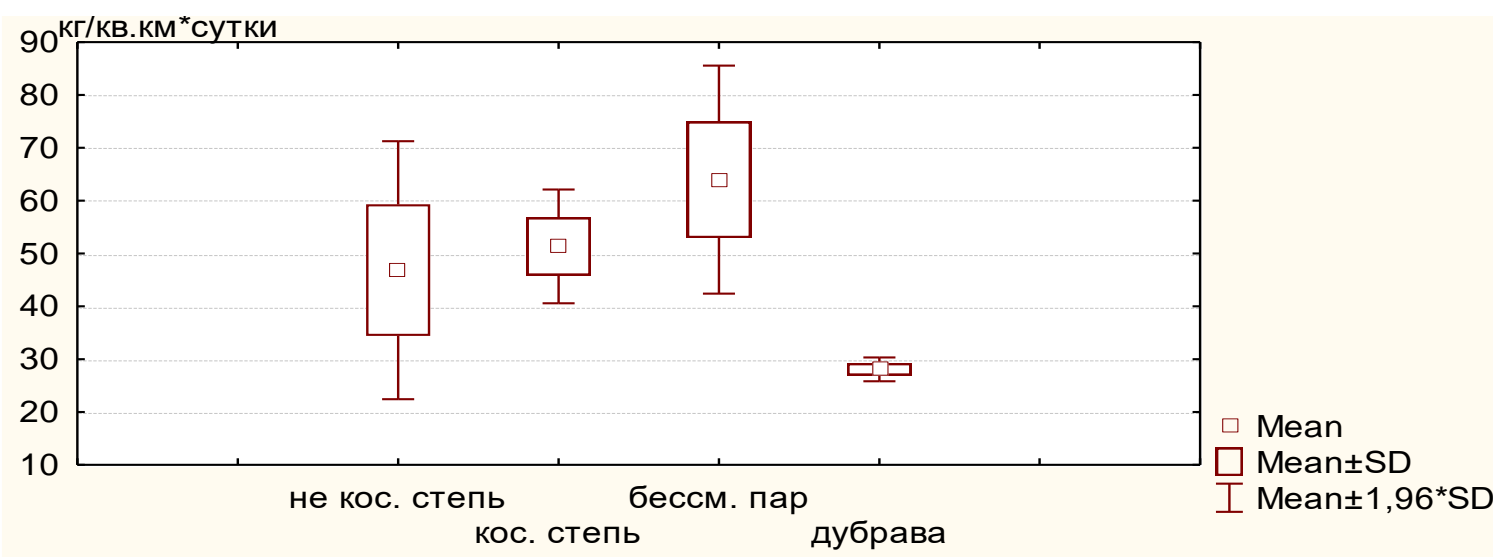

Рисунок 2 - Диаграмма размаха значений пылевой нагрузки(кг/кв.км*сут) участков разного режима заповедания (некосимая степь, косимая степь, бессменный пар и дубрава)

Несколько выше, чем на остальных участках, пылевая нагрузка БП, которая объясняется дефляцией частиц почвы пахотного слоя. Вероятно, значения 
выпадения пыли из атмосферного воздуха на поверхность почвы в сутки не превысили пороговых величин в этом случае в связи с небольшим размером распахиваемой площади (0,6 га), которая окружена степными массивами.

Пылевая нагрузка на поле опыта КМЗ в августе-сентябре 2020 года после уборки озимой пшеницы составила 159 кг/кв.км* сутки (рис. 3), что в соответствии с «Методическими рекомендациями...» [2] соответствует категории низких значений выпадения пыли из атмосферного воздуха на поверхность почвы в сутки, которая составляет для населенных пунктов 100-250 кг/кв.км*сутки.

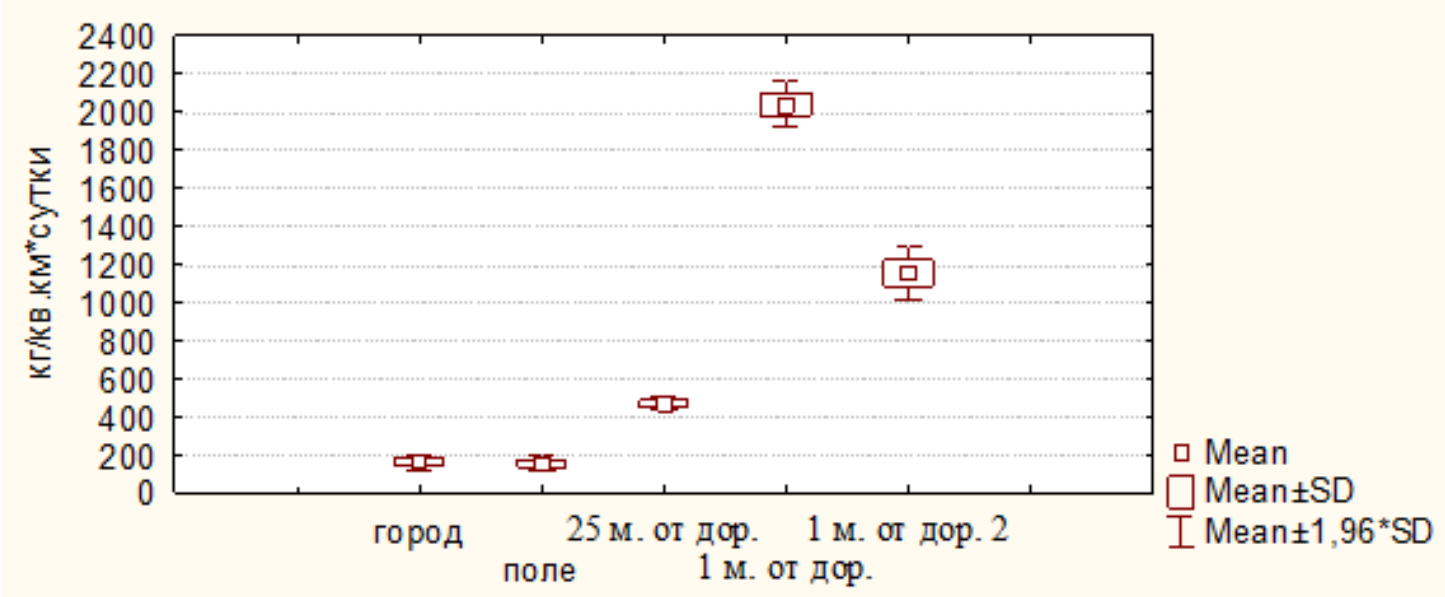

Рисунок 3 - Диаграмма размаха значений пылевой нагрузки(кг/кв.км*сут)

участков исследования: город - в г. Курске; поле - на поле КМЗ;

в с. Любимовка : в 25 м от дороги; в 1 м от дороги в первой декаде августа, в 1 м от дор. 2 - во второй декаде августа

Также не превысили порога значений низкой пылевой нагрузки и выпадения атмосферных микрочастиц в точке наблюдения в городе Курске, составившие 165 кг/кв.км* сутки в исследуемый период. Это может свидетельствовать о благополучной экологической ситуации в данном районе, которая способна поддерживаться обширными зелеными массивами, расположенными поблизости.

В селе Любимовка в 25 м от дороги, ведущей к ХПП, был обнаружен высокий уровень пылевой нагрузки - 471 кг/кв.км* сутки (рис. 3). Рядом с ХПП в 1 м от дороги отмечен очень высокий уровень - 2039 кг/кв.км*сутки в первой декаде августа, при пороговых значениях выпадения пыли для этого уровня всего 850 кг/кв.км* сутки. Во второй декаде августа прошло несколько ливней, но пылевая нагрузка осталась по-прежнему очень высокой 1154 кг/кв.км* сутки, хотя и снизилась при этом почти в два раза по сравнению с предшествующим засушливым периодом (рис.3). Большегрузные автомобили, транспортирующие зерно, поднимают клубы пыли, которая состоит в основном из почвенных частиц, привнесенных с грунтовых дорог, с примесями частиц разрушающегося дорожного полотна, шин, тормозных колодок. Власов и соавторы ранее отмечали, что процесс накопления мелких и крупных пылевых частиц на городских поверхностях значительно ускоряется при некачественной уборке улиц и нарушении норм и правил ландшафтного 
планирования [1]. В районе ХПП для понижения уровня пылевой нагрузки и уменьшения вреда здоровью местных жителей необходимо отремонтировать и периодически увлажнять в засушливые периоды дорожное покрытие, особенно во время хлебоуборочных работ.

Состав и строение собранных твердых аэрозольных выпадений были изучены на микро- и субмикроуровне. В пробах со всех участков исследования содержались как минеральные микрочастицы, так и биогенные. Наибольшее количество и разнообразие атмосферных микрочастиц биогенного происхождения было отмечено на заповедной территории: множество видов пыльцы, спор грибов, актиномицетов, водорослей, фрагменты тканей насекомых и растений. В городе и на селе в пробах также наблюдается пыльца растений, но в этих случаях на поверхности пыльцевых зерен отмечены загрязнение многочисленными тонкими частицами, более значительное, чем в заповеднике (рис.4 $\mathrm{a}, \mathrm{b})$.

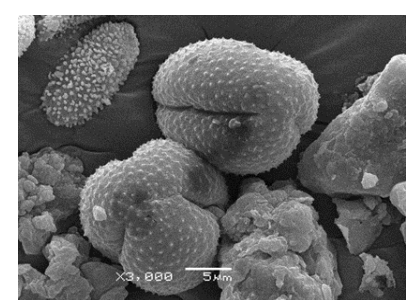

a)

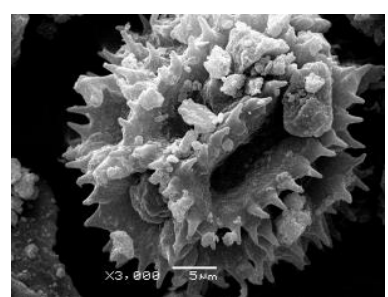

b)

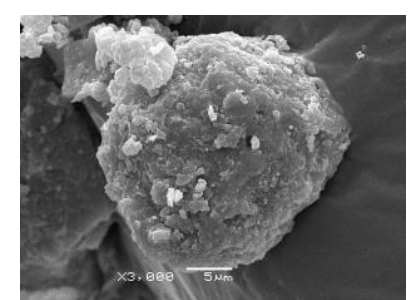

c)

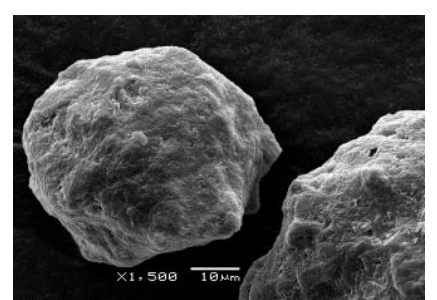

d)

Рисунок 4 - СЭМ фото: а) пыльцевые зерна НКС; b) пыльцевое зерно с микрочастицами на поверхности - город; с) органо-минеральные микроагрегаты с пленками на поверхности; d) минеральная частица округлых очертаний - 1 м от дороги к ХПП. Масштабный отрезок соответствует 5 мкм (а-с увеличение 3000) и 10 мкм (d увеличение 1500)

При сравнении почвенных шлифов поверхностного горизонта черноземов НКС, БП, опыта КМЗ и атмосферных микрочастиц было выявлено сходство их минералогического состава, что подтверждает отсутствие глобального привноса материала из других регионов.

Субмикроскопические исследования показали, что минеральные частицы на своей поверхности имеют пленки, предположительно, органического состава. Наиболее тонкие фракции осаждаются как по отдельности, так и на поверхности более крупных отдельностей, а также образуют микроагрегаты. Часто встречаются микроагрегаты и минеральные кусочки сглаженных очертаний, форма которых объясняется эоловым переносом (рис. 4 c-d).

Таким образом, установлено, что заповедные участки Стрелецкой степи в конце лета, начале осени имеют минимальное количество выпадающих атмосферных микрочастиц среди исследованных объектов. Низкая пылевая нагрузка была отмечена в этот период в Центральном районе города Курска и на опыте КМЗ Курского ФАНЦ.

В августе во время уборки зерновых рядом с дорогой у ХПП в селе Любимовка отмечена максимальная пылевая нагрузка в засушливый период в первой декаде августа. Во второй декаде августа дожди понизили количество 
выпадающих частиц почти вдвое, но пылевая нагрузка оказалась по-прежнему очень высокой, опасной для здоровья людей. На расстоянии 25 м от дороги отмечена высокая пылевая нагрузка в этот период.

Благодарности. Исследование проведено при поддержке РФФИ (проект №19-0550093 - сбор полевого материала, лабораторная обработка, интерпретация данных); государственного задания МГУ, часть 2 (№ 117031410017-4 - разработка методических подходов к исследованию микро- и субмикроморфологии атмосферных микрочастии)

Благодарим сотрудников ЦЧГБЗ, а также Лаборатории защиты почв от эрозии ФБГНУ «Курский ФАНЦ» за оказанную во время полевых работ помощьь.

\title{
Библиографический список
}

1. Власов Д. В., Безбердая Л. А., Касимов Н. С. Техногенная трансформация свойств почв и дорожной пыли Севастополя // Проблемы антропогенной трансформации природной среды. Материалы междунар. конф. (14-15 ноября 2019 г.). - Пермь, 2019. - С. 136-139.

2. Методические рекомендации по оценке степени загрязнения атмосферного воздуха населенных пунктов металлами по их содержанию в снежном покрове и почве / М-во здравоохранения СССР, Глав. сан.-профилакт. упр. - М.: Ин-т минералогии, геохимии и кристаллохимии редких элементов: Глав. сан.-профилакт. упр. МЗ СССР, 1990. - 15 с.

3. Прокофьева Т. В., Шишков В. А., Кирюшин А. В., Калушин И. Ю. Свойства твердых (пылеаэрозольных) атмосферных выпадений придорожных территорий г. Москвы // Известия РАН. Серия географическая. - 2015. - № 3. - С. 107-120

4. Прокофьева Т. В., Шоба С.А., Лысак Л.В. и др. Органические компоненты в составе городского атмосферного пылеаэрозоля: потенциальное влияние на городские почвы // Почвоведение, 2021. - №10. - С. 1247-1261

5. Leonard R.J., McArthur C., Hochuli D.F., Particulate matter deposition on roadside plants and the importance of leaf trait combinations, Urban Forestry and Urban Greening, 2016. Vol. 20. pp. 249-253, DOI: 10.1016/j.ufug.2016.09.008

6. PM2.5-bound SO42- absorption and assimilation of poplar and its physiological responses to PM2.5 pollution / Q. Yang, H. Wang, J. Wang, M. Lu, C. Liu, X. Xia, W. Yin, H. Guo // Environmental and Experimental Botany, 2018. - V. 153. - P. 311-319.

\section{УДК 631.58}

\section{МНОГОКРИТЕРИАЛЬНАЯ ОПТИМИЗАЦИЯ СТРУКТУРЫ ПОСЕВНЫХ ПЛОЩАДЕЙ КАК СПОСОБ ПОВЫШЕНИЯ ЭФФЕКТИВНОСТИ ПОЛЕВОГО РАСТЕНИЕВОДСТВА}

\author{
Свиридов В.И.
}

ФГБНУ «Курский федеральный аграрный научный центр», г. Курск

E-mail: kafdgmu@yandex.ru

Резюме. Рассматриваются методические особенности нахождения многокритериальных компромиссньх решений, излагаются результать апробации данного подхода при оптимизащии структуры посевных площзадей реального хозяйствующего субъекта.

Ключевые слова: оптимизация, эколого-экономико-математическая модель (ЭЭММ), многокритериальное компромиссное решение, структура посевных площадей, устойчивость плана, эффективность.

Сложившаяся к настоящему времени в сельскохозяйственных организациях Курской области структура посевных площадей далеко не в полной мере учитывает адаптивную способность выращиваемых культур, их 
почвозащитную роль и реакцию на степень эродированности почв; эффективность возделывания различных видов культур; средообразующие особенности культивируемых видов растений (влияние на свойства почвы, фитосанитарные условия). При этом не всегда соблюдаются рекомендации научных учреждений зоны по размещению культур (особенно пропашных) для их возделывания на пашне разных агроэкологических групп (АЭГ), допускаются серьезные отступления от севооборотных требований по обеспечению основных культур лучшими предшественниками и от предлагаемых зональной системой земледелия типовых схем различных видов севооборотов.

Отмеченные недостатки в землепользовании агропредприятий влекут за собой негативные экологические и экономические последствия. Так, проведенные нами исследования [1-6] позволили установить, что при возделывании практически всех полевых культур (за исключением однолетних и многолетних трав) не обеспечивается бездефицитность гумусового баланса - его отрицательная величина в среднем по области превышает 0,5 т/га. Дегумификация почвы, как известно, обусловливает ухудшение ее агрохимических, агрофизических и биологических свойств, падение противоэрозионной стойкости, а в конечном счете - снижение урожайности возделываемых культур и падение эффективности ведения отрасли в целом.

Для формирования более эффективного использования пахотных угодий нами с помощью специально разработанной эколого-экономико-математической модели [7] на примере колхоза (ныне - СПК) им. Черняховского Курского района были выполнены расчеты по оптимизации структуры посевных площадей (таблица).

\section{Таблица - Структура посевных площадей СПК им. Черняховского по разным критериям ее оптимизации, \%}

\begin{tabular}{|c|c|c|c|}
\hline \multirow{2}{*}{$\begin{array}{c}\text { Культура, } \\
\text { группа культур }\end{array}$} & \multicolumn{3}{|c|}{ Критерии оптимизации } \\
\cline { 2 - 4 } & «тах прибыли» & «тах гумуса» & $\begin{array}{c}\text { компромиссный } \\
\text { вариант }\end{array}$ \\
\hline \multirow{2}{*}{$\begin{array}{c}\text { Зерновые - всего } \\
\text { в том числе: озимые } \\
\text { яровые }\end{array}$} & 54,8 & 53,1 & 56,3 \\
\cline { 2 - 4 } & 19,1 & 15,2 & 16,5 \\
\hline Зернобобовые & 35,7 & 37,9 & 39,8 \\
\hline Технические & 3,6 & 3,6 & 3,6 \\
\hline $\begin{array}{c}\text { Кормовые - всего } \\
\text { в том числе: }\end{array}$ & 11,1 & 5,2 & 29,1 \\
\cline { 2 - 4 } $\begin{array}{c}\text { однолетние травы } \\
\text { многолетние травы }\end{array}$ & 23,5 & 36,0 & 1,9 \\
\cline { 2 - 4 } & 3,3 & 3,4 & 18,8 \\
\hline Чистый пар & 13,3 & 23,0 & 3,6 \\
\hline Всего пашни & 100,0 & 2,0 & 100,0 \\
\hline
\end{tabular}

Рассчитанная по критерию оптимизации «max прибыли» структура посевных площадей этого хозяйства предусматривает дифференцированное использование пашни и выполнение необходимых севооборотных требований как общих для всех ее категорий, так и специфических для отдельных АЭГ. В оптимальном варианте по сравнению с планом предприятия расширяются площади 
посева наиболее эффективных для существующих на тот момент условий производства товарных и кормовых культур при соответствующем сокращении под менее выгодными из них. При этом посевы озимых зерновых культур на тех категориях пашни, где они размещаются, не превышают размеров рекомендуемых для них предшественников и в то же время обеспечивают размещение после них всех пропашных культур.

Проектируемый на ближайшую перспективу уровень рентабельности сельскохозяйственных отраслей в данном хозяйстве $(45,1 \%)$ обеспечивает расширенное ведение производства продуктов растениеводства и животноводства, однако при этом не на всех выделенных категориях пахотных земель формируется расширенное воспроизводство почвенного плодородия - на наиболее интенсивно используемой пашне со склонами до $3^{\circ}$ достигается лишь нулевое значение баланса гумуса. Поэтому нами были выполнены с применением ЭЭММ дополнительные расчеты для изучения возможностей максимального накопления гумуса на пашне разных агроэкологических групп при сохранении всех предусмотренных этой моделью условий по организации адаптивного землепользования.

В результате проведенного исследования установлено, что предельное значение положительного сальдо годового баланса гумуса может составлять 0,49 т на гектар севооборотной площади данного предприятия. Это становится возможным благодаря расширению посевов культур, повышающих содержание гумуса в почве (прежде всего, многолетних трав), и сокращению посевных площадей тех культур, которые значительно понижают его содержание (в первую очередь, сахарной свеклы), а также чистого пара. Кроме того, увеличиваются объемы вносимого в почву навоза, запасы которого в хозяйстве возрастают в связи с расширением размеров животноводческих отраслей. Однако при этом, как показали наши расчеты, резко снижается рентабельность сельскохозяйственного производства - более чем в 1,5 раза по сравнению с предыдущим вариантом оптимизации структуры посевных площадей, когда задача решалась по критерию «тах прибыли»".

В связи с изложенным, возникает проблема выбора такого варианта структуры посевных площадей в хозяйстве, который был бы относительно одинаково эффективным как для первого («max прибыли»), так и для второго («max гумуса») критериев оптимизации, исходя из предположения их относительной эколого-экономической равнозначности в компромиссном решении. В литературе такие задачи называют многокритериальными или с векторным критерием качества [8]. Условиями возможного компромисса при этом называют минимизацию относительных отклонений от оптимальных значений по всем рассматриваемым критериям, фиксирование одного из критериев на некотором заданном уровне и оптимизация по следующему критерию и др.

В соответствии с различными формулировками условий компромисса мировой наукой разработаны методы нахождения многокритериальных компромиссных решений - так называемые методы определения субоптимальных решений, не получившие в России, к сожалению, пока должного 
распространения. Один из таких методов, предложенный чешским ученым И. Саской, применялся нами для получения компромиссного варианта структуры посевных площадей исследуемого предприятия с двумя равнозначными критериями оптимальности, результаты решения данной задачи по каждому из которых описаны выше. Этот метод получил название метода линейного мультипрограммирования, а его модификация, имеющая непосредственно экономическую интерпретацию, названа методом оптимального компромиссного программирования [9]. Сущность данного подхода заключается в следующем.

Если задано несколько критериев s и оптимальное значение к-го критерия составляет Fk, то методом И. Саски можно найти компромиссный вариант, который соответствует точке в области решений, в наименьшей степени отклоняющейся от всех оптимальных точек заданных критериев из множества S. Технически задача сводится к минимизации абсолютных нормированных отклонений значений k-х целевых функций от их оптимумов. Нормирующей стандартной величиной здесь выступает оптимальное значение критерия $\mathrm{F}^{\mathrm{k}}$. Обозначив $\mathrm{C}^{\mathrm{k}} \mathrm{X}$ значение $\mathrm{k}$-го критерия в компромиссном плане, И. Саска получил следующую целевую функцию задачи:

$$
\mathrm{Fmin}=\max _{1<\mathrm{k}<\mathrm{s}} \frac{\mid \mathrm{F}^{\mathrm{k}}-\mathrm{C}^{\mathrm{k}} \mathrm{X}}{\mathrm{F}^{\mathrm{k}}},
$$

которая должна минимизироваться при условиях: $\mathrm{AX}=\mathrm{B}, \mathrm{X}>0$. Для этого составляют так называемую дополненную задачу линейного мультипрограммирования с введением дополнительной переменной $\mathrm{Xn}+1$ и соответствующих дополнительных условий (по числу рассматриваемых в задаче критериев).

Путем некоторых элементарных преобразований функция приводится к линейной форме. Умножив обе части неравенства на $\mathrm{F}^{\mathrm{k}}$, получим $\mathrm{F}^{\mathrm{k}}-\mathrm{C}^{\mathrm{k}} \mathrm{X}<$ $\mathrm{F}^{\mathrm{k}} \mathrm{Xn}+1$, или $\mathrm{C}^{\mathrm{k}} \mathrm{X}+\mathrm{F}^{\mathrm{k}} \mathrm{Xn}+1>\mathrm{F}^{\mathrm{k}}$.

В случае решения задачи на минимизируемые критерии дополнительные условия имеют вид: $\mathrm{C}^{\mathrm{k}} \mathrm{X}-\mathrm{F}^{\mathrm{k}} \mathrm{Xn}+1<\mathrm{F}^{\mathrm{k}}(\mathrm{k}=1,2, \ldots, \mathrm{S})$.

На основе проведенных расчетов установлено, что вариант структуры посевных площадей, определенный одновременно по двум взятым критериям оптимальности, обеспечивает получение прибыли в размере $78 \%$ от максимально возможного ее уровня, а положительное сальдо годового баланса гумуса в почвах пахотных земель рассматриваемого хозяйствующего субъекта составит 68\% от своего предельного значения. Полученные по результатам компромиссного решения эколого-экономические параметры оптимального использования пашни обеспечивают ведение расширенного воспроизводства сельскохозяйственной продукции с уровнем рентабельности $33 \%$ и ежегодное повышение запасов гумуса на $0,01 \%$.

С целью выявления наиболее адаптированного к колебаниям рыночной конъюнктуры и возможным изменениям производственной структуры варианта оптимального использования пашни анализируемого предприятия нами была проведена математическая оценка устойчивости каждого из трех рассматриваемых оптимальных решений. Концептуальная схема такой оценки предполагает построение интегрального безразмерного показателя, который 
позволяет на простой линейной шкале выбрать наиболее устойчивый вариант оптимального плана [10].

Полученные таким образом оценочные результаты позволяют заключить, что в компромиссном решении достигается наиболее устойчивый план структуры посевных площадей, обеспечивающий максимально возможное отклонение от оптимальных состояний объекта исследования по каждому из выбранных критериев в отдельности без изменения значений последних. Следовательно, именно на базе многокритериальной оптимизации целесообразнее всего осуществлять формирование моделей рационального землепользования, гарантирующих получение необходимого для данных условий хозяйствования экономического эффекта и расширенное воспроизводство почвенного плодородия.

\section{Библиографический список}

1. Новые схемы севооборотов и усовершенствованная структура посевных площадей для хозяйств зерно-свекло-скотоводческой специализации Центрального Черноземья / Г.Н. Черкасов, А.С. Акименко, В.И.Свиридов и др. - Курск.: ВНИИЗиЗПЭ РАСХН, 2006. - 36 с.

2. Методика проектирования и проекты усовершенствованной структуры посевных площадей в хозяйствах различной специализации / Г.Н. Черкасов, Н.П. Масютенко, В.И. Свиридов и др. - Курск: ВНИИЗиЗПЭ РАСХН, 2008. - 50 с.

3. Бутко И.В., Ванин Д.Е., Свиридов В.И. и др. Оптимизация структуры использования пашни как важное условие повышения эффективности полевого растениеводства // Вестник Курской государственной сельскохозяйственной академии. - 2011. - № 4. - С.17-19.

4. Свиридов В.И., Комов В.Г. Формирование рациональной структуры посевных площадей методом оптимального компромиссного программирования // Вестник Курской государственной сельскохозяйственной академии. - 2012. - № 9. - С. 11-13.

5. Свиридов В.И., Комов В.Г. Оптимизация структуры посевных площадей на основе использования экологических и экономических критериев // Вестник Курской государственной сельскохозяйственной академии. - 2015. - № 2. - С. 33-35.

6. Свиридов В.И., Свиридова О.В. Управление балансом гумуса в севооборотах посредством состава и соотношения посевных площадей возделываемых культур // Вестник КГСХА. - 2019. - № 2. - С. 6-11.

7. Свиридов В.И. Эффективность формирования адаптивного землепользования в сельскохозяйственных предприятиях с эрозионноопасным рельефом. - Курск: Изд-во КГСХА, 2002. - 129 c.

8. Кравченко Р.Г. Математическое моделирование экономических процессов в сельском хозяйстве. - М.: Колос, 1978. - 424 с.

9. Онищенко А.М. Специализация сельскохозяйственного производства (методологические проблемы оптимизации). - Киев: Наукова думка, 1973. - 292 с.

10. Свиридов В.И., Петренко Н.Н. Экономико-математическая оценка устойчивости оптимальных решений в аграрном производстве // Международный сельскохозяйственный журнал. - 2005. - № 4. - С. 28-29. 
УДК 631.82

ПРОДУКТИВНОСТЬ КУКУРУЗЫ В МОНОКУЛЬТУРЕ И

СЕВООБОРОТЕ В ДЛИТЕЛЬНОМ ОПЫТЕ С УДОБРЕНИЯМИ

Стахурлова Л.Д. ${ }^{1}$, Стулин А.Ф. ${ }^{2}$

${ }^{1}$ Воронежский государственный университет, Воронеж

${ }^{2}$ Воронежский филиал ФГБНУ ВНИИ кукурузы, Воронежская область

E-mail: stakhurlova@rambler.ru

Резюме. В условиях лесостепи культура кукурузы показала высокую устойчивость к бессменному выращиванию. Использование $N_{60} P_{60} K_{60}$ способствовало повылиению урожайности зеленой массы и зерна кукурузы в среднем на 8,8 и 1,29 m/2а в севообороте и на 10,1 и $1,32 \mathrm{~m} / 2$ в в монокультуре.

Summary. Maize culture is resistant to monoculture. The use of $N_{60} P_{60} K_{60}$ contributed to an increase in the yield of green mass and corn grain by 8.8 and $1.29 \mathrm{t} / \mathrm{ha}$ in the crop rotation and by 10.1 and $1.32 \mathrm{t} / \mathrm{ha}$ in the monoculture.

Кукуруза (Zea mays L.) относится к культурам с уникальным комплексом свойств, существенно выделяющих ее среди других растений семейства мятликовых: $\mathrm{C}_{4}$ - тип фотосинтеза и, соответственно, высокая его интенсивность, значительная величина ассимиляционного аппарата, большое содержание хлорофилла, активное дыхание и интенсивный обмен веществ [4, 5]. Считают, что монокультура кукурузы экономически более целесообразна, приводя статистически сопоставимые урожайные данные на удобренном фоне, как в монокультуре, так и в севообороте [1]. Результаты, полученные в полевых опытах на разных агрохимических фонах в бессменных посевах и севооборотах с разной степенью их насыщения кукурузой, не позволяют сделать однозначные выводы о размерах выхода продукции с 1 га пашни для определенных почвенноклиматических условий $[1,4,5,6]$. В этой связи целью настоящей работы была оценка и анализ результатов многолетних полевых наблюдений с применением минеральных удобрений на продуктивность кукурузы.

Исследования проводили в стационарном полевом комплексе Воронежского филиала ФГБНУ ВНИИ кукурузы. Кукуруза в монокультуре возделывается с 1960 года. Минеральные удобрения (аммиачная селитра, гранулированный суперфосфат и калийная соль) вносятся ежегодно с 1965 г. Посевная площадь делянки составляет $269,5 \mathrm{~m}^{2}$, учетной - 192,5 м². Повторность трехкратная. Агротехника районированных гибридов кукурузы общепринятая для Центрального Черноземья. Урожайность кукурузы определяли методом сплошного учета, данные обрабатывали методом дисперсионного анализа [3]. Почва - чернозем выщелоченный, среднемощный, малогумусный, тяжелосуглинистый, на покровной карбонатной глине, согласно классификации почв 2004 года - агрочернозем глинисто иллювиальный [2].

Урожайность зеленой массы кукурузы на неудобренном фоне в среднем за период наблюдений составила 22,4 т/га, с колебаниями по годам от 12,7 в 2010 г. до 31,7 т/га в 2012 году. Внесение удобрений в дозе $\mathrm{N}_{60} \mathrm{P}_{60} \mathrm{~K}_{60}$ обеспечивало 50-ти процентный прирост урожайности по сравнению с контролем. 
Одинаковая схема внесения удобрений и применяемых агротехнических приемов при выращивании одного и того же гибрида в монокультуре и севообороте позволяет выявить роль севооборотного фактора в урожайности зерна, зеленой массы и сухого вещества кукурузы за 5 ротаций десятипольного севооборота (табл. 1, табл.2).

\section{Таблица 1 - Урожайность зеленой массы кукурузы в монокультуре}

\begin{tabular}{|c|c|c|c|c|}
\hline \multirow{2}{*}{ Вариант } & Средняя урожайность за & Диапазон изменчи- & \multicolumn{2}{|c|}{ Прибавка } \\
\cline { 3 - 5 } & годы исследований & вости урожайности & т/га & $\%$ \\
\hline Без удобрений & 22,4 & $12,7-31,7$ & 0 & 0 \\
\hline $\mathrm{N}_{60} \mathrm{P}_{60} \mathrm{~K}_{60}$ & 33,0 & $14,2-49,3$ & 10,6 & 47,3 \\
\hline $\mathrm{N}_{60} \mathrm{P}_{120} \mathrm{~K}_{60}$ & 32,3 & $14,7-45,0$ & 9,9 & 44,2 \\
\hline $\mathrm{N}_{60} \mathrm{P}_{60} \mathrm{~K}_{120}$ & 32,5 & $14,9-49,7$ & 10,1 & 45,1 \\
\hline $\mathrm{N}_{120} \mathrm{P}_{60} \mathrm{~K}_{60}$ & 36,1 & $15,0-57,6$ & 13,7 & 61,2 \\
\hline $\mathrm{HCP}_{0,5}$ & & & 2,4 & \\
\hline
\end{tabular}

Таблица 2 - Влияние длительного внесения удобрений на продуктивность кукурузы в монокультуре и севообороте, т/га (среднее за 5 ротаций)

\begin{tabular}{|l|c|c|c|c|c|c|}
\hline \multirow{2}{*}{ Вариант } & \multicolumn{3}{|c|}{ Кукуруза в монокультуре } & \multicolumn{3}{c|}{ Кукуруза в севообороте } \\
\cline { 2 - 7 } & зерно & $\begin{array}{c}\text { зеленая } \\
\text { масса }\end{array}$ & $\begin{array}{c}\text { сухое } \\
\text { вещество }\end{array}$ & зерно & $\begin{array}{c}\text { зеленая } \\
\text { масса }\end{array}$ & $\begin{array}{c}\text { сухое } \\
\text { вещество }\end{array}$ \\
\hline Без удобрений & 2,81 & 22,1 & 5,49 & 3,42 & 26,2 & 6,42 \\
\hline $\mathrm{N}_{60} \mathrm{P}_{60} \mathrm{~K}_{60}$ & 1,32 & 10,1 & 2,66 & 1,29 & 8,8 & 2,53 \\
\hline $\mathrm{N}_{60} \mathrm{P}_{120} \mathrm{~K}_{60}$ & 1,29 & 9,5 & 2,73 & 1,24 & 8,7 & 2,60 \\
\hline $\mathrm{N}_{60} \mathrm{P}_{60} \mathrm{~K}_{120}$ & 1,35 & 9,6 & 2,48 & 1,21 & 8,6 & 2,29 \\
\hline $\mathrm{N}_{120} \mathrm{P}_{60} \mathrm{~K}_{60}$ & 1,79 & 13,2 & 3,31 & 1,65 & 11,5 & 2,90 \\
\hline $\mathrm{HCP}_{0,5}$ & 0,32 & 2,4 & 0,66 & 0,35 & 2,9 & 0,70 \\
\hline
\end{tabular}

Примечание: урожайность на контроле без удобрений и прибавки от удобрений

Реакция кукурузы на внесение удобрений была практически одинаковой и не зависела от способа ее выращивания. В севообороте на неудобренном фоне урожайность зерна кукурузы составила 3,42 т/га, с колебаниями по годам от 1,84 (1983 г.) до 5,08 т/га (2015 г.). В монокультуре средняя урожайность зерна составляла 2,81 т/га, с колебаниями от 1,63 т/га (1986 г.) до 4,42 т/га (2015 г.). Диапазон варьирования урожайности зерна кукурузы по вариантам опыта за все годы исследований в севообороте в среднем был в пределах 0,73-1,65 т/га, в монокультуре $0,73-1,79$ т/га. При внесении минеральных удобрений в дозе 60 кг/га урожайность зерна повышалась в севообороте на 38\%, в монокультуре - на 47\%.

Средняя урожайность зеленой массы кукурузы на неудобренном фоне составила в севообороте 26,2 т/га, с колебаниями от 17,4 до 40,7 т/га, в монокультуре - 22,1 т/га с колебаниями от 16,2 до 30,3 т/га. Интервал изменчивости уровня урожайности по ротациям составил: в севообороте - 11,0 т/га, в монокультуре - 7,4 т/га. Внесение $\mathrm{N}_{60} \mathrm{P}_{60} \mathrm{~K}_{60}$ повысило урожайность в севообороте на $33,6 \%$, в монокультуре - на $45,7 \%$, что на $12,1 \%$ выше.

Прирост урожайности кукурузы за счет севооборотного фактора по вариантам опыта был в пределах 2,3-5,4 т/га зеленой массы, 0,31-1,16 т/га сухого 
вещества и 0,47-0,67 т/га зерна. Увеличение количества фосфорного и калийного компонента не отразилось на продуктивности кукурузы как в монокультуре, так и в севообороте, и оказалось экономически не выгодно и экологически нецелесообразно. В то время как увеличение в 2 раза азотного компонента $\left(\mathrm{N}_{120} \mathrm{P}_{60} \mathrm{~K}_{60}\right)$ привело к заметному увеличению урожайности зеленой массы и зерна особенно в монокультуре кукурузы.

Таким образом, в агроэкологических условиях лесостепи Центрального Черноземья кукуруза способна выдерживать длительное выращивание в монокультуре, урожайность зеленой массы за все годы эксперимента на неудобренном фоне составила 22,4 т/га с колебаниями в зависимости от погодных условий от 12,7 до 31,7 т/га. Наиболее сильное и устойчивое по годам действие оказывало ежегодное внесение $\mathrm{N}_{60} \mathrm{P}_{60} \mathrm{~K}_{60}$. Повышение урожайности зеленой массы и зерна кукурузы составило в севообороте 8,8 и 12,9 т/га, в монокультуре 10,1 и 1,32 т/га, при урожайности на неудобренном фоне в севообороте 26,2 и 3,42 т/га, в монокультуре - 22,1 и 2,81 т/га. Приросты урожайности зеленой массы и зерна за счет севооборотного фактора по вариантам опыта были в пределах 2,3-5,4 т/га и 0,5-0,7 т/га.

\title{
Библиографический список
}

1. Daberkow S. Comparing continuous corn and corn-soybean cropping systems / S. Daberkow, J. Payne, J. Schepers // Western Economic Forum. - 2008. - 13 p.

2. Добровольский Г.В. Классификация и диагностика почв России / Г.В. Добровольский - Смоленск: Ойкумена, 2008. - 342 с.

3. Доспехов Б.А. Планирование полевого опыта и статистическая обработка его данных / Б.А. Доспехов. - М.: Колос, 1972. - 205 с.

4. Кошкин Е.А. Частная физиология полевых культур / Е.А. Кошкин, Г.Г. Гатаулина, А.Б. Дьяков - М.: Колос. $-2005 .-344$ с.

5. Лебедь Е.М. Удобрение бессменных посевов кукурузы / Е.М. Лебедь С.М. Крамарев, Л.Г. Подгорная // Кукуруза и сорго. - 2002. - № 6. - С. 8-11.

6. Скороходов В.Ю. Урожайность кукурузы на силос в севооборотах и при бессменном возделывании в зависимости от предшественника на двух уровнях интенсификации в степной зоне южного Урала / В.Ю. Скороходов // Известия Оренбургского государственного аграрного университета. - 2020. - № 2. - С. 68-71.

УДК: 631.421:631.6.02

\section{ПРОБЛЕМЫ ОЦЕНКИ ПОСЛЕДСТВИЙ ЭРОЗИИ В ОПЫТЕ КОНТУРНО-МЕЛИОРАТИВНОГО ЗЕМЛЕДЕЛИЯ}

\author{
Сухановский Ю.П. \\ ФГБНУ «Курский ФАНЦ», г. Курск \\ E-mail:soil-er@kursknet.ru
}

Резюме. Последствия эрозии приводят к трём глобальнылм проблемам: сокращение почвенных ресурсов; уменьшение урожайности; загрязнение окружающей среды. Для решения этих проблем требуется спечиальная методлогия. Подход кеё разработке показан для полевого эксперимента контурно-мелиоративного зеледелия.

Summary. The consequences of erosion lead to three global problems: reduction of soil resources; reduction of yield; environmental pollution. To solve these problems, a special methodology is required. The approach to its development is shown for a field experiment of contour-reclamation agriculture. 
Последствия эрозии почвы приводят к следующим трём глобальным проблемам: сокращение почвенных ресурсов (уменьшение их количества и ухудшение качества); уменьшение урожайности (и уменьшение количества производимой растениеводческой продукции); загрязнение окружающей среды.

Для решения каждой указанной проблемы необходима своя методология (т.е. совокупность методов и правил их применения). В настоящее время такие методологии отсутствуют, что тормозит решение этих проблем.

Оценку последствий можно разделить на оценку последствий, которые произошли в прошлом, и на оценку последствий, ожидаемых в будущем. Зная прошлое, можно лучше оценить будущее. Уменьшение мощности гумусового слоя на пашне можно оценить достоверно через многие десятилетия. В течение 39 лет (с 1982 года) проводится полевой опыт КМЗ (контурно-мелиоративного земледелия) Курского ФАНЦ. Точнее это полевой эксперимент. Он расположен в Медвенском районе Курской области на площади 146 га (чернозёмные почвы). На примере этого эксперимента ниже рассмотрены проблемы оценки последствий эрозии почвы. В настоящее время и в обозримом будущем нереально на всей такой большой площади проводить детальные исследования по указанным трём проблемам. Но это можно делать на небольших ключевых участках. Существует проблема обоснования размеров и размещения таких участков, а также проблема разработки необходимых для этого методов исследования.

1. Сокращение почвенных ресурсов. Организация продовольствия и сельского хозяйства ООН установила [1], что при современном землепользовании эродируемые почвенные ресурсы человек использует как невоспроизводимые (скорость эрозии больше скорости почвообразования). Используя компьютерное моделирование, для чернозёных почв Курской области получено следующее [2]: 1) средняя скорость уменьшения мощности гумусового слоя за 200 лет после распашки целины в 10-100 раз больше скорости почвообразования при современном землепользовании; 2) восстановить мощность гумусового слоя эродированных почв можно только, переводом пашни в залежь с последующим переходом к условиям целины (для этого потребуется 6-9 тыс. лет, что практически нереально).

Bblвод. По важности в оценке последствий эрозии на 1-м месте должна быть динамика мощности гумусового слоя.

Установлено [3], что на эродированных и неэродированных почвах Курской области урожайность зерновых и пропашных культур прямо пропорциональна запасам гумуса в слое почвы 0-50 см. Это означает, что приближенно (с позиции производства растениеводческой продукции) измеряемые запасы гумуса оценивают качество почвы. Уменьшение этих запасов связано, в частности, с эрозией почвы.

Bbıвод. В оценке последствий эрозии на 2-м месте должна быть динамика запасов гумуса в слое почвы 0-50 см.

Состояние почвы со временем изменяется. Его оценивают показателями свойств почвы. Показатель, в свою очередь, определяет меру для свойства почвы. 
Например, почва имеет свойство сохранять воду. Показателем (мерой этого свойства) принята измеряемая влажность почвы. Её определяют массой воды, содержащейся в почве, делённой на массу сухой почвы, и выраженную в процентах. Если для свойства почвы отсутствует мера, то это исключает возможность измерения этого свойства и, как следствие, исключает возможность оценивать изменение свойства во времени. Далее рассмотрены свойства почвы, для которых имеется мера. Результаты прямых и косвенных измерений [4] показателя свойства почвы $X$ представляют в форме интервала погрешности

$$
x_{u 3} \pm \Delta x
$$

где $x_{\text {из }}$ - измеренное значение, $\Delta x$ - его абсолютная погрешность. Интервал погрешности определяет следующее: значение измеряемой величины $X$ находится в этом интервале. Этому интервалу соответсвует определённая доверительная вероятность. Если $\Delta x<x_{u з}$, то значение $x_{u з}$ достоверное. В противоположном случае значение $x_{и з}$ недостоверное.

Проблема оценки репрезентативности выборки измеренных значений. Эта проблема существует, как для условий, когда происходит эрозия, так и для условий при отсутствии эрозии. Для исследуемого участка (с определённой площадью) существует необходимость оценки состояния почвы. Для этого в разных точках участка измеряют значения показателя $X$ интересующего свойства почвы. В результате получают ряд измеренных значений

$$
\left\{x_{i}\right\}, i=1,2, \ldots n,
$$

где $x_{i}$-измеренное значение в $i$-той точке, $n$ - количество измеренных значений. Ряд (2) называют выборкой с объёмом $n$. Она представляет значения показателя свойства почвы исследуемого участка. По выборке (2) для исследуемой площади рассчитывают среднее арифметическое значение $\bar{x}$, которое является результатом косвенных измерений $[4]\left(\bar{x}=x_{u з}\right)$. Это значение зависит от объёма выборки и от размещения на участке точек измерений. Существует понятие «репрезентативность» (т.е. представительность) выборки измеренных значений. В данном случае, показателем репрезентативности является отклонение значения $\bar{x}$ от среднего генеральной совокупности $\mu$, т.е. $\Delta x=|\bar{x}-\mu|$. Поскольку значение $\mu$ неизвестно, то существует проблема оценки репрезентативности выборки (2). Отсутствие абсолютной погрешности $\Delta x$ для выборки исключает оценку достоверности для выборочных средних значений $\bar{x}$ и, как следствие, оценку достоверности разницы двух таких средних значений. В настоящее время идёт поиск решения этой проблемы.

Проблема оценки последствий эрозии на свойства почвы. Для оценки изменения показателя свойства почвы за прошедшее время можно использовать временной ряд

$$
\left\{\overline{x_{i}}\right\}, i=1,2, \ldots m,
$$

где $\overline{x_{i}}-$ измеренное среднее для площади участка значение $\bar{x}$ в $i$-ый момент времени, $m$ - количество измеренных значений в разные моменты времени. Ряд (3) также называют выборкой с объёмом $m$. Она представляет изменение во времени 
среднего для площади участка значения $\bar{x}$. Для выборки (3) можно оценить тренд. Тренд определяют детерминированные факторы, к которым можно отнести эрозию почвы. Например, эрозия во времени определяет тренд уменьшения мощности гумусового слоя, т.е. определяет отрицательный тренд. Следовательно, изменение свойства почвы в прошлом можно оценить трендом измеренных значений показателя свойства почвы.

Для оценки изменения свойства почвы в будущем можно использовать: первое - экстраполяцию тренда, полученного для прошлого; второе - математические (компьютерные) модели, описывающие динамику почвенных процессов.

Bblвodbl. 1. При планировании и при проведении (до настоящего времени) эксперимента КМЗ отсутствовала методология оценки сокращения почвенных ресурсов, подверженных водной эрозии, включающая и оценку достоверности полученных результатов измерний. По этой причине в настоящее время не известно, какое состояние почвы было перед началом эксперимента. Как следствие, нет возможности оценить, насколько оно изменилось за 39 лет. 2. Учитывая возможности новых методов физического, математического и компьютерного моделирования, необходима модернизация проведения эксперимента КМЗ по двум направлениям. Первое - оценка эффективности противоэрозионных мер за прошедшие 39 лет и более. Второе - разработка новой методологии проведения полевых экспериментов, ориентированных на фундаментальные исследования эрозионных процессов и их последствий.

2. Уменьшение урожайности. С увеличением степени эродированности почвы урожайность сельскохозяйственных культур уменьшается. При планировании и при проведении (до настоящего времени) эксперимента КМЗ также отсутствовала методология оценки урожайности, включающая оценку достоверности получаемых результатов. По этой причине также отсутствует возможность достоверно оценить изменение урожайности за 39 лет. В настоящее время, имея многолетний ряд измеренных значений урожайности, можно оценить достоверность среднемноглетней урожайности $[5,6]$. Решение этой задачи основано на анализе выборки (2), но $x_{i}$ означает урожайность за $i$-ый год. На ключевых участках можно получать выборки для урожайности за прошедшее время и оценивать достоверность разницы среднемноголетних урожайностей для разных ключевых участков (для разных вариантов противоэрозионных мер в сравнении с контрольным вариантом). Также, в настоящее время можно сравнивать урожайность на плакоре и на эродированном (в разной степени) ключевом участке склона. Для оценки ожидаемой урожайности в будущем можно использовать функцию плотности вероятности для прошедшего времени. Можно оценивать так же риск получить урожайность меньше заданного минимального значения.

3. Загрязнение окружающей среды. К последствиям эрозии относят заиление и загрязнение поверхностных водных объектов. Экспериментальные исследования почвы, как источника загрязнения, раньше не планировали, и не проводили. В настоящее время к главным угрозам для почвы относят её загрянение [7]. Почва стала сама диффузным загрязнителем для окружающей среды и для растениеводческой продукции. 
Ранее разработанные лабораторией новые методы физического, математического и компьютерного моделирования обеспечивают возможность проведения исследований почвы на водосборах КМЗ как источника загрязнения.

В 2014 г. принят Федеральный закон «О стратегическом планировании в Российской Федерации» [8]. В таком планировании важное место отведено науке. Во исполнение этого закона в 2016 г. разработана «Стратегия научно-технологического развития Российской Федерации» [9]. В Стратегии введено понятие «большой вызов» - совокупность проблем, угроз, их сложность и масштабность, для решения и устранения которых требуется реакция государства (один бизнес не справится с этими вызовами). К большим вызовам отнесены, в частности: 1) «возрастание антропогенных нагрузок на окружающую среду до масштабов, угрожающих воспроизводству природных ресурсов...»; 2) «потребность в обеспечении продовольственной безопасности...». Эрозия почвы уничтожает почвенные ресурсы, которые являются природными и воспроизводимыми ресурсами, а также создаёт угрозу продовольственной безопасности и угрозу загрязнения окружающей среды, опасной для здоровья и жизни населения.

Заключение. На водосборах контурно-мелиоративного земледелия в системе «почва - растение - атмосфера» происходят физические, химические и биологические процессы. На этих объектах необходима организация проведения фундаментальных экспериментальных исследований этих процессов. Исследования должны быть ориентированы на создание научного потенщиала для ответа на указанные большие вызовы.

\section{Библиографический список}

1. Status of the World's Soil Resources (SWSR) - Main Report. Food and Agriculture Organization of the United Nations and Intergovernmental Technical Panel on Soils, Italy: Rome, 2015.

2. Сухановский Ю.П., Прущик А.В., Санжарова С.И., Соловьева Ю.А. Модифицированный метод прогнозирования эрозии почвы и её последствий // Земледелие. 2016. - № 2. - С. 29-32.

3. Сухановский Ю.П., Прущик А.В., Санжарова С.И. Оценка и динамика ресурсов чернозёмов и серых лесных почв сельскохозяйственных угодий Курской области // Вестник курской государственной сельскохозяйственной академии, 2013. - №6. - С. 53-59.

4. РМГ 29-2013 Рекомендации по межгосударственной стандартизации. Государственная система обеспечения единства измерений. Метрология. Основные термины и определения. - М.: Стандартинформ, 2014. - 121 с.

5. Дубовик Д.В., Сухановский Ю.П., Нитченко Л.Б., Прущик А.В. Оценка ожидаемой урожайности по данным краткосрочных полевых опытов // Достижения науки и техники АПК, 2019. - Т. 33. - № 8. - С. 5-9.

6. Сухановский Ю.П., Акименко А.С., Дудкина Т.А., Прущик А.В. Использование методов математической статистики для повышения информативности данных урожайности сельскохозяйственных культур в севооборотах многофакторного полевого опыта // Международный сельскохозяйственный журнал, 2020. - Т. 63. - № 6 (378). - С. 94-97.

7. Rodriguez-Eugenio N., McLaughlin M., Pennock D. (2018). Soil Pollution: a hidden reality, Rome, Italy.

8. О стратегическом планировании в Российской Федерации. Федеральный закон Российской Федерации от 28 июня 2014 г. N 172-Ф3.

9. Стратегия научно-технологического развития Российской Федерации. Указ Президента 
Российской Федерации № 642 от 1.12.2016 г.

УДК 631.6 .02

\title{
ПОЧВОЗАЩИТНАЯ ЭФФЕКТИВНОСТЬ АГРОФОНОВ, СЕЛЬСКОХОЗЯЙСТВЕННЫХ КУЛЬТУР И СЕВООБОРОТОВ
}

\author{
Тарасов C.A.
}

Федеральное государственное бюджетное научное учреждение «Курский федеральный аграрный научный центр», г. Курск

E-mail: sergejtarasov1989@mail.ru

\begin{abstract}
Резюме. Показана почвозащитная эффективность агрономических фонов, сформированных обработкой почвы после уборки яровых культур, посевами озимых культур и многолетних трав в агроландшафтах, подверженных воздействию эрозии почв тальми водами. Сделан анализ эрозионной опасности сельскохозяйственных культур, и приведены значения коэффриичентов эрозионной опасности различных севооборотов.
\end{abstract}

Ключевые слова: эрозия почв, талые воды, ливневые осадки, агрофоны, сельскохозяйственные культуры, севообороты, эрозионная опасность.

В условиях Центрально-Черноземного региона, который характеризуется относительно высокой степенью расчлененности рельефа, основным фактором, приводящим к деградации почв, является водная эрозия. В зависимости от степени увлажнения территории и особенностей рельефа смыв почвы может быть от 1,9 до 18,5 т/га в год [1]. Деградация почв, вызванная эрозией, является одной из причин неустойчивого развития сельскохозяйственного производства. Для повышения продуктивности сельскохозяйственных земель необходимо организовать эффективную защиту их от эрозии [2].

С учетом того, что эрозия почв являются результатом действия природных процессов и хозяйственной деятельности человека, эффективная противоэрозионная защита возможна только с учетом комплекса факторов, влияющих на интенсивность ее проявления. Необходим дифференцированный подход к решению проблемы защиты почв от эрозии в пределах каждой агроландшафтной единицы на основе эколого-ландшафтных принципов организации территории и разработки соответствующих противоэрозионных мероприятий [3]. Наряду с обоснованным использованием лесомелиоративных и гидротехнических противоэрозионных мероприятий на склонах в пределах территориальных единиц агроландшафтов, должны быть также разработаны и обоснованы агротехнические и фитомелиоративные мероприятия в системе почвозащитных севооборотов. Каждая сельскохозяйственная культура в составе севооборота характеризуется определенными биологическими особенностями, которые требуют соответствующей системы агротехнических мероприятий, в том числе и схем посева (культуры сплошного сева и пропашные культуры), систем обработки почвы и других агрономических приемов, влияющих на эрозионную опасность и почвозащитную эффективность. Кроме густоты травостоя и агрономических фонов, сформированных системой обработки почвы, почвозащитная функция сельскохозяйственной культуры зависит также от продолжительности 
вегетации. Например, многолетние травы покрывают и, соответственно, защищают почву от эрозии в течение всего года, тогда как яровые культуры способны защищать почву только от ливневой эрозии в течение трех летних месяцев [4].

При организации защиты почв от водной эрозии следует учитывать, что причиной водной эрозии могут быть как талые воды в весенний период, так и ливневые осадки в период вегетации растений. Поэтому целесообразно представить модель агроландшафта в виде агрономических фонов, сформированных различными сельскохозяйственными культурами и способами обработки почвы. Таким образом, мы учитываем, что во времени и пространстве (в системе севооборотов) различные участки почвы могут быть не занятыми растениями (агрономический фон, который образован после определенной системы обработки почвы), находиться под покровом озимых культур или многолетних трав. Соответственно, почвозащитная эффективность агрофонов будет различной. В.П. Герасименко, М.А. Кумани [5] предлагают эрозионную опасность пашни определять по четырем показателям: сток талых вод, сток ливневых вод, смыв почвы в период снеготаяния и смыв почвы в период вегетации культур. Соответственно, классификацию эрозионной опасности (противоэрозионной эффективности) сельскохозяйственных культур следует давать с учетом водной эрозии, вызванной талыми водами или ливневыми осадками.

В наших исследованиях определяли почвозащитную эффективность агрофонов, сформированных системой обработки почвы после уборки яровых культур (вспашка на глубину 20-25 см), а также посевами озимых культур и многолетних трав относительно действия водно-эрозионных процессов, вызванных стоком талых вод. Проведен анализ экспериментальных данных по стоку и смыву почвы на агрофонах за период с 1988 по 2018 гг. Стационарный опыт заложен в Медвенской районе Курской области на площади 163 га на территории со сложным ложбинно-балочным рельефом. Почвенный покров представлен черноземами выщелоченным и типичным средне- и тяжелосуглинистого гранулометрического состава. Крутизна склонов от 0,1 до 8 градусов, степень эродированности от 16,5 до 27,3\% [6].

Установлено, что самая низкая почвозащитная эффективность в отношении стока талых вод была под посевами озимых культур. В среднем за годы исследований сток талых вод на этом агрофоне составил 49,1 мм, и смыв почвы 8,89 т/га. На вспаханном поле за этот же период в среднем сток талых вод был 16,8 мм, и смыв почвы 2,99 т/га. Под покровом многолетних трав проявлялся сток талых вод, который составил 18,7 мм, что больше в сравнении с фоном вспашки, однако смыва почвы не было. Таким образом, агрономический фон, сформированный под многолетними травами, является надежным средством защиты почв от водной эрозии, вызванной талыми водами [7].

В отличие от других сельскохозяйственных культур, задействованных в севообороте, озимые культуры и многолетние травы подвержены воздействию водной эрозии, вызванной стоком талых вод и ливневых осадков. Почвенный покров под яровыми культурами испытывает действие только ливневых 
осадков. Таким образом, почвозащитную эффективность озимых культур и многолетних трав следует оценивать на фоне действия талых вод и ливневых осадков, и почвозащитную эффективность яровых культур - только на фоне ливневых осадков. Все культуры, входящие в состав севооборотов, подразделяются на культуры сплошного сева и пропашные культуры. Особым фоном в севообороте являются чистые пары, которые наиболее уязвимы в отношении водной эрозии.

Эрозионную опасность покрова почвы, сформированного соответствующей системой обработки почв и культурами севооборота, относительно влияния ливневой эрозии изучали многие исследователи в различных регионах страны. М.И. Лопырев, Е.И. Рябов [8] предложили следующую шкалу оценки эрозионной опасности агрофонов и сельскохозяйственных культур. Если коэффициент эрозионной опасности чистого пара принимать за 1,0, то коэффициент эрозионной опасности пропашных культур составляет от 0,6 до 0,9, яровых и озимых культур сплошного сева, в том числе и с подсевом многолетних трав, а также промежуточных культур - от 0,2 до 0,6. Самая низкая эрозионная опасность по отношению к ливневой эрозии обеспечивается под покровом многолетних трав, которая в зависимости от года пользования составляет от 0,01 до 0,08 .

Разработана также шкала классификации агрофонов и сельскохозяйственных культур, где наиболее уязвимый фон чистого пара имеет коэффициент эрозионной опасности по отношению к ливневой эрозии 5,9, пропашных культур 4,0 , яровых и озимых зерновых культуры сплошного сева 1,0 и многолетних трав 0,2 [5]. В соответствии с данной шкалой мы рассчитали эрозионную опасность различных севооборотов, типичных для Центрального Черноземья. Объектами исследования были зернопаропропашные, зернопропашные, зерновые, плодосменные и зернотравяные (травяно-зерновые) севообороты с количеством полей от 5 до 9. С учетом эрозионной опасности культур (пара) по отношению к ливневой эрозии, входящих в состав севооборота, рассчитывали его усредненный коэффициент эрозионной опасности. Как правило, в зернопаропропашных севооборотах под чистый пар отводится одно из полей севооборота, и под пропашные культуры - не более трех полей. Чем больше в соотношении культур зернопаропропашного севооборота приходится доля на пропашные культуры, тем выше коэффициент эрозионной опасности. С увеличением доли зерновых культур сплошного сева в состав зернопаропропашного севооборота коэффициент эрозионной опасности севооборота снижается. Самый высокий усредненный коэффициент эрозионной опасности, который составил 3,78, оказался в 5-типольном зернопаропропашном севообороте при соотношении пар : пропашные культуры : зерновые культуры сплошного сева 1 : 3 : 1. Количество полей в зернопаропропашном севообороте, как правило, увеличивается за счет ввода зерновых культур. Самый низкий усредненный коэффициент эрозионной опасности, который составил 1,88, оказался в 9-типольном зернопаропропашном севообороте при соотношении пар : пропашные 
культуры : зерновые культуры $1: 1$ : 7 . Усредненный коэффициент эрозионной опасности всех изучаемых зернопаропропашных севооборотов составил 2,63.

Оценка эрозионной опасности зернопропашных севооборотов показала, что она возрастает с увеличением в соотношении пропашные культуры : зерновые культуры доли пропашных культур до трех полей. Самый высокий усредненный коэффициент эрозионной опасности, который составил 2,80, оказался в 5-типольном зернопропашном севообороте при соотношении пропашные культуры : зерновые культуры $3: 2$. С увеличением числа полей в зернопропашных севооборотах за счет зерновых культур сплошного сева их эрозионная опасность снижается. Самый низкий усредненный коэффициент эрозионной опасности, который составил 1,33, оказался в 9-типольном зернопропашном севообороте при соотношении пропашные культуры : зерновые культуры $1: 8$. Усредненный коэффициент эрозионной опасности всех изучаемых зернопропашных севооборотов составил 1,81 .

Плодосменные севообороты, наряду с зерновыми культурами сплошного сева, включают как пропашные культуры с высоким коэффициентом эрозионной опасности, так и многолетние травы с высокой почвозащитной эффективностью. В 5-типольных плодосменных севооборотах не может быть полей пропашных культур более двух, и полей многолетних трав более двух. В плодосменных севооборотах с полями более пяти, количество полей под пропашными культурами, как правило, ограничивается тремя полями, и под многолетними травами, также не бывает больше трех. С учетом указанных ограничений, тем не менее, возможно большое количество различных вариантов соотношения пропашных культур, зерновых культур и многолетних трав в плодосменных севооборотах. Расчеты показали, что самый высокий усредненный коэффициент эрозионной опасности, который составил 2,37, оказался в 6-типольном плодосменном севообороте при соотношении пропашные культуры : зерновые культуры : многолетние травы $3: 2: 1$. Самый низкий усредненный коэффициент эрозионной опасности, который составил 1,07, оказался в 9-типольном плодосменном севообороте при соотношении пропашные культуры : зерновые культуры : многолетние травы $1: 5$ : 3. Усредненный коэффициент эрозионной опасности всех изучаемых плодосменных севооборотов составил 1,56.

В соответствии с принятой шкалой коэффициент эрозионной опасности зерновых севооборотов, в состав которых входят зерновые культуры сплошного сева, по отношению к ливневой эрозии не зависел от количества полей и составлял 1,0. В зернотравяных и, особенно, травяно-зерновых севооборотах, коэффициент эрозионной опасности был самый низким, и в среднем по данным севооборотам с различным количеством полей (полей с многолетними травами не более трех) составил 0,76. Увеличение количества полей за счет включения зерновых культур приводит и к увеличению усредненного коэффициента эрозионной опасности севооборота. Установлено, что самый высокий усредненный коэффициент эрозионной опасности, который составил 0,91, оказался в 9типольном зернотравяном севообороте при соотношении зерновые культуры : многолетние травы 8 : 1. Самый низкий усредненный коэффициент эрозионной 
опасности, который составил 0,52, оказался в 5-типольном травяно-зерновом севообороте при соотношении зерновые культуры : многолетние травы 2 : 3 .

На основании анализа результатов исследования можно заключить, что надежную защиту почв от водной эрозии, вызванной стоком талых вод, обеспечивают многолетние травы, в меньшей степени защищает почву от смыва зяблевая вспашка, и наиболее уязвимым фоном по отношению к стоку талых вод является покров озимых культур. Эрозионная опасность севооборотов по отношению к ливневой эрозии снижается и, соответственно, почвозащитная эффективность возрастает при их градации в следующем порядке: зернопаропропашной севооборот $\rightarrow$ зернопропашной $\rightarrow$ плодосменный $\rightarrow$ зерновой $\rightarrow$ зернотравяной (травяно-зерновой). С увеличением количества полей в зернопаропропашных и зернопропашных севооборотах за счет зерновых культур сплошного сева их эрозионная опасность снижается и почвозащитная эффективность возрастает. В плодосменных и зерновых севооборотах эрозионная опасность и почвозащитная эффективность практически не зависит от количества полей. В зернотравяных (травяно-зерновых) севооборотах с увеличением количества полей за счет зерновых культур эрозионная опасность возрастает.

\section{Библиографический список}

1. Спесивый О.В., Лисецкий Ф.Н. Оценка интенсивности и нормирование эрозионных потерь почвы в Центрально-Черноземном районе на основе бассейнового подхода // Региональные геосистемы, 2014. - Т. 27. - № 10 (181). - С. 125-132.

2. Недикова Е.В. Садыгов Э.А. Оглы, Недиков К.Д. Особенности защиты земель сельскохозяйственного назначения от водной и ветровой эрозии // Регион: системы, экономика, управление, 2019. - № 3 (46). - С. 112-117.

3. Колпакова О.П. Защита сельскохозяйственных земель от эрозионных процессов // International agricultural journal, 2020. - № 4. - C. 107-118. - doi:10.24411/2588-0209-202010200

4. Севообороты для эрозионно опасных агроландшафтов Центрального Черноземья / В.И. Турусов, В.М. Гармашов, О.А. Богатых, Н.В. Дронова, Т.И. Михина // Плодородие, 2017. - № 2 (95). - C. 45-48.

5. Герасименко В.П., Кумани М.В. Рекомендации по регулированию почвенно-гидрологических процессов на пахотных землях. Курск: ВНИИЗиЗПЭ, 2000. - 105 с.

6. Подлесных И.В., Зарудная Т.Я. Контурная организация территории как пример адаптивно-ландшафтной системы земледелия /Современные тенденции развития аграрного комплекса/ материалы международной научно-практической конференции. ФГБНУ «Прикаспийский научно-исследовательский институт аридного земледелия». // Прикаспийский научно-исследовательский институт аридного земледелия (Соленое Займище), 2016. - С. 371-376.

7. Подлесных И.В., Соловьева Ю.А. Новый подход в методологии формирования структуры севооборотов с учетом противоэрозионной роли сельскохозяйственных культур // Достижения науки и техники АПК, 2020. - Т. 34. - № 11. - С. 21-25.

8. Лопырев М.И., Рябов Е.И. Защита земель от эрозии и охрана природы. М.: Агропромиздат, 1989. $-240 \mathrm{c.}$ 


\title{
ТЕХНОЛОГИЯ ВОЗДЕЛЫВАНИЯ НОВЫХ ГИБРИДОВ КУКУРУЗЫ
} В СТЕПНОЙ ЗОНЕ КАБАРДИНО-БАЛКАРИИ

\author{
Тарчоков Х.Ш., Бжинаев Ф.Х., Чочаев М.М. \\ Институт сельского хозяйства - \\ филиал ФГБНУ «Федеральный научный центр \\ «Кабардино-Балкарский научный центр РАН» \\ 360004, КБР, г. Нальчик, ул. Кирова, 224 \\ E-mail:kbniish2007@yandex.ru
}

\begin{abstract}
Резюме. Представлены результаты исследований по определению влияния сроков посева и глубины заделки семян в почву перспективных гибридов кукурузы селекции ИСХ КБНЦ РАН в условиях орошения степной зоны Кабардино-Балкарии. Так, полевая всхожесть семян гибридов Терек и Майский-260МВ наиболее высокая при их посеве во второй декаде апреля на глубину посева $10 \mathrm{~cm}(91,0$ и 86,0\%) по сравнению со сроками их посева в первой декаде апреля на глубину 5 см (81,0 и 80,0\% соответственно). Средняя урожайность зерна этих гибридов была наивысшей (62,0 и 58,5 и/га) при втором сроке их посева 20.04, при раннем сроке 10.04 зерновая продуктивность Терека и Майского 260МВ снижается до 16,5 и 15,0и/га соответственно. Полевая всхожесть семян и урожайность зерна гибридной популяции Кабардинская 3812 при заделке их семян на глубину 10 см была наиболее высокая и составляла 86,0 и 70 uу/2а st влажности.
\end{abstract}

Ключевые слова: кукуруза, гибрид, адаптивность, сроки посева, структура урожая, густота посева, урожайность, глубина заделки семян в почву.

Введение. Кукуруза занимает ведущее место в мировом земледелии, что определяется высокой урожайностью и многогранностью её использования в пищевой промышленности, животноводстве, медицине и других отраслях экономики [1].

Как высокопродуктивное кормовое растение кукуруза представляет важнейшую ценность для сельскохозяйственных животных. На корм скоту используют зерно, силос, зеленую массу и солому [2].

В условиях Северного Кавказа теплолюбивая кукуруза на зерно может быть неплохим предшественником озимых колосовых культур при возделывании среднеранних, среднеспелых и среднепоздних гибридов кукурузы. Позднеспелые формы могут использоваться в этом качестве в южных районах, где безморозный период превышает 200 дней [3].

Растения кукурузы, убранные в фазе молочно-восковой спелости зерна, хорошо силосуются, при условии достаточно высокого уровня содержания сахара в растениях. Именно в этот период зрелости зерна можно получать наибольшую урожайность сухого вещества и его высокое качество, при оптимальном соотношений питательных веществ в силосе [4].

Благодаря своим биологическим особенностям кукуруза получила широкое распространение на полях Кабардино-Балкарской Республики и в поукосных и пожнивных посевах, способствуя при этом более интенсивному использованию пашни в зонах достаточного увлажнения и на орошаемых землях. 
В последнее время благодаря высокому уровню механизации и химизации производства кукуруза возделывается без особых затрат ручного труда. Исключения составляют посевы родительских форм на участках гибридизации, где вручную удаляют нетипичные растения, цветущие метелки материнских форм или метелки у отцовских растений, при ведении участка гибридизации на фертильной основе [5].

Кукуруза, занимая в мире второе место после озимой пшеницы по посевной площади, лидирует по сбору валового урожая среди зерновых культур. Это стало возможным благодаря переходу многих кукурузосеющих стран на возделывание простых межлинейных гибридов, имеющих высокий потенциал урожайности. В настоящее время имеются высокотехнологичные гибриды кукурузы с потенциалом урожайности зерна более $200 ц / г а$. Так, в штате Иллинойс (США) при орошении урожайность зерна у отдельных фермеров превышала 200ц/га.

В Кабардино-Балкарии кукуруза занимает от 20 до 30\% посевной площади севооборотов. В создавшихся сложных экономических и экологических условиях увеличение производства зерна кукурузы на Северном Кавказе не может быть достигнуто за счет расширения площади посева. Кроме того, нет резервов в наращивании интенсификации земледелия в связи с напряженной экологической обстановкой.

Поэтому единственным выходом из создавшейся ситуации может быть разработка и внедрение в производство технологий, основанных на ресурсоэнергосбережении и биологизации растениеводства с использованием достижений селекции, разумным чередованием культур в севооборотах, обработкой почвы, химизацией и мелиорацией земель.

Одним из лимитирующих факторов благоприятного возделывания кукурузы на юге России, в т.ч. и в Кабардино-Балкарии, является влага. Так, некоторые кукурузосеющие районы республики находятся в зоне рискованного земледелия, и нехватка влаги в этих условиях наступает не только в привычно жаркие (июль и август) месяцы года, но и ранней весной и в начале лета. Ситуация усугубляется глобальным потеплением климата во всем мире, способствующее чрезмерному испарению незначительного количества выпадающих осадков в осенне-зимне-весенний периоды, отрицательно влияющие на процессы формирования продуктивности многих яровых сельскохозяйственных культур, в т.ч. и кукурузы.

Ввиду этого одним из основных направлений научно-исследовательских работ лаборатории технологии возделывания полевых культур ИСХ КБНЦ РАН в настоящее время является усовершенствование некоторых элементов технологии возделывания кукурузы, включающие сроки посева, глубину заделки семян в почву, подбор и испытание гибридов наиболее устойчивых к био- и абиотическим факторам их выращивания в условиях степной зоны Кабардино-Балкарии.

Материалы и методика. Исследования проводились на экспериментальном поле лаборатории технологии возделывания полевых культур, 
расположенном в степной зоне Кабардино-Балкарской Республики (пос. Опытный Терского района). Объектом для исследований были три гибрида кукурузы, селекции ИСХ КБНЦ РАН.

Гибрид кукурузы Майский 260 МВ, создан совместно ИСХ КБНЦ РАН и НССС ООО «Белкорн» (ФАО - 260).

Трехлинейный среднеранний гибрид (ФАО 260) универсального назначения использования. Длина вегетационного периода 107-110 дней. Высота растений 220-240 см. Количество рядов на початке 16-18. Масса 100 зерен 300-320 г. выход зерна 84-86 \%, выполненность початка 96 \%. Уборочная влажность зерна не более 14-16 \%. На высоком агрофоне и орошении склонна к образованию вторых початков. Рекомендуемая густота стояния - 60 тыс. растений на богаре и 65 тыс. на орошении на 1 га к уборке.

Рекомендован для возделывания на зерно в республиках Кабардино-Балкария, Северная Осетия-Алания, Чечня, Ингушетия, Дагестан, в Краснодарском, Ставропольском краях, Тамбовской, Орловской и Липецкой областях, на силос - в Белгородской, Воронежской, Курской областях.

Гибрид кукурузы Терек, создан ИСХ КБНЦ РАН (ФАО 450). Простой среднепоздний гибрид. Длина вегетационного периода 120-125 дней.

Гибрид - универсального типа назначения, пригоден для возделывания, как на зерно, так и на силос. Растения высотой 270-290 см, устойчивый к полеганию. Высота прикрепления початка 75-85 см. Початок цилиндрический и слабоконусовидной формы. Масса одного початка 250-280 г. Количество рядов на початке 16-18. Выход зерна при обмолоте 79-83 \%, зерно желтое зубовидное. Устойчив к пузырчатой головне, фузариозу, стеблевым и корневым гнилям. На высоком агрофоне способен давать урожай зерна 95-105 ц/га, силосной массы 520-550 ц/га.

Гибридная популяция Кабардинская 3812, выведена в ИСХ КБНЦ РАН методом гибридных популяций в результате свободного переопыления специально подобранных позднеспелых сортов, гибридов и самоопыленных линий кукурузы. Относится к группе зубовидной кукурузы с желтым зубовидным зерном и красным початковым стержнем. Допустимым отклонением являются початки с желтым зерном и белым початковым стержнем (от 1 до 3 \%) с зубовидными, полузубовидными и кремнистыми зернами.

Растение высокорослое до 380-480 см. Масса початков 350-400 граммов. Рядов зерен на початке 16-18 (12-24). Выход зерна при обмолоте початков 80$82 \%$. Масса 1000 зерен 350-370 граммов. Созревает в степной зоне КБР за 118122 дня.

Гибридная популяция Кабардинская 3812 - позднеспелая (ФАО - 600), поэтому необходимо сеять на орошаемых или влагообеспеченных землях. Отзывчива на внесение удобрений и орошение. На высоком агрофоне обеспечивает получение $82-95$ ц/га сухого зерна. При уборке в фазе молочно-восковой спелости урожай составляет 750-950 ц/га и более зеленой листостебельной массы с початками. 
Оптимальная густота стояния растений, как на зерно, так и на силос 35 тыс. раст/га. При оставлении плотности посевов кукурузы этой популяции больше рекомендуемых растений/га, имеет склонность к полеганию, наблюдается больше потери при уборке. Для получения такой густоты стояния следует высевать не более 40 тыс. зерен на 1 га семян первого класса посевного стандарта.

При уборке на силос комбайнами типа КСС-2,6; КСКУ-200 из-за высокой урожайности масса обычно забивается. Поэтому следует уменьшить на половину захват уборочного агрегата и увеличить скорость его движения.

Опыт заложен в 3-х кратной повторности систематическим методом в два яруса. Закладку опыта и анализы элементов продуктивности растений выполняли в соответствии с требованиями методики полевого опыта. Посев проводили в разные сроки и на разных глубинах с разной нормой всхожих семян на 1 га. Учетная площадь делянки - $120 \mathrm{~m}^{2}$. Уборку урожая зерна кукурузы проводили вручную методом ручной ломки учетной площади делянок и пересчитывали в ц/га стандартной влажности. Урожайные данные обрабатывали методом дисперсионного анализа по Доспехову Б.А. [6].

Среднегодовое количество осадков в данной зоне составляет 450мм с колебанием по годам от 270 до 570мм. В годовом цикле максимум осадков отмечается в июне, а минимум - в январе. По сезонам осадки распределяются следующим образом: в летние месяцы $35-43 \%$, в осенние $19-23 \%$, в зимние 10 $16 \%$ и в весенние $19-23 \%$ от годового количества. Содержание гумуса $-3,6 \%$; $\mathrm{pH}-7,2 ;$ гидролизуемого азота 140,0 мг/кг (по Кьельдалью); $\mathrm{P}_{2} \mathrm{O}_{5}-400$ мг/кг; $\mathrm{K}_{2} \mathrm{O}-80,0$ мг/кг; гидролитическая кислотность - 1,8 м.экв/100г; сумма поглощенных оснований - 28,0 ммоль/100г почвы. Против сорных растений на посевах применяли гербициды высокой эффективности, разрешенных к применению на территории Российской Федерации [7, 8].

Основная обработка почвы на опытном участке - отвальная вспашка, предшественник озимая пшеница на зерно. Под основную обработку почвы осенью вносили комплексное минеральное удобрение $\left(\mathrm{N}_{45} \mathrm{P}_{45} \mathrm{~K}_{45}\right)$, весной в фазе 7-8 листьев, под междурядную культивацию вносили в подкормку аммиачную селитру из расчета 50 кг/га в д.в.

Семена гибридов кукурузы высевали вручную по срокам в соответствии со своими стандартными нормами высева изучаемых гибридов. После появления всходов в фазе 4-5 листьев формировали оптимальную густоту стояния растений: 55тыс/га для гибрида Терек; 62-65тыс/га для гибрида Майский $260 \mathrm{MB} ; 35-40$ тыс/га для гибридной популяции Кабардинская 3812, при вегетационном поливе напуском по бороздам поливной нормой 600-800 м3/га. Удобрения $\left(\mathrm{N}_{60} \mathrm{P}_{90} \mathrm{~K}_{60}\right)$ вносили перед посевом под культивацию зяби.

\section{Результаты исследований.}

В годы проведения исследований погодные условия несколько отличились от среднемноголетних (норма) показателей (табл. 1). Так, количество осадков в 2019 и 2020 годы (395,6 и 417,7 мм) было меньше данных «нормы» на 75,4 и 53,3 мм, соответственно. Температура воздуха за эти годы была на 
уровне 12,7 и $12,1^{\circ} \mathrm{C}$ против $10,4^{\circ} \mathrm{C}$ по «норме». Относительная влажность воздуха в 2019г. была меньше на 4,9\% и больше на 10,1 5 в 2010 г. среднемноголетних данных - 76,9\%.

Таблица 1 - Метеорологические показатели за годы проведения исследований (по данным агрометеорологического поста «Куян», пос. Опытный Терского р-на КБР)

\begin{tabular}{|c|c|c|c|}
\hline Год & Осадки, мм & $\begin{array}{c}\text { Температура воз- } \\
\text { духа, }{ }^{\circ} \mathbf{C}\end{array}$ & $\begin{array}{c}\text { Относительная влаж- } \\
\text { ность воздуха, \% }\end{array}$ \\
\hline 2019 & 395,6 & 12,7 & 72,0 \\
\hline 2020 & 417,7 & 12,1 & 87,0 \\
\hline $\begin{array}{c}\text { Среднемноголетние } \\
\text { данные (норма) }\end{array}$ & 471,0 & 10,4 & 76,9 \\
\hline
\end{tabular}

В технологиях возделывания полевых культур одним из важнейших элементов является сроки и глубина заделки семян в почву. До недавнего времени (35-40 лет тому назад) для условий степной зоны Кабардино-Балкарии оптимальными, научно обоснованными сроками посева кукурузы считался период 25 апреля - 10 ая при глубине заделки семян на 5-6 см.

Однако, в последнее время происходит глобальное изменение климата в сторону его потепления. Это положение способствует изменению температурного режима почвы, где оптимальные условия по тепловому режиму посевного слоя в условиях зоны наступают раньше на 20-25 дней по сравнению с теми параметрами, которые считались нормальными.

Поэтому в задачу наших исследований входило определение влияния различных сроков посева и глубины заделки семян, в почву новых гибридов кукурузы селекции ИСХ КБНЦ РАН на их полевую всхожесть и зерновую продуктивность. Испытываемые гибриды кукурузы высевали в три срока: первый срок - первая декада апреля, второй - вторая декада апреля и третий срок третья декада апреля месяца (табл. 2). Как видно из приведенных данных, полевая всхожесть гибридов кукурузы составляли для Терека $-81,0 ; 83,0$ и 90,0 \%. У Майского 260 МВ она была 80,0; 82,0; 85,0 \% и для гибридной популяции Кабардинская - 3812 эти данные не выходили за пределы 80,0; 82,5 и 85,0\% на фоне глубины заделки семян изучаемых гибридов 5 см.

При условии заделки семян на глубину 10 см отмечается у всех гибридов заметное увеличение полевой всхожести. Однако, для того, чтобы в наибольшей степени реализовать потенциальную продуктивность кукурузного растения важнейшая роль отводится формированию оптимальной густоты стеблестоя к завершению вегетационного периода.

Правда, на это влияют и генетические особенности гибридов разных групп спелости, сроки посева, климатические условия, фон удобренности влагообеспеченность зоны выращивания и т.д.

Поэтому необходимо помнить о том, что регулирование продуктивности полевых культур осуществляется также посредством систем севооборотов, обработки почвы, мелиоративных мероприятий и защиты растений. 
Таблица 2 - Влияние сроков посева и глубины заделки семян в почву на полевую всхожесть и густоту стояния растений гибридов кукурузы (среднее за 2019-2020гг)

\begin{tabular}{|c|c|c|c|c|}
\hline Гибриды & $\begin{array}{l}\text { Сроки по- } \\
\text { сева }\end{array}$ & $\begin{array}{c}\text { Глубина } \\
\text { посева; см }\end{array}$ & $\begin{array}{c}\text { Полевая } \\
\text { всхожесть, \% }\end{array}$ & $\begin{array}{c}\text { Густота стеблестоя } \\
\text { к уборке; } \\
\text { тыс.раст/га }\end{array}$ \\
\hline \multirow{6}{*}{ Терек } & \multirow[t]{2}{*}{$1^{+)}$} & 5 & 81,0 & 76,4 \\
\hline & & 10 & 83,0 & 78,0 \\
\hline & \multirow[t]{2}{*}{$2^{+)}$} & 5 & 90,0 & 84,0 \\
\hline & & 10 & 91,0 & 86,0 \\
\hline & \multirow[t]{2}{*}{$3^{+)}$} & 5 & 81,0 & 77,5 \\
\hline & & 10 & 84,0 & 80,0 \\
\hline \multirow{6}{*}{ Майский-260МВ } & \multirow[t]{2}{*}{1} & 5 & 80,0 & 78,0 \\
\hline & & 10 & 85,0 & 81,0 \\
\hline & \multirow[t]{2}{*}{2} & 5 & 82,0 & 82,0 \\
\hline & & 10 & 86,0 & 81,0 \\
\hline & \multirow[t]{2}{*}{3} & 5 & 85,5 & 80,0 \\
\hline & & 10 & 88,0 & 81,0 \\
\hline \multirow{6}{*}{$\begin{array}{c}\text { Кабардинская } \\
3812\end{array}$} & \multirow[t]{2}{*}{1} & 5 & 80,0 & 40,0 \\
\hline & & 10 & 85,0 & 42,5 \\
\hline & \multirow[t]{2}{*}{2} & 5 & 82,5 & 42,4 \\
\hline & & 10 & 86,0 & 44,4 \\
\hline & \multirow[t]{2}{*}{3} & 5 & 85,0 & 39,5 \\
\hline & & 10 & 88,0 & 41,5 \\
\hline
\end{tabular}

Примечание: +) сроки посева кукурузы:

1-ый срок 10.04; 2-ой срок 20.04; 3 -ий срок 30.04

С точки зрения производственной практики результаты по прибавкам продуктивности сельхозкультур в полевых опытах следует рассматривать как максимально возможные в тех или иных почвенно-климатических условиях $[9,10$, $11]$.

В наших исследованиях, проведенных в условиях степной зоны Кабардино-Балкарии, семена гибридов кукурузы показали наиболее высокую полноту всходов на вариантах второго срока их посева (вторая декада апреля) при глубине заделки семян в почву на $10,0 \mathrm{~cm}$. Это объясняется тем, что на этой глубине больше влаги, оптимальная эффективная температура $-10-12^{\circ} \mathrm{C}$, растения лучше укореняются и развиваются. В первой декаде апреля температура почвы на глубине заделки семян была $5-7^{0} \mathrm{C}$; во второй $8-10^{\circ} \mathrm{C}$ и в третьей $-10-$ $12^{\circ} \mathrm{C}$.

Так, на всех трех гибридах кукурузы структурные показатели урожая зерна при глубине заделки семян на $10 \mathrm{~cm}$ были выше, чем данные на глубине 5см (табл. 3).

Средняя масса десяти початков и количество зерна с них у гибридов кукурузы также были в пользу второго срока посева, при глубине заделки семян как на $5 \mathrm{~cm}$, так и на $10 \mathrm{~cm}$. Масса десяти початков на гибридах Терек, Майский 260 МВ составила при втором сроке посева 1,3-1,5кг, а у Кабардинской $3812-$ 1,4кг на глубине 5см. При посеве на глубину 10 см соответственно 1,4-1,6 кг на гибридах Терек и Майский $260 \mathrm{MB}$, а на гибридной популяции 
Кабардинская 3812 - 1,6кг. Хозяйственная эффективность гибридной популяции Кабардинская 3812 как по срокам, так и по глубине посева была практически одинаковой - 1,4-1,6кг.

Таблица 3 - Структурный анализ урожая зерна гибридов кукурузы в зависимости от приемов ухода (среднее за 2019-2020гг.)

\begin{tabular}{|c|c|c|c|c|c|c|c|c|}
\hline \multirow{2}{*}{$\begin{array}{l}\text { № } \\
\Pi / \Pi\end{array}$} & \multirow{2}{*}{$\begin{array}{c}\text { Гибриды, посе- } \\
\text { янные во вто- } \\
\text { рой декаде ап- } \\
\text { реля м-ца }\end{array}$} & \multirow{2}{*}{$\begin{array}{c}\text { Глубина } \\
\text { заделки } \\
\text { семян, } \\
\text { см }\end{array}$} & \multicolumn{2}{|c|}{ Початок, см } & \multirow{2}{*}{$\begin{array}{c}\text { Кол-во } \\
\text { рядов в } \\
\text { початке, } \\
\text { шт }\end{array}$} & \multicolumn{2}{|c|}{ Macca, кг } & \multirow{2}{*}{$\begin{array}{c}\text { Вес } \\
1000 \\
\text { зерен, } \\
\Gamma\end{array}$} \\
\hline & & & длина & ширина & & $\begin{array}{l}10 \text {-ти } \\
\text { по- } \\
\text { чат- } \\
\text { ков } \\
\end{array}$ & $\begin{array}{c}\text { зерна с } \\
\text { 10-ти по- } \\
\text { чатков }\end{array}$ & \\
\hline \multirow[t]{2}{*}{1} & \multirow[t]{2}{*}{ Терек } & 5 & 16,2 & 4,4 & 16,0 & 1,3 & 1,0 & 271 \\
\hline & & 10 & 16,3 & 4,2 & 16,2 & 1,4 & 1,1 & 284 \\
\hline \multirow[t]{2}{*}{2} & \multirow[t]{2}{*}{ Майский } & 5 & 16,0 & 4,3 & 15,4 & 1,5 & 1,2 & 270 \\
\hline & & 10 & 16,6 & 4,5 & 15,6 & 1,6 & 1,3 & 280 \\
\hline \multirow[t]{2}{*}{3} & \multirow{2}{*}{$\begin{array}{c}\text { Кабардинская } \\
3812\end{array}$} & 5 & 16,7 & 4,3 & 16,7 & 1,4 & 1,1 & 283 \\
\hline & & 10 & 16,8 & 4,3 & 16,8 & 1,6 & 1,2 & 286 \\
\hline
\end{tabular}

Как видно из приведенных данных структурный анализ урожая зерна подтверждает более высокую зерновую продуктивность изучаемых гибридов кукурузы при условии заделки их семян на глубину 10см. при этом наиболее приемлемой датой посева гибридов кукурузы является вторая декада апреля (табл. 4).

\section{Таблица 4 - Влияние сроков посева на урожай зерна гибридов кукурузы} (в ц/га st влажности)

\begin{tabular}{|l|c|c|c|c|c|c|c|c|c|}
\hline \multicolumn{1}{|c|}{$\begin{array}{c}\text { Сроки } \\
\text { посева }\end{array}$} & Терек & $\begin{array}{c}\text { Май- } \\
\text { ский } \\
260 \text { МВ }\end{array}$ & $\begin{array}{c}\text { Кабар } \\
\text { дин- } \\
\text { ская } \\
3812\end{array}$ & Терек & $\begin{array}{c}\text { Май- } \\
\text { ский } \\
260 \text { МВ }\end{array}$ & $\begin{array}{c}\text { Кабар } \\
\text { динская } \\
3812\end{array}$ & Терек & $\begin{array}{c}\text { Май- } \\
\text { ский } \\
260 \text { МВ }\end{array}$ & $\begin{array}{c}\text { Кабар } \\
\text { динская } \\
3812\end{array}$ \\
\hline $\begin{array}{l}\text { 1-ая де- } \\
\text { када ап- } \\
\text { реля } \\
\text { 6-9 IV }\end{array}$ & - & $+)$ & 30,0 & 33,0 & 30,0 & 38,0 & 16,5 & 15,0 & 34,0 \\
\hline $\begin{array}{l}\text { 2-ая де- } \\
\text { када ап- } \\
\text { реля } \\
\text { 12-18 IV }\end{array}$ & 74,0 & 70,0 & 78,0 & 50,0 & 47,0 & 70,0 & 62,0 & 58,5 & 74,0 \\
\hline $\begin{array}{l}3 \text {-ая де- } \\
\text { када ап- } \\
\text { реля } \\
\text { 23-29 IV }\end{array}$ & 70,5 & 68,0 & 75,0 & 42,0 & 40,0 & 65,0 & 56,3 & 54,0 & 70,0 \\
\hline НСР-0,5 & 2,1 & 3,0 & 2,0 & 2,4 & 2,8 & 3,0 & - & - & - \\
\hline
\end{tabular}

Примечание: +) При первом сроке посева в 2019г всходы семян гибридов Терек и Майский $260 \mathrm{MB}$ погибли из-за сильных весенних заморозков

Так, средняя урожайность за 2019-2020 гг. гибридов Терек $(62,0$ ц/га), Майский 260 MB (58,5 ц/га), и Кабардинская 3812 (74,0 ц/га) благоприятно отражаются на их продуктивность при посеве во вторую декаду апреля на глубину 10 см эти данные превосходят результаты, полученные при первом сроке 
посева на 45,5; 43,5 и 40,0 ц/га соответственно. При третьем сроке посева наблюдается также резкое снижение зернопродукции и она составило для Терека-56,3; Майского-260 MB - 54,0 и Кабардинской-3812 - 70,0 с общей потерей зерна от 4,0플 5,7 ц/га в среднем на фонах с посевами изучаемых гибридов кукурузы в условиях степной зоны Кабардино-Балкарии.

Заключение. Оптимальными сроками посева гибридов Терек, Майский260 МВ гибридной популяции Кабардинская-3812 в условиях изменившегося климата следует считать вторую декаду апреля месяца (12-18 IV).

1. Зерновая продуктивность гибридной популяции Кабардинская - 3812 была наибольшей $(34,0-74,0$ ц/га) при всех трех сроках посева по сравнению с данными, полученными на фоне размещения гибридов Терек и Майский - 260 MB (15,0-62,0 ц/га).

2. Семена гибридов кукурузы показали наиболее высокую густоту всходов на вариантах второго срока их посева (вторая декада апреля) при глубине заделки семян на $10 \mathrm{cm.}$

3. Зерновая продуктивность гибрида Терек (ФАО - 400) и гибридной популяции Кабардинская-0 3812 (ФАО - 600) выше, чем результаты, зафиксированные на фоне с посевами относительно раннеспелого (ФАО - 260) гибрида Майский -260 МВ.

\section{Библиографический список}

1. Тарчоков Х.Ш., Чочаев М.М., Матаева О.Х., Бжинаев Ф.Х. Эффективные приемы возделывания гибридов и родительских особей кукурузы в агротехнологиях нового поколения Кабардино-Балкарской республики // Известия Кабардино-Балкарского научного центра РАН. 2021. № 3. С. 82-92.

2. Привалов Ф.И., Лужинский Д.В., Надточаев Н.Ф. Развитие гибридов кукурузы разных групп спелости в зависимости от температурных условий // Кормопроизводство. 2018. № 10. C. 4-11.

3. Тарчоков Х.Ш., Чочаев М.М., Матаева О.Х., Шогенов А.Х., Кушхабиев А.3. Влияние способов посева на интенсивность эрозионных процессов и урожайность сельскохозяйственных культур на склоновых землях Кабардино-Балкарии // Известия Кабардино-Балкарского научного центра РАН. 2020. № 5. С. 5-19.

4. Мазалов В.И., Небытов В.Г. Урожайность гибридов кукурузы в Орловской области в зависимости от абиотических факторов и удобрений // Земледелие. 2021. № 5. С. 45-48.

5. Багринцева В.Н., Шмалько И.А., Никитин С.В., Варданян В.С. Оптимальная густота состояния растений гибридов кукурузы // Зерновое хозяйство России. 2011. № 4. С. 57-60.

6. Доспехов Б.А. Методика полевого опыта. М.: Агропромиздат, 1985. 351с.

7. Котюк А.В., Лукачева Н.Г. Динамика засоренности посевов кукурузы амброзией полыннолистной и гербициды для её уничтожения // Кукуруза и сорго. 2020. № 4. С. 30-35.

8. Список пестицидов и агрохимикатов, разрешенных к применению на территории Российской Федерации в 2020г. Приложение к журналу Защита и карантин растений. Москва 2020 № 4. 832c. В 2020г.

9. Кирюшин В.И. Задачи научно-инновационного обеспечения земледелия России // земледелие. 2018. № 3. С. 3-12.

10. Шарков И.Н., Сорокин О.Д., Колбин С.А. Прогнозированная оценка целесообразности применения средств интенсификации в агротехнологиях // Земледелие. 2019. № 3. С. 14-17. 11. Накаев С.-М.А., Оказова 3.П. Доминирующие сорные растения и их вредоносность в посевах кукурузы // Успехи современной науки. 2017. Т.2. № 12. С. 199-201. 


\title{
СЕВООБОРОТ КУЛЬТУР КАК ЭЛЕМЕНТ \\ АДАПТИВНОГО ЗЕМЛЕДЕЛИЯ
}

\author{
Хлюпина С.В.
}

ФГБНУ «Курский федеральный аграрный научный центр, г. Курск

E-mail: sveta46agro@yandex.ru

\begin{abstract}
Резюме. Определено место севооборота культур в структуре углубленной адаптации элементов технологий их воздельвания. Обосновано его проектирование в неразрывной связи с системой защиты сельскохозяйственных культур от сорняков. Предложены пути снижения рисков последействия применяемых средств защиты растений.

Ключевые слова: севооборот, адаптивное земледелие, последействие средств защиты растений.
\end{abstract}

Summary. Place of crop rotation of crops in structure of in-depth adaptation of elements of technologies of their cultivation is determined. Its design is justified in inextricable connection with the system of protection of crops from weeds. There are proposed ways to reduce risks of effects of applied means of plant protection.

Key words: crop rotation, adaptive farming, effects of plant protection.

Эффективность производства зерна зависит от комплекса природно-климатических, научно-технических, технологических и организационно-экономических факторов с применяемыми системами земледелия [1].

Образовавшийся в настоящее время пласт проблем экономического и экологического характера при выращивании продовольственного зерна для обеспечения его конкурентоспособности на мировом рынке и защиты окружающей среды подтверждает необходимость перехода на новый уровень минимизации использования ресурсов и повышения экологической безопасности. При этом положительно зарекомендовали себя технологии производства зерновых культур адаптированные к группам земель в пределах агроэкологической провинции. Но основной объект земледелия - почвенный покров разнообразен пестротой по физическим свойствам, что не учитывается при разработке агротехнологий и понижает уровень их адаптивности.

На данном этапе развития цифровых технологий обозначились пути дальнейшей более углубленной адаптации земледельческой отрасли. Появилась возможность оперативно принимать решения по управлению продукционным процессом сельскохозяйственных культур с учётом обширной информации о вариабельности среды обитания растений внутри агроэкологической провинции. Поэтому методологической основой совершенствования систем земледелия является углубленная адаптация агротехнологий к условиям произрастания, сужающаяся от объёмной агроэкологической провинции до конкретного поля внутри неё.

Само определение адаптивности технологий интегральное, так как включает в себя составляющие элементы, одним из которых является правильно спроектированный севооборот, когда природные факторы способствуют максимальной реализации продуктивности выращиваемых культур. Суть севооборота состоит в плодосмене, являющемся мощным средством 
позитивного воздействия на продуктивность культур. К примеру, всего лишь использование в качестве предшественника озимой пшеницы чёрного пара вместо кукурузы на силос позволяет повысить урожайность культуры на $33 \%$ [2].

В настоящее время ситуация, возникшая с засорённостью посевов, не может быть в полном объеме разрешена лишь севооборотом и другими агротехническими приёмами и в дополнение к ним используют гербициды, облегчающие борьбу с сорняками. Эффективность их использования повышается с ростом биологических различий между защищаемой культурой и сорняками. Гербициды с продолжительным и значимым последействием вступают в противоречие с плодосменом, так как последующая культура по биологическим свойствам, как правило, подпадает под их действие. С ростом продолжительности последействия противоречия усугубляются, следствием чего является значительное угнетение культур, вплоть до полного уничтожения.

В настоящее время, согласно Списку разрешённых пестицидов и агрохимикатов, на зерновых культурах применяется от 27 до 54\% гербицидов, оказывающих негативное последействие на последующие культуры в севообороте (рисунок).

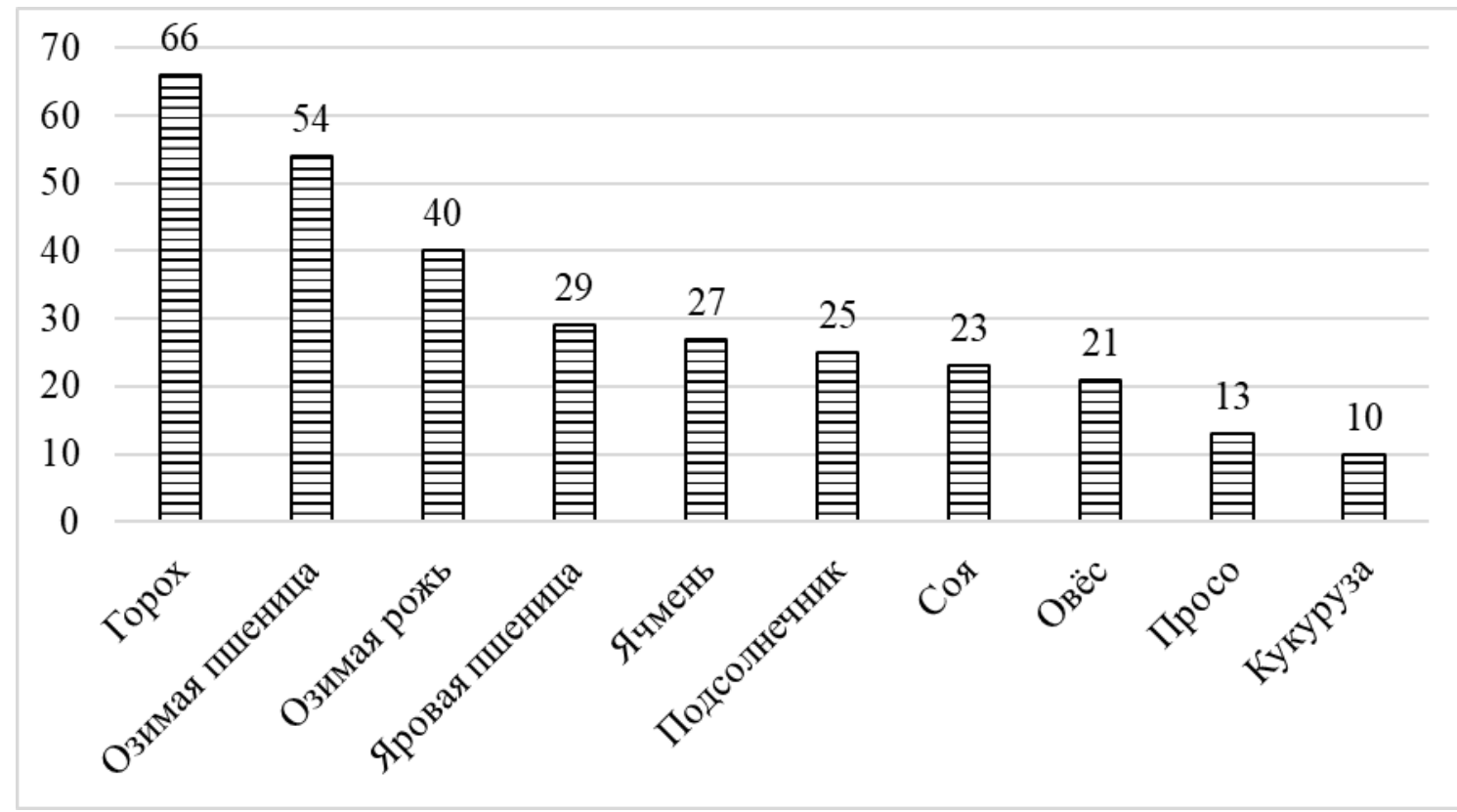

Общее количество гербицидов, разрешенных к применению в РФ - 1809 Среднее по культурам количество гербицидов с последействием - $28 \%$

Рисунок - Количество гербицидов, оказывающих последействие на следующую культуру в севообороте, \%

Вследствие чего, классическое определение севооборота, как научно обоснованное чередование сельскохозяйственных культур (и пара) по полям и во времени, изжило себя. В связи с этим, был предложен новый методологический подход на базе откорректированного определения севооборота как научно обоснованного чередования сельскохозяйственных культур (и пара) по полям и во времени, обеспеченных химическими средствами защиты растений от сорняков [3]. 
Исходя из данного определения, углубленную адаптацию севооборотов следует проводить в неразрывной связи с системой защиты сельскохозяйственных культур от сорняков. Прежде всего, необходимо стремиться использовать гербициды, обладающие минимальным последействием на последующую культуру в севообороте. Помимо этого, для максимального сохранения позитивных свойств севооборота необходимы меры, способствующие ускорению детоксикации гербицидов в почве.

На скорость распада препаратов влияет много факторов: агротехнические мероприятия, тип и структура почвы, её влажность и кислотность, температурный режим и др. Например, сокращают срок последействия препаратов повышенные влажность и кислотность почвы. Дефицит влаги, щелочная реакция почвенного раствора и низкие температуры во время вегетации растений наоборот ведут к увеличению продолжительности последействия гербицидов. При этом пасность их последействия возрастает при использовании в течение нескольких лет препаратов с одним действующим веществом, которое медленно разлагается [4].

С целью регулирования и понижения возникающих рисков последействия гербицидов следует чётко соблюдать регламент и технологию их применения, в рамках которых использовать минимальные их дозировки, а также баковые смеси с другими действующими веществами для получения дополнительных преимуществ. С применением смесей удаётся не только уменьшить дозы действующих веществ, но и замедлить приспособляемость и возникновение устойчивых форм сорной флоры.

Требуется усилить регламент правильной эксплуатации опрыскивающей техники и своевременно производить замену узлов и деталей, выработавших ресурс; следует исключать перекрытия между рабочей шириной захвата техники. Повышенные дозы препаратов на перекрываемых участках, а также неравномерное нанесение рабочего раствора изношенными форсунками увеличивает риск последействия гербицидов.

Таким образом, проектирование севооборотов сельскохозяйственных культур должно осуществляться в неразрывной связи с системой их защиты от сорняков, что позволит нейтрализовать возможные противоречия между плодосменом и применяемыми гербицидами, имеюшими негативное продолжительное последействие.

\section{Библиографический список}

1. Алтухов А.И. Факторы эффективного функционирования зернового хозяйства и рынка зерна в России // Экономика сельского хозяйства России. - 2013. - № 6. - С. 16-29.

2. Лошаков В.Г. Севооборот и плодородие почвы. - М.: Изд-во ВНИИА, 2012. - 512 с.

3. Гуреев И.И. Углубленная адаптация технологий производства зерновых культур в Центрально-Черноземном регионе. - Курск: ФГБНУ «Курский федеральный аграрный научный центр», 2021. - 238 с.

4. Гуреев И.И. Актуальное определение севооборотов // Сахарная свёкла. - 2017. - № 1. - C. 22-24. 
УДК 631.84: 632.95: 631.17: 631.95: 631.8.022.3

\title{
ОПТИМИЗАЦИЯ СОЧЕТАНИЯ СИСТЕМ ЗАЩИТЫ РАСТЕНИЙ И ДОЗ АЗОТНОГО УДОБРЕНИЯ В ТЕХНОЛОГИЯХ ВОЗДЕЛЫВАНИЯ ОЗИМОЙ ПШЕНИЦЫ В 3-Й РОТАЦИИ СЕВООБОРОТА СИ-112
}

\author{
Цимбалист Н.И., Алиев А.М. ${ }^{1}$, Ваулина Г.И.
}

${ }^{1}$ ФББНУ Всероссийский научно-исследовательский институт агрохимии имени Д.Н. Прянишникова, г. Москва

E-mail: ehramova@bk.ru,ntsimb@list.ru

Резюме. Методом расщепленной делянки доказано влияние главных факторов (систем защзиты растений, доз азотных удобрений и окружающей среды) и их взаимодействие на продуктивность, себестоимость и энергозатрать на производство зерна при воздельввнии озимой пшеницы в севообороте СИ-11. Проведена оптимизаџия сочетания СЗР и доз азотных удобрений в технологиях воздельввания озимой пшениџы по ряду показателей.

Ключевые слова: озимая пшеница, севооборот, минеральные удобрения, азотные удобрения, средства защчтыы растений, продуктивность культур, технология воздельввания, оптимизация.

Summary. Using the split plot method, the influence of the main factors (plant protection systems, doses of nitrogen fertilizers and the environment) and their interaction on productivity, cost and energy consumption for grain production during the cultivation of winter wheat in the SI-11 crop rotation was proved. The optimization of the combination of plant protection products and doses of nitrogen fertilizers in the technologies of winter wheat cultivation was carried out for a number of indicators.

Key words: winter wheat, crop rotation, nitrogen fertilizers, plant protection products, crop productivity, cultivation technology, optimization.

В интенсивных технологиях возделывания сельскохозяйственных культур в стационаре СИ-11 на основе междисциплинарного подхода проводятся комплексные исследования продуктивности культур севооборота с учетом охраны окружающей среды: плодородие почвы: биологическая активность почвы, содержание питательных веществ в почве и растениях; фитосанитарное состояние агроценоза, содержание остаточных количеств пестицидов в почве, показатели экономической и энергетической эффективности средств химизации в технологиях возделывания озимой пшеницы и ярового ячменя, комплексная оценка показателей качества зерна озимой пшеницы и ячменя и др. [1-2].

Цель данной работы - определение оптимального сочетания доз азотного удобрения ( $\mathrm{N}_{0}$ и 3 дозы с шагом 45 кг/га на фоне фосфорно-калийного $\left.\mathrm{P}_{60} \mathrm{~K}_{120}\right)$ и систем защиты растений при их применении на основные показатели технологий возделывания озимой пшеницы в 3-й ротации полевого севооборота.

Методика закладки и проведения стационарного опыта представлена в Сборнике докладов Международной научно-практической конференции «Проблемы и перспективы научно-инновационного обеспечения агропромышленного комплекса регионов» [1]. Почва опытного участка дерново-подзолистая

2 Работа выполнена по государственному заданию № 0572-2021 001 
тяжелосуглинистая, средне-окультуренная. Агротехника возделывания сельскохозяйственных культур - общепринятая для зоны [2].

Показатели экономической и энергетической эффективности при сочетании систем защиты растений и доз азотных удобрений в технологиях возделывания озимой пшеницы определяли расчетным путем с помощью алгоритма, осуществленного ранее [3-4]. Статистическую обработку данных

двухфакторного опыта вначале проводили методом расщепленной делянки [5], затем усредненных данных за 3 года простым дисперсионным анализом.

Результаты и обсуждение. При обработке данных по схеме (4x4) выявлено влияние на продуктивность и Кээ при возделывании озимой пшеницы в 3-й ротации севооборота на фоне РК: обоих факторов и их взаимодействия во все 3 года за исключением Кээ в 2007 г. (табл. 1-2).

Таблица 1 - Продуктивность озимой пшеницы в зависимости от систем защиты растений и доз азотного удобрения в 2007-2009 гг., т 3.е./га.

\begin{tabular}{l}
\hline $\begin{array}{l}\text { Система защиты } \\
\text { растений - фактор В }\end{array}$ \\
\cline { 2 - 7 }
\end{tabular}


Таблица 2 - Кээ при возделывании озимой пшеницы в зависимости от сочетания систем защиты растений и доз азотного удобрения, единиц

\begin{tabular}{|c|c|c|c|c|c|c|c|c|}
\hline \multirow{2}{*}{\multicolumn{2}{|c|}{$\begin{array}{l}\text { Система защиты } \\
\text { растений - фактор В }\end{array}$}} & \multicolumn{4}{|c|}{ Азотное удобрение - фактор N } & \multirow{2}{*}{\multicolumn{2}{|c|}{$\begin{array}{c}\text { Средние по фак- } \\
\text { тору В }\end{array}$}} & \multirow{2}{*}{$\begin{array}{c}\text { Груп } \\
\text { па }\end{array}$} \\
\hline & & $\begin{array}{c}\mathrm{N}_{0} \\
\left(\mathrm{n}_{0}\right)\end{array}$ & $\begin{array}{l}\mathrm{N}_{45} \\
\left(\mathrm{n}_{1}\right)\end{array}$ & $\begin{array}{l}\mathrm{N}_{90} \\
\left(\mathrm{n}_{2}\right)\end{array}$ & $\mathrm{N}_{135}\left(\mathrm{n}_{3}\right)$ & & & \\
\hline \multicolumn{9}{|c|}{ Кээ, единиц } \\
\hline $\mathrm{B}_{0}\left(\mathrm{~b}_{0}\right)$ & \multirow{4}{*}{ 官 } & 3,82 & 4,08 & 3,53 & 3,16 & 3,65 & \multirow{4}{*}{ 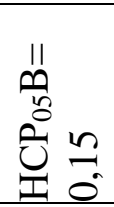 } & $\mathrm{I}$ \\
\hline $\mathrm{B}_{1}\left(\mathrm{~b}_{1}\right)$ & & 4,56 & 4,45 & 4,06 & 3,62 & 4,17 & & II \\
\hline $\mathrm{B}_{2}\left(\mathrm{~b}_{2}\right)$ & & 4,92 & 4,60 & 4,39 & 3,95 & 4,46 & & III \\
\hline $\mathrm{B}_{3}\left(\mathrm{~b}_{3}\right)$ & & 4,68 & 4,40 & 4,15 & 3,65 & 4,22 & & II \\
\hline \multicolumn{2}{|l|}{ Ср.по фактору N } & 4,49 & 4,38 & 4,03 & 3,59 & \multicolumn{2}{|c|}{$<-\mathrm{HCP} 05 \mathrm{~N}=0,11$} & \\
\hline Группа & & \multicolumn{2}{|c|}{ III } & II & $\mathrm{I}$ & & & \\
\hline \multicolumn{9}{|c|}{$\mathrm{HCP}_{05} \mathrm{I}=0,37 ; \mathrm{HCP}_{05} \mathrm{II}=0,24$, взаимодействие $\mathrm{BN}-$ Fфакт. $=2,25<$ Fтабл. $=2,30$} \\
\hline $\mathrm{B}_{0}\left(\mathrm{~b}_{0}\right)$ & \multirow{4}{*}{$\stackrel{\dot{c}}{\infty}$} & 4,43 & 4,38 & 3,29 & 2,81 & 3,73 & \multirow{4}{*}{ 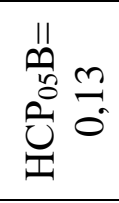 } & $\mathrm{I}$ \\
\hline $\mathrm{B}_{1}\left(\mathrm{~b}_{1}\right)$ & & 5,43 & 5,08 & 4,33 & 3,52 & 4,59 & & II \\
\hline $\mathrm{B}_{2}\left(\mathrm{~b}_{2}\right)$ & & 5,18 & 5,00 & 4,80 & 3,96 & 4,74 & & III \\
\hline $\mathrm{B}_{3}\left(\mathrm{~b}_{3}\right)$ & & 4,89 & 4,78 & 4,45 & 4,05 & 4,54 & & II \\
\hline \multicolumn{2}{|l|}{ Ср.по фактору N } & 4,98 & 4,81 & 4,21 & 3,58 & \multicolumn{2}{|c|}{$<--\mathrm{HCP} 05 \mathrm{~N}=0,18$} & \\
\hline Группа & & \multicolumn{2}{|c|}{ III } & II & $\mathrm{I}$ & & & \\
\hline \multicolumn{9}{|c|}{$\mathrm{HCP}_{05} \mathrm{I}=0,32 ; \mathrm{HCP}_{05} \mathrm{II}=0,33$, взаимодействие $\mathrm{BN}-$ Fфакт. $=4,37>$ Fтабл. $=2,30$} \\
\hline $\mathrm{B}_{0}\left(\mathrm{~b}_{0}\right)$ & \multirow{4}{*}{ ह่ } & 3,48 & 3,34 & 3,05 & 2,86 & 3,18 & \multirow{4}{*}{ 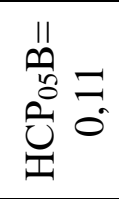 } & \multirow[t]{2}{*}{ I } \\
\hline $\mathrm{B}_{1}\left(\mathrm{~b}_{1}\right)$ & & 3,69 & 3,60 & 3,16 & 3,23 & 3,42 & & \\
\hline $\mathrm{B}_{2}\left(\mathrm{~b}_{2}\right)$ & & 4,05 & 3,66 & 3,90 & 3,61 & 3,81 & & \multirow[t]{2}{*}{ II } \\
\hline $\mathrm{B}_{3}\left(\mathrm{~b}_{3}\right)$ & & 3,91 & 3,67 & 3,93 & 3,45 & 3,74 & & \\
\hline \multicolumn{2}{|l|}{ Ср.по фактору N } & 3,78 & 3,57 & 3,51 & 3,29 & \multirow{2}{*}{\multicolumn{2}{|c|}{$<--\mathrm{HCP} 05 \mathrm{~N}=0,05$}} & \\
\hline Группа & & I & II & IV & III & & & \\
\hline
\end{tabular}

$\mathrm{HCP}_{05} \mathrm{I}=0,26 ; \mathrm{HCP}_{05} \mathrm{II}=0,14$, взаимодействие $\mathrm{BN}-$ Fфакт. $=18,17>$ Fтабл. $=2,30$

По характеру действия главный эффект системы защиты растений по влиянию на продуктивность озимой пшеницы может быть подразделен на 4, а доз азотных удобрений на 3-4 группы, на Кээ СЗР на 2-3 и доз азотных удобрений - на 3-4 (табл. 1-2). С повышением уровня интенсивности использования препаратов в 2007-2009 гг. их действие на продуктивность усиливается и на интегрированной системе превышает стандартную, в которой по схеме опыта на одну обработку фунгицидами меньше, в то время как их действие на Кээ на интегрированной системе равно стандартной.

При повышении продуктивности озимой пшеницы при сочетании $\mathrm{N}_{45}$ со всеми тремя системами защиты растений суммарный эффект систем защиты растений и $\mathrm{N}_{45}$ равен эффекту взаимодействия при $\mathrm{b}_{0} \mathrm{n}_{0}$ и $\mathrm{b}_{1} \mathrm{n}_{1}(2,86 \ldots 2,80), \mathrm{b}_{0} \mathrm{n}_{0}$ и $\mathrm{b}_{2} \mathrm{n}_{1}(3,80 \ldots 3,52)$ и $\mathrm{b}_{0} \mathrm{n}_{0}$ и $\mathrm{b}_{3} \mathrm{n}_{1}(3,22 \ldots .2,99$ - все значения в пределах ошибки) - аддитивность (табл. 3).

Результаты исследований свидетельствуют, что по влиянию на изучаемые показатели (продуктивность озимой пшеницы, Кээ и др.) случаи взаимодействия: синергизм, аддитивность и антогонизм не всегда совпадают. Мы полагаем, что в данном случае с агрохимической, экономической и энергетической точек зрения более важным является определение максимума влияния на тот или иной показатель. Обнаруженное максимальное (минимальное) значение 
будет оптимальным для ряда показателей в технологиях возделывания озимой пшеницы (табл. 3-5).

Исходя из анализа наших исследований, добавляя в качестве 3-го фактора окружающую среду (год исследований), мы пришли к выводу, что для интерпретации данных с большой долей вероятности можно использовать средние по сочетанию СЗР и азотных удобрений (взаимодействие $\mathrm{B}$ x N), так как $\mathrm{F}$ факт. сильно превышает Fтеор. Полученные нами результаты позволяют выбрать технологию с одним из 16 различных сочетаний СЗР и доз азотных удобрений по влиянию на ряд исследуемых показателей, исходя из наличия ресурсов хозяйства независимо от формы собственности (табл. 3-5).

Таблица 3 - Средние по сочетанию СЗP и азотных удобрений BN (продуктивность, т 3.е./га)

\begin{tabular}{|c|c|c|c|c|}
\hline \multirow{2}{*}{ Система защиты растений } & \multicolumn{4}{|c|}{ Доза N удобрений } \\
\hline & N0 (n0) & N45 (n1) & N90 (n2) & $\mathrm{N} 135$ (n3) \\
\hline B0 (b0) & 4,41 & 5,97 & 5,87 & 6,10 \\
\hline B1 (b1) & 5,72 & 7,21 & 7,45 & 7,63 \\
\hline B2 (b2) & 6,66 & 7,93 & 9,41 & 9,23 \\
\hline B3 (b3) & 6,07 & 7,40 & 8,67 & 8,77 \\
\hline
\end{tabular}

Таблица 4 - Средние по сочетанию СЗР и азотных удобрений В х N (Кээ, единиц)

\begin{tabular}{|l|c|c|c|c|}
\hline \multirow{2}{*}{ Система защиты растений } & \multicolumn{4}{|c|}{ Доза N удобрений } \\
\cline { 2 - 5 } & $\mathrm{N} 0(\mathrm{n} 0)$ & $\mathrm{N} 45(\mathrm{n} 1)$ & $\mathrm{N} 90(\mathrm{n} 2)$ & $\mathrm{N} 135(\mathrm{n} 3)$ \\
\hline B0 (b0) & 3,91 & 4,05 & 3,62 & 3,29 \\
\hline B1 (b1) & 4,44 & 4,38 & 4,02 & 3,60 \\
\hline B2 (b2) & 4,38 & 4,25 & 4,36 & 3,94 \\
\hline B3 (b3) & 4,14 & 4,14 & 4,07 & 3,72 \\
\hline
\end{tabular}

Таблица 5 - Влияние сочетания СЗР и азотных удобрений В х $\mathbf{N}$ на показатели в технологиях возделывания озимой пшеницы

\begin{tabular}{|l|c|c|c|c|c|c|}
\hline \multirow{2}{*}{ Показатель } & \multicolumn{7}{|c|}{ Сочетание С3Р и доз N удобрений } & \multirow{2}{*}{ НСР 05} \\
\cline { 2 - 7 } & $\mathrm{b} 1 \mathrm{n} 1$ & $\mathrm{~b} 2 \mathrm{n} 2$ & $\mathrm{~b} 2 \mathrm{n} 3$ & $\mathrm{~b} 3 \mathrm{n} 2$ & $\mathrm{~b} 3 \mathrm{n} 3$ & \\
\hline Окупаемость 1 кг N, кг & 25,0 & 24,4 & 15,1 & 23,0 & 15,9 & 7,1 \\
\hline Кээ, единиц & 4,38 & 4,36 & 3,94 & 4,07 & 3,72 & 0,21 \\
\hline Энергозатраты, МДж/т & 3835 & 3797 & 4295 & 3954 & 4448 & 321 \\
\hline Урожайность, т/га зерна & 5,66 & 7,63 & 7,47 & 7,01 & 7,09 & 0,49 \\
\hline Продуктивность, т 3.е/га & 7,21 & 9,41 & 9,23 & 8,67 & 8,77 & 0,60 \\
\hline Себестоимость* & 5370 & 4996 & 5324 & 5170 & 5426 & 301 \\
\hline 1 т зерна, руб. & 5044 & 4714 & 5040 & 4879 & 5136 & 294 \\
\hline Чистый доход*, тыс.руб./га & 26,8 & 38,4 & 35,0 & 33,9 & 32,6 & 4,0 \\
\cline { 2 - 6 } & 14,5 & 21,5 & 18,4 & 18,4 & 16,9 & 2,9 \\
\hline
\end{tabular}

Примечание. Себестоимость 1 т зерна и условный чистый доход: 1 строка при стоимости зерна 10000 руб./т и семян 12000, 2 строка при стоимости зерна 7500 руб./т и семян 9000. Производственные затраты, включая накладные расходы $10 \%$ и страховые платежи $6,5 \%$. Энергозатраты (МДж/т) и себестоимость 1 т зерна с учетом дополнительной продукции.

Так, при рассматриваемых нами условиях в севообороте только внесением СЗР урожайность зерна $\left(\mathrm{b}_{2} \mathrm{n}_{0}-5,43, \mathrm{~b}_{3} \mathrm{n}_{0}-4,94\right.$ и $\mathrm{b}_{1} \mathrm{n}_{0}-4,54 \mathrm{t} /$ га) обеспечивается 
минимальным уровнем энергозатрат 3532, 3696 и 3708 МДж/т соответственно. В то же время данный уровень энергозатрат, применяя средства химизации, достаточен для более высоких урожаев зерна (табл. 5). В варианте $\mathrm{b}_{0} \mathrm{n}_{0}$ затрачивается 4265 МДж/т при урожае зерна 3,47 т/га.

Сочетание $\left(\mathrm{b}_{2} \mathrm{n}_{2}\right)$ по сравнению c $\left(\mathrm{b}_{2} \mathrm{n}_{3}\right)$ обеспечивает улучшение таких показателей как окупаемость 1 кг $\mathrm{N}$ зерном, Кээ, энергозатраты, себестоимость, а чистый доход при более низкой стоимости зерна.

Заключение. Оптимальным сочетанием систем защиты растений и доз азотных удобрений по влиянию на ряд показателей в технологиях возделывания озимой пшеницы является сочетание $\mathrm{b}_{2} \mathrm{n}_{2}$ - сочетание $\mathrm{N}_{90} \mathrm{c}$ интегрированной системой защиты растений (табл. 5).

\title{
Библиографический список
}

1. Алиев А.М. Сочетание систем защиты растений и доз азотного удобрения в технологиях возделывания озимой пшеницы в 3-й ротации севооборота си-11. / А.М. Алиев, Н.И. Цимбалист, Г.И. Ваулина, С.Н. Цимбалист // Проблемы и перспективы научно-инновационного обеспечения агропромышленного комплекса регионов. Сборник докладов Международной научно-практической конференции, Курск, 28-30 июня 2021 г. - Курск: ФГБНУ «Курский федеральный аграрный научный центр», 2021. - С. 30-35.

2. Ваулина Г.И. Эффективность минеральных удобрений и других средств химизации при возделывании разных сортов зерновых культур на дерново-подзолистой тяжелосуглинистой почве в условиях Центрального района нечерноземной зоны. Дис. ...доктора с.-х. наук. - М., 2007. $-420 \mathrm{c}$.

3. Алиев А.М., Ваулин А.В., Ваулина Г.И., Ефремов Е.Н., Цимбалист Н.И., Шмонин В.А. Экономическая эффективность длительного применения удобрений и химических средств защиты растений при возделывании озимой пшеницы (Triticum aestivum L.) // Проблемы агрохимии и экологии. - 2016. - № 3. - С. 30-37.

4. Ладонин В.Ф., Алиев А.М., Бузько В.А., Шмонин В.А., Цимбалист С.Н. Оценка энергетической эффективности технологий возделывания и уборки озимой пшеницы в шестипольном севообороте многолетнего стационара. Агрохимия, N 7, 2007, 49-63.

5. Васильева Д.В., Васильев И.П., Усманов Р.Р. Методические указания по статистической обработке экспериментальных данных. МСХА им. К.А. Тимирязева. Государственный агропромышленный комитет СССР. М., 1987. - 92 с.

УДК 631.4

\section{НАКОПЛЕНИЕ СОЛЕЙ ПОД ЛЕСНЫМИ ПОЛОСАМИ ЦЕНТРАЛЬНОГО ЧЕРНОЗЕМЬЯ \\ Чевердин Ю.И.}

\author{
Воронежский ФАНЦ им.В.В. Докучаева, Каменная Степь
}

E-mail: cheverdin62@mail.ru

\begin{abstract}
Резюме. Проведены исследования состава солей водной вытяжки под старовозрастной дубовой лесной полосой. Отмечается существенный рост суммы солей в нижних горизонтах почвы (>120-150 см). Среди катионов лидирующее положение занимает натрий, среди анионов - сульфатьл.

Summary. The composition of water extract salts under the old-growth oak forest strip has been studied. There is a significant increase in the amount of salts in the lower soil horizons (>120-150 $\mathrm{cm}$ ). Among the cations, the leading position is occupied by sodium, among the anions - sulfates
\end{abstract}


Посадка лесных полос в степных условиях России послужила серъезным фактором преобразование ландшафтов и изменения свойств почвенного покрова. Многочисленными исследованиями показана высокая мелиоративная роль искусственных лесных насаждений, установлена трансформация физических, химических, физико-химических показателей плодородия черноземных почв (Сухарев И.П. 1966; Вавин В.С. и др., 2007; Чевердин Ю.И., 2013; Чендев Ю.Г., и др., 2020). Лесные полосы, оказывая серьезное влияние на изменения водного баланса территории, влияют на миграцию солей по почвенному профилю.

В связи с этим цель наших исследований - изучение современного состава солей водной вытяжки из почв под старовозрастной лесной полосой.

Методика. Исследования проведены в Воронежском ФАНЦ в 20202021 гг. (Каменная Степь). Объект исследований - дубовая лесная полоса №40 высажена в 1903 г. Состав солей на основе водной вытяжки почв 1:5 (Аринушкина Е.В., 1970). Почвенные образцы отобраны до глубины 300 см.

Результаты и обсуждения. Рассматривая характер современного солевого режима под лесной полосой необходимо отметить существенное увеличение их концентрации в почвенном профиле. Наиболее заметное изменение отмечается в почвенных горизонтах ниже 100-120 см. В верхнем метровом слое концентрация солей отмечается в пределах, не превышающих $0,065 \%$ (см. рис.). Эти показатели близки к значениям фоновых черноземных почв, примыкающих к лесной полосе - 0,043-0,055\%.

Общее содержание водорастворимых солей в почвенной толще увеличивается с глубины 120 см и ниже. Достигает довольно высоких показателей на уровне $0,25-0,27 \%$ в горизонте $200-300 \mathrm{~cm}$. Засоленность на пашне при этом многократно ниже. Она не превышает значений 0,050-0,068\%. Для пахотного участка характерно равномерное распределение солей по всему профилю без явных показателей максимума или минимума.

В черноземах лесной полосы отмечен совсем иной характер формирования солевого профиля. Лесные культуры, обладая высокой транспирационной способностью, способствуют подтягиванию грунтовых вод и концентрации солей на глубине от 150 до 300 см.

Рассматривая качественный состав солей необходимо отметить существенной увеличение доли $\mathrm{Na}^{+}$отчетливо заметное с глубины 140 см. Максимальные значения характерны для слоя почвы ниже 180 см. При этом содержание кальция по почвенному профилю постепенно снижается. Что может свидетельствовать о формирование глубокозасоленных почвенных горизонтов под лесной полосой.

В составе анионов лидирующее место занимают сульфаты $\mathrm{SO}_{4}{ }^{2-}$. Отмечается незначительное увеличение хлоридов и более заметное гидрокарбонатов. 


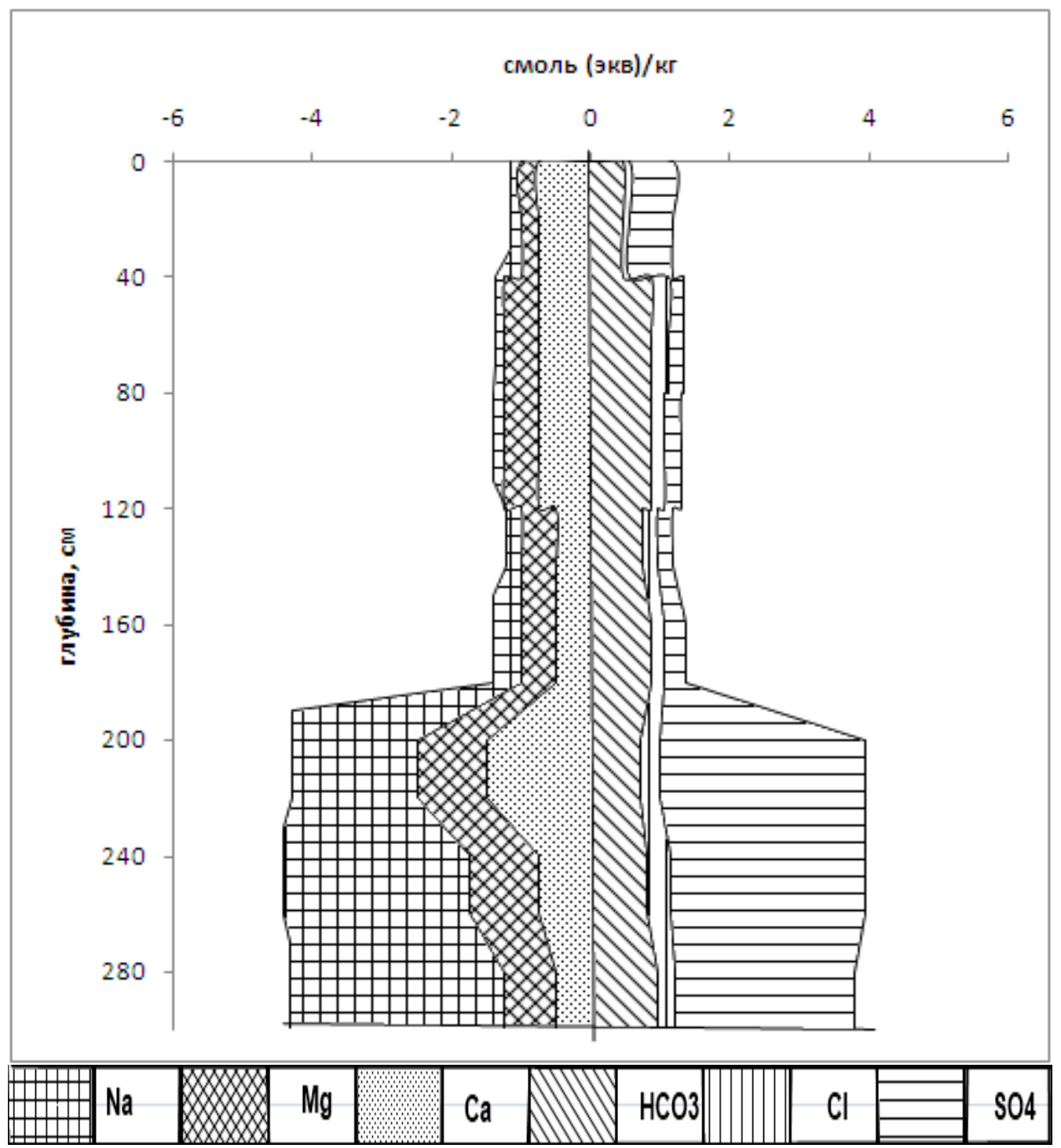

Рисунок - Солевой профиль чернозема под старовозрастной лесной полосой № 40

Выводы. Современное солевое состояние черноземов под лесными полосами определяется целым рядом причин. На первое место необходимо выделить существенную транспирацию влаги древесными культурами.

В состав водной вытяжки в почвенных горизонтах ниже 120-150 см отмечен существенный рост концентрации натрия и сульфатов при одновременном снижении доли кальция. Активизация этих процессов может привести к формированию глубокозасоленных почвенных горизонтов.

\section{Библиографический список}

1. Аринушкина Е.В. Руководство по химическому анализу почв/ Е.В. Аринушкина. - М.: Изд-во МГУ, 1970. -488 с.

2. Вавин В.С., Рымарь В.Т., Ахтямов А.Г., Свиридов Л.Т. Создание долговечных защитных насаждений в условиях юго-востока ЦЧЗ. - Воронеж, 2007. -240 с.

3. Сухарев И.П. Гидрологическая и противоэрозионная роль лесных полос. - Центрально-Черноземной книжное издательство. - Воронеж, 1966. -119 с.

4. Чевердин Ю.И. Изменения свойств почв юго-востока Центрального Черноземья под влиянием антропогенного воздействия. - Монография: Воронеж «Истоки», 2013. - 336 с. 
5. Чендев Ю.Г., Геннадиев А.Н., Лукин С.В., Соэр Т.Д., Заздравных Е.А., Белеванцев В.Г., Смирнова М.А. Изменение лесостепных черноземов под влиянием лесополос на юге Среднерусской возвышенности // Почвоведение, 2020. - № 8. - C. 934-947. DOI: $10.31857 / \mathrm{S} 0032180 \mathrm{X} 20080031$.

УДК 631.81:633.12

\section{ВЛИЯНИЕ БИОПРЕПАРАТОВ НА БИОМЕТРИЧЕСКИЕ ПОКАЗАТЕЛИ КУЛЬТУРЫ ГРЕЧИХА \\ Чуян Н.А.}

ФГБНУ «Курский федеральный аграрный научный центр», г. Курск

E-mail: Chuyan.6546@yandex.ru

Резюме. Выявлено положительное действие всех факторов (азотных удобрений и микробиологических препаратов - Грибофита и Имуназота) опыта на рост и развитие культуры гречихи сорта «Деметра», независимо от фаз развития растения (бутонизации и ияветения). Действие биопрепаратов в фазу бутонизаџии гречихи способствовало более интенсивному процессу увеличения роста наземной биомассы культуры.

Summary. A positive effect of all the factors of the experiment, i.e. nitrogen fertilizers and microbiological preparations Gribofit and Imunazot, on the growth and development of Demeter variety buckwheat, regardless of plant development phases (budding and blossoming) is found. The impact of biopreparations in the budding phase contributed to more intensive process of increased growth of the crop above-ground biomass.

В немногочисленных научных работах приведены отдельные результаты применения биопрепаратов при выращивании гречихи. Установлено, что инокуляция семян гречихи биопрепаратами способствовала оптимальному росту и развитию растений [1]. Под действием биопрепаратов формируется более мощная корневая система, усиливается рост надземной биомассы и облиственность растений; биопрепараты стимулируют приток пластических веществ к репродуктивным органам и под их действием реализуется высокий потенциал урожайности.

Микробиологические препараты являются довольно мощным инструментом, влияющим на процессы изменения структуры микробного ценоза и обеспеченность растений биогенными элементами. В свою очередь состояние почвенной среды обусловливает, во многом, ростовые процессы, происходящие в наземной вегетативной части растений [2].

При раздельном использовании микробных препаратов и минеральных туков их влияние на ростовые процессы было равноценным. В тоже время, совместное их применение в 1,5 - 2,0 раза увеличивало показатели роста и развития растений в посевах гречихи [3].

Но большую актуальность и практическую ценность в настоящее время приобретают исследования комплексного использования различных видов минеральных удобрений, соломы и микробиологических препаратов [4], с целью их влияние на развитие и формирование продуктивности гречихи.

Цель работы - изучить влияние биопрепаратов (Грибофита и Имуназота) с внесением послеуборочных остатков в качестве удобрения и комплексного 
их внесения с азотными удобрениями на биометрические показатели гречихи в фазы бутонизации и цветения.

Исследования проводили в 2018-2020 гг. на опытном поле ФГБНУ «Курский ФАНЦ», расположенном в с. Панино Медвенского района Курской области. Оценку развития и роста гречихи проводили в 2021 году на всех вариантах научно-производственного опыта в посевах гречихи сорта «Деметра», размещенной в зернопропашном севообороте «озимая пшеница - подсолнечник ячмень - соя - гречиха».

На всех вариантах опыта после уборки предшествующих культур всю побочную продукцию использовали в качестве удобрения путем поверхностной заделки их в почву [5].

Схема опыта включала следующие варианты:

1. измельчен солома растительные остатки (контроль);

2. измельченная солома + азотные удобрения из расчета 10 кг д.в. $\mathrm{N}$ на т соломы зерновых культур;

3. измельченная солома + биопрепараты (обработка семян биопрепаратами Грибофит (2 л/т) и Имуназот (3 л/т) перед посевом + обработка почвы перед посевом биопрепаратами Грибофит (5 л/га) и Имуназот (3 л/га) + обработка посевов 2 раза в течение вегетации биопрепаратами Грибофит (5 л/га) и Имуназот (3 л/га) + обработка растительных остатков перед заделкой Грибофит (5 л/га) и Имуназот (3 л/га);

4. измельченная солома + биопрепараты (обработка семян биопрепаратами Грибофит (2 л/т) и Имуназот (3 л/т) перед посевом + обработка почвы перед посевом биопрепаратами Грибофит (5 л/га) и Имуназот (3 л/га) + обработка посевов 2 раза в течение вегетации биопрепаратами Грибофит (5 л/га) и Имуназот (3 л/га) + обработка растительных остатков перед заделкой Грибофит (5 л/га) и Имуназот (3 л/га) + азотные удобрения из расчета 10 кг д.в. $\mathrm{N}$ на т соломы зерновых культур).

Основные действующие компоненты агробиотехнологии, применяемые в нашем опыте - это культуры двух микроорганизмов: гриба Trichoderma, представленного в форме биопрепарата Грибофита и Pseudomonas, представленного в форме Имуназота.

Почва опытного поля - чернозем типичный слабоэродированный тяжелосуглинистый на карбонатном лессовидном суглинке.

Динамику роста гречихи в высоту учитывали по двум фазам развития культуры: бутонизация и цветения путем измерения 20 растений при проходе по диагонали делянок в двух несмежных повторениях.

Анализ биометрических показателей гречихи показал увеличение роста растения как в фазу бутонизации, так и в фазу цветения на всех удобренных участках по сравнению с контролем (без азотных удобрений и биопрепаратов). Причем, более заметные изменения характерны при переходе гречихи от фазы бутонизации к фазе цветения, где наблюдалось увеличение роста культуры на 58,45 см на контроле (без инокуляции семян и внесения азотных удобрений), на удобренных участках: по азотным удобрениям и на варианте совместного 
их внесения с биопрепаратами на 79,45 и 73,65 см, соответственно. Использование микробных препаратов стимулировало рост и развитие гречихи почти в 3 раза относительно фаз развития культуры (бутонизация - цветения).

Гречиха в фазу бутонизации в развитии и росте отреагировала на азотные удобрения, где наблюдалась максимальная величина высоты растения - 62,95 см, что значимо превышало контроль на 13,3 \% при $\left(\mathrm{HCP}_{05}=5,78\right)$. Но активный процесс развития вегетативной массы гречихи может негативно сказаться на зерновой продуктивности культуры.

Фаза цветения гречихи характеризовалась положительным действием всех факторов (азотных удобрений, биопрепаратов) на интенсивность роста гречихи по отношению к контролю на 11,5, 16,2 и 13,0 cм, соответственно вариантов с внесением Имуназота и Грибофита, азотных удобрений и комплексного использования вышеназванных факторов.

Развитие и рост гречихи в фазу цветения позволило биопрепаратам реализовать свой потенциал, где показатель высоты растения составлял 141,6 см, что превышало величину роста растения по сравнению с контролем на 35,8 см и находился на уровне варианта с внесение азотных удобрений - 142,4 см. Прием совместного внесения азотных удобрений и биопрепаратов в фазу цветения обеспечивал рост растения по отношению к контролю на 28 см, но несколько уступал действию азотных удобрений и микробиологических препаратов, внесенных отдельно (рис. 1).

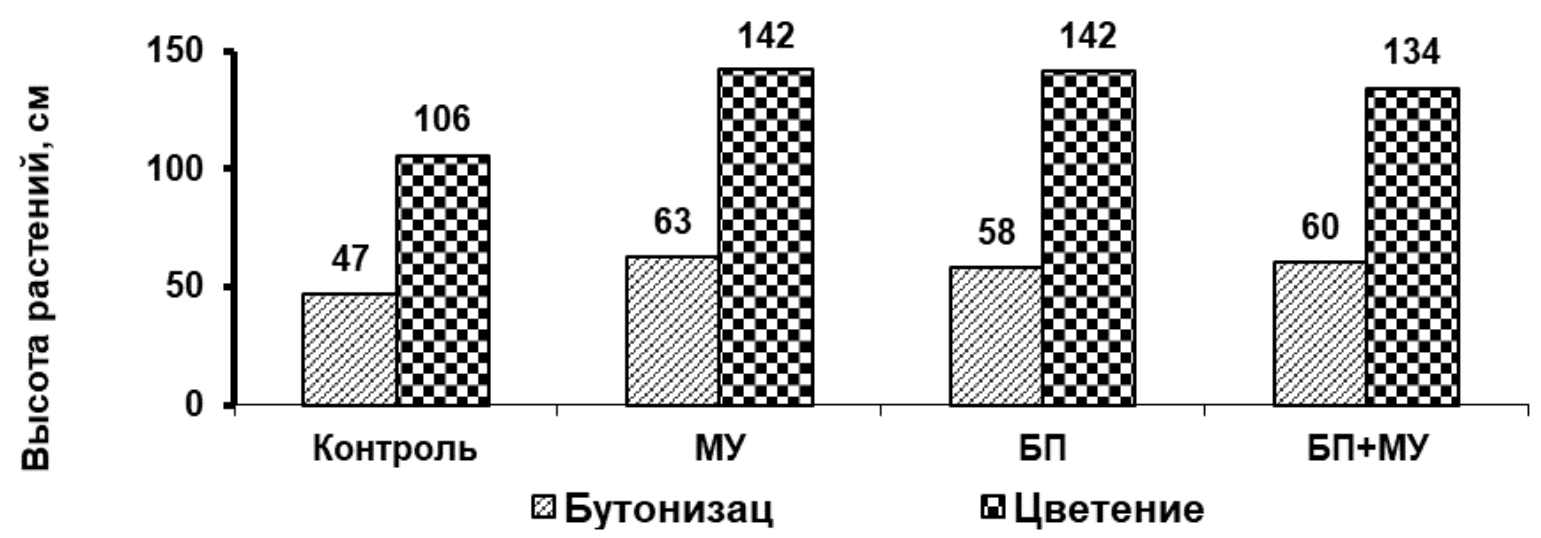

Рисунок 1 - Изменение высоты растения по фазам развития гречихи в опыте с внесением биопрепаратов

Фаза бутонизации характеризовалась равномерной интенсивностью формирования массы растения гречихи по всем факторам опыта. Наблюдалось положительное влияние азотных удобрений, микробиологических препаратов и комплексного их использования на прибавку веса растения гречихи в 2,0, 2,3 и 1,8 раза, соответственно по отношению к контролю, но азотные удобрения несколько превосходили действию биопрепаратов и совместного их внесения с азотными удобрениями (табл. 2).

В фазу цветения по фону с биопрепаратами имело место и увеличение массы растения в 2,3 раза по сравнению с контролем. Вариант с использованием одних микробиологических препаратов отличался наибольшим показателем веса растения, что превышало данный показатель на вариантах с 
внесением азотных удобрений и совместного внесения их с биопрепаратами на 17 и $37 \%$, соответственно.

Комплексное внесение азотных удобрений и биопрепаратов в фазу цветения уступало действию вариантов с биопрепаратами, так и с азотными удобрениями, но превышало контроль по весу растения на 14,02 г. (рис. 2).

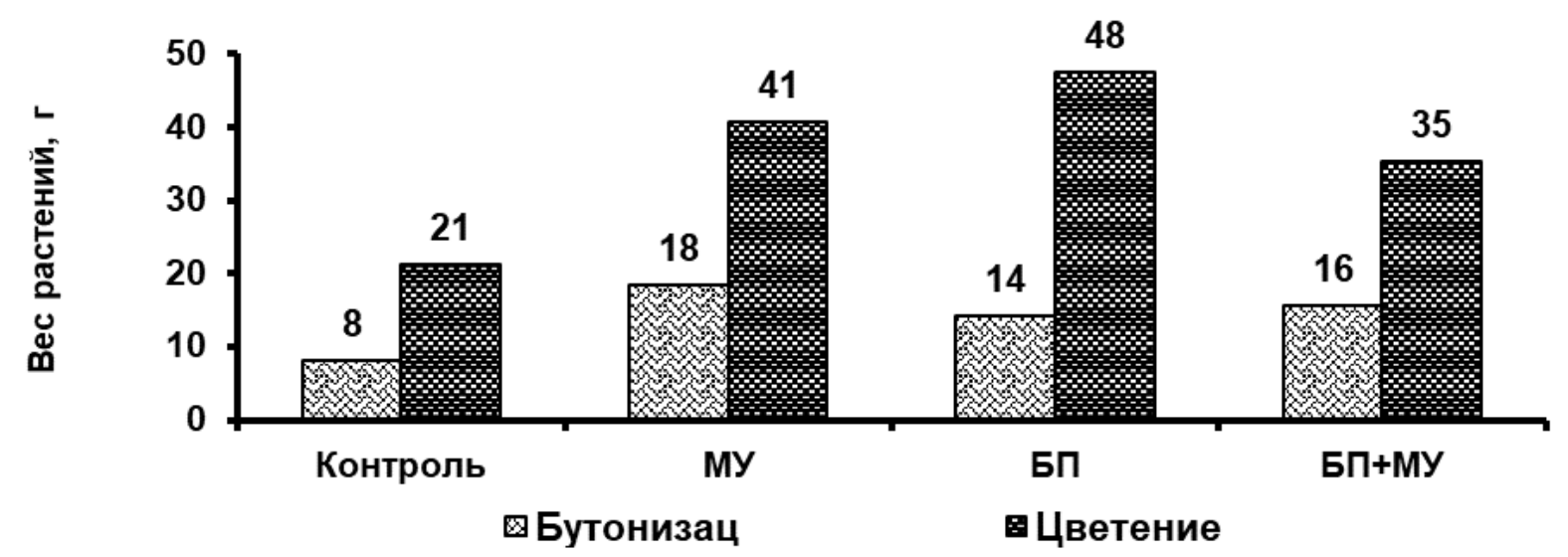

Рисунок 2 - Изменение массы растения по фазам развития гречихи в опыте с внесением биопрепаратов

Активному развитию и росту культуры благоприятствовали гидротермические условия месяца мая, сопряженные с посевом гречихи и появлением ее всходов.

Таким образом, результаты исследований показали положительную роль микробиологических препаратов (Грибофита и Имуназота) и в сочетании их с азотными удобрениями (из расчета 10 кг д.в. $\mathrm{N}$ на т соломы зерновых культур) при поверхностной заделке послеуборочных остатков на формирование вегетативной массы гречихи, где отмечалось увеличение высоты растения гречихи и ее массы. Но интенсивный рост культуры может спровоцировать полегание посева гречихи и снижение ее продуктивности.

\section{Библиографический список}

1. Глазова 3.И., Наумкин В.Н. Биологизация технологии возделывания гречихи // Агро XXI. - 2001. - №9. - 22 c.

2. Чевердин А.Ю. Влияние биопрепаратов на основе ассоциативных микроорганизмов на плодородие чернозема обыкновенного и урожайность ячменя ЦЧР / Диссертация канд. с.-Х. наук, Рамонь, 2021. - 167 с.

3. Юрченко Е.С. Влияние минеральных удобрений и биопрепаратов на агрохимические свойства чернозема выщелоченного и продуктивность гречихи в Поволжье / Диссертация канд. с.-х. наук. - Саратов, 2007. - 143 с.

4. Arshad Ullah M., Sarfraz M., Sadig M., Mehdi S.M., Hassan G. Effects of pre-sowing seed treatments with micronutrients on growth parameters of Raya //Asian Journal of Plant Sciences. 2012. - №. 1 (1). - P. 22-23.

5. Технология эффективного использования растительных остатков как органических удобрений на черноземах Лесостепи ЦЧЗ. - Курск, 2005. - 20 с. 
ИЗВЕСТКОВАНИЕ КИСЛЫХ ПОЧВ В АГРОЛАНДШАФТАХ ЦЧР Чуян О.Г.

ФГБНУ «Курский ФАНЦ»- ВНИИЗиЗПЭ, ул. Карла Маркса, 706, г. Курск, Россия

E-mail: agrochemgis@mail.ru

\begin{abstract}
Резюме. По результатам исследований представлены оценочные данные по разработке комплекса мероприятий, направленных на оптимизацию физико-химических свойств кислых почв с учетом рационального использования почвенно-климатических и агротехнических ресурсов на региональном уровне Центрального Черноземья.
\end{abstract}

Ключевые слова: пахотные почвы, физико-химические свойства, кислотность почв, баланс оснований, известкование почв.

Почвенный покров областей Центрального Черноземья характеризуется высокой долей кислых почв: Белгородской - 44,3\%, Воронежской- 28,2 \%, Курской- 68,0, Липецкой- 73,8 \% и Тамбовской-76,0 \%. Несмотря на то, что черноземы ЦЧР являются самыми продуктивными в России, они в то же время в значительной мере уязвимы к различным видам деградации. От первых туров агрохимического обследования (1964-1970 гг) количество кислых почв в наибольшей степени увеличилось в Тамбовской области - на 30,4 \%, в Белгородской - на $21,5 \%$ и Курской - на $6,2 \%[1,2]$.

Сплошные массивы почв с кислой реакцией среды в ЦЧР расположены в северо-западных районах, поскольку почвенный покров здесь представлен серыми лесными почвами, черноземами оподзоленными и выщелоченными. Длительное сельскохозяйственное использование земель приводит к повышению темпов и масштабов подкисления почв, что обусловлено ростом отрицательного баланса обменных оснований верхних горизонтов почв, а также не скомпенсированных потерь в результате выноса их урожаем культур и применения минеральных удобрений [3]. Почвы с повышенной кислотностью имеют неблагоприятные агрономические свойства, которые могут быть улучшены известкованием. Уровни параметров агрохимических свойств почв не являются самоцелью как объект управления, а средством достижения целесообразного уровня продуктивности агроценоза при минимальных и экономически обоснованных затратах агрохимических ресурсов в длительном цикле.

Целью исследований является расчет и оценка необходимого комплекса мероприятий для регулирования плодородия кислых почв Центрального Черноземья.

Использованы материалы федеральной службы государственной статистики Белгородской, Воронежской, Курской, Липецкой и Тамбовской областей [4]. Данные по тепло-влагообеспеченности соответствующих территорий использовали из летописей погоды [5]. В исследовании использованы методы анализа агроклиматических условий [6], агрохимических свойств почв [7], а также расчетов комплекса мелиоративнных и адаптивных приемов оптимизации и поддержания плодородия кислых почв $[8,9]$. 
Результаты и обсуждение. В современных условиях производства стратегия оптимальной дифференциации мелиоративных ресурсов земледелия должна быть ориентирована на обеспечение целесообразной агрономической и экономической их эффективности. Относительный приоритет почвоулучшающих мероприятий целесообразно решать путем ранжирования территориальных объектов по величине потенциала оптимизации кислотности почв, характеризующего величину приращения продуктивности пашни. Определение нуждаемости почв в известковании, очередности и приоритета по участкам является самостоятельной задачей и обосновывается возможным эффектом от самого приема. Общий принцип состоит в том, что наибольший эффект почвоулучшающие мероприятия показывают там, где кислотность почв является наиболее лимитирующим параметром плодородия, более высокие значения сопутствующих параметров плодородия и более высокие величины климатического потенциала продуктивности пашни.

Относительный эффект повышения продуктивности пашни при оптимизации исходной кислотности почв ЦЧР составляет: сильнокислых 23-32, среднекислых 15-23, слабокислых 7-14, близких к нейтральным 2-6 \%. Расчетный потенциал оптимизации кислотности почв на территории ЦЧР (табл. 1, рис. 1, ц 3.е./га) зависит от степени кислотности самой почвы, обеспеченности почвы другими факторами плодородия и климатического потенциала продуктивности пашни: Липецкая $(4,9)>$ Тамбовская $(4,1)>$ Курская $(4,0)>$ Белгородская $(3,0)>$ Воронежская область $(1,4)$.

Расчет мелиоративных доз извести проведен на количество кальция в составе гидролитически щелочных соединений $\left(\mathrm{CaCO}_{3}, \mathrm{~T} / г \mathrm{a}\right)$, которое входит в состав почвенного поглощающего комплекса в расчете на изменение кислотности до $\mathrm{pH}_{\mathrm{KCL}}=6,0$ с учетом буферных свойств почвы (табл. 1, рис. 2). Физическая потребность в известковых материалах (т/га, $\left.\mathrm{CaCO}_{3}\right)$ зависит от фактической кислотности почв и ее буферности, связанной с емкостью катионного обмена, содержанием гумуса и гранулометрическим составом: Тамбовская $(4,9 \pm 2,0)>$ Липецкая $(4,8 \pm 1,30)>$ Курская $(3,3 \pm 1,90)>$ Белгородская $(2,4 \pm 2,0)>$ Воронежская $(1,1 \pm 1,20)$. При этом меры по повышению плодородия почв, включающие использование мелиорантов, требуют значительных финансовых затрат. Поэтому наиболее обоснованным критерием к применению известковых мелиорантов выступает их окупаемость, которая напрямую связана с длительностью действия. Время действия прямо зависит от величины доз извести, сокращается с повышением влажности климата и возрастает с ростом буферности почвы.

Дозы известковых материалов для поддерживающего известкования рассчитываются на основании баланса оснований. Учитываются потери $\mathrm{CaCO}_{3}$ на вымывание из почвы, потери при внесении минеральных удобрений и вынос с урожаем культур. Расчетная промываемость почв по территории областей ЦЧР (мм) определяется гидротермическими условиями и гранулометрическим составом: Курская (41-104) > Липецкая (42-84) > Белгородская (25-78) > Тамбовская (32-59) > Воронежская (17-57). 
Таблица 1 - Оценка необходимого комплекса мер для регулирования плодородия кислых почв Центрального Черноземья

\begin{tabular}{|c|c|c|c|}
\hline Показатель & $\mathrm{X} \pm \mathrm{Sd}$ & Lim & $\mathrm{V}, \%$ \\
\hline \multicolumn{4}{|c|}{ Курская область, n=28 } \\
\hline Потенциал оптимизации, ц з.е./га & $4,0 \pm 1,95$ & $0,19-7,35$ & 48,7 \\
\hline Мелиоративные дозы извести, т/га & $3,3 \pm 1,90$ & $0,0-7,2$ & 56,3 \\
\hline Поддерживающие дозы извести, т/га & $1,9 \pm 0,20$ & $1,5-2,3$ & 11,1 \\
\hline Период действия, лет & $6,7 \pm 3,8$ & $0,0-15,6$ & 57,2 \\
\hline Окупаемость известкования, т з.е./т & $0,39 \pm 0,20$ & $0,0-0,77$ & 50,7 \\
\hline Доля многолетних трав, \% & $17,3 \pm 3,2$ & $12,0-23,0$ & 18,7 \\
\hline \multicolumn{4}{|c|}{ Белгородская область, $\mathrm{n}=21$} \\
\hline Потенциал оптимизации, ц з.е./га & $3,0 \pm 2,05$ & $0,0-5,95$ & 68,1 \\
\hline Мелиоративные дозы извести, т/га & $2,4 \pm 2,0$ & $0,0-5,4$ & 82,1 \\
\hline Поддерживающие дозы извести, т/га & $1,6 \pm 0,2$ & $1,3-2,0$ & 13,3 \\
\hline Период действия, лет & $5,3 \pm 4,4$ & $0,0-14,9$ & 83,5 \\
\hline Окупаемость известкования, т з.е./т & $0,31 \pm 0,24$ & $0,0-0,77$ & 77,0 \\
\hline Доля многолетних трав, \% & $18,8 \pm 1,8$ & $15,0-22,0$ & 9,5 \\
\hline \multicolumn{4}{|c|}{ Воронежская область, $\mathrm{n}=32$} \\
\hline Потенциал оптимизации, ц з.е./га & $1,43 \pm 1,12$ & $0,16-3,84$ & 78,2 \\
\hline Мелиоративные дозы извести, т/га & $1,1 \pm 1,20$ & $0,0-3,5$ & 108,2 \\
\hline Поддерживающие дозы извести, т/га & $1,3 \pm 0,20$ & $0,9-1,8$ & 17,9 \\
\hline Период действия, лет & $3,0 \pm 3,0$ & $0,0-9,5$ & 98,7 \\
\hline Окупаемость известкования, т з.е./т & $0,17 \pm 0,15$ & $0,0-0,45$ & 90,3 \\
\hline Доля многолетних трав, \% & $15,2 \pm 1,7$ & $12,0-19,0$ & 11,5 \\
\hline \multicolumn{4}{|c|}{ Липецкая область, $\mathrm{n}=18$} \\
\hline Потенциал оптимизации, ц з.е./га & $4,87 \pm 1,20$ & $1,32-6,55$ & 24,7 \\
\hline Мелиоративные дозы извести, т/га & $4,8 \pm 1,30$ & $0,7-6,5$ & 26,9 \\
\hline Поддерживающие дозы извести, т/га & $1,6 \pm 0,20$ & $1,4-1,9$ & 9,5 \\
\hline Период действия, лет & $11,0 \pm 3,0$ & $1,9-14,9$ & 27,7 \\
\hline Окупаемость известкования, т з.е./т & $0,55 \pm 13$ & $0,18-0,72$ & 23,7 \\
\hline Доля многолетних трав, \% & $20,5 \pm 1,4$ & $18,0-23,0$ & 6,9 \\
\hline \multicolumn{4}{|c|}{ Тамбовская область, $\mathrm{n}=23$} \\
\hline Потенциал оптимизации, ц з.е./га & $4,14 \pm 1,44$ & $1,48-6,09$ & 34,8 \\
\hline Мелиоративные дозы извести, т/га & $4,9 \pm 2,0$ & $1,4-7,3$ & 40,3 \\
\hline Поддерживающие дозы извести, т/га & $1,3 \pm 0,2$ & $1,1-1,7$ & 12,6 \\
\hline Период действия, лет & $14,5 \pm 6,2$ & $3,7-22,5$ & 42,8 \\
\hline Окупаемость известкования, т з.е./т & $0,59 \pm 0,22$ & $0,22-0,88$ & 36,2 \\
\hline Доля многолетних трав, \% & $13,5 \pm 1,3$ & $11,0-16,0$ & 9,7 \\
\hline
\end{tabular}


Окупаемость известкования почв за период действия мелиорантов (тыс. 3.е./т извести): Тамбовская $(0,59)>$ Липецкая $(0,55)>$ Курская $(0,39)>$ Белгородская $(0,31)>$ Воронежская $(0,17)$.

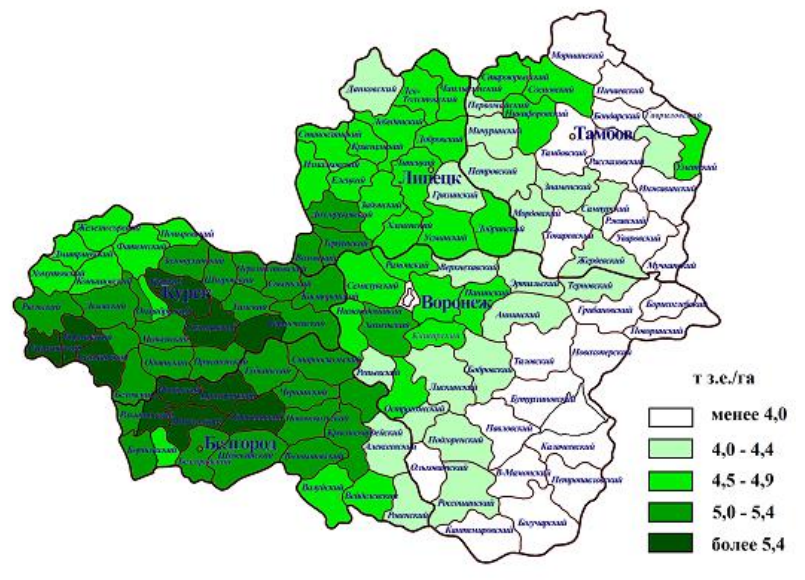

a)

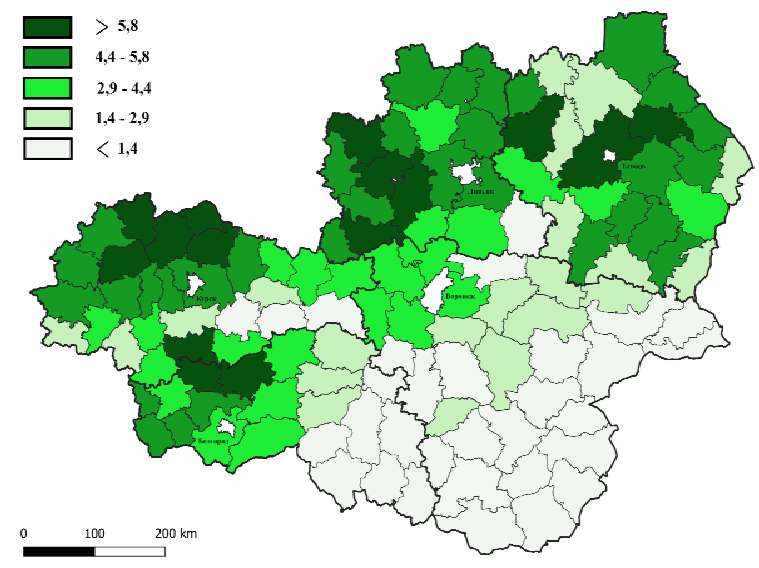

б)

Рисунок 1 - Действительно-возможная продуктивность пашни (a, т.з.е./га) и расчетный потенциал оптимизации кислотности почв (б, ц з.е./га)

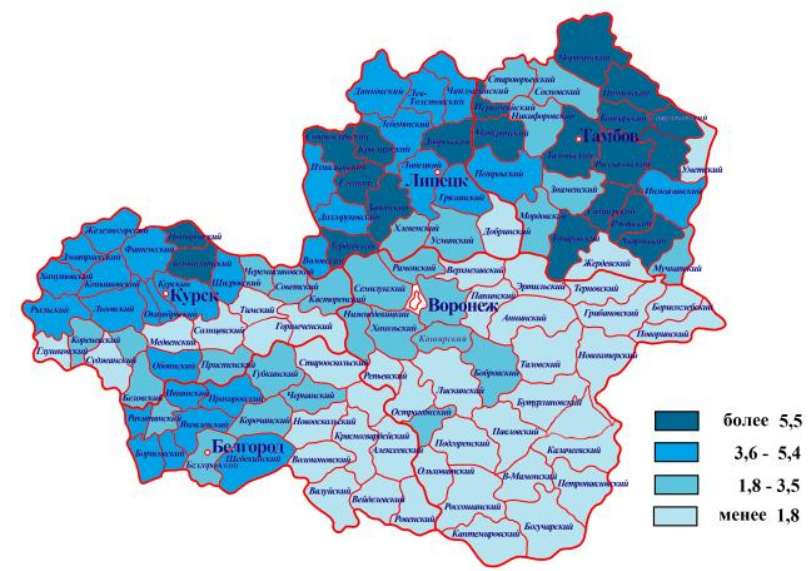

a)

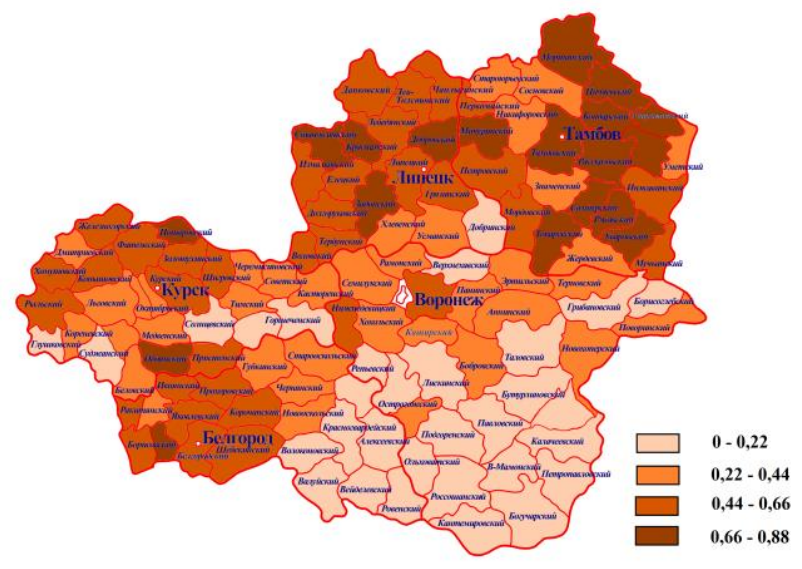

б)

Рисунок 2 - Мелиоративные дозы извести (а, для достижения уровней $\mathrm{pH} 6,0$, т/га) и окупаемость известковых доз за период действия $(6, \mathrm{\tau} / \mathrm{T})$

Интенсивность потерь оснований из почв (кг/га $\mathrm{CaCO}_{3}$ ) по территории областей ЦЧР составляет: Курская (122-295) > Белгородская (106-219) > Липецкая (114-203) > Тамбовская (82-150) > Воронежская (70-169). Расчетный (на 4 года) уровень поддерживающих доз извести (т/га) по территориям областей ЦЧР в основном зависит от гидротермического режима и уровня применения минеральных удобрений (рис. 3) : Курская $(1,5-2,3)>$ Белгородская $(1,3-2,0)>$ Липецкая $(1,4-1,9)>$ Тамбовская $(1,1-1,7)>$ Воронежская $(0,9-1,8)$. Для почв, попадающих в категорию поддерживающего известкования, возможно применение адаптивных приемов. Стабилизация кислотности почв обеспечивается насыщением севооборота многолетними травами. 

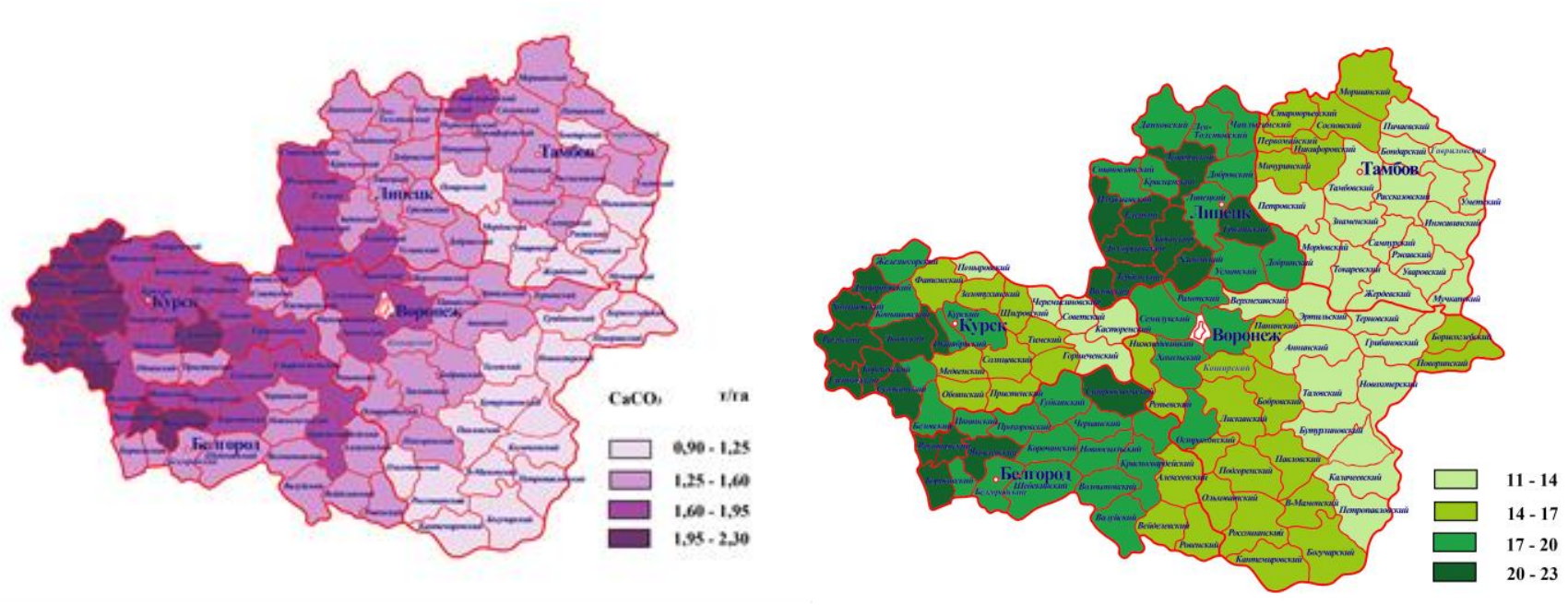

Рисунок 3 - Поддерживающие дозы извести (т/га) по территориям районов областей ЦЧР (а) и уровни насыщения пашни многолетними бобовыми травами (б)

Таким образом, очередность и интенсивность применения почвоулучшающих мероприятий целесообразно решать для каждого уровня территориального деления. Следует учитывать, что отдача от таких мероприятий будет выше там, где почвенное плодородие является лимитирующим фактором продуктивности и эффективность его использования при этом достаточно высокая. Приоритеты повышения плодородия почв на 30 - 40 \% обусловлены климатическим потенциалом продуктивности пашни и до $60-70 \%$ - уровнем качества почв.

\section{Библиографический список}

1. Чекмарев П.А., Лукин С.В., Сискевич, Юмашев Н.П., Корчагин В.И., Хижняков А.Н. Мониторинг кислотности пахотных почв Центрально-черноземного района // Достижения науки и техники АПК. 2011, №7. - С. 6-8.

2. Чекмарев П.А., Лукин С.В. Динамика плодородия пахотных почв, использования удобрений и урожайности основных сельскохозяйственных культур в центрально-черноземных областях России// Международный сельскохозяйственный журнал, 2017. - №4. - С 41-44.

3. Хомяков Д.Н. Изменение кислотности природной среды и известкование почв в регионах с гумидным климатом //Агрохимия, 2000. - № 3. - С. 81-91.

4. Паспорт муниципального образования (munst14 - Белгородская область; munst20 - Boронежская область; munst38 - Курская область; munst42 - Липецкая область; munst68 - Тамбовская область). [Электронный ресурс]. - Режим доступа: URL: https://rosstat.gov.ru/scripts/db_inet2/passport/munr.aspx? base=munst 14. - (дата обращения: 20.05.2021.)

5. Температура воздуха и осадки по месяцам и годам: ( $=31$ Белгородская область; $=36$ Воронежская область; $=46$ - Курская область; $=48$ - Липецкая область; $=68$ - Тамбовская область), Россия. [Электронный ресурс]. - Режим доступа: URL: http://www.pogodaiklimat.ru/history.php?id= ru\&region=31. 05.04.2021).

6. Чуян, О.Г., Дериглазова, Г.М. Оценка агроклиматического потенциала продуктивности пашни для модели управления агрохимическими свойствами почв // Земледелие, 2018. - № 7. - C. 6-11. 
7. Фрид А.С., Чуян О.Г., Соловиченко В.Д., Тютюнов С.И. Оценка плодородия // Научные основы предотвращения деградации почв (земель) сельскохозяйственных угодий России и формирования систем воспроизводства их плодородия в адаптивно-ландшафтном земледелии. М.: Почвенный ин-т им. В. В. Докучаева Россельхозакадемии, 2013. - С. 17-34.

8. Чуян О.Г. База данных для регулирования физико-химических свойств кислых почв в адаптивно-ландшафтном земледелии (для Центрального Черноземья). - Курск: ГНУ ВНИИЗиЗПЭ РАСХН, 2012. - 78 с.

9. Чуян О.Г., Дубовик Д.В., Масютенко Н.П., Лазарев В.И. Научно-практические рекомендации по известкованию почв в Курской области. - Курск: ФГБНУ «Курский федеральный аграрный научный центр», Комитет АПК Курской области, 2019. - 30 с.

\title{
УДК 631.51:631.582(470.55)
}

\section{ИННОВАЦИОННЫЕ РЕСУРСЫ ПОВЫШЕНИЯ КАЧЕСТВО ЗЕРНА ЯРОВОЙ ПШЕНИЦЫ НА ЮЖНОМ УРАЛЕ}

\author{
Шаталина Л.П., Анисимов Ю.Б., Калюжина Е.Л. \\ ФГБНУ «Челябинский НИИСХ», г. Челябинск \\ E-mail: chniisx2@mail.ru
}

\begin{abstract}
Резюме. В опыте проведена оченка качества зерна яровой мягкой пшеницы при воздельвании в различных севооборотах на двух фонах минерального питания с 2014-2019 г2. Повышение качества содержания клейковины в зерне яровой пшеницы за счёт предшественника достигало 2,3-2,9\%, натуры зерна 16-17 г/л, массы 1000 зёрен 2,1 г. От удобрений увеличение клейковины на 4,8\%, белка на 1,55\%. От условий года различия по клейковине составили 1,2-5,1\%, по белку 0,9-1,2\%, по массе 1000 зёрен 3,4-8,42.

Ключевые слова: предшественник, севооборот, натура зерна, клейковина, белок, масса 1000 зёрен.
\end{abstract}

Summary. In the experiment, the quality of grain of spring soft wheat was assessed during cultivation in different crop rotations on two backgrounds of mineral nutrition from 2014-2019. The increase in the quality of the gluten content in the grain of spring wheat due to the predecessor reached 2.3-2.9\%, the grain nature was $16-17 \mathrm{~g} / \mathrm{l}$, the mass of 1000 grains was $2.1 \mathrm{~g}$. From fertilizers, the increase in gluten by $4.8 \%$, protein by $1.55 \%$. From the conditions of the year, the differences in gluten were 1.2-5.1\%, in protein 0.9-1.2\%, in the mass of 1000 grains 3.4-8.4 g.

Key words: predecessor, crop rotation, grain nature, gluten, protein, 1000 grain weight.

Производство зерна яровой пшеницы, одной из наиболее распространённых зерновых культур в мире, испытывает определённые изменения, связанные с уровнем химизации, эффективности применяемых технологий возделывания, наличием современной сельскохозяйственной техники $[1,2]$. В итоге у сельхозпроизводителей возникла проблема получения зерна яровой мягкой пшеницы высокого качества, для обеспечения отраслей агропромышленного комплекса. На предприятиях для повышения качества муки всё чаще применяются химические улучшители, которые приводят к изменению традиционного вкуса хлеба и снижению его потребления. Поэтому единственным ресурсом повышения качества хлеба остается естественное улучшение исходных характеристик муки, а соответственно технологических показателей качества зерна яровой мягкой пшеницы [3]. В разных странах мира созданы все более новые высокобелковые и высокоурожайные сорта и серии почти изогенных линий, которые обеспечивают перспективу для научных исследований в селекции яровой 
пшеницы [4]. Отмечены отечественные научные разработки Саратовского университета по выявлению сортовой вариации по изучаемым критериям качества и взаимосвязи между одноимёнными индексами у сортообразцов выращенных по пару [5]. Учёные Поляков М.В., Белкина Р.И., Летяго Ю.А. установили, что у сортов яровой пшеницы изменчивость натуры зерна незначительная - коэффициент вариации менее 10\% [6]. Исследования, посвящённые изучению ресурсов повышения качества зерна яровой пшеницы в условиях перехода на ресурсосберегающие технологии в настоящее время востребованы и актуальны. Целью наших исследований было изучить ресурсный потенциал повышения качества зерна яровой пшеницы в условиях северной лесостепи Южного Урала, при использовании нулевой технологии возделывания по различным предшественникам, на двух фонах удобренности.

Методика исследований. Опыт был заложен на территории опытного поля ФГБНУ «Челябинский НИИСХ» с 2014 по 2019 год.

Схема опыта реализована на двух фонах минерального питания $\mathrm{P}$ - без удобрений и NP - по схеме.

\begin{tabular}{|l|c|}
\hline \multicolumn{1}{|c|}{$\begin{array}{c}\text { Севооборот } \\
\text { № варианта }\end{array}$} & Фон \\
\hline \multirow{2}{*}{ 1. Пар-оз.рожь+горох +овёс-пшеница } & Без удобрений \\
\cline { 2 - 2 } 2.Рапс-пшеница-горох +овёс-пшеница & $\mathrm{N}_{17,5}$ \\
\cline { 2 - 2 } 3.Люпин-пшеница-пшеница-ячмень & Без удобрений \\
\cline { 2 - 2 } 4.Соя-пшеница-горох +овёс-ячмень & $\mathrm{N}_{30}$ \\
\hline \multirow{2}{*}{ 5.Пар-оз.рожь-люпин-пшеница-лён-пшеница } & $\mathrm{N}_{32,5}$ \\
\cline { 2 - 2 } & Без удобрений \\
\hline \multirow{2}{*}{ 6.Пар-рапс-пшеница-ячмень } & $\mathrm{N}_{22,5}$ \\
\cline { 2 - 2 } 7.Пшеница (бессменно) контроль & $\mathrm{N}_{20}$ \\
\cline { 2 - 2 } & Без удобрений \\
\cline { 2 - 2 } & $\mathrm{N}_{25}$ \\
\hline
\end{tabular}

Агротехника в опыте основана на нулевой технологии обработки почвы модифицированной для северной лесостепной зоны Южного Урала, при которой механические способы обработки почвы не проводятся, а в борьбе с сорняками применяются различные гербициды. Азотные удобрения вносятся поверхностно перед посевом, а фосфорные - при посеве в рядок.

Почва опытного участка - чернозем выщелоченный маломощный. 
Метеоусловия по годам исследований

\begin{tabular}{|c|c|c|c|}
\hline Год & ГТК & $\begin{array}{c}\text { Сумма осадков } \\
\text { 3a V-IX месяцы, мм. }\end{array}$ & $\begin{array}{c}\text { Сумма } \\
\text { положительных } \\
\text { температур, C }\end{array}$ \\
\hline 2014 & 1,5 & 294,0 & 2393 \\
\hline 2015 & 1,7 & 353,7 & 2605 \\
\hline 2016 & 1,3 & 292,2 & 2844 \\
\hline 2017 & 1,1 & 273,7 & 2567 \\
\hline 2018 & 1,3 & 328,1 & 2451 \\
\hline 2019 & 1,0 & 257,9 & 2429 \\
\hline
\end{tabular}

В результате исследований установлено влияние метеоусловий года, минеральных удобрений, предшественника и севооборота на основные показатели качества зерна яровой пшеницы: клейковину, белок, натуру и массу 1000 зёрен. Содержание клейковины по годам исследований существенно изменилось в 2015, 2016 и 2019 году на 1,19-5,14\% (таблица 1).

Таблица 1 - Содержание клейковины в зерне яровой мягкой пшеницы, \%

\begin{tabular}{|c|c|c|c|c|c|c|c|}
\hline \multirow{2}{*}{$\begin{array}{c}\text { Предшественник } \\
\text { (Фактор А) }\end{array}$} & \multirow{2}{*}{$\begin{array}{c}\text { Фон } \\
\text { (Фактор В) }\end{array}$} & \multicolumn{6}{|c|}{ Год (Фактор С) } \\
\hline & & 2014 & 2015 & 2016 & 2017 & 2018 & 2019 \\
\hline \multirow{2}{*}{ 1. Горох (1в.), } & $\mathrm{P}$ & 16,5 & 25,6 & 18,8 & 15,8 & 16,3 & 16,0 \\
\hline & NP & 25,4 & 28,0 & 29,6 & 19,9 & 19,7 & 25,9 \\
\hline \multirow{2}{*}{ 2. Горох (2 в.), } & $\mathrm{P}$ & 23,3 & 23,6 & 29,6 & 22,5 & 20,3 & 18,6 \\
\hline & NP & 27,5 & 25,7 & 31,1 & 20,4 & 22,9 & 24,9 \\
\hline \multirow{2}{*}{ 3.Рапс (2 в.), } & $\mathrm{P}$ & 19,3 & 27,2 & 18,7 & 25,4 & 21,5 & 18,4 \\
\hline & NP & 22,5 & 30,4 & 23,6 & 30,6 & 24,8 & 22,4 \\
\hline \multirow{2}{*}{ 4. Люпин (3 в.), } & $\mathrm{P}$ & 20,0 & 23,6 & 20,4 & 23,1 & 21,9 & 19,1 \\
\hline & $\mathrm{NP}$ & 27,2 & 28,8 & 31,7 & 25,8 & 25,6 & 24,3 \\
\hline \multirow{2}{*}{ 5. Пшеница (3 в.), } & $\mathrm{P}$ & 20,2 & 25,2 & 24,0 & 30,0 & 19,1 & 16,0 \\
\hline & NP & 22,1 & 28,7 & 29,1 & 33,2 & 19,7 & 21,8 \\
\hline \multirow{2}{*}{ 6. Соя (4 в.), } & $\mathrm{P}$ & 18,5 & 22,0 & 24,2 & 21,1 & 16,7 & 13,0 \\
\hline & NP & 28,0 & 30,0 & 26,1 & 22,8 & 20,7 & 18,9 \\
\hline \multirow{2}{*}{ 7. Люпин (5 в.), } & $\mathrm{P}$ & 19,0 & 26,5 & 15,3 & 21,2 & 24,3 & 17,6 \\
\hline & NP & 21,8 & 29,6 & 32,3 & 30,8 & 24,1 & 24,9 \\
\hline \multirow{2}{*}{ 8. Лён (5 в.), } & $\mathrm{P}$ & 21,6 & 28,3 & 18,3 & 18,8 & 21,6 & 12,7 \\
\hline & NP & 25,2 & 33,4 & 23,0 & 21,6 & 21,2 & 25,5 \\
\hline \multirow{2}{*}{$\begin{array}{l}\text { 9. Пшеница } \\
\text { бессменно. }\end{array}$} & $\mathrm{P}$ & 20,6 & 25,7 & 24,4 & 16,0 & 20,7 & 16,8 \\
\hline & NP & 25,6 & 34,4 & 28,5 & 19,9 & 21,8 & 22,1 \\
\hline
\end{tabular}

В среднем в 2015 году содержание клейковины было 27,6\%, 2016 году 24,9\%, 2019 году 19,9\% это обусловлено метеоусловиями года. Фон минеральных удобрений по схеме опыта обеспечивал увеличение содержания клейковины в среднем на 4,8\%. В среднем по предшественникам содержание клейковины изменялось от 21,4 до $24,29 \%$. Бобовые предшественники увеличивали содержание клейковины на 2,39-2,88\%. В годы с оптимальными 
метеоусловиями содержание клейковины в зерне яровой мягкой пшеницы по предшественникам достигало 25,7-34,4\% на фоне удобренности NP.

Внесение минеральных удобрений на всех вариантах опыта достоверно увеличило содержание клейковины в зерне яровой пшеницы, при этом получено зерно не ниже третьего класса.

Изменения содержания белка в зерне яровой мягкой пшеницы по изучаемым ресурсам представлены в таблице 2 .

Таблица 2 - Содержание белка в зерне яровой мягкой пшеницы, \%

\begin{tabular}{|c|c|c|c|c|c|c|c|}
\hline \multirow{2}{*}{$\begin{array}{l}\text { Предшественник } \\
\text { (Фактор А) }\end{array}$} & \multirow{2}{*}{$\begin{array}{c}\text { Фон } \\
\text { (Фактор В) }\end{array}$} & \multicolumn{6}{|c|}{ Год (Фактор С) } \\
\hline & & 2014 & 2015 & 2016 & 2017 & 2018 & 2019 \\
\hline \multirow{2}{*}{ 1. Горох (1в.), } & $\mathrm{P}$ & 12,21 & 13,01 & 12,61 & 11,89 & 13,01 & 12,29 \\
\hline & NP & 14,04 & 14,04 & 15,56 & 12,37 & 14,92 & 13,88 \\
\hline \multirow{2}{*}{ 2. Горох (2 в.), } & $\mathrm{P}$ & 13,17 & 10,93 & 15,64 & 12,29 & 12,29 & 12,45 \\
\hline & NP & 16,12 & 11,73 & 16,84 & 13,09 & 12,85 & 15,00 \\
\hline \multirow{2}{*}{ 3.Рапс (2 в.), } & $\mathrm{P}$ & 12,77 & 14,20 & 13,65 & 12,37 & 11,97 & 11,09 \\
\hline & NP & 14,36 & 15,00 & 14,20 & 14,84 & 12,77 & 12,05 \\
\hline \multirow{2}{*}{ 4. Люпин (3 в.), } & $\mathrm{P}$ & 12,93 & 11,01 & 13,25 & 12,98 & 11,33 & 12,69 \\
\hline & NP & 16,36 & 13,73 & 15,48 & 13,57 & 13,09 & 15,24 \\
\hline \multirow{2}{*}{ 5. Пшеница (3 в.), } & $\mathrm{P}$ & 13,09 & 13,33 & 14,04 & 15,00 & 13,09 & 12,31 \\
\hline & NP & 15,16 & 13,17 & 14,68 & 16,36 & 13,57 & 14,36 \\
\hline \multirow{2}{*}{ 6. Соя (4 в.), } & $\mathrm{P}$ & 13,57 & 9,18 & 13,17 & 12,13 & 11,25 & 13,17 \\
\hline & NP & 16,52 & 14,60 & 14,36 & 13,25 & 11,81 & 14,20 \\
\hline \multirow{2}{*}{ 7. Люпин (5 в.), } & $\mathrm{P}$ & 12,85 & 13,80 & 8,30 & 13,57 & 14,04 & 11,57 \\
\hline & NP & 14,84 & 12,29 & 16,28 & 15,24 & 13,73 & 14,52 \\
\hline \multirow{2}{*}{ 8. Лён (5 в.), } & $\mathrm{P}$ & 13,17 & 13,80 & 12,85 & 12,69 & 13,41 & 11,17 \\
\hline & NP & 14,04 & 14,52 & 13,80 & 13,17 & 12,77 & 15,08 \\
\hline \multirow{2}{*}{ 9. Пшеница бессменно. } & $\mathrm{P}$ & 13,33 & 13,73 & 13,73 & 10,61 & 11,81 & 13,17 \\
\hline & NP & 15,16 & 15,32 & 14,04 & 12,61 & 14,08 & 14,20 \\
\hline
\end{tabular}

$\mathrm{HCP}_{05} \mathrm{C}=0,75 ; \mathrm{HCP}_{05} \mathrm{~B}=0,43 ; \mathrm{HCP}_{05} \mathrm{~A}=0,92$ несущ.;

$\mathrm{HCP}_{05} \mathrm{AB}=1,30$ несущ.; $\mathrm{HCP}_{05} \mathrm{AC}=2,25$ несущ; $\mathrm{HCP}_{05} \mathrm{BC}=1,06$ несущ

Содержание белка в зерне яровой пшеницы можно регулировать только внесением минеральных удобрений, влияние предшественника несущественно. Метеоусловия года приводили к изменениям содержания белка на 0,68-1,17\%. Особенно это проявилось в 2017 и 2018 году, когда снижение содержания белка составило $0,87-1,17 \%$. Фон минерального питания увеличивал содержание белка в среднем с 12,7 до $14,25 \%$, т. е. на $1,55 \%$.

Важным показателем качества зерна яровой мягкой пшеницы является натура зерна и масса 1000 зёрен. Влияние метеоусловий, фона удобренности и предшественников представлено в таблицах 3,4 .

Натура зерна существенно снижается при посеве яровой пшеницы по зерновым предшественникам в среднем по годам на 16,7-17,7 г/л. Влияние же фактора предшественник по незерновым предшественникам несущественно. 
Таблица 3 - Натура зерна яровой мягкой пшеницы, г/л

\begin{tabular}{|c|c|c|c|c|c|c|c|}
\hline \multirow{2}{*}{$\begin{array}{l}\text { Предшественник } \\
\text { (Фактор А) }\end{array}$} & \multirow{2}{*}{$\begin{array}{c}\text { Фон } \\
\text { (Фактор В) }\end{array}$} & \multicolumn{6}{|c|}{ Год (Фактор С) } \\
\hline & & 2014 & 2015 & 2016 & 2017 & 2018 & 2019 \\
\hline \multirow{2}{*}{ 1. Горох (1в.), } & $\mathrm{P}$ & 699 & 788 & 763 & 788 & 786 & 722 \\
\hline & NP & 691 & 763 & 692 & 788 & 771 & 722 \\
\hline \multirow{2}{*}{ 2. Горох (2 в.), } & $\mathrm{P}$ & 679 & 792 & 694 & 801 & 795 & 717 \\
\hline & NP & 676 & 771 & 695 & 765 & 791 & 707 \\
\hline \multirow{2}{*}{ 3.Рапс (2 в.), } & $\mathrm{P}$ & 700 & 770 & 734 & 771 & 796 & 719 \\
\hline & NP & 681 & 752 & 685 & 759 & 795 & 711 \\
\hline \multirow{2}{*}{ 4. Люпин (3 в.), } & $\mathrm{P}$ & 683 & 798 & 757 & 795 & 784 & 716 \\
\hline & NP & 661 & 762 & 715 & 799 & 767 & 728 \\
\hline \multirow{2}{*}{ 5. Пшеница (3 в.), } & $\mathrm{P}$ & 687 & 759 & 698 & 761 & 795 & 727 \\
\hline & NP & 680 & 754 & 740 & 734 & 717 & 727 \\
\hline \multirow{2}{*}{ 6. Соя (4 в.), } & $\mathrm{P}$ & 687 & 769 & 750 & 796 & 774 & 714 \\
\hline & $\mathrm{NP}$ & 666 & 748 & 745 & 792 & 762 & 721 \\
\hline \multirow{2}{*}{ 7. Люпин (5 в.), } & $\mathrm{P}$ & 692 & 779 & 748 & 793 & 779 & 726 \\
\hline & NP & 674 & 776 & 701 & 754 & 781 & 727 \\
\hline \multirow{2}{*}{ 8. Лён (5 в.), } & $\mathrm{P}$ & 668 & 775 & 712 & 777 & 791 & 716 \\
\hline & NP & 660 & 758 & 718 & 809 & 787 & 713 \\
\hline \multirow[b]{2}{*}{ 9. Пшеница бессменно. } & $\mathrm{P}$ & 689 & 749 & 713 & 765 & 775 & 715 \\
\hline & NP & 676 & 726 & 749 & 764 & 740 & 699 \\
\hline
\end{tabular}

Таблица 4 - Масса 1000 зерен яровой мягкой пшеницы, г.

\begin{tabular}{|c|c|c|c|c|c|c|c|}
\hline \multirow{2}{*}{$\begin{array}{r}\text { Предшественник } \\
\text { (Фактор А) }\end{array}$} & \multirow{2}{*}{$\begin{array}{c}\text { Фон } \\
\text { (Фактор В) }\end{array}$} & \multicolumn{6}{|c|}{ Год (Фактор С) } \\
\hline & & 2014 & 2015 & 2016 & 2017 & 2018 & 2019 \\
\hline \multirow{2}{*}{ 1. Горох (1в.), } & $\mathrm{P}$ & 29,7 & 28,9 & 21,3 & 31,1 & 31,1 & 27,1 \\
\hline & $\mathrm{NP}$ & 28,9 & 27,1 & 18,5 & 31,5 & 32,4 & 24,5 \\
\hline \multirow{2}{*}{ 2. Горох (2 в.), } & $\mathrm{P}$ & 29,2 & 29,6 & 18,4 & 28,9 & 35,0 & 25,0 \\
\hline & NP & 27,3 & 27,7 & 17,6 & 27,5 & 35,4 & 25,1 \\
\hline \multirow{2}{*}{ 3.Рапс (2 в.), } & $\mathrm{P}$ & 29,5 & 27,7 & 19,8 & 27,4 & 36,2 & 24,3 \\
\hline & NP & 27,0 & 25,3 & 16,3 & 26,2 & 35,0 & 23,5 \\
\hline \multirow{2}{*}{ 4. Люпин (3 в.), } & $\mathrm{P}$ & 28,6 & 31,0 & 22,2 & 27,4 & 32,0 & 23,9 \\
\hline & NP & 24,2 & 28,6 & 18,5 & 29,3 & 34,1 & 26,5 \\
\hline \multirow{2}{*}{ 5. Пшеница (3 в.), } & $\mathrm{P}$ & 28,0 & 25,7 & 19,6 & 26,0 & 32,4 & 26,2 \\
\hline & $\mathrm{NP}$ & 27,7 & 24,0 & 21,2 & 23,4 & 28,6 & 24,5 \\
\hline \multirow{2}{*}{ 6. Соя (4 в.), } & $\mathrm{P}$ & 29,1 & 28,8 & 22,2 & 28,4 & 26,6 & 22,9 \\
\hline & $\mathrm{NP}$ & 25,9 & 25,4 & 21,0 & 29,7 & 29,2 & 24,9 \\
\hline \multirow{2}{*}{ 7. Люпин (5 в.), } & $\mathrm{P}$ & 26,3 & 28,7 & 21,5 & 27,1 & 35,2 & 25,9 \\
\hline & NP & 30,6 & 27,7 & 17,4 & 26,4 & 35,0 & 25,1 \\
\hline \multirow{2}{*}{ 8. Лён (5 в.), } & $\mathrm{P}$ & 28,7 & 28,3 & 19,2 & 29,5 & 31,4 & 23,9 \\
\hline & NP & 26,6 & 27,2 & 19,1 & 30,1 & 33,9 & 22,6 \\
\hline \multirow{2}{*}{ 9. Пшеница бессменно. } & $\mathrm{P}$ & 30,5 & 24,2 & 20,2 & 26,7 & 31,6 & 22,7 \\
\hline & $\overline{\mathrm{NP}}$ & 26,8 & 22,7 & 19,7 & 26,0 & 30,7 & 24,3 \\
\hline
\end{tabular}


Различия по годам составили в среднем 38-98 г/л. Натура зерна на фоне без удобрений на 12,6 г/л больше. Натурное зерно получено на вариантах 4 и 5 в 2017 и 2018 году до 778-777 г/л.

На массу 1000 зёрен оказывали существенное влияние все три фактора: метеоусловия, фон минерального питания и предшественник. Зерно с наибольшей массой 1000 зёрен получено в 2018 году от 31,75-35,60 в зависимости от предшественника, на удобренном фоне. Отмечено снижение массы 1000 зёрен по предшественникам рапс, пшеница, соя на 1,15-2,17 г. Наибольшая масса 1000 зёрен получена при посеве яровой пшеницы по бобовым предшественникам горох и люпин что согласуется с данными учёных Ульяновской государственной академии [7]. От метеоусловий масса 1000 зёрен изменялась на 3,48,4 г. особенно в 2016, 2018 году.

Таким образом, в условиях современного состояния сельскохозяйственного производства для получения зерна высокого качества, особенно при прямом посеве, можно использовать такие ресурсы как: введение в севообороты бобовых культур, предшественник для яровой пшеницы, умеренные дозы минеральных удобрений.

\section{Библиографический список}

1. Усенко С.В., Усенко В.И. Гаркуша А.А. Качество зерна пшеницы в зависимости от предшественника, обработки почвы, удобрений и средств защиты растений в лесостепи юга Западной Сибири // Достижения науки и техники АПК. - 2020. - Т.34. - №7. - С.32-37. DOI:10.24411/0235-2451-2020-10705

2. Юшкевич Л.В., Щитов А.Г., Пахотина И.В. Урожайность и качество зерна яровой пшеницы в зависимости от технологии возделывания в лесостепи Западной Сибири / Земдежделие. - 2019. - №1. - С.32-34. DOI: 10.24411/0044-3913-2019-10109

3. Хлёсткина Е.К. Журавлёва Г.А. Реализация генетического потенциала сортов мягкой яровой пшеницы под влиянием условий внешней среды: современные возможности улучшения качества зерна и хлебопекарной продукции // Сельскохозяйственная биология. 2017. - T.52. - C.501-514 DOI: 10.15389/agrobiology.2017.3.501rus

4. Митрофанова О.П., Хакимова А.Г. Новые генетические ресурсы в селекции пшеницы на увеличение содержания белка в зерне // Вавиловский журнал генетики и селекции. - 2016. - 20(4). - C. 545-554 DOI:10.18699/VJ16.177

5. Кулеватова Т.Б., Злобина Л.Н. Влияние предшественника на показатели качества зерна яровой мягкой пшеницы // Известия Саратовского университета. Новая серия: Химия. Биология. Экология. - 2019 - T.19. - C.64-69. DOI:0.18500/1816-9775-2019-19-1-64-69

6. Тойгиль А.Л., Подсевалов М.И., Аюпов Д.Э.Формирование урожая и качества зерна яровой пшеницы при биологизации севооборотов лесостепной зоны Поволжья // Вестник Ульяновской государственной сельскохозяйственной академии. - 2019. - №4(48). - С.44-50. DOI:10.18286/1816-4501-2019-4-44-50

7. Поляков М.В., Белкина Р.И., Летяго Ю.А. Варьирование признаков качества зерна у сортов яровой мягкой пшеницы в условиях Северного Зауралья // Вестник Бурятской сельскохозяйственной академии им. В.Р. Филиппова. - 2020. - № 4(61). - С.20-26. 
УДК: 631.84:631.416.2

\section{ВЛИЯНИЕ МИНЕРАЛЬНЫХ УДОБРЕНИЙ НА ПЛОДОРОДИЕ ВЫЩЕЛОЧЕННОГО ЧЕРНОЗЕМА}

Юмашев Х.C.

ФГБНУ «Челябинский НИИСХ» п. Тимирязевский, Челябинская область E-mail: chniisx2@mail.ru

Резюме. В статье представлены результаты научных исследований по влиянию длительного применения азотно-фосфорных удобрений на плодородие выщелоченного чернозёма. Применение: фосфорных удобрений в дозах превышающих вынос с урожаями культур в севообороте приводит к зафосфачиванию почвы; азотно-фосфорные удобрения повышиют гидролитическую и обменную кислотность почвы.

Ключевые слова: удобрения, фосфор, кислотность, выщелоченный чернозем.

Summary. The article presents the results of scientific research on the effect of long-term use of nitrogen-phosphorus fertilizers on the fertility of leached chernozem. Application: phosphorus fertilizers in doses exceeding the removal of crops with crops in crop rotation leads to soil phosphatization; nitrogen-phosphorus fertilizers increase the hydrolytic and exchangeable acidity of the soil.

Key words: fertilizers, phosphorus, acidity, leached chernozem.

Введение. Величина валовых сборов зерновых и кормовых культур неразрывно связана с увеличением объёмов применения минеральных и органических удобрений. В связи с этим, на заре индустриализации страны, с развитием коллективных форм собственности перед исследователями встали вопросы эффективного использования агрохимических средств, применительно к различным регионам страны. Начиная с 40-х годов прошлого столетия, в СССР начали разворачиваться научно-исследовательские работы при МТС и совхозах, что послужило основой создания Географической сети опытов с удобрениями. Основанием проведения этих опытов стало выступление Д.Н. Прянишникова в Госплане СССР с докладом о химизации земледелия, широком применении удобрений (1941 г.).

Обоснование и методика проведения исследований. Агрохимические исследования в Челябинском НИИСХ начали проводиться в 40 годах прошлого столетия. На первом этапе исследования носили фрагментарный, рекогносцировочный характер в краткосрочных опытах, где эффективность удобрений оценивалась в основном по полученным прибавкам урожая, без увязки с плодородием почвы, погодными условиями и др. существенными факторами, влияющими на урожайность полевых культур.

В этот период было проведено множество полевых, вегетационных и вегетационно-полевых опытов, в которых наряду с изучением эффективности минеральных удобрений, проводились исследования с органическими, органоминеральными и бактериальными формами удобрений.

На первый план выдвигалась задача установления состава и рациональных доз удобрений под ведущие зерновые культуры, а также эффективности основных элементов питания применительно к зональным особенностям региона. 
Однако, в краткосрочных опытах в недостаточной мере учитывались факторы взаимодействия элементов питания и их запасы в почве, а также взаимное влияние полевых культур и элементов питания при возделывании их в севооборотах. Ответ на эти вопросы могли дать только длительные стационары, где более полно характеризуется всё многообразие почвенно-климатических условий выращивания полевых культур.

С этой целью в 1972 году под руководством заслуженного агронома РФ Кушниренко Ю.Д. заложен длительный стационарный опыт по изучению влияния доз и соотношений удобрений при их систематическом внесении на продуктивность плодосменного севооборота и монокультур, который впоследствии был включен в реестр длительных опытов Геосети РФ. В 1993 году в данном стационаре произошла реконструкция, плодосменный севооборот был преобразован в зернопаротравяной севооборот.

Схема стационарного опыта включает четыре уровня азота и четыре уровня фосфора. На вариантах со средними нормами азота и фосфора дополнительно вносится калий. Пространственная реализация схемы осуществляется в двух блоках с равной суммой эффектов в обоих блоках по принципу ортогональности.

Систематическое внесение минеральных удобрений сопровождается изменением всех показателей плодородия почв, в том числе и их физико-химических свойств. Физико-химические свойства почвы оказывают влияние не только непосредственно на рост и развитие растений, но и на превращение в почве удобрений [2-5].

За 25 лет систематического внесения фосфорных удобрений в выщелоченном чернозёме было внесено около 1000-3000 кг/га д.в. фосфора.

В результате этого в почве произошли значительные изменения в обеспеченности её подвижным фосфором. При внесении 1000 кг/га удобрения содержание доступного растениям фосфора возросло до 155 мг/кг почвы, при внесении 3000 кг/га - до 218 мг/кг. При этом затраты фосфора на повышение содержания подвижного фосфора на 1 мг/кг составляли 11,4-28,6 кг/га. На фоне азотного удобрения затраты фосфорного удобрения на повышение содержания подвижного фосфора возрастали, что связано с большим выносом данного элемента питания из-за более высокого уровня урожайности в этих вариантах (табл.1).

Аналогичные результаты по изменению фосфатного режима почв при применении удобрений получили в своих исследованиях Соколов А.В., Чумаченко И.Н. и др. $[6,8,9]$.

В чернозёмных почвах с нестабильным водным режимом и ограниченным промачиванием подкисление под влиянием удобрений достигает значительных размеров, но наблюдается только в верхних (пахотном и подпахотном) слоях почвы [7]. 


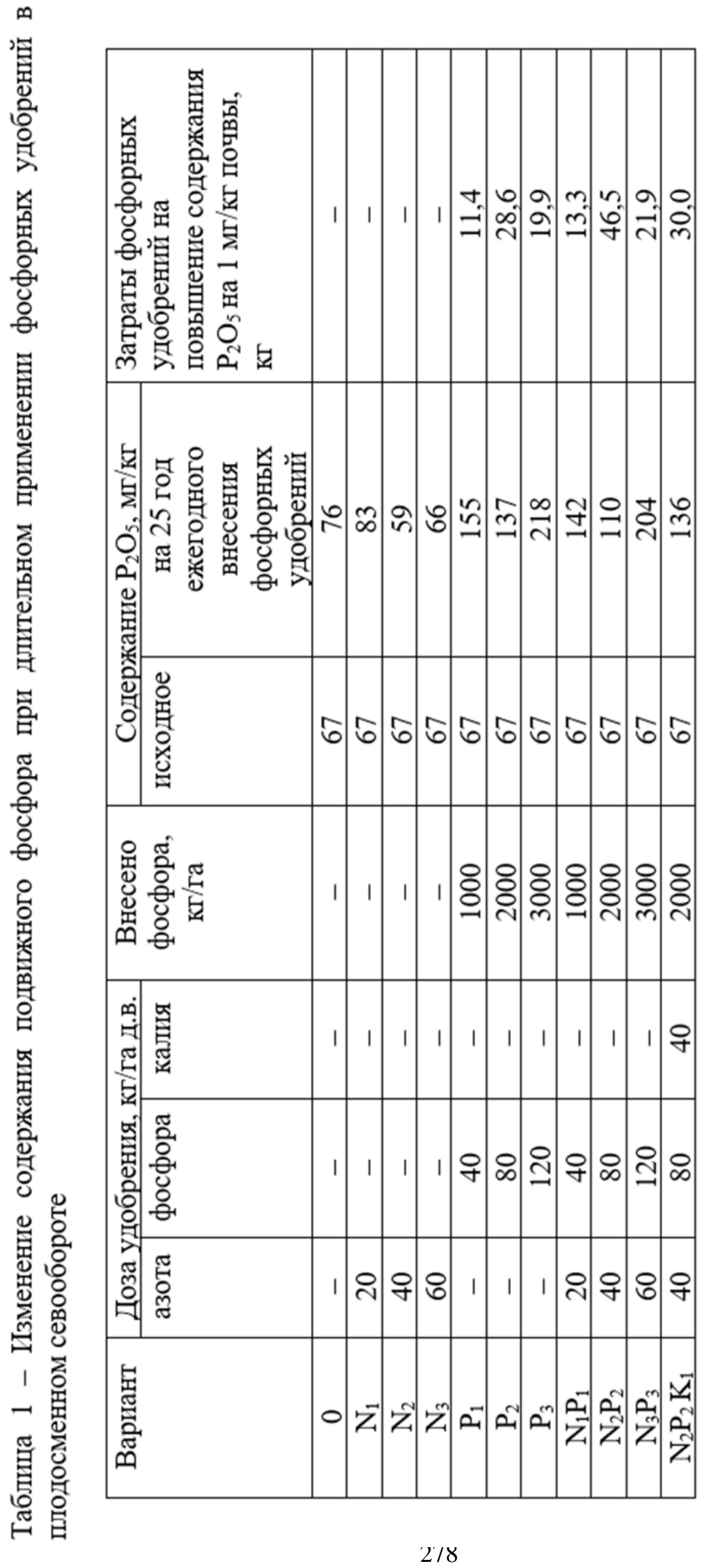


Результатами исследований, проведенных в Челябинском НИИСХ на выщелоченном чернозёме, выявлено, что под действием длительного применения азотно-фосфорных удобрений изменилась кислотность почвенного раствора: гидролитическая кислотность возросла в два раза, причём с увеличением дозы удобрения соответственно возрастала и кислотность; обменная кислотность почвы за этот же период исследований возросла на 8-16 \%. Сумма поглощённых оснований под действием удобрений изменялась незначительно, небольшое снижение суммы поглощённых оснований наблюдалось при внесении повышенной дозы азотного удобрения (табл. 2).

\section{Таблица 2 - Изменение физико-химических свойств выщелоченного чернозёма при длительном применении минеральных удобрений в севообороте}

\begin{tabular}{|c|c|c|c|c|c|c|c|c|}
\hline \multirow[t]{3}{*}{ Вариант } & \multirow{2}{*}{\multicolumn{2}{|c|}{$\begin{array}{c}\text { Доза удобре- } \\
\text { ния, } \\
\text { кг/га д.в. }\end{array}$}} & \multicolumn{6}{|c|}{ Показатель } \\
\hline & & & \multicolumn{3}{|c|}{ Исходное (1971 г.) } & \multicolumn{3}{|c|}{2017 г. } \\
\hline & азота & $\begin{array}{l}\text { фоc- } \\
\text { фора }\end{array}$ & $\mathrm{pH}$ кCL & $\begin{array}{l}\text { Нг., МГ- } \\
\text { ЭКВ } / 100 \text { Г. }\end{array}$ & $\begin{array}{l}\text { SocH, мГ- } \\
\text { ЭКВ } 100 \Gamma \text {. }\end{array}$ & $\mathrm{pH}$ кCL & $\begin{array}{l}\text { Нг, МГ- } \\
\text { ЭКВ/100 Г }\end{array}$ & $\begin{array}{l}\text { SocH, МГ- } \\
\text { ЭКВ } / 100 \text { Г. }\end{array}$ \\
\hline 0 & - & - & 6,15 & 1,9 & 34,0 & 5,79 & 3,31 & 36,08 \\
\hline $\mathrm{N}_{1}$ & 25 & - & 6,15 & 1,9 & 34,0 & 5,61 & 4,12 & 35,50 \\
\hline $\mathrm{N}_{2}$ & 60 & - & 6,15 & 1,9 & 34,0 & 5,39 & 5,01 & 34,98 \\
\hline $\mathrm{N}_{3}$ & 90 & - & 6,15 & 1,9 & 34,0 & 5,45 & 4,34 & 32,24 \\
\hline $\mathrm{P}_{1}$ & - & 32 & 6,15 & 1,9 & 34,0 & 5,62 & 3,95 & 36,21 \\
\hline $\mathrm{P}_{2}$ & - & 65 & 6,15 & 1,9 & 34,0 & 5,66 & 3,57 & 35,89 \\
\hline $\mathrm{P}_{3}$ & - & 98 & 6,15 & 1,9 & 34,0 & 5,50 & 4,34 & 34,98 \\
\hline $\mathrm{N}_{1} \mathrm{P}_{1}$ & 25 & 32 & 6,15 & 1,9 & 34,0 & 5,59 & 4,29 & 34,71 \\
\hline $\mathrm{N}_{2} \mathrm{P}_{2}$ & 60 & 65 & 6,15 & 1,9 & 34,0 & 5,64 & 3,92 & 33,29 \\
\hline $\mathrm{N}_{3} \mathrm{P}_{3}$ & 90 & 98 & 6,15 & 1,9 & 34,0 & 5,19 & 5,61 & 34,06 \\
\hline
\end{tabular}

Заключение. Таким образом, длительное внесение азотно-фосфорных удобрений приводит к изменению плодородия почвы фосфорные удобрения способствуют увеличению в почве содержания подвижного фосфора, а азотнофосфорные удобрения оказывают влияние на рост кислотности почвы.

\section{Библиографический список}

1. Прянишников Д.Н. Изб. Соч. Том 1 Агрохимия М., 1952. -692 с.

2. К Кирюшин В.И. Агрономическое почвоведение. - М.: КолосС, 2010. - 687 с.

3. Агробиологический цикл фосфора / А.Л. Иванов и др. - М.: Россельхозиздат, 2010. $512 \mathrm{c}$.

4. Гамзиков Г.П. Агрохимия азота Сибирских почв при длительном применении удобрений / Материалы Всероссийской конференции учреждений-участников Географической сети опытов с удобрениями 26-27 июня 2012 года «Состояние и пути повышения эффективности исследований в системе Географической сети опытов с удобрениями» Под редакцией академика РАСХН В.Г.Сычева - М: ВНИИА, 2012. - С. 7-10.

5. Шейджен А.Х. Агрохимические свойства чернозема выщелоченного при длительном применении удобрений / А.Х. Шейджен, Л.М. Онищенко, Ю.А. Исупова // Материалы Всероссийской конференции учреждений-участников Географической сети опытов с удобрениями 26-27 июня 2012 года «Состояние и пути повышения эффективности исследований в системе Географической сети опытов с удобрениями» Под редакцией академика РАСХН В.Г. Сычева - М: ВНИИА, 2012. - С. 10-13. 
6. Ваулин А.В. Изменение фосфатного режима дерново-подзолистой среднесуглинистой почвы при внесении высоких доз фосфорных удобрений / А.В. Ваулин, А.А. Коваленко, В.А. Варламов //Агрохимический вестник, 2010. - №6. - С. 10-12.

7. Труды ВИУА. Плодородие почв и эффективность удобрений, М.: 1986. -152 с.

8. Соколов А.В. Агрохимия фосфора. Изд-во академии наук СССР. - M, 1950. - 152 с.

9. Чумаченко И.Н. Фосфор в жизни растений и плодородии почв.

УДК 633.112.:575.1.

\section{ЛИНИИ ЯЧМЕНЯ ПИВОВАРЕННОГО НАПРАВЛЕНИЯ СЕЛЕКЦИИ ОМСКОГО АГРАРНОГО НАУЧНОГО ЦЕНТРА ДЛЯ УСЛОВИЙ ОРГАНИЧЕСКОГО ЗЕМЛЕДЕЛИЯ}

Юсова О.А., Николаев П.Н.

ФГБНУ «Омский АНЦ», г. Омск

E-mail: yusova@anc55.ru; nikolaev@anc55.ru

Резюме. Цель исследований - выделить в селекционном материале Омского АНЦ перспективные генотипь ячменя пивоваренного направления для дальнейшей селекционной работы. В результате длительных исследований продуктивности и качественных показателей, выделены по комплексу признаков для дальнейших исследований линии Омский $95 \times$ Беатрис (2) и Омский $95 \times$ Беатрис (3).

Ключевые слова: ячмень, генотип, пивоваренные качества, урожайность.

Summary. The purpose of the research is to identify promising genotypes of malting barley in the breeding material of the Omsk ANC for further breeding work. As a result of long-term studies of productivity and quality indicators, the lines Omskiy $95 \times$ Beatrice (2) and Omskiy $95 \times$ Beatrice (3) were identified according to a set of signs for further research.

Keywords: barley, genotype, brewing qualities, yield.

Обеспечение пивоваренной отрасли сырьем отечественных сортов ячменя является приоритетным направлением селекции и семеноводства, в соответствии осуществление доктрины продовольственной безопасности РФ. В Российской Федерации основное производство пивоваренного ячменя сконцентрировано в Центрально-Черноземном районе, на юге Сибири. В последние годы отмечено его продвижение на север - в Ленинградскую и Ярославскую области [1].

Одним из структурных подразделений Центра является лаборатория селекции зернофуражных культур. За период с 1936 г. коллективом данной лаборатории создано 22 сорта ячменя, которые внесены в Государственный реестр селекционных достижений РФ; из них 3 сорта пивоваренного направления (Омский 90, Омский 91 и Омский 100). В 2021 г. передан на Государственное сортоиспытание новый перспективный сорт пивоваренного направления Омский 102.

Современные реалии диктуют необходимость получения научных результатов и технологий, которые будут являться основой инновационного развития внутреннего рынка продуктов и услуг, что обеспечит научно-технологическое развитие Российской Федерации и устойчивое её положение на внешних рынках [2]. 
Цель исследований - выделить в селекционном материале Омского АНЦ перспективные генотипы ячменя пивоваренного направления для дальнейшей селекционной работы.

Исследования проведены в 2015-2020 гг. в ФГБНУ «Омский аграрный научный центр» (южная лесостепь Западной Сибири).

Ежегодно в Омском аграрном научном центре проводятся исследования более 100 образцов ячменя пивоваренного направления отечественной и зарубежной селекции, перспективные из которых включаются в программу гибридизации.

В настоящее время сорта пивоваренного направления оцениваются более, чем по двадцати показателям, однако основных - несколько, на которые опираются селекционеры, отбирая селекционный материал и проводя отбор в популяциях. Согласно ГОСТ-5060-86 это следующие признаки:

- высокая экстрактивность (не менее 75-78\%)

- масса 1000 зерен более 40 г.

- содержание белка не более $12 \%$

\section{Таблица - Качественные и урожайные показатели линий}

\begin{tabular}{|c|c|c|c|c|c|}
\hline Линия & $\begin{array}{c}\text { Содер- } \\
\text { жание } \\
\text { белка, \% }\end{array}$ & $\begin{array}{c}\text { Содержа- } \\
\text { ние крах- } \\
\text { мала, \% }\end{array}$ & \begin{tabular}{|c} 
Экстрактив- \\
ность \\
зерна, \%
\end{tabular} & $\begin{array}{c}\text { Macca } \\
1000 \text { зе- } \\
\text { рен г, }\end{array}$ & $\begin{array}{c}\text { Урожай- } \\
\text { ность, } \\
\text { т/га }\end{array}$ \\
\hline Саша $\times$ Гетьман (1) & 13,5 & 56,0 & 79,6 & 50,0 & 5,0 \\
\hline Саша $\times$ Гетьман (2) & 13,8 & 56,2 & 79,3 & 49,3 & 4,8 \\
\hline Саша $\times$ Margret & 11,1 & 58,8 & 82,0 & 52,1 & 5,1 \\
\hline Омский 95 × Viva & 12,2 & 55,1 & 81,0 & 52,1 & 5,5 \\
\hline Омский $90 \times$ Margret & 12,7 & 57,8 & 81,0 & 54,5 & 4,2 \\
\hline Подарок Сибири × Гетьман (1) & 12,9 & 57,2 & 80,2 & 50,6 & 5,0 \\
\hline Подарок Сибири × Гетьман (2) & 14,0 & 56,2 & 79,2 & 50,0 & 5,5 \\
\hline Подарок Сибири × Гетьман (3) & 13,5 & 54,9 & 79,5 & 48,9 & 5,8 \\
\hline Омский $100 \times$ Margret & 12,6 & 53,5 & 79,9 & 46,5 & 5,9 \\
\hline Омский 95 × Беатрис (1) & 11,4 & 56,8 & 82,0 & 53,8 & 5,4 \\
\hline Омский 95 × Беатрис (2) & 12,1 & 56,8 & 80,7 & 49,5 & 6,1 \\
\hline Омский 95 × Беатрис (3) & 11,4 & 56,5 & 81,4 & 50,1 & 6,2 \\
\hline Омский 95 × Деспина & 12,4 & 59,8 & 80,7 & 51,0 & 5,5 \\
\hline $\bar{x}$ по признаку & 12,7 & 56,6 & 80,4 & 50,6 & 5,4 \\
\hline $\mathrm{CV}, \%$ & 8,0 & 2,8 & 1,3 & 4,0 & 10,1 \\
\hline$S_{\bar{x}}$ & 0,3 & 0,8 & 0,3 & 0,5 & 0,1 \\
\hline
\end{tabular}

Все линии по содержанию белка существенно ниже среднего значения данного признака у родительских форм $(-0,6 \ldots-3,0 \%)$ и значительное превышали по данному признаку средние значения родительских форм $(+0,3 \ldots+1,5$ т/га), рис.

Повышенное содержание в зерне крахмала $(+2,7 \ldots+5,0 \%$ к средним данным родительских форм) характерны для линий Подарок Сибири $\times$ Гетьман (1), Омский 95 × Беатрис $(2,3)$, Омский 95 × Деспина. 
Наиболее экстрактивно зерно линий Омский $95 \times$ Viva, Омский $90 \times$ Margret, Подарок Сибири $\times$ Гетьман $(1)$, Омский $95 \times$ Беатрис $(1,2,3)$ и Омский $95 \times$ Деспина $(+0,7 \ldots .2,5 \%$ экстрактивности к средним показателям родительских форм).

По крупности зерна максимальную выраженность признака имела только популяция Омский 95 × Беатрис (1) (+7,5 г к родительским сортам).

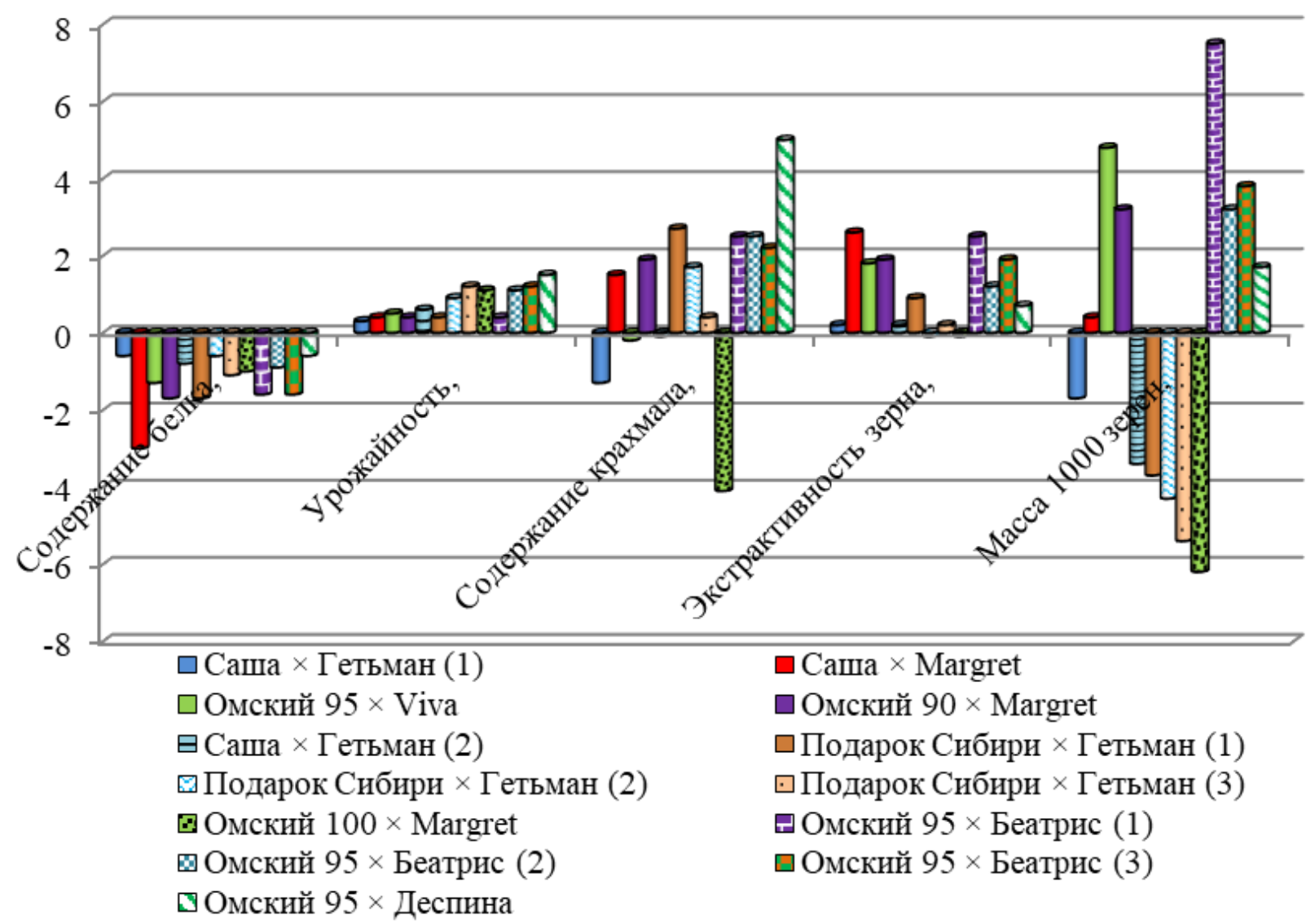

Рисунок - Качество и урожайность линий по отношению к среднему значению признаков у родительских форм

Выводы. В результате длительных исследований продуктивности и качества зерна пивоваренных линий, лишь две из них удалось выделить по комплексу признаков для дальнейших исследований (Омский $95 \times$ Беатрис (2) и Омский $95 \times$ Беатрис (3)).

\section{Библиографический список}

1. Пономарёва Ю.Н., Захарова О.А. Действие минеральных удобрений и регулятора роста на урожайность и качество пивоваренного ячменя в условиях засухи // Вестник Рязанского государственного агротехнологического университета им. П.А. Костычева, 2015. - № 3 (27). - C. 36-42.

2. Occurrence of Fusariumlangsethiae and T-2 and HT-2 Toxins in Italian Malting Barley / Morcia C. Tumino G., Ghizzoni R., et al. // Toxins. 2016. - № 8. - P. 247. DOI: 10.3390/toxins8080247. 
УДК 595.2; 595.7; 574

\title{
ИСПОЛЬЗОВАНИЕ ДАННЫХ МНОГОЛЕТНЕГО МОНИТОРИНГА ЛЁТА ЯБЛОННОЙ ПЛОДОЖОРКИ ДЛЯ ПРОГНОЗА ПРОВЕДЕНИЯ ЗАЩИТНЫХ МЕРОПРИЯТИЙ В ПЛОДОВЫХ САДАХ ЦЕНТРАЛЬНОЙ ЗОНЫ КРАСНОДАРСКОГО КРАЯ
}

\author{
Яковук В.А.
}

ФГБНУ «Федеральный научный центр биологической защиты растений», Краснодар

E-mail: ykovuk00bk@yandex.ru

\begin{abstract}
Резюме. Получены экспериментальные данные многолетнего мониторинга яблонной плодожорки (2004-2016), использование математической обработки позволило выявить особенности лёта самщов яблонной плодожорки. Определены пики лёта вредителей подекадно в течение вегетационного сезона и рекомендовано проведение защитных мероприятий в установленные оптимальные сроки.

Ключевые слова. Яблонная плодожорка, многолетний мониторинг, феромонная ловушка, фитофаг, садовая экосистема.

Summary. Experimental data were obtained from long-term monitoring of the moth (2004-2016). The use of mathematical processing made it possible to reveal the features of the flight of males of the moth. The maximum flight of pests was determined every ten days during the growing season and it was recommended to carry out protective measures at the optimal time
\end{abstract}

Key words: Apple moth, monitoring, pheromone trap, phytophage, garden ecosystem.

Материалы и методы. Опытную работу проводили в яблоневом саду учхоза «Кубань» ФГБОУ ВПО КубГАУ города Краснодар. Данные приведены за период 2004-2016гг. Наблюдения продолжаются и в настоящее время.

Плодовые насаждения представляют собой смесь осенних и зимних сортов - Флорина, Прима, Топаз, Гала, Либерти, Айдаред и др. Сад заложен в 1997 году по схеме 5х3. В исследовании использовались стандартные феромонные ловушки «Атракон», изготовленные в ВНИИБЗР (Всероссийский научно-исследовательский институт биологической защиты растений). Содержание феромона в одном диспенсере составляло 1мг. Ловушки размещались 4 шт. на 1 га на высоте 1,5 м от земли через 15 метров по диагонали сада. Учёты количества самцов яблонной плодожорки, отловленных феромонными ловушками, проводили в течение вегетационного сезона ежедекадно с апреля по сентябрь. Первичный материал ежегодно обрабатывался и использовался в отчетах и статьях.

По мере накопления статистического материала был проведён дисперсионный анализ по максимальному развитию яблонной плодожорки, а также анализ количества яблонной плодожорки на основе средней величины лёта по декадам месяцев учётов [2].

По данным математического анализа установлено наиболее опасная численность вредителей в садовом агроценозе, в связи с этим рекомендована схема защитных мероприятий, позволяющие сократить стандартные, существующие в настоящее время 25-30 обработок до 9 за сезон с результатом 
повреждения плодов не более 1-2 \%. Отсюда идут и другие положительные результаты, которые обсуждались в других публикациях $[1,3,5,6]$.

Результаты исследований. Анализ данных многолетних наблюдений за развитием лёта самцов яблонной плодожорки (ЯП) в плодовом саду в течение вегетационного периода, длящегося с апреля по сентябрь, подтвердил выводы о трёх поколениях ЯП, развивающихся в плодовых насаждениях. Известны такие поколения, как: перезимовавшее, первое летнее и второе летнее поколения.

Установлена продолжительность лёта поколений. Так, лёт яблонной плодожорки «перезимовавшего поколения» продолжается примерно 80 суток (со второй декады апреля по первую декаду июля), лёт «первого летнего поколения» около 70 суток (со второй декады июня по вторую декаду августа), и, наконец, лёт «второго летнего поколения» - 70 суток (со второй декады июля по вторую декаду сентября).

Впервые подтверждено зарождение переходного периода в зимнем поколении первого летнего, занимающее отрезок 30 дней (со второй декады июня по первую декаду июля), такое же явление отмечено при переходе первого летнего поколения во второе летнее поколение, период взаимодействия длится 30 суток (с первой по третью декады августа) [4, 7, 8].

В таблице 1 приведены сравнительные данные дисперсионного анализа среднего лёта самцов яблонной плодожорки, отловленные феромонными ловушками подекадно за период 2004-2016 гг.

Таблица 1 - Уловистость феромонных ловушек самцов яблонной плодожорки в среднем по декадам с 2004 по 2016 (апрель-сентябрь), экз./ лов. декада

\begin{tabular}{|l|l|c|}
\hline Месяц & Декада & Самцы яблонной плодожорки, экз./ лов. декада \\
\hline Апрель & II & 0,1 \\
& III & 0,6 \\
\hline Май & I & 4,0 \\
& II & 7,2 \\
& III & 6,4 \\
\hline Июнь & I & 2,9 \\
& II & 3,1 \\
& III & 3,4 \\
\hline Июль & I & 6,1 \\
& II & 6,3 \\
& III & 7,8 \\
\hline Август & I & 8,7 \\
& II & 7,7 \\
& III & 6,4 \\
\hline Сентябрь & I & 0,8 \\
& II & 0,2 \\
\hline НСР $_{0,5}$ & & 2,74 \\
\hline
\end{tabular}

Начало массового лёта яблонной плодожорки за наблюдаемые нами годы происходит во второй и третий декадах мая 7.2 и 6.4. В июне интенсивность лёта снижается, составив 2.9, 3.1, 3.4 по декадам. Однако вредоносность 
возрастает, что видно во всех декадах июля: 6.1, 6.3, 7.8 и августа 8.7, 7.7, 6.4 соответственно.

На основе полученных данных рекомендуем защиту во второй и третьей декадах мая, в третьей декаде июня, последовательно в трёх декадах июля и августа. По оценке биологической эффективности баковых смесей препаратов предлагается следующие сочетания защитных веществ: лепидоцид + фитоверм; лепидоцид + битоксибациллин; димилин + лепидоцид; люфокс + лепидоцид.

Получены данные max (максимального) развития самцов яблонной плодожорки, представленные в таблице 2, в плодовом саду в течение вегетационного сезона (апрель-сентябрь).

Таблица 2 - Максимальные значения уловистости феромонных ловушек самцов яблонной плодожорки по декадам с 2004 по 2016 (апрель-сентябрь), экз./ лов. декада

\begin{tabular}{|l|l|c|}
\hline Месяц & Декада & Мах улов яблонной плодожорки, экз./ лов. декада \\
\hline Апрель & II & 0,2 \\
& III & 1,2 \\
\hline Май & I & 5,3 \\
& II & 11,2 \\
& III & 11,8 \\
\hline Июнь & I & 4,3 \\
& II & 5,5 \\
& III & 7,2 \\
\hline Июль & I & 8,3 \\
& II & 13,1 \\
& III & 14,0 \\
\hline Август & I & 13,6 \\
& II & 13,9 \\
& III & 11,6 \\
\hline Сентябрь & I & 0,7 \\
& II & 4,6 \\
\hline НСР 0,5 & & 0,4 \\
\hline
\end{tabular}

Для данной схемы опыта величина $\mathrm{HCP}_{0,5}$ составила 4.6. Максимальное развитие плодожорки отмечается во 2 и 3 декадах мая, 11.2 и 11.8, во 2 и 3 декадах июня, 5.5 и 7.2, в июле в трёх декадах 8.3, 13.1, 14.0 соответственно, а также в августе $13.6,13.9,11.6$. Предлагаем провести защиту по рекомендованной схеме, представленной выше.

Таким образом, полученные экспериментальные данные позволили математическим анализом выявить такие важнейшие биологические особенности, как максимальное развитие, так и среднее состояние яблонной плодожорки в плодовом саду. 


\section{Выводы}

•Определена средняя многолетняя сезонная динамика лёта поколений яблонной плодожорки: перезимовавшего поколения - 80 суток, первого летнего - 70 суток, второго летнего поколения - 70 суток

-Впервые установлен совместный лёт одного поколения с другим, так с перезимовавшим поколением начинается совместный лёт первого летнего, длящееся 30 суток. Это же наблюдается при переходе первого летнего поколения во второе летнее поколение

-В результате математического анализа установлено наиболее опасное время развития вредителей в садовом агроценозе, а именно: вторая и третья декады мая, вторая и третья декады июня, все декады июля и августа

-Анализа полученных многолетних данных динамики численности лёта яблонной плодожорки позволяет прогнозировать сроки защитных мероприятий и снизить по сравнению со стандартными обработками 25-30 за сезон в 3 раза

-Рекомендуем использовать баковые смеси препаратов в следующем сочетании защитных веществ: лепидоцид + фитоверм; лепидоцид + битоксибациллин; димилин + лепидоцид; люфокс + лепидоцид.

\section{Библиографический список}

1. Абдунабиев Ф.С. Биологическая защита яблони от яблонной плодожорки (Cydia pomonella L.) в условиях Северного Таджикистана / дис...кандидата c/x наук. Таджикский аграрный университет, $2017-146 \mathrm{C}$.

2. Доспехов Б.А. Методика полевого опыта (с основами статистической обработки результатов исследований). - 5-е изд., доп. и перераб. - М.: Агропромиздат, 1985. - 351 с.

3. Савушкин А.О. Биоэкологическое обоснование использования феромонов и устойчивых сортов для защиты от вредителей, повреждающих генеративные органы яблони / Автореферат на соискание к.б.н. // Защита растений. Москва, 2009. - 170 с.

4. Сугоняев Е.С., Балахнина И.В., Дорошенко Т.Н., Яковук В.А., Шевченко О.С., Васильева Л.А., Пастернак И.Н. Видовое разнообразие и численность зоофагов как базовый биологический ресурс программы экологического управления популяциями яблонной плодожорки Cydia pomonella (L.) (Lepidoptera, Tortricidae) и вредных видов членистоногих второго плана в агроэкосистемах яблоневых садов на юге России // Энтомологическое обозрение, 2014. - Т. 93, вып. 2. - С. 341-366

5. Павлов И.Н. Биоэкологические особенности развития яблонной плодожорки и совершенствование защиты яблони от нее в южной части северо-западного региона России / Автореф. дис. канд. биол. наук. СПб: Пушкин, 2002. - 21 с.

6. Поддубная Е.Н. Совершенствование приемов и методов борьбы с яблонной плодожоркой на основе мониторинга в лесостепи Барабы // Новосибирский гос. аграрный университет / Автореферат на соискание к.б.н. // Защита растений. Новосибирск, 2007. - 19 с.

7. Яковук В.А., Пушня М.В., Родионова Е.Ю., Балахнина И.В., Собина А.Ю., Абдрахманова А.С., Пачкин А.А. Анализ многолетнего мониторинга лёта яблонной плодожорки как основа планирования защитных мероприятий // Земледелие, 2020. - № 7. - С. 39-43.

8. Яковук В.А., Балахнина И.В., Дорошенко Т.Н., Яковук В.М Сезонная динамика лёта яблонной плодожорки (Cydia pomonella L. Lepidoptera: Tortricidae) в Краснодарском крае по данным феромониторинга // Энтомол.обозрение, 2020. - Т. 99, - № 2. - С. 264-270 


\section{СОДЕРЖАНИЕ}

Гостев А.В., Масютенко Н.П. Научно-практическая деятельность академика А.П. Щербакова в годы работы во ВНИИ земледелия и защиты почв от эрозии........................ 7 Агеев А.А., Анисимов Ю.Б., Калюжина Е.Л. Влияние технологий возделывания на продуктивность полевых севооборотов и их экономическая оценка в южном зауралье.... 11 Анисимов В.С., Анисимова Л.Н., Санжаров А.И., Фригидов Р.А. Поведение цинка в компонентах модельной системы почва - почвенный раствор - растение.

Анисимов Ю.Б., Агеев А.А., Калюжина Е.Л., Мошкина Ю.С. Эффективность полевых севооборотов в технологии прямого посева в условиях Челябинской Области .................20 Афонченко Н.В. Варьирование агрохимических показателей почвы в склоновом

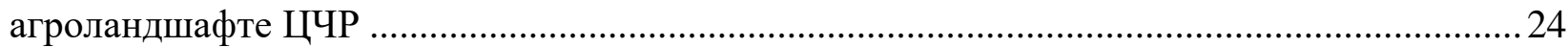
Афонченко Н.В. Пространственное варьирование показателей структуры почвы в

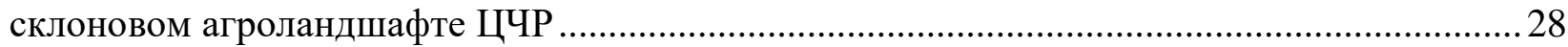
Безуглова О.С., Бесчетников В.В. О механизме влияния гуминовых веществ на ростовые

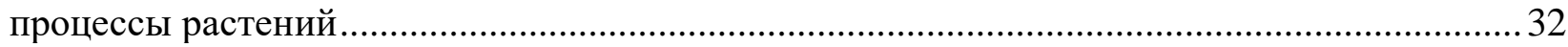
Бесчетников В.В., Безуглова О.С. Влияние загрязнения медью на ростовые процессы растений и роль гуматов в нейтрализации стресса ....................................................... 37 Бовсун М. А., Нестеров В. В., Нестерова О. В., Брикманс А. В., Семаль В. А. Влияние последействия биоугля на потоки $\mathrm{N}_{2} \mathrm{O}$ и $\mathrm{NH}_{3}$ из почв

Бойко В.С., Тимохин А.Ю., Михайлов В.В. Влияние длительного сельскохозяйственного использования на показатели плодородия орошаемой лугово-черноземной почвы ............46 Болдырева В.Э., Жолудев Р.О., Кайдалова Н.В., Крупенина Е.Б., Кучменко Е.В., Литвинов Ю.А., Меженков А.А., Минаева Е.Н. Создание крупномасштабной цифровой почвенной карты Ростовской Области

Брескина Г.М. Особенности развития почвенной микрофлоры при использовании побочной продукции на удобрение ..........................................................................53 Вавин В.Г. Видовой состав и численность основных фитофагов и энтомофагов на опытных

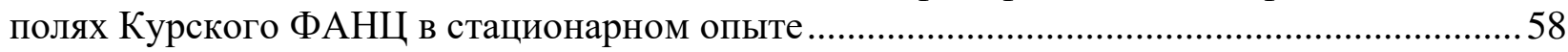
Волошенко И.В., Новых Л.Л. Качество структуры лугово-черноземных почв при

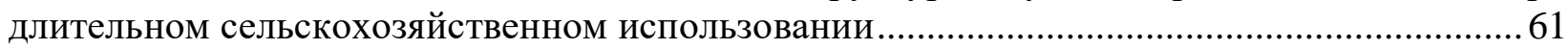
Вытовтов В.А. Изучение равномерности распределения капель дождя по площади

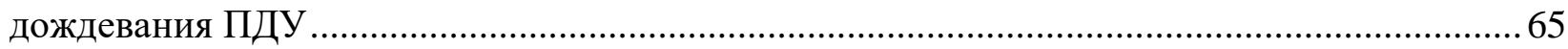
Гармашов В.М., Нужная Н.А., Говоров В.Н., Крячкова М.П., Паутова В.С. Биоэнергетическая эффективность выращивания однолетних трав при минимализации

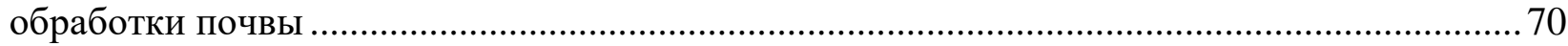
Глазунов Г.П. Оценка содержания запасов продуктивной влаги в условиях склонового

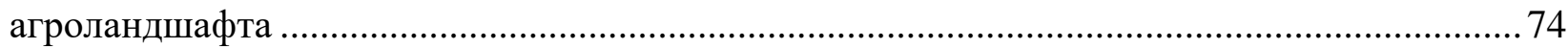
Гуреев И.И. Научно-методологические основы цифровой оптимизации агротехнологий. 79 Двойных В.В. Целлюлозоразлагающая активность почвы как один из показателей её

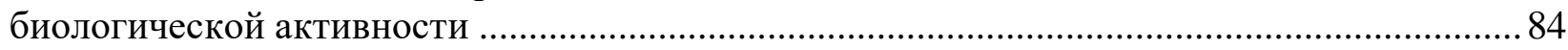
Девятова Т.А., Горбунова Ю.С. Биодиагностика экологического состояния черноземов

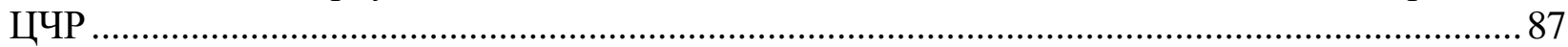

Дериглазова Г.М. Влияние различных технологий возделывания яровой пшеницы на

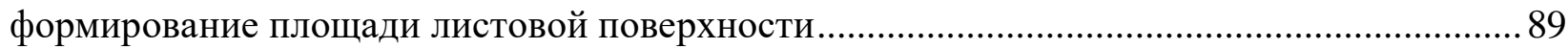
Дериглазова Г.М. Рост и развитие яровой пшеницы при различных технологиях

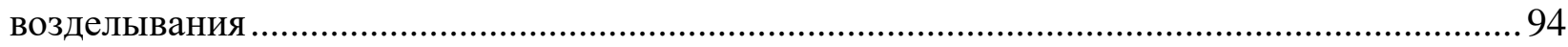
Дубовик Д.В., Дубовик Е.В., Морозов А.Н. Влияние основной обработки почвы на урожайность и качество продукции зернового севооборота.............................................. 98 Дудкина Т.А. Влияние севооборота и минеральных удобрений на качественные показатели продовольственного зерна озимой пшеницы ..... 
Елисеева Н.В., Слюсаренко Э.Е., Тешева С.А. Педоэкологические особенности рисовых

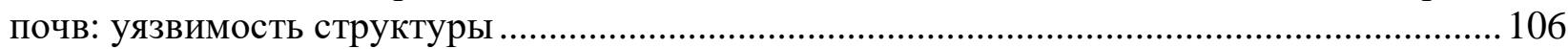
Емельянова А.А., Логвинова Е.В. Оценка сортов озимой твердой пшеницы в питомнике

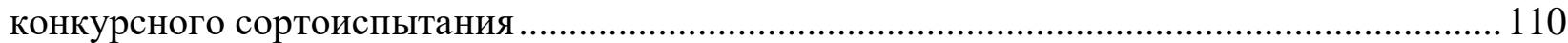
Зинченко С.И., Рыжова Л.Е. Особенности использования влаги озимой рожью в

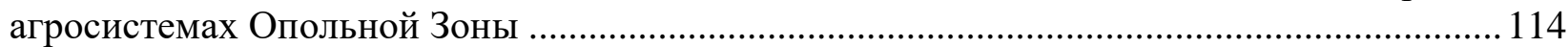
Золотухин А.Н., Суховеева О.Э., Карелин Д.В. Площадные показатели эмиссии $\mathrm{CO}_{2}$ из почвы различных биотопов Медвенского района Курской области ................................. 120 Иванкова А.И., Козлова А.А., Гилев А.М., Брикманс А.В., Нестерова О.В. Базовые физические и физико-химические показатели агропочв спустя месяц после внесения биоугля 125

Караулова Л.Н. Оценка территории ЦЧР для производства подсолнечника .................... 127 Карташев С.С., Безуглова О.С. Влияние гуминового препарата на структуру чернозема обыкновенного под горохом. 132 Кильдюшкин В.М., Животовская Е.Г. Влияние различных систем основной обработки на агрофизические показатели чернозема выщелоченного деградированного и урожайность озимой пшеницы на Кубани 137 Крамаренко В.Я. Продуктивность бинарных и поливидовых травосмесей с использованием вики озимой и пелюшки. 139 Кузнецов А.В., Припутнева М.А. Влияние биопрепаратов на содержание и состав подвижных гумусовых веществ в чернозёме типичном в посевах ярового ячменя ........... 143 Кухарук Е.С., Корман Ю.Х., Кухарук Р.А. Защита почв от эрозии в бассейне реки Бэлцата Республики Молдова 147 Лазарев В.И., Минченко Ж.Н. Оценка эффективности применения комплексных удобрений с микроэлементами на посевах сои в условиях Курской области..................................... 151 Лазарев В.И., Минченко Ж.Н. Эффективность новых форм жидких азотных удобрений на посевах озимой пшеницы в условиях Курской области 155 Лапа В.В., Матыченков Д.В., Азаренок Т.Н., Матыченкова О.В., Дыдышко С.В. База данных лимитирующих урожай факторов сельскохозяйственных культур для почвенных информационных систем ..... 161 Логвинова Е.В., Емельянова А.А. Изучение устойчивости к полеганию сортообразцов озимой тритикале в конкурсном сортоиспытании ФГБНУ «Курский ФАНЦ» ................. 165 Лукьянов В.А. Урожайность и качество зерна озимой пшеницы в севооборотах ЦЧР при

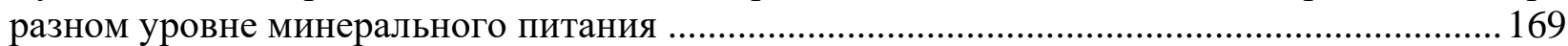
Масютенко М.Н. Влияние обработки биопрепаратами побочной продукции сои на структурно-агрегатный состав чернозема типичного слабоэродированного .................... 173 Масютенко Н.П. Проблемы и перспективы сохранения и повышения плодородия почв 178 Митрохина О.А. Динамика микроэлементов в почвах Курской области и факторы,

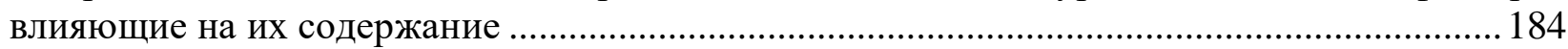
Несветаев М.Ю., Ларькин М.А., Губарев Д.И., Ефимова В.И. Гетерогенность ландшафта как основной фактор продуктивности в пространстве-времени ...................................... 187 Николаев П.Н., Юсова О.А. Новый перспективный сорт ярового ячменя Омский 102 для

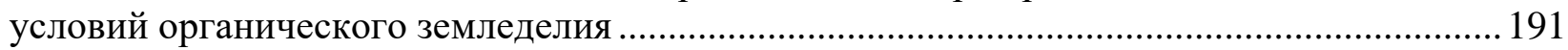
Нитченко Л.Б. Эффективность возделывания ячменя при минимизации основной

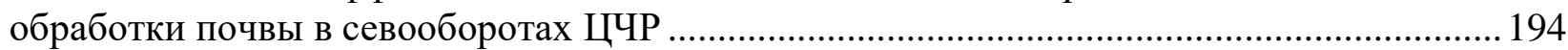
Окунева А.А. Влияние биопрепаратов на структурно-агрегатный состав чернозема типичного слабосмытого в посевах кормовых бобов .................................................... 198 Осипов Ю.Ф., Новикова А.А., Шаповалова Е.В., Шевченко А.А. Использование математического моделирования при определении оптимальных доз удобрения под

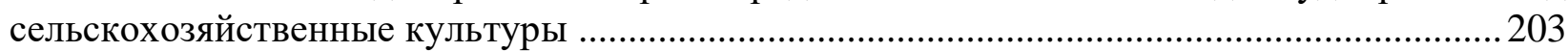


Панкова Т.И. Оценка связи плотности почвы с показателями плодородия чернозема типичного

Подлесных И.В. Влияние узких водорегулирующих лесных полос различной пространственной ориентации на рост и развитие гречихи ..............................................209 Прущик А.В. Влияние основной обработки на свойства почвы при возделывании гречихи

Рыспеков Т.Р. Выпадение атмосферных осадков за летний период в почвенных подзонах степной зоны, как показатели экономических рисков

Салимгареева О.А. К вопросу об изучении пылевой нагрузки и особенностей атмосферных микрочастиц В курской области

Свиридов В.И. Многокритериальная оптимизация структуры посевных площадей как способ повышения эффективности полевого растениеводства. 226 Стахурлова Л.Д., Стулин А.Ф. Продуктивность кукурузы в монокультуре и севообороте в длительном опыте с удобрениями 231 Сухановский Ю.П. Проблемы оценки последствий эрозии в опыте контурномелиоративного земледелия 233 Тарасов С.А. Почвозащитная эффективность агрофонов, сельскохозяйственных культур и севооборотов 238 Тарчоков Х.Ш., Бжинаев Ф.Х., Чочаев М.М. Технология возделывания новых гибридов кукурузы в степной зоне КабардинО-Балкарии .

Хлюпина С.В. Севооборот культур как элемент адаптивного земледелия 251 Цимбалист Н.И., Алиев А.М., Ваулина Г.И. Оптимизация сочетания систем защиты растений и доз азотного удобрения в технологиях возделывания озимой пшеницы в 3-й ротации севооборота СИ-11 254 Чевердин Ю.И. Накопление солей под лесными полосами Центрального Черноземья ... 258 Чуян Н.А. Влияние биопрепаратов на биометрические показатели культуры гречиха ....261 Чуян О.Г. Известкование кислых почв в агроландшафтах ЦЧР .........................................2265 Шаталина Л.П., Анисимов Ю.Б., Калюжина Е.Л. Инновационные ресурсы повышения качество зерна яровой пшеницы на Южном Урале 270 Юмашев Х.С. Влияние минеральных удобрений на плодородие выщелоченного чернозема 276

Юсова О.А., Николаев П.Н. Линии ячменя пивоваренного направления селекции Омского аграрного научного центра для условий органического земледелия 280 Яковук В.А. Использование данных многолетнего мониторинга лёта яблонной плодожорки для прогноза проведения защитных мероприятий в плодовых садах Центральной зоны Краснодарского края 283 


\section{Научное издание}

Рациональное землепользование: оптимизация земледелия и растениеводства. Сборник докладов Международной научно-практической конференции, посвященной 80-летию со дня рождения академика РАСХН А.П. Щербакова, Курск, 28-30 сентября 2021 г. - Курск: ФГБНУ «Курский федеральный аграрный научный центр», 2021. - 289 с.

Компьютерная верстка: Г.П. Глазунов

Сдано в набор 20.09.21 г. Подписано в печать 28.09.21 г. Формат 60x84 1/16. Бумага офсетная. Печать цифровая.

Усл. печ. л. 18. Тираж 500 экз. Заказ № 504.

Отпечатано: «Деловая полиграфия»

ИП Бескровный Александр Васильевич

г. Курск, ул. К.Маркса, 61 Б.

E-mail: zakaz-zachetka@mail.ru 